\title{
MÚLTIPLAS POSSIBILIDADES: \\ A Estruturação dos Projetos Experimentais no Ensino de Jornalismo
}

Tese apresentada ao Programa de PósGraduação em Ciências da Comunicação, Área de Concentração Interfaces Sociais da Comunicação, da Escola de Comunicações e Artes da Universidade de São Paulo, como exigência parcial para obtenção do Título de Doutor em Ciências da Comunicação, sob a orientação da Profạ. Dra. Alice Mitika Koshiyama.

São Paulo - SP 


\section{MÚLTIPLAS POSSIBILIDADES: \\ A Estruturação dos Projetos Experimentais no Ensino de Jornalismo}

Tese apresentada ao Programa de PósGraduação em Ciências da Comunicação, Área de Concentração Interfaces Sociais da Comunicação, da Escola de Comunicações e Artes da Universidade de São Paulo, como exigência parcial para obtenção do Título de Doutor em Ciências da Comunicação, sob a orientação da Profạ. Dra. Alice Mitika Koshiyama.

São Paulo - SP

2009 


\section{FOLHA DE APROVAÇÃO}

Eliane Freire de Oliveira

MÚLTIPLAS POSSIBILIDADES:

A Estruturação dos Projetos Experimentais no Ensino de Jornalismo

Tese apresentada ao Programa de PósGraduação em Ciências da Comunicação da Escola de Comunicações e Artes da Universidade de São Paulo para obtenção do Título de Doutor.

Área de Concentração: Interfaces Sociais da Comunicação.

Aprovado em:

\section{Banca Examinadora}

Prof ${ }^{a}$. Dra. Alice Mitika Koshiyama (Orientadora)

Universidade de São Paulo

$\operatorname{Prof}(\mathrm{a}) . \operatorname{Dr}(\mathrm{a})$.

Instituição:

$\operatorname{Prof}(\mathrm{a}) . \operatorname{Dr}(\mathrm{a})$.

Instituição:

$\operatorname{Prof}(\mathrm{a}) . \operatorname{Dr}(\mathrm{a})$.

Instituição:

Prof(a). Dr(a).

Instituição: 


\section{Dedicatória}

À minha avó, à minha mãe, à minha filha.

Com amor. 


\section{Agradecimentos}

A Deus, por ter me guiado até aqui.

À professora Alice Mitika, por sua infinita paciência.

À Universidade de Taubaté, pelo financiamento da pesquisa. Aos professores e coordenadores, que colaboraram com os resultados obtidos. 
Ler torna um homem completo, ensinar Ihe dá preparo, escrever o torna consciente.

Francis Bacon 


\section{RESUMO}

OLIVEIRA, E. F. Múltiplas Possibilidades: A Estruturação dos Projetos Experimentais no Ensino de Jornalismo. 2009. 222 p. Tese (Doutorado). Escola de Comunicações e Artes, Universidade de São Paulo, São Paulo, 2009.

O ensino de Jornalismo é objeto freqüente de reflexão, principalmente no que diz respeito à aquisição e compreensão de ferramentas e conhecimentos necessários para a formação de um profissional com múltiplas habilidades e competências. A implantação dos Projetos Experimentais no currículo da Habilitação Jornalismo nos cursos de Comunicação Social no Brasil ocorreu em 12 de abril de 1978, recebendo posteriormente, a partir da Resolução do CFE no 002/84, o tratamento de disciplina regida por normas específicas de acordo com os projetos pedagógicos das instituições de ensino superior. A pesquisa investiga o papel exercido pelos Projetos Experimentais em universidades paulistas, que possibilitam, por meio de diferentes experiências adotadas, a vivência, a aquisição e o domínio de técnicas importantes da produção jornalística para a formação ética e profissional dos graduandos em Jornalismo. Por meio de estudo de casos múltiplos e tendo como referência principal as Diretrizes Curriculares Nacionais dos cursos de Comunicação Social (Parecer CNE/CES no 492/2001), verifica-se que os Projetos Experimentais têm importante papel no exercício de cidadania frente aos desafios e responsabilidades da profissão, especialmente quanto à contribuição para a sociedade, à formação do bem comum e à consciência do papel do Jornalismo na realidade.

Palavras-chave: Ensino de Jornalismo; Projetos Experimentais; Diretrizes Curriculares; Projetos Pedagógicos; Trabalhos de Conclusão de Curso. 


\begin{abstract}
OLIVEIRA, E. F. Multiple Possibilities: The Structuring of the Experimental Projects in the Journalism Education. 2009. 222 p. Thesis (Doctoral). Escola de Comunicações e Artes, Universidade de São Paulo, São Paulo, 2009.

The education of Journalism is a frequent object of reflection, mainly in what concerns the acquisition and understanding of tools and necessary knowledge for the formation of a professional with multiple skills and abilities. The implementation of the Experimental Projects in the curriculum of the competence Journalism in the courses of Social Communication in Brazil occurred on April 12, 1978, receiving subsequently, from the Resolution of the CFE number 002/84, the handling of discipline governed by specific standards according to the pedagogical projects of the institutions of higher education. The research investigates the paper exerted by the Experimental Projects in universities of the state of São Paulo that enable through different adopted experiences, the knowledge, the acquisition and the domain of important techniques of the journalistic output for the ethical and professional formation of the graduating students in Journalism. Through multiple case studies and having as main reference the National Curricular Directives of the courses of Social Communication (CNE/CES Study number 492/2001), are verified that the Experimental Projects have important paper in the exercise of citizenship facing the challenges and responsibilities of the profession, specially as regards the contribution for the society, to the formation of the welfare and to the conscience of the paper of the Journalism nowadays.
\end{abstract}

Key words: Journalism Education; Experimental Projects; Curricular Directives; Pedagogical Projects; Course Final Papers. 


\section{SUMÁRIO}

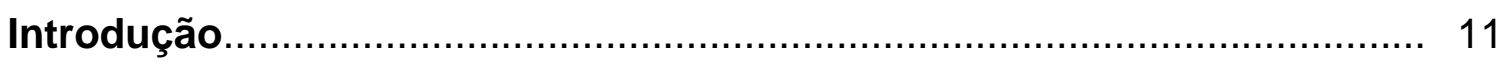

1. Ensino de Jornalismo .................................................................. 20

1.1. Diretrizes Curriculares.............................................................. 30

1.2. Projetos Pedagógicos................................................................... 41

1.3. Práticas laboratoriais........................................................................ 51

1.4. Processo ensino-aprendizagem...................................................... 61

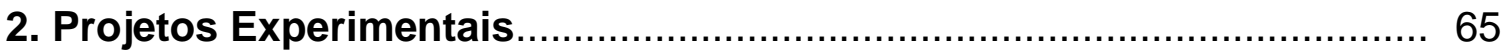

2.1. Implantação nas IES.................................................................... 76

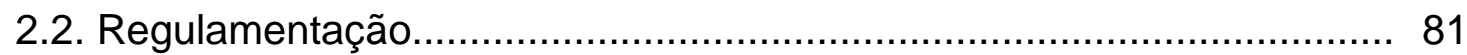

2.3. Objetivos e características................................................................ 83

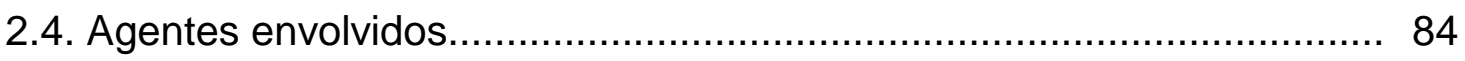

3. Estruturação dos Projetos Experimentais: Casos Múltiplos................. 87

3.1. O cenário nas IES paulistas......................................................... 89

3.2. O papel dos Projetos Experimentais.................................................. 96

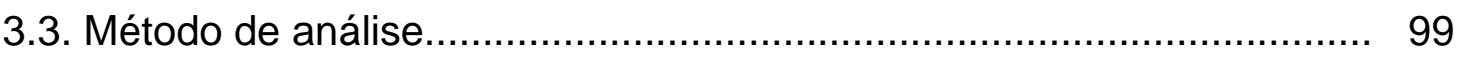

4. Operacionalização de Projetos Experimentais ...................................... 102

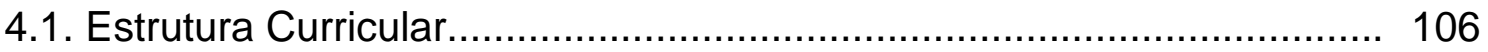

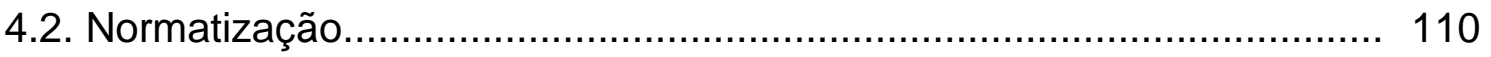

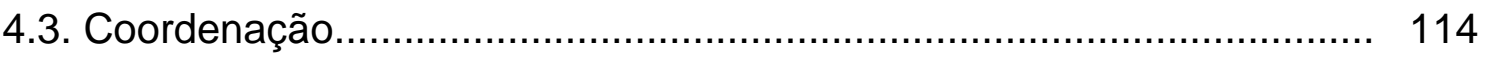

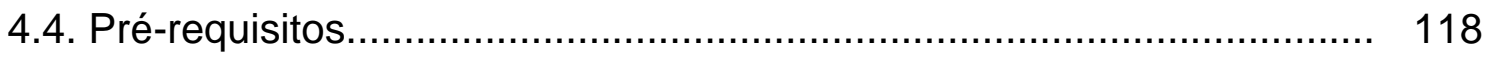


4.5. Prazo de elaboração....................................................................... 122

4.6. Avaliação ................................................................................ 125

4.7. Relação com o mercado.................................................................... 130

5. Orientação de Projetos Experimentais............................................... 135

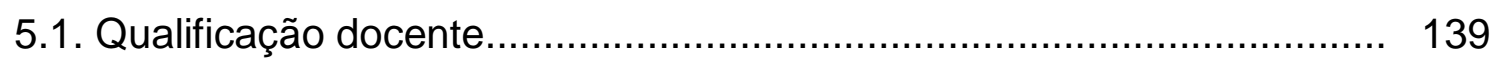

5.2. Critérios de escolha do Orientador................................................... 141

5.3. Envolvimento docente, impasses e incentivos.................................... 142

5.4. Processo de orientação................................................................... 143

5.5. Pré-bancas e Bancas Examinadoras................................................... 148

6. Elaboração de Projetos Experimentais................................................. 154

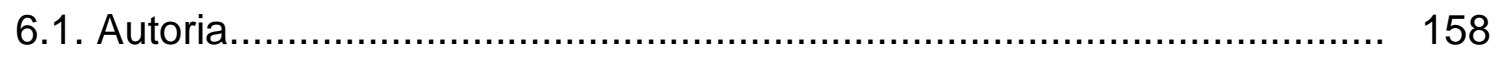

6.2. Escolha dos temas e formatos...................................................... 161

6.3. Prazo e condições de produção......................................................... 167

6.4. Processo de elaboração................................................................ 169

6.5. Uso de laboratórios..................................................................... 175

6.6. Experiência profissional................................................................. 177

6.7. Visão crítica do mercado e da profissão................................................ 180

6.8. Mito da Banca Examinadora............................................................. 186

6.9. Espírito Empreendedor............................................................... 190

Conclusão

Referências Bibliográficas................................................................. 201

Anexos 


\section{Introdução}

A disciplina Projetos Experimentais (PE) foi implantada nos cursos de Comunicação Social no Brasil no dia 12 de abril de 1978, pela Resolução nº 003/78 do Conselho Federal de Educação. Exatos vinte anos depois, em abril de 1998, eu iniciava minha carreira docente na Universidade de Taubaté como auxiliar de ensino na habilitação Jornalismo. Minha primeira atividade docente foi participar de pré-bancas de Projetos Experimentais, uma espécie de qualificação para alunos de graduação que estão desenvolvendo seus trabalhos de conclusão de curso, requisito parcial para a obtenção do diploma de Bacharel em Comunicação Social.

Esta experiência me marcou definitivamente, pois foi a primeira vez que ouvi de colegas professores - alguns com vários anos de docência - uma expressão que se repetiria frequentemente: "É fazendo o Projeto Experimental que o aluno se torna jornalista". Esta frase me acompanhou nos últimos dez anos, tanto nos momentos em que atuava como orientadora e avaliadora nas instituições de ensino nas quais ministro aulas, como em congressos e encontros dos quais participei e em que se discutia o ensino de Jornalismo. Foi a inquietação provocada por esta frase que me direcionou à pesquisa sobre o papel dos Projetos Experimentais e sua estruturação no Ensino de Jornalismo.

A princípio, procurei estudar os formatos desenvolvidos como PE (ou TCC, como os alunos gostam de nomear, apesar de não ser o termo mais adotado pelas Instituições de Ensino Superior - IES) por estudantes de Jornalismo, em especial aqueles que se aprofundavam nos caminhos de uma grande-reportagem. Porém, percebi que o formato de um Projeto Experimental é apenas uma mínima parte de 
um todo muito mais amplo e complexo. E, como professora, entendi que existem elementos e agentes envolvidos nos Projetos Experimentais que refletem práticas pedagógicas de grande importância para a formação de jornalista, que sempre foi alvo de inúmeras discussões nas faculdades, sindicatos, congressos, simpósios, e, especialmente, nos programas de pós-graduação. No foco das discussões estão as deficiências curriculares, como adequar diretrizes à realidade regional e estabelecer um diálogo efetivo entre a faculdade e o mercado de trabalho. Nota-se, porém, que dentre esses debates, poucos direcionam atenção ao papel dos Projetos Experimentais na formação dos futuros profissionais.

A disciplina Projetos Experimentais (PE) foi implantada com dois objetivos iniciais: obrigar a prática profissional nos cursos e contribuir para a criação uma estrutura tecnicista no ensino de Jornalismo. Os alunos, à época da implantação, recebiam um ensino teórico que, em muitos casos, eram desdobramentos dos cursos de Filosofia ou de Letras. Não havia laboratórios nas faculdades e nem elaboração de produtos jornalísticos. Os Projetos Experimentais deveriam incentivar a prática profissional efetiva, visando a diminuir a carência e a distância das Escolas em relação ao mercado. (cf. ABECOM, 1990)

Com a implantação da Resolução do Conselho Federal de Educação ํo 002/84, uma carga horária mínima de 270 horas/aula de atividades foi estabelecida para o desenvolvimento de Projetos Experimentais, especialmente no último semestre ou ano do curso. Muitas escolas optaram em transformar essa disciplina em uma prática laboratorial na produção de produtos, como: jornais, revistas, vídeos, documentários, programas de rádio, entre outros. Outras escolas resolveram continuar produzindo produtos jornalísticos para os alunos do último ano e criar também outra atividade, que foi denominada, em alguns casos, 
Trabalho de Conclusão de Curso (TCC). Era a oportunidade em que os alunos, em pequenos grupos ou individualmente, poderiam aprofundar seus conhecimentos, produzindo e experimentando novas linguagens e modelos comunicacionais de maneira autônoma. (cf. OLIVEIRA \& SILVA, 2003, p. 216)

Dessa experiência resultaram inúmeros projetos profissionais, com destaque para grandes reportagens, com temas que apontam para questões sociais, biografias e perfis, resgates históricos e reportagens investigativas, propiciando a seus autores - jovens jornalistas em formação - experiências enriquecedoras que, muitas vezes, não foram vivenciadas ao longo da graduação. Tais resultados receberam diferentes suportes, como vídeo documentários, livros, revistas impressas e digitais, ensaios fotográficos, entre outros. As experiências reveladas pelos Projetos Experimentais valorizam os trabalhos de conclusão de curso como passo importante na formação profissional e acadêmica do aluno.

Assim, o objetivo desta pesquisa é demonstrar, por meio das experiências pedagógicas ocorridas em instituições de ensino superior que oferecem a Habilitação Jornalismo no Estado de São Paulo - delimitadas as universidades que procuram atender ao disposto nas Diretrizes Curriculares Nacionais dos cursos de Comunicação Social (Parecer CNE/CES n 492/2001) - as múltiplas possibilidades oferecidas pelos Projetos Experimentais, revelando que é possível oferecer aos graduandos a vivência da produção jornalística e o domínio de técnicas importantes para a formação ética e profissional dos futuros jornalistas, possibilitando um exercício de cidadania frente aos desafios e responsabilidades de sua profissão, no que tange à contribuição para a sociedade, à formação do bem comum e à consciência de seu papel na realidade. 
Para a obtenção dos resultados apresentados na pesquisa foi realizado um estudo de casos múltiplos, estruturados de acordo com Robert K. Yin (2005) como uma investigação empírica de "um fenômeno contemporâneo dentro de seu contexto da vida real, especialmente quando os limites entre o fenômeno e o contexto não estão claramente definidos" (2005, p. 32). O corpus da pesquisa são os regulamentos que regem os Projetos Experimentais de dez Instituições de Ensino Superior que oferecem a graduação em Comunicação com habilitação em Jornalismo no Estado de São Paulo. A pesquisa documental também se apóia em papers com relatos de experiências da estruturação e das práticas oferecidas pelas IES no que tange ao ensino de Jornalismo e que foram apresentados em congressos e simpósios.

A análise engloba também um paralelo entre os regulamentos e as Diretrizes Curriculares Nacionais dos cursos de Comunicação Social - Parecer CNE/CES no 492/2001 - de forma a verificar como estão estruturados os processos de ensino-aprendizagem relacionados aos Projetos Experimentais e de que maneira os alunos têm a oportunidade de aprofundar e experimentar, em alguns casos, os maiores desafios até então propostos durante a graduação. Tal análise visa à compreensão do direcionamento dado pelas IES à prática que envolve temas de interesse social, com os quais o futuro jornalista se torna mais consciente de seus direitos e deveres para com a sociedade, estreitando a relação entre Jornalismo e cidadania e, de certa forma, contribuindo para modificar uma visão distorcida sobre o papel do jornalista na sociedade.

Assim, as hipóteses que norteiam a pesquisa estabelecem que: a produção de Projetos Experimentais por estudantes de Jornalismo em IES do Estado de São Paulo é importante instrumento de sua formação; faz-se necessário compreender o 
diálogo existente os regulamentos estabelecidos pelas IES e os agentes envolvidos na elaboração de Projetos Experimentais no que diz respeito à relação ensinoaprendizagem e o papel dos mesmos na formação do jornalista; a estruturação dos Projetos Experimentais frente às Diretrizes Curriculares oferece múltiplas possibilidades aos graduandos, de maneira a permitir que vivenciem de forma autônoma os caminhos da formação profissional em Jornalismo.

As Diretrizes Curriculares de Comunicação Social aprovadas pelo Ministério da Educação (MEC), em 2001, definem que aluno de Jornalismo deve desenvolver a capacidade de reflexão para analisar os padrões e práticas jornalísticas, exercitando sua capacidade criativa no sentido de experimentar novas linguagens e produtos de comunicação. Cabe à escola também discutir questões socioculturais e políticas com ensinamentos sobre novas tecnologias aplicados à linguagem jornalística, criando condições para que o aluno exercite sua capacidade criativa, experimente novas ferramentas e assimile aspetos teórico-práticos de sua formação. Assim, busca-se um egresso dos cursos de Jornalismo que tenha a capacidade de compreender os mecanismos envolvidos no processo de recepção de mensagens e seu impacto sobre os diversos setores sociais.

A fim de descrever qual o papel dos Projetos Experimentais nesse processo e qual a estruturação dos mesmos nas IES, o primeiro capítulo da tese se dedica à exposição sobre o ensino de Jornalismo, o processo histórico e a legislação que determina a oferta de cursos de Comunicação Social com habilitação em Jornalismo no Brasil. Uma característica básica do profissional de Jornalismo é a capacidade de refletir sobre sua responsabilidade social, uma vez que seu trabalho bem realizado amplia o conhecimento da população e permite mudar a realidade. A informação permite à sociedade opções de escolha, interpretação, participação das 
decisões democráticas e construção de novos caminhos. Assim, o capítulo detalha as Diretrizes Curriculares e a importância dos Projetos Pedagógicos definidos e desenvolvidos pelas IES, cada qual com particularidades e que definem o perfil desejado do profissional que pretendem formar, bem como os caminhos que oferecem para tal formação.

O primeiro capítulo aborda ainda como se dá o processo ensinoaprendizagem na articulação teórico-prática proporcionada por currículos dinâmicos e que possibilitam a oferta de práticas laboratoriais como instrumentos de formação dos jornalistas. A possibilidade com que pode aprofundar tanto a experimentação das técnicas jornalísticas, quanto a vivência da realidade das questões sociais pode contribuir para a (trans)formação desse aluno em um jornalista consciente de seus direitos e deveres, uma vez que as práticas laboratoriais visam também à construção de uma visão crítica e reflexiva sobre o papel do Jornalismo na sociedade, uma formação centrada nas Ciências Humanas, a percepção mais apurada da realidade, a capacidade de compreender a interação entre a teoria e a prática, além da consciência ética profissional.

Os Projetos Experimentais são o foco do segundo capítulo, com o detalhamento histórico desde a Resolução do CFE no 003/78, de 12 de abril de 1978, que instituiu as atividades de cunho prático nos cursos de Jornalismo, recebendo posteriormente, a partir da Resolução do CFE no 002/84, o tratamento de disciplina regida por normas específicas de acordo com os projetos pedagógicos das Instituições de Ensino Superior. De lá para cá, ao longo de mais de três décadas, as experiências realizadas ainda no ambiente acadêmico no que diz respeito à elaboração dos Projetos Experimentais como trabalhos de conclusão de curso ou produtos laboratoriais - e que, por vezes, superam vivências da trajetória 
profissional - possibilitou a implantação de regulamentos específicos para o desenvolvimento do processo, resultando na formatação de normas e regimentos das IES para o desenvolvimento dos Projetos Experimentais. Devido à diversidade temática, à profundidade da investigação jornalística, ao papel dos orientadores, ao relato da experiência vivenciada pelos graduandos e à contribuição para a sociedade nas abordagens de questões sociais, o segundo capítulo descreve os objetivos e particularidades dos Projetos Experimentais adotados como trabalhos de conclusão de curso e os agentes envolvidos, como coordenadores, professores orientadores e avaliadores e alunos. Discorre também sobre a nomenclatura adotada para definir Projetos Experimentais, em alguns casos utilizada como sinônimo de trabalho de conclusão de curso (TCC), em outros como sinônimo de práticas laboratoriais, ou ainda empregada como diferencial entre um trabalho de caráter profissional e outro de caráter acadêmico (como uma monografia, resultado de uma pesquisa científica, por exemplo).

O terceiro capítulo enfoca o estudo de casos múltiplos, descrevendo a pesquisa bibliográfica e documental que subsidiou a análise do corpus do trabalho. O método utilizado e a coleta de dados são detalhados de forma a organizar e sumariar dados que contribuíram para a verificação das hipóteses da pesquisa, e também para a compreensão de legislação pertinente, das normas regimentais das Instituições de Ensino Superior e dos instrumentos de planejamento, elaboração e avaliação utilizados para definir a estruturação dos Projetos Experimentais. O capítulo oferece também o cenário de parte das IES paulistas que utilizam regulamentos específicos para os Projetos Experimentais, descrevendo particularidades pertinentes à análise realizada. 
Como a tese se propõe também a demonstrar a estruturação dos Projetos Experimentais, ou seja, como se organizam as diversas partes que compõem a estrutura de PE nas Instituições de Ensino Superior no Estado de São Paulo, os capítulos seguintes demonstram como isso frequentemente acontece, de acordo com o que prevêem os regulamentos de PE adotados. O quarto capítulo trata da operacionalização dos Projetos Experimentais, evidenciando tópicos como: a presença da disciplina na estrutura curricular; a normatização e os acréscimos e riscos decorrentes de sua utilização; o papel da coordenação específica na gestão do processo de planejamento, elaboração e avaliação dos Projetos Experimentais; a adoção de pré-requisitos para a efetiva realização de PE como trabalhos de conclusão de curso; os prazos definidos para elaboração em IES que adotam regimes semestrais e anuais; as formas de avaliação adotadas durante o processo de realização de PE; e, por fim, qual a relação dos Projetos Experimentais de caráter profissional com o mercado jornalístico.

O quinto capítulo enfatiza o papel dos docentes na estruturação dos Projetos Experimentais. Evidenciando que a orientação de PE no âmbito acadêmico contribui para a formação de jornalistas como atores sociais capazes de refletir sobre suas responsabilidades sociais e conscientes de que seu trabalho bem realizado amplia conhecimento e permite mudar a realidade, o docente que se dedica ao ensino de Jornalismo tem muitos desafios. No que tange à orientação de PE, vários aspectos estão interligados no processo ensino-aprendizagem, desde a qualificação docente e os critérios que definem a escolha do orientador até o processo de orientação e de avaliação. Neste capítulo, estão detalhados os elementos previstos nos regulamentos das IES que dizem respeito à orientação, ao envolvimento docente no trabalho, aos impasses enfrentados e aos incentivos, 
incluindo a remuneração e o reconhecimento (ou premiação, em alguns casos) pela orientação. Demonstra-se também como funcionam as pré-bancas de qualificação dos PE e as Bancas Examinadoras, que avaliam os resultados finais do processo de elaboração dos Projetos Experimentais.

Considerando que na elaboração de PE os futuros jornalistas podem trabalhar com a cobertura das questões sociais, valorizando ações que promovam impacto social, participação democrática e tornando públicos aspectos da vida em sociedade e discussões que afetam diariamente o cotidiano das pessoas, o sexto capítulo é dedicado a esse processo. Verificando como os regulamentos sobre PE das Instituições de Ensino Superior abordam questões como autoria, escolha dos temas e formatos, prazos e condições de produção, disponibilidade e uso de laboratórios na realização de Projetos Experimentais, o capítulo demonstra qual a relação entre a estruturação dos PE, o que definem as Diretrizes Curriculares para a formação do jornalista e as possibilidades de vivenciar a experiência profissional, de adquirir visão crítica do mercado e da profissão e de desenvolver espírito empreendedor frente ao Jornalismo. O sexto capítulo descreve também o funcionamento das Bancas Examinadoras e como o processo de avaliação dos Projetos Experimentais legitima novos discursos, traz à tona idéias originais, dá voz a opiniões divergentes e conceitos distintos para fortalecer o debate e a construção de novos caminhos no Jornalismo.

Como resultado da análise, a tese é concluída com as discussões sobre as hipóteses levantadas, com o propósito de apontar aspectos fundamentais sobre a estruturação dos Projetos Experimentais no ensino de Jornalismo. Na seqüência, estão incluídos as referências bibliográficas e os anexos, como Diretrizes Curriculares e regulamentos de Projetos Experimentais das IES pesquisadas. 


\section{Ensino de Jornalismo}

O ensino de Jornalismo no Brasil tem como marco histórico a data de 16 de maio de 1947, quando começou a funcionar o Curso de Jornalismo Cásper Líbero, em São Paulo, formalizado pelo Decreto no 22.245 de 6 de dezembro de 1946, que dispunha de sua organização curricular. Porém, seus antecedentes remontam quatro décadas, haja vista que, em 1908, o jornalista Gustavo Lacerda, ao assumir a presidência da Associação de Imprensa - hoje Associação Brasileira de Imprensa (ABI) - estabeleceu como meta a criação de um curso de Jornalismo no país.

A concretização de tal objetivo passou por entraves. Em 1918, no Primeiro Congresso Brasileiro de Jornalistas realizado pela entidade, novas propostas seriam oficializadas, sugerindo que a escola "não faria doutores nem bacharéis, mas se propunha unicamente a propiciar a seus alunos o ensino de matérias julgadas essenciais à prática da profissão", conforme as palavras proferidas, em 1955, pelo jornalista Victor de Sá.

Alguns nomes estão envolvidos nas reivindicações pela criação do curso de Jornalismo, entre eles, o educador Anísio Teixeira e o jornalista Costa Rego. Ao

criar, em 1935, no Rio de Janeiro, a Universidade do Distrito Federal, Anísio Teixeira convidou o então redator-chefe do Correio da Manhã para organizar o novo curso, mas não houve avanços. Posteriormente, a Universidade seria extinta no Estado Novo. Oito anos depois, em São Paulo, Vitorino Prata Castello Branco recebeu o apoio da Associação dos Profissionais de Imprensa de São Paulo (APISP) e, com o lema "Jornalistas de todo o Brasil uni-vos", ofereceu o primeiro Curso Livre de Jornalismo no país, iniciativa que não durou muito. 
Em 13 de maio de 1943, o presidente da República Getúlio Vargas assinou o Decreto-Lei $n^{\circ}$ 5.480, criando o curso de Jornalismo que deveria funcionar na Faculdade Nacional de Filosofia, no Rio de Janeiro, com o apoio da Associação Brasileira de Imprensa, prevendo em seu artigo $3^{\circ}$ a cooperação de sindicatos dos empregados e dos empregadores das empresas jornalísticas.

Laurenti (2002, p.32) ressalta que:

Embora o Decreto-lei assinado por Getúlio Vargas delegasse à Faculdade Nacional de Filosofia a oferta do curso, foi a Fundação Cásper Líbero, em convênio com a Faculdade de Filosofia, Ciências e Letras de São Bento da Pontifícia Universidade Católica de São Paulo, que acabou por instituí-lo em 1947, tendo em vista o precedente aberto no artigo 9o do Decreto no 22.245/46 que informava: 'aplica-se no que couber, ao curso de Jornalismo, o regime escolar previsto para a Faculdade de Filosofia a que se subordinar'.

A Escola Cásper Líbero da Faculdade de Filosofia, Ciências e Letras de São Bento da PUC-SP foi reconhecida em 28 de novembro de 1949, ano em que o curso de Jornalismo também passou a funcionar na Faculdade Nacional de Filosofia da Universidade do Brasil. Importante defensor do ensino de Jornalismo, Luiz Beltrão apontou que as duas escolas foram inspiradas nas correntes pedagógicas norte-americanas Pulitzer e Elliot, "mais humanísticas do que técnicoprofissional, e isso não somente pela falta de equipamento nas escolas como pela própria inexperiência dos professores, a maioria dos quais sabia fazer jornalismo, mas não sabia ensinar teoricamente como fazê-lo". (BELTRÃO, 1972, p. 47)

Beltrão teve grande empenho, tanto por sua experiência como jornalista na região Nordeste, quanto por sua visão sobre o preparo dos profissionais da imprensa, na batalha pela criação de um curso de Jornalismo adequado à realidade brasileira. Marques de Melo (2006, p. 8) destaca que quando iniciou sua trajetória no âmbito universitário fundando o curso de Jornalismo da Universidade Católica 
de Pernambuco em 1961, Beltrão estava "respaldado pela bem sucedida militância na prática jornalística”, visto que contabilizava um quarto de século como jornalista profissional, desde que iniciara sua carreira no Diário Pernambucano em 1936. Acabara de publicar também o ensaio "Introdução à Filosofia do Jornalismo" e contava com a atenção de profissionais e intelectuais ligados ao Jornalismo da época.

Faltava-Ihe, contudo, experiência pedagógica. Consciente disso, ele planejou antecipadamente a ação didática que iria desenvolver como regente da Cátedra 'Técnica de Jornal', a espinha dorsal do curso de Jornalismo. Segmentada em três disciplinas anuais, a estrutura da cadeira foi planejada de modo seqüencial, reservando ao primeiro ano a visão teórica do Jornalismo e aos dois restantes o conhecimento aplicado, ou seja, a iniciação na prática profissional. (MARQUES DE MELO, 2006, p. 8)

Outro defensor da formação acadêmica dos profissionais de Jornalismo foi Carlos Rizzini, jornalista que atuou como professor do curso da Universidade do Brasil e investigou a formação de jornalistas em diferentes escolas pelo mundo. Em pesquisas realizadas nos Estados Unidos, teve contato com os cursos de Jornalismo de Missouri - fundada em 1908 - e Columbia - em funcionamento desde 1912 - onde se dedicou a analisar as estruturas curriculares norteamericanas, formulando posteriormente propostas para um modelo brasileiro. Um de seus papéis nesse sentido foi o de difundir a enorme quantidade de cursos de Jornalismo que existiam mundo afora, sendo que em 1951, apenas nos Estados Unidos, havia 40 departamentos de escolas de Jornalismo vinculados a colégios e universidades. Para Rizzini,

Cabe ao ensino universitário instruir, educar, orientar e ilustrar as vocações para que maiores sejam os efeitos e, para que, de modo geral se eleve o nível da imprensa [...] Os jornais, mesmo sem colaborar com o curso, terão de reconhecer a superioridade de um jornalista culto. Certamente, não o recusarão por isso. Mas, sem dúvida, não o preterirão, se ele não souber passar para o papel a 
sua cultura. Repetimos: não adianta saber como se faz o jornal - é preciso saber fazê-lo. (RIZZINI, 1953, p. 56)

O fato é que desde que o ensino de Jornalismo foi definido pelo Decreto $n^{\circ}$ 22.245 de 1946, os cursos instalados no país enfrentaram inúmeras dificuldades, principalmente no que diz respeito aos aspectos burocráticos que subordinavam a oferta do ensino de Jornalismo às faculdades de Filosofia, como se fosse um estudo de importância menor. Havia ainda a falta de condições para aplicação laboratorial dos conhecimentos teórico-práticos ministrados, uma vez que não existiam condições para a confecção de jornais, por exemplo, como instrumento de práticas laboratoriais. A autonomia dos cursos de Jornalismo só foi possível a partir de 1958 com a promulgação do Decreto no 43.839 que possibilitou a implantação de um regimento próprio e a oferta em instituto autônomo integrante de uma universidade ou faculdade.

Porém, a legislação de 1946 formalizou a organização do currículo de Jornalismo em um curso de três anos que compreendia as seções Formação, Aperfeiçoamento e Extensão Cultural. De acordo com Laurenti,

\begin{abstract}
Nota-se no primeiro currículo o predomínio do conhecimento humanístico recortado em disciplinas de cunho teórico-cultural. A formação intelectual do jornalista foi privilegiada nessa composição curricular e a prática ficou relegada a uma disciplina apenas: Técnica de Jornalismo. Todavia, devem ser enfatizados dois aspectos relevantes: o rol das matérias eletivas e o estágio. (2002, p. 39)
\end{abstract}

A mesma autora aponta que o ensino de Jornalismo no Brasil teve três fases distintas. A primeira teve início com a instituição do curso de Jornalismo da Faculdade de Filosofia da Universidade do Brasil. Esta fase durou até a promulgação da Lei de Diretrizes e Bases da Educação Nacional - Lei no 4.024 de 
20 de novembro de 1961. Tal legislação educacional instituiu o currículo mínimo para os cursos superiores.

Não há como negar a evolução no ensino de graduação na área de Comunicação em suas diferentes habilitações. Da exigência do currículo mínimo nos cursos de Comunicação em 1961, quando só havia a habilitação de Jornalismo, as dificuldades eram imensas e surgia a necessidade de formação ampla, generalista, teórica e ao mesmo tempo específica e tecnicista, apontada para o curso de Jornalismo.

A segunda fase começou com o Parecer no 323/62 - com a criação do primeiro currículo mínimo para o curso de Jornalismo - permanecendo até a promulgação da Lei de Diretrizes e Bases da Educação Nacional - Lei no 9.394 de 20 de dezembro de 1996. Esta fase assegurou às escolas a atribuição de fixar currículos com mais autonomia. O mercado que absorvia profissionais de comunicação, porém, exigia cada vez mais um profissional versátil, que as formações específicas, sozinhas, não conseguiam formar adequadamente. Era comum encontrar currículos típicos da concepção dos anos 60, de formação básica, de tronco comum nos dois primeiros anos e a específica nos dois últimos, que também não contemplava, plenamente, as especificidades do Jornalismo.

O profissional de Jornalismo precisava ser, ao mesmo tempo, um generalista, com formação humanística e especializada, e um tecnicista, com amplo domínio das técnicas pertinentes à atuação em diferentes espaços midiáticos. Da aparente contradição nasceu a Resolução no 002/84 do Conselho Federal de Educação, e as escolas de Comunicação do país partiram para reformas curriculares com perspectivas próprias, mas ainda baseadas em um currículo 
mínimo, possibilitando, num primeiro momento, modelos criativos de propostas curriculares, logo adaptadas por outras escolas.

Advém, por conseqüência, a terceira fase, com a deliberação das Diretrizes Curriculares, propostas desde 1995, com a aprovação do Parecer CNE/CES no 492/2001, de 3 de abril de 2001, pelo Conselho Nacional de Educação, especificamente para os cursos de Comunicação Social. A formação do profissional de Jornalismo, conseqüentemente, passou por mudanças fundamentais. Ora favorecendo a formação humanística, ora privilegiando a formação específica e tecnicista e, finalmente, tentando uma formação híbrida que dê conta da demanda do mercado e, ao mesmo tempo, que possibilite uma formação cultural sólida.

Marco dessa trajetória foi a influência do Centro Internacional de Estudos Superiores de Periodismo para a América Latina - CIESPAL - órgão mantido pela UNESCO com sede em Quito, no Equador. A principal contribuição da entidade foi oferecer seminários para o desenvolvimento de estudos de Comunicação Social, tanto em relação ao ensino da área quanto ao crescimento dos meios de comunicação de massa.

Os seminários do CIESPAL aconteceram nas cidades de Medellín (Colômbia), Cidade do México (México), Buenos Aires (Argentina) e Rio de Janeiro (Brasil) no ano de 1965 e tiveram a participação de jornalistas e professores brasileiros, entre eles Carlos Rizzini e Luiz Beltrão. O resultado dos seminários também patrocinado pela $\mathrm{ABI}$ no Brasil - foi transformado em um importante documento publicado pelo órgão que se mostrou fundamental para a renovação de escolas de Jornalismo na América Latina. De acordo com Lopes,

Depois de quatro seminários, o CIESPAL, baseado em suas conclusões, propôs que a formação de jornalistas habilitados para a interpretação correta dos fatos se fizesse em três sentidos: a) fenomenológico - pelo conhecimento da natureza dos efeitos 
psicossociais determinados por sua tarefa; b) instrumental - pelo manejo adequado da linguagem e das práticas que aperfeiçoam sua expressão; c) cultural - por uma formação básica, atualizada, fundada nas humanidades. (1989, p. 29)

O professor Celso Kelly, à época dirigente da Associação Brasileira de Imprensa, foi quem presidiu o seminário no Rio de Janeiro e levou as sugestões apontadas ao Conselho Federal de Educação, o que resultou no currículo mínimo de 1969. No mesmo ano, com a regulamentação da profissão, houve a exigência da implantação dos órgãos laboratoriais nos cursos de Jornalismo. A formação do jornalista passou por transformações desde então, inicialmente num aspecto clássico-humanístico, no qual a integração dos cursos de Jornalismo às faculdades de Filosofia oferecia pouca ênfase ao treinamento técnico e caracterizava-se pela chamada "ditadura da teoria"; e, a partir da Resolução no 002/84, a ênfase passou a ser o aspecto científico-técnico, em que os cursos procuravam reproduzir aspectos do mercado, valorizando o ensino da Comunicação Social e não só do Jornalismo. Foi então que a ditadura da teoria foi substituída pela "ditadura da prática", com cursos excessivamente tecnicizantes.

Por diferentes ocasiões, o currículo mínimo dos cursos de Jornalismo foi alterado até que fossem definidos os parâmetros da Resolução № 002/84. Quase uma década depois, em 20 de dezembro de 1996, a nova Lei de Diretrizes e Bases (LDB), passa a garantir autonomia às instituições de ensino superior e extingue a obrigatoriedade do currículo mínimo. O curso de Comunicação Social passa a ser discutido a partir das Novas Diretrizes Curriculares e cada instituição passa a ter autonomia para realizar suas práticas laboratoriais.

No ano de 2003, existiam no Brasil 312 cursos de Comunicação Social com ênfase em Jornalismo, o que representava um aumento de $70 \%$ no número de 
cursos em relação ao ano de 2000. Os dados são de uma pesquisa divulgada em agosto de 2005 pelo Instituto Nacional de Estudos e Pesquisas Educacionais (INEP), que registrou ainda a existência de 423 cursos de Comunicação Social no país, com suas diversas habilitações. A proliferação desses cursos fez com que a Federação Nacional dos Jornalistas (Fenaj), pleiteasse, em outubro de 2004, um recesso na aprovação de novos cursos de Jornalismo pelo Ministério da Educação e Cultura (MEC).

Eduardo Meditsch salienta que
A atividade jornalística, desde a escola, tem se caracterizado por uma violenta dicotomia entre o saber sobre e o saber fazer. A pesquisa teórica e a produção crítica passam ao largo dos problemas da prática, como se esta fosse uma dimensão estranha ao pensamento, e respondem a perguntas formuladas em contextos alheios. O saber fazer, no mais das vezes, despreza esta teoria e se reproduz com base na experiência acumulada e nas influências culturais, políticas, econômicas e tecnológicas que atuam sobre ela. Este descompasso, no entanto, se é típico das áreas de jornalismo e da comunicação social, não é uma exclusividade delas. E foi por diagnosticá-lo e pretender enfrentá-lo na sua área de atuação, a pedagogia, que Paulo Freire desenvolveu o seu método de ensino- aprendizagem e toda a sua concepção filosófica da educação. (2003, p. 241)

Em 2009, o sítio do INEP informa a existência de 368 cursos de Comunicação Social com habilitação em Jornalismo em funcionamento em todo o país, sendo 103 deles somente no Estado de São Paulo. Incluindo outras habilitações, são 623 cursos espalhados pelo Brasil. São inegáveis as alterações estruturais dos cursos de Comunicação, quer no âmbito curricular, quer na infra-estrutura laboratorial. Verifica-se, cada vez mais, um equilíbrio entre as disciplinas teóricas e práticas, com um corpo docente, oriundo da academia e do mercado, trabalhando muitas vezes em conjunto. O tradicional distanciamento entre a teoria e prática está sendo vencida pela iniciativa de professores, coordenadores e instituições que procuram 
batalhar para a superação de problemas de infra-estrutura laboratorial e de deficiências na estruturação curricular adequada ao papel da universidade.

É importante lembrar que o exercício competente da profissão se dá no exercício cotidiano da cidadania. A questão, porém, é saber se o papel da universidade é formar apenas para o mercado ou possibilitar, além da formação específica, uma dimensão crítica da própria sociedade, visando a sua transformação. Obviamente, a conciliação dessas duas vertentes é o grande desafio dos professores, que não podem se furtar a seu papel formador.

Para Peruzzo, o perfil comum do egresso corresponde a um objetivo de formação geral que deve ser atendido por todos os Cursos da área e em todas as habilitações de Comunicação, qualquer que seja sua ênfase ou especificidade. "Trata-se da base que, assumida na estrutura curricular, garante a identidade do Curso como sendo de Comunicação, e que caracteriza em geral componentes do perfil de todas as profissões da área”. (2003, p. 131)

Apesar do surgimento das primeiras escolas de Comunicação no Brasil, no final da década de 1940, com a Escola de Jornalismo Cásper Líbero, em São Paulo, inúmeras foram as tentativas de conciliar a necessária formação cultural e humanística às disciplinas técnicas indispensáveis ao exercício profissional. Num primeiro momento, predominante nos anos 60 , mas que se mantém até hoje, em algumas escolas, a existência do "ciclo básico", com formação em dois anos, era comum a todas as habilitações, havendo, em seguida, a opção pela carreira: jornalismo, publicidade e propaganda ou relações públicas. Em seguida, os cursos separaram-se por habilitações, embora guardassem, em seus currículos, disciplinas comuns, mesmo com enfoques diferenciados.

Para Peruzzo, 
Embora a formação do "aluno-sujeito" não se limite ao ambiente da educação formal, a faculdade e a universidade têm um papel primordial nesse sentido. Sua missão vai além de ensinar habilidades e técnicas profissionais. Educar é contribuir para a formação de um cidadão que compreenda o todo e possa atuar ativamente no espaço da vida social onde vive. É ver o que está dado hoje, no contexto de nossas sociedades marcadas por desigualdades, exclusão, violência, desrespeito à coisa pública, apenas com um indicativo, um ponto de passagem e não um abrigo ou porto seguro de ancoragem. A responsabilidade da instituição universitária e do educador é preparar para o futuro, para uma sociedade mais humana, igualitária e livre. É contribuir para o estudante estar com o mundo e não no mundo. É facilitar para que ele possa participar, interferir e transformar a realidade, mas também usufruir das benesses e riquezas construídas socialmente. Em poucas palavras: tornar-se sujeito. (2003, p. 123)

Com as freqüentes reformas curriculares, verificam-se idas e vindas de disciplinas de formação geral, como Política, História, Economia, Sociologia, Filosofia, Linguagem, entre outras, que são fundamentais para a formação geral do profissional da Comunicação, qualquer que seja a habilitação escolhida, assim como as disciplinas técnicas, específicas. Mesmo nas disciplinas técnicas, observase, também, o cruzamento das habilitações, considerando-se que, na vida profissional, as ferramentas adquiridas ao longo dos diferentes cursos da área são utilizadas em maior ou menor grau pelas diversas habilitações. Para Graça Caldas, tal fenômeno se revela porque

As ofertas de novos cursos na área de Comunicação são uma constante, a cada vestibular. O fascínio que a área exerce nos jovens, pelo glamour das profissionais e atuações estratégicas nas empresas, fez com que empresários do ensino particular ampliassem o leque dos cursos oferecidos, sendo os de Publicidade e Propaganda e Jornalismo os mais procurados, superando, muitas vezes, até mesmo nas escolas públicas, a relação candidatos-vaga de cursos tradicionais da área de exatas. (2003, p. 20)

Na visão de José Marques de Melo (apud CALDAS, 2003), as novas Diretrizes certamente contribuíram para agilizar as necessárias reformas de muitos dos cursos, principalmente daqueles que estavam engessados pelo currículo mínimo. Entretanto, como as avaliações estabelecidas pelo Ministério da Educação 
para a área tinham como parâmetro esse documento de 1999, instituído a partir de uma discussão ampla entre professores de Comunicação, profissionais da área e sindicatos, os limites das mudanças e autonomia dos cursos estavam claramente estabelecidos.

Com a atual estratégia, professores de Comunicação e MEC atuam em conjunto para garantir uma qualidade mínima na abertura de novos cursos. Dessa forma, contribuem para uma redução paulatina da concentração dos cursos nas regiões Sudeste e Sul do país. Com uma distribuição em que é possível pensar na fixação de profissionais competentes nas demais regiões, ampliando, ainda, o fluxo de comunicação e intercâmbio entre as escolas. Nos encontros anuais da Intercom, é visível a melhoria da qualidade de projetos experimentais expostos pelos alunos na Expocom. (CALDAS, 2003, p. 23)

\subsection{Diretrizes Curriculares}

Em 2006, o I Endecom - Fórum Nacional em Defesa da Qualidade do Ensino de Comunicação, promovido pela Intercom com o tema "Ensino de Qualidade para Todos: A Batalha do Novo Século" e realizado na escola de Comunicações e Artes da Universidade de São Paulo, debateu diferentes temas associados à formação dos profissionais de Comunicação em grupos de trabalho ora conjuntos, ora distintos. No grupo que reuniu professores e pesquisadores de Jornalismo, os temas centrais foram a adaptação pelas instituições de ensino superior às Novas Diretrizes Curriculares e a oferta de práticas laboratoriais como um conjunto de atividades que visam a transformar o aluno em um profissional e, particularmente, os meios e as realizações de produção, sobre a qual repousam as estruturas sociais. 
O evento revelou também os números relativos à oferta de novos profissionais de Jornalismo a um mercado cada vez mais diversificado. No ano de 2003 , existiam no Brasil 312 cursos de Comunicação Social com habilitação em Jornalismo, o que representava um aumento de $70 \%$ no número de cursos em relação ao ano de 2000. Os dados, divulgados em agosto de 2005 pelo Instituto Nacional de Estudos e Pesquisas Educacionais (INEP), revelou a existência de 423 cursos de Comunicação Social no país em 2003, com suas diversas habilitações, frente aos 623 cursos oferecidos atualmente e que destinam ao mercado de trabalho 23 mil profissionais de Comunicação por ano. Desse total, pouco menos de 1/3 se forma em Jornalismo, sendo que apenas $8 \%$ dos bacharéis alcançarão o mercado de trabalho, segundo informação do Sindicato dos Jornalistas Profissionais no Estado de São Paulo. A proliferação desses cursos fez com que a Federação Nacional dos Jornalistas (Fenaj), pleiteasse, em outubro de 2004, um recesso na aprovação de novos cursos com habilitação em Jornalismo pelo Ministério da Educação e Cultura (MEC).

As Diretrizes Curriculares que dispõem sobre a habilitação em Jornalismo, aprovadas pelo Ministério da Educação em 2001, definem que aluno do curso de Comunicação Social deverá desenvolver a capacidade de reflexão para analisar os padrões e práticas jornalísticas, exercitando sua capacidade criativa no sentido de experimentar novas linguagens e produtos de comunicação. Cabe à escola também discutir questões socioculturais e políticas e oferecer ensinamentos sobre novas tecnologias aplicadas à linguagem jornalística. Os cursos deverão criar condições para que o aluno exercite sua capacidade criativa, no sentido de experimentar novas linguagens e produtos de comunicação. Finalmente, é necessário que o egresso tenha a capacidade de compreender os mecanismos envolvidos no 
processo de recepção de mensagens e seu impacto sobre os diversos setores sociais.

De acordo com as Diretrizes, o jornalista deve ter ampla formação humanística voltada para a reflexão crítica dos acontecimentos sociais; deve ser capaz de conhecer as técnicas de captação, codificação e divulgação das informações de interesse público, interpretando, com critério jornalístico, os fatos cotidianos. Como profissional de comunicação, deve ser capaz de entrevistar, escrever editoriais, artigos, crônicas, reportagens e comentários sobre assuntos diversos na mídia impressa e eletrônica, contribuindo para a reflexão e transformação social, e considerando, para isso, a necessidade de atualização permanente frente às novas tecnologias de comunicação; ser criativo e ter iniciativa para experimentar novas linguagens e produtos de comunicação; apresentar formação ética social e profissional, compromisso com a cidadania e humildade diante da realidade. (Disponível em: <http://www.mec.gov.br/diretrizes>)

Assim, a habilitação em Jornalismo busca formar um profissional com cultura ampla, curiosidade intelectual, criatividade, domínio do idioma e das estruturas narrativas e expositivas voltadas às mensagens jornalísticas. Entretanto, o Jornalismo hoje se vê frente a novos desafios e mudanças que são comuns em determinados momentos da evolução do conhecimento. O graduando precisa se atualizar e continuar se adequando ao novo patamar. Porém, a mesma estrutura jornalística está presente nessa nova etapa. A diferença está presa ao veículo e na forma de passar a informação. O que é notícia no meio impresso também é notícia no meio eletrônico. A apuração e a responsabilidade precisam estar adequadas a cada matéria que é divulgada a cada minuto ou segundo. 
Dessa forma, o debate sobre o ensino de Jornalismo se mantém impondo como questões temas discutidos há décadas. Na obra "Ideologia e Poder no Ensino de Comunicação", o capítulo "A formação do jornalista", elaborado pelo professor Gaudêncio Torquato, já chamava a atenção para as deficiências curriculares. Ele dividiu o curso em três fases: o ciclo bacharelesco, o ciclo tecnicista-pragmático e ciclo misto. Torquato defendia, à época, que era necessário repensar a função do professor para sensibilizar o futuro jornalista sobre seu papel na sociedade. Para ele, o comunicador social é mais do que "um simples decodificador de mensagens" (MARQUES DE MELO et al, 1979, p. 164).

Frente a esse contexto, é preciso ressaltar a pertinência de uma experiência jornalística na graduação que remeta, simultaneamente, tanto à possibilidade de proporcionar aos alunos a vivência da produção jornalística, o domínio de técnicas e a apreensão de valores importantes para a sua formação ética e profissional, quanto ao tratamento dado à informação como produto dessa conquista.

De acordo com José Salvador Faro (2003), o processo de discussão e de elaboração das Diretrizes Curriculares para os cursos de Comunicação Social teve início com a aprovação, pelo Congresso Nacional, da Lei de Diretrizes e Bases, em 1996, que acabou com todos os currículos mínimos que vigoravam de acordo com as resoluções do antigo Conselho Federal de Educação, estabelecendo em seu lugar a idéia de que o ensino superior de graduação, em qualquer área do conhecimento, deveria nortear-se, na sua estrutura, por um conjunto de normas gerais que assegurassem, às instituições, liberdade na formulação de seus projetos pedagógicos. No caso dos cursos de Comunicação Social, essa nova ordem significou o fim da Resolução no 002/84, embora, no momento da vigência da nova 
LDB, nada existisse como alternativa para a orientação dos cursos e suas diversas habilitações.

Tal modificação ocorreu da existência de um vazio legal que não mais obrigava os cursos a pautarem sua estrutura curricular pelas normas antigas nem os obrigava a seguir qualquer outra norma. Esse período, que se estende de 1997 a 2001, constituiu-se num primeiro teste para o exercício da autonomia curricular tantas vezes reivindicada por todos os que se preocupavam com a formação acadêmico/profissional na área da Comunicação Social baseada na "camisa de força" em que a Resolução nº 002/84 havia se transformado (FARO, 2003, p.140).

Os debates contemplaram variadas temáticas e receberam diferentes propostas, manifestando-se não apenas as instituições de ensino superior, mas também as entidades acadêmicas e/ou profissionais envolvidas com as várias habilitações, as associações representantes da própria área da Comunicação e entidades de natureza corporativa e sindical, além da Executiva Nacional dos Estudantes de Comunicação (Enecos). O Ministério da Educação proporcionou o espaço para a discussão sobre o assunto "num momento em que a área da Comunicação Social apresentava-se desequilibrada frente ao desafio de reunir, numa única proposta, a heterogeneidade com a qual as diversas habilitações compreendiam a sua inserção nos cursos de graduação", ressalta Faro. A intenção era verificar a possibilidade das habilitações conseguirem adquirir o perfil de cursos autônomos, já que a perspectiva de uma ótica que privilegiava a formação técnicoprofissional, no lugar de uma formação mais propriamente universitária não parecia consenso.

A história do documento que reuniu as diversas contribuições para que se finalizasse a proposta de Diretrizes Curriculares a ser enviada ao CNE tem dois momentos bastante distintos. O primeiro é o de sua formulação preliminar, isto é, a formulação que resultou 
não apenas das sugestões que chegaram às mãos da CEE-COM, mas também aquelas que foram produzidas durante as discussões ocorridas em Brasília no início de 1999. Esse primeiro momento foi marcado pelo aprofundamento das divergências em torno do maior ou menor grau de abertura que a proposta oferecia às demandas específicas do Jornalismo. Na verdade, esse foi o instante de maior radicalismo no debate, até mesmo porque a própria SESU havia encampado a proposta de uma comissão específica de ensino para Jornalismo, tendo encaminhado o pedido de sua criação ao CNE, ainda que, em paralelo, um grupo bastante representativo de professores e profissionais, engajado na discussão, FENAJ e Sindicato dos Jornalistas de São Paulo, inclusive, tenha organizado em Campinas, em abril de 1999, o seminário que daria origem a uma proposta integradora das Diretrizes Curriculares, naturalmente bem mais extensiva à habilitação específica do que o documento da CEE-COM previa. (FARO, 2003, p. 142)

De qualquer forma, três premissas serviram para nortear as Novas Diretrizes: orientam para que as formações. A versão final das Diretrizes Curriculares encaminhada ao CNE em julho de 1999 acabou se transformando no produto de um consenso bastante delicado, uma vez que várias das reivindicações provenientes das demandas do Jornalismo foram incorporadas ao texto. De acordo com o Parecer CNE/CES 492/2001, as Diretrizes Curriculares da Área da Comunicação, cujo texto estabelece um padrão básico de referência para todas as instituições que mantenham Cursos de Graduação em Comunicação Social com habilitações em Jornalismo, Relações Públicas, Publicidade e Propaganda, Cinema, Radialismo, Editoração, ou outras habilitações pertinentes ao campo da Comunicação Social que venham a ser criadas, foram elaboradas procurando atender a dois objetivos fundamentais:

a) flexibilizar a estruturação dos cursos, tanto para atender a variedades de circunstâncias geográficas, político-sociais e acadêmicas, como para ajustar-se ao dinamismo da área, e para viabilizar o surgimento de propostas pedagógicas inovadoras e eficientes;

b) estabelecer orientações para a obtenção de padrão de qualidade na formação oferecida. (Parecer CNE/CES 492/2001, vide anexos) 
No documento, o perfil comum do egresso corresponde a um objetivo de formação geral que deve ser atendido por todos os Cursos da área e em todas as habilitações de Comunicação Social, qualquer que seja sua ênfase ou especificidade. Trata-se de base que garanta a identidade do Curso como de Comunicação. Assim, o egresso de Curso de Graduação em Comunicação Social, em qualquer de suas habilitações, caracteriza-se por:

1. sua capacidade de criação, produção, distribuição, recepção, e análise crítica referentes às mídias, às práticas profissionais e sociais relacionadas com estas, e as suas inserções culturais, políticas e econômicas;

2. sua habilidade em refletir a variedade e mutabilidade de demandas sociais e profissionais na área, adequando-se à complexidade e velocidade do mundo contemporâneo;

3. sua visão integradora e horizontalizada - genérica e ao mesmo tempo especializada de seu campo de trabalho possibilitando o entendimento da dinâmica das diversas modalidades comunicacionais e das suas relações com os processos sociais que as originam e que destas decorrem.

4. utilizar criticamente o instrumental teórico-prático oferecido em seu curso, sendo portanto competente para posicionar-se de um ponto de vista ético-político sobre o exercício do poder na comunicação, sobre os constrangimentos a que a comunicação pode ser submetida, sobre as repercussões sociais que enseja e ainda sobre as necessidades da sociedade contemporânea em relação à comunicação social. (Parecer CNE/CES 492/2001, vide anexos)

As Diretrizes Curriculares estabelecem também os perfis específicos que resultam das habilitações, caracterizados por uma abrangência sobre diferentes meios, linguagens e práticas profissionais e de pesquisa e, na atualidade, por envolver um acelerado dinamismo social e tecnológico. Para assegurar o desenvolvimento histórico desta área de formação, estudos e exercício profissional, as habilitações, definidoras dos perfis específicos, se organizam conforme as seguintes premissas: 
a) é mantida a referência básica às habilitações historicamente estabelecidas: jornalismo, relações públicas, publicidade e propaganda, radialismo, editoração, e cinema (assim como à sua denominação alternativa, cinema e vídeo);

b) podem ser criadas ênfases específicas em cada uma destas habilitações, que serão então referidas pela denominação básica, acrescida de denominação complementar que caracterize a ênfase adotada;

c) podem ser criadas novas habilitações pertinentes ao campo da Comunicação. (Parecer CNE/CES 492/2001, vide anexos)

De acordo com o Parecer CNE/CES 492/2001, as Diretrizes Curriculares da Área da Comunicação, o perfil do egresso em Jornalismo se caracteriza:

1. pela produção de informações relacionadas a fatos, circunstâncias e contextos do momento presente;

2. pelo exercício da objetividade na apuração, interpretação, registro e divulgação dos fatos sociais;

3. pelo exercício da tradução e disseminação de informações de modo a qualificar o senso comum;

4. pelo exercício de relações com outras áreas sociais, culturais e econômicas com as quais o jornalismo faz interface. (idem, op. cit.)

No que diz respeito às competências e habilidades dos graduados em Jornalismo, as Diretrizes Curriculares comportam dois níveis, um geral para todas as profissões e formações do campo da Comunicação e um especializado por habilitação. As competências e habilidades gerais para os diferentes perfis são as seguintes: assimilar criticamente conceitos que permitam a apreensão de teorias; usar tais conceitos e teorias em análises críticas da realidade; posicionar-se de modo ético-político; dominar as linguagens habitualmente usadas nos processos de comunicação, nas dimensões de criação, de produção, de interpretação e da técnica; experimentar e inovar no uso destas linguagens; refletir criticamente sobre as práticas profissionais no campo da Comunicação; ter competência no uso da língua nacional para escrita e interpretação de textos gerais e especializados na área. (cf. Parecer CNE/CES 492/2001, vide anexos) 
Já as competências e habilidades específicas dos graduados em Jornalismo, são definidas pelas Diretrizes como o que se objetiva promover com a formação oferecida, ou seja, um profissional capaz de:

- registrar fatos jornalísticos, apurando, interpretando, editando e transformando-os em notícias e reportagens;

- interpretar, explicar e contextualizar informações;

- investigar informações, produzir textos e mensagens jornalísticas com clareza e correção e editá-los em espaço e período de tempo limitados;

- formular pautas e planejar coberturas jornalísticas;

- formular questões e conduzir entrevistas;

- relacionar-se com fontes de informação de qualquer natureza;

- trabalhar em equipe com profissionais da área;

- compreender e saber sistematizar e organizar os processos de produção jornalística;

- desenvolver, planejar, propor, executar e avaliar projetos na área de comunicação jornalística;

- avaliar criticamente produtos, práticas e empreendimentos jornalísticos;

- compreender os processos envolvidos na recepção de mensagens jornalísticas e seus impactos sobre os diversos setores da sociedade;

- buscar a verdade jornalística, com postura ética e compromisso com a cidadania;

- dominar a língua nacional e as estruturas narrativas e expositivas aplicáveis às mensagens jornalísticas, abrangendo-se leitura, compreensão, interpretação e redação;

- dominar a linguagem jornalística apropriada aos diferentes meios e modalidades tecnológicas de comunicação. (Parecer CNE/CES 492/2001, vide anexos)

As Diretrizes também diferenciam os conteúdos curriculares em Conteúdos Básicos e Conteúdos Específicos. Os conteúdos básicos são aqueles relacionados tanto à parte comum do curso quanto às diferentes habilitações. Os conteúdos específicos são aqueles que cada instituição, livremente, deve eleger para organizar seu currículo pleno, tendo como referência os objetivos e os perfis comum e específicos anteriormente definidos. 
O Parecer CNE/CES 492/2001 define caracteriza os conteúdos básicos como os destinados à formação geral da área, o que envolve tanto conhecimentos teóricos como práticos, reflexões e aplicações relacionadas ao campo da Comunicação e à área configurada pela habilitação específica. Estes conhecimentos são assim categorizados: conteúdos teórico-conceituais; conteúdos analíticos e informativos sobre a atualidade; conteúdos de linguagens, técnicas e tecnologias midiáticas, conteúdos éticos-políticos. Já os conteúdos específicos têm como objetivo favorecer reflexões e práticas da habilitação específica, "correspondendo a recortes dentro do campo geral da Comunicação", de forma a organizar conhecimentos e práticas profissionais, abordar questões teóricas, elaborar críticas, discutir a atualidade e desenvolver práticas sobre linguagens e estruturas.

As Diretrizes Curriculares estabelecem item específico sobre estágios e atividades complementares, destacando que os primeiros referem-se a estudos e práticas supervisionados em atividades externas à unidade de oferecimento do Curso e que as atividades complementares devem ser realizadas sob a supervisão de um docente e buscam promover o relacionamento do estudante com a realidade social, econômica e cultural, e de iniciação à pesquisa e ao ensino. Na íntegra do documento, está explícito que tais tipos de ação pedagógica caracterizam mecanismos de interação com o mundo do trabalho, assim como o confronto com possibilidades metodológicas visando à promoção de uma formação complexa. O texto especifica que além das disciplinas típicas e tradicionais da sala de aula e de práticas ditas laboratoriais, segundo o padrão de turma/docente/horas-aula semanais, podem ser previstas Atividades Complementares, com atribuição de 
créditos ou computação de horas para efeito de integralização do total previsto para o Curso, tais como:

- programas especiais de capacitação do estudante (tipo CAPES/PET);

- atividades de monitoria;

- outras atividades laboratoriais além das já previstas no padrão turma/horas-aula;

- $\quad$ atividades de extensão;

- atividades de pesquisa etc. (Parecer CNE/CES 492/2001, vide anexos)

As Diretrizes também descrevem o que caracteriza este conjunto de atividades, ou seja, a flexibilidade de carga horária semanal, com controle do tempo total de dedicação do estudante durante o semestre ou ano letivo. Esta flexibilidade horária semanal deverá permitir: a adoção de um sistema de atribuição de créditos de horas baseada em decisões específicas para cada caso, projeto ou atividade específica, e em função do trabalho desenvolvido; a ênfase em procedimentos de orientação e/ou supervisão pelo docente; a ampliação da autonomia do estudante para organizar seus horários, objetivos e direcionamento. Destaca-se, neste ponto, que:

O número máximo de horas dedicadas a este tipo de atividade não pode ultrapassar $20 \%$ do total do curso, não incluídas nesta porcentagem de $20 \%$ as horas dedicadas ao Trabalho de Conclusão de Curso (ou Projetos Experimentais). (Parecer CNE/CES 492/2001, vide anexos)

Por fim, as Diretrizes Curriculares determinam a estrutura do curso de Comunicação Social, que pode ser oferecido por créditos, com atenção para uma seqüência equilibrada de conteúdos curriculares e acompanhamento planejado da formação. O documento sinaliza que se mostra necessária uma avaliação periódica, que deve ser realizada em articulação com o Projeto Acadêmico do curso sob três ângulos: pertinência da estrutura do Curso, de suas propostas e da 
adequação dos meios postos em ação para realizá-las; aplicação dos critérios para a sua avaliação; e mecanismos de acompanhamento e avaliação externa e interna do próprio curso.

\subsection{Projetos Pedagógicos}

A Resolução CNE/CES 16/2002, de 13 de março de 2002, na qual o Conselho Nacional de Educação estabelece que as Diretrizes Curriculares para a área de Comunicação Social e suas habilitações, com base no disposto no Parecer CNE/CES 492/2001 e no Parecer CNE/CES 1.363/2001, deverão orientar a formulação do projeto pedagógico do referido curso, especifica no Art. $2^{\circ}$ que 0 Projeto Pedagógico de formação profissional na área de Comunicação Social e suas habilitações deve explicitar:

a) o perfil comum e os perfis específicos por habilitação;

b) as competências e habilidades gerais e específicas por habilitação a serem desenvolvidas, durante o período de formação;

c) os conteúdos básicos relacionados à parte comum e às diferentes habilitações e os conteúdos específicos escolhidos pela instituição para organizar seu currículo pleno;

d) as características dos estágios;

e) as atividades complementares e respectiva carga horária;

f) a estrutura do curso;

g) as formas de acompanhamento e avaliação da formação ministrada. (Disponível em: <http://www.mec.gov.br/diretrizes>)

Para Almeida (2007, p. 49), o Projeto Pedagógico é a "expressão do perfil de um curso, pois trata da utopia da formação e transformação do aluno em um profissional que possa atuar no mercado de trabalho com competência ética, 
humanística e técnica", sendo por meio do Projeto Pedagógico que se define o profissional que se quer formar.

Com a implantação das novas Diretrizes Curriculares para os cursos de Comunicação Social, surgiu uma oportunidade para a reforma curricular dos cursos, com vistas à constante atualização consonante com as transformações sociais e mercadológicas e à autonomia dos gestores do ensino em Comunicação. Muitas mudanças foram fomentadas pela necessidade de sanar problemas como a sobreposição/lacuna de conteúdos, ausência de seqüência lógica na distribuição espacial e temporal das disciplinas, frágil articulação da teoria com a prática e pouca possibilidade de integração com a comunidade e com o mercado. Para atender às Diretrizes Curriculares da área de Comunicação Social e suas habilitações (Pareceres CNE/CES 492/2001 e 1363/2001, homologados respectivamente em 09/07/01 e 25/01/02), que permitem a flexibilidade do currículo, possibilitando aos alunos não só o cumprimento de atividades curriculares obrigatórias, mas também o desenvolvimento e a escolha de atividades que os tornassem co-responsáveis pela construção de seu currículo e de sua formação universitária, é importante que os autores do Projeto Pedagógico destaquem como o curso estaria inserido nesse contexto, como ressalta Almeida:

É importante identificar o curso com a sociedade, enquanto espaço de cidadania, e com o mercado de trabalho como lugar onde o futuro profissional irá exercer com competência a sua profissão, tendo como referência a ética. Seria importante também tratar da dicotomia entre teoria/prática no sentido da possível superação das novas tecnologias, destacando sua importância na formação do egresso, do corpo docente, sua capacitação e perfil para atender os objetivos de formação do futuro profissional e das políticas institucionais que prevêem a capacitação continuada. (ALMEIDA, 2007, p. 51) 
O processo de discussão e proposição do Projeto Pedagógico de Comunicação Social em alguns casos mobiliza a comunidade acadêmica gestores, docentes e discentes - com a apresentação de propostas e/ou sugestões, resultando em características que devem ser contempladas como flexibilidade, atualização, adequação, seqüência lógica e articulação teoria/prática. O Projeto Pedagógico deve conceber o Currículo Pleno como um conjunto de atividades pedagógicas relevantes, e não como mera listagem de disciplinas, definindo suas disciplinas, atividades, conteúdos específicos e procedimentos em função dos perfis, das competências e habilidades pretendidas. Entende-se que o currículo deve ser dinâmico, buscando sempre se adequar aos avanços tecnológicos e científicos a fim de acompanhar as tendências do mercado regional/nacional, com vistas à formação profissional/cidadã.

A área de Comunicação Social é extremamente dinâmica. A habilitação Jornalismo - por força de um mercado profissional altamente competitivo e das constantes inovações tecnológicas relacionadas aos meios de comunicação, que causam impacto tanto nas formas de produção e transmissão como também nos conteúdos - necessita estar em constante evolução. Na última década, o perfil do profissional especialista deu lugar ao do generalista. O profissional deve dominar todo o processo comunicativo e ter amplo e atualizado conhecimento de mundo. Pode-se ver agora a convergência das mídias, a discussão em torno da mídia massiva versus a mídia dirigida, a TV fechada, a Internet, a TV digital, a comunicação total ou integrada, a construção de marcas, a discussão sobre novos papéis da comunicação e das empresas de comunicação, a informação globalizada, o fenômeno da mobilidade e da produção de conteúdos de forma 
colaborativa e, ao mesmo tempo, o crescimento acentuado dos mercados regionais.

Conforme as Diretrizes Curriculares para a área de Comunicação Social, a mudança do currículo da habilitação em Jornalismo nas IES se justifica em função de uma maior flexibilização da estrutura dos próprios cursos. Como em outras áreas de atuação, o Jornalismo se defronta a cada dia com um novo fazer, tanto frente às novas tecnologias, que surgem como suporte para as produções jornalísticas, quanto em relação às reflexões críticas a que a atividade profissional se propõe. Para Almeida,

As Diretrizes Curriculares propõem um perfil comum do egresso correspondente a um objetivo de formação geral que deve ser atendido por todos os cursos da área e em todas as habilitações de Comunicação, qualquer que seja sua ênfase ou especificidade. [...] Os perfis específicos resultam das habilitações diferenciadas, que se caracteriza por uma abrangência sobre diferentes meios, linguagens e práticas profissionais e de pesquisa e, na atualidade, por envolver um acelerado dinamismo social e tecnológico. (ALMEIDA, 2007, p. 51)

A especialização em certas áreas do conhecimento e da prática jornalística se fortalece em alguns setores da sociedade, enquanto outros exigem um profissional com visão e atuação holísticas. Nesse contexto, o Projeto Pedagógico deve atender às variedades geográficas, político-sociais e acadêmicas, bem como para ajustar-se ao dinamismo da área. Hoje, a nova orientação quanto à teoria e à prática oferecidas no novo currículo, baseado nas Diretrizes Curriculares recentemente aprovadas, possibilita a oferta de um curso com maior abrangência de conteúdos, maior participação dos discentes em atividades de pesquisa, extensão e prática profissional. A conseqüência destas reformulações é a possibilidade de oferecer mais qualidade e dinamismo na formação dos profissionais de Jornalismo. 
Essa flexibilidade permite que o discente organize sua formação a partir de sua própria realidade social, econômica e cultural. O desenvolvimento do Projeto Pedagógico deve estar voltado para a formação profissional do comunicador na habilitação de Jornalismo, alinhando-a às exigências do mercado atual e à consciência do papel cidadão do comunicador como agente social por meio de ações pedagógicas abrangentes.

Neste sentido, o ideal é que toda e qualquer iniciativa acadêmica possa alinhar-se às ações presentes no Projeto Pedagógico, cuja operacionalização deve basicamente: implementar a interdisciplinaridade (das disciplinas e dos cursos); minimizar o artificialismo das disciplinas práticas; proporcionar a reflexão e a leitura crítica da realidade, dinamizar os Órgãos Laboratoriais, as Atividades Complementares e os Projetos Experimentais; favorecer e facilitar a prática e o aprimoramento profissional; contribuir com a comunidade com o mercado; desenvolver a cidadania e a ética profissional; atualizar e modernizar a formação oferecida.

As ações pedagógicas podem se viabilizar por meio de pressupostos, como: a atuação e o junto à comunidade local e regional onde está inserida a IES; a aproximação e o atendimento às demandas do mercado com vistas também ao empreendedorismo; a prática laboratorial de experimentação acadêmica e profissional em diferentes veículos de Comunicação. Há de se considerar ainda o aprimoramento e o fortalecimento da dinâmica ensino-pesquisa-extensão proporcionada pelo ambiente acadêmico, com a qual as IES permitem oferecer aos estudantes a possibilidade tanto de reflexão teórica específica de cada área quanto o desenvolvimento do espírito profissional, seja no aspecto ético, político ou social. Além disso, o compromisso social visa inserir o aluno na comunidade, tornando-o 
presença ativa como sujeito-agente dos acontecimentos. Por outro lado, a aproximação e o atendimento às demandas profissionais têm como pretensão estreitar as relações entre o ambiente acadêmico e o mercado, propiciando ao aluno a possibilidade de aplicação das teorias adquiridas ao longo do curso, o conhecimento do mercado e o incentivo ao empreendedorismo. Tal entendimento aponta a preocupação das IES em fazer do aprendizado acadêmico um fator de contribuição para o desenvolvimento social e o repensar das práticas mercadológicas.

Para Almeida Jr. (1999, p. 3), o processo de acelerada mudança sócioeconômico-cultural que caracteriza a atualidade, pressupõe pensar que a elaboração de um Projeto Pedagógico para um curso da área de Comunicação Social é situar, com a maior precisão possível, a questão da qualidade da formação profissional no atual contexto de globalização, neoliberalismo, modernidade e pósmodernidade.

A identidade da instituição como Universidade será construída no tempo e coletivamente com seus pares, na medida em que realiza seu projeto de educação calcado em valores como:

- o reconhecimento da realidade regional e dos seus condicionantes histórico-político-sociais;

-a formação de profissionais competentes e críticos capazes de atuar sobre essa realidade;

- o compromisso com os interesses básicos da população, em especial, a mais necessitada;

-a reflexão crítica sobre a verdade e a produção de conhecimento útil;

-as condições de trabalho docente e funcional, em vista da qualidade do ensino ministrado;

- a vinculação entre as atividades básicas de ensino com a pesquisa e com a extensão de serviços à população. (ALMEIDA JR., 1999, p. 8)

São de fundamental importância num curso de Comunicação Social o trabalho e a experimentação do acadêmico em diversos suportes midiáticos (impressos e eletrônicos). Portanto, as atividades laboratoriais inerentes à prática 
das disciplinas e às atividades complementares colocam o aluno em consonância com as novas tecnologias da área de Comunicação, oferecendo dinamismo, atualização e experimentação permanentes ao curso. Especificamente, um Projeto Pedagógico pode propor ações pedagógicas que objetivam: aprimorar e aprofundar as teorias e práticas desenvolvidas no curso; propiciar a vivência e o desenvolvimento de atividades e/ou produtos de interesse para a comunidade; promover, dinamizar e fortalecer a interação da IES com a comunidade; estimular o desenvolvimento da cidadania e da responsabilidade social; propiciar a aplicação de conhecimentos vistos ao longo do curso no desenvolvimento de trabalhos/pesquisas/produtos na área de Comunicação; dinamizar as ações didático-pedagógicas, produzindo trabalhos que atendam às expectativas do mercado; promover parcerias e estreitar as relações com o mercado; estimular o desenvolvimento e aprimoramento técnico-profissional do aluno; promover e dinamizar a produção do conhecimento. De acordo com Almeida Jr.,

O que se pretende com o Projeto Pedagógico é evidenciar e articular forças de todos os segmentos da comunidade de ensino e da sociedade em geral para, a partir daí, institucionalizar os meios que possibilitem o avanço de todos em busca dos valores acadêmicos do curso, em direção à identidade cidadã da instituição universitária. Assim, um Projeto Pedagógico se faz através do tempo, possibilitando a transformação de anseios em planos, de planos em ações concretas e destas ações, por meio da reflexão crítica constante, em novos planos que resultarão outras ações, indefinidamente, respeitando o ritmo das pessoas envolvidas e suas aspirações em termos de realidade social. (ALMEIDA JR., 1999, p. 8)

O processo é complexo e pressupõe a observação, a coleta de dados e a sistematização das informações obtidas de forma a atender os requisitos mínimos previstos nas Diretrizes Curriculares. Em 1999, a Comissão de Especialistas de Ensino em Comunicação Social (CEE - Com), encarregada de elaborar as Diretrizes Curriculares para a Área da Comunicação e suas habilitações 
(Jornalismo, Relações Públicas, Editoração, Radialismo, Cinema, Publicidade e Propaganda), buscou ouvir extensamente a área, incluindo as IES, as entidades de classe representantes de escolas, professores, pesquisadores, estudantes e profissionais. Com base no material enviado, foi realizado um seminário em Brasília entre a CEE - Com e representantes de entidades (Associação Nacional dos Programas de Pós-Graduação em Comunicação - Compós; Conselho Federal de Relações Públicas - Conferp; Executiva Nacional dos Estudantes de Comunicação Enecos; Federação Nacional dos Jornalistas - Fenaj; Sociedade Brasileira de Estudos Interdisciplinares da Comunicação - Intercom; Associação Paulista dos Bacharéis em Relações Públicas - Apbrp; e União Cristã Brasileira de Comunicação Social - Ucbc).

Deste seminário resultou um texto provisório, que foi largamente disseminado, via Internet, para efeito de apresentação de críticas, comentários e novas proposições. Nesta fase, além de manifestações das mesmas entidades, o processo foi novamente aberto para escolas e professores, pesquisadores, profissionais e estudantes que individualmente quisessem trazer suas contribuições. (CCE-COM, 1999, on line)

Reunidas e sistematizadas as informações e a experiência acumulada ao longo dos anos sobre a formação dos profissionais do campo da Comunicação, algumas premissas básicas foram percebidas como predominantes, norteando a redação final das Diretrizes Curriculares. São elas:

a) a área da Comunicação, embora estruturada a partir de diversas especialidades e profissões, apresenta uma forte organicidade, com interpenetração de perspectivas teóricas e de questões referentes a problemas concretos no espaço social. Decorre daí uma premissa que considera um risco para a formação pedagógica e para os diferentes exercícios profissionais qualquer desmembramento dos diferentes cursos da área; e enfatiza a importância de manutenção de todas as formações da área em um mesmo texto de Diretrizes Curriculares;

b) o que deve direcionar o funcionamento dos cursos, no espaço das presentes diretrizes, é um Projeto Acadêmico - que deixa de ser nucleado em listagens de disciplinas, devendo expressar 
as concepções gerais que o norteiam, articulando a estas os conteúdos curriculares e os procedimentos pedagógicos;

c) este Projeto Acadêmico deve conceber o currículo pleno do Curso como um conjunto de atividades pedagógicas relevantes, e não como mera listagem de disciplinas;

d) o Projeto Acadêmico definirá suas disciplinas, atividades, conteúdos específicos e procedimentos em função tanto dos perfis, das competências e habilidades, e dos conteúdos básicos expressos nas Diretrizes, como de suas próprias propostas e objetivos de formação, de suas posições intelectuais, críticas e propositivas sobre as formações;

e) a diversidade de Projetos Acadêmicos, assim viabilizada pela Lei de Diretrizes e pelo presente documento, longe de ser uma liberdade isolacionista, deve tornar-se um campo de experimentação pedagógica e organizacional, de pesquisa, de desenvolvimento profissional, e de troca e realimentação mútua entre os projetos diversos, entre escolas portanto;

f) correlata à flexibilidade legal e normativa, a presença dinâmica das entidades da área torna-se um requisito fundamental no sentido de estimular o aperfeiçoamento constante da formação. A formação não estando mais contida e aprisionada em um documento formal (como o Currículo Mínimo), seu direcionamento e sua qualidade passam a depender de um trabalho coletivo constante, envolvendo as escolas, as entidades e a Comissão de Especialistas em Comunicação do MEC, através de suas interações locais, regionais e nacionais;

g) a flexibilidade pretendida deve possibilitar aos estudantes não só a realização de atividades curriculares obrigatórias, mas de um leque significativo de atividades optativas, tornando-os coresponsáveis pela construção de seu currículo pleno e de sua formação universitária;

h) não há correlação entre a formação teórica e a parte geral do Curso; nem entre a formação técnico-profissional e a parte habilitacional. Em primeiro lugar, porque estas diretrizes buscam superar a antiga dicotomia entre teoria e prática, introduzindo como diferenciados e essenciais os conteúdos éticos-políticos e analítico-informativos acerca da atualidade. Em segundo lugar porque tanto a parte comum quanto o momento habilitacional envolvem reflexões teóricas, conteúdos analítico-informativos e éticos-políticos, e perspectivas práticas, relativas às tecnologias, técnicas e linguagens da comunicação e de suas habilitações. (CCE-COM, 1999, on line)

O que o documento denomina como Projeto Acadêmico pode ser entendido como o Projeto Pedagógico do curso, destacando-se no item Estrutura Geral do Curso um roteiro didático desenvolvido para elaboração do Projeto de Curso de 
Graduação. A proposta deixa claro que este caráter "é fundamental para a compreensão e a instrumentalização das diretrizes curriculares, estimulando que os Cursos se organizem de modo abrangente e consistente", procurando favorecer a organização de seus objetivos e procedimentos, assim como os trabalhos de acompanhamento e avaliação, internos e externos (CEE-COM, 1999, on line).

O documento que fundamentou o Parecer CNE/CES 492/2001, elaborado pela Comissão de Especialistas de Ensino em Comunicação Social (CEE - Com), destaca que o Projeto Pedagógico deve prever uma consistente perspectiva humanística, para permitir ao estudante ultrapassar os aspectos utilitários e alcançar as interações entre a Comunicação e a cultura, a política e a economia. Para tanto, precisa incluir conteúdos teórico-conceituais, conteúdos analíticos e informativos sobre a atualidade, conteúdos de linguagens, técnicas e tecnologias midiáticas e conteúdos éticos-políticos. Já os conteúdos específicos se apóiam no que caracteriza a parte habilitacional dos cursos correspondente ao recorte, dentro do campo geral da Comunicação, de conhecimentos e de práticas profissionais, caracterizando uma "habilitação" - e que, também dentro desse recorte determinado, inclui as questões básicas referidas a reflexões teóricas, problematizações críticas, conhecimento de atualidade, e práticas sobre linguagens e estruturas.

De acordo com o documento,

O Projeto Acadêmico deve, ao organizar as concepções gerais e os conteúdos que norteiam o currículo do curso, expressar a necessária articulação entre estas concepções gerais, os conteúdos curriculares e os diversos formatos pedagógicos (aulas preletivas, laboratórios, oficinas, estudo orientado, trabalhos de conclusão de curso, e demais atividades) estabelecidos como procedimentos do curso. A adequação pedagógica entre concepções, formatos, procedimentos e conteúdos deve ser ressaltada e incorporada como momento significativo do Projeto Acadêmico. (CCE-COM, 1999, on line) 
Dessa forma, o Projeto Pedagógico deve prever e expor com clareza todas as características de estrutura e de funcionamento do Curso, assim como os padrões e métodos destinados a assegurar sua qualidade. É seu objetivo, inclusive, proporcionar visibilidade para o conjunto de recursos materiais e humanos mobilizados, bem como o modo de articulá-los e empregá-los na formação dos futuros profissionais.

\subsection{Práticas laboratoriais}

Um dos pontos principais do documento que fundamentou o Parecer CNE/CES 492/2001, elaborado pela Comissão de Especialistas de Ensino em Comunicação Social (CEE - Com), é a descrição de que o Projeto Pedagógico do Curso deve prever e expor com clareza o conjunto de requisitos necessários ao estudante para integralizar sua formação.

Entende-se a Proposta Pedagógica como um documento mais abrangente que uma simples listagem de disciplinas com suas ementas e cargas horárias. Deve envolver, sobretudo, os conceitos e objetivos que dão organicidade ao Curso, o conjunto de disciplinas e demais atividades escolares com as justificativas que dão pertinência àqueles objetivos, os procedimentos de oferta e de interação entre os componentes do Curso e entre docentes e discentes, e todos os demais indicadores que explicitem e organizem o projeto de formação. (CCE-COM, 1999, on line)

Entre as especificações do Projeto Pedagógico, devem constar os objetivos, a formulação curricular e a organização das atividades laboratoriais que favoreçam os objetivos educacionais e o planejamento de harmonia de procedimentos relativos a teorias e práticas. Incluem-se também os modos de integração entre as perspectivas teóricas e técnicas no Curso; as atividades complementares e os 
estágios que eventualmente se integram ao currículo pleno; e as formas de distinção, valorização e divulgação do Trabalho de Conclusão de Curso (com esta denominação ou como Projetos Experimentais) dos discentes, que deve, obrigatoriamente, caracterizar a finalização da formação superior em Comunicação, entre outros aspectos.

Sobre este ponto, deve-se considerar o papel das práticas laboratoriais nos cursos de Comunicação Social com habilitação em Jornalismo. Para os especialistas que formularam o documento, Projeto Pedagógico deve ainda prever e expor com clareza os procedimentos por meio dos quais assegurará uma efetiva interação com a sociedade, cumprindo a responsabilidade das IES de fornecer recursos humanos qualificados ao mercado de trabalho e de aperfeiçoar o próprio funcionamento social com perspectivas inovadoras e críticas. Há de se considerar que muito se tem discutido, nesse início de século, qual é o caminho para o Jornalismo. Diversos textos e teorias vêm sendo elaborados para descrever as formas de divulgação jornalística.

Entre o relato do fato e o comentário sobre o mesmo, a informação sob a forma de notícia ainda continua sendo a matéria-prima do Jornalismo. As características básicas de um texto jornalístico, como clareza e objetividade, continuam presentes da mesma forma na cobertura dos acontecimentos. O que se poderia considerar de novo no texto jornalístico, na verdade, tem apenas outra roupagem. O profissional desta área precisa saber levantar o fato, entrevistar e escrever, visando atingir um leitor ávido de informações, com uma boa formação cultural.

Assim, nas próximas décadas, será possível perceber muitas transformações no mundo jornalístico, possivelmente não no conceito ético e profissional e sim em 
sua estrutura. A forma da tradicional mídia eletrônica e impressa está passando por transformações profundas, com mudanças também de conteúdo. Não se deve esquecer que o Jornalismo e a importância da informação não mudaram e nunca mudarão. O que mudou foi o suporte e a dinâmica de recepção da informação, e o profissional desta área precisa na verdade saber levantar o fato, captar a informação, buscar elementos de interpretação e traduzir discursos.

A maioria dos livros sobre técnicas de elaboração de reportagens aponta que para elaborar esse tipo de matéria é necessário, primeiro, encontrar um bom tema, ter um bom enfoque. Depois é preciso ter abordagens humanas sobre questões sociais. Os textos precisam ser profundos e analíticos, envolvendo o leitor com o acontecimento. O fato principal, no Jornalismo, é a descoberta da verdade por meio de histórias de vida e o papel do jornalista deve ser o de oferecer o contexto da informação. De acordo com Edvaldo Pereira Lima,

O jornalista deve refletir sobre sua responsabilidade social. Seu trabalho bem realizado amplia conhecimento da população e permite mudar a realidade. A informação permite à sociedade opções de escolha, interpretação, participação das decisões democráticas e construção de novos caminhos. O ser humano é o eixo de toda reportagem; comunidades que espelham cooperação e empreendedorismo; associação à realidade cotidiana. (LIMA, 2003: 47).

Um dos aspectos mais importantes para elaboração de uma reportagem é ter domínio sobre 0 assunto. O jornalista em formação precisa buscar 0 entendimento, a compreensão sobre o fato, e quando não há clareza nas informações obtidas, deve realizar entrevistas, procurar analogias e exemplos práticos para compreender.

A reportagem narrativa, mais precisamente o relato jornalístico, foi, por sinal, tema da primeira tese sobre o Jornalismo de que se tem notícia. Tobias Peucer, autor da obra De relationibus novellis, faz parte de um grupo que, na primeira 
metade do século XVII, começou a pesquisar e a publicar os resultados de suas investigações nas universidades alemãs. O trabalho pioneiro desse alemão de Görlitz deu início, em 1690, na cidade de Leipzig, ao conhecimento acumulado e sistemático do Jornalismo, iniciando as chamadas teorias que permeiam a atividade e a filosofia dessa prática profissional. São de Peucer as palavras traduzidas e publicadas pela Revista Comunicação e Sociedade:

Não há nada mais apto para o deleite que as mutações dos tempos e as vicissitudes da sorte, que, apesar de não poder escolhê-las no momento de vivê-las, do mesmo modo, serão agradáveis de ler. O registro sem necessidade da dor passada é um deleite; e para os que se escaparam sem nenhuma moléstia pessoal vêem os dramas dos outros sem nenhuma dor, pois também a compaixão em si mesma é agradável. De fato, a ordem mesma dos anais não é que eles atraiam tanto, pelo que têm de simples enumeração cronológica. Em troca, as situações incertas e variadas de uma personagem muitas vezes destacada, contêm admiração, expectativas, alegria, moléstia, esperança, temor, e se terminam com um sucesso notável, o espírito sacia-se do prazer de uma leitura altamente amena. (...) Porque todo relato é mais agradável se se conhecem o local, as pessoas notáveis que foram autoras de um feito, ou as causas pelas quais se empenharam. (PEUCER, 2000: 204)

Fica latente que o Jornalismo possui uma técnica específica de explorar a realidade. Muitos jornalistas e escritores acreditam que o dia-a-dia do Jornalismo ajuda a assimilação de elementos que depuram o texto, no sentido de torná-lo direto e mais conciso. Assim, o principal para a reportagem seria a sensibilidade, associada à verossimilhança, como recurso para dar força ao texto imaginário. Em boa parte da bibliografia que detalha a técnica e a arte da reportagem ficam ressaltadas diferentes naturezas do fazer jornalístico: textos profundos e analíticos; deve envolver o leitor com o acontecimento; o fato principal no Jornalismo é a descoberta da verdade por meio de histórias de vida; o jornalista deve oferecer o contexto da informação; deve ser uma forma envolvente e profunda de contar 
histórias; o texto jornalístico deve estar preso à verdade e não pode ter compromisso com a periodicidade.

Num aspecto tecnicista, as definições se assemelham àquelas encontradas nos manuais de redação, em que a reportagem deve buscar a contextualização dos fatos, apresentando antecedentes e perspectivas, buscando sempre a humanização do texto de forma a se conseguir maior generalização.

A reportagem é o núcleo essencial do Jornalismo. Ela deve sempre conter: a descrição do fato, todas as versões das partes envolvidas e, se possível, a opinião de especialistas. A reportagem não pode se confundir com um artigo. Todas as versões contraditórias devem ser oferecidas ao leitor. (MANUAL da Redação Folha de S. Paulo, 2001: 116)

A reportagem pode ser considerada a própria essência de um jornal e difere da notícia pelo conteúdo, extensão e profundidade. A notícia de modo geral, descreve o fato e, no máximo, seus efeitos e conseqüências. A reportagem busca mais: partindo da própria notícia, desenvolve uma seqüência investigativa que não cabe na notícia. Assim, apura não somente as origens do fato, mas suas razões e efeitos. Abre o debate sobre o acontecimento, desdobra-o em seus aspectos mais importantes e divide-os, quando se justifica, em retrancas diferentes que poderão ser agrupadas em uma ou mais páginas. A notícia não esgota o fato; a reportagem pretende fazê-lo. (MARTINS, 1997: 254)

Para o aluno de graduação, ou seja, o jornalista em formação, não somente as obras que detalham as técnicas serão necessárias, mas também um conjunto multidisciplinar que inclua a reflexão crítica e a possibilidade da prática laboratorial. Porém, para o exercício da reportagem que pode servir de parâmetro para o jornalista em formação acadêmica e profissional é preciso que o aluno vivencie o Jornalismo investigativo e apreenda conceitos e valores fundamentais da profissão.

A prática da reportagem propicia um aprendizado para a vida acadêmica e profissional do futuro jornalista. Os estudantes de Jornalismo devem ser incentivados a elaborar reportagens e grandes reportagens porque por meio dessa produção e de um acompanhamento intensivo por parte dos orientadores, seu 
aprendizado se torna mais aprofundado. Além disso, nada supera a experiência de sair a campo e realizar investigações que irão contribuir com a sociedade. $\mathrm{O}$ resultado da grande reportagem não precisa, necessariamente, ter o formato de livro. Também pode ser feito destinado a ocupar espaços em jornais, revistas, documentários em vídeo, rádio-documentários ou sites com conteúdo jornalístico.

Por meio da reportagem e do aprendizado da pauta especializada, do texto interpretativo, da investigação e da edição da grande reportagem, os alunos têm a oportunidade de aprofundar e experimentar, em alguns casos, os maiores desafios até então propostos durante a graduação. Nesse sentido, os temas trabalhados nas reportagens em profundidade são, na maioria dos casos, abordagens sobre a questão social (pobreza, desigualdade, combate à pobreza e à fome, soluções, estatísticas/indicadores, causas, conseqüências, civismo/cidadania, preconceito, inclusão/exclusão, diferenças, regionais, mobilização social e desenvolvimento humano etc.). Fora dessa abordagem, outros temas de interesse remetem à elaboração de perfis e biografias, o que, de certa forma, se reflete nos erros do Jornalismo atual apontados por Clóvis Rossi: a capacidade limitada de transmitir a informação; a utilização de conceitos reducionistas; pouca pesquisa; a reprodução do discurso de poucas e cotidianas fontes; pouco cuidado no tratamento dos dados; a falta de abrangência e precisão. Tais lacunas refletem-se tanto na grande imprensa quanto nas produções discentes nos cursos de Jornalismo. Verifica-se ainda que o Jornalismo investigativo apresenta-se como uma prática que exige maturidade, algo obtido com anos de vivência na profissão.

As práticas laboratoriais oferecidas pelas IES os graduandos - em sua grande maioria jovens idealistas e dispostos a aventurar-se na prática profissional nem sempre permitem a profundidade e a vivência necessárias na formação dos 
futuros jornalistas. Em primeiro lugar, entende-se que o jornalista é ator social, que deve atuar refletindo sobre sua responsabilidade social. Seu trabalho bem realizado amplia conhecimento da população e permite mudar a realidade, constrói memória registrando os acontecimentos e permite a compreensão do mundo ao redor.

Outro elemento de reflexão permite perceber que desenvolvimento social e investigação caminham lado a lado, ou seja, as perguntas-chave do Jornalismo direcionam caminhos, revelando a quem interessa o fato, quem perde e quem ganha com ele e, principalmente, qual o impacto na vida das pessoas. Nesse sentido, o resultado deve estar à altura e o jornalista tem por dever qualificar o texto, procurando compreender os conceitos do que se escreve, trabalhando com abordagens que possam mudar o enfoque da reportagem, o entendimento e o grau de repercussão e impacto.

Se a humanização do texto é característica da reportagem, então é preciso evitar a veneração a números e estatísticas. Tais elementos são importantes, mas em excesso distanciam do leitor da realidade, retira o foco do ser humano. A cobertura das questões sociais deve valorizar ações que promovam qualidade de vida, impacto social, participação democrática, empreendedorismo. A reportagem ideal é aquela que promove o debate, aquele em que o jornalista torna pública a discussão que afeta diariamente a vida das pessoas. Informação permite à sociedade opções de escolha, interpretação, participação das decisões democráticas e construção de novos caminhos.

O texto da reportagem deve ser de natureza impressionista, sem ser piegas, mas com tintas nas proporções exatas para valorizar protagonistas, uma vez que 0 ser humano é o eixo de toda reportagem. Dessa forma se permite ao leitor a associação à realidade cotidiana. Com a boa investigação somam-se o 
acompanhamento atento dos atos e políticas públicas e a utilização de documentos oficiais e o suporte na legislação vigente, que dão maior credibilidade ao assunto, especialmente em casos de denúncias.

Ter domínio sobre o assunto antes de produzir a reportagem é a recomendação constante em quase todas as obras sobre o jornalismo investigativo. É preciso, dizem os autores em inúmeros exemplos, buscar o entendimento, quando não há clareza deve-se repetir entrevistas, procurar analogias e exemplos práticos para compreender. E que o leitor receba mais do que isso: compreende e tire conclusões, formando opinião.

E, finalmente, buscar nas fontes novos atores sociais, pois além de ouvir fontes oficiais é preciso legitimar novos discursos, trazer à tona novas idéias, ouvir opiniões divergentes e conceitos distintos para fortalecer o debate.

Para finalizar, é importante desenvolver no aluno a descoberta da reportagem e a importância da informação precisa e correta. É necessário que o estudante perceba o seu papel dentro da sociedade. É necessário que ele compreenda os mecanismos envolvidos em todo o processo de elaboração de uma reportagem. Desde a pauta, apuração, edição e sua divulgação nos meios impressos ou eletrônicos. É possível perceber nas práticas laboratoriais oferecidas na graduação que é produzindo que o aluno adquire uma visão holística e percebe que a reportagem não morreu e nunca morrerá. Parafraseando jornalistas de renome, "lugar de repórter é na rua".

Com a instituição das Diretrizes Curriculares para os Cursos de Comunicação Social (Parecer CNE/CES 492/2001, publicado no Diário Oficial da União em 9 de julho de 2001), novos desafios se apresentaram à formação de profissionais de Jornalismo, uma vez que elas foram elaboradas procurando atender a dois 
objetivos fundamentais (cf. PERUZZO \& SILVA, 2003: 339-340): a) flexibilizar a estruturação dos cursos, tanto para atender a variedades de circunstâncias geográficas político-sociais e acadêmicas, como para ajustar-se ao dinamismo da área, e para viabilizar o surgimento de propostas pedagógicas inovadoras e eficientes; b) estabelecer orientações para obtenção de padrão de qualidade na formação oferecida.

Nas Diretrizes Curriculares, o Conselho Nacional de Educação (CNE) e a Câmara Superior de Educação (CSE) estabelecem que o perfil do egresso em Jornalismo se caracteriza: pela produção de informações relacionadas a fatos, circunstâncias e contextos do momento presente; pelo exercício da objetividade na apuração, interpretação, registro e divulgação dos fatos sociais; pelo exercício da tradução e disseminação de informações de modo a qualificar o senso comum; pelo exercício de relações com outras áreas sociais, culturais e econômicas com as quais o Jornalismo faz interface. E aponta ainda as Competências e Habilidades que o profissional da área precisa adquirir e assimilar.

$\mathrm{Na}$ discussão sobre teoria e prática, passam pelo aprendizado constante do aluno em práticas laboratoriais que abranjam todos os afazeres da profissão, cada vez com maior profundidade. Tais práticas pretendem contemplar ambiciosamente a síntese da profissão: preparar profissionais que possam transitar pelos mais diferentes meios de comunicação, dotados das competências e habilidades estabelecidas pelas diretrizes acima. Sobre isso, estudiosos do tema como José Marques de Melo, Cremilda Medina e Dirceu Fernandes Lopes, entre outros, vêm há muitos anos debatendo sobre a questão do aprendizado prático nas escolas de Comunicação como forma para preparar o futuro profissional. Lopes (1989: 13) destaca a preocupação da época logo na introdução de seu trabalho: 
Formar bons profissionais destinados às empresas jornalísticas continua sendo um desafio para as faculdades de Comunicação. (...) Os meios de comunicação, salvo raras exceções, consideram os profissionais formados pela universidade despreparados para enfrentar o mercado de trabalho do país. (...) Algumas inquietações já fazem parte da rotina dos estudiosos da Comunicação: que tipo de profissional está sendo formado? A que mercado se destina o profissional egresso das faculdades? Onde estão as falhas mais acentuadas das faculdades de comunicação: nos currículos, no despreparo do corpo docente, no baixo nível dos alunos ou na estrutura geral do ensino?

De lá para cá muito se caminhou, mas ainda persistem discussões sobre a melhor forma de preparação do futuro jornalista profissional e, isso passa, necessariamente, pelo aprendizado teórico e prático, dotando os graduandos de habilidades e competências que formem o homem e não apenas o técnico. Dessa experiência resultaram inúmeros projetos profissionais, com destaque para as reportagens investigativas, propiciando a seus autores - jovens jornalistas em formação - experiências enriquecedoras que, muitas vezes, não foram vivenciadas ao longo da graduação. Lima (2003) salienta a diversidade temática dessa possibilidade profissional, a construção cena-a-cena, o uso de diálogos significativos, o dinamismo, a fluência e a alternância de perspectivas presentes nos textos jornalísticos elaborados pelos formandos.

A prática da reportagem propicia um aprendizado para a vida acadêmica e profissional do futuro jornalista, uma vez que nada supera a experiência de sair a campo e realizar investigações que irão contribuir com a sociedade. Por meio da reportagem e do aprendizado da pauta especializada, do texto interpretativo, da investigação e da edição de conteúdos em órgãos laboratoriais, os alunos têm a oportunidade de aprofundar e experimentar, em alguns casos, os maiores desafios até então propostos durante a graduação. E, uma vez direcionando a prática a temas de interesse social, o futuro jornalista se torna mais consciente de seus direitos e deveres para com a sociedade, estreitando a relação entre Jornalismo e 
Cidadania e, de certa forma, contribuindo para modificar uma visão distorcida sobre o papel do jornalista na sociedade.

\subsection{Processo ensino-aprendizagem}

Em 1972, o pesquisador Luiz Beltrão, importantíssimo defensor da formação superior em Jornalismo, escreveu um capítulo da coletânea "O ensino de Jornalismo", publicada pela Escola de Comunicações e Artes da Universidade de São Paulo, intitulado "Estrutura Curricular dos cursos de Jornalismo no Brasil", reproduzido na década de 1990 pelo Anuário da Cátedra UNESCO/Metodista (1997). Reconhecido hoje como um homem à frente de seu tempo, Beltrão já enfatizava, há mais de três décadas, as necessidades de uma formação aprimorada dos profissionais da área, destacando que

As condições de organização, permanência e desenvolvimento das empresas jornalísticas na fase de transição de uma indústria rotineira para uma indústria dinâmica e em constante mutação, criaram também condições especialíssimas para o recrutamento de profissionais. Como não há mais tempo nem lugar para uma aprendizagem direta, a indústria jornalística exige:

a) habilitação real, e não improvisação do profissional. Este deve ser capaz de conhecer em profundidade os meios, as técnicas, os métodos de produção da informação;

b) para tanto, há de aprimorar a sua cultura na Universidade, não limitando os seus conhecimentos a uma linha histórico-literária, mas adquirindo um acervo de conhecimentos sobretudo na área das Ciências Sociais e daquelas que se apliquem aos fenômenos gerados pelos novos meios de Comunicação, sua linguagem específica, seus efeitos na psicologia e no comportamento da audiência,sua influência no desenvolvimento cultural, econômico e social do País;

c) esse acervo cultural e o conhecimento e manejo das técnicas e métodos de captação, elaboração e transmissão das informações deve desenvolver no jornalista realmente habilitado um espírito aberto às inovações, desde que o processo da Comunicação está sempre sujeito a mutações, provocadas tanto pela transformação dos meios como pelas extensões do sistema geral das comunicações. (BELTRÂO, 1997, p. 291) 
A visão de Luiz Beltrão revela que o processo ensino-aprendizagem, definido como a integração entre os agentes e fatores que contribuem para a formação do aluno, deve ser dinâmico, uma vez que no caso do ensino de Jornalismo várias questões se aplicam, entre elas: a distribuição de disciplinas em currículos que não dão conta das mudanças ocorridas no campo da Comunicação Social; a distância entre as práticas laboratoriais oferecidas pelas IES e as tecnologias de Comunicação adotadas no mercado; as frustrações dos graduandos que esperam que as práticas jornalísticas reproduzam modelos consolidados no cenário profissional; a reprodução dos sistemas de produção adotados pela imprensa e que se contrapõem às propostas acadêmicas e a dificuldade de promover a interdisciplinaridade nos vários projetos práticos oferecidos pelos cursos.

Para Fadul (1979), embora uma condição necessária, o domínio de uma técnica não é suficiente para que o profissional consiga encontrar alternativas para uma prática futura.

Entender o ensino das técnicas como a simples transmissão de uma prática válida hoje, poderia levar a uma rápida superação desse ensino, pois a evolução tecnológica tornaria rapidamente obsoleta a prática atual. A única forma de esse ensino manter-se atualizado seria transmitir ao aluno uma formação ao mesmo tempo teórica e prática, de forma a permitir, a esse aluno, a sua própria reciclagem frente às novas técnicas revolucionárias. (FADUL, 1979, p. 52)

Hoje, o Jornalismo se vê frente a novos desafios e mudanças que são comuns em determinados momentos da evolução do conhecimento. $O$ aluno precisa se atualizar e continuar se adequando ao novo patamar. Porém, a mesma estrutura jornalística está presente nessa nova etapa. A diferença está presa ao veículo e na forma de passar a informação. O que é notícia no meio impresso também é notícia 
no meio eletrônico. A apuração e a responsabilidade precisam estar adequadas a cada matéria que é divulgada a cada minuto ou segundo.

As Diretrizes Curriculares de Jornalismo aprovadas pelo Ministério da Educação (MEC), em 2001, definem que aluno do curso deverá desenvolver a capacidade de reflexão para analisar os padrões e práticas jornalísticas, exercitando sua capacidade criativa no sentido de experimentar novas linguagens e produtos de comunicação. Cabe à escola também discutir questões socioculturais e políticas com ensinamentos sobre novas tecnologias aplicadas à linguagem jornalística. Os cursos deverão criar condições para que o aluno exercite sua capacidade criativa, no sentido de experimentar novas linguagens e produtos de comunicação. Finalmente, é necessário que o egresso tenha a capacidade de compreender os mecanismos envolvidos no processo de recepção de mensagens e seu impacto sobre os diversos setores sociais.

De acordo com as Diretrizes, esse profissional deve ter ampla formação humanística voltada para a reflexão crítica dos acontecimentos sociais; deve ser capaz de conhecer as técnicas de captação, codificação e divulgação das informações de interesse público, interpretando, com critério jornalístico, os fatos cotidianos. Como profissional de comunicação, deve ser capaz de entrevistar, escrever editoriais, artigos, crônicas, reportagens e comentários sobre assuntos diversos na mídia impressa e eletrônica, contribuindo para a reflexão e transformação social, e considerando, para isso, a necessidade de atualização permanente frente às novas tecnologias de comunicação; ser criativo e ter iniciativa para experimentar novas linguagens e produtos de comunicação; apresentar formação ética social e profissional, compromisso com a cidadania e humildade diante da realidade. Assim, a habilitação de Jornalismo busca formar um 
profissional com cultura ampla, curiosidade intelectual, criatividade, domínio do idioma e das estruturas narrativas e expositivas voltadas às mensagens jornalísticas.

Não se deve esquecer que o Jornalismo e a importância da informação não mudaram e nunca mudarão. O que mudou foi o suporte que, antes, era impresso ou apenas eletrônico e, agora, além do eletrônico, ficou interativo em tempo real. A notícia ainda continua sendo a matéria-prima do Jornalismo. As características básicas de um texto jornalístico, como a clareza e a importância da notícia, continuam sendo feitos da mesma forma. O novo texto jornalístico, na verdade, tem apenas outra roupagem. O profissional desta área precisa na verdade saber levantar o fato, entrevistar e escrever, visando atingir um leitor ávido de notícias, com uma boa formação cultural e com pouca paciência. O que se mostra um constante desafio para as IES que formam jornalistas. 


\section{Projetos Experimentais}

A disciplina Projetos Experimentais (PE) foi implantada há 31 anos nos cursos de Comunicação Social no Brasil, pela Resolução № 003/78 do Conselho Federal de Educação, órgão do Ministério da Educação e Cultura responsável pela elaboração e instituição dos currículos mínimos do ensino de Jornalismo e, posteriormente, do ensino de Comunicação Social em suas diversas habilitações, como: Relações Públicas, Publicidade e Propaganda, Editoração, Radialismo, Cinema etc. O CFE foi extinto a partir da instituição da Lei de Diretrizes e Bases da Educação (LDB) de 1996 e substituído pelo Conselho Nacional de Educação (CNE). Inicialmente, os Projetos Experimentais em Jornalismo tinham dois objetivos: obrigar a prática profissional nos cursos e contribuir para a criação uma estrutura tecnicista no ensino de Jornalismo. Os alunos, naquela época, recebiam um ensino teórico que, em muitos casos, eram desdobramentos dos cursos de Filosofia ou de Letras. Não havia laboratórios nas faculdades e nem elaboração de produtos jornalísticos. Os Projetos Experimentais deveriam incentivar a prática profissional efetiva, visando diminuir a carência e a distância das Escolas em relação ao mercado.

De acordo com Mattos (2005, p. 6), conforme solicitação do Conselho Federal de Educação (CFE), a Associação Brasileira de Ensino e Pesquisa de Comunicação (Abepec) elaborou e encaminhou ao Conselho um anteprojeto para a criação de novo currículo mínimo para a área. Este fato gerou um conflito entre duas perspectivas de ensino e pesquisa em comunicação: uma que privilegiava os aspectos ético-humanistas, teóricos e críticos da formação do comunicador social e 
outra que defendia a formação especializada do futuro profissional, enfatizando as dimensões técnicas e instrumentais das habilitações.

Os adeptos da segunda perspectiva organizaram um movimento nacional de reação à proposta da Abepec, a fim de barrar a sua tramitação. Esses não apenas conseguiram impedir a aprovação daquela proposta, como também foram designados pelo CFE a formar outra comissão para elaborar nova proposta curricular, cuja conclusão foi apresentada em 1977 e expressa no Parecer № 1203/1977 e na Resolução 03/1978, que regulamentavam novo currículo do ensino de Comunicação Social. Esses documentos expressaram, pela primeira vez, a idéia de Projeto Experimental (no artigo $4^{\circ}$ e parágrafos), cujo objetivo central era tornar compulsória a prática profissional no ensino de comunicação e em suas habilitações. Por essa razão, a introdução dessa disciplina foi vista à época como uma alternativa ao estágio, especialmente nos jornais, onde eram proibidos pela legislação trabalhista, atendendo a uma reivindicação dos sindicatos da categoria que viam na atividade uma exploração de mão-de-obra barata, na verdade, sem remuneração alguma. (MATTOS, 2005, p. 7)

A discussão na época centrava-se na opinião de a nova disciplina tinha em vista evitar o teoricismo presente na estrutura curricular durante a década de 1970 e, nesse sentido, obrigar as IES a dotarem seus cursos de um mínimo indispensável de prática laboratorial, referenciada na prática profissional desenvolvida no mercado de trabalho.

Em 1984, com a implantação da Resolução nº 002/84, uma carga horária mínima de 270 horas/aula de atividades foi estabelecida para o desenvolvimento de Projetos Experimentais, especialmente no último semestre ou ano do curso. A disciplina recebia a seguinte redação:

Art. $3^{0}$ - Os Projetos Experimentais corresponderão à produção, no último semestre do curso, de trabalho relacionado com a habilitação específica, em forma de monografia, fita gravada de som ou imagem e som, campanha publicitária, plano de editoração ou planejamento de Relações Públicas - sempre realizados nos laboratórios da própria escola. 
Muitas escolas optaram em transformar essa disciplina em uma prática laboratorial na produção de produtos, como: jornais, revistas, vídeos, documentários, programas de rádio, entre outros. Outras escolas resolveram continuar produzindo produtos jornalísticos para os alunos do último ano e criar também outra atividade que foi denominada Trabalho de Conclusão de Curso (TCC). Era a oportunidade em que os alunos, em pequenos grupos ou individualmente, poderiam aprofundar seus conhecimentos, produzindo e experimentando novas linguagens e modelos comunicacionais.

Para Mattos $(2005$, p. 6), outros fatores que influenciaram a elaboração da Resolução dos Projetos Experimentais, ligados, sobretudo, aos interesses das empresas de comunicação, notadamente as empresas jornalísticas:

Ainda que não explicitamente, sem dúvida, a disciplina foi criada para pôr fim, ou, pelo menos, amenizar a polêmica suscitada por setores significativos da grande imprensa nacional sobre a validade da exigência de um diploma para o exercício da profissão de jornalista. Entre outras coisas, questionava-se a qualidade do ensino nas escolas de Comunicação e a competência dos profissionais por ela formados, para enfrentar a prática intrínseca à vida cotidiana do comunicólogo, entre todas as suas vertentes (TARGINO \& MAGALHÃES apud MATTOS, 2005, p. 6).

No entender da autora, os projetos experimentais deveriam ser vistos como práticas complementares e não como alternativas. E dada a proibição de estágios na área (formal e não real), as práticas laboratoriais dos cursos de Comunicação acabam sendo encaradas como recriação das condições que efetivamente existiriam no mercado de trabalho.

O Projeto Experimental deve ser visto como o coroamento desse processo de experimentação; como aquele momento em que o estudante, tendo já adquirido uma considerável vivência de formas de linguagens e toda uma bagagem técnica, através de práticas laboratoriais, vai, mais uma vez, experimentar e desta vez dentro de um projeto de sua livre escolha. (MATTOS, 2005, p. 9). 
Pode-se compreender também o direcionamento dado pelas IES à prática que envolve temas de interesse social, com os quais o futuro jornalista se torna mais consciente de seus direitos e deveres para com a sociedade, estreitando a relação entre Jornalismo e cidadania e, de certa forma, contribuindo para modificar uma visão distorcida sobre o papel do jornalista na sociedade. Uma vez que a produção de Projetos Experimentais por estudantes de Jornalismo em IES do Estado de São Paulo é importante instrumento de sua formação, faz-se necessário compreender o diálogo existente os regulamentos estabelecidos pelas IES e os agentes envolvidos na elaboração de Projetos Experimentais no que diz respeito à relação ensinoaprendizagem e o papel dos mesmos na formação do jornalista; a estruturação dos Projetos Experimentais frente às Diretrizes Curriculares oferece múltiplas possibilidades aos graduandos, de maneira a permitir que vivenciem de forma autônoma os caminhos da formação profissional em Jornalismo.

O Projeto Experimental deveria ser visto como o coroamento desse processo de experimentação; como aquele momento em que o estudante, tendo já adquirido uma considerável vivência de formas e linguagens e toda a bagagem técnica, através das práticas laboratoriais, vai, mais uma vez, experimentar e desta vez dentro de um projeto de sua livre escolha, dando plena vazão à sua criatividade, ousando, tentando ir além, buscando superar-se e inclusive questionando práticas e modelos vigentes no mercado. (PALÁCIOS, apud ROCHA, 1998, p. 88).

As Diretrizes Curriculares de Comunicação Social aprovadas pelo Ministério da Educação (MEC), em 2001, definem que aluno de Jornalismo deve desenvolver a capacidade de reflexão para analisar os padrões e práticas jornalísticas, exercitando sua capacidade criativa no sentido de experimentar novas linguagens e produtos de comunicação. Cabe à escola também discutir questões socioculturais e políticas com ensinamentos sobre novas tecnologias aplicados à linguagem jornalística, criando condições para que o aluno exercite sua capacidade criativa, 
experimente novas ferramentas e assimile aspetos teórico-práticos de sua formação. Assim, busca-se um egresso dos cursos de Jornalismo que tenha a capacidade de compreender os mecanismos envolvidos no processo de recepção de mensagens e seu impacto sobre os diversos setores sociais.

A prática laboratorial pode preparar o estudante para o mercado profissional, mas também pode se constituir em fator inibidor da criatividade, inovação e experimentação de linguagens, uma vez que pode adotar uma postura conformista frente à normatização imposta nos órgãos laboratoriais e também nos PE. Todavia, os Projetos Experimentais podem contemplar inúmeras possibilidades pedagógicas e formas de linguagem e apresentação estética, além de abrir espaço para o desenvolvimento de trabalhos de caráter acadêmico, como monografias, que pressupõem cunho reflexivo e crítico.

A fim de descrever qual o papel dos Projetos Experimentais nesse processo e qual a estruturação dos mesmos nas IES, verifica-se que a regulamentação os Projetos Experimentais no ensino de Jornalismo obedece tanto ao processo histórico, quanto à legislação que determina a oferta de cursos de Comunicação Social com habilitação em Jornalismo no Brasil. Uma característica básica do profissional de Jornalismo é a capacidade de refletir sobre sua responsabilidade social, uma vez que seu trabalho bem realizado amplia o conhecimento da população e permite mudar a realidade. A informação permite à sociedade opções de escolha, interpretação, participação das decisões democráticas e construção de novos caminhos. Assim, existem relações concretas entre as Diretrizes Curriculares e a importância dos Projetos Pedagógicos definidos e desenvolvidos pelas IES, cada qual com particularidades e que definem o perfil desejado do profissional que pretendem formar, bem como os caminhos que oferecem para tal formação. 
Para Rocha (1998), há também a possibilidade dos Projetos Experimentais atuarem como intermediários entre os cursos de graduação e a comunidade, oferecendo ao mercado outras opções de caráter técnico ou respaldo teórico.

\begin{abstract}
A escola, que deveria ser um espaço de criação e inovação, em lugar de permanecer a reboque do mercado, não está conseguindo acompanhar o avanço dos meios de comunicação. $O$ descompasso entre os cursos e as empresas estimula os alunos a atuarem, o mais cedo possível, no mercado de trabalho, em detrimento do ensino universitário e da formação cultural, não somente técnica. A universidade representa um dos principais espaços para o debate sobre os meios de comunicação. Nas empresas, o tempo do jornalista destina-se quase que exclusivamente à produção, restando pouco tempo à reflexão. [...] Cabe, portanto, aos cursos da área atender às expectativas dos alunos e sintonizar o meio acadêmico com o mercado de trabalho, exercendo, de fato, suas responsabilidades na formação de um profissional crítico e cidadão. (ROCHA, 1998, p. 243)
\end{abstract}

A formação do jornalista já foi alvo de inúmeras discussões nas faculdades, sindicatos, congressos, simpósios, e, especialmente, na Abecom e na Intercom. Esta última, sempre foi um fórum permanente para esse debate. Em 1979, a Intercom lançou o livro "Ideologia e Poder no Ensino de Comunicação". No capítulo "A formação do jornalista", o professor Gaudêncio Torquato já chamava a atenção para as deficiências curriculares. Ele dividiu o curso em três fases: o ciclo bacharelesco, o ciclo tecnicista-pragmático e ciclo misto. Torquato defende, então, que era necessário repensar a função do professor para sensibilizar o futuro jornalista sobre seu papel na sociedade. Para ele, o comunicador social é mais do que "um simples decodificador de mensagens".

No I Encontro Nacional de Coordenadores de Projetos Experimentais, promovido pela Abecom em Belo Horizonte, o professor José Marques de Melo explicou que a disciplina PE foi implantada para "superar o caráter generalista" dos cursos de Comunicação. Desde 1988, agravou-se a situação e a frustração dos 
alunos, que exigiam projetos inovadores e reivindicavam às escolas equipamentos e disponibilidade de recursos para sua execução.

Hoje, após 31 anos da implantação dos Projetos Experimentais, momento em que o Brasil tem mais de trezentas escolas de Jornalismo, novos caminhos foram traçados e diversas experiências pedagógicas foram inseridas. A Intercom novamente utilizou seu espaço para analisar, comparar e divulgar, junto à comunidade científica e aos estudantes de todo o Brasil, a riqueza da produção na área de Comunicação. Um desses espaços são as exposições e premiações da Expocom (Exposição da Pesquisa Experimental em Comunicação). A mostra apresenta os melhores trabalhos produzidos anualmente pelas escolas de Comunicação. Assim, os congressos da Intercom tornaram-se o único lugar no Brasil onde é possível avaliar esse crescimento e amadurecimento. E, dentre várias categorias, existe na área de Jornalismo a premiação para livro-reportagem. Nessa modalidade pode-se avaliar o estágio avançado em que as escolas se encontram. A maioria dos trabalhos está preparada para publicação, incorporando as mais modernas técnicas de planejamento gráfico-visual com imagens e fotos, não devendo nada para os livros dos grandes autores.

As experiências reveladas, a cada ano, na Expocom, podem servir de proposta pedagógica para novos modelos de Projetos Experimentais. Sabe-se, hoje, que muitas escolas ainda não adotaram normas específicas para a realização dos Projetos Experimentais. Em alguns casos, fazem adaptações de modelos de outras instituições, sem levar em consideração o perfil do profissional que pretendem formar. Uma vez que os Projetos Experimentais constituem passo importante na formação profissional e acadêmica do aluno, o objetivo desta reflexão é demonstrar que, por meio das experiências pedagógicas, ocorridas em 
duas escolas de Jornalismo no Estado de São Paulo, é possível levar o aluno a vivenciar a produção jornalística e o domínio de técnicas importantes para a sua formação ética e profissional.

Com o desenvolvimento das artes gráficas e a aquisição, por parte das instituições, de equipamentos de informática, os projetos começaram a ganhar uma nova forma. Os professores perceberam que o projeto poderia ser uma estratégia bastante eficiente de ensinar, praticando um ensino de jornalismo aliado à qualidade. O aluno passou a ter orientações semanais em pequenos grupos ou individualmente. Também foram realizadas diversas experiências com novos formatos e uma grande diversificação dos temas.

A prática da grande reportagem propicia um aprendizado para a vida acadêmica e profissional do futuro jornalista. Os estudantes de Jornalismo devem ser incentivados a elaborar grandes reportagens, porque por meio dessa produção e de um acompanhamento intensivo por parte dos orientadores, seu aprendizado se torna mais aprofundado. Além disso, nada supera a experiência de sair a campo e realizar investigações que irão contribuir com a sociedade. O resultado da grande reportagem não precisa, necessariamente, ter o formato de livro. Também pode ser feito destinado a jornais, revistas, documentários de vídeo, rádio documentários ou sites com conteúdo jornalístico.

As disciplinas Projetos Experimentais ou Trabalho de Conclusão de Curso (assim denominadas em algumas IES) devem levar em consideração o contexto necessário para a formação profissional. Por meio da reportagem e do aprendizado da pauta especializada, do texto interpretativo, da investigação e da edição da grande reportagem, os alunos têm a oportunidade de aprofundar e experimentar, em alguns casos, os maiores desafios até então propostos durante a graduação. 
No livro Páginas Ampliadas, o professor e jornalista Edvaldo Pereira Lima cita a importância do livro-reportagem afirmando que por intermédio dele, "é possível exercer um papel extensor do jornalismo impresso cotidiano". Pereira Lima observa que é possível impor três condições para elaboração de uma boa reportagem: 1 contextualização, 2 - mapeamento do tempo e 3 - identificação do tema.

Muito se tem discutido, nesse início de século, qual é o caminho para o Jornalismo. Diversos textos e teorias estão sendo elaboradas para entender uma nova forma de divulgação jornalística. A notícia ainda continua sendo a matériaprima do Jornalismo. As características básicas de um texto jornalístico, como clareza e objetividade, continuam sendo feitos da mesma forma. O que se poderia considerar de novo no texto jornalístico, na verdade, tem apenas outra roupagem. O profissional desta área precisa saber levantar o fato, entrevistar e escrever, visando atingir um leitor ávido de notícias, com uma boa formação cultural. Assim, possivelmente nas próximas décadas veremos muitas transformações no mundo jornalístico, mas não no conceito ético e profissional e na sua estrutura. A mudança de forma e conteúdo está passando por transformações profundas, mas ainda conviveremos por muito tempo com a tradicional mídia eletrônica e impressa.

Ao explicar a importância da notícia, o site Observatório da Imprensa, cita o famoso jornalista americano Gay Talese, "o que um jornal vende são notícias, informações, não necessariamente uma bela embalagem para os olhos. Muitos jornais, tradicionalmente sóbrios no tratamento da informação, têm sucumbido às regras ditadas pelas novas tecnologias e pela televisão. A força da imagem, evidente e indiscutível, gerou um notável complexo de inferioridade nas redações dos jornais. Perdeu-se, freqüentemente, a capacidade de produzir informação relevante e qualificada. Esqueceu-se - o que jamais ocorreu com o New York Times 
- que a melhor arma do jornal para se adaptar às novas tecnologias é a qualidade do seu conteúdo".

Um dos aspectos mais importantes para elaboração de uma reportagem é ter domínio sobre o assunto. O aluno precisa buscar o entendimento, e quando não há clareza nas informações obtidas, deve realizar entrevistas, procurar analogias e exemplos práticos para compreender.

Edvaldo Pereira Lima (2003) analisa assim as interações da literatura contemporânea com a imprensa moderna: "O jornalismo absorve elementos do fazer literário, mas, camaleão, transforma-os, dá-lhes um aproveitamento direcionado a outro fim. A literatura está, até então, basicamente interessada na escrita. Mesmo quando representa o real, por meio da ficção, a factualidade concreta, efetiva - de acontecimentos, personagens e ambientes perfeitamente existentes e nominados, no espaço social verdadeiro - não é, na maioria dos casos o item primordial. [...] Mas, grosso modo, não há na literatura contemporânea aos primórdios da imprensa moderna atual a necessidade do reportar. E é esta tarefa, a de sair do real para coletar dados para retratá-los, a missão que o Jornalismo exige das formas de expressão que passa a importar da literatura, seqüência investigativa que não cabe na notícia. Assim, apura não somente as origens do fato, mas suas razões e efeitos. Abre o debate sobre o acontecimento, desdobra-o em seus aspectos mais importantes e divide-os, quando se justifica, em retrancas diferentes que poderão ser agrupadas em uma ou mais páginas. A notícia não esgota o fato; a reportagem pretende fazê-lo."

O livro-reportagem trabalha com a literatura de realidade, um trabalho autoral que ousa experimentar opções inovadoras de observação, análise e expressão e que "exige a imersão intensa do repórter no cenário sobre o qual escreve, resgata a dimensão humana dos personagens, lança os recursos de linguagem aos extremos da arte de comunicar, gratifica o leitor com inteligência e sensibilidade, instiga a 
descoberta de novos significados, transforma a compreensão do mundo" (LIMA, 2003).

Quem que opta pelo livro-reportagem como formato para seu Projeto Experimental vive experiências que, muitas vezes, não foram possíveis durante toda a graduação, nem mesmo nas práticas laboratoriais oferecidas. A possibilidade com que pode aprofundar, tanto a experimentação das técnicas jornalísticas, quanto a vivência da realidade das questões sociais pode transformar esse aluno em um jornalista mais consciente de seus direitos e deveres.

Assim, quando o futuro jornalista tem a possibilidade de experimentar a elaboração de um livro-reportagem é importante que perceba o seu papel dentro da sociedade, adquirindo uma visão holística, e entenda que a grande reportagem é um formato de fôlego para o jornalismo impresso. O aluno muitas vezes constrói uma reportagem grande, ao invés de uma grande reportagem, pois não consegue perceber, por vezes, que o livro-reportagem, como prática laboratorial na formação do jornalista, é um exercício de cidadania que reúne a construção de uma visão crítica e reflexiva sobre o papel do Jornalismo na sociedade, uma formação centrada nas Ciências Humanas, a percepção mais apurada da realidade, a capacidade de compreender o leitor e a interação entre a teoria e a prática, além da consciência ética profissional.

Com os livros-reportagem, os futuros jornalistas podem trabalhar com a cobertura das questões sociais, valorizando ações que promovam qualidade de vida, impacto social, participação democrática e tornando pública a discussão que afeta diariamente a vida das pessoas. Assim, legitima novos discursos, traz à tona novas idéias, ouve opiniões divergentes e conceitos distintos para fortalecer o debate, oferecendo a informação que permite à sociedade opções de escolha, 
interpretação, participação das decisões democráticas e construção de novos caminhos.

Assim, torna-se importante desenvolver no aluno a descoberta da notícia e a importância da informação precisa e correta. É necessário que o estudante perceba o seu papel dentro da sociedade. É necessário que ele compreenda os mecanismos envolvidos em todo o processo de elaboração de uma reportagem. Desde a pauta, apuração, edição e sua divulgação nos meios impressos ou eletrônicos. Pelas experiências realizadas nas IES sob a forma de Projetos Experimentais foi possível perceber que é produzindo que o aluno adquire uma visão holística e percebe que a reportagem é a essência do trabalho jornalístico.

\subsection{Implantação nas IES}

Para Tarsitano (1999, p. 92), os Projetos Experimentais podem ajudar nobremente na missão de aproximar a academia do mercado. "Basta que tanto o estudante quanto os professores e coordenadores olhem com mais atenção para a importância de se viabilizar os projetos". Porém, na visão do pesquisador, é preciso promover uma urgente reforma no ensino e aprimorar ainda mais os Projetos Experimentais. Reforçando seus argumentos, em sua tese defendida na Universidade Metodista de São Paulo em 1999, ele apresenta a reflexão do Prof. Dr. José Marques de Melo (1991, p. 72-75) sobre os benefícios que foram trazidos com a implantação dos Projetos Experimentais aos cursos de Comunicação, reproduzida quase integralmente abaixo: 
a) A aproximação com o mercado de trabalho tem oxigenado a vida de alguns cursas. A procura de clientes reais contribui para potencializar a iniciativa profissional dos formandos. A presença de clientes ou de profissionais renomados na composição das Bancas Examinadoras funciona como canal de crítica do mercado em relação às diretrizes vigentes nas escolas. Muitas lacunas e distorções começam a ser preenchidas ou corrigidas em decorrência dessas constatações feitas nos exames públicos dos Projetos Experimentais.

b) A demonstração de criatividade e competência feita pelos formandos em seus projetos tem neutralizado a imagem negativa que os empresários alimentavam a propósito das escolas de Comunicação. Trabalhos significativos estão sendo apoiados pelas empresas, governos locais, organizações de serviço. As experiências realizadas pelos estudantes, sob orientação dos professores, acabam sendo absorvidas pelos clientes, que financiam sua implementação real, com resultados satisfatórios.

c) A preparação dos Projetos Experimentais tem servido para explicitar as deficiências didáticas das escolas. Através do acompanhamento das iniciativas dos formandos, os professores orientadores podem verificar as lacunas de conhecimentos, as inadequações metodológicas e as desatualizações tecnológicas decorrentes dos currículos e da infra-estrutura que serviram para formar os futuros profissionais. Na medida em que os estudantes necessitam globalizar os elementos cognitivos adquiridos durante o curso, para efetuar as tarefas dos projetos, as dificuldades enfrentadas podem oferecer indicadores para as mudanças a serem introduzidas na estrutura educacional das instituições. 
d) Algumas monografias apresentadas pelos estudantes de graduação revelam vocações de pesquisadores da Comunicação. Além de contribuir para a estocagem de conhecimentos descritivos sobre os sistemas locais de comunicação, esses trabalhos permitem selecionar futuros candidatos aos cursos de pósgraduação. Ou então, possibilitam o aproveitamento ocupacional desses formandos em atividades de avaliação e planejamento nas empresas ou no serviço público.

e) Através das mostras, festivais e concursos, organizados pelas próprias escolas ou pelas entidades profissionais da área respectiva, vem se configurando uma saudável competitividade entre os formandos. Isso conduz a uma busca de qualidade, eficiência e inovatividade nos Projetos Experimentais, perceptível ano a ano. Desta maneira, o estudante de Comunicação deixa de comportar de forma marginal ao mercado, como ocorrera no anos 70 e grande parte da década de 80 , cobrando das escolas um desempenho pedagógico compatível com suas possibilidades de êxito nas competições profissionais realizadas ao final do curso [...] A natureza dos Projetos Experimentais em cada escola reflete o perfil educacional da instituição - profissionalizante ou academicista -, resgatando a tensão entre a formação básica e a preparação especifica do estudante. Onde a disciplinas do tronco comum assumem um papel hegemônico na preparação do comunicador social, os Projetos Experimentais encaminham-se para a vertente da pesquisa empírica ou da análise de ideologia. Assumem um comportamento geralmente negativo em relação à atividade profissional e nem sempre correspondem às especificidades da respectiva habilitação. Onde predominam os conhecimentos profissionais e a formação teórico-prática se encaminham para capacitar comunicadores especializados, os Projetos Experimentais assumem uma 
dimensão utilitária, articulando-se com as demandas sociais, de modo a buscar respostas para os desafios identificados no meio ambiente.

A ambigüidade existente entre atividades laboratoriais e Projetos Experimentais tem contribuído para a formulação diferenciada dessa equação nas diversas escolas. Algumas rotulam como Projetos Experimentais os veículos, campanhas ou produções realizadas pelos alunos durante o curso, sob a supervisão dos professores, nos laboratórios da universidade. Ao final da carreira, os alunos apresentam Trabalhos de Conclusão de Curso, sob a forma de monografia ou de memórias descritivas dos estudos feitos sobre temas determinados. Outras escolas interpretam ao pé da letra a resolução do CFE e somente possibilitam o acesso dos alunos aos laboratórios e equipamentos profissionais no último semestre do curso, para que editem jornais, produzam vídeos ou realizem campanhas publicitárias. Existem ainda as escolas que estimulam trabalhos de pesquisa bibliográfica, por falta de laboratórios, ou porque privilegiam o estudo da comunicação sob a ótica das Ciências Humanas.

O caráter individual ou coletivo dos projetos constitui uma incógnita para as escolas de comunicação. Algumas prescrevem a natureza individual do projeto. Outras admitem que seja grupal. No primeiro caso, predominam as monografias, mais factíveis de serem realizadas isoladamente. No segundo caso assumem principalmente a turma de produtos, elaboradas para inserção num determinado veículo ou concebidas como ação comunicativa integrada. 
[...] Finalmente, uma questão estratégica. Para que serve o Projeto Experimental? Destina-se a servir como passaporte do aluno para a obtenção do diploma representando mero instrumento da burocracia universitária? Ou pretende ser um elo de ligação do formando com sua atividade profissional, permitindo um diálogo com as formas instituídas de comunicação e possibilitando ao mesmo tempo uma intervenção crítica no mercado? Trata-se de um desafio até agora não enfrentado pelas escolas de Comunicação. Vale a pena refletir sobre ele, pois do seu equacionamento depende o comportamento a ser assumido pelas universidades diante das tarefas que se avizinham, nesta conjuntura de reconstrução democrática e mutações tecnológicas.

As escolas de Comunicação ainda não encontraram seu lugar em nossa sociedade. Através dos Projetos Experimentais elas podem diagnosticar as demandas coletivas e corresponder aos anseios das comunidades locais em que estão inseridos. Se não tiverem sensibilidade para esse diálogo com o meio ambiente poderão converter-se em instituições alienadas, acríticas e inúteis. (MARQUES DE MELO, 1991, p. 72-75)

Tarsitano raciocina sobre como a proximidade entre escola e mercado possibilitada pelos Projetos Experimentais, com profissionais desempenhando duplamente o papel de cliente e avaliador, "é enriquecedora para o estudante que vivencia uma situação real e aprende muito com ela, como para o próprio ensino que igualmente enriquece na medida em que utiliza as críticas que vêm dos profissionais de mercado para aprimorar o trabalho que realiza junto aos seus alunos" (1999, p. 95). E destaca que 
As reflexões feitas por Marques de Meio dão bem uma mostra da importância dos Projetos Experimentais para o ensino de Comunicação no Brasil. Sinalizam que esse processo de aperfeiçoamento está simplesmente sendo iniciado e mostra a necessidade de incrementá-lo; um dos caminhos para isso é a própria melhoria dos projetos, dando-lhe uma finalidade real, levando seu trabalho para que se transforme num instrumento a serviço das comunidades e da sociedade como um todo. (Idem, op. cit.)

O Projeto Experimental, porém, não tem o papel de enfatizar somente os aspectos favoráveis da profissão, nem tampouco demonstrar fragilidades da carreira profissional. Ele é um Projeto porque está em construção, e é Experimental porque oferece múltiplas possibilidades, a principal delas, conquistar e vivenciar experiências das mais variadas formas.

\subsection{Regulamentação}

Para Rocha (1998), os Projetos Experimentais tanto poderiam ser entendidos como atividades de produção e planejamento de bens comunicacionais quanto seria facultada a possibilidade de serem apresentados sob a forma de monografias acadêmicas. Mas algumas IES adotaram a nomenclatura Trabalho de Conclusão de Curso (TCC) para designar monografias, ou seja, resultado de uma produção de pesquisa científica acadêmica. Outras IES utilizam a sigla TCC em que os dois nomes são sinônimos.

A Resolução do nº 002/84 define, no Art. 3ํㅜㄹ que os Projetos Experimentais compreenderão "a produção, no último semestre do curso, de trabalho relacionado com a habilitação específica [...] sempre realizados nos laboratórios da própria escola". Já no Art. 6º , define que $10 \%$ da carga horária mínima total do curso, ou seja, 2700 horas/aula, devem corresponder aos Projetos Experimentais, perfazendo 
um total de 270 horas/aula. No entendimento de Rocha (1998, p. 85), a Resolução pretendia tornar compulsória a prática profissional, contornando, ainda que não diretamente, a inadequação dos currículos ao exercício da profissão. Assim, as escolas de Comunicação que já haviam conseguido um equilíbrio teórico-prático na formação de seus alunos "desconheceram a orientação do CFE e continuaram a incentivar os Projetos Experimentais nos laboratórios didáticos (jornais, revistas, vídeos, filmes, livros, etc.)", primando também pelos projetos monográficos, que ficaram mais conhecidos como "Trabalho de Conclusão de Curso", uma vez que a disciplina constava na grade do último semestre.

Ocorre também certa confusão sobre a nomenclatura adotada para definir Projetos Experimentais, em alguns casos, utilizada como sinônimo de Trabalho de Conclusão de Curso (TCC), em outros como sinônimo de práticas laboratoriais, ou ainda empregada como diferencial entre um trabalho de caráter profissional e outro de caráter acadêmico (como uma monografia, resultado de uma pesquisa científica, por exemplo). O termo monografia, como resultado de pesquisa acadêmica, designa o trabalho científico cuja abordagem se reduz a um único assunto - mono quer dizer um só - sendo monográfico o que se refere a um objeto analisado e descrito.

Um dos estudiosos da área que defendem a substituição do termo Projetos Experimentais - PE - por Trabalho de Conclusão de Curso - TCC é Zapata (apud ROCHA, 1998, p. 88). "O autor explica que é extremamente prejudicial e negativo dizer que alunos, a seis meses de serem profissionais, estão desenvolvendo atividades experimentais. Avalia que, no TCC, o estudante compromete-se com o que faz e mostra que está pronto para enfrentar o mercado de trabalho." Outros consideram o debate quanto aos termos desnecessário, uma vez que os Projetos 
Experimentais "equivalem à última avaliação formal do aluno e, portanto, são Trabalhos de Conclusão de Curso" (idem, op. cit.). O fato é que os estudantes de Comunicação, por natureza muito criativos, usam as siglas TCC e PROJEX para nomear, às vezes com respeito e orgulho, às vezes com temor, o resultado de seus esforços e dedicação.

\subsection{Objetivos e características}

Desde a implantação da Resolução no 002/84, ao longo de mais de três décadas, as experiências realizadas ainda no ambiente acadêmico no que diz respeito à elaboração dos Projetos Experimentais como trabalhos de conclusão de curso ou produtos laboratoriais - e que, por vezes, superam vivências da trajetória profissional - possibilitou a implantação de regulamentos específicos para o desenvolvimento do processo, resultando na formatação de normas e regimentos das IES para o desenvolvimento dos Projetos Experimentais.

Devido à diversidade temática, à profundidade da investigação jornalística, ao papel dos orientadores, ao relato da experiência vivenciada pelos graduandos e à contribuição para a sociedade nas abordagens de questões sociais, os objetivos

e particularidades dos Projetos Experimentais adotados como trabalhos de conclusão de curso são reconhecidos como fundamentais pelos agentes envolvidos, como coordenadores, professores orientadores e avaliadores e alunos.

Para Marques de Melo (2000) a formação dos profissionais da Comunicação Social pressupõe três blocos cognitivos a serem dinamicamente articulados. 0 primeiro está relacionado aos conceitos comunicacionais, pois "são os fundamentos 
que demarcam a identidade do campo acadêmico (embasados na teoria da comunicação de massas' e na 'estrutura dos sistemas midiáticos (indústrias/serviços)" e dos respectivos segmentos ocupacionais. O segundo trata dos processos midiáticos que configuram a produção, difusão e avaliação dos bens culturais correspondentes a cada segmento ocupacional, inclusive as rotinas profissionais, as linguagens, tecnologias e preceitos legais, os métodos de planejamento e gestão, bem como os instrumentos de retroalimentação, no sentido de manter plena sintonia entre as expectativas do mercado consumidor e as estratégias dos produtores culturais e dos patrocinadores.

Marques de Melo destaca como terceiro bloco cognitivo os conteúdos culturais, que dão sentido às mensagens implícitas nos bens simbólicos construídos e/ou difundidos pelas indústrias/serviços midiáticos. "As três dimensões devem compor necessariamente a grade curricular dos Cursos de Comunicação Social, sendo recomendável que sua estrutura resulte de um diálogo permanente entre a universidade, as indústrias / serviços midiáticos e as corporações profissionais" (MARQUES DE MELO, 2000, on line).

\subsection{Agentes envolvidos}

Em algumas IES, tais atribuições são delegadas a um coordenador específico de Projetos Experimentais, cargo exercido geralmente por professores titulados e com experiência em orientação e avaliação de Trabalhos de Conclusão de Curso. Há em regulamentos, inclusive, a descrição detalhada das funções do coordenador que incluem desde o recebimento de fichas de inscrição até a 
distribuição de horas/aulas aos orientadores e o envio das avaliações às secretarias acadêmicas dos cursos.

O ensino do Jornalismo, por variadas circunstâncias, encontra-se vulnerável por vários fatores, entre eles a dificuldade dos professores em considerar a técnica como uma atividade pouco intelectual por parte dos estudantes de Jornalismo. Cabe às IES criar uma cultura acadêmica, dento de seus propósitos como instituição de ensino-pesquisa-extensão de forma que tanto docentes quanto alunos possam entender e usar as novas tecnologias sem perder o foco jornalístico. É preciso considerar que o Jornalismo é uma atividade intelectual e os jornalistas também têm o papel de educadores, reconhecendo que bons jornalistas podem ter presença necessária na comunidade acadêmica.

As IES podem criar meios para motivar seus professores para pesquisar, escrever e publicar sobre Jornalismo, dando exemplo aos alunos e desenvolvendo linhas de pesquisa de pensamento e prática, inclusive com a criação de programas de pós-graduação focados no Jornalismo. O grande desafio das orientações de Projetos Experimentais, em muitos casos, é educar estudantes para pensar criticamente, preparando os futuros jornalistas para serem profissionais de inovação e competência.

É papel da IES estimular o desenvolvimento da cidadania e da responsabilidade social dos profissionais que está formando, propiciando a aplicação de conhecimentos vistos ao longo do curso no desenvolvimento de Projetos Experimentais bem direcionados. O papel dos orientadores é dinamizar as ações didático-pedagógicas, produzindo trabalhos que atendam às expectativas do mercado, estimulando a promoção de parcerias e estreitando as relações com o cenário no qual o futuro jornalista irá atuar. Entre suas atribuições principais estão: 
estimular o desenvolvimento e aprimoramento técnico-profissional do aluno, além de promover e dinamizar a produção do conhecimento.

Para Brum, "a Universidade, assim, ao conservar valores, conhecimentos, a cultura historicamente acumulada, ao recriar, regenerar é o fórum para a transformação individual e coletiva. Mais que formar profissionais, sua tarefa fundamental é contribuir com o desejo utópico de restauração de sujeitos responsáveis" (2003, p. 39). Esse processo pressupõe a questão da autoria, da identificação da figura do jornalista, mentor intelectual do resultado apresentado. $\mathrm{O}$ produto final deve refletir a preparação, ou seja, a formação pessoal e profissional do autor; como se deu sua especialização acadêmica e no ambiente de desenvolvimento do trabalho, como o jornalista (repórter) desenvolveu seu estilo próprio e o que este estilo revela; qual a responsabilidade jurídica, social e política do aluno em relação ao Projeto Experimental elaborado; como se deu a liberdade de imprensa e de expressão do autor; de que maneira se revelam os segredos da profissão e a natureza jurídica e organização da profissão naquilo que o trabalho de conclusão de curso resultou. 


\section{Estruturação dos Projetos Experimentais: Casos Múltiplos}

Dada a complexidade do tema aqui analisado e suas variadas vertentes, optou-se pela realização de um estudo de casos múltiplos para a obtenção dos resultados. De acordo com Yin (2005), o estudo de caso como estratégia de pesquisa compreende um método que abrange tudo - tratando da lógica de planejamento, das técnicas de coleta de dados e das abordagens específicas à análise dos mesmos. "O estudo de caso não é nem uma tática para a coleta de dados nem meramente uma característica do planejamento em si, mas uma estratégia de pesquisa abrangente (STOECKER apud YIN, 2005, p. 33).

Assim, todo estudo de caso pressupõe o detalhamento das escolhas do pesquisador quanto ao corpus e quanto à análise pretendida. No caso dos Projetos Experimentais, uma visão detalhada a respeito das práticas e experiências nas IES poderia demandar em uma coleta de dados de caráter qualitativo, incluindo entrevistas estruturadas com os agentes envolvidos, ou seja, gestores, orientadores, avaliadores e corpo discente. Tal levantamento, porém, não ofereceria a descrição da estruturação tal como é possível verificar no que estabelecem os regulamentos de Projetos Experimentais das IES, objetivo pretendido pela pesquisa.

Uma das mais significativas investigações acerca dos PE no Brasil foi realizada pela pesquisadora Samantha Viana Castelo Branco Rocha, que defendeu o título de Mestre na Universidade Metodista de São Paulo em 1998 com a dissertação "Os desafios dos Projetos Experimentais em Jornalismo". Sob orientação da Prof ${ }^{a}$. Dra. Graça Caldas, a pesquisadora procurou verificar em que 
medida os cursos de Jornalismo à época cumpriam as exigências do Ministério da Educação no que dizia respeito ao desenvolvimento dos Projetos Experimentais e qual a contribuição efetiva para melhorar a formação cultural e profissional dos estudantes da área. A análise se dedicou a três instituições: Faculdade de Comunicação Cásper Líbero, Escola de Comunicações e Artes da Universidade de São Paulo e Pontifícia Universidade Católica de Campinas, tendo como amostra os coordenadores de curso, chefes de departamento e coordenadores de PE, professores orientadores e estudantes matriculados na disciplina no primeiro semestre de 1997, período de coleta de dados.

Os resultados obtidos há mais de uma década revelam que nenhuma das três escolas cumpria integralmente o estabelecido pela Resolução nํ 002/84; não existia uniformidade entre os regulamentos internos das IES; os estudantes desconheciam o processo que envolvia a execução dos Projetos Experimentais; a maioria dos docentes discordava da obrigatoriedade de realização dos PE nos laboratórios das instituições, entre outras conclusões, como a preferência pela orientação por um único professor e pela banca examinadora como a melhor forma de avaliação. À época da pesquisa, a disciplina Projetos Experimentais completava duas décadas de implantação num cenário em que o primeiro curso de Jornalismo no Brasil existia há cinqüenta anos. A opção pelo método qualitativo utilizado na dissertação visou compreender os fenômenos segundo a participação dos sujeitos, ou seja, dos agentes envolvidos na problematização da pesquisa.

A contribuição de Rocha (1998) para os estudos acerca dos Projetos Experimentais é essencial para a compreensão do cenário que se estabelece hoje. Assim, um novo olhar sobre a disciplina pode prescindir do entendimento não só do papel dos agentes envolvidos, como fundamentalmente da maneira como as IES 
estruturaram os PE em suas propostas curriculares. Daí a opção pela análise dos regulamentos que regem os Projetos Experimentais - pois se trata da formalização por meio de documentos - e seu paralelo com o que prevêem as Diretrizes Curriculares Nacionais dos cursos de Comunicação Social (Parecer CNE/CES no 492/2001), em vigor atualmente. A amostra escolhida para análise é a que se detalha a seguir.

\subsection{O cenário nas IES paulistas}

Em 2009, a implantação do primeiro curso superior voltado para a formação em Jornalismo completa mais de seis décadas, uma vez que a Escola de Jornalismo Cásper Líbero - a pioneira - foi criada em 19 de maio de 1947. Por sua vez, a inclusão dos Projetos Experimentais contabiliza pouco mais de quarenta anos, considerando sua implantação em 12 de abril de 1978. Hoje, o Instituto Nacional de Estudos e Pesquisas Educacionais (INEP) do Ministério da Educação informa a existência de 368 cursos de Comunicação Social com habilitação em Jornalismo em funcionamento em todo o país, sendo 103 deles somente no Estado de São Paulo. Incluindo outras habilitações, são 623 cursos espalhados pelo Brasil. Como pólo de produção acadêmica, a Região Sudeste sempre se destacou na área da Comunicação Social e, pela demanda dos cursos oferecidos, percebe-se que quase um terço dos cursos de Jornalismo da região é ofertado em São Paulo.

Os 103 cursos de Jornalismo oferecidos no Estado de São Paulo estão sob responsabilidade de 77 Instituições de Ensino Superior, sendo vinte faculdades particulares, cinco faculdades públicas, vinte e um centros universitários 
particulares, um centro universitário público, vinte e seis universidades particulares e quatro universidades públicas. A maioria dos cursos é ofertada na Capital paulista: 41 cursos têm endereço em São Paulo. As cidades de Osasco, Santos, Campinas e Ribeirão Preto possuem pelo menos três cursos de Comunicação Social com habilitação em Jornalismo em funcionamento atualmente. Do total de cursos descritos no sítio do INEP, quatorze ainda não são reconhecidos no Estado de São Paulo, o que representa mais de $10 \%$ do total. As IES que oferecem cursos reconhecidos anteriormente ao ano de 1998 são dezessete, sendo dezesseis universidades e uma faculdade, a Cásper Líbero.

Foi nesse universo que se estabeleceu a definição da amostra da pesquisa, ou seja, cursos de Jornalismo ofertados no Estado de São Paulo e reconhecidos pelo Ministério da Educação há pelo menos uma década. O marco temporal justifica-se por dois motivos: primeiro, nesse período de tempo houve a transição dos currículos formatados a partir da Resolução no 002/84 para as Diretrizes Curriculares Nacionais dos cursos de Comunicação Social (Parecer CNE/CES no 492/2001); e, segundo, a maior parte das IES consolidou a regulamentação da disciplina Projetos Experimentais nos últimos dez anos. Assim, das dezessete IES que oferecem cursos reconhecidos anteriormente ao ano de 1998, compõem o corpus de análise os regulamentos que regem os Projetos Experimentais (também denominados como Trabalhos de Conclusão de Curso, em alguns casos) das seguintes IES:

- Faculdade Cásper Líbero;

- Escola de Comunicações e Artes da Universidade de São Paulo;

- Pontifícia Universidade Católica de Campinas;

- Pontifícia Universidade Católica de São Paulo; 
- Universidade Católica de Santos;

- Universidade Metodista de São Paulo;

- Universidade de Mogi das Cruzes;

- Universidade de Ribeirão Preto;

- Universidade Santa Cecília;

- Universidade de Taubaté.

A seguir, o detalhamento da amostra da pesquisa enfatiza informações fornecidas pelo INEP (Disponível em: http://www.educacaaosuperior.inep.gov.br) dos cursos de Jornalismo ofertados no Estado de São Paulo e reconhecidos há mais de uma década:

\section{FACULDADE CÁSPER LÍBERO - FCL}

Categoria Administrativa: $\quad$ Faculdade Privada Filantrópica

Data de Criação:

19 de maio de 1947

Data de Reconhecimento:

28 de dezembro de 1949

Início de Funcionamento:

19 de maio de 1947

Município de Funcionamento:

São Paulo - SP

Modalidade:

Ensino Presencial

Carga Horária do Curso:

2752 horas/aula

Prazo para Integralização:

4 anos

Regime Letivo:

Anual

Vagas Autorizadas:

100 vagas no período diurno

100 vagas no período noturno 


\begin{tabular}{|ll|}
\hline \multicolumn{1}{|c|}{ UNIVERSIDADE DE SÃO PAULO - ECA/USP } \\
\hline Categoria Administrativa: & Universidade Pública Estadual \\
Data de Criação: & $1^{\circ}$ de agosto de 1974 \\
Data de Reconhecimento: & $1^{\circ}$ de agosto de 1974 \\
Início de Funcionamento: & 16 de junho de 1966 \\
Município de Funcionamento: & São Paulo - SP \\
Modalidade: & Ensino Presencial \\
Carga Horária do Curso: & 4455 horas/aula \\
Prazo para Integralização: & 10 semestres \\
Regime Letivo: & Semestral \\
Vagas Autorizadas: & 25 vagas no período diurno \\
& 25 vagas no período noturno \\
\end{tabular}

\begin{tabular}{|ll|}
\hline \multicolumn{1}{|c|}{ PONTIFÍCIA UNIVERSIDADE CATÓLICA DE CAMPINAS - PUCCAMP } \\
\hline Categoria Administrativa: & Universidade Privada Confessional Filantrópica \\
Data de Criação: & 10 de outubro de 1969 \\
Data de Reconhecimento: & 26 de novembro de 1974 \\
Início de Funcionamento: & 2 de março de 1970 \\
Município de Funcionamento: & Campinas - SP \\
Modalidade: & Ensino Presencial \\
Carga Horária do Curso: & 2856 horas/aula \\
Prazo para Integralização: & 8 semestres \\
Regime Letivo: & Semestral \\
Vagas Autorizadas: & 90 vagas no período diurno \\
& 90 vagas no período noturno \\
& \\
\hline
\end{tabular}




\begin{tabular}{|ll|}
\hline \multicolumn{1}{|c|}{ PONTIFÍCIA UNIVERSIDADE CATÓLICA DE SÃO PAULO - PUCSP } \\
\hline Categoria Administrativa: & Universidade Privada Confessional Filantrópica \\
Data de Criação: & 10 de outubro de 1969 \\
Data de Reconhecimento: & 26 de novembro de 1974 \\
Início de Funcionamento: & 1 o de março de 1978 \\
Município de Funcionamento: & São Paulo - SP \\
Modalidade: & Ensino Presencial \\
Carga Horária do Curso: & 2820 horas/aula \\
Prazo para Integralização: & 8 semestres \\
Regime Letivo: & Semestral \\
Vagas Autorizadas: & 50 vagas no período diurno \\
& 50 vagas no período noturno \\
\hline
\end{tabular}

\section{UNIVERSIDADE CATÓLICA DE SANTOS - UNISANTOS}

$\begin{array}{ll}\text { Categoria Administrativa: } & \text { Universidade Privada Filantrópica } \\ \text { Data de Criação: } & 27 \text { de novembro de } 1970 \\ \text { Data de Reconhecimento: } & 27 \text { de agosto de } 1974 \\ \text { Início de Funcionamento: } & 1 \text { o de março de } 1971 \\ \text { Município de Funcionamento: } & \text { Santos - SP } \\ \text { Modalidade: } & \text { Ensino Presencial } \\ \text { Carga Horária do Curso: } & 3240 \text { horas/aula } \\ \text { Prazo para Integralização: } & 8 \text { semestres } \\ \text { Regime Letivo: } & \text { Semestral } \\ \text { Vagas Autorizadas: } & 65 \text { vagas no período diurno } \\ & 65 \text { vagas no período noturno }\end{array}$




\section{UNIVERSIDADE METODISTA DE SÃO PAULO - UMESP}

$\begin{array}{ll}\text { Categoria Administrativa: } & \text { Universidade Privada Confessional } \\ \text { Data de Criação: } & 31 \text { de agosto de } 1972 \\ \text { Data de Reconhecimento: } & 13 \text { de fevereiro de } 1976 \\ \text { Início de Funcionamento: } & 1^{\circ} \text { de agosto de } 1972 \\ \text { Município de Funcionamento: } & \text { São Bernardo do Campo - SP } \\ \text { Modalidade: } & \text { Ensino Presencial } \\ \text { Carga Horária do Curso: } & 3240 \text { horas/aula } \\ \text { Prazo para Integralização: } & 8 \text { semestres } \\ \text { Regime Letivo: } & \text { Semestral } \\ \text { Vagas Autorizadas: } & 240 \text { vagas no período diurno } \\ & 80 \text { vagas no período noturno }\end{array}$

\begin{tabular}{|ll|}
\hline \multicolumn{2}{|c|}{ UNIVERSIDADE DE MOGI DAS CRUZES - UMC } \\
\hline Categoria Administrativa: & Universidade Privada \\
Data de Criação: & 12 de dezembro de 1973 \\
Data de Reconhecimento: & 30 de maio de 1977 \\
Início de Funcionamento: & $1^{\circ}$ de março de 1974 \\
Município de Funcionamento: & Mogi das Cruzes - SP \\
Modalidade: & Ensino Presencial \\
Carga Horária do Curso: & 2700 horas/aula \\
Prazo para Integralização: & 8 semestres \\
Regime Letivo: & Semestral \\
Vagas Autorizadas: & 100 vagas no período diurno \\
& 240 vagas no período noturno \\
\hline
\end{tabular}




\section{UNIVERSIDADE DE RIBEIRÃO PRETO - UNAERP}

$\begin{array}{ll}\text { Categoria Administrativa: } & \text { Universidade Privada Filantrópica } \\ \text { Data de Criação: } & 25 \text { de junho de } 1973 \\ \text { Data de Reconhecimento: } & 11 \text { de fevereiro de } 1977 \\ \text { Início de Funcionamento: } & 6 \text { de fevereiro de } 1971 \\ \text { Município de Funcionamento: } & \text { Ribeirão Preto }- \text { SP } \\ \text { Modalidade: } & \text { Ensino Presencial } \\ \text { Carga Horária do Curso: } & 3040 \text { horas/aula } \\ \text { Prazo para Integralização: } & 8 \text { semestres } \\ \text { Regime Letivo: } & \text { Semestral } \\ \text { Vagas Autorizadas: } & 80 \text { vagas no período diurno } \\ & 80 \text { vagas no período noturno }\end{array}$

\section{UNIVERSIDADE SANTA CECÍLIA - UNISANTA}

Categoria Administrativa:

Data de Criação:

Data de Reconhecimento:

Início de Funcionamento:

Município de Funcionamento:

Modalidade:

Carga Horária do Curso:

Prazo para Integralização:

Regime Letivo:

Vagas Autorizadas:
Universidade Privada

16 de novembro de 1992

18 de março de 1997

8 de fevereiro de 1993

Santos - SP

Ensino Presencial

3094 horas/aula

8 semestres

Semestral

60 vagas no período diurno

140 vagas no período noturno 


\begin{tabular}{|ll|}
\hline \multicolumn{1}{|c|}{ UNIVERSIDADE DE TAUBATÉ - UNITAU } \\
\hline Categoria Administrativa: & Universidade Pública Municipal \\
Data de Criação: & 21 de novembro de 1978 \\
Data de Reconhecimento: & 14 de setembro de 1983 \\
Início de Funcionamento: & 1 o de março de 1979 \\
Município de Funcionamento: & Taubaté - SP \\
Modalidade: & Ensino Presencial \\
Carga Horária do Curso: & 3082 horas/aula \\
Prazo para Integralização: & 4 anos \\
Regime Letivo: & Anual \\
Vagas Autorizadas: & 30 vagas no período diurno \\
& 60 vagas no período noturno \\
\hline
\end{tabular}

Fonte: INEP (Disponível em: http://www.educacaaosuperior.inep.gov.br)

\subsection{O papel dos Projetos Experimentais}

A Resolução nำ002/84, estabelecida para o desenvolvimento de Projetos Experimentais, especialmente no último semestre ou ano do curso, recebia a seguinte redação:

Art. 3ํㅡ - Os Projetos Experimentais corresponderão à produção, no último semestre do curso, de trabalho relacionado com a habilitação específica, em forma de monografia, fita gravada de som ou imagem e som, campanha publicitária, plano de editoração ou planejamento de Relações Públicas - sempre realizados nos laboratórios da própria escola.

As Diretrizes Curriculares (Parecer CNE/CES 492/2001) também descrevem o que caracteriza este conjunto de atividades, ou seja, a flexibilidade de carga 
horária semanal, com controle do tempo total de dedicação do estudante durante o semestre ou ano letivo. Esta flexibilidade horária semanal deverá permitir: a adoção de um sistema de atribuição de créditos de horas baseada em decisões específicas para cada caso, projeto ou atividade específica, e em função do trabalho desenvolvido; a ênfase em procedimentos de orientação e/ou supervisão pelo docente; a ampliação da autonomia do estudante para organizar seus horários, objetivos e direcionamento. Destaca-se, neste ponto, que:

O número máximo de horas dedicadas a este tipo de atividade não pode ultrapassar $20 \%$ do total do curso, não incluídas nesta porcentagem de $20 \%$ as horas dedicadas ao Trabalho de Conclusão de Curso (ou Projetos Experimentais). (Parecer CNE/CES 492/2001, vide anexos)

Curiosamente, é o conteúdo descrito na Resolução nº 002/84 que determina o funcionamento de boa parte dos Projetos Experimentais nas IES paulistas, principalmente no que diz respeito à carga horária e ao uso dos laboratórios da instituição obrigatoriamente. Cabe ressaltar que a redação do Art. 3ํ indicava inclusive o suporte midiático para veiculação do conteúdo - fita gravada de som e imagem e som - além de fazer a distinção entre monografia e projeto de caráter profissional. Na mesma medida em que o artigo da Resolução nº 002/84 é bem específico, o item do Parecer CNE/CES 492/2001 também descrevem o que caracteriza a flexibilidade de carga horária e nada mais.

Complementando a informação presente nas Diretrizes Curriculares está O documento que fundamentou o Parecer CNE/CES 492/2001, elaborado pela Comissão de Especialistas de Ensino em Comunicação Social (CEE - Com), deixa claro que o Projeto Acadêmico do Curso deve prever e expor com clareza o conjunto de requisitos necessários ao estudante para integralizar sua formação, 
destacando que a proposta pedagógica deve envolver sobretudo os conceitos e objetivos que dão organicidade ao Curso, o conjunto de disciplinas e demais atividades escolares com as justificativas que dão pertinência àqueles objetivos, os procedimentos de oferta e de interação entre os componentes do Curso e entre docentes e discentes, e todos os demais indicadores que explicitem e organizem o projeto de formação. Para tanto, deve especificar:

- formas de distinção, valorização e divulgação do Trabalho de Conclusão de Curso (com esta denominação ou como Projetos Experimentais) dos discentes, que deve, obrigatoriamente, caracterizar a finalização da formação superior em Comunicação;

- além de bases para uma produção curricular teórica e técnica cuja circulação ou disponibilidade transcenda o público dos corpos docente e discente.

Nessa perspectiva, pressupõe-se que os trabalhos de conclusão do curso possibilitem a sistematização e articulação de conhecimentos adquiridos pelos alunos ao longo de sua trajetória acadêmica, refletindo também a busca de novos saberes teóricometodológicos, ético-estéticos e profissionais. Acredita-se ainda que a realização de projetos contribua para a superação da dicotomia teoria e prática e propicie a construção de um ambiente de produção reflexiva no qual o aluno se torne sujeito do processo de conhecimento, bem como favorecer a criação de uma cultura de pesquisa no curso de Comunicação Social e nas habilitações. (MATTOS, 2005, p. 7)

Todo Projeto Experimental deve ser considerado como um trabalho a ser executado com responsabilidade de elaboração, buscando os resultados esperados com quantificação de benefícios e prazo para execução pré-estabelecidos, considerando os recursos humanos, financeiros, materiais e de equipamentos, bem como as áreas envolvidas necessárias a seu desempenho. É uma iniciativa que visa ao mercado real e resulta na produção de um projeto teórico-prático. Considerando que o aluno de Jornalismo demonstra seu esforço ao realizar o 
Projeto Experimental, tal esforço pode gerar repercussão, que gera oportunidade de trabalho.

Pelo descrito no documento e nas Diretrizes, os Projetos Experimentais incorporam outros objetivos, tais como desenvolver no aluno a capacidade de problematizar e pensar cientificamente os objetos pertinentes e relevantes do campo da Comunicação Social, incrementar a articulação dos diversos saberes adquiridos no curso sob perspectiva inter ou transdisciplinar, sem perder de vista que o objeto central de estudo é a Comunicação Social; promover maior articulação entre conhecimentos teóricos e empíricos, possibilitar a integração entre as pesquisas dos professores e alunos, estimular e qualificar os alunos para 0 ingresso nos cursos de pós-graduação. (cf. MATTOS, 2005, p. 7)

\subsection{Método de análise}

Para o autor Robert K. Yin, que sistematizou o método de estudo de caso em uma obra recente, há uma tendência em se estereotipar esta metodologia com algo sem precisão, objetividade e rigor suficientes. Em defesa, Yin (2005) afirma que o método é modelo freqüente para a pesquisa em diferentes disciplinas e áreas das Ciências Sociais, desde que bem definidos o problema da pesquisa, seu delineamento, a coleta de dados, a análise dos dados e a composição e apresentação dos resultados.

Em geral, os estudos de caso representam a estratégia preferida quando se colocam questões do tipo "como" e "por que", quando o pesquisador tem pouco controle sobre os acontecimentos e quando o foco se encontra em fenômenos contemporâneos inseridos em algum contexto da vida real. (YIN, 2005, p. 19) 
De acordo com Yin (2005), o estudo de caso como estratégia de pesquisa compreende um método que abrange tudo - tratando da lógica de planejamento, das técnicas de coleta de dados e das abordagens específicas à análise dos mesmos. O autor cita que o estudo de caso não é nem uma tática para a coleta de dados nem meramente uma característica do planejamento em si, mas uma estratégia de pesquisa abrangente.

A essência de um estudo de caso, a principal tendência em todos os tipos de estudo de caso, é que ela tenta esclarecer uma decisão ou um conjunto de decisões: o motivo pelo qual foram tomadas, como foram implementadas e com quais resultados. (YIN, 2005, p. 31)

A pesquisa de estudo de caso inclui tanto estudos de caso único quanto de casos múltiplos, utilizando inclusive métodos comparativos, porém a estratégia não deve ser confundida com pesquisa qualitativa. Há cinco aplicações diferentes para um estudo de caso: a mais importante é explicar vínculos, a segunda é descrever um contexto, a terceira é ilustrar certos tópicos, a quarta é explorar situações e a quinta seria uma meta-avaliação, ou seja, o estudo de uma avaliação.

A investigação de estudo de caso enfrenta uma situação
tecnicamente única em que haverá muito mais variáveis de
interesse do que pontos de dados e, como resultado, baseia-se em
várias fontes de evidências, como dados precisando convergir em
um formato de triângulo. E, como outro resultado, beneficia-se do
desenvolvimento prévio de proposições teóricas para conduzir a
coleta e a análise de dados. (YIN, 2005, p. 33)

Assim, o que se pretende analisar com o método de estudo de casos múltiplos é como se dá a estruturação dos Projetos Experimentais por meio de seus regulamentos. Tenta esclarecer uma decisão ou um conjunto de decisões, ou seja, o motivo pelo qual tais regulamentos foram adotados, como foram implementados e com quais resultados. Para tanto, verifica o teor desses regulamentos adotados por 
IES previamente identificadas na amostra, estabelecendo sua relação com instrumentos norteadores do ensino de Jornalismo mais utilizados, como as Diretrizes Curriculares Nacionais para os cursos de Comunicação Social e sua Habilitações. 


\section{Operacionalização de Projetos Experimentais}

Nas Instituições de Ensino Superior do Estado de São Paulo, diferentes experiências foram adotadas para colocar em prática tanto as exigências das diretrizes curriculares previstas pelas portarias e resoluções do Ministério da Educação, quanto para aproximar teoria e práticas laboratoriais. Assim, verifica-se a adoção de parâmetros de funcionamento e elaboração dos Projetos Experimentais nas IES. Boa parte foi idealizada a partir de experiências da própria IES, desde a Resolução № 002/84, nas quais coordenadores, professores e alunos vivenciaram verdadeiros desafios na execução de Projetos Experimentais. Há casos em que a realização de Projetos Experimentais previstos na grade dos cursos existe há mais de duas décadas, permitindo que experiências sejam compartilhadas e aprimoradas.

Em outras IES, a elaboração dos Projetos Experimentais foi inspirada em cursos mais experientes, cuja proposta de execução e avaliação dos Projetos Experimentais já estava fundamentada há algum tempo e permitiu a reprodução de modelos por parte dos cursos mais recentes. É relativamente comum, em alguns casos, a contratação de professores com experiência em outras IES para coordenar os Projetos Experimentais quando um novo curso se aproxima de formar sua primeira turma. Isso porque os Projetos Experimentais, na grande maioria dos casos, estão previstos na carga horária do último ano ou semestre do curso.

A seguir, a definição de Projetos Experimentais nos regulamentos adotados pelas IES que compõem a amostra da pesquisa: 


\section{FACULDADE CÁSPER LÍBERO - FCL}

"A disciplina Projetos Experimentais convida o aluno a desenvolver experimentalmente a criação e a produção de um produto jornalístico ou uma monografia, que possam contribuir com os meios profissionais e acadêmicos aos quais estejam vinculados.

Embora se trate de um campo afeito, por natureza, à experimentação, será exigido do trabalho o rigor necessário à sua realização, pressupondo que os alunos estejam aptos a ingressar, formalmente, no mercado de trabalho. Portanto, os projetos devem apresentar nível profissional inconteste. Quando o trabalho não tiver viabilidade comercial, terá que necessariamente demonstrar relevância cultural.

Um projeto experimental pode seguir o padrão acadêmico ou o padrão jornalístico. Isto significa que o aluno deve optar entre a monografia (em que prevalece a pesquisa científica clássica na área das ciências humanas) e a elaboração de um produto de imprensa (revista, jornal, livro-reportagem, programa de rádio, de televisão ou multimídia ou documentário radiofônico ou televisivo)."

Fonte: "TCC: Guia para consulta" - 2007 (vide anexos)

\section{PONTIFÍCIA UNIVERSIDADE CATÓLICA DE CAMPINAS - PUCCAMP}

"Como é de conhecimento dos que acompanharam o desenvolvimento dos currículos das habilitações em Comunicação Social, a disciplina Projeto Experimental, alocada no último semestre do curso, nasceu a partir da Resolução № 002/84, baixada pelo Ministério da Educação em 24 de janeiro daquele ano (BRASIL, 1984). Em seu texto original, a ementa proposta para a disciplina é genérica para as habilitações em Relações Públicas, Publicidade e Propaganda, e Jornalismo e Editoração, tendo a seguinte redação original:

"Os Projetos Experimentais compreenderão a produção, no último semestre do curso, de trabalho relacionado com a habilitação específica, em forma de monografia, fita gravada de som e imagem ou de som, filme cinematográfico sonoro, publicação impressa, campanha publicitária, plano de editoração, ou planejamento de programas de Relações Públicas, sempre realizados nos laboratórios da própria escola".

Como já tivemos a oportunidade de ressaltar em oportunidade anterior (ZANOTTI, 1999), as monografias, como se viu na ementa, constituem uma alternativa às produções usualmente feitas em rádio, vídeo ou área impressa, entre outras. Portanto, é incorreto dizer que todos os Projetos Experimentais precisam ser acompanhados de uma monografia, embora um texto -ao qual os professores de Jornalismo da PUC-Campinas deram o nome de Relatório de Fundamentação Teórica- deva obrigatoriamente fazer parte de todos estes trabalhos de conclusão do curso, à exceção dos trabalhos monográficos, já que estes não constituem atividade típica da produção jornalística propriamente dita.

$\mathrm{Na}$ Faculdade de Jornalismo da PUC-Campinas, entende-se que todas as práticas profissionais contempladas pelo mercado de trabalho e consumo midiático, na área do jornalismo, encaixam-se como possibilidades de Projetos Experimentais."

Fonte: "A estrutura dos Relatórios de Fundamentação nos Projetos de Jornalismo" - 2005 (vide anexos) 


\section{PONTIFÍCIA UNIVERSIDADE CATÓLICA DE SÃO PAULO - PUCSP}

"Os Trabalhos de Conclusão de Curso (TCCs) constituem a etapa final de formação dos estudantes de Jornalismo da PUC-SP e é requisito indispensável para que o aluno, uma vez aprovado, faça jus ao título de graduado.

O TCC deve permitir que os estudantes, individualmente ou em grupo, acompanhados a partir do 7ㅇ․ Semestre do curso por um professor-orientador, desenvolvam reflexão aprofundada em torno de um tema de relevância para os estudos da Comunicação Social ou do Jornalismo.

Os TCCs com características de Projetos Experimentais são trabalhos desenvolvidos integralmente por um grupo de alunos (no mínimo 3; no máximo 5) sob a perspectiva jornalística, documentária ou teórica com extensão a ser definida em comum acordo entre o grupo e o professor-orientador."

Fonte: "Regulamento dos Trabalhos de Conclusão do Curso de Jornalismo da PUC-SP" - 2006 (vide anexos)

\section{UNIVERSIDADE CATÓLICA DE SANTOS - UNISANTOS}

"O Trabalho de Conclusão de Curso (TCC) na Universidade Católica de Santos deve constituir-se em um trabalho científico no qual o aluno tenha oportunidade de mostrar sua capacidade de produção/sistematização de conhecimentos por meio de um processo reflexivo e crítico.

\section{Características do TCC na UNISANTOS}

a) O TCC é entendido como etapa conclusiva do processo de ensino-aprendizagem do aluno, devidamente conceituado e definido nos Projetos Políticos Pedagógicos dos Cursos. Portanto, mais do que uma exigência legal estabelecida nas Diretrizes Curriculares, o TCC deve ser significativo para a formação profissional e para o perfil do egresso.

b) O TCC é resultado de um processo integrador/interdisciplinar de acordo com o estabelecido pelos Projetos Políticos Pedagógicos dos Cursos."

Fonte: "Guia Acadêmico Unisantos" - 2007 (vide anexos)

\section{UNIVERSIDADE METODISTA DE SÃO PAULO - UMESP}

"Os Projetos Experimentais (PE's) no Curso de Jornalismo da Umesp objetivam finalizar a formação do aluno no âmbito da graduação, por meio de um trabalho mais aprofundado nas áreas teórica ou prática, aperfeiçoando, assim, o processo de reflexão na área, sendo obrigatório para obtenção do título de bacharel em Comunicação Social - habilitação Jornalismo. O PE é uma oportunidade para o aluno realizar, com supervisão de um professor do Curso, um trabalho criterioso e de qualidade sobre o tema de sua preferência e na área de sua escolha: livro-reportagem, revista impressa, jornal impresso, assessoria de comunicação, vídeo-doćumentário, telejornal, radiojornal, jornalismo digital, fotojornalismo ou monografia.É uma disciplina regular da grade curricular e passou a ser regulamentada com normas aprovadas pelo Colegiado do Curso, a partir do ano 2000.

Nesse sentido, os PE's do Curso de Jornalismo estão centrados no objetivo de contribuir para a formação de jornalistas conscientes de seu papel de formadores de opinião na sociedade e incentivar críticas, questionamentos e contribuições referentes ao jornalismo praticado em diferentes áreas, veículos e empresas."

Fonte: "Regulamento dos Projetos Experimentais do Curso de Jornalismo" - 2005 (vide anexos) 


\section{UNIVERSIDADE DE MOGI DAS CRUZES - UMC}

"Conforme determinação do MEC, Parecer 480/83 de 6 de outubro de 1983, entende-se por projeto experimental a produção, no último ano do curso, de trabalho relacionado com a habilitação específica, em forma de monografia, fita gravada de som e imagem ou de som, filme cinematográfico sonoro, publicação impressa, campanha publicitária, plano de editoração - sempre realizados nos laboratórios da própria escola. O Projeto Experimental é de caráter obrigatório para a obtenção do certificado de conclusão do curso.

O Projeto Experimental, no curso de Comunicação Social da Universidade de Mogi das Cruzes é organizado de forma a solidificar os conhecimentos adquiridos no decorrer dos quatro anos em que se desenvolve o curso. O objetivo é promover a vinculação entre os temas e conteúdos abordados nas disciplinas a um projeto experimental, no qual se evidencie a prática embasada em fundamentos metodológicos e teóricos, que contribua para a formação profissional do corpo discente."

Fonte: "Projeto Vôo Solo" - 2008 (vide anexos)

\section{UNIVERSIDADE DE RIBEIRÃO PRETO - UNAERP}

"Art.1 Este regulamento dispõe sobre a monografia de Pesquisa em graduação, que constitui pré-requisito para a conclusão do curso de graduação em Comunicação Social habilitações em Jornalismo e Publicidade e Propaganda - de acordo com o Novo Currículo, de n 295 (Jornalismo) e de n 296 (Publicidade e Propaganda), aprovado em reunião do Conselho de Ensino e Pesquisa da Universidade de Ribeirão Preto, em 8 de dezembro de 1997.

Art.2 As atividades referentes à elaboração da Monografia de Pesquisa em Comunicação serão desenvolvidas basicamente na Atividade Complementar II_ prevista no currículo pleno do curso de Comunicação Social, desta Universidade com a duração de dois semestres, conforme as determinações regimentais do Curso de Comunicação Social. Art.5 Para efeitos deste Regulamento entende-se:

I-Monografia de Pesquisa em Comunicação: "Item não seriado, isto é, completo, constituído de uma só parte, ou que se pretende completar em um número preestabelecido de partes separadas".

§1 A monografia de pesquisa em Comunicação terá caráter eminentemente didático, como treino e iniciação à investigação científica.

§2 Para sua elaboração, não se exigirá que o trabalho seja a comunicação de uma nova teoria, de nova explicação e interpretação dos fatos ou a investigação científica com a característica da originalidade. Exigir-se-á, todavia, que seja pessoal, fruto de reflexão e rigor científico."

Fonte: "Regulamentação da Monografia de Pesquisa em Comunicação para Conclusão do Curso" - 2002 (vide anexos)

\section{UNIVERSIDADE SANTA CECÍLIA - UNISANTA}

“Art. 3․ - O TCC consiste em um estudo aprofundado sobre determinado tema de interesse, vinculado ao Curso no qual o aluno está se graduando.

Art. 40. - O TCC propicia a complementação do processo ensino-aprendizagem. É planejado, executado, acompanhado e avaliado conforme os conteúdos programáticos e calendários escolares, constituindo-se em enriquecimento curricular, no que tange ao aperfeiçoamento técnico-cultural, científico e humano."

Fonte: "Diretrizes para Elaboração de Trabalho de Conclusão de Curso de Graduação (TCC)" - 2007 (vide anexos) 


\section{UNIVERSIDADE DE TAUBATÉ - UNITAU}

“Art. 2. O Projeto Experimental consiste em um estudo aprofundado no nível de Graduação - Monografia ou Trabalho Profissional - sobre tema vinculado à habilitação na qual o aluno estará se formando - Jornalismo, Publicidade e Propaganda e Relações Públicas, sob a orientação de um professor escolhido pelo graduando.

Art. 3. O Projeto Experimental tem como objetivo possibilitar uma organização sistemática dos conhecimentos adquiridos durante os 4 anos do curso pelo aluno, além de fornecer subsídios para desenvolver pesquisas e descobrir soluções para a área de Comunicação Social."

Fonte: "Normas para Elaboração dos Projetos Experimentais" - 2008 - (vide anexos)

\subsection{Estrutura Curricular}

Toda proposta pedagógica envolve conceitos e objetivos que dão uma forma organizada a um curso superior. Para tanto, deve expor de forma clara o projeto de formação, destacando as habilidade e competências que se pretende formar. Para que haja clareza na exposição de uma proposta pedagógica, é preciso trabalhar com direcionamento, planejamento e requisitos muito claros. Para o professor Erom Brum, em artigo da obra Retratos do Ensino em Comunicação no Brasil (2005),

A construção de um projeto pedagógico é um trabalho coletivo, fruto de contribuições, vivências, histórias de vida, práticas e reflexões individuais. Tal projeto não pode ser absoluto, nem tampouco acabado, mas pode e deve ter as linhas mestras que conduzem os debates e as reflexões sobre os caminhos que educandos e educadores devem trilhar. Mais que estabelecer grades curriculares 'modernas', o projeto pedagógico para um curso de Jornalismo deve ser instrumento e fórum permanente para a discussão de elementos fundamentais para a formação de profissionais, quais sejam: a noção de jornalismo que perseguimos, as teorias e os métodos apropriados, a difícil e necessária prática interdisciplinar, as habilidades e as competências desejáveis a este profissional, 0 papel ético e cultural que se pretende à Universidade e, por conseqüência, a seus formandos. (BRUM, 2003, p. 29) 
Um projeto pedagógico deve prever um processo de formação na busca de um aperfeiçoamento qualitativo, mantendo um relacionamento estreito com o mercado de trabalho de forma a observar seu funcionamento e direcionar suas práticas de forma crítica e adequada à realidade em que o curso está inserido. Como a grande maioria dos cursos do país se mantém estruturada conforme orienta a Resolução oㅜ 002/84, do então Conselho Federal de Educação (CFE), existe uma expressiva diferença em relação aos cursos que obtiveram autorização de funcionamento mais recentemente e que já foram estruturados com base nas novas Diretrizes Curriculares. Para Brum, os cursos mais antigos têm agora a oportunidade e o compromisso de promoverem as adequações necessárias às expectativas e ao dinamismo da sociedade.

O parecer CNE/CES 492/2001, que instituiu as novas Diretrizes, além de procurar estabelecer orientações para a obtenção de padrão de qualidade na formação, objetiva flexibilizar a estruturação dos cursos, tanto para atender a variedades de circunstâncias geográficas, político-sociais e acadêmicas, como para ajustar-se ao dinamismo da área, e para viabilizar o surgimento de propostas pedagógicas inovadoras e eficientes. Esta flexibilização está proporcionando às universidades - professores, estudantes e colaboradores - o estudo de alterações mais significativas em tais estruturas. Este, portanto, é um momento rico e produtivo para o processo de construção dos cursos - o debate está aberto, e amplia-se para auscultar anseios e necessidades do mercado profissional e da sociedade como um todo. (BRUM, 2003, p. 30)

Considerando que boa parte dos cursos de Jornalismo se encontra em pleno processo de reformulação, ou que pretenda encarar tal desafio recentemente, Brum propõe a reflexão sobre alguns aspectos em torno das vertentes teóricas e práticas, metodológicas e didáticas que possam contribuir para a formação de jornalistas que, "além de capazes tecnicamente, tenham a oportunidade de ampliar sua visão de mundo e, sobretudo, desenvolverem a sensibilidade para atribuir significados ao momento histórico em que se vive" (2003, p. 31). 
É necessário considerar que um projeto pedagógico deve assegurar uma efetiva interação com a sociedade, cumprindo a responsabilidade de fornecer recursos humanos capacitados, que demonstrem habilidades e competências para o mercado de trabalho. Trata-se ainda de prever práticas extensionistas ajudem a integrar as atividades do campo da Comunicação Social com aquelas desenvolvidas pelas instituições de ensino superior. Por esse raciocínio, pode-se compreender que um relato das ações humanas é fruto da observação/percepção e, ao mesmo tempo, da reflexão desses fenômenos.

\begin{abstract}
A partir dessa consciência e responsabilidade inerentes a cada profissional, podemos assinalar aqui os atributos que consideramos indispensáveis para a prática jornalística: $\mathrm{O}$ compromisso do comunicador envolve a observação e reflexão de mundo, de modo que, percebendo-o, possa expressá-lo. Não Ihe cabe, portanto, somente a função técnica, mas a função social de comprometer-se com o mundo, de reconhecer que sua autoria responsável deve ser fruto do diálogo social, de sua cumplicidade/solidariedade com o público - os outros seres humanos. Assim, as habilidades e competências específicas preconizadas pelas novas Diretrizes podem ser conseqüências, ou frutos, dessa concepção de 'habilidades essenciais', dessa perspectiva que atribui ao sercomunicador muito mais que o "noticiar fatos", mas a expressão contextualizada e significativa de mundo. (BRUM, 2003, p. 34)
\end{abstract}

Trata-se de discutir, debater a diversidade de questões que afligem a formação do profissional da área de Comunicação Social, mais especificamente do Jornalismo mundo, para que não se incorra em juízos precipitados ou pouco refletidos. "Além dessa relação horizontal entre as habilidades e os desafios, devese pensar nas relações verticais e transversais entre estes pontos", salienta Brum. Toda a estrutura do projeto pedagógico deve contemplar não só as características do currículo, mas a qualificação do corpo docente, a infra-estrutura física e os recursos disponíveis, a possibilidade das práticas laboratoriais, a integração ensinopesquisa e extensão e os processos de avaliação e acompanhamento. 
Para Brum, "a Universidade, assim, ao conservar valores, conhecimentos, a cultura historicamente acumulada, ao recriar, regenerar é o fórum para a transformação individual e coletiva. Mais que formar profissionais, sua tarefa fundamental é contribuir com o desejo utópico de restauração de sujeitos responsáveis" (2003, p. 39). Assim, é preciso adequar o projeto pedagógico do curso com as condições sócio-econômicas e culturais existentes da região em que estiver o curso localizado, valorizando a formação de profissionais atentos às demandas regionais.

Parece que a grande reflexão para a construção de um projeto pedagógico - e mais que isso, a sua execução e a permanente realimentação - exige de jornalistas-educadores a compreensão de que, acima de "ensinar jornalismo", nosso maior desafio é continuar "aprendendo jornalismo". Tentar acompanhar os recursos das inovações tecnológicas é imprescindível, mas é igualmente necessário ampliar nossa visão de mundo e ter a humildade de reconhecer que o ensinar é indissociável do aprender. A mesma humildade - por favor, não confundir com subserviência - deve ser adotada para o saudável, rico e inadiável diálogo de saberes. (BRUM, 2003, p. 43)

No texto das Diretrizes Curriculares, Parecer CNE/CES 492/2001, os

Projetos Experimentais são mencionados no item 4, dedicado aos estágios e Atividades Complementares, com a seguinte redação:

O que caracteriza este conjunto de atividades é a flexibilidade de carga horária semanal, com controle do tempo total de dedicação do estudante durante o semestre ou ano letivo. Esta flexibilidade horária semanal deverá permitir a:

a) adoção de um sistema de creditação de horas baseada em decisões específicas para cada caso, projeto ou atividade específica, e em função do trabalho desenvolvido;

b) ênfase em procedimentos de orientação e/ou supervisão pelo docente;

c) ampliação da autonomia do estudante para organizar seus horários, objetivos e direcionamento.

O número máximo de horas dedicadas a este tipo de atividade não pode ultrapassar $20 \%$ do total do curso, não incluídas nesta porcentagem de $20 \%$ as horas dedicadas ao Trabalho de Conclusão de Curso (ou Projetos Experimentais). 
Tal redação permite a interpretação do mesmo parâmetro adotado anteriormente pela Resolução nº 002/84, que recomendava $10 \%$ da carga horária do curso dedicada aos Projetos Experimentais. Por se tratar de uma carga horária ampla e, considerando-se as questões de infra-estrutura das IES, percebe-se que a adoção de normas e regulamentos objetiva facilitar o processo de elaboração dos Projetos Experimentais.

\subsection{Normatização}

Denominados como normas, regulamentos, regimentos, instruções e até mesmo manuais e cartilhas, os parâmetros - como conjunto de características e especificações para a elaboração de Projetos Experimentais - têm sido adotados pelas IES de forma ampla e variada. Sua utilização é vista de forma positiva na maioria das IES, visto que permite nortear a produção dos Projetos Experimentais em diferentes etapas, considerando particularidades no que se refere aos agentes envolvidos - coordenadores, professores orientadores e avaliadores e alunos.

Os regulamentos, como são comumente nomeados, descrevem várias particularidades relativas aos Projetos Experimentais, tais como:

- a definição e/ou conceituação de Projetos Experimentais ou Trabalhos de Conclusão de Curso;

- quais os agentes envolvidos e seus respectivos papéis e responsabilidades;

- a partir de qual momento e em que prazo deve ser realizado;

- quais os formatos possíveis, incluindo a monografia (resultado de uma pesquisa científica) e os suportes profissionais (rádio, TV, impresso, assessoria, etc.); 
- quais os pré-requisitos para a elaboração dos Projetos Experimentais;

- quais as especificações e condições materiais para a realização dos projetos;

- como, onde e quando devem ser realizadas as orientações e quais as atribuições dos professores orientadores e avaliadores;

- como se dará o processo de avaliação dos Projetos Experimentais, incluindo elaboração de relatórios de produção e de freqüência, pré-bancas e bancas examinadoras finais;

- modelos de formatação dos Projetos Experimentais, incluindo normas da ABNT para configuração e citação de autores e referências;

- modelos de fichas de avaliação, entre outras informações.

É importante ressaltar que os regulamentos auxiliam o processo de execução e avaliação, tanto para orientadores quanto para alunos, porém existe, em algumas situações, o risco de uma padronização no resultado final dos projetos. O que ocorre é que as experiências vividas pelas IES vão alimentando o que se pode ou o que se torna obrigatório e também o que passa a ser proibido na realização dos projetos. Isso acaba por restringir o processo criativo do aluno, uma vez que novos modelos podem enfrentar resistência num processo de avaliação dos Projetos Experimentais.

Há ainda a preocupação dos docentes em relação às chamadas "fôrmas de bolo", ou seja, mudam-se os ingredientes - no caso do Jornalismo, as pautas mas o resultado continua o mesmo. Isso ocorre porque orientadores seguem uma linha fechada de orientação para a realização dos projetos, indicando as mesmas referências de leitura e até mesmo projetos anteriores como modelos, inclusive no que se refere ao projeto gráfico. Para os alunos, trata-se de uma preocupação a menos, uma vez que têm que dar atenção ao TCC ao mesmo tempo em que 
cumprem disciplinas, participam de órgãos laboratoriais como revistas e telejornais e, em muitos casos, realizam estágios em veículos dentro e fora das IES.

Das Universidades averiguadas, a maioria mantém normas e regulamentos para a execução dos Projetos Experimentais, material disponibilizado em brochuras nas bibliotecas ou em arquivos no formato PDF em sites dos cursos.

A seguir, a definição do caráter dos regulamentos de Projetos Experimentais adotados pelas IES que compõem a amostra da pesquisa, expresso no próprio material:

\section{PONTIFÍCIA UNIVERSIDADE CATÓLICA DE SÃO PAULO - PUCSP}

"As presentes normas são obrigatórias, portanto, para todos os estudantes do curso e tomam como base regulamentos congêneres existentes em outras Faculdades de Comunicação Social com habilitação em Jornalismo, respeitadas as especificidades do projeto pedagógico da Pontifícia Úniversidade Católica de São Paulo. Ao mesmo tempo, obedecem as disposições da Associação Brasileira de Normas Técnicas (ABNT).

Estão incluídos neste documento parâmetros gerais que podem servir como roteiro de avaliação para as comissões julgadoras dos TCCs."

Fonte: "Regulamento dos Trabalhos de Conclusão do Curso de Jornalismo da PUC-SP" - 2006 (vide anexos)

\section{UNIVERSIDADE CATÓLICA DE SANTOS - UNISANTOS}

"Para a graduação exige-se do aluno a elaboração de um Trabalho de Conclusão (TCC/TFG). Cada curso possui regulamento específico para seu trabalho de conclusão, conforme diretrizes da Pró-Reitoria Acadêmica. Caberá a cada Curso a elaboração de normas ou regulamentos para o desenvolvimento das atividades acadêmicas e administrativas do TCC."

Fonte: "Guia Acadêmico Unisantos" - 2007 (vide anexos)

\section{UNIVERSIDADE DE RIBEIRÃO PRETO - UNAERP}

"Art.1 Este regulamento dispõe sobre a monografia de Pesquisa em graduação, que constitui pré-requisito para a conclusão do curso de graduação em Comunicação Social habilitações em Jornalismo e Publicidade e Propaganda - de acordo com o Novo Currículo, de n 295 (Jornalismo) e de n 296 (Publicidade e Propaganda), aprovado em reunião do Conselho de Ensino e Pesquisa da Universidade de Ribeirão Preto, em 8 de dezembro de 1997." 


\section{UNIVERSIDADE METODISTA DE SÃO PAULO - UMESP}

"Este regulamento contém as normas para elaboração e apresentação dos Projetos Experimentais (PE's), do curso de Jornalismo, da Faculdade de Jornalismo e Relações Públicas, da Universidade Metodista de São Paulo.

As regras aqui definidas têm como base o Regulamento do curso e as Normas da Associação Brasileira de Normas Técnicas (ABNT). Também oferece parâmetros para a apreciação dos trabalhos pelas bancas examinadoras, além de auxiliar o estudante de graduação na elaboração de seu Projeto Experimental.

Este Regulamento entra em vigor em 16 de fevereiro de 2004 (aprovado em reunião do Colegiado do Curso), tornando-se obrigatório para todos os alunos do curso."

Fonte: "Regulamento dos Projetos Experimentais do Curso de Jornalismo" - 2005 (vide anexos)

\section{UNIVERSIDADE SANTA CECÍLIA - UNISANTA}

"A Universidade Santa Cecília (UNISANTA), atenta à produção, ao registro e à divulgação do conhecimento no âmbito da universidade, traz aos corpos docente e discente a segunda versão das Diretrizes Para Elaboração de Trabalho de Conclusão de Curso de Graduação (TCC), dividida em três partes.

Num primeiro momento, seguem normas destinadas à realização dos Trabalhos de Conclusão de Curso dos diversos Cursos de Graduação mantidos pela Universidade Santa Cecília (UNISANTA). Todo e qualquer TCC desenvolvido nesta Universidade, a partir do $1^{\circ}$. semestre letivo de 2007, passa a ser regido por tais diretrizes, devidamente apreciadas e aprovadas pelo Conselho de Ensino, Pesquisa e Extensão de Serviços à Comunidade e homologadas pelo Conselho Universitário.

Em segundo lugar, aponta-se a estrutura formal de um trabalho científico, com a devida explanação de cada elemento constitutivo de um texto acadêmico. Em terceiro plano, colocam-se instruções gerais para elaboração de trabalhos acadêmicos."

Fonte: “Diretrizes para Elaboração de Trabalho de Conclusão de Curso de Graduação (TCC)” - 2007 (vide anexos)

\section{UNIVERSIDADE DE TAUBATÉ - UNITAU}

"Este regulamento visa estabelecer as diretrizes gerais para as atividades relacionadas com o Projeto Experimental do currículo pleno do curso de Comunicação Social da Universidade de Taubaté. Os casos omissos neste Regulamento serão resolvidos pela Comissão de Projetos Experimentais."

Fonte: "Normas para Elaboração dos Projetos Experimentais" - 2008 - (vide anexos) 


\subsection{Coordenação}

A operacionalização dos Projetos Experimentais exige infra-estrutura e também a gestão de diferentes processos que englobam desde a inscrição e/ou definição dos trabalhos, o planejamento das ações, o agendamento dos horários de orientação, a distribuição de carga horária para os professores orientadores, a utilização dos laboratórios até as pré-bancas e bancas examinadoras finais.

Em algumas IES, tais atribuições são delegadas a um coordenador específico de Projetos Experimentais, cargo exercido geralmente por professores titulados e com experiência em orientação e avaliação de Trabalhos de Conclusão de Curso. Há em regulamentos, inclusive, a descrição detalhada das funções do coordenador que incluem desde o recebimento de fichas de inscrição até a distribuição de horas/aulas aos orientadores e o envio das avaliações às secretarias acadêmicas dos cursos.

A carga horária de um coordenador de Projetos Experimentais varia entre 10 h/a $20 \mathrm{~h} / \mathrm{a}$, mas há registros de coordenadores atuando por apenas 2 h/a, o que impossibilita um efetivo acompanhamento de todo o processo, sobrecarregando o docente que, muitas vezes, acumula várias atividades associadas ou não aos Trabalhos de Conclusão de Curso.

Outras IES atribuem ao coordenador de área ou de curso, geralmente nomeado de Coordenador de Jornalismo, também a função de gerir o desenvolvimento de Projetos Experimentais. Em IES particulares esta é uma realidade que está relacionada ao enxugamento de custos na distribuição de horasaulas. Há de se destacar também que a função de coordenador pressupõe intenso trabalho burocrático, geralmente com o manejo de fichas e formulários de 
freqüência e de avaliação, sem contar o desafio de montar as grades de bancas examinadoras finais.

Tal atividade é a mais trabalhosa para os coordenadores e coincide com o período de fechamento de semestre ou ano letivo, quando os professores orientadores - e também aqueles que não o são - estão envolvidos com provas, trabalhos, entregas de notas e cumprimento da carga horária e dos programas de ensino das disciplinas que ministram. A composição das bancas examinadoras trata-se de um verdadeiro quebra-cabeça para os coordenadores, que têm que definir datas, horários, locais de apresentação dos trabalhos e ainda quem serão os componentes das bancas, o que inclui o professor orientador e ao menos dois professores avaliadores que tenham afinidade com o tema do Projeto Experimental, ou com o formato e suporte (vídeo, rádio, impresso, etc.), e ainda estejam disponíveis na data agendada para a banca examinadora.

Este é o momento em que o coordenador de Projetos Experimentais deve demonstrar imensa capacidade de negociação e se revelar um bom estrategista, a fim de que todas as bancas recebam a atenção necessária para uma avaliação cuidadosa e isenta.

Durante o processo de execução dos Projetos Experimentais, cabe aos coordenadores fazer com que os regulamentos sejam cumpridos, que o uso de laboratórios seja adequado, que o relacionamento orientador-aluno seja cordial e expressivo, gerando os resultados esperados. A seguir, a definição das atribuições do coordenador de Projetos Experimentais expressa nos regulamentos adotados pelas IES que compõem a amostra da pesquisa: 


\section{FACULDADE CÁSPER LÍBERO - FCL}

"O coordenador de projetos experimentais é o professor da Faculdade Cásper Líbero designado para esta função pelo coordenador do Curso de Jornalismo. As decisões, pareceres, anúncios e deliberações da coordenação de projetos experimentais serão sempre publicados no site da Coordenaria de Jornalismo.

O coordenador é responsável pela organização das atividades ligadas aos projetos e das etapas de avaliação dos trabalhos até a realização da banca examinadora, pela fiscalização e pelo cumprimento do regulamento por parte de alunos e orientadores e pela organização das bancas. O coordenador presidirá todas as bancas, exceto quando ele próprio for orientador do trabalho apresentado ou quando forem realizadas mais de uma banca no mesmo horário.

Neste caso, um outro membro da comissão de projetos experimentais assumirá a função. Compete ao coordenador não só presidir a mesa, mas também mediar o debate entre alunos e argüidores, e a deliberação dos argüidores para atribuição da nota."

Fonte: “TCC: Guia para consulta" - 2007 (vide anexos)

\section{PONTIFÍCIA UNIVERSIDADE CATÓLICA DE SÃO PAULO - PUCSP}

"O acompanhamento geral das atividades decorrentes da escolha dos temas dos TCCs, da definição dos professores-orientadores, da composição das bancas, do calendário geral de apresentações e dos resultados finais obtidos pelos alunos ficará a cargo da Coordenação Geral dos Trabalhos de Conclusão de Curso do Departamento de Jornalismo, exercida por docente escolhido por seus pares.

Caberá a essa Coordenação a elaboração de eventuais critérios específicos para cada uma das modalidades de TCCs, critérios esses que deverão ser levados em conta nas atividades de orientação dos alunos."

Fonte: "Regulamento dos Trabalhos de Conclusão do Curso de Jornalismo da PUC-SP" - 2006 (vide anexos)

\section{UNIVERSIDADE CATÓLICA DE SANTOS - UNISANTOS}

\section{"Funções do professor responsável}

a) Acompanhar todas as atividades inerentes à realização do TCC.

b) Responsabilizar-se pelos trâmites administrativos junto à Secretaria, mantendo a Direção do Centro/Coordenação do Curso informadas.

c) Atender aos grupos/alunos no que se refere a orientações de caráter geral, prazos, normas ou regulamentos.

d) Elaborar a listagem dos orientadores credenciados.

e) Encaminhar aos orientadores a relação dos TCC e dos grupos/alunos a eles destinados.

f) Manter com os orientadores espaço para discussão das atividades inerentes ao processo de orientação e o adequado desenvolvimento do TCC.

g) Garantir o processo de orientação dos alunos (em grupo ou individual).

h) Organizar o processo de apresentação do TCC, elaborando o respectivo cronograma.

i) Quando a apresentação do TCC exigir banca examinadora caberá ao professor responsável homologar os nomes indicados para compô-la.

j) Garantir o cumprimento das normas ou regulamentos do TCC pelos orientadores e grupos/alunos."

Fonte: "Guia Acadêmico Unisantos" - 2007 (vide anexos) 


\section{UNIVERSIDADE METODISTA DE SÃO PAULO - UMESP}

“A Coordenação dos Projetos Experimentais atuará como mediadora entre a Coordenação do Curso de Jornalismo e os grupos formados por alunos e professores orientadores. “

Fonte: "Regulamento dos Projetos Experimentais do Curso de Jornalismo" - 2005 (vide anexos)

\section{UNIVERSIDADE DE RIBEIRÃO PRETO - UNAERP}

\section{"Da Comissão de Monografia em Comunicação}

Art.19 A Comissão de Monografia em Comunicação, do Curso de Comunicação, tem caráter de coordenação, ressalvada a autonomia intelectual, didática e pedagógica dos professores orientadores, e seus estudos, pareceres, relatórios e decisões ficam submetidos ao Núcleo de Produção Científica em Comunicação.

Art.20 A comissão, constituída por ato do Coordenador do Curso, será composta por até 3 (três) membros do corpo docente lotados ou não no Curso de Comunicação Social, escolhidos e indicados em conformidade com as normas da Instituição. A Comissão será presidida por um de seus membros.

Art.21 A Comissão reunir-se-á ordinariamente de acordo com o seu calendário, e extraordinariamente, por necessidade de deliberação urgente ou quando convocada pelo Coordenador do NPC ou pelo Coordenador do Curso de Comunicação.

Art. 22 São atribuições e competência da Comissão:

I. Deliberar sobre as atividades regulares, apreciando os pareceres ou documentos que Ihe forem encaminhados, e emitir pareceres, obedecidas as diretrizes deste Regulamento.

II. Responder às consultas encaminhadas pelo Coordenador do Núcleo de Produção Científica, coordenador do curso, membros do Corpo Docente e outros.

III. Emitir parecer sobre recursos interpostos.

IV. Rever suas próprias decisões ou pedidos de reconsideração, quando postulados, em razão de fato novo que a justifique.

V. Elaborar o calendário semestral da Comissão.

VI. Supervisionar a elaboração do horário, local e data da realização das Bancas Examinadoras.

VII. Distribuir eqüitativamente as monografias entre os Professores do Curso, compatibilizando-se, quando possível, a área de atuação do Professor.

Art.23 Compete ao Presidente da Comissão de Monografia em Comunicação:

I. Presidir a Comissão.

II. Determinar a distribuição e a ordem dos trabalhos, bem, como conduzi-los.

III. Conceder vistas de processos.

IV. Comunicar ao Coordenador do Núcleo de Produção Científica em Comunicação as deliberações da Comissão e as que reclamem providências ulteriores.

V. Assinar os atos resultantes das deliberações e decisões da Comissão no prazo de até 3 (três) dias úteis após a reunião da mesma.

Art.24 A Secretaria do Núcleo de Produção Científica em Comunicação auxiliará a Comissão, no que couber."

Fonte: "Regulamentação da Monografia de Pesquisa em Comunicação para Conclusão do Curso" - 2002 (vide anexos) 


\section{UNIVERSIDADE DE TAUBATÉ - UNITAU}

“Art. 5. Compete à Coordenação de Projetos Experimentais:

I - atender aos alunos matriculados na disciplina Projetos Experimentais em horário e local preestabelecidos;

II - elaborar e encaminhar aos professores orientadores todos os formulários relativos à disciplina Projetos Experimentais;

III - convocar, sempre que necessário, reuniões com os professores orientadores e alunos matriculados na disciplina Projetos Experimentais;

IV - sugerir professores orientadores para os alunos que não os têm;

V - submeter à Chefia do Departamento nomes dos professores orientadores e sua respectiva carga horária;

VI - definir cronograma de execução das atividades dos alunos;

VII - manter arquivos atualizados dos Projetos em andamento;

VIII - receber os Projetos e encaminhá-los à Banca Examinadora;

IX - providenciar o encaminhamento de cópias dos Projetos Experimentais aprovados à Biblioteca do Departamento;

$\mathbf{X}$ - apresentar à Secretaria do Departamento, ao final do ano letivo, as notas atribuídas à disciplina Projetos Experimentais;

XI - levantar as linhas de pesquisa dos professores orientadores e divulgá-las aos alunos;

XII - tomar, no âmbito de sua competência, todas as medidas necessárias para o efetivo cumprimento deste Regulamento.

Art. 6. Parágrafo Único. Á Comissão de Projetos será composta pelos seguintes membros:

I - Chefe do Departamento;

II - Coordenador de Projetos Experimentais;

III - Coordenador do Curso envolvido;

IV - Orientador(es) responsável(eis) pelo Projeto."

Fonte: “Normas para Elaboração dos Projetos Experimentais" - 2008 - (vide anexos)

\subsection{Pré-requisitos}

Como os Projetos Experimentais são definidos na maioria das IES como trabalhos de conclusão de curso, cuja carga horária está distribuída no último semestre ou ano letivo, a maioria das universidades pesquisadas estabelece como pré-requisitos o cumprimento de parte ou todas as disciplinas ou créditos referentes à conclusão do curso. 
Na Universidade de São Paulo, por exemplo, o graduando somente elabora seu Projeto Experimental quando conclui todos os créditos devidos para 0 cumprimento da carga horária do curso. Isso acontece por volta do sétimo semestre e, portanto, no oitavo semestre o aluno gerencia de forma autônoma a elaboração de seu trabalho de conclusão de curso, optando por um orientador, um formato monografia ou projeto profissional - e um tema de seu interesse.

Em outras IES, a carga horária de Projetos Experimentais geralmente representa $10 \%$ da carga horária total do curso, sendo pelo menos $270 \mathrm{~h} / \mathrm{a}$ como determinam as Diretrizes Curriculares. Este total de horas divide a grade horária com outras disciplinas, pertencentes tanto ao tronco comum de Comunicação Social quanto ao tronco específico. Geralmente, em uma grade anual, o número de disciplinas cursadas é menor do que nos anos anteriores, por exemplo, se no primeiro, segundo e terceiros anos o graduando deve cursar dez ou onze disciplinas na semana, no último ano ele deve cursar três ou quatro disciplinas, mais a carga horária de Projetos Experimentais.

O maior problema nesses casos é quando fica reservada ao último ano ou semestre, uma disciplina obrigatória cuja proposta pedagógica inclui uma prática laboratorial. Não é incomum que o aluno participe de jornais e revistas laboratórios no último ano ou semestre, ou ainda, telejornais, radiojornais, agências de notícias on line ou outros veículos laboratoriais. A dificuldade para os graduandos é conciliar o cumprimento de disciplinas da grade do último ano ou semestre, incluindo seus trabalhos e avaliações, as práticas laboratoriais - que exigem apuração, redação e execução de conteúdos jornalísticos adequados aos veículos laboratórios - e ainda a execução dos Projetos Experimentais, cuja elaboração depende de fôlego - leiase tempo, dedicação e aprofundamento - do graduando para sua conclusão. 
Essa situação torna-se ainda mais complicada para alunos que cursam o período noturno oferecido pelas IES. Na maior parte dos casos, os graduandos trabalham em horário integral - jornadas semanais das $8 \mathrm{~h}$ às $17 \mathrm{~h}$ em comércios, serviços e indústrias - ou ainda estão dedicados a estágios remunerados, ainda que esta não seja uma prática regulamentada. Sobram, nesses casos, os finais de semana, feriados e as madrugadas para a realização de pautas, agendamento de entrevistas, captação de imagens e sonoras, pesquisas bibliográficas e documentais, edição, diagramação e finalização de produtos jornalísticos. Ou seja, aquilo que se pode chamar de trabalho hercúleo para quem ainda nem se formou ainda.

Outro pré-requisito adotado pelas IES é o cumprimento de uma ou mais disciplinas no ano ou semestre letivo anterior ao dedicado aos Projetos Experimentais cujo objetivo principal é a preparação do graduando para a jornada que virá a seguir. Geralmente, a disciplina está nomeada com as expressões "metodologia", "pesquisa", "projeto" ou "planejamento" e oferece na ementa a proposta de pesquisa, planejamento e execução de ações a partir do referencial teórico e metodológico visando ao aprofundamento de natureza monográfica ou profissional para elaboração do Trabalho de Conclusão de Curso ou Projeto Experimental.

A disciplina trabalha na estruturação do projeto, definindo estratégias de ação do projeto, de preparação do material de trabalho, da identificação, objetivos e justificativa do projeto, incluindo também um planejamento orçamentário e cronograma físico-financeiro do projeto. É a partir das atividades desenvolvidas na disciplina que os alunos desenvolvem um pré-projeto, ou anteprojeto, seja de uma monografia, seja de um trabalho profissional de Jornalismo. 
A disciplina tem ainda a proposta de familiarizar os graduandos com as instruções normativas que acompanham os Projetos Experimentais, tais como regulamentos e cronogramas e ainda com as normas da ABNT, amplamente utilizadas na confecção de trabalhos acadêmicos.

A seguir, o que expressam sobre tais requisitos os regulamentos de Projetos Experimentais adotados pelas IES que compõem a amostra da pesquisa:

\section{PONTIFÍCIA UNIVERSIDADE CATÓLICA DE SÃO PAULO - PUCSP}

"Todo aluno, a partir do 7‥ Semestre do curso, deve estar envolvido - em grupo ou individualmente - na elaboração de um TCC. Também no 7․ e $8^{\circ}$. Semestres, individualmente ou em grupo, os alunos passam a receber orientação de um professor do Departamento de Comunicação Jornalística, que deve ser escolhido pelos próprios estudantes no início do $7^{\circ}$. Semestre, a partir da convergência entre o tema que será desenvolvido no trabalho e a área de especialidade do docente. $O$ pré-requisito para a elaboração do TCC é a disciplina "Elaboração de Projetos" ministrada no 6‥ Semestre (Disciplina modulada com 2 horas-aula semanais).

O envolvimento do aluno com as atividades de elaboração do TCC não o isenta do cumprimento de outras obrigações acadêmicas a que estiver sujeito, como as próprias disciplinas constantes da grade dos $7^{\circ}$. e $8^{\circ}$. Semestres, dependências, adaptações etc. A aceitação da orientação pelo docente dependerá de aprovação, por este, de pré-projeto apresentado pelos alunos."

Fonte: "Regulamento dos Trabalhos de Conclusão do Curso de Jornalismo da PUC-SP" - 2006 (vide anexos)

\section{UNIVERSIDADE METODISTA DE SÃO PAULO - UMESP}

"O Projeto Experimental deve ser executado pelo aluno matriculado no último semestre do curso (oitavo semestre), juntamente a disciplina de Metodologia, com o objetivo de garantir a qualidade dos trabalhos. No caso de dependência (DP) em outras disciplinas de semestres anteriores (no máximo duas), o aluno deve executá-las sem prejuízos na elaboração do PE, devendo comprovar, inclusive, disponibilidade para cumprir a carga horária exigida. Para a realização do Projeto Experimental, o aluno deve cursar, no sétimo semestre, uma disciplina preparatória - "Introdução ao Projeto Experimental", na qual serão discutidas as questões metodológicas e as relacionadas à viabilidade do projeto. Ao final dessa disciplina, o aluno deve apresentar o projeto do trabalho, inclusive com modalidade e área definidos, além de sugerir o professor orientador."

\footnotetext{
Fonte: "Regulamento dos Projetos Experimentais do Curso de Jornalismo" - 2005 (vide anexos)
} 


\section{UNIVERSIDADE DE RIBEIRÃO PRETO - UNAERP}

"Art.7 O anteprojeto da Monografia de Pesquisa em Comunicação poderá ser elaborado e concluído na disciplina Metodologia Científica II e será apresentado para a obtenção de aprovação na referida atividade.

Parágrafo Único. Os alunos que não quiserem utilizar o anteprojeto executado na disciplina Metodologia Científica II, deverão elaborar outro anteprojeto sobre novo tema.

Art.8 O anteprojeto deverá ser elaborado e apresentado por grupos de, no máximo, 3 (três) alunos.

Art.9 O anteprojeto deverá ser apresentado ao Núcleo de Produção Científica em Comunicação, no prazo designado pelo calendário elaborado especialmente para esse fim, para ser avaliado pela coordenação do referido Núcleo. Caso seja aprovado e, de acordo com o tema proposto, o projeto será encaminhado pelo Núcleo a um orientador, seguindo critérios que dizem respeito às linhas de pesquisa existentes no Núcleo e às atividades de pesquisa executadas pelo Corpo Docente Orientador.

Art.10 O projeto de pesquisa será elaborado, efetivamente, na disciplina Monografia I.

Parágrafo Único. Enquanto não obtiver a aprovação do projeto (Monografia I), pelo professor orientador, o aluno não poderá matricular-se em Monografia II.

Art.11 A Monografia de Pesquisa em Comunicação será de caráter obrigatório para os alunos do curso de Comunicação Social, habilitações em Jornalismo e Publicidade e Propaganda, e constitui pré-requisito para a colação de grau.

Art.12 Submeter-se-ão à elaboração da Monografia de Pesquisa em Comunicação os alunos das habilitações em Jornalismo e Publicidade e Propaganda matriculados na Atividade Complementar II, que terá a duração mínima de dois semestres."

Fonte: "Regulamentação da Monografia de Pesquisa em Comunicação para Conclusão do Curso" - 2002 (vide anexos)

\section{UNIVERSIDADE DE SÃO PAULO - ECA/USP}

Ao realizar sua inscrição ao Trabalho de Conclusão de Curso, os alunos indicam o título, a modalidade, o professor orientador e detalham uma proposta de trabalho em formulário próprio. A proposta é avaliada por uma comissão do Departamento e o aluno é considerado apto ou não ao TCC, que deve ser realizado com o cumprimento total dos créditos ou concomitantemente ao cumprimento de uma única disciplina no último semestre do curso.

Fonte: "Formulários Departamento de Jornalismo e Editoração ECA/USP" - 2008 (vide anexos)

\subsection{Prazo de elaboração}

Nas IES pesquisadas, o prazo para realização dos Projetos Experimentais é definido pelos períodos letivos adotados pelas universidades, ou seja, semestrais ou anuais. Porém, considerando as diferentes etapas do processo de elaboração 
dos Projetos Experimentais, os alunos têm, em média, 8 meses para a execução de seus trabalhos de conclusão de curso.

Considerando que num currículo em que a carga horária de 270 h/a deve ser integralizada em um ano letivo, dividindo-se entre os 200 dias letivos de um ano acadêmico, têm-se 9h/a semanais repartidas na grade do último ano. Se considerados os processos de inscrição do formato, do tema e a escolha do orientador, a execução em diferentes etapas de apuração, elaboração e finalização, avaliação e orientação, entrega e apresentação à banca examinadora final, o graduando tem alguns meses para desenvolver de forma autônoma um produto jornalístico ou uma pesquisa científica. Essa autonomia deve ser considerada um dos pilares dos Projetos Experimentais, pois todas as produções laboratoriais as quais o aluno realiza são planejadas previamente, fazendo parte de um Projeto Pedagógico do curso e são executadas sob a supervisão de uma equipe de professores, geralmente experientes na área, seja rádio, TV, impresso ou internet.

Quando o prazo de elaboração estipulado compreende um semestre letivo, o aluno deve cumprir a carga horária total do período letivo executando seu trabalho de conclusão de curso. Na maioria das IES, esta carga horária inclui o uso de laboratórios destinados às práticas jornalísticas, como informática, rádio, televisão e fotografia, e também os horários de orientação com o professor responsável pelo projeto ou a equipe de professores encarregada das orientações às equipes.

A seguir, o que expressam sobre os prazos de realização de Projetos Experimentais os regulamentos adotados pelas IES que compõem a amostra da pesquisa: 


\section{FACULDADE CÁSPER LÍBERO - FCL}

"No período que compreende o início do terceiro semestre do $3^{\circ}$ ano do curso de jornalismo até o início do ano letivo seguinte (consulte o calendário no site), os alunos deverão inscrever seus projetos junto à coordenação da disciplina. Os trabalhos devem seguir os critérios exigidos para cada gênero de projeto experimental (leia mais orientações)."

Fonte: "TCC: Guia para consulta" - 2007 (vide anexos)

\section{PONTIFÍCIA UNIVERSIDADE CATÓLICA DE SÃO PAULO - PUCSP}

"O TCC deve permitir que os estudantes, individualmente ou em grupo, acompanhados a partir do $7^{\circ}$. Semestre do curso por um professor-orientador, desenvolvam reflexão aprofundada em torno de um tema de relevância para os estudos da Comunicação Social ou do Jornalismo."

Fonte: "Regulamento dos Trabalhos de Conclusão do Curso de Jornalismo da PUC-SP" - 2006 (vide anexos)

\section{UNIVERSIDADE METODISTA DE SÃO PAULO - UMESP}

"Para cada dia de atraso na entrega da versão definitiva do PE será descontado 0,5 (meio) ponto na média final do projeto (de cada integrante do grupo). Alertamos que entende-se por versão definitiva a cópia avaliada pela banca examinadora. E por média final a composição das notas dadas pela banca e pelo orientador."

Fonte: "Regulamento dos Projetos Experimentais do Curso de Jornalismo" - 2005 (vide anexos)

\section{UNIVERSIDADE DE MOGI DAS CRUZES - UMC}

"Nos dois últimos semestres do curso, na Habilitação Jornalismo o patamar é o Escolher. O projeto chama-se Vôo Solo, uma evidente alusão ao momento muito especial que o aluno vivenciará em seu último ano de curso, quando começará a agir, cada vez mais, com iniciativa própria, finalizando sua preparação para a vida profissional, num mercado que exige, cada vez mais, gente com iniciativa de ações adequadas. É hora, portanto, de fazer o que se convenciona chamar de Projeto Experimental.

Conforme determinação do MEC, Parecer 480/83 de 6 de outubro de 1983, entende-se por projeto experimental a produção, no último ano do curso, de trabalho relacionado com a habilitação específica, em forma de monografia, fita gravada de som e imagem ou de som, filme cinematográfico sonoro, publicação impressa, campanha publicitária, plano de editoração - sempre realizados nos laboratórios da própria escola. O Projeto Experimental é de caráter obrigatório para a obtenção do certificado de conclusão do curso."

Fonte: "Projeto Vôo Solo" - 2008 (vide anexos) 


\section{UNIVERSIDADE DE TAUBATÉ - UNITAU}

“Art. 20. Todas as vias impressas dos Projetos, material produzido (mínimo 4) e uma cópia digital, deverão ser entregues e protocoladas na Coordenação de Projetos, conforme Cronograma (Anexo I).

§ 1‥ Não serão aceitos, em hipótese alguma, trabalhos após o prazo estabelecido, estando automaticamente reprovados os alunos cujos trabalhos forem entregues fora do prazo.

§ 2‥ Não será permitida, em hipótese alguma, a substituição de cópias entregues no período regular, nem o acréscimo de material além do que foi entregue na Coordenação.

§ 3‥ Os Trabalhos interdisciplinares deverão entregar cópias para todos os professoresavaliadores."

Fonte: "Normas para Elaboração dos Projetos Experimentais" - 2008 - (vide anexos)

\section{UNIVERSIDADE DE RIBEIRÃO PRETO - UNAERP}

"Art.13 Os alunos matriculados na Atividade Complementar II deverão apresentar termo de compromisso do Orientador assinado, no prazo designado pelo calendário elaborado especialmente para esse fim.

Art.14 Durante o primeiro semestre os alunos matriculados na Atividade Complementar II elaborarão o projeto de pesquisa e, no segundo semestre, executarão o projeto realizando a monografia.

Art.15 Cursará o segundo semestre de Atividade Complementar II o aluno aprovado no primeiro semestre da referida Atividade, com média igual ou superior àquela exigida para a aprovação nas demais disciplinas do curso de Comunicação Social da UNAERP, ou seja, 5,0 (cinco inteiros), desde que tenha entregado também o projeto e parecer favorável do Orientador .

Parágrafo Único. Ficará retido no primeiro semestre da Atividade Complementar II o aluno aprovado que não entregar o projeto nos prazos designados pelo calendário especialmente elaborado para esse fim, ainda que cumprido o disposto no caput deste artigo.

Art.16 Ao término do segundo semestre da Atividade Complementar II, conforme calendário estabelecido, os alunos deverão apresentar a Monografia de Pesquisa em Comunicação para a avaliação de uma Banca Examinadora."

Fonte: "Regulamentação da Monografia de Pesquisa em Comunicação para Conclusão do Curso" - 2002 (vide anexos)

\subsection{Avaliação}

O processo de avaliação dos Projetos Experimentais é considerado o ponto culminante do trabalho desenvolvido pela coordenação, professores e alunos. Como, na maioria dos casos, os Projetos Experimentais são definidos como uma 
disciplina regida por normas específicas, não há um controle de freqüência às orientações e de cumprimento da carga horária igual ao adotado para as demais disciplinas do curso. Assim, faz-se uso de relatórios e fichas de acompanhamento para preenchimento dos alunos e dos orientadores.

Em algumas IES, no início do processo de elaboração dos Projetos Experimentais, há uma espécie de qualificação - também chamada de pré-banca em que os alunos apresentam suas propostas de trabalho, incluindo e descrição dos seguintes elementos: o tema e suas particularidades, as características do formato escolhido, os objetivos e a justificativa do projeto, o público alvo ao qual se destina o produto jornalístico, os referenciais teóricos que embasam o desenvolvimento do trabalho de conclusão de curso, as possíveis fontes de apuração, a descrição das etapas de desenvolvimento, o cronograma de execução, o orçamento para elaboração, a bibliografia que se pretende utilizar e as etapas desenvolvidas até o momento.

Com a apresentação detalhada das propostas, os avaliadores das prébancas podem verificar 0 andamento dos Projetos Experimentais, sugerir direcionamentos, oferecer dicas de finalização e tratamento das informações, propor a utilização de técnicas não previstas pelos alunos e recomendar bibliografias para subsidiar a execução dos trabalhos de conclusão de curso. As qualificações ou pré-bancas não têm caráter restritivo, ou seja, não se propõem à reprovação ou aprovação para continuidade dos trabalhos, mas apresentam sim um caráter de orientação, sugerindo caminhos ainda não considerados ou apontando que o desenvolvimento segue um curso adequado até então.

A adoção de avaliações ao longo do processo de elaboração dos Projetos Experimentais visa facilitar e acompanhar o desenvolvimento dos trabalhos ao 
longo do período letivo, mas o principal momento de avaliação se dá nas Bancas

Examinadoras Finais. Depois de elaboração e entrega de exemplares dos Projetos

Experimentais, é chegada a hora da defesa dos trabalhos pelos graduandos e este é um processo dos mais delicados.

Se os Projetos Experimentais foram realizados de forma individual ou por equipes, é nas Bancas Examinadoras que os alunos enfrentarão o momento mais crítico do processo, sendo pelo fato de que as avaliações são públicas na maioria dos casos, seja porque o momento representará um julgamento detalhado dos acertos e erros cometidos pelos graduandos. E não são poucos os motivos para preocupação. A seguir, a definição do processo de avaliação de Projetos Experimentais expressa nos regulamentos adotados pelas IES que compõem a amostra da pesquisa:

\section{UNIVERSIDADE METODISTA DE SÃO PAULO - UMESP}

"É dever do aluno comparecer às horas/aula de orientação combinadas previamente com o professor orientador. Também faz parte das atividades concernentes aos PE's as etapas extraclasse, bem como todas as tarefas determinadas pelo orientador.

É obrigatório que o professor mantenha um diário de orientação (modelo na Secretaria do Curso), em que possa registrar os encontros com seu orientando e as etapas cumpridas. Ao final de cada orientação, professor e aluno devem assinar o referido diário."

Fonte: "Regulamento dos Projetos Experimentais do Curso de Jornalismo" - 2005 (vide anexos)

\section{FACULDADE CÁSPER LÍBERO - FCL}

"Em até duas semanas depois do recebimento das inscrições, serão entregues aos representantes de cada trabalho os pareceres emitidos pelos professores que avaliaram os projetos inscritos. Os alunos que tiverem seus projetos reprovados poderão apresentar um novo projeto em data a ser definida pela coordenação ou integrarem-se a um grupo cujo trabalho tenha sido aprovado.

Publicação da lista de projetos aprovados:

Uma vez publicada a lista final de inscrições não serão permitidas alterações de temas e transferências de alunos para outros grupos. Casos especiais deverão ser submetidos à coordenação da disciplina e/ou do curso de jornalismo.

Avaliação bimestral dos projetos:

A avaliação dos projetos experimentais será feita bimestralmente, de acordo com o calendário escolar e respeitando os seguintes critérios:

No primeiro bimestre, o professor orientador, por meio de ficha de acompanhamento 
própria (ver anexo), atribuirá uma nota ao grupo baseado na freqüência dos alunos às sessões de orientação previamente agendadas e nos indícios efetivos do desenvolvimento inicial do trabalho.

No segundo bimestre, o professor orientador, por meio da mesma ficha de acompanhamento, atribuirá sua nota baseado no material de trabalho apresentado como exame de qualificação, que deverá respeitar os critérios descritos adiante. No terceiro bimestre, o professor orientador, por meio ainda da ficha de acompanhamento, atribuirá sua nota baseado na progressão efetiva que o trabalho tenha alcançado em relação ao exame de qualificação.

Observações:

1. Os alunos que obtiverem, nos três primeiros bimestres, uma soma de pontos igual ou inferior a 20,5 serão reprovados na disciplina, devendo matricular-se nela no ano seguinte. Já os trabalhos dos alunos que somarem 21 pontos ou mais serão encaminhados às bancas de avaliação, que serão realizadas em novembro ou dezembro (consulte 0 calendário no site).

2. As notas obtidas nos três primeiros bimestres terão peso 1 e a nota obtida no $4^{\circ}$ bimestre (atribuída pela banca de avaliação) terá peso 3.

3. Tanto o professor orientador ao longo dos três primeiros bimestres quanto a banca, no quarto bimestre, poderão atribuir notas diferentes aos alunos de um mesmo grupo, caso seja possível verificar a diferença de empenho de seus integrantes e o resultado do trabalho apurado individualmente.

4. O objetivo do sistema de avaliação é o de valorizar o processo de elaboração do projeto (sem diminuir a importância do resultado final, de peso, vale notar, equivalente ao do percurso do trabalho), cujas etapas são fundamentais para sua consecução."

Fonte: "TCC: Guia para consulta" - 2007 (vide anexos)

\section{UNIVERSIDADE DE TAUBATÉ - UNITAU}

"Art. 17. Os Projetos Experimentais passarão por duas etapas de avaliação:

1. Avaliação do processo pedagógico, realizada pelo orientador.

O orientador deverá entregar à Coordenação um relatório pormenorizado (conforme modelo disponível na Coordenação) avaliando as atividades executadas durante o ano, atribuindo a nota de cada aluno para a Banca Examinadora Final. Valor de 0 (zero) a $(2,0)$ dois pontos. CASO O PROJETO SEJA AVALIADO COM A NOTA O (ZERO), NÃO IRÁ PARA A BANCA FINAL ESTANDO REPROVADO. Estará anexado ao Relatório Final as observações da Pré-banca.

1.1. Pré-bancas:

Para as Pré-bancas, os alunos devem entregar à Coordenação 3 (três) vias da Proposta e apresentar-se em dia, horário e local determinados, para serem avaliados observando as seguintes orientações:

I - As Pré-bancas serão compostas por, no máximo, 2 (dois) professores, que farão OBSERVAÇÕES E SUGESTÕES sobre o projeto, sendo que estas deverão obrigatoriamente ser registradas no Relatório de Pré-banca (modelo disponível na Coordenação).

II - O grupo deverá relatar o que foi desenvolvido no $1^{\circ}$ semestre e o que pretende desenvolver nas próximas etapas do Projeto.

III - Cada grupo terá no máximo 10 minutos para expor o Trabalho.

IV - Os professores avaliadores terão, no máximo, 5 minutos para as suas considerações.

V - Cada apresentação deverá ter um presidente e não deverá exceder 20 minutos no tempo total.

VI - Caso seja necessário conversar com o grupo além do tempo regulamentar, a prébanca deverá anotar no relatório e solicitar uma reunião com o grupo ou com o orientador. 
VII - O professor orientador não participará desta etapa de avaliação.

VIII - Os membros da banca deverão levar em consideração na apresentação os seguintes aspectos: 1) Comunicação Oral; 2) Objetividade; 3) Relevância para área de Comunicação Social; 4) Coerência entre o Tema e o Trabalho; 5) Pesquisa (campo, entrevista, opinião, mercado, outras); 6) Etapas desenvolvidas (Cronograma); 7) Referencial Bibliográfico.

2. Avaliação da banca examinadora final.

Nesta segunda etapa, a avaliação será efetuada pela Banca Examinadora, de conformidade com o previsto no Capítulo XIV.

Esta avaliação será realizada pela Banca Examinadora, com notas individuais de 0 (zero) a 8 (oito), com intervalo de 0,1 ponto.

À média atribuída pelos professores-avaliadores será acrescida a nota do orientador $(2,0)$ dois pontos, as quais comporão a Média Final, que constará do histórico escolar do aluno na disciplina Projetos Experimentais."

Fonte: "Normas para Elaboração dos Projetos Experimentais" - 2008 - (vide anexos)

\section{UNIVERSIDADE SANTA CECÍLIA - UNISANTA}

"Art. 17 - O processo de avaliação do TCC ocorrerá em 3 (três) etapas, antes da Banca Examinadora:

a) Primeira Avaliação: o aluno/grupo irá elaborar uma Proposta de Trabalho (briefing, anteprojeto ou similares) onde deverão constar todas as informações sobre 0 desenvolvimento do seu trabalho durante o ano. Ex: Introdução ou Apresentação, Objetivos, Custos, Cronograma, Metodologia, Referências.

b) Segunda Avaliação: cada aluno/grupo fará uma apresentação pública do Trabalho. Para tanto, deverá entregar um resumo com as atividades desenvolvidas e a desenvolver, para a pré-banca, composta de dois professores, que argüirão e avaliarão o aluno/grupo. É facultada a participação do orientador. Critérios para a apresentação: 10 minutos de exposição e 5 minutos para a argüição de cada avaliador (anexo D)

c) Terceira Avaliação: o orientador deverá elaborar um relatório onde descreverá, de forma clara, objetiva e criteriosa, o desenvolvimento de seu(s) orientando(s). Nesse documento, ele deverá atribuir uma nota de 0 (zero) a 10,0 (dez) a cada aluno. Nota inferior a 5,0 (cinco) implica reprovação, isto é, o aluno/grupo só poderá apresentar o trabalho no semestre seguinte, conforme calendário estipulado pela Comissão de TCC de cada curso. Itens mínimos presentes no relatório: freqüência/participação; cumprimento do cronograma; pesquisa bibliográfica; desenvolvimento do trabalho; redação do texto; métodos empregados.

Art. 18 - Os trabalhos que, após as três avaliações explicitadas no art. 17, forem aprovados para a apresentação final deverão ser entregues e protocolados na Secretaria da Direção ou na Coordenação de Curso e/ou Coordenação de TCC de cada curso, na data determinada pela Comissão de TCC. Após essa data, não será mais possível proceder à sua entrega.

Art. 19 - A atribuição de notas dar-se-á após o encerramento da etapa de argüição, obedecendo ao sistema de notas individuais por examinador, levando em consideração o texto escrito (monografia ou relatório técnico), a parte prática (quando for o caso), a sua exposição oral e a defesa, quando da argüição pela banca examinadora.

$\S 1$ o - Utilizar-se-ão, para a atribuição das notas, fichas de avaliação individuais (anexo E), onde o professor aporá suas notas para cada item a ser considerado.

$\S 2^{\circ}$ - A nota final do aluno será o resultado da média aritmética das notas atribuídas pelos membros da comissão examinadora e da avaliação feita pelo professor-orientador (vide capítulo VIII - art. 17 - item c).

$\S 3^{\circ}$ - Para aprovação, o aluno deverá obter nota igual ou superior a 7,0 (sete) na média das notas individuais atribuídas pelos membros da banca examinadora. Ao aluno/grupo 
que obtiver média abaixo de 7,0 (sete), será concedido um prazo para a refacção do TCC. Esse prazo será estabelecido pela Comissão de TCC de cada curso.

Parágrafo único: A nota final do aluno/grupo que refizer o trabalho terá o valor máximo de 7,0 (sete) , sendo o valor mínimo 5,0.

Art. 20 - O discente que, sem justificativa, deixar de comparecer à apresentação oral de seu trabalho será reprovado.

Parágrafo único - O aluno/grupo poderá solicitar recurso à Comissão de TCC de seu curso, que analisará o pedido, observando o regimento da Universidade.

Fonte: "Diretrizes para Elaboração de Trabalho de Conclusão de Curso de Graduação (TCC)" - 2007 (vide anexos)

\subsection{Relação com o mercado}

Os Projetos Experimentais permitem a reflexão dos processos e práticas da Comunicação a partir das diferentes metodologias com vistas à compreensão da importância da pesquisa científica e da construção do conhecimento para o profissional de Comunicação Social. Sua elaboração requer o domínio das técnicas de coletas de dados para aquisição de conhecimento científico e empírico na área, bem como o domínio de linguagens e competências estéticas e técnicas para criar, orientar e julgar materiais de Comunicação pertinentes às suas atividades, utilizando a criatividade como instrumento para a busca de soluções de problemas comunicacionais, especialmente na área do Jornalismo.

A relação dessas competências com a formação profissional caracteriza os Projetos Experimentais como importantes ferramentas de relação com o mercado de trabalho, abrindo portas e servindo como um portfólio de realizações conquistadas pelo graduando de Jornalismo. A seguir, a definição dos objetivos dos Projetos Experimentais expressa nos regulamentos adotados pelas IES que compõem a amostra da pesquisa: 


\section{UNIVERSIDADE DE MOGI DAS CRUZES - UMC}

"O Projeto Experimental, no curso de Comunicação Social da Universidade de Mogi das Cruzes é organizado de forma a solidificar os conhecimentos adquiridos no decorrer dos quatro anos em que se desenvolve o curso. O objetivo é promover a vinculação entre os temas e conteúdos abordados nas disciplinas a um projeto experimental, no qual se evidencie a prática embasada em fundamentos metodológicos e teóricos, que contribua para a formação profissional do corpo discente.

A realização do Projeto Experimental está concebida também em perfeita consonância com o projeto pedagógico do curso, direcionado para os alunos do sétimo e oitavo semestres, no qual o aluno é gradativamente levado a tomar atitudes conscientes, críticas e indicar, ele próprio, o tema que gostaria de abordar e qual segmento pretende escolher para realizar sua última atividade no curso."

Fonte: "Projeto Vôo Solo" - 2008 (vide anexos)

\section{FACULDADE CÁSPER LÍBERO - FCL}

"Ao entregar o projeto experimental para avaliação da banca examinadora, no final dos trabalhos, o aluno também deve apresentar um memorial descritivo. Sua finalidade é inserir o projeto de trabalho no projeto pessoal mais amplo do aluno, configurando-se como uma narrativa simultaneamente histórica e reflexiva. Deve, então, ser composto sob a forma de um relato histórico, analítico e crítico, que dê conta dos fatos e dos acontecimentos que constituíram a trajetória do trabalho, de tal modo que o leitor possa ter uma informação completa do itinerário percorrido. Deve dar conta também de uma avaliação de cada etapa, expressando o que cada momento significou, as contribuições ou perdas que representou.

O aluno deve fazer um esforço para situar esses fatos e acontecimentos no contexto histórico-cultural mais amplo em que se inscrevem, já que eles não ocorreram dessa ou daquela maneira só em função de sua vontade ou de sua omissão, mas também em função de outras variáveis. É importante ressaltar as fontes e as marcas das influências sofridas, das trocas realizadas com outras pessoas ou com as situações culturais. É importante também frisar, por outro lado, os próprios posicionamentos, teóricos ou práticos, que foram sendo assumidos a cada momento. Deste ponto de vista, o memorial deve expressar a evolução que caracteriza a história particular do trabalho.

O memorial deve iniciar-se com um breve relato biográfico do(s) autor(es) do projeto e, a partir daí, cobrir o período de confecção do trabalho, sintetizando os momentos menos marcantes e desenvolvendo os mais significativos; depois, deve destacar os investimentos e experiências no âmbito do trabalho, avaliando sua repercussão na vida pessoal e no amadurecimento intelectual do(s) participante(s). O memorial não deve se transformar nem numa peça de autoelogio nem numa peça de autoflagelo: deve buscar retratar, com a maior segurança possível, com fidelidade e tranqüilidade, a trajetória real que foi seguida, que sempre é tecida de altos e baixos, de conquistas e de perdas. Para encerrar, o memorial deve indicar o rumo que se pretende assumir ou que se está assumindo no momento atual, tendo como pano de fundo a história pré-relatada."

Fonte: "TCC: Guia para consulta" - 2007 (vide anexos) 


\section{UNIVERSIDADE CATÓLICA DE SANTOS - UNISANTOS}

\section{"Objetivos do TCC na UNISANTOS:}

a) Ampliar o domínio específico sobre um determinado tema.

b) Favorecer ao grupo/aluno a realização de uma síntese integradora de conhecimentos teóricos e práticos.

c) Desenvolver/ampliar o espírito investigativo.

d) Favorecer a reflexão sobre a prática profissional.

e) Desenvolver habilidades que favoreçam ao grupo/aluno a busca de alternativas criadoras no exercício profissional.

f) Desenvolver estudos e projetos interdisciplinares."

Fonte: "Guia Acadêmico Unisantos" - 2007 (vide anexos)

\section{PONTIFÍCIA UNIVERSIDADE CATÓLICA DE SÃO PAULO - PUCSP}

"A Universidade cumpre uma dupla função: é espaço de reflexão teórica e, ao mesmo tempo, espaço de experimentação. São características indissociáveis tanto do ensino quanto da pesquisa - atividades através das quais a formação acadêmica estende sua ação ao conjunto da sociedade. No caso do curso de Jornalismo da PUC-SP esse conjunto de compromissos é perseguido através de princípios que estruturam as atividades docentes e discentes: densa formação humanística, rigorosa capacidade de observação e de análise dos processos sociais, discernimento no tratamento dado ao universo das linguagens que lidam com os fatos do mundo, perspectiva crítica na abordagem dos contextos em que se desenvolvem as ações humanas em todas as esferas, compromisso com a ética profissional e com a ética social.

No curso de Jornalismo, tais características podem, grosso modo, ser sintetizadas nas atividades de apuração dos fatos noticiosos, de sua interpretação e contextualização, de sua elaboração discursiva compatível com um determinado suporte midiático, e de sua disseminação para audiências segmentadas ou massivas. Ao longo de sua formação, o estudante convive com diferentes e complexas abordagens curriculares que the permitem desenvolver a acuidade intelectual e aplicada pertinente a essas práticas, culminando no encerramento do curso quando, então, submete à apreciação de uma banca de professores e/ou profissionais um produto que representa e expressa a acumulação de sua competência analítica e experimental."

Fonte: "Regulamento dos Trabalhos de Conclusão do Curso de Jornalismo da PUC-SP" - 2006 (vide anexos)

\section{UNIVERSIDADE METODISTA DE SÃO PAULO - UMESP}

"Projeto Experimental (PE) é uma disciplina regular da grade curricular do curso de Jornalismo, cuja carga horária é de 360 h/a. Compreende a produção de um projeto, no último semestre do Curso, sob orientação acadêmica, que reúna as técnicas e os conhecimentos teóricos adquiridos ao longo da graduação. O objetivo do PE é fazer com que o estudante realize, em suas diversas etapas, um trabalho mais aprofundado, nas áreas teórica ou prática, aperfeiçoando, assim, o processo de reflexão na área."

\footnotetext{
Fonte: "Regulamento dos Projetos Experimentais do Curso de Jornalismo" - 2005 (vide anexos)
} 


\section{PONTIFÍCIA UNIVERSIDADE CATÓLICA DE CAMPINAS - PUCCAMP}

"A gama de possibilidades aberta às produções acadêmicas em Projetos Experimentais encontra amparo na própria grade curricular do curso, decorrente de um projeto pedagógico que busca formar um jornalista de caráter "multimídia e generalista" - ou seja, habilitado a transitar em todas as áreas de produção jornalística, bem como preparado a iniciar-se nos temas que mais habitualmente são objeto de coberturas deste ramo de produção midiática. Para tanto, o curso busca adotar um modelo de currículo denominado "dinâmico-dialógico", que inclui disciplinas visando a formação humanística do acadêmico, orientada para os compromissos sociais assumidos pelo curso e pela Universidade. Paralelamente, não se abandona a necessidade de oferecer ao estudante uma boa formação técnica, que o capacite, em termos práticos e teóricos, a encontrar seu espaço no mercado de trabalho e realizar-se na profissão que escolheu. Bem por isso, em linhas gerais, segundo recomenda Goergen (1999: 13), no curso de Jornalismo da PUCCampinas, "o estudo não deve render ao aluno o estabelecido, apenas instrumentalizando-o para que possa ter sucesso em meio à miséria, mas ajudá-lo a abrir os olhos para que veja estas contradições [da estrutura social em que estamos inseridos] e se sinta também responsável pela sua superação".

A realização dos Projetos Experimentais, no último semestre do curso, é portanto vista como a etapa que encerra todo o processo de formação de jornalistas com o perfil desejado no projeto pedagógico curso. Para tanto, os professores deliberaram que trabalhos desta natureza devam ser acompanhados, obrigatoriamente, de um texto que explicite as opções feitas pelos acadêmicos durante sua concepção/realização, não apenas no nível técnico, mas também conceitual e político. Tais textos, aos quais se deu o nome de Relatórios de Fundamentação Teórica, são encarados como uma etapa que, com acompanhamento docente, ainda proporciona ao aluno um espaço considerável para o amadurecimento intelectual.

Fonte: "A estrutura dos Relatórios de Fundamentação nos Projetos de Jornalismo" - 2005 (vide anexos)

A fim de propiciar modos de integração com a sociedade e com o mercado de trabalho, o documento que fundamentou o Parecer CNE/CES 492/2001, elaborado pela Comissão de Especialistas de Ensino em Comunicação Social (CEE - Com), estabelece que o Projeto Acadêmico do Curso deva ainda prever e expor com clareza os procedimentos através dos quais assegurará uma efetiva interação com a sociedade, cumprindo sua responsabilidade de fornecer recursos humanos qualificados ao mercado de trabalho e de aperfeiçoar o próprio funcionamento social através de suas perspectivas inovadoras e críticas. Devem, portanto, ser relacionados:

- $\quad$ as atividades regulares de Extensão; 
- os meios de acompanhamento da integração dos profissionais formados pela escola ao mercado de trabalho;

- a interação entre o Curso, através de docentes, discentes e profissionais dos serviços de apoio, com entidades representativas dos diversos segmentos da área das comunicações, orientada para a solução de problemas referentes ao mercado de trabalho e cooperação no que se refere às atividades de Ensino, Pesquisa e Extensão;

- a interação entre o Curso, através de docentes, discentes e profissionais dos serviços de apoio, com entidades representativas dos diversos segmentos da área das comunicações e com setores da sociedade civil em geral, que atuem no sentido da busca de soluções para os problemas de interesse público da área;

- a existência de um programa de estágio orientado por objetivos de Ensino, Pesquisa e Extensão e que seja regulamentado e fiscalizado com a participação dos Sindicatos representativos dos setores profissionais pertinentes com jurisdição na região, para evitar o aviltamento do mercado de trabalho;

- a integração das atividades de formação com os veículos e estruturas de serviço e produção de comunicação da própria instituição de ensino superior (publicações, emissoras de rádio e TV, inclusive canais de TV por assinatura, produtoras, agências, editoras ou assessorias);

- previsões referentes ao desenvolvimento de uma vocação regional que oriente aspectos determinados e delimitados na formação, promovendo a adequação do curso às condições sócio-econômicas e culturais da região em que estiver localizada a Instituição e valorizando as habilitações frente às demandas sociais da região; 
- o desenvolvimento de atividades de ensino, pesquisa e extensão que estimulem a geração de mercado de trabalho e o surgimento de demandas sociais por atividades profissionais relevantes dos egressos. (CEE-COM, 1999, on line) 


\section{Orientação de Projetos Experimentais}

O ensino de Jornalismo não é uma tarefa fácil e seus desafios alimentam polêmicas em vários setores, embora haja uma suficiente experiência prática e acadêmica para alimentar não só tais debates, como possibilitar a implantação e desenvolvimento de projetos direcionados às necessidades atuais e futuras da profissão. Para Koshiyama (2007, p. 9),

Para um curso de jornalismo hoje, emerge a questão de construir um paradigma de ensino que problematize temas propostos por agentes do mercado tais como: profissionalismo, competência, neutralidade. Concluímos que a relação ensino-mercado para o jornalismo e os jornalistas neste tempo, apresenta desafios que só podem ser superados com a compreensão da dimensão social e política do trabalho no capitalismo do início do século XXI. Capitalismo que incorpora o próprio sistema das corporações de comunicação, cuja organização procura subordinar o exercício do jornalismo aos objetivos empresariais.

No caso dos Projetos Experimentais, isso envolve o papel do corpo docente no acompanhamento dos trabalhos desenvolvidos por alunos dos cursos de Jornalismo na última etapa da vida acadêmica. Esse trabalho conjunto envolve dimensões que exigem reflexão dos fenômenos e contextos vividos tanto pelo corpo docente quanto pelo corpo discente das IES. No que diz respeito ao papel do professor, é preciso conscientização de suas possibilidades e limitações.

A partir dessa consciência e responsabilidade inerentes a cada profissional, podemos assinalar aqui os atributos que consideramos indispensáveis para a prática jornalística: $O$ compromisso do comunicador envolve a observação e reflexão de mundo, de modo que, percebendo-o, possa expressá-lo. Não lhe cabe, portanto, somente a função técnica, mas a função social de comprometer-se com o mundo, de reconhecer que sua autoria responsável deve ser fruto do diálogo social, de sua cumplicidade/solidariedade com o público - os outros seres humanos. Assim, as habilidades e competências específicas preconizadas pelas novas Diretrizes podem ser conseqüências, ou frutos, dessa concepção de 'habilidades essenciais', dessa perspectiva que atribui ao ser- 
comunicador muito mais que o "noticiar fatos", mas a expressão contextualizada e significativa de mundo. (BRUM, 2003, p. 34)

Assim, não existe um modelo padrão para o desenvolvimento do Projetos Experimentais, mas as experiências de algumas IES revelam pontos em comum, como a existência de coordenações ou setores específicos para a gestão do processo, sendo importante ponto de referência para orientadores e estudantes. Há também a formulação de regulamentos, manuais e regras, principalmente no que diz respeito a questões como o cronograma, os formatos e temas possíveis, exigências mínimas de conteúdo, a distribuição dos projetos entre os docentes, a formação de banca avaliadora, entre outros aspectos.

Faz parte da dinâmica da orientação de projetos o desenvolvimento de propostas ou planos de pesquisa, cuja finalidade é o planejamento do trabalho, seja de caráter acadêmico (monografia) ou profissional (prático). Mas, o momento crucial dos Projetos Experimentais nas IES são as Bancas Examinadoras, nas quais a apresentação para avaliadores e convidados exige seriedade dos alunos, domínio e desenvoltura durante a defesa do trabalho. A banca aponta os erros e acertos, permitindo o diálogo mais profundo sobre o material entregue, como se fosse a última aula dos estudantes. Em todos estes momentos, o papel dos orientadores é crucial, uma vez que são responsáveis pela formação de novos profissionais, capazes de fazer uso de suas capacidades intelectuais, éticas e técnicas.

A necessidade de preparação para orientar graduandos que irão exercer a profissão com habilidade e responsabilidade é condição vital nas IES atualmente, em parte porque "conhecimentos e experiências de vida importam para o jornalista de hoje e do futuro, o que significa assumir novas concepções de educação, a partir 
da compreensão das condições do mundo nesse processo de reestruturação produtiva, da mudança de valores, com os paradigmas da globalização e da flexibilização do trabalho" (KOSHIYAMA, 2007, p. 9).

As normas e regulamentos de Projetos Experimentais nas IES, de certa forma, direcionam ao entendimento e conhecimento do papel dos orientadores nesse processo. A seguir, o detalhamento do processo de orientação dos Projetos Experimentais expressa nos regulamentos adotados pelas IES que compõem a amostra da pesquisa:

\section{UNIVERSIDADE METODISTA DE SÃO PAULO - UMESP}

Os Projetos Experimentais deverão ser orientados preferencialmente por professores do Curso de Jornalismo da Universidade, havendo a possibilidade, em alguns casos, de orientador pertencer a outro curso da área de Comunicação da instituição. Ressalta-se que, no caso dos trabalhos monográficos, os mesmos devem ser orientados preferencialmente por docentes do Curso de Pós-Graduação em Comunicação Social da Umesp.

O aluno deverá, quando da definição do PE, relacionar três possíveis orientadores, na ordem de preferência. O que não significa que necessariamente essa ordem será mantida. A Coordenação dos Projetos Experimentais fará a consulta prévia ao professor convidado para verificação da aceitação da tarefa por parte dele. No entanto, cabe à Coordenação do Curso, em conjunto com a Coordenação dos Projetos Experimentais, a aprovação final do orientador indicado. Os encontros com o professor escolhido devem resultar em 1h/aula de orientação por semana, na Umesp.

Cada professor pode orientar, no máximo, cinco projetos por semestre, com o objetivo de garantir a qualidade do processo de orientação e execução dos trabalhos.

Os alunos devem apresentar os projetos de trabalho previamente (veja cronograma) para que, em reunião do Colegiado, os professores do Curso possam aprovar o número de Projetos e a pertinência das temáticas.

Fonte: "Regulamento dos Projetos Experimentais do Curso de Jornalismo" - 2005 (vide anexos)

\section{PONTIFÍCIA UNIVERSIDADE CATÓLICA DE SÃO PAULO - PUCSP}

"A escolha do professor-orientador do TCC é feita pelos alunos e deve ser definida no início do $7^{\circ}$. Semestre, levando em conta a pertinência entre o tema do trabalho e a especialidade acadêmica ou profissional do docente. $O$ aceite o professor-orientador será dado depois que os alunos apresentarem a ele o pré-projeto a ser desenvolvido.

As atividades de orientação serão desenvolvidas semanalmente, em horário a ser agendado entre o professor e o(s) aluno(s), ocupando a carga-horária de 2 (duas) horasaula semanais no $7^{\circ}$. e no $8^{\circ}$. Semestres. E de responsabilidade do professor-orientador a aferição da freqüência dos alunos às sessões de orientação dos trabalhos."

Fonte: "Regulamento dos Trabalhos de Conclusão do Curso de Jornalismo da PUC-SP" - 2006 (vide anexos) 


\section{UNIVERSIDADE CATÓLICA DE SANTOS - UNISANTOS}

"Disposições gerais:

a) O professor responsável deverá ser escolhido pela Direção do Centro/Coordenação do Curso, de acordo com o perfil desejado para esse tipo de atividade acadêmica e administrativa.

b) Os orientadores deverão estar credenciados para a função e poderão ser substituídos quando não cumprirem as normas ou regulamentos estabelecidos pelo Curso.

c) Preferencialmente, deverá estar prevista nas grades curriculares, a carga horária destinada ao processo de orientação.

d) Quando a orientação do TCC não constar da carga horária da grade curricular, essa será remunerada em horas/atividade de acordo com tabela elaborada pela Pró-Reitoria Acadêmica.

e) O processo de orientação deverá ocorrer no recinto escolar."

Fonte: "Guia Acadêmico Unisantos" - 2007 (vide anexos)

\section{UNIVERSIDADE DE TAUBATÉ - UNITAU}

"Art. 14. O Projeto Experimental deverá ser orientado por um professor do Curso de Comunicação Social solicitado pelo(s) aluno(s);

I - Os alunos, quando forem propor o nome dos seus respectivos orientadores, deverão levar em consideração os seguintes aspectos: a - experiência docente e/ou profissional; b - afinidades intelectuais, profissionais e pessoais; c - linha de pesquisa mais adequada ao seu trabalho.

II - Os trabalhos que tiverem natureza profissional deverão ser orientados apenas por professores das respectivas habilitações específicas (JO, PP e RP). Somente haverá exceção quando for comprovado, por parte do orientador, experiência profissional ou titulação acadêmica em área afim do projeto.

III - Será facultada aos alunos e professores a mudança de orientação, proposta e tema, conforme cronograma (Anexo I). Para oficializar a alteração será necessário preencher um novo formulário de inscrição e encaminhá-lo à Coordenação de Projetos, podendo ser deferido ou não.

IV - Caso seja necessário haver a colaboração de outros professores em algumas fases específicas do Projeto, estes poderão dar assessoria ou apoio técnico para a execução de algumas tarefas como: fotografia, vídeo, áudio, planejamento gráfico etc.

V. Como regra geral, a orientação deverá ocorrer nas salas dos quartos anos do Departamento, quando não houver aula ou em sala de estudo.

VI - Cada orientador perceberá uma hora/aula semanal por trabalho orientado."

Fonte: "Normas para Elaboração dos Projetos Experimentais" - 2008 - (vide anexos)

O que não se pode esquecer são as condições de trabalho em muitas

escolas de Jornalismo brasileiras, ponto fundamental quando se discute a qualidade de ensino. Não só existem situações precárias de infra-estrutura e de laboratórios, como os docentes acumulam inúmeras tarefas e responsabilidades 
sendo remunerados por um número reduzido de horas/aulas e com o risco iminente de um desligamento, uma vez que muitas IES não mantêm planos de carreira docente, nem sequer condições estáveis para a maioria de seu corpo docente. "Nesses locais, docentes são tratada como mão de obra descartável e mal remunerada e discentes valorizados apenas como clientela pagadora de serviços. Para completar, algumas escolas têm aproveitado a atual liberdade curricular para eliminar investimentos em órgãos laboratoriais - que a história do ensino de Jornalismo já comprovou serem essenciais para a formação profissional". (KOSHIYAMA, 2007, p. 9).

\subsection{Qualificação docente}

O documento que fundamentou as Diretrizes Curriculares (Parecer CNE/CES 492/2001) determina que o Projeto Acadêmico do Curso deva prever e expor com clareza a estrutura, a formação e a organização do seu corpo docente, de modo a assegurar a efetiva realização competente dos objetivos de ensino, pesquisa e extensão do Curso. Devem, portanto, estar especificados:

- a caracterização das competências, formação, experiência, dedicação e perspectivas pedagógicas que dão consistência ao conjunto de professores do Curso, explicitando assim o Perfil do Corpo Docente;

- a comprovação de que os docentes têm o perfil, a formação e a experiência adequados aos conteúdos, aos procedimentos e aos objetivos das disciplinas e demais atividades pelas quais se responsabilizam;

- o estabelecimento de titulação mínima do corpo docente; 
- a definição do regime de trabalho dos docentes;

- a orientação e o estímulo à capacitação didático-pedagógica dos docentes, desde o início das suas atividades na Instituição;

- o estabelecimento de metas de produção acadêmica teórica, cultural e técnica pelos docentes;

- a definição de efetivo envolvimento de docentes em atividades de pesquisa científica na área da comunicação;

- a existência de plano de capacitação dos docentes com estímulos para a pósgraduação em níveis de especialização, mestrado e doutorado;

- a existência de programa de atualização, reciclagem e qualificação continuada do corpo docente, através de cursos, estágios técnicos e outras formas de intercâmbio com o mercado de trabalho e com setores de reflexão e pesquisa, considerando as disciplinas teóricas e técnicas;

- existência de programa de aperfeiçoamento dos coordenadores e demais gestores dos cursos;

- o índice de dedicação dos professores ao desenvolvimento de atividades de pesquisa e extensão;

- a existência de um determinado número de docentes que ministram disciplinas técnicas e que desenvolvam o exercício profissional em suas áreas de competência especializada pertinente, de forma simultânea à atividade docente, sem deixar de buscar condições que possibilitem sua titulação pós-graduada;

- a existência de um plano de carreira profissional para os docentes. (CEE-COM, 1999, on line) 


\subsection{Critérios de escolha do Orientador}

Curiosamente, somente uma das normas selecionadas como amostra detalha alguns critérios para a escolha do professor orientador, porém, trata-se de um aspecto de fundamental importância na elaboração dos Projetos Experimentais. Entre as preocupações dos alunos e as indicações das coordenações, alguns aspectos são observados, como:

- se o projeto for profissional, o orientador deve ser jornalista por formação, se o projeto for monográfico, o orientador deve possuir o título de mestre;

- capacitação profissional e afinidade com a área de atuação do formato escolhido (impresso, foto, rádio, TV, assessoria, etc.) é o critério mais considerado;

- afinidade pessoal com o aluno e/ou com os membros do grupo também conta;

- afinidade com o tema (se o orientador não se sente à vontade com determinado tema, ele pode recusar a orientação);

- disponibilidade de tempo e de horário para orientação (um orientador pode orientar um número limite de Projetos por semestre ou por ano);

- deve ter demonstrado experiência anterior na orientação de projetos semelhantes;

- apresentar postura ética e comprometimento com o projeto;

- considera-se também o histórico do professor como docente, como orientador e como avaliador em bancas finais. 
A seguir, o detalhamento dos critérios sugeridos para escolha dos orientadores dos Projetos Experimentais expressa nos regulamentos adotados pelas IES que compõem a amostra da pesquisa:

\section{UNIVERSIDADE SANTA CECÍLIA - UNISANTA}

"Art. 9 - O aluno/grupo poderá indicar seu professor-orientador, dentre o Corpo Docente do Curso.

Parágrafo único - O aluno/grupo poderá solicitar a troca de orientador, desde que apresente, por escrito, justificativa para tal solicitação e declaração de disponibilidade do novo orientador para exercer a função.Tal justificativa será avaliada pela Comissão de TCC responsável pelo curso (anexo $B$ ).

Art. 10 - A Coordenação do Curso reservará, no Plano de Trabalho dos membros do Corpo Docente, 01 (uma) hora-aula semanal, por trabalho, para orientação, exame e elaboração de pareceres para a aferição do TCC.

Art. 11 - O aluno/grupo, quando da indicação de seu orientador, deverá considerar os seguintes aspectos:

a) experiência docente;

b) afinidades intelectuais, profissionais e pessoais;

c) linhas de pesquisa mais adequadas ao seu trabalho;

d) disponibilidade do docente."

Fonte: "Diretrizes para Elaboração de Trabalho de Conclusão de Curso de Graduação (TCC)" - 2007 (vide anexos)

\subsection{Envolvimento docente, impasses e incentivos}

Dentre as atribuições de um professor orientador são destacados nos regulamentos os seguintes aspectos:

- acompanhar o trabalho em todas as suas etapas (proposta, pré-banca ou qualificação, desenvolvimento e Banca Examinadora);

- dedicar as horas/aula correspondentes de orientação presencial por semana a cada grupo em data, local e horários fixos; 
- orientar ações, formular sugestões, propor leituras, efetuar correções de textos, direcionar os alunos ao cumprimento das etapas previstas, avaliar os alunos no meio e ao final do projeto;

- permitir ao aluno a aplicação de conhecimentos técnicos e práticos de forma concreta na execução do Projeto Experimental;

- ensinar como se aplicam os conhecimentos obtidos ao longo do curso no desenvolvimento de um projeto profissional ou acadêmico, respeitando individualidades e estimulando posturas inovadoras e criativas;

- propor desafios e permitir que o aluno compreenda os limites e alcances do projeto que está desenvolvendo;

- planejar etapas de trabalho, propor metas a curto, médio e longo prazos e tornar possível o cumprimento de um cronograma para execução do projeto;

- recusar, quando for o caso, o acompanhamento de grupos e/ou alunos que não estejam cumprindo o que foi estabelecido desde o início do projeto. O orientador pode desistir da orientação, na maioria dos casos, em qualquer momento do desenvolvimento, mediante justificativa cabível e somente com anuência da coordenação de Projetos Experimentais.

A seguir, o detalhamento alguns dos critérios sugeridos para escolha dos orientadores dos Projetos Experimentais expressa nos regulamentos adotados pelas IES que compõem a amostra da pesquisa:

\section{UNIVERSIDADE DE SÃO PAULO - ECA/USP}

O aluno escolhe o orientador dentro de uma lista prévia fornecida pela coordenação do Curso e cada professor pode orientar até quatro projetos por semestre.

Fonte: "Formulários Departamento de Jornalismo e Editoração ECA/USP" - 2008 (vide anexos) 


\subsection{Processo de orientação}

O ensino do Jornalismo, por variadas circunstâncias, encontra-se vulnerável por vários fatores, entre eles a dificuldade dos professores em considerar a técnica como uma atividade pouco intelectual por parte dos estudantes de Jornalismo. Cabe às IES criar uma cultura acadêmica, dento de seus propósitos como instituição de ensino-pesquisa-extensão de forma que tanto docentes quanto alunos possam entender e usar as novas tecnologias sem perder o foco jornalístico. É preciso considerar que o Jornalismo é uma atividade intelectual e os jornalistas também têm o papel de educadores, reconhecendo que bons jornalistas podem ter presença necessária na comunidade acadêmica.

As IES podem criar meios para motivar seus professores para pesquisar, escrever e publicar sobre Jornalismo, dando exemplo aos alunos e desenvolvendo linhas de pesquisa de pensamento e prática, inclusive com a criação de programas de pós-graduação focados no Jornalismo. O grande desafio das orientações de Projetos Experimentais, em muitos casos, é educar estudantes para pensar criticamente, preparando os futuros jornalistas para serem profissionais de inovação e competência. A seguir, o detalhamento das atribuições dos orientadores dos Projetos Experimentais expressa nos regulamentos adotados pelas IES que compõem a amostra da pesquisa:

\section{PONTIFÍCIA UNIVERSIDADE CATÓLICA DE SÃO PAULO - PUCSP}

"Cada professor-orientador poderá orientar um máximo de 3 trabalhos e poderá exigir a respeito de cada um deles relatórios parciais de desenvolvimento.

Cabe ao professor-orientador, junto à Coordenação de TCCs, o agendamento da data da apresentação do trabalho, bem como as providências para o convite à banca julgadora, local e condições que viabilizem o evento. Ao final do julgamento, é de responsabilidade do professor-orientador a confecção de ata em que conste o nome dos julgadores e 0 resultado final obtido pelo(s) aluno(s)."

Fonte: "Regulamento dos Trabalhos de Conclusão do Curso de Jornalismo da PUC-SP" - 2006 (vide anexos) 
"Todo aluno tem direito a desenvolver seu projeto sob a supervisão de um orientador, professor da Faculdade Cásper Líbero, convidado a fazer o acompanhamento pedagógico do trabalho. Recomenda-se que o aluno procure um orientador da área de interesse de seu projeto (consulte o item "Professores orientadores"). A escolha do orientador passará pela aprovação da Comissão de Projetos Experimentais, que indicará outro professor caso necessário.

É dever do orientador avaliar a viabilidade do projeto sugerido antes que se efetue a inscrição definitiva do trabalho. Após analisar a proposta, o professor convidado tem 0 direito de aceitar, ou não, ser o orientador do projeto. Caso o aluno não consiga a concordância de um orientador, poderá, ainda assim, fazer a inscrição de seu projeto e requerer o auxílio da coordenação de projetos experimentais, solicitando formalmente a indicação de um orientador.

A orientação do projeto se dará em horário a ser definido e divulgado pela coordenação de projetos experimentais no início do ano letivo. O atendimento do orientador será feito exclusivamente nas dependências da faculdade. Cabe também ao orientador avaliar continuamente o desenvolvimento do TCC, bimestralmente (ver o item "Etapas de avaliação do projeto"), qualificá-lo no meio do ano e, no terceiro bimestre, reprová-lo ou encaminhá-lo para

seu desenvolvimento final.

É importante lembrar que o orientador não é co-autor do trabalho. Cabe a ele apoiar e auxiliar o aluno nessa empreitada, seja na pesquisa e no ajuste do projeto em processo, seja sobre eventuais dúvidas que surgirem ao longo do processo, mas não redigir, revisar ou editar o trabalho."

Fonte: "TCC: Guia para consulta" - 2007 (vide anexos)

\section{UNIVERSIDADE DE RIBEIRÃO PRETO - UNAERP}

"Art.34 - São atribuições, competências e requisitos do Orientador da Monografia de Pesquisa em Comunicação:

I. Assinar o termo de compromisso e responsabilidade no prazo estipulado.

II. Responsabilizar-se pelo projeto da Monografia de Pesquisa em Comunicação, emitindo parecer sobre o mesmo, no prazo estipulado pelo calendário da Atividade Complementar II.

III. Responsabilizar-se pela condução e elaboração da Monografia de Pesquisa em Comunicação deliberando e exigindo cumprimento das atividades que programou.

IV. Elaborar e comentar circunstanciadamente o relatório de acompanhamento do grupo de Orientador matriculado na Atividade Complementar II que conterá parecer favorável.

V. Presidir e conduzir as atividades da Banca Examinadora, bem como apurar as notas e divulgar o resultado final.

VI. Preencher o formulário da reunião da Banca e devolvê-lo ao Núcleo de Produção Científica em Comunicação, juntamente com a cópia da Monografia que tiver obtido aprovação."

Fonte: "Regulamentação da Monografia de Pesquisa em Comunicação para Conclusão do Curso" - 2002 (vide anexos) 


\section{UNIVERSIDADE CATÓLICA DE SANTOS - UNISANTOS}

"O processo de orientação consiste em uma relação essencialmente educativa, onde orientador e orientando interagem no sentido do preparo e desenvolvimento do aluno para a elaboração de um trabalho científico. Esse processo supõe:

a) que o orientador mantenha com o grupo/aluno diálogo franco e aberto;

b) que transmita segurança e conhecimento em relação ao conteúdo e desenvolvimento do trabalho;

c) que auxilie a construção de todo o procedimento metodológico para o conhecimento científico;

d) que incentive e auxilie o grupo/aluno a superar possíveis lacunas de sua formação;

e) que discuta com o grupo/aluno, a viabilidade e consistência da proposta do trabalho, as idéias e que apresente sugestões e críticas;

f) que cuide do processo de amadurecimento intelectual do grupo/aluno, não assumindo as tarefas por ele;

g) que esteja atento para a coerência entre objetivos, metodologia, referencial teórico e resultados obtidos;

h) que oriente a redação do trabalho para evitar ambigüidades, generalidades e imprecisão;

i) que seja rigoroso quanto à disciplina intelectual, sem ser desestimulador;

j) que seja presente e atenda ao grupo/aluno nos horários marcados para orientação;

I) que esteja atento aos prazos e procedimentos administrativos e acadêmicos;

m) que garanta ao aluno/grupo a avaliação sistemática do trabalho, obedecendo aos critérios pré-estabelecidos nas normas ou regulamentos do TCC;

$\mathrm{n})$ que atenda às determinações das normas ou regulamentos do TCC, mantendo o professor responsável sempre informado de possíveis intercorrências durante o processo de orientação."

Fonte: "Guia Acadêmico Unisantos" - 2007 (vide anexos)

\section{UNIVERSIDADE METODISTA DE SÃO PAULO - UMESP}

"Além de contar com o professor de Metodologia Científica, titular da disciplina Consultoria Metodológica que ordena sistematicamente os passos do trabalho, o estudante precisará escolher um orientador de conteúdo, que o acompanhará e orientará a monografia no que ela tem de específico e da sua pertinência em relação ao objeto de estudo.

Uma vez escolhido o orientador, a relação orientando/orientador deve levar em conta o diálogo consciente e coerente, de forma que cada um desempenhe seu papel na discussão conjunta e que as decisões relativas ao trabalho sejam partilhadas com maturidade intelectual.

Quanto mais assíduos forem os encontros, mais o processo de produção do PE será implementado e a ciência, o mercado de trabalho e a instituição de ensino superior, sairão ganhando nesse diálogo profissional."

Fonte: "Regulamento dos Projetos Experimentais do Curso de Jornalismo" - 2005 (vide anexos) 


\section{UNIVERSIDADE DE TAUBATÉ - UNITAU}

“Art. 16. Compete ao professor orientador:

I - participar das reuniões convocadas pela Coordenação de Projetos Experimentais;

II - fornecer horários de orientação à Coordenação de Projetos;

III - atender semanalmente seus orientandos, em horário e local previamente fixados;

IV - entregar à Coordenação os relatórios de avaliação e nota de seus orientandos, conforme cronograma (Anexo I);

V - providenciar formas de controle das orientações (lista de chamada, relatório etc.) dos seus grupos, pois dessa forma poderá fazer um acompanhamento constante dos trabalhos facilitando a elaboração das avaliações;

VI - presidir a defesa pública do Projeto de seu orientando;

VII - elaborar e assinar, juntamente com os demais membros da Banca Examinadora, a ata final de defesa pública do Projeto;

VIII - zelar pela avaliação correta do Projeto, permitindo que os demais avaliadores tenham liberdade e autonomia ao fazer suas análises e notas;

IX - cumprir e fazer cumprir este regulamento.

§ 1‥ O professor orientador poderá assumir no máximo 4 (quatro) trabalhos por período (matutino/noturno).

§ 2‥ A troca de professor orientador somente será permitida quando outro professor assumir formalmente a orientação, mediante concordância expressa do professor orientador e anuência do Coordenador Geral de Projetos."

Fonte: "Normas para Elaboração dos Projetos Experimentais" - 2008 - (vide anexos)

\section{UNIVERSIDADE SANTA CECÍLIA - UNISANTA}

“Art. 12 - Cabe ao Professor-Orientador do TCC:

I - organizar e supervisionar todas as atividades do TCC;

II - criar mecanismos operacionais que facilitem a condução, com segurança e aproveitamento, do TCC desenvolvido pelo aluno/grupo;

III - orientar o aluno/grupo no desempenho de suas atividades, complementando a formação educacional/profissional do discente;

IV - fazer cumprir os cronogramas e os prazos das atividades do TCC;

V - registrar todas as atividades desenvolvidas com o aluno/grupo, em ficha padronizada (anexo C). Tal ficha deverá ser entregue à Comissão de TCC de cada curso, segundo o cronograma estabelecido por tal comissão;

VI - zelar pelo cumprimento das Diretrizes e Normas do TCC.

Art. 13 - Cada Professor-Orientador assumirá, no máximo, 4 (quatro) trabalhos. Casos excepcionais serão resolvidos pela Comissão de TCC de cada curso."

Fonte: "Diretrizes para Elaboração de Trabalho de Conclusão de Curso de Graduação (TCC)" - 2007 (vide anexos)

\section{UNIVERSIDADE DE SÃO PAULO - ECA/USP}

A coordenação do Curso fornece um formulário de acompanhamento de freqüência do aluno às orientações para a descrição das atividades e registro dos encontros efetuados.

Fonte: "Formulários Departamento de Jornalismo e Editoração ECA/USP" - 2008 (vide anexos) 


\subsection{Pré-bancas e Bancas Examinadoras}

Todo Projeto Experimental de Jornalismo que será avaliado por professores que compõem as Bancas Examinadoras devem ser examinados sob vários aspectos. Os mais adotados pelas IES em seus regulamentos incluem a reflexão sobre os seguintes tópicos: tema, formato, pertinência, inovação, etc.

Há também uma análise quanto ao envolvimento dos membros do grupo e o domínio do tema e do formato no momento da exposição à Banca, porém, os avaliadores costumam atribuir ao projeto um conceito de qualidade quanto ao processo, quanto ao produto final e quanto aos objetivos propostos, questionado ainda: Como o projeto poderia ser melhorado? Ele pode ser considerado uma referência para outros alunos? Por que? É possível identificar a participação ou o acompanhamento do orientador no projeto? Em geral, as Bancas Examinadoras funcionam como uma última aula aos alunos concluintes do curso de Jornalismo. A seguir, o detalhamento do funcionamento das Bancas Examinadoras dos Projetos Experimentais expressa nos regulamentos adotados pelas IES que compõem a amostra da pesquisa:

\section{PONTIFÍCIA UNIVERSIDADE CATÓLICA DE CAMPINAS - PUCCAMP}

"Como é do conhecimento da comunidade acadêmica que compõe a Faculdade de Jornalismo da PUC-Campinas, a avaliação em banca reserva 30 minutos para a exposição do trabalho por parte dos alunos e 10 minutos para a manifestação de cada docente que compõe a banca examinadora. Sendo assim, o Relatório de Fundamentação Teórica é considerado elemento estratégico na defesa das idéias e propostas dos alunos em face ao trabalho desenvolvido."

Fonte: "A estrutura dos Relatórios de Fundamentação nos Projetos de Jornalismo" - 2005 (vide anexos) 


\section{FACULDADE CÁSPER LÍBERO - FCL}

"Funcionamento das bancas

Apresentação:

Cada aluno ou grupo tem até 15 minutos para apresentar seu trabalho à banca, priorizando questões de ordem metodológica e evitando informações redundantes. Consecutivamente, os membros da banca têm até 10 minutos cada um para fazerem sua argüição. Reservam-se ainda 10 minutos finais para eventuais réplicas e tréplicas por parte de alunos e argüidores. Com vista a uma eficiente utilização do tempo, cada apresentação deve ter a duração máxima de 1 hora e 15 minutos.

Dinâmica:

Cada banca deverá contar, necessariamente, com um professor da Faculdade e com pelo menos um profissional ou acadêmico de reconhecida autoridade na área e/ou tema do projeto. Os nomes dos participantes da banca serão estabelecidos de comum acordo entre alunos e orientador, e submetidos à aprovação da coordenação de projetos experimentais.

O critério de aprovação desses nomes seguirá o regulamento e princípios éticos que evitem conflitos de interesse. Não serão aceitos convidados que tenham qualquer grau de parentesco com o aluno ou o orientador, interesses comerciais no projeto, relações profissionais independentemente do nível hierárquico, envolvimento direto com o trabalho (como fontes e consultores diretos do projeto) ou qualquer outra relação que possa comprometer o rigor da avaliação.

Caberá ao aluno convidar os membros da banca, com auxílio de seu orientador, e encaminhar aos convidados as cópias do trabalho que será avaliado. Cada banca examinadora será presidida pelo coordenador de projetos experimentais. No caso de o coordenador ser orientador do trabalho avaliado, ou quando forem realizadas mais de uma banca no mesmo horário, outro membro da comissão de projetos experimentais assumirá a presidência da banca.

Cabe ao presidente da banca orientar os examinadores sobre os critérios de avaliação, mediar o debate entre alunos e argüidores e a deliberação dos argüidores para atribuição da nota, assegurando o cumprimento das demais normas estabelecidas por este regulamento e as boas condições da apresentação e das argüições. Sempre que julgar necessário, poderá expor sua opinião sobre a qualidade do projeto, no compromisso de zelar pelo equilíbrio, equanimidade e coerência das avaliações."

Fonte: “TCC: Guia para consulta” - 2007 (vide anexos)

\section{UNIVERSIDADE CATÓLICA DE SANTOS - UNISANTOS}

"f) Quando o TCC exigir banca examinadora, essa deverá ser composta por professores do quadro da Universidade Católica de Santos.

g) Dependendo da temática poderão ser convidados examinadores externos, só havendo remuneração para esses, salvo se prevista no custo do Curso."

Fonte: "Guia Acadêmico Unisantos" - 2007 (vide anexos) 


\section{PONTIFÍCIA UNIVERSIDADE CATÓLICA DE SÃO PAULO - PUCSP}

"Formação das bancas ou comissões julgadoras e critérios de avaliação:

Os TCCs serão avaliados por uma banca de 3 membros composta da seguinte forma:

- professor-orientador (na qualidade de presidente da comissão)

- 1 convidado externo

- 1 convidado interno

Os membros convidados a integrarem a banca devem ser professores e/ou especialistas/profissionais de áreas de conhecimento ou de atuação pertinentes ao tema desenvolvido no TCC.

É de responsabilidade dos responsáveis pelo trabalho, em comum acordo com o professor-orientador, o convite, o agendamento e as condições de locomoção do convidado externo. Não haverá qualquer forma de remuneração pela participação na comissão julgadora, responsabilizando-se a secretaria da Comfil pela confecção de certificado de participação a ser entregue, ao final da sessão, tanto ao convidado externo quanto ao convidado interno.

A disponibilidade e a organização dos recursos necessários à apresentação dos trabalhos são de responsabilidade do(s) aluno(s), cabendo ao professor-orientador estabelecer os procedimentos de argüição do(s) candidato(s).

Ao final da apresentação, os membros da banca atribuirão individualmente suas notas de acordo com critérios coerentes com a natureza do trabalho apresentado e com as exigências de qualidade técnico-acadêmicas feitas pelo curso de Jornalismo da PUC-SP. As notas serão expressas em valores de zero a 10 (dez).

Será considerado aprovado o trabalho que obtiver média igual ou superior a 7,0.

A final da sessão de julgamento, o professor-orientador registrará em ata específica as notas individuais dos componentes da banca, a média final obtida bem como o resultado conseguido pelo(s) aluno(s)."

Fonte: "Regulamento dos Trabalhos de Conclusão do Curso de Jornalismo da PUC-SP" - 2006 (vide anexos)

\section{UNIVERSIDADE DE RIBEIRÃO PRETO - UNAERP}

"Art.38 Os critérios de avaliação da Banca Examinadora compõem-se dos seguintes elementos:

I. Relevância do assunto e delimitação do tema - 0 a 10 pontos / II. Aspecto formal - 0 a 10 pontos / III. Conteúdo da Monografia - 0 a 10 pontos / IV. Apresentação Oral - 0 a 10 pontos

Parágrafo Único. A soma da média dos quatro elementos de cada membro da Banca Examinadora será dividida por 4 (quatro) obtendo-se a média final que não será arredondada.

Art.39 A média de aprovação será igual ou superior a 5 (cinco) pontos, desde que nenhuma das notas atribuídas por qualquer membro da Banca Examinadora seja inferior a 4 (quatro) pontos.

Art.40 Ocorrendo insuficiência da média mínima para aprovação, o grupo de Examinados estará obrigado a inscrever-se novamente no segundo semestre da Atividade Complementar II, para habilitar-se à nova fase e cumprirá as exigências da Atividade e deste Regulamento.

§1 O grupo de alunos reprovados poderá habilitar-se à Banca Examinadora, no semestre seguinte, facultando-se o aproveitamento do mesmo tema utilizado anteriormente.

§2 A ausência de qualquer aluno às apresentações dos trabalhos, implica na reprovação automática do mesmo."

Fonte: "Regulamentação da Monografia de Pesquisa em Comunicação para Conclusão do Curso" - 2002 (vide anexos) 


\section{UNIVERSIDADE METODISTA DE SÃO PAULO - UMESP}

"Os Projetos Experimentais já concluídos serão avaliados por uma banca examinadora composta de três membros, sendo: 1 . um deles o orientador do trabalho; 2 . um convidado interno - professor do Curso de Jornalismo da UMESP; 3. um convidado externo, podendo este ser um professor de outra instituição ou um profissional do mercado de trabalho que atue na área com a qual se relaciona o projeto, ou professor de outro curso da Instituição.

a) A banca examinadora tem a função de avaliar e emitir notas finais para a aprovação ou reprovação dos Projetos Experimentais e, conseqüentemente, do aluno;

b) Compete ao professor orientador, com o conhecimento do aluno, indicar a composição da banca examinadora, cabendo à Coordenação do Curso, juntamente a Coordenação dos Projetos Experimentais, a aprovação final dos membros indicados;

c) O grupo deverá entregar quando da solicitação de defesa do projeto, em data previamente definida no calendário, um currículo síntese (até 10 linhas) do professor/profissional externo convidado;

d) Os componentes das bancas devem ser convidados e nomeados com, no mínimo, 15 dias de antecedência da data de apresentação dos PE's. Além disso, cada componente deve receber, individualmente, uma cópia do trabalho/produto, uma cópia do relatório técnico que acompanha o projeto (produtos) e os critérios de avaliação dos Projetos com pelo menos 10 (dez) dias antes da data da apresentação do mesmo.

e) Caso não compareça um ou mais componentes da banca, a apresentação do PE será suspensa e caberá ao professor orientador marcar nova data e horário para exposição do trabalho.

f) O convidado interno - professor da UMESP - não poderá participar de mais de 4 (quatro) bancas examinadoras (este número não inclui as bancas de projetos orientados por ele).

g) Após definição e publicação do calendário de defesas a data, horário e local de realização somente poderão ser alterados com autorização prévia da Coordenação dos Projetos Experimentais.

Avaliação:

a) A banca examinadora (convidados interno e externo) avaliará os PE's em três aspectos: 1) Idéia proposta; 2) Produto final e 3) Defesa. (critérios em anexo).

b) Cada componente da banca examinadora, após conversa/reunião sem a presença dos autores do trabalho, deve atribuir uma nota, separadamente para cada quesito, de 0 (zero) a 10,0 (dez). As notas individuais serão somadas e calculada a média aritmética simples, obtendo a média final do PE. Essa média será aquela que permitirá a participação dos projetos no Prêmio Metodista de Jornalismo e nos concursos externos (atendendo ao critério de estar entre 9 e dez).

c) A média final do grupo será obtida através da soma da nota da banca com a nota da avaliação individual (de 0 (zero) a 10,0 (dez)) atribuída pelo orientado e calculada a média aritmética simples. Esse valor resultará na média final do Projeto Experimental para cada aluno do grupo. A média final deve atingir, no mínimo, 7,0 (sete) e, no máximo, 10,0 (dez) para garantir a aprovação do aluno/grupo;

d) Assim como nas outras disciplinas do Curso, o Projeto Experimental que obtiver média inferior a 7,0 (sete) ficará reprovado, cabendo ao aluno refazer a disciplina no próximo ano;

e) Cada membro da banca examinadora deve assinar a planilha de avaliação fornecida no dia da defesa. Nessa planilha deve conter a nota individual dada pelos membro da banca e a média final da banca, além das notas individuais dadas pelo orientador. As planilhas de avaliação devem ser entregues pelo orientador na Secretaria do Curso;

f) A banca examinadora poderá atribuir ao trabalho a distinção "com louvor", devendo registrá-la na planilha de avaliação. No histórico escolar do aluno constará apenas a nota do Projeto Experimental. 
g) Cabe ao Curso de Jornalismo a divulgação das notas obtidas por todos os alunos do semestre. Também é função do Curso divulgar os melhores trabalhos, por meio de mostras e exposições.

h) As equipes com trabalhos que receberem médias finas de 9,0 (nove) a 10,0 (dez) terão seus PEs indicados para concursos externos, cabendo ao aluno comparecer aos eventos nos quais seu trabalho será exposto ou julgado.

i) Se o professor orientador considerar que o trabalho do aluno não tem condições de ser apresentado para avaliação da banca examinadora, caberá ao professor levar o caso à Coordenação dos PE's, acompanhado de justificativa por escrito. Assim, o aluno estará automaticamente reprovado, cabendo a ele refazer o projeto no semestre seguinte, desde que a disciplina PE's seja oferecida pelo Curso.

j) No decorrer da orientação, o professor orientador poderá reprovar um ou mais integrantes do grupo, inclusive retirando-o da apresentação do trabalho à banca e, conseqüente, dos créditos referidos."

Fonte: "Regulamento dos Projetos Experimentais do Curso de Jornalismo" - 2005 (vide anexos)

\section{UNIVERSIDADE SANTA CECÍLIA - UNISANTA}

“Art. 14 - A Banca Examinadora será composta, obrigatoriamente, pelo professororientador, que a preside, e por outros 2 (dois) membros, indicados e designados pela Comissão de TCC.

§ 1‥ - Poderá fazer parte da Banca Examinadora um membro escolhido entre os professores de outras áreas, com interesse na área de abrangência da pesquisa, ou de Cursos de Instituições de Ensino Superior, ou ainda entre profissionais de nível superior que exerçam atividades afins com o tema do TCC.

§ 20. - A banca examinadora somente poderá realizar seus trabalhos com a presença dos 3 (três) membros.

§ 3‥ - Não comparecendo algum dos professores designados para a Banca Examinadora, tal ausência deverá ser comunicada, por escrito, à Comissão de TCC.

§ 4․ - Não havendo o comparecimento do número mínimo de membros da Banca

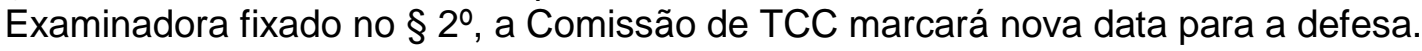

§ 5․ - Deverá, sempre que possível, ser mantida a eqüidade no número de indicações de cada professor para compor as Bancas Examinadoras, procurando, ainda, evitar-se a designação de quaisquer dos docentes para um número superior a 10 (dez) bancas examinadoras por ano. "

Fonte: “Diretrizes para Elaboração de Trabalho de Conclusão de Curso de Graduação (TCC)" - 2007 (vide anexos)

\section{UNIVERSIDADE DE TAUBATÉ - UNITAU}

"Art. 21. A versão final do Projeto será apresentada pelo(s) membro(s) do grupo perante a Banca Examinadora composta pelo professor orientador, que a preside, e por outros dois membros.

$\S 11^{\circ}$. No caso de Projetos Interdisciplinares, a Banca Examinadora deverá ter, além dos orientadores, outros dois professores sendo um de cada área específica.

$\S 2$ ‥ Para participar da Banca Examinadora os professores do Departamento devem se inscrever para o Projeto de sua área de atuação profissional e/ou acadêmica. Os professores serão indicados pela Comissão de Projetos Experimentais, podendo o orientador vetar a participação de algum membro, encaminhando justificativa para a Comissão de Projetos que analisará, deferindo ou não o veto. 
$\S 3^{\circ}$. Os professores que forneceram assessoria ou apoio técnico não poderão participar destes respectivos Projeto nas Bancas Examinadoras.

$\S 4$. É facultado ao aluno e orientador convidar 1 (um) participante de fora - desde que esteja ligado ao tema - para compor a Banca como assistente. Esse convidado poderá analisar o Projeto, mas não atribuirá nota. Ao realizar o convite, os alunos deverão avisar com antecedência a Coordenação de Projetos e ter o aceite do orientador.

$\S 5$ 5. É facultado ao orientador convidar no máximo 1 (um) docente de outro Departamento da Unitau ou de outra Universidade para participar da Banca como professor convidado. Ele deverá ser de área afim ao trabalho e poderá, caso o orientador permita, atribuir nota como os demais professores da Banca.

$\S$ 6‥ Caso algum membro da Banca Examinadora falte no dia da apresentação, ela deverá funcionar, excepcionalmente, com 2 (dois) professores. A Banca somente será adiada na ausência do orientador ou dos outros dois membros.

$\S 7^{\circ}$. Não comparecendo todos os membros da Banca Examinadora, deverá ser marcada nova data para a apresentação.

$\S 8^{\circ}$. O professor que se comprometer em participar da Banca e se ausentar no dia da apresentação receberá falta.

§ 9‥ A avaliação da Banca Examinadora é soberana não cabendo recursos após sua avaliação final.

$\S 10^{\circ}$ A Banca Examinadora avaliará os seguintes aspectos:

I - O trabalho entregue por escrito antecipadamente;

II - Apresentação oral;

III - O material produzido pelos alunos. (Ex: vídeo, fotos, cartazes, etc.)

$\S 11^{\circ}$ Cada membro da Banca atribuirá notas individuais de 0 (zero) a 8,0 (oito), com intervalo de 0,1 ponto, para cada aluno do trabalho apresentado. Após a soma e divisão das notas, utilizando a média aritmética simples será acrescida a nota do orientador $(2,0)$ dois pontos,compondo assim a Média Final de cada aluno.

$\S 12$ Os membros da Banca deverão, logo após a apresentação do(s) aluno(s), avaliar o Projeto e o presidente comunicar em seguida as médias parciais a média final para os membros do grupo.

$\S$ 13. Estarão aprovados os alunos cujos Trabalhos tiverem Média igual ou superior a 6,0 (seis)."

Fonte: "Normas para Elaboração dos Projetos Experimentais" - 2008 - (vide anexos)

\section{UNIVERSIDADE DE SÃO PAULO - ECA/USP}

A Banca é composta por três avaliadores, sendo um o professor orientador, e os outros dois titulares. É permitida a substituição posterior dos avaliadores por suplentes indicados pelo aluno. Todos os membros da Banca atribuem notas de 0 (zero) a 10,0 (dez) e recomendam possíveis alterações.

Fonte: "Formulários Departamento de Jornalismo e Editoração ECA/USP" - 2008 (vide anexos)

É papel da IES estimular o desenvolvimento da cidadania e da responsabilidade social dos profissionais que está formando, propiciando a aplicação de conhecimentos vistos ao longo do curso no desenvolvimento de 
Projetos Experimentais bem direcionados. O papel dos orientadores é dinamizar as ações didático-pedagógicas, produzindo trabalhos que atendam às expectativas do mercado, estimulando a promoção de parcerias e estreitando as relações com o cenário no qual o futuro jornalista irá atuar. Entre suas atribuições principais estão: estimular o desenvolvimento e aprimoramento técnico-profissional do aluno, além de promover e dinamizar a produção do conhecimento.

Na maior parte das IES, os principais critérios e indicações dos regulamentos para avaliação dos Projetos Experimentais se dedicam a considerações sobre o tema, como a viabilidade e relevância para a área; à forma quanto o texto se apresenta, como clareza, objetividade, ortografia e adequação da linguagem ao tema proposto; à profundidade da pesquisa bibliográfica, de campo e das entrevistas; e quanto à clareza, correção, postura, desembaraço e utilização de recursos audiovisuais nas Bancas Examinadoras. 


\section{Elaboração de Projetos Experimentais}

O processo de elaboração de um Projeto Experimental exige do aluno de Jornalismo um trabalho intenso, tendo em vista a busca de uma ou mais respostas ao problema proposto, seja no campo da pesquisa acadêmica, seja em busca de soluções para problemas comunicacionais que se apresentem na preparação de conteúdos jornalísticos em diferentes suportes. Essa busca, que mais se assemelha a uma garimpagem intelectual, denomina-se pesquisa, ainda que no campo profissional, pois exige do graduando a utilização de métodos e técnicas específicas.

A realização de um Projeto Experimental caracteriza-se por buscar saídas inteligentes para problemas cuja solução não exista repertório disponível, de tal modo que fique evidente a relação de causa e efeito existente entre os elementos envolvidos no problema. Após a definição do assunto a ser estudado, deve-se definir o caminho a ser seguido, ou seja, quais os elementos são necessários e como utilizá-los para que os objetivos sejam atingidos. A forma como utilizar os recursos disponíveis, a apresentação dos objetivos e o procedimento do aluno para atingir o resultado esperado também estão previstas nos regulamentos de Projetos Experimentais das IES.

Pela profundidade que se espera de um trabalho de conclusão de curso, a elaboração se apresenta como um processo minucioso que se propõe a aprofundar determinado tema. Sobre esse aspecto, as Diretrizes Curriculares propõe que o jornalista deve ter ampla formação humanística voltada para a reflexão crítica dos acontecimentos sociais; deve ser capaz de conhecer as técnicas de captação, 
codificação e divulgação das informações de interesse público, interpretando, com critério jornalístico, os fatos cotidianos. Como profissional de comunicação, deve ser capaz de entrevistar, escrever editoriais, artigos, crônicas, reportagens e comentários sobre assuntos diversos na mídia impressa e eletrônica, contribuindo para a reflexão e transformação social, e considerando, para isso, a necessidade de atualização permanente frente às novas tecnologias de comunicação; ser criativo e ter iniciativa para experimentar novas linguagens e produtos de comunicação; apresentar formação ética social e profissional, compromisso com a cidadania e humildade diante da realidade. (BRASIL, 2001, on line)

Os regulamentos também são instrumentos que fornecem, resumidamente, uma visão geral do Projeto Experimental a ser realizado, situando o problema no contexto a ser trabalhado. Neles também estão contidas as justificativas de como o tema abordado e ES escolhas iniciais podem ser adotadas. A seguir, a exposição sobre o processo de elaboração dos Projetos Experimentais expressa nos regulamentos adotados pelas IES que compõem a amostra da pesquisa:

\section{UNIVERSIDADE DE TAUBATÉ - UNITAU}

"Art. 13. Compete ao aluno:

I - escolher o professor orientador e o tema para o seu Trabalho;

II - participar das atividades para as quais for convocado pelo professor orientador ou pela Coordenação;

III - respeitar o cronograma de trabalho, aprovado pelo orientador;

IV - cumprir as tarefas solicitadas pelo orientador;

$\mathrm{V}$ - entregar ao orientador e à Coordenação os relatórios e as avaliações das atividades desenvolvidas;

VI - entregar à Coordenação de Projetos Experimentais no mínimo 4 (quatro) cópias impressas e 01 cópia digital (disquete ou Cd) do Trabalho Final, autorizado pelo professor orientador. Estas cópias servirão para análise pelos componentes da Banca Examinadora e para a Biblioteca do Departamento.

VII - comparecer no dia, hora e local determinados para acompanhar apresentação do Trabalho Final perante a Banca Examinadora."

Fonte: "Normas para Elaboração dos Projetos Experimentais" - 2008 - (vide anexos) 
"O aluno tem ampla liberdade para explorar o tema e o formato escolhido, experimentar métodos, técnicas e linguagens. Assim, caberá a ele a realização do projeto proposto dentro dos prazos delimitados pelo professor orientador e a coordenação de projetos experimentais.

Para um bom andamento do trabalho, é importante que o cronograma de encontros acertado com o orientador seja cumprido. É importante notar também que o não comparecimento às reuniões agendadas pode ser prejudicial ao acompanhamento do TCC. Em caso de qualquer dúvida ou problemas de relacionamento com o orientador ou grupo, o aluno deverá se reportar à coordenação de projetos experimentais.

Colaboradores

Embora não seja proibida, deve-se evitar a participação de professores da Faculdade como colaboradores, fontes de informação e qualquer outra forma de participação direta no conteúdo do projeto - a não ser os casos em que esses professores forem fontes únicas ou especialistas sem pares na especialidade.

Profissionais da mídia impressa só serão aceitos como colunistas, cronistas ou articulistas, na proporção de dois colaboradores por projeto, e cujos textos sejam inéditos. São permitidos colaboradores nas áreas de design gráfico, arte final, ilustração, fotografia, programação de HTML e outras linguagens, Flash, infográfico e produção gráfica, assim como eventuais patrocínios e anúncios de apoio ao projeto, desde que não seja desvirtuado o caráter pedagógico. No entanto, é preciso lembrar que essas iniciativas não devem implicar uma avaliação mais favorável do projeto, seja nas fases de qualificação, seja na apresentação à banca examinadora.

Programas de rádio e televisão podem receber a colaboração de técnicos, locutores, cenógrafos e sonoplastas, mas a criação, roteiro, reportagem e direção do programa devem ser necessariamente realizados pelo aluno."

Fonte: “TCC: Guia para consulta” - 2007 (vide anexos)

As Diretrizes Curriculares que dispõem sobre a habilitação em Jornalismo definem que aluno do curso de Comunicação Social deverá desenvolver a capacidade de reflexão para analisar os padrões e práticas jornalísticas, exercitando sua capacidade criativa no sentido de experimentar novas linguagens e produtos de comunicação. Compete à IES também discutir questões socioculturais e políticas e oferecer ensinamentos sobre novas tecnologias aplicadas à linguagem jornalística, criando condições para que o aluno exercite sua capacidade criativa, no sentido de experimentar novas linguagens e produtos de comunicação. Também é necessário que o egresso tenha a capacidade de compreender os mecanismos envolvidos no processo de recepção de mensagens e seu impacto sobre os diversos setores sociais, como no caso da IES abaixo: 


\section{UNIVERSIDADE METODISTA DE SÃO PAULO - UMESP}

"Local de realização e condições de produção:

1) Com o objetivo de igualar as condições utilizadas pelos alunos na elaboração dos PE's, os mesmos devem ser preferencialmente executados nos laboratórios da própria Universidade $_{2}$ incluindo etapas que exijam gravações, edição em rádio e TV, diagramação etc.

2) Os equipamentos de vídeo e equipe deverão ser agendados, obedecendo ao cronograma previamente definido pela coordenação do curso de Jornalismo e pelo coordenador dos laboratórios de TV e Rádio.

3) Os equipamentos de vídeo e equipe somente poderão ser alocados para atividades relativas aos PE's na Grande São Paulo.

4) As fitas de áudio e vídeo são de responsabilidade dos alunos/grupo. A Universidade não emprestará ou cederá as fitas de áudio, vídeo e filmes fotográficos.

5) Não serão permitidas ligações internacionais e interurbanas na Universidade para a realização do $\mathrm{PE}$.

6) Os alunos/grupos deverão obedecer rigorosamente à planilha de horários, disponibilidade/locais das equipes e dias para a utilização de todos os equipamentos de áudio, vídeo, equipes, laboratórios de informática e estúdios; objetivando o desenvolvimento dos PE's.

7) Os alunos poderão imprimir as monografias e os relatórios que acompanham os PE's nos laboratórios de informática da Faculdade de acordo com a cota de cópias previamente definida para a turma, respeitando a quantidade autorizada para cada grupo/aluno.

8) É de responsabilidade dos alunos/grupos a obediência aos prazos de entrega dos PE's.

9) Para o uso dos equipamentos para a gravação das entrevistas (viva-voz) do Curso terão prioridades os grupos que estão desenvolvendo projetos na área de Rádio. Para as demais modalidades o uso deverá ser autorizadas previamente pelo orientador do PE e pelo coordenador(a) do curso de Jornalismo ou coordenador(a) dos Projetos Experimentais; obedecendo/respeitando a disponibilidade do equipamento.

10) No caso de projetos realizados parcialmente ou totalmente em laboratórios externos, 0 aluno e o professor orientador devem registrar a opção no relatório técnico que acompanha o produto, inclusive esclarecendo os motivos da utilização de equipamentos e laboratórios de outras instituições ou empresas do mercado de trabalho. Essa atitude servirá para situar a banca examinadora dentro do processo de realização do trabalho, minimizando as possíveis desigualdades de execução e facilitando a avaliação por parte dos examinadores.

11) Patrocínios, apoios e financiamentos externos serão possíveis, desde que avaliados e autorizados pelo professor orientador, juntamente a Coordenação dos Projetos Experimentais. Ainda assim, a opção deve ser registrada no relatório técnico, acompanhada de justificativa.

12) Para as modalidades em Jornalismo Televisivo e Radiofônico o número de projetos, por turma, não poderá ultrapassar 5 (cinco). As modalidades individuais (monografia e fotojornalismo) somente serão permitidas se os projetos em grupo (de no mínimo 5 integrantes) não atingirem o número de 18 por turma.

13) Em caso de plágio (comprovado) no PE fica definida a reprovação sumária de todo o grupo na disciplina.

14) Qualquer atuação referente ao desenvolvimento do PE que demande necessidades fora da Grande São Paulo, será de inteira responsabilidade do aluno.

15) Os casos omissos serão decididos pela coordenação do Curso de Jornalismo e pela coordenação dos Projetos Experimentais, com aprovação do Colegiado do curso."

Fonte: "Regulamento dos Projetos Experimentais do Curso de Jornalismo" - 2005 (vide anexos) 


\subsection{Autoria}

A elaboração de um Projeto Experimental deve ser encarada como um método sistemático de solucionar problemas, ou seja, um plano razoável para atacar e solucionar um problema que está sob investigação, usando não a intuição, mas princípios científicos e de recursos que se apóiam na articulação teóricoprática presente nos cursos de Jornalismo. As técnicas que serão utilizadas, embora variem de veículo ou suporte para o conteúdo jornalístico, incluem os seguintes passos principais: localização e coleta de dados necessários para servir de base para qualquer apuração; análise e organização lógica desses dados de forma a apresentá-los de maneira adequada; interpretação das informações obtidas para chegar a um produto jornalístico que seja singular.

Esse processo pressupõe a questão da autoria, da identificação da figura do jornalista, mentor intelectual do resultado apresentado. O produto final deve refletir a preparação, ou seja, a formação pessoal e profissional do autor; como se deu sua especialização acadêmica e no ambiente de desenvolvimento do trabalho, como o jornalista (repórter) desenvolveu seu estilo próprio e o que este estilo revela; qual a responsabilidade jurídica, social e política do aluno em relação ao Projeto Experimental elaborado; como se deu a liberdade de imprensa e de expressão do autor; de que maneira se revelam os segredos da profissão e a natureza jurídica e organização da profissão naquilo que o trabalho de conclusão de curso resultou.

A seguir, o que expressam sobre a autoria e composição das equipes os regulamentos dos Projetos Experimentais adotados pelas IES que compõem a amostra da pesquisa: 


\section{FACULDADE CÁSPER LÍBERO - FCL}

"Número de participantes por gênero de projeto: Além de respeitar os limites de tamanho e duração, os alunos deverão atentar para a importância (quando não para a real necessidade) de fazerem seus projetos em grupo, respeitando o espírito gregário da boa prática jornalística.

Livros reportagem

podem ser feitos individualmente ou em até 4 alunos; monografias poderão ser feitas individualmente ou em duplas; jornais e revistas devem ter entre 3 e 6 alunos; e programas de rádio e TV e trabalhos multimídia (reportagens, site, Podcast), entre 3 e 4 integrantes. Os únicos gêneros possíveis de serem realizados individualmente são os previstos nas normas: livro reportagem e monografia. Não serão abertas exceções.

Para qualquer outro formato que eventualmente seja proposto (como newsletter eletrônica, portal, blogs, conteúdo colaborativo, projeto de assessoria de imprensa, publicação institucional e livro reportagem fotográfico, por exemplo), a aprovação da proposta e a adequação do número de alunos participantes serão definidas pelo orientador do trabalho, pela coordenação de projetos experimentais e pela coordenadoria de jornalismo, pautados, sobretudo, pelos objetivos e alcance da proposta de trabalho."

Fonte: "TCC: Guia para consulta" - 2007 (vide anexos)

\section{UNIVERSIDADE METODISTA DE SÃO PAULO - UMESP}

"Os PE's devem ser desenvolvidos preferencialmente em grupo (mínimo 5 componentes), no caso de elaboração de produtos na área jornalística (ver modalidades abaixo), ou individualmente, quando a opção for por trabalhos monográficos ou na área de fotojornalismo, conforme descrição no item seguinte. Na produção dos projetos, todas as atividades, especialmente as desenvolvidas por jornalistas, devem ser executadas por integrantes das equipes, inclusive a locução/narração, diagramação e fotografias. Duplas, trios e quartetos só serão permitidos caso o no de projetos não ultrapasse 18 (dezoito).

Para as modalidades em Jornalismo Televisivo e Radiofônico o número de projetos, por turma, não poderá ultrapassar 5 (cinco). As modalidades individuais (monografia e fotojornalismo) somente serão permitidas se os projetos em grupo (de no mínimo 5 integrantes) não atingirem o número de 18 por turma."

Fonte: "Regulamento dos Projetos Experimentais do Curso de Jornalismo" - 2005 (vide anexos)

\section{UNIVERSIDADE SANTA CECÍLIA - UNISANTA}

"Art. 5․ - - O tema do TCC poderá ser desenvolvido individualmente ou em grupo com número de componentes a ser definido pela Comissão de TCC de cada curso. O tema é de livre escolha do(s) aluno(s), devendo ter vínculos com a atuação profissional futura ou com o campo da Comunicação Social ou de Artes. Poderá ser desenvolvido individualmente ou até em grupo de 3 (três) alunos no caso de Jornalismo e grupo de até 4 (quatro) em Publicidade e Propaganda e Educação Artística ou no caso de Trabalho interdisciplinar (Ex: Jornalismo e PP).

Parágrafo Único: Caso o aluno escolha fazer uma monografia esta deverá ser feita individualmente e orientada por um professor da FaAC, com titulação de Mestre ou Doutor."

Fonte: "Diretrizes para Elaboração de Trabalho de Conclusão de Curso de Graduação (TCC)" - 2007 (vide anexos) 


\section{UNIVERSIDADE DE TAUBATÉ - UNITAU}

"Art. 8. O Projeto Experimental de caráter monográfico poderá ser desenvolvido por, no máximo, dois alunos.

Art. 9. O Projeto Experimental de natureza profissional poderá ser desenvolvido ou em grupo de até 3 (três) alunos da mesma habilitação ou de até 4 (quatro) alunos em habilitações diferentes. (Projeto Interdisciplinar), porém sendo do próprio Departamento (ex: Jornalismo e Publicidade ou Relações Públicas e Jornalismo etc.).

Art. 10. O Projeto poderá ter caráter interdisciplinar, teórico e/ ou prático e deverá estar integrado à linha de pesquisa de cada professor orientador.

Parágrafo Único - Os Trabalhos que forem realizados por alunos de habilitações diferentes (Publicidade e Propaganda, Jornalismo e Relações Públicas), dependendo da natureza do Projeto ou linha de pesquisa, deverão ser orientados por um ou mais docentes. $\mathrm{O}(\mathrm{s})$ professor(es)-orientador(es) e a Banca Examinadora deverão levar em conta a interdisciplinaridade da proposta e avaliar o Projeto como um trabalho único e não dividido pelas respectivas habilitações.

Art. 11.0 tema é de livre escolha do(s) aluno(s), devendo ter vínculos com a atuação profissional futura ou com a sua habilitação específica. "

Fonte: "Normas para Elaboração dos Projetos Experimentais" - 2008 - (vide anexos)

Como a habilitação em Jornalismo busca formar um profissional com cultura ampla, curiosidade intelectual, criatividade, domínio do idioma e das estruturas narrativas e expositivas voltadas às mensagens jornalísticas, é fundamental perceber como é importante a autonomia desse novo profissional na realização do Projeto Experimental. Principalmente porque o Jornalismo hoje se vê frente a novos desafios e mudanças que são comuns em determinados momentos da evolução do conhecimento e o graduando precisa se atualizar e continuar se adequando ao novo patamar.

As Diretrizes Curriculares estabelecem também os perfis específicos que resultam das habilitações, caracterizados por uma abrangência sobre diferentes meios, linguagens e práticas profissionais e de pesquisa e, na atualidade, por envolver um acelerado dinamismo social e tecnológico. Para assegurar o desenvolvimento da formação em Jornalismo, estudos e exercício profissional, as habilitações, definidoras dos perfis específicos, se organizam conforme premissas, como dominar as linguagens habitualmente usadas nos processos de 
comunicação, nas dimensões de criação, de produção, de interpretação e da técnica; experimentar e inovar no uso destas linguagens e refletir criticamente sobre as práticas profissionais no campo da Comunicação. Daí a importância da autonomia dos alunos em escolher os temas e formatos dos Projetos Experimentais.

\subsection{Escolha dos temas e formatos}

Ao escolher um tema e um formato - suporte impresso ou eletrônico para apresentação do conteúdo jornalístico - o graduando tem a finalidade de testar seus conhecimentos na execução de um Projeto Experimental, sua confirmação ou desaprovação, ou descobrir um princípio sobre o qual se fundamenta o domínio das técnicas inerentes à profissão, suas reações ou interações no campo da Comunicação. Uma das etapas do Projeto Experimental consiste em determinar um objeto de apuração, selecionar as variáveis que sejam capazes de influenciá-lo, e observar os efeitos que cada variável produz no objeto dentro de um contexto específico, principalmente por meio de reportagens.

A maioria das técnicas de elaboração de reportagens aponta que para sua elaboração é necessário, primeiro, encontrar um bom tema, ter um bom enfoque. Depois é preciso ter abordagens humanas sobre questões sociais. Os resultados precisam ser profundos e analíticos, envolvendo o leitor, ouvinte ou telespectador com o acontecimento. O fato principal, no Jornalismo, é a descoberta da verdade

por meio de histórias de vida e o papel do jornalista deve ser o de oferecer o contexto da informação. 
Assim, é comum a escolha de temas de Projetos Experimentais que priorizam a cobertura das questões sociais, valorizando ações que promovam qualidade de vida, impacto social, participação democrática, empreendedorismo. A reportagem ideal é aquela que promove o debate, aquele em que o jornalista torna pública a discussão que afeta diariamente a vida das pessoas. Informação permite à sociedade opções de escolha, interpretação, participação das decisões democráticas e construção de novos caminhos.

Na escolha do que se irá fazer e como será feito, é preciso buscar nas fontes novos atores sociais, pois além de ouvir fontes oficiais é preciso legitimar novos discursos, trazer à tona novas idéias, ouvir opiniões divergentes e conceitos distintos para fortalecer o debate. A seguir, o que expressam sobre os temas e formatos dos Projetos Experimentais os regulamentos dos adotados pelas IES que compõem a amostra da pesquisa:

\section{PONTIFÍCIA UNIVERSIDADE CATÓLICA DE CAMPINAS - PUCCAMP}

"Na Faculdade de Jornalismo da PUC-Campinas, entende-se que todas as práticas profissionais contempladas pelo mercado de trabalho e consumo midiático, na área do jornalismo, encaixam-se como possibilidades de Projetos Experimentais. Sendo assim, é facultada aos alunos, ou equipes de alunos, a escolha de uma modalidade, dentro de um leque abrangente de opções, para o desenvolvimento de seu trabalho. Este leque vai de documentários em vídeo e rádio a jornais impressos, passando por revistas, livrosreportagem, programas e reportagens de TV, ensaios fotográficos, projetos e produtos de assessoria de imprensa, sítios de internet, produções em CD/DVD e quaisquer outras hipóteses que encontrem equivalência no mercado de trabalho ou que possam vir a sê-lo numa oportunidade futura, desde que encontrem fundamento na área do jornalismo."

Fonte: "A estrutura dos Relatórios de Fundamentação nos Projetos de Jornalismo" - 2005 (vide anexos)

\section{UNIVERSIDADE DE SÃO PAULO - ECA/USP}

Denominado Trabalho de Conclusão de Curso (TCC), o Projeto Experimental pode ser realizado nas seguintes modalidades: monografia, produto editorial, documentário ou reportagem apresentada sob a forma de livro, vídeo, impresso, televisão, rádio, multimídia, fotografia, CD ROM, etc.

Fonte: "Formulários Departamento de Jornalismo e Editoração ECA/USP" - 2008 (vide anexos) 
"Gêneros e formatos

Livro reportagem e Monografia: mínimo de 150 mil caracteres.

TV: no mínimo, 30 minutos de programa editado.

Rádio: no mínimo, 30 minutos de programa editado e dividido em capítulos.

Revistas: mínimo de 50 páginas editadas.

Jornais: mínimo de 24 páginas editadas para formato convencional e de 32 páginas editadas para formato tablóide.

Multimídia: para sites, mínimo de 3 níveis: Home > Sub home (canal) > Reportagens/Matérias, e 4 canais; Reportagem Multimídia, mínimo 4 unidades narrativas com pelo menos duas combinações de vídeo/texto/áudio/fotografia/infográfico animado; Podcast, mínimo 8 programas.

Monografia

A apresentação de pesquisa monográfica deverá o mesmo modelo de projeto, mas deverá ser incluído o item "Hipóteses", depois da Justificativa:

Apresentação das hipóteses: A tese propriamente dita, ou hipótese geral, gira em torno da idéia central que o trabalho se propõe demonstrar. É preciso não confundir hipótese com pressuposto, com evidência prévia. Hipótese é o que se pretende demonstrar e não o que já se tem demonstrado evidente desde o ponto de partida. Muitas vezes ocorre esta confusão, ao se tomar como hipóteses proposições já evidentes no âmbito do referencial teórico ou da metodologia adotados. Nestes casos, não há mais nada a demonstrar, e não se chegará a nenhuma conquista."

Fonte: "TCC: Guia para consulta" - 2007 (vide anexos)

\section{PONTIFÍCIA UNIVERSIDADE CATÓLICA DE SÃO PAULO - PUCSP}

"Os TCCs com características de Projetos Experimentais são trabalhos desenvolvidos integralmente por um grupo de alunos (no mínimo 3; no máximo 5) sob a perspectiva jornalística, documentária ou teórica com extensão a ser definida em comum acordo entre o grupo e o professor-orientador. São as seguintes as modalidades desse gênero de TCC:

A. Jornalismo impresso (jornal, revista ou livro-reportagem)

B. TeleJornalismo

C. RadioJornalismo

D. Jornalismo digital

E. Vídeo-documentário ou demais expressões audiovisuais

Trabalhos de Conclusão de Curso sob a forma de produção e reflexão individual:

Produções desenvolvidas integral e individualmente pelo aluno também sob a perspectiva jornalística, documentária ou teórica, igualmente com extensão a ser definida em conjunto com o professor-orientador. As modalidades são as seguintes:
A. Livro-reportagem
B. Monografia
C. FotoJornalismo"

Fonte: "Regulamento dos Trabalhos de Conclusão do Curso de Jornalismo da PUC-SP" - 2006 (vide anexos) 


\section{UNIVERSIDADE METODISTA DE SÃO PAULO - UMESP}

"Os Projetos Experimentais podem ser desenvolvidos em oito modalidades, algumas com subdivisões:

a) Livro-reportagem

b) Jornalismo Impresso (revista e jornal)

c) Assessoria de comunicação

d) Jornalismo Televisivo

e) Jornalismo Radiofônico

f) Jornalismo Digital

g) Fotojornalismo - categoria individual ou coletiva (caso o projeto justifique a presença de mais de um participante)

h) Monografia - categoria individual

As monografias consistem em trabalho de pesquisa, com cunho acadêmico e científico, que aborda um tema de escolha do aluno, dentro do campo do Jornalismo.

No caso dos trabalhos práticos, além da elaboração do referido produto jornalístico, o aluno deverá entregar um memorial que explicite todas as fases de produção, tarefas executadas pelos componentes do grupo, objetivos, tema, dificuldades encontradas, relevância social do projeto etc., de acordo com modelo previamente definido."

Fonte: "Regulamento dos Projetos Experimentais do Curso de Jornalismo" - 2005 (vide anexos)

\section{UNIVERSIDADE DE MOGI DAS CRUZES - UMC}

"Para realizar o Projeto Experimental, o aluno deverá escolher um segmento específico da área de Jornalismo. Nesta habilitação o aluno irá optar por realizar um trabalho de maior envergadura acadêmica em uma dos seguintes segmentos:

Para realizar o Projeto Experimental o aluno poderá optar por um dos seguintes segmentos de trabalho:

A - Impresso

a1) Produção e edição de material jornalístico na forma de jornal ou revista , tendo por base um tema central, condutor das pautas necessárias para compor o produto editorial pretendido. Produto final: relatório de fundamentação, boneco da edição, textos finais e prova pré-print da edição, no formato final pretendido.

a2) Livro-reportagem texto, centrado em tema único. O texto final deverá ter um mínimo de 100 mil caracteres. Produto final: livro com dimensões em conformidade com normas da ABNT - Associação Brasileira de Normas Técnicas -, encadernado com lombada quadrada, paginado, eventualmente ilustrado com fotografias. É obrigatório incluir no conteúdo do livro a fundamentação e, sempre que for adequado, um capítulo destinado a analisar como o tema é tratado pela Imprensa em geral.

a3) Livro-reportagem fotográfico , centrado em tema único. Este tipo de livro-reportagem tem como linguagem principal a fotografia [mínimo de 80 fotos na edição], com textos acessórios e complementares. Produto final: livro com dimensões em conformidade com normas da ABNT - Associação Brasileira de Normas Técnicas -, encadernado com lombada quadrada, paginado. É obrigatório incluir no conteúdo do livro a fundamentação e, sempre que for adequado, um capítulo destinado a analisar como o tema é tratado pela Imprensa em geral.

B - Televisivo

b1) Produção de documentário, em formato vídeo, com duração mínima de 26 minutos e máxima de 28 minutos, necessariamente em dois blocos. Produto final: 1 fita de vídeo em sistema NTSC/SVHS, acompanhada de relatório de fundamentação do trabalho, com material de pesquisa e roteiro completo do documentário.

b2) Produção de vídeo-reportagem, com duração mínima de 12 minutos e máxima de 14 minutos. Produto final: 1 fita de vídeo em sistema NTSC/SVHS, acompanhada de relatório 
de fundamentação do trabalho, com material de pesquisa e roteiro completo da reportagem.

b3) Produção de uma edição experimental de telejornal temático , com duração mínima de 20 minutos e máxima de 28 minutos. Produto final: 1 fita de vídeo em sistema NTSC/SVHS, acompanhada de relatório de fundamentação do trabalho, com material de pesquisa e roteiro completo da edição do telejornal.

b4) Produção de um programa jornalístico especial, criado para o meio televisão, com duração mínima de 14 minutos e máxima de 28 minutos. Produto final: 1 fita de vídeo em sistema NTSC/SVHS, acompanhada de relatório de fundamentação do trabalho, com material de pesquisa e roteiro completo do programa.

C - Radiofônico

c1) Produção de uma edição experimental de radiojornal temático, com duração mínima de 15 minutos e máxima de 60 minutos. Produto final: 1 fita para reprodução, em sistema cassete ou DAT acompanhada de relatório de fundamentação do trabalho, com material de pesquisa e roteiro completo do radiojornal.

c2) Produção de um programa jornalístico especial, com duração mínima de 20 minutos e máxima de 40 minutos. Produto final: 1 fita para reprodução, em sistema cassete ou DAT, acompanhada de relatório de fundamentação do trabalho, com material de pesquisa e roteiro completo do programa especial.

C3) Produção de uma reportagem especial, com duração mínima de 10 minutos e máxima de 15 minutos. Produto final: 1 fita para reprodução, em sistema cassete ou DAT, acompanhada de relatório de fundamentação do trabalho, com material de pesquisa e roteiro completo da reportagem especial.

E - Fotográfico

Produção de ensaio fotográfico, acompanhado de textos de contextualização das imagens e apresentação sob a forma de livro, exposição estática ou dinâmica (vídeo-visual-sonora). Produto final: relatório de fundamentação teórica e metodológica, fotografias em cor ou PB, organizadas em pasta ou em forma de publicação encadernada. [OBS: Não confundir com livro-reportagem-fotográfica]

F - Monografia

Estudo e análise de um tema, centrado em aspecto comunicacional, fundamentado em pesquisa adequada a este tipo de trabalho. O texto final deverá ter um mínimo de 90 mil caracteres. Produto final: Documento, em formato A4, encadernado com capa dura, em cor verde, caracteres em preto, que corresponda efetivamente a um estudo monográfico.

$\mathrm{G}$ - Jornalismo Empresarial

Estudo sobre uma empresa, organização não governamental ou instituição de fins não lucrativos e formulação de um plano completo de comunicação para público externo e interno, com apresentação obrigatória de produtos exemplificativos sugeridos no plano. Produto final: Relatório de fundamentação teórica e metodológica, com o plano e layouts exemplificativos dos mecanismos de comunicação sugeridos no plano.

$\mathrm{H}$ - Multimídia

Criação, desenvolvimento e materialização de produtos digitais (e-book, site e áudiovisual) com a correspondente operação experimental, sendo ou não veiculados na rede mundial de computadores. Produto final: Relatório de fundamentação teórica e metodológica, textos e imagens do produto digital pretendido e demonstração em computador, sendo obrigatório, no caso de site, um mínimo de 20 páginas."

Fonte: "Projeto Vôo Solo" - 2008 (vide anexos) 


\section{UNIVERSIDADE DE RIBEIRÃO PRETO - UNAERP}

"Art.35 A Monografia de Pesquisa em Comunicação e o Projeto, devem seguir as normas da Associação Brasileira de Normas Técnicas (ABNT), bem como as normas contidas nesta seção e as instruções anexas neste regulamento.

Art.36 A Monografia de Pesquisa em Comunicação apresentada conterá, no mínimo, 40 (quarenta) laudas de conteúdo temático datilografadas no anverso, em papel sulfite tamanho oficio (A4), branco, digitada em editor de texto para computador, corpo 14, fonte "Times New Roman" (Word), sobre tema na área de Comunicação de livre escolha do grupo que irá executar."

Fonte: "Regulamentação da Monografia de Pesquisa em Comunicação para Conclusão do Curso" - 2002 (vide anexos)

\section{UNIVERSIDADE SANTA CECÍLIA - UNISANTA}

"1) Projetos na área Teórica

Linha de Pesquisa: Fundamentos Teóricos da Comunicação: temas relacionados com a Comunicação Social .- Orientação individual e realizada por um professor Mestre ou Doutor.

2) Projetos na área Profissional:

2.1 - Linha de Pesquisa - Produção Impressa:

Jornal, Revista, Livro-reportagem, Ensaio Fotográfico

2.2 - Linha de Pesquisa - Produção Eletrônica:

A - RÁDIO - Enfoque Jornalístico

Programa de rádio, Radiojornal, Rádio-documentário.

B - TV (mínimo 2 componentes).

Telejornal, Programa Televisivo com enfoque jornalístico, Vídeo-documentários.

2.3 - Linha de Pesquisa - Produção Digital (Conteúdo Jornalístico)

CD-ROOM, Sites

Projetos de Assessoria - (Planejamento, Pesquisa, Execução)

Comunicação, Imprensa."

Fonte: "Diretrizes para Elaboração de Trabalho de Conclusão de Curso de Graduação (TCC)" - 2007 (vide anexos)

\section{UNIVERSIDADE DE TAUBATÉ - UNITAU}

"Art. 7. O Projeto Experimental pode ser:

I - Pesquisa de natureza Acadêmica (Monografia): Trabalho no qual se deve privilegiar a fundamentação teórica para estimular o interesse pela pesquisa. A monografia só poderá ser orientada por doutores, mestres ou mestrandos. Casos especiais serão avaliados pela Comissão de Projetos.

II - Projeto de natureza Profissional: Trabalho no qual se devem privilegiar produtos e serviços voltados para o mercado de Comunicação Social. Exemplos: 1) Grande Reportagem; 2) Organização de Assessorias de Comunicação; 3) Filmes, vídeos, fotos e audiovisuais científicos ou artísticos; 4) Campanhas; 5) Eventos; 6) Planejamento de Marketing; 7) Projetos de Relações Públicas; 8) Programas de Identidade Visual. Outras modalidades serão encaminhadas para avaliação da Comissão de Projetos."

Fonte: "Normas para Elaboração dos Projetos Experimentais" - 2008 - (vide anexos) 
O documento que fundamentou o Parecer CNE/CES 492/2001, elaborado pela Comissão de Especialistas de Ensino em Comunicação Social (CEE - Com), destaca nesse aspecto que são os conteúdos analíticos e informativos sobre a atualidade presentes na estrutura curricular de Jornalismo que objetivam propiciar aos alunos um rico estoque de informações sobre variados aspectos da atualidade, pois esta constitui a matéria-prima essencial para os futuros profissionais da comunicação. Estas informações devem, simultaneamente, assegurar a apreensão de interpretações consistentes da realidade e possibilitar aos estudantes a realização de análises qualificadas acerca dos fatos e contextos culturais, políticos, econômicos e sociais.

\subsection{Prazo e condições de produção}

Os Projetos Experimentais se caracterizam como um trabalho a ser executado com responsabilidade de execução, resultados esperados com quantificação de benefícios e prazo para execução pré-estabelecidos, considerando os recursos humanos, financeiros, materiais e de equipamentos, bem como as áreas envolvidas necessárias a seu desempenho. É uma iniciativa que visa ao mercado real e resulta na produção de um projeto teórico-prático. Denomina-se como Projeto porque não é definitivo, e como Experimental, porque pode ser o novo, o que ainda não foi feito, estimulando o aluno a criar algo novo, aprimorando o que já existe.

Sua realização exige maturidade e dedicação, uma vez que Projeto Experimental pode ser considerado um rito de passagem em que todo aprendizado 
é colocado à prova. Como trabalho de conclusão de curso, permite demonstrar a capacidade do futuro profissional de lidar com o dia-a-dia da carreira escolhida, uma vez que o mercado quer qualidade, ou seja, bons projetos indicam bons profissionais. Quando o Projeto Experimental se revela uma boa idéia, está revelando também o envolvimento com a profissão, uma vez que estimula a utilização de todas as ferramentas obtidas durante o curso.

Nesse aspecto, o prazo para realização é fundamental, pois a viabilidade da idéia deve ser pesquisada, de forma a atender tanto ao panorama do mercado quanto aos pressupostos técnicos da área. Em alguns casos, a realização do projeto vale tanto quanto um estágio. A seguir, como estão descritas as condições de produção dos Projetos Experimentais nos regulamentos dos adotados pelas IES que compõem a amostra da pesquisa:

\section{UNIVERSIDADE CATÓLICA DE SANTOS - UNISANTOS}

"Características do TCC na UNISANTOS

a) O TCC é entendido como etapa conclusiva do processo de ensino-aprendizagem do aluno, devidamente conceituado e definido nos Projetos Políticos Pedagógicos dos Cursos. Portanto, mais do que uma exigência legal estabelecida nas Diretrizes Curriculares, o TCC deve ser significativo para a formação profissional e para o perfil do egresso.

b) O TCC é resultado de um processo integrador/interdisciplinar de acordo com o estabelecido pelos Projetos Políticos Pedagógicos dos Cursos.

c) O TCC será anual e realizado no último ano de formação, mesmo no regime semestral.

d) O TCC será realizado em grupo ou individualmente, de acordo com o que for estabelecido nas normas ou regulamentos de cada curso.

e) O TCC deverá ser devidamente orientado."

Fonte: "Guia Acadêmico Unisantos" - 2007 (vide anexos)

O documento que fundamentou o Parecer CNE/CES 492/2001, elaborado pela Comissão de Especialistas de Ensino em Comunicação Social (CEE - Com), destaca que os conteúdos de linguagens, técnicas e tecnologias midiáticas devem assegurar ao estudante o domínio das linguagens, das técnicas e tecnologias 
tipicamente empregadas nos processos e nas habilitações de comunicação, bem como assegurar uma reflexão rigorosa sobre suas aplicações e processos. Também devem possibilitar a pesquisa e a experimentação de inovações das linguagens, técnicas e tecnologias, visando à formação de um profissional versátil e em sintonia com as tendências de acelerada mutabilidade dos sistemas e práticas de comunicação e suas habilitações na contemporaneidade.

Descreve também os conteúdos éticos-políticos, que devem permitir ao estudante posicionar-se sobre a atuação dos profissionais da comunicação, sobre o exercício do poder da comunicação, sobre os constrangimentos a que a comunicação pode ser submetida, sobre as repercussões sociais que ela enseja e sobre as demandas e necessidades da sociedade contemporânea, sempre em uma perspectiva de fortalecimento da idéia de cidadania, com o estímulo do respeito aos direitos humanos, às liberdades, à pluralidade e à diversidade, à justiça social e à democracia, inclusive na área da Comunicação.

\subsection{Processo de elaboração}

Todo Projeto Experimental deve ser considerado como um trabalho a ser executado com responsabilidade de elaboração, buscando os resultados esperados com quantificação de benefícios e prazo para execução pré-estabelecidos, considerando os recursos humanos, financeiros, materiais e de equipamentos, bem como as áreas envolvidas necessárias a seu desempenho. É uma iniciativa que visa ao mercado real e resulta na produção de um projeto teórico-prático. Considerando que o aluno de Jornalismo demonstra seu esforço ao realizar o 
Projeto Experimental, tal esforço pode gerar repercussão, que gera oportunidade de trabalho.

Deve-se considerar que sua elaboração proporciona fortalecimento do convívio entre professores e alunos, e muitas vezes, é o momento ou o espaço em que o estudante vive a primeira oportunidade de experiência profissional. Mas é preciso respeitar certas etapas, sendo a elaboração da proposta o planejamento inicial. Porém, o desenvolvimento exige planejamento mais apurado uma vez que todo Projeto Experimental exige intensa pesquisa. Uma vez percebidas as etapas necessárias para a realização do $\mathrm{PE}$, o principal aspecto a ser observado é a motivação do aluno e sua afinidade com o formato e com o tema.

Para o planejamento do $\mathrm{PE}$, deve-se realizar uma análise realista da situação atual e potencial, verificando prazos, recursos e orçamentos necessários para obtenção dos resultados. Todo planejamento pressupõe a relação e avaliação de informações e atividades que deverão ser executadas num prazo definido, visando à conquista e realização de objetivos pré-determinados. A seguir, como estão descritos os processos de elaboração dos Projetos Experimentais nos regulamentos dos adotados pelas IES que compõem a amostra da pesquisa:

\section{FACULDADE CÁSPER LÍBERO - FCL}

"Todo projeto experimental, de corte acadêmico ou jornalístico, pode ser alterado no decorrer do processo. Isto é normal e até positivo, uma vez que revela eventuais descobertas, avanços e o aprofundamento das idéias do aluno.

Seja qual for o trabalho, porém, o projeto do aluno deve ser apresentado formalmente, por escrito e em data definida pela coordenação de projetos experimentais (consulte 0 calendário no site) no ato da inscrição, em uma proposta que deve conter os aspectos relacionados a seguir, no caso de projetos de revista, jornal, livro reportagem, programa de televisão, rádio ou multimídia:"

Fonte: "TCC: Guia para consulta" - 2007 (vide anexos) 


\section{PONTIFÍCIA UNIVERSIDADE CATÓLICA DE CAMPINAS - PUCCAMP}

"A realização dos Projetos Experimentais, no último semestre do curso, é portanto vista como a etapa que encerra todo o processo de formação de jornalistas com o perfil desejado no projeto pedagógico curso. Para tanto, os professores deliberaram que trabalhos desta natureza devam ser acompanhados, obrigatoriamente, de um texto que explicite as opções feitas pelos acadêmicos durante sua concepção/realização, não apenas no nível técnico, mas também conceitual e político. Tais textos, aos quais se deu o nome de Relatórios de Fundamentação Teórica, são encarados como uma etapa que, com acompanhamento docente, ainda proporciona ao aluno um espaço considerável para o amadurecimento intelectual.

A rigor, a parte destinada à Introdução deverá equivaler a um primeiro capítulo dos RFTs. É neste espaço, portanto, que o aluno precisará expor os objetivos do trabalho, o contexto em que foi realizado e os conceitos com os quais trabalhou, fazendo ao final conexões para com seus segmentos posteriores. Entre os principais tópicos que devem estar contidos na Introdução, seria de muita utilidade que o aluno abordasse os seguintes itens (cuja divisão em subitens pode ser muito valioso):

a- O contexto em que o trabalho é realizado: finalidade, período histórico e objetivos a serem alcançados;

b- A relevância do trabalho (a produção jornalística) no contexto em que se insere;

c- A metodologia de trabalho empreendida, que vai desde a pesquisa em obras de referência até à realização de entrevistas e leituras documentais para a elaboração do "produto" jornalístico e do próprio RFT em examinação por parte da banca de avaliadores; d- O público pretendido, espaço este em que o aluno debate aspectos relativos às suas

expectativas de recepção para o modelo proposto de comunicação midiática, evidentemente sustentado por leituras de obras de referência, aulas e manuais;

1 Vale lembrar que o relatório a ser encaminhado aos examinadores refere-se a uma produção já concluída, e não a uma intenção de realizá-la.

e- Os conceitos que envolvem a produção, desde aqueles que tratam propriamente do suporte escolhido até os conceitos relativos aos fundamentos da Comunicação, do Jornalismo e da modalidade de produção midiática escolhida. É bom lembrar que, para determinados casos, as questões relativas à autoria também precisam ser discutidas ou estar referenciadas, o que se percebe com mais clareza nas produções de caráter autoral que caracterizam principalmente os livros e/ou os documentários em vídeo, sem que se perca como referência os fundamentos da área em questão, ou seja, o Jornalismo;

$\mathrm{f}-\mathrm{E}$, muito embora exista, entre os jornalistas, uma relativa aversão a algumas das leis que regem o mercado de consumo de bens midiáticos, esta dimensão não pode ser escamoteada na argumentação contida nos relatórios que acompanham os Projetos Experimentais;

g-Por fim, ressalte-se que, embora tenham a designação de experimental, os projetos em Jornalismo também não se constituem espaços para experimentalismo irrefletido, já que são embasados em um longo acúmulo de conhecimentos que caracterizam as práticas profissionais deste campo, objeto de estudo ao longo dos quatro anos que compõem a formação do aluno.

Assim sendo, os experimentalismos em tais produções devem se orientar pelos referenciais específicos deste campo, com argumentação cujo grau de convencimento deverá ser objeto de avaliação por parte das bancas examinadoras.

TEMÁTICA

A segunda parte do corpo dos RFTs deverá ser dedicada ao debate e explicitação do tema que está sendo objeto da apropriação jornalística em questão, ou seja, a temática que domina a produção midiática elaborada pelo acadêmico, em seus aspectos macro e micro. Neste sentido, sugere-se ao aluno que, ao elaborar este segmento do trabalho, não se esqueça de incluir elementos como:

a- Uma breve abordagem histórica do tema que está sendo objeto de estudo, a partir de 
uma investigação de caráter vertical e horizontal, ou seja, observando-se seus antecedentes e o contexto em que a temática se apresenta na atualidade;

b- Podem fazer parte deste levantamento as entrevistas eventualmente realizadas para a produção jornalística, devendo ser referenciadas no texto conforme as normas da ABNT;

C- $\mathrm{E} O$ recorte jornalístico que o trabalho pretendeu realizar, incluindo no item os diferenciais que possam existir em relação às produções midiáticas que convencionalmente chegam ao público;

PRODUÇÃO

A partir do recorte jornalístico explicitado no item anterior, nesta terceira e última parte do corpo do trabalho o aluno deverá debater e explicar, com base em técnicas e estratégias de comunicação jornalística, todas as decisões tomadas durante a elaboração de seu projeto de conclusão de curso. Como se tratam de produções contempladas por um grande leque de possibilidades (do vídeo ao rádio, passando por livros, revistas e CDRoms, entre outros), cada trabalho deverá conter itens e subitens que lhes são absolutamente próprios. Abaixo, numa tentativa de categorizar elementos das produções midiáticas, apontamos, no geral, alguns tópicos cuja abordagem não poderia ser esquecida:

a- Título da produção;

b- Pauta;

c- Fontes, entrevistas, sonoras, depoimentos;

d- Edição, diagramação, paginação, roteiro, narrativa, espelho de edição, hiperlinks, navegação;

e- Vinhetas, selos, logotipo, colunas, trilha sonora;

f- Enquadramentos, uso de microfones, de gravadores, créditos;

g- Uso ou não de cores e quaisquer efeitos visuais;

h- Uso de primeira pessoa, impessoalidade, transcrições literais;

i- Uso de elementos ficcionais;

Etc.

Neste último segmento do trabalho reserva-se espaço para que os alunos, após a trajetória percorrida até então, teçam seus comentários acerca do trabalho desenvolvido, seja no sentido de avaliar os fundamentos do jornalismo aplicados à temática em estudo e às técnicas empregadas; seja para indicar novos rumos de abordagem ao tema escolhido; seja para avaliar o grau de sucesso e eficiência atingidos com a aplicação das técnicas e estratégias adotadas. A rigor, este é um espaço em que o(s) autor(es) do projeto manifesta $(m)$ a consciência de incompletude que caracteriza os trabalhos acadêmicos, mesmo porque a totalidade e a perfeição são, por natureza, propriedades inatingíveis com a intervenção humana. Não há demérito, portanto, na autocrítica e na admissão da falibilidade nesta etapa do trabalho."

Fonte: "A estrutura dos Relatórios de Fundamentação nos Projetos de Jornalismo" - 2005 (vide anexos)

\section{UNIVERSIDADE SANTA CECÍLIA - UNISANTA}

"Art. 8 - São as seguintes as fases do TCC:

I - escolha do tema;

II - indicação do Professor-Orientador;

III - preenchimento e protocolização, na Secretaria ou Coordenação do Curso, da Ficha de Inscrição para Início de Orientação (anexo A).

Da Apresentação do Trabalho de Conclusão de Curso

Art. 15 - A apresentação do TCC dar-se-á em duas etapas - escrita e oral - e obedecerá às exigências constantes das presentes Normas na parte referente ao Regulamento da Defesa, que assim se dispõe:

I - Quanto à parte escrita da monografia ou do relatório técnico:

a) Cada aluno/grupo deverá fornecer 3 (três) cópias espiraladas do TCC, sendo 1 (uma) 
para o Professor-Orientador e 2 (duas) para os outros 2 (dois) membros da Banca Examinadora.

b) Após a defesa oral, o aluno/grupo aprovado terá prazo máximo de 15 (quinze) dias para entregar ao Coordenador de TCC a versão final do trabalho, ou seja, uma cópia em capa dura, com as devidas correções sugeridas pela Banca e acatadas pelo orientador. ATENÇÃO: a divulgação da nota está condicionada a essa entrega. Ressalta-se que só farão parte do acervo da biblioteca da UNISANTA trabalhos que obtiverem nota igual ou superior a 9,0 (nove).

c) O TCC, obrigatoriamente, deverá conter pré-texto, texto e pós-texto, especificados na parte 2 deste documento.

II - Quanto à parte oral:

a) O cronograma de apresentação será fornecido pela Comissão de TCC de cada curso, respeitado o calendário escolar.

b) Todo TCC será defendido, oralmente, pelo seu(s) autor(es). No caso de trabalhos realizados em grupo, todos os integrantes do mesmo devem expor, individualmente, a parte pela qual ficaram responsáveis.

c) Serão concedidos, no máximo, 30 minutos para o aluno/grupo apresentar seu trabalho, podendo utilizar-se dos meios disponíveis pela Universidade para uma suficiente defesa do TCC.

d) Cada integrante da Banca Examinadora terá prazo máximo de 10 minutos para argüir o aluno/grupo, sendo obrigatória a participação de todos os docentes.

e) A sessão de defesa do TCC será pública.

Parágrafo único - Não será permitido aos membros das bancas examinadoras tornarem públicos os conteúdos dos trabalhos antes de suas defesas.

Art. 16 - O aluno/grupo somente poderá participar da defesa oral mediante aprovação do Professor-Orientador."

Fonte: "Diretrizes para Elaboração de Trabalho de Conclusão de Curso de Graduação (TCC)" - 2007 (vide anexos)

\section{UNIVERSIDADE DE TAUBATÉ - UNITAU}

"Art. 18. Os Trabalhos de natureza acadêmica (monografias) serão normatizados pela Coordenação de Projetos Experimentais.

$\S 1^{\circ}$. Caso o Trabalho seja de natureza profissional, como: a elaboração de filme, vídeo, fotos, audiovisual ou produção semelhante, o grupo deverá elaborar suportes que permitam a análise do material pela Banca Examinadora, como por exemplo: cópias das fitas, roteiro, fotos ou outras produções.

$\S 2^{\circ}$. Os trabalhos profissionais ou técnicos na área de Jornalismo deverão ser acompanhados por um relatório técnico fundamentando, onde estarão descritas todas as etapas do processo de produção e criação. Estão isentos de Relatório na área de PP os seguintes trabalhos: Planejamento de Campanha, Planejamento de Marketing e Identidade Visual.

Art. 19. Todos os Projetos deverão ser apresentados pelo(s) membro(s) do grupo de forma oral e pública para uma Banca Examinadora, cuja exposição deve acontecer no prazo de 20 minutos, acompanhada ou não de recursos audiovisuais.

$\S$ 1‥ A data de apresentação dos Projetos será determinada pela Coordenação de Projetos levando em conta a disponibilidade de horário dos professores orientadores.

$\S 2^{\circ}$. O aluno que, sem justificativa, deixar de comparecer à apresentação oral de seu trabalho, será reprovado. Poderá o aluno solicitar recurso à Comissão de Projetos, que analisará o seu pedido, observando o mérito ou não da questão. Caso seja aprovada a solicitação será marcada uma nova data para a apresentação.

Art. 20. Todas as vias impressas dos Projetos, material produzido (mínimo 4) e uma cópia digital, deverão ser entregues e protocoladas na Coordenação de Projetos, conforme 
Cronograma (Anexo I).

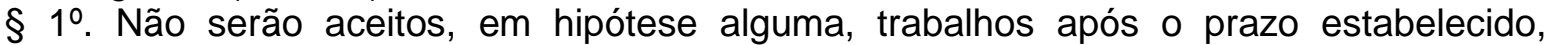
estando automaticamente reprovados os alunos cujos trabalhos forem entregues fora do prazo.

$\S 2^{\circ}$. Não será permitida, em hipótese alguma, a substituição de cópias entregues no período regular, nem o acréscimo de material além do que foi entregue na Coordenação.

$\S 3^{\circ}$. Os Trabalhos interdisciplinares deverão entregar cópias para todos os professoresavaliadores."

Fonte: "Normas para Elaboração dos Projetos Experimentais" - 2008 - (vide anexos)

De acordo com o documento que fundamentou o Parecer CNE/CES 492/2001, elaborado pela Comissão de Especialistas de Ensino em Comunicação Social (CEE - Com), o Projeto Pedagógico deve prever e expor com clareza todas as características de estrutura e de funcionamento do Curso, assim como os padrões e métodos destinados a assegurar sua qualidade. O objetivo é proporcionar a necessária visibilidade para o conjunto de recursos materiais e humanos mobilizados, bem como o modo de articulá-los e empregá-los na formação dos futuros profissionais.

O Projeto deve incluir descrições e proposições referentes à proposta pedagógica, ao corpo docente, às estruturas de serviço e infra-estrutura material, a modos de integração com a sociedade e o mercado de trabalho e a procedimentos de acompanhamento e avaliação. Inclui também a necessidade de prever e expor com clareza os procedimentos por meio dos quais assegurará uma efetiva interação com a sociedade, cumprindo sua responsabilidade de fornecer recursos humanos qualificados ao mercado de trabalho e de aperfeiçoar o próprio funcionamento social por meio de suas perspectivas inovadoras e críticas. Isso diz respeito também ao desenvolvimento de atividades de ensino, pesquisa e extensão que estimulem a geração de mercado de trabalho e o surgimento de demandas sociais por atividades profissionais relevantes dos egressos. (CEE-COM, 1999, on line) 


\subsection{Uso de laboratórios}

A elaboração de Projetos Experimentais pressupõe a aplicação dos conhecimentos obtidos pelos alunos nas diferentes áreas de formação, no caso Radiojornalismo, Fotojornalismo, Telejornalismo, Webjornalismo, Jornalismo Impresso, Assessoria de Imprensa, etc. Sua execução deve possibilitar o conhecimento das técnicas de planejar, organizar e executar projetos práticos e específicos de Jornalismo, por meio de um contato direto com questões sociais, desenvolvendo um projeto de Jornalismo que se ajuste à realidade.

Há, portanto, a conscientização da necessidade da prática do Jornalismo como elemento transformador da realidade e para tal é preciso por a mão na massa, ou seja, vivenciar o Jornalismo em práticas e laboratórios, seja em órgãos laboratoriais, seja no desenvolvimento do trabalho de conclusão de curso. A Resolução no 002/84 determinava a obrigatoriedade de realizar os Projetos Experimentais nos laboratórios das IES, mas as Diretrizes Curriculares aprovadas em 2001, não têm esta determinação. A seguir, o que expressam sobre o uso dos laboratórios das IES os regulamentos de Projetos Experimentais adotados pelas IES que compõem a amostra da pesquisa:

\section{PONTIFÍCIA UNIVERSIDADE CATÓLICA DE SÃO PAULO - PUCSP}

"Os equipamentos laboratoriais disponíveis na PUC e eventualmente necessários para a realização dos TCCs devem ter seu uso previamente agendado nos setores correspondentes, não se responsabilizando o Departamento de Comunicação Jornalística nem o docente-orientador do trabalho pelo não-cumprimento da programação. As despesas decorrentes do uso de qualquer material não disponível ou sem uso autorizado pela PUC-SP (inclusive consumo de papel, utilização de impressoras, fitas de vídeo etc.) correrão por conta do(s) alunos(s) interessados.

Os alunos poderão obter financiamento para a realização de seus TCCs, desde que o apoio seja avaliado em sua conveniência ética e didático-pedagógica pelo professororientador."

Fonte: "Regulamento dos Trabalhos de Conclusão do Curso de Jornalismo da PUC-SP" - 2006 (vide anexos) 


\section{UNIVERSIDADE METODISTA DE SÃO PAULO - UMESP}

"1) Com o objetivo de igualar as condições utilizadas pelos alunos na elaboração dos PE's, os mesmos devem ser preferencialmente executados nos laboratórios da própria Universidade ${ }_{2}$ incluindo etapas que exijam gravações, edição em rádio e TV, diagramação. 2) Os equipamentos de vídeo e equipe deverão ser agendados, obedecendo ao cronograma previamente definido pela coordenação do curso de Jornalismo e pelo coordenador dos laboratórios de TV e Rádio.

3) Os equipamentos de vídeo e equipe somente poderão ser alocados para atividades relativas aos PE's na Grande São Paulo.

6) Os alunos/grupos deverão obedecer rigorosamente à planilha de horários, disponibilidade / locais das equipes e dias para a utilização de todos os equipamentos de áudio, vídeo, equipes, laboratórios de informática e estúdios; objetivando o desenvolvimento dos PE's.

7) Os alunos poderão imprimir as monografias e os relatórios que acompanham os PE's nos laboratórios de informática da Faculdade de acordo com a cota de cópias previamente definida para a turma, respeitando a quantidade autorizada para cada grupo/aluno.

10) No caso de projetos realizados parcialmente ou totalmente em laboratórios externos, o aluno e o professor orientador devem registrar a opção no relatório técnico que acompanha o produto, inclusive esclarecendo os motivos da utilização de equipamentos e laboratórios de outras instituições ou empresas do mercado de trabalho. Essa atitude servirá para situar a banca examinadora dentro do processo de realização do trabalho, minimizando as possíveis desigualdades de execução e facilitando a avaliação por parte dos examinadores."

Fonte: "Regulamento dos Projetos Experimentais do Curso de Jornalismo" - 2005 (vide anexos)

Sobre as estruturas de serviço e infra-estrutura material, o documento que fundamentou o Parecer CNE/CES 492/2001, elaborado pela Comissão de Especialistas de Ensino em Comunicação Social (CEE - Com), descreve que o Projeto Acadêmico do Curso deve prever e expor com clareza a estrutura, a formação e a organização de seu corpo técnico e de serviços, e de sua infraestrutura material requeridos para a efetiva realização competente dos objetivos de ensino, pesquisa e extensão do Curso. Devem, portanto, estar especificados:

- a dimensão, a diversidade de especialidades e a qualificação do corpo técnicoadministrativo responsável pelas atividades de apoio;

- a definição de estímulos à formação continuada do corpo técnico-administrativo;

- as salas de aula, salas para docentes e espaços físicos especialmente destinados às atividades de Pesquisa e Extensão, em número e dimensões 
compatíveis com a quantidade de estudantes, de docentes, e com a diversidade de atividades previstas;

- os laboratórios voltados para as habilitações em funcionamento, levando em conta os diferentes suportes tecnológicos necessários para suas práticas, com os equipamentos adequados - em quantidade e qualidade - especificando-se o número máximo de alunos por turma, que se mostre adequado ao aproveitamento pedagógico nas disciplinas técnicas;

- os produtos de uso laboratorial existentes para formação práticoprofissionalizante dos estudantes, especificando seu caráter permanente ou eventual e sua periodicidade de reposição;

- um sistema de dados englobando: biblioteca e hemeroteca básicas; acervo com arquivo de sons e imagens; arquivo de fotografias; e todos os demais acervos e coleções requeridos pelos objetivos de Ensino, Pesquisa e Extensão;

- as condições físicas do conjunto de locais, assegurando os níveis de claridade, aeração, conforto e adequação à saúde coletiva pertinentes aos objetivos educacionais e necessários para a reunião e presença continuada do número de pessoas envolvidas. (CEE-COM, 1999, on line)

\subsection{Experiência profissional}

Os Projetos Experimentais devem ser elaborados levando-se em conta o cenário social e mercadológico. Em muitos casos há a falta de um diagnóstico mais profundo e os alunos buscam soluções tradicionais e corriqueiras, o que gera certa limitação do alcance dos projetos e sua eficácia. Os integrantes 
devem ter consciência do que significa o projeto e dos problemas que enfrentarão na sua execução, tanto no relacionamento com os colegas, professores e fontes. O principal momento de discutir em profundidade é na definição do tema e do formato do Projeto Experimental. De acordo com França \& Freitas (1997) é preciso considerar:

- Avaliação da situação: O que se pretende fazer e em que formato pretende fazer / Análise da situação (pessoal, profissional) / Priorizar afinidades (pessoais, do grupo).

- Levantamento das necessidades e expectativas do mercado: Os concorrentes / O clima (cultura e viabilidade) / O que já foi feito e o que precisa ser feito / Analisar as possibilidades do novo ou aprimoramento do antigo.

- Desenvolvimento de um modelo conceitual: Ainda é uma idéia, mas deve-se levar em conta as expectativas externas e de possíveis públicos sobre a idéia.

- Aprovação da idéia: Submeter a idéia a quem entende do assunto = professores, orientadores, profissionais, colegas com mais experiência etc.

- Planejamento da elaboração do modelo: Curto, médio e longo prazo / O que é preciso planejar (formato, objetivo, justificativa, público-alvo, linguagem, mensagem) / Estrutura do conteúdo / Recursos materiais (equipamentos, equipe) / Tamanho, tempo, verbas, resultados esperados.

- Avaliação do impacto: Elencar aspectos positivos e negativos do projeto em questão / O que se espera do projeto final. 
- Estabelecimento de metas: Por onde começar / Quais os esforços, prazos, custos e recursos necessários / O que fazer, como fazer, quando fazer.

A fim de propiciar modos de integração com a sociedade e com o mercado de trabalho, o documento que fundamentou o Parecer CNE/CES 492/2001, elaborado pela Comissão de Especialistas de Ensino em Comunicação Social (CEE - Com), estabelece que o Projeto Acadêmico do Curso deva ainda prever e expor com clareza os procedimentos através dos quais assegurará uma efetiva interação com a sociedade, cumprindo sua responsabilidade de fornecer recursos humanos qualificados ao mercado de trabalho e de aperfeiçoar o próprio funcionamento social através de suas perspectivas inovadoras e críticas. Devem, portanto, ser relacionados:

- $\quad$ as atividades regulares de Extensão;

- os meios de acompanhamento da integração dos profissionais formados pela escola ao mercado de trabalho;

- a interação entre o Curso, através de docentes, discentes e profissionais dos serviços de apoio, com entidades representativas dos diversos segmentos da área das comunicações, orientada para a solução de problemas referentes ao mercado de trabalho e cooperação no que se refere às atividades de Ensino, Pesquisa e Extensão;

- a interação entre o Curso, através de docentes, discentes e profissionais dos serviços de apoio, com entidades representativas dos diversos segmentos da área das comunicações e com setores da sociedade civil em geral, que atuem no sentido da busca de soluções para os problemas de interesse público da área; 
- a existência de um programa de estágio orientado por objetivos de Ensino, Pesquisa e Extensão e que seja regulamentado e fiscalizado com a participação dos Sindicatos representativos dos setores profissionais pertinentes com jurisdição na região, para evitar o aviltamento do mercado de trabalho;

- a integração das atividades de formação com os veículos e estruturas de serviço e produção de comunicação da própria instituição de ensino superior (publicações, emissoras de rádio e TV, inclusive canais de TV por assinatura, produtoras, agências, editoras ou assessorias);

- previsões referentes ao desenvolvimento de uma vocação regional que oriente aspectos determinados e delimitados na formação, promovendo a adequação do curso às condições sócio-econômicas e culturais da região em que estiver localizada a Instituição e valorizando as habilitações frente às demandas sociais da região;

- o desenvolvimento de atividades de ensino, pesquisa e extensão que estimulem a geração de mercado de trabalho e o surgimento de demandas sociais por atividades profissionais relevantes dos egressos. (CEE-COM, 1999, on line)

\subsection{Visão crítica do mercado e da profissão}

A elaboração dos Projetos Experimentais determina a necessidade de uma pesquisa profunda sobre $\mathrm{o}$ assunto e $\mathrm{o}$ formato. Este levantamento garante $\mathrm{o}$ diagnóstico completo da realidade e do mercado, eliminando aquilo que França \& Freitas (1997) denominam como "achismo" e a insegurança. Possibilita também o estabelecimento de estratégias de ação, levando o aluno a valorizar o interesse do 
público no produto jornalístico que está desenvolvendo. Todo planejamento torna claro a importância de uma postura profissional e seu resultado demonstra ainda a importância da qualidade do projeto. Para França \& Freitas (1997), tal postura obriga o aluno a tratar seus objetivos em uma dimensão técnica e operacional, deixando de lado a improvisação e o amadorismo. O resultado pode valorizar o trabalho profissional como um portfólio de realizações, um cartão de recomendação para o mercado.

No caso do Jornalismo, há de se considerar os objetivos dos produtos jornalísticos, incluindo o perfil do público-alvo a ser atingido (perfil), ou seja, que tipo de leitor (idade, sexo, faixa etária); qual a possibilidade de se interessar pelo tema; quais os hábitos de leitura e interesse por determinados conteúdos; quais os pontos de distribuição para atingir esse público; em relação a produtos similares, qual o diferencial; qual o conteúdo adequado para esse público e em que linguagem.

Outros elementos a considerar num planejamento são as condições econômicas do mercado, os recursos financeiros disponíveis para elaboração do tema e do formato, qual a infra-estrutura de produção; como se apresenta a concorrência externa, ou seja, no mercado e quais as formas de viabilização e distribuição. Nas IES, há certa preferência para determinados formatos de Projetos Experimentais, definidos inclusive nos regulamentos com certas particularidades e orientações, como demonstrado no item 6.2 da análise, sendo os mais comuns (cf. ALMEIDA et al, 2005, p. 66-77):

\section{1) Assessoria de Imprensa}

É necessário que, para elaboração de uma assessoria de imprensa, exista um cliente real, para que os alunos vivenciem o contato com o mercado. 


\section{2) Ensaio Fotográfico}

Produção de fotografias sobre determinado tema. Juntamente com o trabalho, deve ser apresentado um relatório técnico, com um número mínimo de fotos.

\section{3) Grande Reportagem Impressa}

Elaboração de grande reportagem especificamente para mídia impressa, como complemento ou caderno encartado. Segue os mesmos critérios do jornal impresso. No trabalho final deve constar relatório técnico, conforme etapas mínimas.

\section{4) Livro-reportagem}

Elaboração de um livro-reportagem, passando pela coleta de dados, redação do texto e projeto gráfico do livro. Deve vir acompanhado de relatório técnico e ter um mínimo de páginas.

\section{5) Grande Reportagem em Vídeo}

É uma matéria jornalística, que obedece aos padrões do telejornalismo. Busca ouvir e mostrar todos os enfoques possíveis de um fato. Possui na figura do repórter o elo de ligação entre as informações. Sua abordagem não é superficial, devendo buscar o maior número de informantes. Deve ter duração mínima expressa em minutos.

\section{6) Jornal Digital}

Concepção de um jornal de veiculação na Internet ou outro meio digital. Pode ser criado para um cliente real ou um projeto empreendedor. Deve ser acompanhado de relatório técnico. 


\section{7) Jornal Impresso}

Concepção de um jornal impresso para um cliente real ou um projeto empreendedor. Deve ser acompanhado de relatório técnico, conforme itens mínimos como número de páginas no formato standard ou tablóide.

\section{8) Programa de Rádio}

Concepção e produção de um programa de rádio. Entre outros, pode ser um rádiojornal. Deve ter um tempo mínimo de minutos.

\section{9) Rádio-Documentário}

Elaboração, a partir de um tema previamente selecionado, de um documentário a ser veiculado no rádio. Deve ter duração mínima de minutos e ser acompanhado de relatório técnico.

\section{0) Programa Jornalístico}

É uma produção que utiliza os formatos do telejornalismo e de programas de entretenimento para veicular informações. Sua estrutura está baseada tanto em apresentador ou âncora, como em repórter, assim como, tanto em estúdio ou locação, quanto em produção externa. A produção deve ter de 20 a 30 minutos de duração. Ex: talk-show, debate, utilidade pública etc. Deve ser acompanhado de relatório técnico.

\section{1) Publicacão Empresarial}

Elaboração de uma publicação para um cliente real, podendo ser periódica ou uma publicação comemorativa, um relatório anual etc. Publicação deve ter o porte necessário para um Projeto Experimental, ou se enquadrar em um projeto de assessoria de imprensa. Pode apresentar o formato de publicação (jornal, revista, vídeo etc.). 


\section{2) Revista Digital}

Elaboração de uma revista a ser veiculada na Internet ou outro meio digital. Capa e conteúdo devem ter alta qualidade nas imagens e texto, este composto por reportagens de cunho investigativo ou interpretativo. É sugerido um mínimo de seções/editorias, valorizando o uso do hipertexto e de recursos de computação gráfica. Pode ser feita para um cliente real ou ser um projeto empreendedor. Pode ser acompanhada de relatório técnico impresso.

\section{3) Revista Impressa}

Elaboração de uma publicação periódica para meio impresso. O conteúdo deve ser composto por reportagens de cunho investigativo ou interpretativo. As imagens, inclusive da capa, devem ter boa resolução e alta qualidade de impressão, em papel couché ou similar. O exemplar deve ter um mínimo de páginas de miolo. Pode ser feita para um cliente real ou ser um projeto empreendedor. Deve ser acompanhada de relatório técnico.

\section{4) Telejornal}

Para a concepção de um telejornal, devem ser previstos todos os aspectos técnicos e de conteúdo que envolvem um programa jornalístico televisivo, conforme itens mínimos. Deve ter uma duração mínima de minutos.

\section{5) Vídeo-documentário}

É um relato único, uma documentação de fatos. Pressupõe a existência de personagens, que podem direcionar o rumo da história, diferente da grande reportagem. É um recorte, que pode ser parcial, de um fenômeno com grande aprofundamento nas reflexões. Deve ter duração mínima de minutos e ser acompanhado de relatório técnico. 


\section{6) Outros Formatos}

Formatos de trabalhos não descritos acima são previstos e aceitos, desde que aprovados pelo orientador e pela coordenação de Projetos Experimentais. Cada projeto terá etapas específicas a serem seguidas, que serão definidas pelo orientador juntamente com os alunos proponentes do projeto. Abaixo alguns elementos característicos de um relatório técnico que pode servir de referência e deverá ser adaptado para cada caso especificamente.

Em relação aos formatos apresentados, é possível traçar um paralelo com o documento que fundamentou o Parecer CNE/CES 492/2001, elaborado pela Comissão de Especialistas de Ensino em Comunicação Social (CEE - Com), no que diz respeito ao perfil do egresso em Jornalismo, que se caracteriza:

- pela produção de conhecimento e cultura voltada para seleções factuais sobre a atualidade e para a estruturação e disponibilização de informações que atendam a necessidades e interesses sociais no que se refere ao conhecimento dos fatos, das circunstâncias e dos contextos do momento presente;

- pelo exercício da objetividade jornalística na apuração, interpretação, registro e divulgação dos fatos sociais;

- pelo exercício da tradução e disseminação de conhecimento sobre a atualidade em termos de percepção geral e de modo a qualificar o senso comum;

- pelo trabalho em veículos de comunicação e instituições que incluam atividades caracterizadas como de imprensa e de informação jornalística de interesse geral ou setorializado, e de divulgação de informações de atualidade;

- pelo exercício de relações entre as funções típicas de Jornalismo e as demais funções profissionais ou empresariais existentes na área da Comunicação, e 
ainda com outras áreas sociais, culturais e econômicas com as quais o Jornalismo faz interface;

- pelo exercício de todas as demais atividades que, no estado então vigente da profissão, sejam reconhecidas pelo bom senso, pelas entidades representativas ou pela legislação pertinente, como características do Jornalista. (CEE-COM, 1999, on line)

\subsection{Mito da Banca Examinadora}

Todo Projeto Experimental de Jornalismo que será avaliado por professores que compõem as Bancas Examinadoras devem ser examinados sob vários aspectos. Os mais adotados pelas IES em seus regulamentos incluem a reflexão sobre os seguintes tópicos:

1) Quanto ao tema: É pertinente? Contribui para a reflexão social? O projeto registra parte da história ou constrói memória? O formato escolhido foi adequado para o tema tratado? O projeto demonstra ter contribuído para a formação profissional dos autores? O que há de inovador no projeto?

2) Quanto aos objetivos: O projeto cumpre os objetivos propostos? É uma idéia viável profissionalmente? Consegue demonstrar preocupação com a realidade? Utiliza técnicas jornalísticas adequadas? Poderia ser melhor em que aspectos?

3) Quanto ao público-alvo: Foi claramente definido? Por que? O produto final atende ao público previsto? Faltou acrescentar elementos que definissem melhor esse público? 
4) Quanto às fontes utilizadas: São pertinentes? Faltou ouvir ou entrevistar fontes primordiais? As fontes se limitaram a pessoas? A quantidade de fontes pessoais utilizadas foi suficiente? Por que? Quais fontes documentais foram utilizadas? 0 que é possível analisar como positivo e negativo na escolha das fontes?

5) quanto às etapas de desenvolvimento: Foram definidas claramente? São adequadas? O que faltou fazer? O que demonstrou engajamento dos autores? Por que?

6) Quanto ao cronograma: Corresponde ao que foi feito realmente, ou é mera sugestão? O que há de positivo ou negativo a considerar? O projeto demonstra ter sido planejado ou ter sido feito às pressas?

7) Quanto às referências bibliográficas: São adequadas? São pertinentes? Atendem às normas da ABNT? Faltou mencionar alguma referência? Utilizaram outros Projetos Experimentais como referências?

Há também uma análise quanto ao envolvimento dos membros do grupo e o domínio do tema e do formato no momento da exposição à Banca, porém, os avaliadores costumam atribuir ao projeto um conceito de qualidade quanto ao processo, quanto ao produto final e quanto aos objetivos propostos, questionado ainda: Como o projeto poderia ser melhorado? Ele pode ser considerado uma referência para outros alunos? Por que? É possível identificar a participação ou o acompanhamento do orientador no projeto? Em geral, as Bancas Examinadoras funcionam como uma última aula aos alunos concluintes do curso de Jornalismo. A seguir, como estão descritos critérios de avaliação das Bancas Examinadoras dos Projetos Experimentais nos regulamentos dos adotados pelas IES que compõem a amostra da pesquisa: 


\section{PONTIFÍCIA UNIVERSIDADE CATÓLICA DE SÃO PAULO - PUCSP}

\section{"Parâmetros sugeridos para a avaliação dos TCCs}

No projeto:

- relevância social e profissional do tema escolhido

- consistência metodológica e fundamentação

- originalidade e criatividade

- estrutura do projeto e ousadia na experimentação

- domínio das linguagens de suporte

Na apresentação:

- consistência da argumentação com a banca

- abrangência das respostas à argüição da banca

- adequação entre recursos técnicos e temática"

Fonte: "Regulamento dos Trabalhos de Conclusão do Curso de Jornalismo da PUC-SP" - 2006 (vide anexos)

\section{UNIVERSIDADE METODISTA DE SÃO PAULO - UMESP}

“1) Embora o objeto de análise seja um projeto experimental, afeito a inovações diversas, como linguagens, formatos, modelos e métodos, característicos e fundamentais a experimentação, julgue o material com o rigor necessário, pressupondo que os alunos estejam aptos a ingressar no mercado de trabalho. Os projetos devem apresentar nível de qualidade e interesse jornalístico.

2) Analise o material apresentado e não as intenções que ele pode sugerir nas entrelinhas. O trabalho deve testemunhar um semestre de dedicação e esforço centralizado que os alunos Ihe destinaram, além de demonstrar a formação (teórico/prática) recebida pelo aluno nos quatro anos do curso de Jornalismo. Evite, portanto, adotar uma postura complacente.

3) Quando o trabalho não apresentar viabilidade comercial, terá que, necessariamente, demonstrar relevância cultural e/ou acadêmica.

4) Avalie o material apresentado de acordo com os critérios abaixo definidos.

a) Projeto - Idéia - Proposta

Importância do tema escolhido e relevância social;

Métodos utilizados na produção do trabalho;

Originalidade na abordagem e/ ou ineditismo;

Relevância das fontes, entrevistas e das pesquisas realizadas;

Coerência com a natureza do projeto;

Domínio da norma culta do português contemporâneo expressa no texto.

b) Produto - Resultado

Criatividade na produção do trabalho;

Diagramação/edição/montagem estética do trabalho;

Capacidade de síntese e comunicabilidade;

Grau de informação veiculado;

Experimentação / Inovação na linguagem, formato etc.;

Qualidade do projeto e do memorial.

c) Defesa oral (a ser avaliado no dia da defesa do Trabalho)

Capacidade argumentativa oral;

Adequação das respostas aos questionamentos da banca;

Conclusão e dedução lógica dos fatos;

Adequação do material utilizado na exposição."

Fonte: "Regulamento dos Projetos Experimentais do Curso de Jornalismo" - 2005 (vide anexos) 


\section{UNIVERSIDADE SANTA CECÍLIA - UNISANTA}

"Normas das Bancas

1. O ORIENTADOR É O PRESIDENTE da BANCA. A este cabe coordenar os Trabalhos e zelar pela avaliação correta do Projeto, permitindo aos demais professores a liberdade e autonomia de analisarem os Trabalhos.

2. O tempo total dos TRABALHOS NÃO DEVERÁ ULTRAPASSAR $1 \mathrm{~h} 10$.

3. Os alunos deverão fazer uma exposição resumida de no máximo $\mathbf{3 0}$ minutos, acompanhados ou não de recursos audiovisuais.

4. Caso o ORIENTADOR ou outro membro da Banca Examinadora falte na apresentação, esta SERÁ CANCELADA. .

5. Cada membro da Banca Examinadora terá $\mathbf{1 0}$ minutos no máximo, para fazer os comentários sobre o Trabalho. Os Examinadores deverão procurar cumprir o horário determinado, para não prejudicarem o andamento dos outros Projetos.

6. É facultado ao Orientador fazer uma explanação pertinente de no máximo dez minutos após argüição da Banca Examinadora

7. As notas NÃO deverão ser divulgadas para o grupo no dia da Apresentação. Deverão ser encaminhadas para a Secretaria da Faculdade em envelope fechado, sendo posteriormente divulgadas. O presidente poderá apenas informar aos alunos se a nota foi Suficiente ou não para serem Aprovados. Estarão aprovados os Trabalhos que obtiverem nota acima de 5,0 (cinco) pontos na Média Final.

8. Os Projetos que foram entregues fora do prazo perderão 1 (um) ponto no $1^{\circ}$ dia de atraso, dois pontos no $2^{\circ}$ dia de atraso três pontos no $3^{\circ}$ dia de atraso, respectivamente na Média Final."

Fonte: "Diretrizes para Elaboração de Trabalho de Conclusão de Curso de Graduação (TCC)" - 2007 (vide anexos)

\section{UNIVERSIDADE DE SÃO PAULO - ECA/USP}

\section{"Itens para orientação dos argüidores:}

Monografia: adequação, redação, desenvolvimento, fundamentação/bibliografia.

Projeto: qualidade técnica, criatividade, originalidade, domínio da linguagem.

Apresentação: capacidade de exposição, coerência, domínio do item."

Fonte: "Formulários Departamento de Jornalismo e Editoração ECA/USP" - 2008 (vide anexos)

Em relação aos critérios apresentados, é possível traçar um paralelo com o documento que fundamentou o Parecer CNE/CES 492/2001, elaborado pela Comissão de Especialistas de Ensino em Comunicação Social (CEE - Com), no que diz respeito aos procedimentos de acompanhamento e avaliação externa e interna do próprio curso. Estes procedimentos devem incluir, minimamente:

- descrição dos instrumentos e processos através dos quais o Curso observará seu próprio funcionamento para imprimir redirecionamentos e corrigir problemas, em busca de seu aperfeiçoamento qualitativo; 
- projeto de acolhimento de visitas externas de entidades representativas das áreas relacionadas a suas formações, de representantes de setores educacionais públicos e de personalidades competentes nestas formações, com o objetivo de observar seu funcionamento e encaminhar avaliações e propostas de aperfeiçoamento;

- modos de disponibilização, aos setores públicos pertinentes, de informações sobre seus procedimentos pedagógicos, sobre sua estrutura, em quaisquer dos aspectos abordados no presente documento, e sobre os resultados quantitativos e qualitativos de sua atuação;

- definição de uma Comissão de Qualidade da Formação Profissional com existência formalmente assegurada no âmbito da escola. Esta Comissão deve ter participação efetiva na vida administrativa e social da escola, sendo integrada por representantes eleitos por professores e por estudantes, e deve ser aberta à participação das entidades representativas das diversas atividades de Comunicação com jurisdição na região.

- definição de procedimentos para promoção de integração entre os corpos docente e discente, como fator crítico para consecução dos objetivos curriculares e extra-curriculares, e como estímulo didático-pedagógico e político para o exercício da cidadania. (CEE-COM, 1999, on line)

\subsection{Espírito Empreendedor}

Os Projetos Experimentais, em muitos casos, se configuram como um rito de passagem na medida em que se aproxima do último período do curso de graduação 
e o estudante percebe que precisa de maturidade e dedicação para se tornar um profissional. Nesta fase de transição do ambiente acadêmico para a carreira profissional, que de tão marcante se configura, todo o aprendizado é colocado à prova, assim como a capacidade do recém-formado em lidar com o dia-a-dia da carreira escolhida. Em certas situações, a experiência pode ser traumática para uns, mas há também aqueles que tiram proveito dessa etapa acadêmica.

Quando um Projeto Experimental de caráter profissional demonstra qualidade, muitas vezes assemelhando-se a um produto realizado pelo próprio mercado, o resultado pode ser um importante cartão de visitas ou portfólio para o recém-formado na busca por uma vaga no mercado. Mais do isso, se a experiência com a realização do trabalho de conclusão de curso foi intensa e profícua, o profissional formado pode se sentir preparado para vôos empreendedores. As empresas sabem disso e são estes estudantes com alguma história empreendedora para contar que conseguem atrair a atenção do mercado.

O diferencial pode ser Projeto Experimental de qualidade, trabalhando em cima de uma boa idéia e que tenha exigido o máximo de envolvimento do aluno com a realidade de sua profissão. Diante disso, estudantes e IES percebem cada vez mais a importância dos Projetos Experimentais, o que se reflete nos resultados de algumas experiências. É o caso de jovens jornalistas que saem da faculdade com contratos com editoras para publicação de livros-reportagem realizados na conclusão do curso. Eles conquistam visibilidade e abertura de portas no mercado profissional, o que não ocorreria se os mesmos trabalhos ficassem só na biblioteca das IES após a conclusão da graduação.

Há também situações em que os jovens profissionais recebem encomendas por conta daquilo que realizaram na graduação, seja em que suporte for, muitas 
oportunidades surgem da realização de produtos customizados, ou seja, um produto sob encomenda, adaptado às necessidades do cliente. Customizar vem do verbo "to customize" que, por sua vez, deriva de "costumer", ou cliente, consumidor, e pode ser substituída pela palavra "personalizar". Há possibilidades de elaboração de revistas, com fidelização de forma elaborada, direta e sofisticada, ou outras publicações e produtos eletrônicos como programas de rádio e TV, vídeo documentários, reportagens investigativas, blogs especializados e projetos de assessoria, entre outros.

Trata-se uma produção terceirizada, porém, bem remunerada, pois em muitos casos, são estratégias de marketing desenvolvidas pelo cliente que banca a produção. A experiência empreendedora deve considerar critérios de qualidade do processo, do produto e do benefício, analisando também as seguintes variáveis: a posição social, econômica, social e cultural do público em questão de forma a expressar pontos de vista semelhantes; a exposição das necessidades individuais do cliente para servir como gancho para aquelas de interesse público; a divulgação de informações de forma didática, sem perder seu contexto e profundidade; o conceito de responsabilidade social da imprensa, assumindo os efeitos sociais das informações divulgadas e o de utilidade social visando ao atendimento de interesses concretos do cidadão; a proximidade com o público, pela adoção de elementos do universo cultural em questão no contexto.

Em um projeto empreendedor, há de se considerar a divulgação de informações de interesse público, relatadas de maneira humanizada; a ampliação do conhecimento do público sobre o mundo, substituindo o ponto de vista individual pelo ponto de vista do cidadão ou da comunidade, sem entrar no campo do sensacional e do espetacular, cumprindo a responsabilidade social do Jornalismo. 


\section{Conclusão}

Em algum momento de minha carreira docente eu me recordo de ter ouvido que um professor deve acreditar naquilo que faz e defender as posições daquilo que acredita. Se isso resultar numa tese, tanto melhor. Assim, chego aos resultados da pesquisa com a convicção de que os Projetos Experimentais cumprem importante papel no ensino de Jornalismo, a tal ponto que não basta o caráter de disciplina, não basta uma carga horária diferenciada, não basta o respeito que recebe do corpo docente e discente. É necessário um regimento específico para seu funcionamento e realização.

Como tinha por propósito me apoiar em uma pesquisa documental para demonstrar, por meio das experiências pedagógicas ocorridas em instituições de ensino superior que oferecem a Habilitação Jornalismo no Estado de São Paulo delimitadas as universidades que procuram atender ao disposto nas Diretrizes Curriculares Nacionais dos cursos de Comunicação Social (Parecer CNE/CES no 492/2001) - as múltiplas possibilidades oferecidas pelos Projetos Experimentais, submeti à análise os regulamentos, guias, normas, orientações e regimentos relativos aos Projetos Experimentais buscando revelar que é possível oferecer aos graduandos a vivência da produção jornalística e o domínio de técnicas importantes para a formação ética e profissional dos futuros jornalistas, possibilitando um exercício de cidadania frente aos desafios e responsabilidades de sua profissão, no que tange à contribuição para a sociedade, à formação do bem comum e à consciência de seu papel na realidade. 
É possível chegar a algumas conclusões sobre os regulamentos que regem os Projetos Experimentais de dez Instituições de Ensino Superior que oferecem a graduação em Comunicação com habilitação em Jornalismo no Estado de São Paulo. Existe sim um paralelo entre os regulamentos e as Diretrizes Curriculares Nacionais dos cursos de Comunicação Social - Parecer CNE/CES no 492/2001 de forma a verificar como estão estruturados os processos de ensino-aprendizagem relacionados aos Projetos Experimentais e de que maneira os alunos têm a oportunidade de aprofundar e experimentar, em alguns casos, os maiores desafios até então propostos durante a graduação. Porém, há de se destacar que muitas IES entendem o processo de elaboração dos PE ainda sob a ótica proposta pela Resolução no 002/84, deixando isso muito claro, inclusive na redação de regulamentos.

Pode-se compreender também o direcionamento dado pelas IES à prática que envolve temas de interesse social, com os quais o futuro jornalista se torna mais consciente de seus direitos e deveres para com a sociedade, estreitando a relação entre Jornalismo e cidadania e, de certa forma, contribuindo para modificar uma visão distorcida sobre o papel do jornalista na sociedade. Os regulamentos privilegiam claramente certos formatos - ou suportes midiáticos - específicos para a veiculação de conteúdos que a grande imprensa muitas vezes despreza por questões mercadológicas. È o caso do livro-reportagem, suporte para grandes reportagens impressas, muito estimuladas nas IES, cujas particularidades incluem a profundidade da investigação e o domínio do texto narrativo-descritivo Isso confirma as hipóteses que nortearam a pesquisa, uma vez que a produção de Projetos Experimentais por estudantes de Jornalismo em IES do Estado de São Paulo é importante instrumento de sua formação; faz-se necessário compreender o 
diálogo existente os regulamentos estabelecidos pelas IES e os agentes envolvidos na elaboração de Projetos Experimentais no que diz respeito à relação ensinoaprendizagem e o papel dos mesmos na formação do jornalista; a estruturação dos Projetos Experimentais frente às Diretrizes Curriculares oferece múltiplas possibilidades aos graduandos, de maneira a permitir que vivenciem de forma autônoma os caminhos da formação profissional em Jornalismo.

As Diretrizes Curriculares de Comunicação Social aprovadas pelo Ministério da Educação (MEC), em 2001, definem que aluno de Jornalismo deve desenvolver a capacidade de reflexão para analisar os padrões e práticas jornalísticas, exercitando sua capacidade criativa no sentido de experimentar novas linguagens e produtos de comunicação. Cabe à escola também discutir questões socioculturais e políticas com ensinamentos sobre novas tecnologias aplicados à linguagem jornalística, criando condições para que o aluno exercite sua capacidade criativa, experimente novas ferramentas e assimile aspetos teórico-práticos de sua formação. Assim, busca-se um egresso dos cursos de Jornalismo que tenha a capacidade de compreender os mecanismos envolvidos no processo de recepção de mensagens e seu impacto sobre os diversos setores sociais. O que os regulamentos apontam neste sentido é que os alunos têm autonomia na escolha de temas, formatos, orientadores e na possibilidade de experimentação no fazer jornalístico. Há de se considerar que as IES que privilegiam apenas a elaboração de monografias - resultados de pesquisa científica simplesmente - visa à produção do conhecimento na área da Comunicação Social e o estímulo ao ingresso posterior do aluno em programas de pós-graduação. O que não deixa de ser uma estratégia de mercado também. 
A fim de descrever qual o papel dos Projetos Experimentais nesse processo e qual a estruturação dos mesmos nas IES, verifica-se que a regulamentação os Projetos Experimentais no ensino de Jornalismo obedece tanto ao processo histórico, quanto à legislação que determina a oferta de cursos de Comunicação Social com habilitação em Jornalismo no Brasil. Uma característica básica do profissional de Jornalismo é a capacidade de refletir sobre sua responsabilidade social, uma vez que seu trabalho bem realizado amplia o conhecimento da população e permite mudar a realidade. Assim, existem relações concretas entre as Diretrizes Curriculares e a importância dos Projetos Pedagógicos definidos e desenvolvidos pelas IES, cada qual com particularidades e que definem o perfil desejado do profissional que pretendem formar, bem como os caminhos que oferecem para tal formação. É como se os regulamentos refletissem a síntese dos Projetos Pedagógicos das IES, ou seja, em todos os aspectos - corpo docente, discente, infra-estrutura, objetivos do curso, etc. - estão descritos nos regulamentos como a IES pretende formar seus profissionais, com quais possibilidades e com que resultados esperados.

Os Projetos Experimentais representam um processo ensino-aprendizagem na articulação teórico-prática proporcionada por currículos dinâmicos e que possibilitam a oferta de práticas laboratoriais como instrumentos de formação dos jornalistas. A possibilidade com que pode aprofundar tanto a experimentação das técnicas jornalísticas, quanto a vivência da realidade das questões sociais pode contribuir para a (trans)formação desse aluno em um jornalista com visão crítica e reflexiva sobre o papel do Jornalismo na sociedade, uma formação centrada nas Ciências Humanas, a percepção mais apurada da realidade, a capacidade de compreender a interação entre a teoria e a prática, além da consciência ética 
profissional. Porém, não foi objetivo da pesquisa ouvir as partes envolvidas no fenômeno, pois tal método incluiria um aspecto subjetivo na discussão. É fato que os Projetos Experimentais suscitam polêmicas, seja por parte do corpo docente mal remunerado e pouco valorizado por algumas IES quanto à orientação, seja pelo corpo discente que não se sente motivado e, às vezes, nem preparado para a execução autônoma de um trabalho de conclusão de curso.

Desde a implantação da Resolução no 002/84, ao longo de mais de três décadas, as experiências realizadas ainda no ambiente acadêmico no que diz respeito à elaboração dos Projetos Experimentais como trabalhos de conclusão de curso ou produtos laboratoriais - e que, por vezes, superam vivências da trajetória profissional - possibilitou a implantação de regulamentos específicos para o desenvolvimento do processo, resultando na formatação de normas e regimentos das IES para o desenvolvimento dos Projetos Experimentais. Devido à diversidade temática, à profundidade da investigação jornalística, ao papel dos orientadores, ao relato da experiência vivenciada pelos graduandos e à contribuição para a sociedade nas abordagens de questões sociais, os objetivos e particularidades dos Projetos Experimentais adotados como trabalhos de conclusão de curso são reconhecidos como fundamentais pelos agentes envolvidos, como coordenadores, professores orientadores e avaliadores e alunos. Ocorre também certa confusão sobre a nomenclatura adotada para definir Projetos Experimentais, em alguns casos utilizada como sinônimo de trabalho de conclusão de curso (TCC), em outros como sinônimo de práticas laboratoriais, ou ainda empregada como diferencial entre um trabalho de caráter profissional e outro de caráter acadêmico (como uma monografia, resultado de uma pesquisa científica, por exemplo). 
Como a tese se propõe também a demonstrar a estruturação dos Projetos Experimentais, ou seja, como se organizam as diversas partes que compõem a estrutura de PE nas Instituições de Ensino Superior no Estado de São Paulo, foi possível demonstrar como isso frequentemente acontece, de acordo com o que prevêem os regulamentos de PE adotados. A operacionalização dos Projetos Experimentais, evidenciando tópicos como: a presença da disciplina na estrutura curricular; a normatização e os acréscimos e riscos decorrentes de sua utilização; o papel da coordenação específica na gestão do processo de planejamento, elaboração e avaliação dos Projetos Experimentais; a adoção de pré-requisitos para a efetiva realização de PE como trabalhos de conclusão de curso; os prazos definidos para elaboração em IES que adotam regimes semestrais e anuais; as formas de avaliação adotadas durante o processo de realização de PE; e, por fim, qual a relação dos Projetos Experimentais de caráter profissional com o mercado jornalístico.

Há de se enfatizar também o papel dos docentes na estruturação dos Projetos Experimentais, evidenciando que a orientação de PE no âmbito acadêmico contribui para a formação de jornalistas como atores sociais capazes de refletir sobre suas responsabilidades sociais e conscientes de que seu trabalho bem realizado amplia conhecimento e permite mudar a realidade, o docente que se dedica ao ensino de Jornalismo tem muitos desafios. No que tange à orientação de PE, vários aspectos estão interligados no processo ensino-aprendizagem, desde a qualificação docente e os critérios que definem a escolha do orientador até o processo de orientação e de avaliação. Foi possível perceber que os elementos previstos nos regulamentos das IES que dizem respeito à orientação, ao envolvimento docente no trabalho, aos impasses enfrentados e aos incentivos, 
incluindo a remuneração e o reconhecimento (ou premiação, em alguns casos) pela orientação. Demonstra-se também como funcionam as pré-bancas de qualificação dos PE e as Bancas Examinadoras, que avaliam os resultados finais do processo de elaboração dos Projetos Experimentais.

Considerando que na elaboração de PE os futuros jornalistas podem trabalhar com a cobertura das questões sociais, valorizando ações que promovam impacto social, participação democrática e tornando públicos aspectos da vida em sociedade e discussões que afetam diariamente o cotidiano das pessoas, 0 processo de elaboração dos Projetos Experimentais pode transformar aquele aluno que não se sentiu motivado pelo curso como um todo. Verificando como os regulamentos sobre PE das Instituições de Ensino Superior abordam questões como autoria, escolha dos temas e formatos, prazos e condições de produção, disponibilidade e uso de laboratórios na realização de Projetos Experimentais, é possível identificar qual a relação entre a estruturação dos PE, o que definem as Diretrizes Curriculares para a formação do jornalista e as possibilidades de vivenciar a experiência profissional, de adquirir visão crítica do mercado e da profissão e de desenvolver espírito empreendedor frente ao Jornalismo. Ou seja, também o funcionamento das Bancas Examinadoras como o processo de avaliação dos Projetos Experimentais legitima novos discursos, traz à tona idéias originais, dá voz a opiniões divergentes e conceitos distintos para fortalecer o debate e a construção de novos caminhos no Jornalismo.

O que preocupa os envolvidos com os Projetos Experimentais é o que diz respeito ao investimento e ao custo-benefício que eles representam para as IES, seja em relação à carga horária e remuneração docente, ao uso de laboratórios, à infra-estrutura necessária para sua realização e mesmo o fato de que representam 
uma despesa extra para os estudantes, uma vez que quanto mais um produto jornalístico feito de forma experimental resulte em algo que aparenta ser profissional, melhor o resultado de um trabalho de conclusão de curso é avaliado. Considerando-se que há um ganho inequívoco quanto ao processo ensinoaprendizagem, muitas IES utilizam também o resultado dos Projetos Experimentais como estratégia mercadológica, especialmente se os mesmos são objeto de premiações e repercussão no cenário acadêmico e profissional do Jornalismo.

A principal defesa desta tese é de que os Projetos Experimentais realizados como trabalhos de conclusão de curso - refletem o ensino de Jornalismo oferecido pelas IES, independentemente do caráter que assumem. É como se eles coroassem o processo a que se propõe a escola quanto à formação de seus profissionais, com todos os acertos e equívocos que isso envolve. Os PE representam um momento de excelência do curso, em que há respeito, envolvimento e dedicação ao que se faz em todas as etapas e, dificilmente uma disciplina recebe tanto atenção quanto os Projetos Experimentais - e não só porque a legislação determina uma carga horária expressiva, mas por que os agentes envolvidos acreditam nas possibilidades que os PE oferecem. É possível fazer esta afirmação com base nos regulamentos, porque eles são o resultado do debate de idéias, experiências e vivências ocorridas nas Instituições de Ensino Superior e sua estruturação representa a preocupação - não em formar padrões ou igualar a produção - e sim em priorizar padrões mínimos de qualidade quanto ao produto, ao processo de realização e ao benefício decorrente dos resultados. E isso significa valorizar o ensino de Jornalismo. 
Referências Bibliográficas

ABECOM. Relatório do I Encontro Nacional de Coordenadores de Projetos Experimentais. São Paulo, ABECOM, 1990.

ALMEIDA, E. M.; CARNIELLO, M. F.; GUEDES, C. M. (org.) A pesquisa científica na Universidade: manual de orientação para produção científica e projetos experimentais do Departamento de Comunicação Social da Universidade de Taubaté. Taubaté: UNITAU / Departamento de Comunicação Social, 2005, 87p.

ALMEIDA, F. A. Projeto Pedagógico e Currículo. In: PINHO, J. B. (org.). A Clava Forte: Comunicação Brasileira no Século XXI. Coleção Verde-amarela, v. 3. São Paulo: Intercom, 2007, p. 49-54.

ALMEIDA JR., J. B. A Construção do Projeto Pedagógico dos Cursos de Comunicação: indicadores de qualidade numa sociedade em processo de mudança acelerada. In: Anais do XXII Congresso Brasileiro de Ciências da Comunicação - Intercom, 1999, Rio de Janeiro: XXII Congresso Brasileiro de Ciências da Comunicação - Intercom, 1999, p. 01-10.

BELTRÃO, L. Teoria e prática do Jornalismo. Adamantina, SP: FAI / Cátedra Unesco Metodista de Comunicação para o Desenvolvimento Regional, 2006.

. Estrutura Curricular dos cursos de Jornalismo no Brasil. In: ANUÁRIO Unesco Metodista de Comunicação Regional. Cátedra Unesco Metodista de Comunicação para o Desenvolvimento Regional, v. 1, n. 1, setembro de 1997. São Bernardo do Campo: Universidade Metodista de São Paulo, 1997, p. 287-300.

Arte, 1992.

Introdução à filosofia do jornalismo. 2. ed. São Paulo: EDUSP/Com-

Estrutura curricular dos cursos de Jornalismo no Brasil. In: O Ensino de Jornalismo: Documentos da 4⿳亠丷厂 Semana de Estudos de Jornalismo. São Paulo: ECA-USP, 1972.

BRASIL. Ministério da Educação. Conselho Nacional de Educação. Diretrizes Curriculares para os Cursos de Comunicação Social e suas Habilitações. Resolução CNE/CES 16/2002. Brasília, DF: 13 de março de 2002. Disponível em: $<$ http://www.mec.gov.br>.

. Ministério da Educação. Conselho Nacional de Educação. Diretrizes Curriculares para os Cursos de Comunicação Social e suas Habilitações. Parecer CNE/CSE 492/2001. Brasília, DF: 3 de abril de 2001. Disponível em: <http://www.mec.gov.br>.

Ministério da Educação. Lei de Diretrizes e Bases da Educação Nacional. Lei no 9.394. Brasília, DF: 20 de dezembro de 1996. Disponível em: <http://www.mec.gov.br>. 
. Conselho Federal de Educação. Resolução no 02/84, de 24 de janeiro de 1984. Fixa o currículo mínimo do curso de Comunicação Social e dá outras providências. Documentos. Brasília, fev. 1984, no 278, p. 209-211.

BRUM, E. . Ensinar Jornalismo...ou Aprender Jornalismo?. In: In: PERUZZO, C. M. K.; SILVA, R. B. Retrato do Ensino em Comunicação no Brasil. São Paulo: INTERCOM / UNITAU, 2003, p. 29-44.

BRUM, E.; FERNANDEZ, A. F. Os caminhos do ensino da Comunicação nas instituições do Centro-Oeste. In: Revista Brasileira de Ciências da Comunicação, vol. 28, n. 2, São Paulo: Intercom, julho/dezembro de 2005, p. 85101.

CALDAS, G.; CAPRINO, M. Formação do jornalista e reforma curricular: a experiência da Metodista. In: Revista Brasileira de Ciências da Comunicação, vol. 23, n. 2, São Paulo: Intercom, julho/dezembro de 2000, p. 101-117.

CALDAS, M. G. C . Ensino da Comunicação no Brasil: Panorama e Perspectivas. In: PERUZZO, C. M. K.; SILVA, R. B. Retrato do Ensino em Comunicação no Brasil. São Paulo: INTERCOM / UNITAU, 2003, p. 15-27.

CEE-COM. Comissão de Especialistas de Ensino em Comunicação Social. Diretrizes Curriculares: documento que fundamentou o Parecer CNE/CES 492/2001 elaborado originalmente pela CEE-COM. Brasília, DF: 20 de julho de 1999. Disponível em: <http://www.portal.mec.gov.br/arquivos/pdf>.

DIRETRIZES Curriculares da Área de Comunicação e suas Habilitações. Disponível em: <http://www.inep.org.br>.

FADUL, A. A ação pedagógica na Escola de Comunicação: notas para uma reflexão. In: MARQUES DE MELO, J.; FADUL A. e LINS DA SILVA, C.E. (orgs.) Ideologia e Poder no ensino de Comunicação. São Paulo: Cortez \& MoraesIntercom, 1979, p. 50-58.

FARO, J. S. Diretrizes Curriculares para o ensino de Comunicação Social: uma história que mudou as perspectivas dos cursos. In: PERUZZO, C. M. K.; SILVA, R. B. Retrato do Ensino em Comunicação no Brasil. São Paulo: INTERCOM / UNITAU, 2003, p. 139-146.

FOLHA de São Paulo. Manual da Redação. 2 ed. São Paulo: Publifolha, 2001.

FRANÇA, F.; FREITAS, S. G. Manual da qualidade em projetos de Comunicação. São Paulo: Pioneira, 1997.

INEP. Instituto Nacional de Estudos e Pesquisa Educacionais Anísio Teixeira. (Banco de dados) Disponível em: < http://www.educacaaosuperior.inep.gov.br>.

KOSHIYAMA, A. M. Ensino de Jornalismo e formação para a cidadania. In: Anais do XXX Congresso Brasileiro de Ciências da Comunicação - Intercom, 2007. Santos, 2007. 
KUNSCH, M. M. K. (org.) Ensino de Comunicação: qualidade na formação acadêmico-profissional. São Paulo: ECA-USP / Intercom, 2007.

LAURENTI, M. E. A. A formação do jornalista sob a égide da Legislação Educacional: um estudo sobre as organizações curriculares. Tese. (Doutorado em Ciências da Comunicação). São Paulo: Escola de Comunicações e Artes da Universidade de São Paulo, 2002.

LIMA, E. P. Páginas Ampliadas: o Livro-reportagem como extensão do Jornalismo e da Literatura. (Edição revista e atualizada). Barueri, SP: Manole, 2003.

LOPES, D. F. Jornal-laboratório: Do exercício escolar ao compromisso com o público leitor. São Paulo: Summus, 1989.

MARQUES DE MELO, J.; FADUL A. e LINS DA SILVA, C.E. (orgs.) Ideologia e Poder no ensino de Comunicação. São Paulo: Cortez \& Moraes-Intercom, 1979.

MARQUES DE MELO, J. Pensamento jornalístico: a moderna tradição brasileira. In: Revista Brasileira de Ciências da Comunicação, vol. 30, n. 2, São Paulo: Intercom, julho/dezembro de 2007, p. 15-39.

Nota introdutória. In: BELTRÃO, L. Teoria e prática do Jornalismo. Adamantina, SP: FAI / Cátedra Unesco Metodista de Comunicação para o desenvolvimento regional, 2006, p. 8-9.

O campo comunicacional. (Artigo) Sociedade Brasileira de Estudos Interdisciplinares da Comunicação. São Paulo, Intercom, 2000. Disponível em: $<$ http://www.intercom.org.br>.

Comunicação e Modernidade: o ensino e a pesquisa nas escolas de Comunicação. São Paulo: Loyola, 1991.

Paulo: Paulinas, 1974.

Contribuições para uma Pedagogia da Comunicação. São

MARTINS, E. Manual de redação e estilo. 3 ed. São Paulo: Jornal O Estado de S. Paulo, 1997.

MATTOS, M. A. O Saber Comunicacional e os Projetos Experimentais no Ensino de Comunicação Social da PUC Minas. In: Anais do XXVIII Congresso Brasileiro de Ciências da comunicação, 2005. Ensino e Pesquisa em Comunicação, Rio de Janeiro, 2005.

MEDINA, C. Profissão Jornalista: Responsabilidade social. Rio de Janeiro: Forense Universitária, 1982.

MEDITSCH, E. A questão da prática em Paulo Freire e o projeto Universidade Aberta do Curso de Jornalismo da UFSC. 2003. Disponível em: <http://www.jornalismo.ufsc.br/bancodedados/meditisch_paulo_freire_unaberta.zip> 
MOREIRA, S. V.; VIEIRA, J. P. D. (orgs.) Ensino e pesquisa em Comunicação: São Paulo: Intercom / Rio de Janeiro: UERJ, 2006.

OBSERVATÓRIO da Imprensa (Banco de dados) Disponível em: <http://www.observatoriodaimprensa.com.br>

OLIVEIRA, E. F.; SILVA, R. B. A experiência da Grande Reportagem nos Projetos Experimentais de Jornalismo. In PERUZZO, C. M. K.; SILVA, R. B. Retrato do Ensino em Comunicação no Brasil. São Paulo: INTERCOM / UNITAU, 2003, p215-224.

PERUZZO, C. M. K.; SILVA, R. B. Retrato do Ensino em Comunicação no Brasil. São Paulo: INTERCOM / UNITAU, 2003.

PEUCER, T. Os relatos jornalísticos. Tradução de Paulo da Rocha Dias. In: Revista Comunicação \& Sociedade. Universidade Metodista de São Paulo, n. 33. São Bernardo do Campo: Umesp, 2000, p. 199-214.

RAMADAN, N. N. A. Jornalismo na era digital: construindo uma filosofia de ensino. Tese. (Doutorado em Ciências da Comunicação). São Paulo: Escola de Comunicações e Artes da Universidade de São Paulo, 2000.

RIZZINI, C. O ensino do Jornalismo. Rio de Janeiro: Departamento de Imprensa Nacional, 1953.

ROCHA, S. V. C. B. Os desafios dos projetos experimentais em jornalismo. Dissertação de mestrado em Comunicação Social. Universidade Metodista de São Paulo (Umesp). São Bernardo do Campo, 1998, 282p.

ROSSI, C. O que é Jornalismo. São Paulo: Brasiliense, 1995.

TARSITANO, P. R. A Expocom como agente gerador de qualidade no Ensino de Comunicação Social no Brasil. Tese de Doutorado em Comunicação Social. Universidade Metodista de São Paulo (Umesp). São Bernardo do Campo, 1999, 273p.

VIEIRA JR., A. Uma Pedagogia para o Jornal-laboratório. Tese. (Doutorado em Ciências da Comunicação). São Paulo: Escola de Comunicações e Artes da Universidade de São Paulo, 2002.

YIN, R. K. Estudo de caso: planejamento e métodos. 3 ed. Porto Alegre: Bookman, 2005. 
ANEXOS 


\section{MINISTÉRIO DA EDUCAÇÃO \\ CONSELHO NACIONAL DE EDUCAÇÃO}

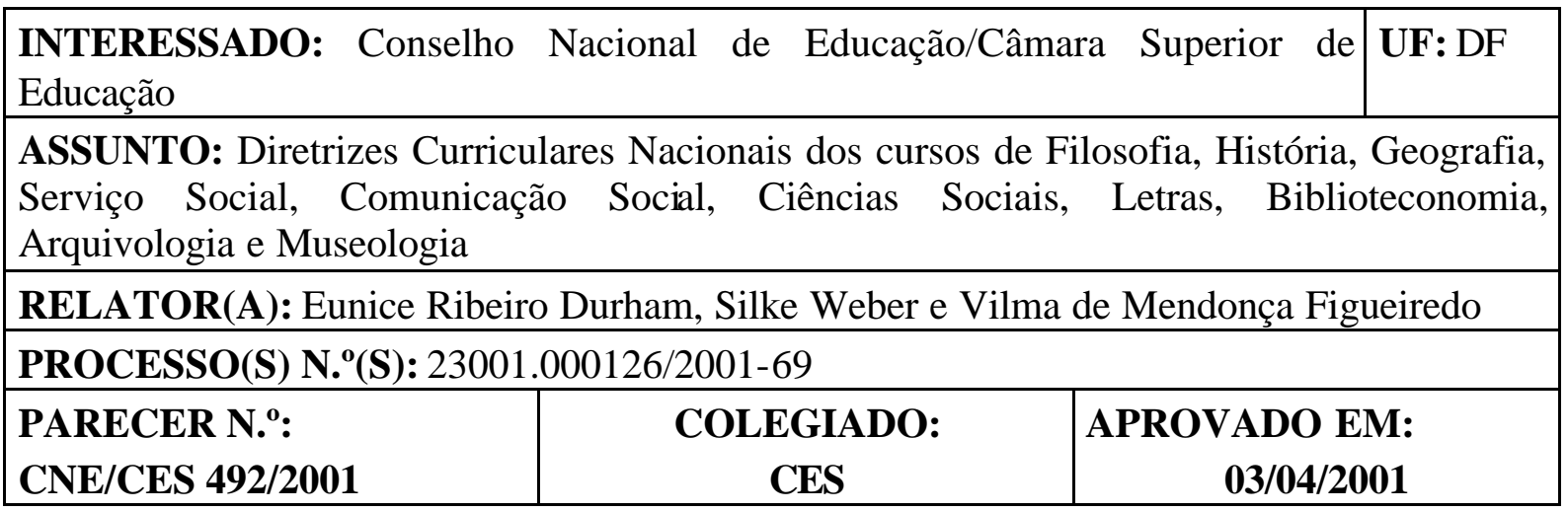

\section{I - RELATÓRIO}

Trata o presente de diversos processos acerca das Diretrizes Curriculares Nacionais dos cursos de Filosofia, História, Geografia, Serviço Social, Comunicação Social, Ciências Sociais, Letras, Biblioteconomia, Arquivologia e Museologia remetidas pela SESu/MEC para apreciação da CES/CNE.

A Comissão constituída pelas Conselheiras Eunice Ribeiro Durham, Vilma de Mendonça Figueiredo e Silke Weber analisou as propostas provindas da SESu referentes aos cursos mencionados e procedeu a algumas alterações com o objetivo de adequá-las ao Parecer 776/97 da Câmara de Educação Superior, respeitando, no entanto, o formato adotado pelas respectivas Comissões de Especialistas que as elaboraram. A Comissão retirou, apenas de cada uma das propostas, o item relativo à duração do curso, considerando o entendimento de que o mesmo não constitui propriamente uma diretriz e será objeto de uma Resolução específica da Câmara de Educação Superior, o que foi objeto do Parecer CNE/CES 583/2001.

\section{II - VOTO DO(A) RELATOR(A)}

A Comissão recomenda a aprovação das propostas de diretrizes dos cursos mencionados na forma ora apresentada.

Brasília(DF), 03 de abril de 2001.

Conselheiro(a) Silke Weber - Relator(a)

Conselheiro(a) Eunice Ribeiro Durham 


\section{III - DECISÃO DA CÂMARA}

A Câmara de Educação Superior aprova por unanimidade o voto do(a) Relator(a).

Sala das Sessões, em 03 de abril de 2001.

Conselheiro Arthur Roquete de Macedo - Presidente

Conselheiro Jose Carlos Almeida da Silva - Vice-Presidente 


\section{DIRETRIZES CURRICULARES \\ PARA OS CURSOS DE GRADUAÇÃO EM FILOSOFIA}

\section{Diretrizes Curriculares}

\section{Perfil dos Formandos}

Sólida formação de história da filosofia, que capacite para a compreensão e a transmissão dos principais temas, problemas, sistemas filosóficos, assim como para a análise e reflexão crítica da realidade social em que se insere.

O licenciado deverá estar habilitado para enfrentar com sucesso os desafios e as dificuldades inerentes à tarefa de despertar os jovens para a reflexão filosófica, bem como transmitir aos alunos do Ensino Médio o legado da tradição e o gosto pelo pensamento inovador, crítico e independente.

O bacharel deverá estar credenciado para a pesquisa acadêmica e eventualmente para a reflexão trans-disciplinar

Os egressos podem contribuir profissionalmente também em outras áreas, no debate interdisciplinar, nas assessorias culturais etc.

\section{Competências e Habilidades}

- Capacitação para um modo especificamente filosófico de formular e propor soluções a problemas, nos diversos campos do conhecimento;

- Capacidade de desenvolver uma consciência crítica sobre conhecimento, razão e realidade sócio-histórico-política;

- Capacidade para análise, interpretação e comentário de textos teóricos, segundo os mais rigorosos procedimentos de técnica hermenêutica;

- Compreensão da importância das questões acerca do sentido e da significação da própria existência e das produções culturais;

- Percepção da integração necessária entre a filosofia e a produção científica, artística, bem como com o agir pessoal e político;

.Capacidade de relacionar o exercício da crítica filosófica com a promoção integral da cidadania e com o respeito à pessoa, dentro da tradição de defesa dos direitos humanos.

.Capacidade de leitura e compreensão de textos filosóficos em língua estrangeira

Competência na utilização da informática.

\section{Conteúdos Curriculares}

O elenco tradicional das cinco disciplinas básicas (História da Filosofia, Teoria do Conhecimento, Ética, Lógica, Filosofia Geral: Problemas Metafísicos, - além de duas matérias científicas), tem se comprovado como uma sábia diretriz. Tal elenco vem permitindo aos melhores cursos do País um ensino flexível e adequado da Filosofia. 
Entretanto, tendo em vista o desenvolvimento da Filosofia nas últimas décadas, algumas áreas merecem ser consideradas, como: Filosofia Política, Filosofia da Ciência (ou Epistemologia), Estética, Filosofia da Linguagem e Filosofia da Mente.

No caso da licenciatura, deverão ser incluídos os conteúdos definidos para a educação básica, as didáticas próprias de cada conteúdo e as pesquisas que as embasam.

\section{Organização do Curso}

Os cursos deverão formar bacharéis ou licenciados em Filosofia. O bacharelado deve caracterizar-se principalmente pela pesquisa, em geral direcionada aos programas de pósgraduação em Filosofia, bem como ao magistério superior. A licenciatura, a ser orientada também pelas Diretrizes para a Formação Inicial de Professores da Educação Básica em cursos de nível superior, volta-se sobretudo para o ensino de Filosofia no nível médio. Ambos os cursos devem oferecer substancialmente a mesma formação, em termos de conteúdo e de qualidade, organizada em conteúdo básicos e núcleos temáticos.

\section{Estruturação do Curso}

Os cursos devem incluir no seu projeto pedagógico os critérios para o estabelecimento das disciplinas obrigatórias e optativas, das atividades acadêmicas do bacharelado e da licenciatura, e a sua forma de organização: modular, por crédito ou seriado.

\section{Estágios e Atividades Complementares}

Devem integralizar a estrutura curricular, com computação de carga horária, atividades acadêmicas autorizadas pelo Colegiado tais como: estágios, iniciação científica, laboratórios, trabalho em pesquisa, trabalho de conclusão de curso, participação em eventos científicos, seminários extra-classe, projetos de extensão.

\section{Conexão com a Avaliação Institucional}

Os cursos deverão criar seus próprios critérios para avaliação periódica, em consonância com os critérios definidos pela IES à qual pertencem. 


\section{DIRETRIZES CURRICULARES DOS CURSOS DE HISTÓRIA}

\section{Introdução}

Este texto apresenta-se como proposta cuja finalidade é substituir o currículo mínimo dos cursos de Graduação em História, que fornecia os parâmetros básicos a sua organização curricular no contexto da antiga Lei de Diretrizes e Bases da educação Nacional.

Para os profissionais que integram a área de conhecimento da História, a substituição do currículo mínimo por instrumento diferente não é necessidade que decorra unicamente da aprovação de nova Lei de Diretrizes e Bases da Educação Nacional: ela se impunha, há já bastante tempo, pelas transformações ocorridas desde a década de 1960 na mencionada área de conhecimento, como configurada no Brasil. Com efeito, quando do estabelecimento do antigo currículo mínimo, na década de 1960, os cursos de Graduação em História apresentavam quase todos, neste país, baixo grau de profissionalização e uma presença muito limitada (quando não a simples ausência) de atividades de pesquisa desenvolvidas por docentes e, com maior razão, por estudantes. Os professores universitários trabalhavam em condições difíceis, marcadas quase sempre pela ausência do regime de dedicação exclusiva; inexistia um sistema de bolsas de pesquisa para docentes e discentes. A época inaugurada pela década seguinte, entretanto, em função de mudanças que se davam no seio da área de conhecimento e de transformações institucionais importantes - surgimento e expansão do regime de dedicação exclusiva, implantação progressiva de um sistema nacional de PósGraduação em História, aparecimento de um sistema consistente e permanente de bolsas de pesquisa para professores e alunos, mais tardiamente uma proliferação das revistas e outras publicações especializadas -, foi marcada por passos muito importantes no sentido da profissionalização dos historiadores e da consciência da necessária indissociabilidade do ensino, da pesquisa e da extensão na Universidade, ponto posteriormente transformado em preceito constitucional. Eis aí algumas das razões que explicam ter-se transformado o antigo currículo mínimo em instrumento arcaico, acanhado e em descompasso com os progressos do setor.

Outrossim, as mudanças foram ainda mais gerais, no campo da História e para os historiadores. Com efeito, nos anos que vão de 1968 a 1980 apareceram, em diferentes cronologias segundo os países (por exemplo já claramente em 1974 no caso da França, em 1980 nos Estados Unidos, bem mais tarde entre nós, pelo menos como consciência de rupturas radicais), questões que kvavam à nova e mais complexa configuração do quadro em que se desenvolviam os estudos históricos. Se houve querelas epistemológicas e teóricas às vezes acirradas, o que mais interessa a nosso assunto é a formidável ampliação ocorrida nos objetos e enfoques disponíveis para os historiadores. Diante dela, o currículo mínimo passou a ser mais do que nunca uma camisa de força; e a solução não seria a simples inclusão de novas áreas de conhecimento histórico e disciplinas afins em sua lista, já que a mencionada ampliação foi de tal ordem que, de fato, impunha a introdução de escolhas: não seria possível, obviamente, tentar esgotar a totalidade do campo percebido para os estudos da História no âmbito de um curso de Graduação, cuja duração deve obedecer a limites de ordem prática e relativos aos custos aceitáveis na formação de especialistas.

A mesma ampliação se dava quanto às ocupações funcionais dos profissionais formados em História no Brasil. Se a tradicional dicotomia entre Bacharelado e Licenciatura parecia bastar no começo da década de 1960, ela parece cada vez mais limitada ou acanhada numa época como a nossa, quando, além das tradicionais destinações (ensino de primeiro e segundo grau, 
por um lado; ensino universitário ao qual se vinculava a pesquisa, por outro), pessoas formadas em História atuam, crescentemente (e a lista a seguir é seletiva, incompleta): em institutos de pesquisa que não desenvolvem atividades de ensino; realizando pesquisas ligadas a questões vinculadas ao patrimônio artístico e cultural, à cultura material (associação Arqueologia/História, atuação em museus) ou a serviço dos meios de comunicação de massa (imprensa, televisão etc.); funcionando em assessorias culturais e políticas também; trabalhando na constituição e gestão de bancos de dados, na organização de arquivos e em outras áreas de um modo geral ligadas à reunião e preservação da informação.

Note-se que a esta ampliação das áreas de atuação corresponde outra, relativa às linguagens cujo manejo pelos profissionais formados em História tornou-se corrente. Se a forma discursiva continua sendo o meio mais usual de expressão entre historiadores, o domínio de técnicas de análise semântica ou semiótica aplicadas a diferentes linguagens (textual, iconográfica, audiovisual etc.), a possibilidade de elaborar vídeos e CD-ROMs ao lado dos textos tradicionais, em certos casos (como por exemplo em História Econômica e em Demografia Histórica) o manejo da estatística e de simulações complexas utilizando o computador, vieram a ser corriqueiros. Tornava-se cada vez mais urgente, portanto, um aggiornamento na formação de Graduação em História.

Observe-se que, com todas estas novidades e em especial com sua busca de contatos interdisciplinares e transdisciplinares em proporções nunca vistas, a História sempre manteve a sua especificidade como área do conhecimento. Especificidade esta que não tem a ver tanto com o objeto - em termos gerais, comum a todas as ciências humanas e sociais - mas, sim, com uma forma particular de lidar com as temporalidades e com a exigência de uma formação específica que habilite o profissional de História a um trabalho com variadas fontes documentais, respeitando em cada caso os parâmetros sociais e culturais de seu contexto de formação época a época.

Ao mesmo tempo, não é possível deixar de considerar a enorme diversidade, sob vários pontos de vista, das regiões do Brasil e, mais especificamente, nelas (ou mesmo no interior de cada região), dos programas de História existentes. Se nos limitarmos exclusivamente ao que é específico, uma grande diferença existe, por exemplo, entre os programas de História que oferecem exclusivamente formação na Graduação e aqueles - em número muito minoritário ainda - que possuem a Pós-Graduação stricto sensu.

De início, nos tempos pioneiros da expansão do ensino de Pós-Graduação, mais de um quarto de século atrás, notava-se certa hostilidade, muitas vezes não de todo aberta ou explícita, entre uma Pós-Graduação ainda e docentes ainda não titulados como doutores (e que portanto não desempenhavam tarefas de ensino e orientação na Pós-Graduação) cujo trabalho se desenvolvia numa Graduação eivada de problemas, a começar pela matrícula de alunos cada vez mais numerosos. Com o tempo, entretanto, bem como com os progressos consideráveis ocorridos na titulação dos profissionais e a ampliação das atividades de pesquisa mesmo entre os estudantes da Graduação, tendeu-se, pelo contrário, a uma crescente integração entre Graduação e Pós-Graduação nos programas de História: a qual, não achando, nas estruturas derivadas do antigo currículo mínimo de Graduação e da legislação específica (pensamos nas leis nacionais mas também nas regras de organização interna das universidades) relativa à Pós-Graduação, bases institucionais suficientes, buscou soluções diversas, a exemplo dos laboratórios que integravam docentes e discentes do programa na sua totalidade (Graduação e Pós-Graduação). Tais soluções tinham a desvantagem de uma falta de sanção suficiente às suas atividades: em muitos casos, as atividades dos laboratórios ou das outras formas 
pensadas para promover a integração Graduação/Pós-Graduação não podiam, por exemplo, ser computadas no regime de horas de trabalho semanais dos docentes, ou como créditos para os discentes. Aos poucos surgiram tentativas mais ambiciosas no sentido da integração - o programa PROIN/CAPES, por exemplo, tem resultado por vezes em práticas e produtos de grande interesse - mas sem dúvida é necessário que a própria organização curricular contribua para tal integração e a favoreça.

É preciso reconhecer, entretanto, que numerosos programas de História no país, além de não disporem ainda de uma pós-graduação stricto sensu, estão longe de estabelecê-la. Por mais que tais programas, por vezes, criem cursos de Pós-Graduação lato sensu de enorme interesse e da maior importância, por exemplo, na formação continuada dos profissionais que atuam no ensino fundamental e no ensino médio e nas necessárias atividades de extensão que inserem as instituições de ensino superior em suas respectivas regiões e contextos sociais, continua sendo verdadeiro que grandes diferenças constatam-se segundo esteja ausente ou presente a formação pós-graduada stricto sensu num dado programa.

Razões diversas podem, também, levar alguns programas a reforçar setores que, em outras instituições de ensino superior, encontram-se muito menos desenvolvidos. Assim, a História da África Negra, por exemplo, que sem dúvida deveria estar mais presente entre nós, em alguns casos de fato está, enquanto em outros não conseguiu ainda estabelecer-se minimamente por falta de meios suficientes para tal. Setores como a História Antiga e Medieval, de difícil desenvolvimento devido à necessidade de aprendizagem de línguas ditas "mortas" ou da associação Arqueologia/História, assumem dimensões e importância relativamente grandes em alguns programas, em que abrem opções específicas para os alunos já na Graduação, mas não em outros, onde existem só minimamente.

Muitos programas de formação em História manifestam preocupação especial com a História Regional, por exemplo em áreas do país em que a produção de obras históricas a elas relativa é ainda pequena, sendo desejável reforçar desde a Graduação o interesse pelos assuntos regionais numa perspectiva histórica. Por razões que são extremamente variáveis, certas especialidades em História do Brasil estão muito mais presentes em alguns programas de Graduação (e Pós-Graduação) do que em outros. E estes são somente uns poucos exemplos tomados ao acaso.

Estes e outros fatores de diversidade, bem como a vontade de abrir escolhas flexíveis numa época em que o campo possível de atuação dos profissionais formados em história se ampliou muito, conduzem à necessidade de diretrizes curriculares bem mais abertas do que as do antigo currículo mínimo.

\section{Diretrizes Curriculares}

\section{Perfil dos Formandos}

O graduado deverá estar capacitado ao exercício do trabalho de Historiador, em todas as suas dimensões, o que supõe pleno domínio da natureza do conhecimento histórico e das práticas essenciais de sua produção e difusão. Atendidas estas exigências básicas e conforme as possibilidades, necessidades e interesses das IES, com formação complementar e interdisciplinar, o profissional estará em condições de suprir demandas sociais específicas relativas ao seu campo de conhecimento (magistério em todos os graus, preservação do 
patrimônio, assessorias a entidades públicas e privadas nos setores culturais, artísticos, turísticos etc.

\section{Competências e Habilidades}

A) Gerais

a. Dominar as diferentes concepções metodológicas que referenciam a construção de categorias para a investigação e a análise das relações sócio-históricas;

b. Problematizar, nas múltiplas dimensões das experiências dos sujeitos históricos, a constituição de diferentes relações de tempo e espaço;

c. Conhecer as informações básicas referentes às diferentes épocas históricas nas várias tradições civilizatórias assim como sua interrelação;

d. Transitar pelas fronteiras entre a História e outras áreas do conhecimento;

e. Desenvolver a pesquisa, a produção do conhecimento e sua difusão não só no âmbito acadêmico, mas também em instituições de ensino, museus, em órgãos de preservação de documentos e no desenvolvimento de políticas e projetos de gestão do patrimônio cultural.

f. competência na utilização da informática.

B) Específicas para licenciatura

a. Domínio dos conteúdos básicos que são objeto de ensino - aprendizagem no ensino fundamental e médio;

b. domínio dos métodos e técnicas pedagógicos que permitem a transmissão do conhecimento para os diferentes níveis de ensino.

\section{Estruturação dos Cursos}

Os colegiados das instituições deverão estruturar seus cursos, programas, disciplinas, áreas, setores ou outras modalidades, de acordo com seus objetivos específicos, assegurada a plena formação do historiador. Deverão incluir no seu projeto pedagógico os critérios para o estabelecimento das disciplinas obrigatórias e optativas, das atividades acadêmicas do bacharelado e da licenciatura, e a sua forma de organização: modular, por crédito ou seriado. O curso de licenciatura deverá ser orientado também pelas Diretrizes para a Formação Inicial de Professores da Educação Básica em cursos de nível superior.

\section{Conteúdos Curriculares}

Os conteúdos básicos e complementares da área de História se organizam em torno de:

1. Conteúdos histórico/historiográficos e práticas de pesquisa que, sob diferentes matizes e concepções teórico-metodológicas, definem e problematizam os grandes recortes espaçotemporais.

2. Conteúdos que permitam tratamento especializado e maior verticalidade na abordagem dos temas, resguardadas as especificidades de cada instituição e dos profissionais que nelas atuam. As instituições devem assegurar que o graduando possa realizar atividades acadêmicas optativas em áreas correlatas de modo a consolidar a interlocução com outras áreas de conhecimento. 
3. Conteúdos complementares que forneçam instrumentação mínima, permitindo a diferenciação de profissionais da área, tais como: atividades pedagógicas, fundamentos de arquivologia, de museologia, gerenciamento de patrimônio histórico, necessariamente acompanhadas de estágio.

No caso da licenciatura deverão ser incluídos os conteúdos definidos para a educação básica, as didáticas próprias de cada conteúdo e as pesquisas que as embasam.

\section{Estágios e Atividades Complementares}

1. As atividades de prática de ensino deverão ser desenvolvidas no interior dos cursos de História, e sob sua responsabilidade, tendo em vista a necessidade de associar prática pedagógica e conteúdo de forma sistemática e permanente.

2. As atividades acadêmicas complementares ( estágios, iniciação científica, projetos de extensão, seminários extra-classe, participação em eventos científicos) poderão ocorrer fora do ambiente escolar, em várias modalidades que deverão ser reconhecidas, supervisionadas e homologadas pelos Colegiados/Coordenações dos Cursos.

\section{Conexão com a Avaliação Institucional}

Os cursos deverão criar seus próprios critérios para avaliação periódica, em consonância com os critérios definidos pela IES à qual pertencem. 


\section{DIRETRIZES CURRICULARES PARA OS CURSOS DE GEOGRAFIA}

\section{Introdução}

A geografia, em seu processo de desenvolvimento histórico como área do conhecimento, veio consolidando teoricamente sua posição como uma ciência que busca conhecer e explicar as múltiplas interações entre a sociedade e a natureza. Isso significa dizer que possui um conjunto muito amplo de interfaces com outras áreas do conhecimento científico. Assim, coloca-se a necessidade de buscar compreender essa realidade espacial, natural e humana, não de uma forma fragmentada, mas como uma totalidade dinâmica.

A geografia vem evoluindo, nas últimas décadas, tanto pela introdução e aprofundamento de metodologias e tecnologias de representação do espaço (geoprocessamento e sistemas geográficos de informação, cartografia automatizada, sensoriamento remoto etc.) quanto no que concerne ao seu acervo teórico e metodológico em nível de pesquisa básica ( campos novos ou renovados como geo-ecologia, teoria das redes geográficas, geografia cultural, geografia econômica, geografia política e recursos naturais, etc.), quanto em nível de pesquisa aplicada (planejamento e gestão ambiental, urbana e rural).

Assim sendo, devemos admitir que essas transformações no campo dos conhecimentos geográficos vêm colocando desafios para a formação não apenas do geógrafos-pesquisador (técnico e planejador) como também para o geógrafo-professor do ensino fundamental, médio e superior.

A atual dinâmica das transformações pelas quais o mundo passa, com as novas tecnologias, com os novos recortes de espaço e tempo, com a predominância do instantâneo e do simultâneo, com as complexas interações entre as esferas do local e do global afetando profundamente o quotidiano das pessoas, exige que a Geografia procure caminhos teóricos e metodológicos capazes de interpretar e explicar esta realidade dinâmica.

Dessa forma, os Departamentos ou Colegiados de Curso de Geografia, enquanto instâncias responsáveis pelo dinamismo e implementação das mudanças que se façam necessárias no currículo, não podem desconhecer novas possibilidades abertas pela LDB na perspectiva de flexibilização das estruturas curriculares, transformando conteúdos e técnicas em percursos possíveis para a formação do pesquisador e profissional em Geografia. Devem buscar, então, caminhos para superar a "cultura da cartilha" e para assumir a liberdade da crítica e da criação, como uma área do conhecimento que tem seu objeto específico, sem abrir mão do rigor científico e metodológico.

Esses são pressupostos que norteiam a atual proposta das Diretrizes Curriculares para o curso de Geografia.

\section{Diretrizes curriculares}

\section{Perfil do Formando}

Compreender os elementos e processos concernentes ao meio natural e ao construído, com base nos fundamentos filosóficos, teóricos e metodológicos da Geografia .

Dominar e aprimorar as abordagens científicas pertinentes ao processo de produção e aplicação do conhecimento geográfico 


\section{Competências e Habilidades}

\section{A) Gerais}

Os cursos de Graduação devem proporcionar o desenvolvimento das seguintes habilidades gerais:

a. Identificar e explicar a dimensão geográfica presente nas diversas manifestações do conhecimentos;

b. Articular elementos empíricos e conceituais, concernentes ao conhecimento científico dos processos espaciais;

c. Reconhecer as diferentes escalas de ocorrência e manifestação dos fatos, fenômenos e eventos geográficos;

d. Planejar e realizar atividades de campo referentes à investigação geográfica;

e. Dominar técnicas laboratoriais concernentes a produção e aplicação do conhecimento geográficos;

f. Propor e elaborar projetos de pesquisa e executivos no âmbito de área de atuação da Geografia ;

g. Utilizar os recursos da informática;

h. Dominar a língua portuguesa e um idioma estrangeiro no qual seja significativa a produção e a difusão do conhecimento geográfico;

i. Trabalhar de maneira integrada e contributiva em equipes multidisciplinares.

B) Específicas

a. Identificar, descrever, compreender, analisar e representar os sistemas naturais:

b. identificar, descrever, analisar, compreender e explicar as diferentes práticas e concepções concernentes ao processo de produção do espaço;

c. selecionar a linguagem científica mais adequada para tratar a informação geográfica, considerando suas características e o problema proposto;

d. avaliar representações ou tratamentos ;gráficos e matemático-estatísticos

e. elaborar mapas temáticos e outras representações gráficas.

f. dominar os conteúdos básicos que são objeto de aprendizagem nos níveis fundamental e médio;

g. organizar o conhecimento espacial adequando-o ao processo de ensino-aprendizagem em geografia nos diferentes níveis de ensino.

\section{Organização do Curso}

Os colegiados das instituições poderão estruturar o curso em 4 níveis de formação (de bacharéis, aplicada-profissional, de docentes e de pesquisadores) e devem indicar sua organização modular, por créditos ou seriada. O curso de licenciatura deverá ser orientado também pelas Diretrizes para a Formação Inicial de Professores da Educação Básica em cursos de nível superior.

\section{Conteúdos Curriculares}

Os conteúdos básicos e complementares da Geografia organizam-se em torno de: . núcleo específico - conteúdos referentes ao conhecimento geográfico; 
- núcleo complementar - conteúdos considerados necessários à aquisição de conhecimento geográfico e que podem ser oriundos de outras áreas de conhecimento, mas não excluem os de natureza específica da Geografia;

. núcleo de opções livres - composto de conteúdos a serem escolhidos pelo próprio aluno.

No caso da licenciatura deverão ser incluídos os conteúdos definidos para a educação básica, as didáticas próprias de cada conteúdo e as pesquisas que as embasam.

\section{Estágios e Atividades Complementares}

Os estágios e atividades complementares fazem parte da necessidade de que haja articulação entre a teoria e a prática , e entre a pesquisa básica e a aplicada. Para que esta articulação se processe no âmbito do currículo é necessário que o entendamos como "qualquer conjunto de atividades acadêmicas previstas pela IES para a integralização de um curso" e, como atividade acadêmica, "aquela considerada relevante para que o estudante adquira, durante a integralização curricular, o saber e as habilidades necessárias à sua formação e que contemplem processos avaliativos."

Neste contexto, são consideradas atividades integrantes da formação do aluno de Geografia, além da disciplina: estágios, que poderão ocorrer em qualquer etapa do curso, desde que seus objetivos sejam claramente explicitados; seminários; participação em eventos; discussões temáticas; atividades acadêmicas à distância; iniciação à pesquisa, docência e extensão; vivência profissional complementar; estágios curriculares, trabalhos orientados de campo, monografias, estágios em laboratórios; elaboração de projetos de pesquisa e executivos, além de outras atividades acadêmicas a juízo do colegiado do curso.

Caberá aos colegiados de curso organizar essas atividades ao longo do tempo de integralização curricular.

\section{Conexão com a Avaliação Institucional}

Os cursos deverão criar seus próprios critérios para avaliação periódica, em consonância com os critérios definidos pela IES à qual pertencem. 


\section{DIRETRIZES CURRICULARES PARA OS CURSOS DE SERVIÇO SOCIAL}

\section{Perfil dos Formandos}

Profissional que atua nas expressões da questão social, formulando e implementando propostas de intervenção para seu enfrentamento, com capacidade de promover o exercício pleno da cidadania e a inserção criativa e propositiva dos usuários do Serviço Social no conjunto das relações sociais e no mercado de trabalho.

\section{Competências e Habilidades}

\section{A) Gerais}

A formação profissional deve viabilizar uma capacitação teórico-metodológica e éticopolítica, como requisito fundamental para o exercício de atividades técnico-operativas, com vistas à

- compreensão do significado social da profissão e de seu desenvolvimento sócio-histórico, nos cenários internacional e nacional, desvelando as possibilidades de ação contidas na realidade;

- identificação das demandas presentes na sociedade, visando a formular respostas profissionais para o enfrentamento da questão social;

- utilização dos recur sos da informática.

B) Específicas

A formação profissional deverá desenvolver a capacidade de

- elaborar, executar e avaliar planos, programas e projetos na área social;

- contribuir para viabilizar a participação dos usuários nas decisões institucionais;

- planejar, organizar e administrar benefícios e serviços sociais;

- realizar pesquisas que subsidiem formulação de políticas e ações profissionais;

- prestar assessoria e consultoria a órgãos da administração pública, empresas privadas e movimentos sociais em matéria relacionada às políticas sociais e à garantia dos direitos civis, políticos e sociais da coletividade;

- orientar a população na identificação de recursos para atendimento e defesa de seus direitos;

- realizar visitas, perícias técnicas, laudos, informações e pareceres sobre matéria de Serviço Social.

\section{Organização do Curso}

- Flexibilidade dos currículos plenos, integrando o ensino das disciplinas com outros componentes curriculares, tais como: oficinas, seminários temáticos, estágio, atividades complementares;

- rigoroso trato teórico, histórico e metodológico da realidade social e do Serviço Social, que possibilite a compreensão dos problemas e desafios com os quais o profissional se defronta;

- estabelecimento das dimensões investigativa e interpretativa como princípios formativos e condição central da formação profissional, e da relação teoria e realidade; 
- presença da interdisciplinaridade no projeto de formação profissional;

- exercício do pluralismo teórico-metodológico como elemento próprio da vida acadêmica e profissional;

- respeito à ética profissional;

- indissociabilidade entre a supervisão acadêmica e profissional na atividade de estágio.

\section{Conteúdos Curriculares}

A organização curricular deve superar as fragmentações do processo de ensino e aprendizagem, abrindo novos caminhos para a construção de conhecimentos como experiência concreta no decorrer da formação profissional. Sustenta-se no tripé dos conhecimentos constituídos pelos núcleos de fundamentação da formação profissional, quais sejam:

- núcleo de fundamentos teórico-metodológicos da vida social, que compreende um conjunto de fundamentos teórico-metodológicos e ético-políticos para conhecer o ser social;

- núcleo de fundamentos da formação sócio-histórica da sociedade brasileira, que remete à compreensão das características históricas particulares que presidem a sua formação e desenvolvimento urbano e rural, em suas diversidades regionais e locais;

- núcleo de fundamentos do trabalho profissional, que compreende os elementos constitutivos do Serviço Social como uma especialização do trabalho: sua trajetória histórica, teórica, metodológica e técnica, os componentes éticos que envolvem o exercício profissional, a pesquisa, o planejamento e a administração em Serviço Social e o estágio supervisionado.

Os núcleos englobam um conjunto de conhecimentos e habilidades que se especifica em atividades acadêmicas, enquanto conhecimentos necessários à formação profissional. Essas atividades, a serem definidas pelos colegiados, se desdobram em disciplinas, seminários temáticos, oficinas/laboratórios, atividades complementares e outros componentes curriculares.

\section{Estágio Supervisionado e Trabalho de Conclusão de Curso (Tcc)}

O Estágio Supervisionado e o Trabalho de Conclusão de Curso devem ser desenvolvidos durante o processo de formação a partir do desdobramento dos componentes curriculares, concomitante ao período letivo escolar.

O Estágio Supervisionado é uma atividade curricular obrigatória que se configura a partir da inserção do aluno no espaço sócio-institucional, objetivando capacitá-lo para o exercício profissional, o que pressupõe supervisão sistemática. Esta supervisão será feita conjuntamente por professor supervisor e por profissional do campo, com base em planos de estágio elaborados em conjunto pelas unidades de ensino e organizações que oferecem estágio. 


\section{Atividades Complementares}

As atividades complementares, dentre as quais podem ser destacadas a monitoria, visitas monitoradas, iniciação científica, projeto de extensão, participação em seminários, publicação de produção científica e outras atividades definidas no plano acadêmico do curso. 


\section{DIRETRIZES CURRICULARES A ÁREA DE COMUNICAÇÃO SOCIAL E SUAS HABILITAÇÕES}

\section{Introdução}

Estas Diretrizes Curriculares da Área da Comunicação foram elaboradas procurando atender a dois objetivos fundamentais:

a) flexibilizar a estruturação dos cursos, tanto para atender a variedades de circunstâncias geográficas, político-sociais e acadêmicas, como para ajustar-se ao dinamismo da área, e para viabilizar o surgimento de propostas pedagógicas inovadoras e eficientes;

b) estabelecer orientações para a obtenção de padrão de qualidade na formação oferecida.

O presente texto estabelece um padrão básico de referência para todas as instituições que mantenham Cursos de Graduação em Comunicação com habilitações em Jornalismo, Relações Públicas, Publicidade e Propaganda, Cinema, Radialismo, Editoração, ou outras habilitações pertinentes ao campo da Comunicação que venham a ser criadas.

\section{Diretrizes Curriculares}

\section{Perfil dos Formandos}

\section{PERFIL COMUM}

O perfil comum do egresso corresponde a um objetivo de formação geral que deve ser atendido por todos os Cursos da área e em todas as habilitações de Comunicação, qualquer que seja sua ênfase ou especificidade. Trata-se de base que garanta a identidade do Curso como de Comunicação.

O egresso de Curso de Graduação em Comunicação, em qualquer de suas habilitações, caracteriza-se por:

1. sua capacidade de criação, produção, distribuição, recepção, e análise crítica referentes às mídias, às práticas profissionais e sociais relacionadas com estas, e a suas inserções culturais, políticas e econômicas;

2. sua habilidade em refletir a variedade e mutabilidade de demandas sociais e profissionais na área, adequando-se à complexidade e velocidade do mundo contemporâneo;

3. sua visão integradora e horizontalizada - genérica e ao mesmo tempo especializada de seu campo de trabalho possibilitando o entendimento da dinâmica das diversas modalidades comunicacionais e das suas relações com os processos sociais que as originam e que destas decorrem.

4. utilizar criticamente o instrumental teórico-prático oferecido em seu curso, sendo portanto competente para posicionar-se de um ponto de vista ético-político sobre o exercício do poder na comunicação, sobre os constrangimentos a que a comunicação pode ser submetida, sobre 
as repercussões sociais que enseja e ainda sobre as necessidades da sociedade contemporânea em relação à comunicação social.

\section{PERFIS ESPECÍFICOS}

Os perfis específicos resultam das habilitações diferenciadas do campo da Comunicação, que se caracteriza por uma abrangência sobre diferentes meios, linguagens e práticas profissionais e de pesquisa e, na atualidade, por envolver um acelerado dinamismo social e tecnológico. Para assegurar o desenvolvimento histórico desta área de formação, estudos e exercício profissional, serão desenvolvidas habilitações com uma variedade de perfis específicos. Estas habilitações, definidoras dos perfis específicos, se organizam conforme as seguintes premissas:

a) é mantida a referência básica às habilitações historicamente estabelecidas: jornalismo, relações públicas, publicidade e propaganda, radialismo, editoração, e cinema (assim como à sua denominação alternativa, cinema e vídeo);

b) podem ser criadas ênfases específicas em cada uma destas habilitações, que serão então referidas pela denominação básica, acrescida de denominação complementar que caracterize a ênfase adotada;

c) podem ser criadas novas habilitações pertinentes ao campo da Comunicação.

As habilitações referidas nos itens "b" e "c" acima serão reconhecidas como pertinentes ao campo da Comunicação na medida em que contemplem :

- a dimensão e a complexidade temática e de objeto de estudo;

- a existência de vinculações profissionais e conceituais com o campo da Comunicação;

- a delimitação de uma habilitação específica, que comporte linguagem e práticas profissionais próprias.

\section{PERFIS ESPECÍFICOS POR HABILITAÇÃo}

Para as habilitações já estabelecidas, além do perfil comum relacionado no item anterior, devem se objetivar os perfis a seguir explicitados:

\section{Jornalismo}

O perfil do egresso em Jornalismo se caracteriza :

1. pela produção de informações relacionadas a fatos, circunstâncias e contextos do momento presente;

2. pelo exercício da objetividade na apuração, interpretação, registro e divulgação dos fatos sociais;

3. pelo exercício da tradução e disseminação de informações de modo a qualificar o senso comum;

4. pelo exercício de relações com outras áreas sociais, culturais e econômicas com as quais o jornalismo faz interface. 


\section{Relações Públicas}

O perfil do egresso em Relações Públicas se caracteriza:

1. pela administração do relacionamento das organizações com seus diversos públicos, tanto externos como internos;

2. pela elaboração de diagnósticos, prognósticos, estratégias e políticas voltadas para o aperfeiçoamento das relações entre instituições, grupos humanos organizados, setores de atividades públicas ou privadas, e a sociedade em geral;

3. pelo exercício de interlocução entre as funções típicas de relações públicas e as demais funções profissionais ou empresariais existentes na área da Comunicação.

\section{Radialismo}

O perfil do egresso em Radialismo se caracteriza:

1. pela percepção, interpretação , recriação e registro da realidade social, cultural e da natural através de som e imagem ;

2. pelas formulações audiovisuais habituais, documentárias, de narração, musicais, descritivas, expositivas, ou quaisquer outras adequadas aos suportes com que trabalha;

3. pelo domínio técnico, estético e de procedimentos expressivos pertinentes a essa elaboração audiovisual;

4. pela atividade em emissoras de rádio ou televisão ou quaisquer instituições de criação, produção, desenvolvimento e interpretação de materiais audiovisuais;

5. pelo exercício de interlocução entre as funções típicas de radialismo e as demais funções profissionais ou empresariais da área da Comunicação.

\section{Publicidade e Propaganda}

O perfil do egresso em Publicidade e Propaganda se caracteriza:

1. pelo conhecimento e domínio de técnicas e instrumentos necessários para a proposição e execução de soluções de comunicação eficazes para os objetivos de mercado, de negócios de anunciantes e institucionais;

2. pela tradução em objetivos e procedimentos de comunicação apropriados os objetivos institucionais, empresariais e mercadológicos;

3. pelo planejamento, criação, produção, difusão e gestão da comunicação publicitária, de ações promocionais e de incentivo, eventos e patrocínio, atividades de marketing, venda pessoal, design de embalagens e de identidade corporativa, e de assessoria publicitária de informação.

\section{Editoração}

O perfil do egresso em Editoração se caracteriza: 
1. pela gestão e produção de processos editoriais, de multiplicação, reprodução e difusão, que envolvam obras literárias, científicas, instrumentais e culturais;

2. pelo desenvolvimento de atividades relacionadas à produção de livros e impressos em geral, livros eletrônicos, CDROMs e outros produtos multimídia, vídeos, discos, páginas de Internet, e quaisquer outros suportes impressos, sonoros, audiovisuais e digitais;

3. pelo domínio dos processos editoriais, tais como planejamento de produto, seleção e edição de textos, imagens e sons, redação e preparação de originais, produção gráfica e diagramação de impressos, roteirização de produtos em diferentes suportes, gravações, montagens, bem como divulgação e comercialização de produtos editoriais.

\section{Cinema}

O perfil do egresso da habilitação em Cinema (com esta denominação ou na denominação alternativa Cinema e Vídeo) se caracteriza:

1. pela produção audiovisual nas bitolas e formatos cinematográficos, videográficos, cinevideográficos ou digitais, incluindo-se nessa produção direção geral, direção de arte, direção de fotografia, elaboração de argumentos e roteiros, montagem/edição, animação, continuidade, sonorização, finalização e demais atividades relacionadas; e ainda pela preservação e fomento da memória audiovisual da nação;

2. pela percepção, interpretação, recriação e registro cinematográfico de aspectos da realidade social, cultural, natural de modo a torná-las disponíveis à sociedade por intermédio de estruturações narrativas, documentárias, artísticas, ou experimentais;

3. pela iniciativa e pela participação na discussão pública sobre a criação cinematográfica e videográfica no país e no mundo, através de estudos críticos e interpretativos sobre produtos cinematográficos, sobre a história das artes cinematográficas, e sobre as teorias de cinema;

4. pelo desenvolvimento de atividades e especialidades de produção cinematográfica e videográfica;

\section{Competência e Habilidades}

Assim como os perfis dos egressos, organizados em uma parte geral comum e uma parte específica por habilitação, as competências e habilidades também comportam dois níveis, um geral para todas as profissões e formações do campo da Comunicação e um especializado por habilitação.

\section{A) Gerais}

As competências e habilidades gerais para os diferentes perfis são as seguintes:

1. assimilar criticamente conceitos que permitam a apreensão de teorias;

2. usar tais conceitos e teorias em análises críticas da realidade;

3. posicionar-se de modo ético-político; 
4. dominar as linguagens habitualmente usadas nos processos de comunicação, nas dimensões de criação, de produção, de interpretação e da técnica;

5. experimentar e inovar no uso destas linguagens;

6. refletir criticamente sobre as práticas profissionais no campo da Comunicação;

7. ter competência no uso da língua nacional para escrita e interpretação de textos gerais e especializados na área.

B) Específicas por Habilitação

Além das competências e habilidades gerais acima referidas, há que se promover o desenvolvimento de competências específicas.

\section{Jornalismo}

- registrar fatos jornalísticos, apurando, interpretando, editando e transformando-os em notícias e reportagens;

- interpretar, explicar e contextualizar informações;

- investigar informações, produzir textos e mensagens jornalísticas com clareza e correção e editá- los em espaço e período de tempo limitados;

- formular pautas e planejar coberturas jornalísticas;

- formular questões e conduzir entrevistas;

- relacionar-se com fontes de informação de qualquer natureza;

- trabalhar em equipe com profissionais da área;

- compreender e saber sistematizar e organizar os processos de produção jornalística;

- desenvolver, planejar, propor, executar e avaliar projetos na área de comunicação jornalística;

- avaliar criticamente produtos, práticas e empreendimentos jornalísticos;

- compreender os processos envolvidos na recepção de mensagens jornalísticas e seus impactos sobre os diversos setores da sociedade;

- buscar a verdade jornalística, com postura ética e compromisso com a cidadania;

- dominar a língua nacional e as estruturas narrativas e expositivas aplicáveis às mensagens jornalísticas, abrangendo-se leitura, compreensão, interpretação e redação;

- dominar a linguagem jornalística apropriada aos diferentes meios e modalidades tecnológicas de comunicação;

\section{Relações Públicas}

- desenvolver pesquisas e auditorias de opinião e imagem;

- realizar diagnósticos com base em pesquisas e auditorias de opinião e imagem;

- elaborar planejamentos estratégicos de comunicação institucional; 
- estabelecer programas de comunicação estratégica para criação e manutenção do relacionamento das instituições com seus públicos de interesse;

- coordenar o desenvolvimento de materiais de comunicação, em diferentes meios e suportes, voltados para a realização dos objetivos estratégicos do exercício da função de Relações Públicas;

- dominar as linguagens verbais e audiovisuais para seu uso efetivo a serviço dos programas de comunicação que desenvolve;

- identificar a responsabilidade social da profissão, mantendo os compromissos éticos estabelecidos;

- assimilar criticamente conceitos que permitam a compreensão das práticas e teorias referentes às estratégias e processos de Relações Públicas.

\section{Radialismo}

- gerar produtos audiovisuais em suas especialidades criativas, como escrever originais ou roteiros para realização de projetos audiovisuais; adaptar originais de terceiros; responder pela direção, realização e transmissão de programas audiovisuais; editar e finalizar programas analógicos ou digitais;

- $\quad$ saber como planejar, orçar e produzir programas para serem gravados ou transmitidos; administrar, planejar e orçar estruturas de emissoras ou produtoras;

- dominar as linguagens e gêneros relacionados às criações aud iovisuais;

- conceber projetos de criação e produção audiovisual em formatos adequados a sua veiculação nos meios massivos, como rádio e televisão, em formatos de divulgação presencial, como vídeo e gravações sonoras, e em formatos típicos de inserção em sistemas eletrônicos em rede, como CDROMs e outros produtos digitais;

- compreender as incidências culturais, éticas, educacionais e emocionais da produção audiovisual mediatizada em uma sociedade de comunicação;

- assimilar criticamente conceitos que permitam a compreensão das práticas e teorias referentes à área audiovisual.

\section{Cinema (ou Cinema e Vídeo)}

- gerar produtos cinematográficos em suas especialidades criativas, como direção geral, direção de arte, direção de fotografia, argumento e roteiro, mont agem/edição, animação, continuidade, sonorização, finalização, e outras atividades relacionadas;

- promover a geração e disseminação de produtos cinematográficos em suas especialidades de gestão, como produção, distribuição, exibição, divulgação, e outras atividades relacionadas;

- dominar as diversas técnicas audiovisuais envolvidas nos processos de criação cinematográfica, em qualquer de seus suportes, e nos processos de divulgação;

- interagir com áreas vizinhas à criação e divulgação cinematográfica, como a televisão, o rádio, as artes performáticas e as novas mídias digitais;

- avaliar, quantificar, formar e influenciar o gosto público no que diz respeito ao consumo de produtos audiovisuais; 
- inovar e reinventar alternativas criativas e mercadológicas para a produção de filmes e vídeos;

- interpretar, analisar, explicar e contextualizar a linguagem cinematográfica apropriada aos diferentes meios e modalidades da comunicação audiovisual;

- compreender os processos cognitivos envolvidos na produção, emissão e recepção da mensagem cinematográfica e seus impactos sobre a cultura e a sociedade;

- articular as práticas cinematográficas, em seus aspectos técnicos e conceituais, à produção científica, artística e tecnológica que caracteriza nossa cultura, e ao exercício do pensamento em seus aspectos estéticos, éticos e políticos;

- assimilar criticamente conceitos que permitam a compreensão das práticas e teorias referentes à criação, produção e circulação cultural do Cinema.

\section{Publicidade e Propaganda}

- ordenar as informações conhecidas e fazer diagnóstico da situação dos clientes;

- realizar pesquisas de consumo, de motivação, de concorrência, de argumentos etc;

- definir objetivos e estratégias de comunicação como soluções para problemas de mercado e institucionais dos anunciantes;

- conceber meios de avaliar e corrigir resultados de programas estabelecidos;

- executar e orientar o trabalho de criação e produção de campanhas de propaganda em veículos impressos, eletrônicos e digitais;

- realizar e interpretar pesquisas de criação como subsídio para a preparação de campanhas publicitárias;

- dominar linguagens e competências estéticas e técnicas para criar, orientar e julgar materiais de comunicação pertinentes a suas atividades;

- planejar, executar e administrar campanhas de comunicação com o mercado, envolvendo o uso da propaganda e de outras formas de comunicação, como a promoção de vendas, o merchandising e o marketing direto;

- identificar e analisar as rápidas mudanças econômicas e sociais em escala global e nacional que influem no ambiente empresarial;

- identificar a responsabilidade social da profissão, mantendo os compromissos éticos estabelecidos;

- assimilar criticamente conceitos que permitam a compreensão das práticas e teorias referentes à publicidade e à propaganda.

\section{Editoração}

- dominar processos de edição de texto tais como: resumos, apresentações, textos de capa de livros, textos de revistas, textos que acompanham edições sonoras, audiovisuais e de multimídia, textos para publicações digitais, tratamento de textos didáticos e paradidáticos, textos de compilação, de crítica e de criação; 
- dominar a língua nacional e as estruturas de linguagem aplicáveis a obras literárias, científicas, instrumentais, culturais e de divulgação em suas diferentes formas: kitura, redação, interpretação, avaliação e crítica;

- atentar para os diferentes níveis de proficiência dos públicos a que se destinam as produções editoriais;

- ter competências de linguagem visual, como o conhecimento de produção de imagens préfotográficas, fotográficas e pós-fotográficas e os principais processos de design gráfico, desde tipologias até edição digital;

- ter competências de linguagem de multimídia, como o conhecimento de processos de produção de registros sonoros, videográficos e digitais, tais como CDs, vídeos, edição de páginas e outras publicações em Internet;

- desenvolver ações de planejamento, organização e sistematização dos processos editoriais, tais como o acompanhamento gráfico de produtos editoriais, seleção de originais, projetos de obras e publicações, planejamento e organização de séries e de coleções, planejamento de distribuição, veiculação e tratamento publicitário de produtos editorial;

- ter conhecimentos sobre a história do livro, a história da arte e da cultura;

- fazer avaliações críticas das produções editoriais e do mercado da cultura.

- agir no sentido de democratização da leitura e do acesso às informações e aos bens culturais.

- assimilar criticamente conceitos que permitam a compreensão das práticas e teorias referentes aos processos de Editoração.

\section{Conteúdos Curriculares}

Os conteúdos curriculares são diferenciados em Conteúdos Básicos e Conteúdos Específicos. Os conteúdos básicos são aqueles relacionados tanto à parte comum do curso quanto às diferentes habilitações. Os conteúdos específicos são aqueles que cada instituição, livremente, deve eleger para organizar seu currículo pleno, tendo como referência os objetivos e os perfis comum e específicos anteriormente definidos.

\section{a. Conteúdos Básicos}

Os conteúdos básicos são caracterizadores da formação geral da área, devendo atravessar a formação dos graduandos de todas as habilitações. Envolvem tanto conhecimentos teóricos como práticos, reflexões e aplicações relacionadas ao campo da Comunicação e à área configurada pela habilitação específica. Estes conhecimentos são assim categorizados: conteúdos teórico-conceituais; conteúdos analíticos e informativos sobre a atualidade; conteúdos de linguagens, técnicas e tecnologias midiáticas, conteúdos ético-políticos.

\section{b. Conteúdos Específicos}

Os conteúdos específicos serão definidos pelo colegiado do curso, tanto para favorecer reflexões e práticas no campo geral da Comunicação, como para incentivar reflexões e práticas da habilitação específica. 
Cada habilitação correspondendo a recortes dentro do campo geral da Comunicação, organiza conhecimentos e práticas profissionais, aborda questões teóricas, elabora críticas, discute a atualidade e desenvolve práticas sobre linguagens e estruturas.

\section{Estágios e Atividades Complementares}

O Estágio orientado por objetivos de formação refere-se a estudos e práticas supervisionados em atividades externas à unidade de oferecimento do Curso. As atividades complementares realizadas sob a supervisão de um docente buscam promover o relacionamento do estudante com a realidade social, econômica e cultural, e de iniciação à pesquisa e ao ensino.

Tais tipos de ação pedagógica caracterizam mecanismos de interação com o mundo do trabalho, assim como o confronto com possibilidades metodológicas visando a promoção de uma formação complexa.

Assim, além das disciplinas típicas e tradicionais da sala de aula e de práticas ditas laboratoriais, segundo o padrão de turma/docente/horas-aula semanais, podem ser previstas Atividades Complementares, com atribuição de créditos ou computação de horas para efeito de integralização do total previsto para o Curso, tais como:

- programas especiais de capacitação do estudante (tipo CAPES/PET);

- atividades de monitoria;

- outras atividades laboratoriais além das já previstas no padrão turma/horas-aula;

- $\quad$ atividades de extensão;

- atividades de pesquisa etc.

O que caracteriza este conjunto de atividades é a flexibilidade de carga horária semanal, com controle do tempo total de dedicação do estudante durante o semestre ou ano letivo. Esta flexibilidade horária semanal deverá permitir a:

a) adoção de um sistema de creditação de horas baseada em decisões específicas para cada caso, projeto ou atividade específica, e em função do trabalho desenvolvido;

b) ênfase em procedimentos de orientação e/ou supervisão pelo docente;

c) ampliação da autonomia do estudante para organizar seus horários, objetivos e direcionamento.

O número máximo de horas dedicadas a este tipo de atividades não pode ultrapassar $20 \%$ do total do curso, não incluídas nesta porcentagem de $20 \%$ as horas dedicadas ao Trabalho de Conclusão de Curso (ou Projetos Experimentais).

\section{Estrutura do Curso}

O curso de Comunicação Social pode ser oferecido por créditos, havendo, no entanto, atenção para uma seqüência equilibrada de conteúdos curriculares e acompanhamento planejado da formação.

$\mathrm{Na}$ oferta seriada importa considerar, além de uma sequiência harmônica e lógica, a flexibilidade de caminhos alternativos. 
Na organização modular, deverá ser esclarecido o seu modo de inserção na estrutura geral do curso.

\section{Acompanhamento e Avaliação}

A avaliação é peródica e se realiza em articulação com o Projeto Acadêmico do curso sob três ângulos:

a) pertinência da estrutura do Curso, observando o fundamento de suas propostas e a adequação dos meios postos em ação para realizá-las;

b) aplicação dos critérios definidos pelo colegiado de curso, para a sua avaliação;

c) mecanismos de acompanhamento e avaliação externa e interna do próprio curso. 


\section{DIRETRIZES CURRICULARES PARA OS CURSOS DE GRADUAÇÃO EM CIÊNCIAS SOCIAIS - ANTROPOLOGIA, CIÊNCIA POLÍTICA, SOCIOLOGIA}

Princípios norteadores da concepção das diretrizes curriculares:

- Propiciar aos estudantes uma formação teórico-metodológica sólida em torno dos eixos que formam a identidade do curso ( Antropologia, Ciência Política e Sociologia ) e fornecer instrumentos para estabelecer relações com a pesquisa e a prática social.

- Criar uma estrutura curricular que estimule a autonomia intelectual, a capacidade analítica dos estudantes e uma ampla formação humanística.

- Partir da idéia de que o curso é um percurso que abre um campo de possibilidades com alternativas de trajetórias e não apenas uma grade curricular.

- Estimular a produção de um projeto pedagógico que explicite os objetivos do curso, a articulação entre disciplinas, as linhas e núcleos de pesquisa, as especificidades de formação, a tutoria e os projetos de extensão.

- Estimular avaliações institucionais no sentido do aperfeiçoamento constante do curso.

\section{Diretrizes Curriculares}

\section{Perfil dos Formandos}

- Professor de ensino fundamental, de ensino médio e de ensino superior.

- Pesquisador seja na área acadêmica ou não acadêmica.

- Profissional que atue em planejamento, consultoria, formação e assessoria junto a empresas públicas, privadas, organizações não governamentais, governamentais, partidos políticos, movimentos sociais e atividades similares.

\section{Competências e Habilidades}

A) Gerais

- Domínio da bibliografia teórica e metodológica básica

- Autonomia intelectual

- Capacidade analítica

- Competência na articulação entre teoria, pesquisa e prática social

- Compromisso social

- Competência na utilização da informática

- B)Específicas para licenciatura

- Domínio dos conteúdos básicos que são objeto de ensino e aprendizagem no ensino fundamental e médio

- Domínio dos métodos e técnicas pedagógicos que permitem a transposição do conhecimento para os diferentes níveis de ensino

\section{Organização do Curso}

Bacharelado e licenciatura. 


\section{Conteúdos Curriculares}

O currículo será organizado em torno de três eixos : Formação Específica, Formação Complementar e Formação Livre.

Esta proposta está ancorada em uma concepção que privilegia a especificidade da formação no curso, reforçando a integração entre as áreas de Antropologia, Ciência Política e Sociologia, ao mesmo tempo em que possibilita a abertura para o conhecimento em outras áreas. Recusando a especialização precoce, o que se propõe é o estabelecimento de conjuntos de atividades acadêmicas definidos a partir de temas, linhas de pesquisa, problemas teóricos e sociais relevantes, bem como campos de atuação profissional.

- O Eixo de Formação Específica deve constituir a base do saber característico da área de atuação do cientista social. Entende-se que tal Eixo deva ser composto de um conjunto de atividades acadêmicas obrigatórias, optativas e complementares que fazem parte da identidade do curso (Antropologia, Ciência Política e Sociologia ). Cabe ao Colegiado do curso definir criteriosamente as atividades que definem a especificidade do curso bem como a tradução destas em carga horária.

- O Eixo de Formação Complementar compreende atividades acadêmicas obrigatórias, optativas e atividades definidas a partir dos conjuntos temáticos das áreas específicas de formação do curso, bem como de atividades acadêmicas que fazem interface com aqueles conjuntos advindas de outros cursos da IES, definidas previamente no projeto pedagógico do curso.

- O Eixo de Formação Livre compreende e atividades acadêmicas de livre escolha do aluno no contexto da IES.

O Colegiado do curso deve definir a proporcionalidade de cada Eixo na totalidade do Currículo.

No caso da licenciatura, deverão ser incluídos os conteúdos definidos para a educação básica, as didáticas próprias de cada conteúdo e as pesquisas que as embasam.

\section{Estruturação do Curso}

Os cursos devem incluir no seu projeto pedagógico os critérios para o estabelecimento das disciplinas obrigatórias e optativas, das atividades acadêmicas do bacharelado e da licenciatura, e a sua forma de organização: modular, por crédito ou seriado.

O curso de licenciatura deverá ser orientado também pelas Diretrizes para a Formação Inicial de Professores da Educação Básica em cursos de nível superior.

\section{Estágios e Atividades Complementares}

Devem integralizar a estrutura curricular (com atribuições de créditos), atividades acadêmicas autorizadas pelo Colegiado tais como : estágios, iniciação científica, laboratórios, trabalho em pesquisa, trabalho de conclusão de curso, participação em eventos científicos, seminários extra-classe, empresa júnior, projetos de extensão. 


\section{Conexão com a Avaliação Institucional.}

Os cursos deverão criar seus próprios critérios para avaliação periódica, em consonância com os critérios definidos pela IES à qual pertencem . 


\section{DIRETRIZES CURRICULARES PARA OS CURSOS DE LETRAS}

\section{Introdução}

Esta proposta de Diretrizes Curriculares leva em consideração os desafios da educação superior diante das intensas transformações que têm ocorrido na sociedade contemporânea, no mercado de trabalho e nas condições de exercício profissional. Concebe-se a Universidade não apenas como produtora e detentora do conhecimento e do saber, mas, também, como instância voltada para atender às necessidades educativas e tecnológicas da sociedade. Ressalta-se, no entanto, que a Universidade não pode ser vista apenas como instância reflexa da sociedade e do mundo do trabalho. Ela deve ser um espaço de cultura e de imaginação criativa, capaz de intervir na sociedade, transformando-a em termos éticos.

A área de Letras, abrigada nas ciências humanas, põe em relevo a relação dialética entre o pragmatismo da sociedade moderna e o cultivo dos valores humanistas.

Decorre daí que os cursos de graduação em Letras deverão ter estruturas flexíveis que:

- facultem ao profissional a ser formado opções de conhecimento e de atuação mo mercado de trabalho;

- criem oportunidade para o desenvolvimento de habilidades necessárias para se atingir a competência desejada no desempenho profissional;

- dêem prioridade à abordagem pedagógica centrada no desenvolvimento da autonomia do aluno;

- promovam articulação constante entre ensino, pesquisa e extensão, além de articulação direta com a pós-graduação;

- propiciem o exercício da autonomia universitária, ficando a cargo da Instituição de Ensino Superior definições como perfil profissional, carga horária, atividades curriculares básicas, complementares e de estágio.

Portanto, é necessário que se amplie o conceito de currículo, que deve ser concebido como construção cultural que propicie a aquisição do saber de forma articulada. Por sua natureza teórico-prática, essencialmente orgânica, o currículo deve ser constituído tanto pelo conjunto de conhecimentos, competências e habilidades, como pelos objetivos que busca alcançar. Assim, define-se currículo como todo e qualquer conjunto de atividades acadêmicas que integralizam um curso. Essa definição introduz o conceito de atividade acadêmica curricular - aquela considerada relevante para que o estudante adquira competências e habilidades necessárias a sua formação e que possa ser avaliada interna e externamente como processo contínuo e transformador, conceito que não exclui as disciplinas convencionais.

Os princípios que norteiam esta proposta de Diretrizes Curriculares são a flexibilidade na organização do curso de Letras e a consciência da diversidade / heterogeneidade do conhecimento do aluno, tanto no que se refere à sua formação anterior, quanto aos interesses e expectativas em relação ao curso e ao futuro exercício da profissão.

A flexibilização curricular, para responder às novas demandas sociais e aos princípios expostos, é entendida como a possibilidade de:

- eliminar a rigidez estrutural do curso;

- imprimir ritmo e duração ao curso, nos limites adiante estabelecidos;

- utilizar, de modo mais eficiente, os recursos de formação já existentes nas instituições de ensino superior.

A flexibilização do currículo, na qual se prevê nova validação de atividades acadêmicas, requer o desdobramento do papel de professor na figura de orientador, que deverá responder 
não só pelo ensino de conteúdos programáticos, mas também pela qualidade da formação do aluno.

Da mesma forma, o colegiado de graduação do curso de Letras é a instância competente para a concepção e o acompanhamento da diversidade curricular que a IES implantará.

\section{Diretrizes Curriculares}

\section{Perfil dos Formandos}

O objetivo do Curso de Letras é formar profissionais interculturalmente competentes, capazes de lidar, de forma crítica, com as linguagens, especialmente a verbal, nos contextos oral e escrito, e conscientes de sua inserção na sociedade e das relações com o outro.

Independentemente da modalidade escolhida, o profissional em Letras deve ter domínio do uso da língua ou das línguas que sejam objeto de seus estudos, em termos de sua estrutura, funcionamento e manifestações culturais, além de ter consciência das variedades lingüísticas e culturais. Deve ser capaz de refletir teoricamente sobre a linguagem, de fazer uso de novas tecnologias e de compreender sua formação profissional como processo contínuo, autônomo e permanente. A pesquisa e a extensão, além do ensino, devem articular-se neste processo. $\mathrm{O}$ profissional deve, ainda, ter capacidade de reflexão crítica sobre temas e questões relativas aos conhecimentos lingüísticos e literários.

\section{Competências e Habilidades}

O graduado em Letras, tanto em língua materna quanto em língua estrangeira clássica ou moderna, nas modalidades de bacharelado e de licenciatura, deverá ser identificado por múltiplas competências e habilidades adquiridas durante sua formação acadêmica convencional, teórica e prática, ou fora dela.

Nesse sentido, visando à formação de profissionais que demandem o domínio da língua estudada e suas culturas para atuar como professores, pesquisadores, críticos literários, tradutores, intérpretes, revisores de textos, roteiristas, secretários, assessores culturais, entre outras atividades, o curso de Letras deve contribuir para o desenvolvimento das seguintes competências e habilidades:

- domínio do uso da língua portuguesa ou de uma língua estrangeira, nas suas manifestações oral e escrita, em termos de recepção e produção de textos;

- reflexão analítica e crítica sobre a linguagem como fenômeno psicológico, educacional, social, histórico, cultural, político e ideológico;

- visão crítica das perspectivas teóricas adotadas nas investigações lingüísticas e literárias, que fundamentam sua formação profissional;

- preparação profissional atualizada, de acordo com a dinâmica do mercado de trabalho;

- percepção de diferentes contextos interculturais;

- utilização dos recursos da informática;

- domínio dos conteúdos básicos que são objeto dos processos de ensino e aprendizagem no ensino fundamental e médio;

- domínio dos métodos e técnicas pedagógicas que permitam a transposição dos conhecimentos para os diferentes níveis de ensino.

O resultado do processo de aprendizagem deverá ser a formação de profissional que, além da base específica consolidada, esteja apto a atuar, interdisciplinarmente, em áreas afins. Deverá ter, também, a capacidade de resolver problemas, tomar decisões, trabalhar em equipe e 
comunicar-se dentro da multidisciplinaridade dos diversos saberes que compõem a formação universitária em Letras. O profissional de Letras deverá, ainda, estar compromissado com a ética, com a responsabilidade social e educacional, e com as consequiências de sua atuação no mundo do trabalho. Finalmente, deverá ampliar o senso crítico necessário para compreender a importância da busca permanente da educação continuada e do desenvolvimento profissional.

\section{Conteúdos Curriculares}

Considerando os diversos profissionais que o curso de Letras pode formar, os conteúdos caracterizadores básicos devem estar ligados à área dos Estudos Lingüísticos e Literários, contemplando o desenvolvimento de competências e habilidades específicas. Os estudos lingüísticos e literários devem fundar-se na percepção da língua e da literatura como prática social e como forma mais elaborada das manifestações culturais. Devem articular a reflexão teórico-crítica com os domínios da prática - essenciais aos profissionais de Letras, de modo a dar prioridade à abordagem intercultural, que concebe a diferença como valor antropológico e como forma de desenvolver o espírito crítico frente à realidade.

De forma integrada aos conteúdos caracterizadores básicos do curso de Letras, devem estar os conteúdos caracterizadores de formação profissional em Letras. Estes devem ser entendidos como toda e qualquer atividade acadêmica que constitua o processo de aquisição de competências e habilidades necessárias ao exercício da profissão, e incluem os estudos linguiísticos e literários, práticas profissionalizantes, estudos complementares, estágios, seminários, congressos, projetos de pesquisa, de extensão e de docência, cursos seqüenciais, de acordo com as diferentes propostas dos colegiados das IES e cursadas pelos estudantes.

No caso das licenciaturas deverão ser incluídos os conteúdos definidos para a educação básica, as didáticas próprias de cada conteúdo e as pesquisas que as embasam.

O processo articulatório entre habilidades e competências no curso de Letras pressupõe o desenvolvimento de atividades de caráter prático durante o período de integralização do curso.

\section{Estruturação do Curso}

Os cursos devem incluir no seu projeto pedagógico os critérios para o estabelecimento das disciplinas obrigatórias e optativas das atividades acadêmicas do bacharelado e da licenciatura, e a sua forma de organização: modular, por crédito ou seriado.

Os cursos de licenciatura deverão ser orientados também pelas Diretrizes para a Formação Inicial de Professores da Educação Básica em cursos de nível superior.

\section{Avaliação}

A avaliação a ser implementada pelo colegiado do curso de Letras deve constituir processo de aperfeiçoamento contínuo e de crescimento qualitativo, devendo pautar-se:

- pela coerência das atividades quanto à concepção e aos objetivos do projeto pedagógico e quanto ao perfil do profissional formado pelo curso de Letras;

- pela validação das atividades acadêmicas por colegiados competentes;

- pela orientação acadêmica individualizada;

- pela adoção de instrumentos variados de avaliação interna;

- pela disposição permanente de participar de avaliação externa. 


\title{
DIRETRIZES CURRICULARES PARA OS CURSOS DE BIBLIOTECONOMIA
}

\author{
Diretrizes Curriculares
}

\section{Perfil dos Formandos}

A formação do bibliotecário supõe o desenvolvimento de determinadas competências e habilidades e o domínio dos conteúdos da Biblioteconomia. Além de preparados para enfrentar com proficiência e criatividade os problemas de sua prática profissional, produzir e difundir conhecimentos, refletir criticamente sobre a realidade que os envolve, buscar aprimoramento contínuo e observar padrões éticos de conduta, os egressos dos referidos cursos deverão ser capazes de atuar junto a instituições e serviços que demandem intervenções de natureza e alcance variados: bibliotecas, centros de documentação ou informação, centros culturais, serviços ou redes de informação, órgãos de gestão do patrimônio cultural etc.

As IES poderão acentuar, nos projetos acadêmicos e na organização curricular, características do egresso que, sem prejuízo do patamar mínimo aqui considerado, componham perfis específicos.

\section{Competências e Habilidades}

Dentre as competências e habilidades dos graduados em Biblioteconomia enumeram-se as típicas desse nível de formação.

A) Gerais

- gerar produtos a partir dos conhecimentos adquiridos e divulgá-los;

- formular e executar políticas institucionais;

- elaborar, coordenar, executar e avaliar planos, programas e projetos;

- utilizar racionalmente os recursos disponíveis;

- desenvolver e utilizar novas tecnologias;

- traduzir as necessidades de indivíduos, grupos e comunidades nas respectivas áreas de atuação;

- desenvolver atividades profissionais autônomas, de modo a orientar, dirigir, assessorar, prestar consultoria, realizar perícias e emitir laudos técnicos e pareceres;

- responder a demandas sociais de informação produzidas pelas transformações tecnológicas que caracterizam o mundo contemporâneo.

B) Específicas

Interagir e agregar valor nos processos de geração, transferência e uso da informação, em todo e qualquer ambiente;

- Criticar, investigar, propor, planejar, executar e avaliar recursos e produtos de informação;

- Trabalhar com fontes de informação de qualquer natureza; 
- Processar a informação registrada em diferentes tipos de suporte, mediante a aplicação de conhecimentos teóricos e práticos de coleta, processamento, armazenamento e difusão da informação;

- realizar pesquisas relativas a produtos, processamento, transferência e uso da informação.

\section{Conteúdos Curriculares}

Os conteúdos dos cursos distribuem-se em conteúdos de formação geral, destinadas a oferecer referências cardeais externas aos campos de conhecimento próprios da Biblioteconomia e em conteúdos de formação específica, que são nucleares em relação a cada uma das identidades profissionais em pauta.

De caráter propedêutico ou não, os conteúdos de formação geral envolvem elementos teóricos e práticos e têm por objetivo o melhor aproveitamento dos conteúdos específicos de cada curso.

Os conteúdos específicos ou profissionalizantes, sem prejuízo de ênfases ou aprofundamentos programados pelas IES, têm caráter terminal. Constituem o núcleo básico no qual se inscreve a formação de bibliotecários.

O desenvolvimento de determinados conteúdos como a Metodologia da Pesquisa ou as Tecnologias em Informação, entre outras - poderá ser objeto de itens curriculares formalmente constituídos para este fim ou de atividades praticadas no âmbito de uma ou mais conteúdos.

Recomenda-se que os projetos acadêmicos acentuem a adoção de uma perspectiva humanística na formulação dos conteúdos, conferindo-lhes um sentido social e cultural que ultrapasse os aspectos utilitários mais imediatos sugeridos por determinados itens.

As IES podem adotar modalidades de parceria com outros cursos para:

- ministrar matérias comuns;

- $\quad$ promover ênfases específicas em determinados aspectos da carreira;

- ampliar o núcleo de formação básica;

- complementar conhecimentos auferidos em outras área.

\section{Estágios e Atividades Complementares}

Mecanismos de interação do aluno com o mundo do trabalho em sua área, os estágios serão desenvolvidos no interior dos programas dos cursos, com intensidade variável segundo a natureza das atividades acadêmicas, sob a responsabilidade imediata de cada docente. Constituem instrumentos privilegiados para associar desempenho e conteúdo de forma sistemática e permanente.

Além disso, o colegiado do curso poderá estabelecer o desenvolvimento de atividades complementares de monitoria, pesquisa, participação em seminários e congressos, visitas programadas e outras atividades acadêmicas e culturais, igualmente orientadas por docentes (de preferência em regime de tutoria) a serem computadas como carga horária. 


\section{Estrutura do Curso}

A estrutura geral do curso de Biblioteconomia deverá ser definida pelo respectivo colegiado, que indicará a modalidades de seriação, de sistema de créditos ou modular.

\section{Avaliação Institucional}

Os cursos deverão criar seus próprios critérios para a avaliação periódica, em consonância com os critérios definidos pela IES à qual pertence, incluindo aspectos técnico-científicos, didático-pedagógicos e atitudinais. 


\section{DIRETRIZES CURRICULARES PARA OS CURSOS DE ARQUIVOLOGIA}

\section{Diretrizes Curriculares}

\section{Perfil dos Formandos}

O arquivista ter o domínio dos conteúdos da Arquivologia e estar preparado para enfrentar com proficiência e criatividade os problemas de sua prática profissional, particularmente as que demandem intervenções em arquivos, centros de documentação ou informação , centros culturais, serviços ou redes de informação, órgãos de gestão do patrimônio cultural .

\section{Competências e Habilidades}

Dentre as competências e habilidades dos graduados em Arquivologia enumeram-se as de caráter geral e comum, típicas desse nível de formação, e aquelas de caráter específico.

A) Gerais

- identificar as fronteiras que demarcam o respectivo campo de conhecimento;

- gerar produtos a partir dos conhecimentos adquiridos e divulga-los;

- formular e executar políticas institucionais;

- elaborar, coordenar, executar e avaliar planos, programas e projetos;

- desenvolver e utilizar novas tecnologias;

- traduzir as necessidades de indivíduos, grupos e comunidades nas respectivas áreas de atuação;

- desenvolver atividades profissionais autonômas, de modo a orientar, dirigir, assessorar, prestar consultoria, realizar perícias e emitir laudos técnicos e pareceres;

- responder a demandas de informação produzidas pelas transformações que caracterizam o mundo contemporâneo.

B) Específicas

- compreender o estatuto probatório dos documentos de arquivo;

- identificar o contexto de produção de documentos no âmbito de instituições públicas e privadas;

- planejar e elaborar instrumentos de gestão de documentos de arquivo que permitam sua organização, avaliação e utilização;

- realizar operações de arranjo, descrição e difusão.

\section{Conteúdos Curriculares}

Os conteúdos do curso distribuem-se em atividades acadêmicas de formação geral, destinadas a oferecer referências cardeais externas aos campos de conhecimento próprios da Arquivologia, e em atividades acadêmicas de formação específica.

\section{a. Conteúdos de Formação Geral}

De caráter propedêutico ou não, os conteúdos de formação geral envolvem elementos teóricos e práticos, que forneçam fundamentos para os conteúdos específicos do curso. 


\section{b. Conteúdos de Formação Específica}

Os conteúdos específicos ou profissionalizantes, sem prejuízo de ênfases ou aprofundamentos, constituem o núcleo básico no qual se inscreve a formação de arquivistas .

O desenvolvimento de determinados conteúdos como o relacionados com Metodologia da Pesquisa ou com as Tecnologias em Informação, entre outras - poderá ser objeto de itens curriculares.

As IES podem adotar modalidades de parceria com outros cursos para:

- ministrar matérias comuns;

- promover ênfases específicas em determinados aspectos do campo profissio nal;

- ampliar o núcleo de formação básica;

- complementar conhecimentos auferidos em outras áreas.

\section{Estágios e Atividades Complementares}

Mecanismos de interação do aluno com o mundo do trabalho em sua área, os estágios são desenvolvidos no interior dos programas dos cursos, com intensidade variável segundo a natureza das atividades acadêmicas desenvolvidas, sob a responsabilidade imediata de cada docente.

Além disso, o colegiado do curso estabelecerá o desenvolvimento de atividades complementares de monitoria, pesquisa, participação em seminários e congressos, visitas programadas e outras atividades acadêmicas e culturais, orientadas por docentes.

\section{Estrutura do Curso}

Os cursos devem incluir no seu projeto pedagógico os critérios para o estabelecimento das atividades acadêmicas obrigatórias e optativas e a organização modular, por créditos ou seriada.

\section{Conexão com a Avaliação Institucional}

Os cursos deverão criar seus próprios critérios para a avaliação periódica em consonância com os critérios definidos pela IES à qual pertencem, esclarecendo as ênfases atribuídas aos aspectos técnico-científicos; didático-pedagógicos e atitudinais. 


\section{DIRETRIZES CURRICULARES PARA OS CURSOS DE MUSEOLOGIA}

\section{Perfil dos Formandos}

A formação do museólogo supõe o domínio dos conteúdos da Museologia e a preparação para enfrentar com proficiência e criatividade os problemas de sua prática profissional, especialmente, aqueles que demandem intervenções em museus, centros de documentação ou informação , centros culturais, serviços ou redes de informação, órgãos de gestão do patrimônio cultural.

\section{Competências e Habilidades}

Dentre as competências e habilidades dos graduados em Museologia, enumeram-se as de caráter geral e comum, típicas desse nível de formação, e aquelas de caráter específico.

\section{A) Gerais}

- identificar as fronteiras que demarcam o respectivo campo de conhecimento;

- gerar produtos a partir dos conhecimentos adquiridos e divulga-los;

- desenvolver e aplicar instrumentos de trabalho adequados;

- formular e executar políticas institucionais;

- elaborar, coordenar, executar e avaliar planos, programas e projetos;

- desenvolver e utilizar novas tecnologias;

- traduzir as necessidades de indivíduos, grupos e comunidades nas respectivas áreas de atuação;

- desenvolver atividades profissionais autônomas, de modo a orientar, dirigir, assessorar, prestar consultoria, realizar perícias e emitir laudos técnicos e pareceres;

- responder a demandas de informação determinadas pelas transformações que caracterizam o mundo contemporâneo.

C) Específicas

- Compreender o Museu como fenômeno que se expressa sob diferentes formas, consoante sistemas de pensamento e códigos sociais;

- Interpretar as relações entre homem, cultura e natureza, no contexto temporal e espacial;

- Intervir, de forma responsável, nos processos de identificação, musealização, preservação e uso do patrimônio, entendido como representação da atividade humana no tempo e no espaço;

- Realizar operações de registro, classificação, catalogação e inventário do patrimônio natural e cultural;

- Planejar e desenvolver exposições e programas educativos e culturais.

\section{Tópicos de Estudo}

Os conteúdos dos cursos distribuem-se em atividades acadêmicas de formação geral, destinadas a oferecer referências cardeais externas aos campos de conhecimento próprios da Museologia, e em atividades acadêmicas de formação específica. 


\section{A. Conteúdos de Formação Geral}

De caráter propedêutico ou não, as matérias de formação geral envolvem elementos teóricos e práticos e têm por objetivo o melhor aproveitamento dos conteúdos específicos do curso.

B. Conteúdos de formação específica

Os Conteúdos específicas ou profissionalizantes, sem prejuízo de ênfases ou aprofundamentos programados pelas IES, constituem o núcleo básico no qual se inscreve a formação de arquivistas.

As IES podem adotar modalidades de parceria com outros cursos para:

- ministrar matérias comuns;

- promover ênfases específicas em determinados aspectos da carreira;

- ampliar o núcleo de formação básica;

- complementar conhecimentos auferidos em outras áreas.

\section{Estágios e Atividades Complementares}

Mecanismos de interação do aluno com o mundo do trabalho em sua área, os estágios serão desenvolvidos no interior dos programas dos cursos, com intensidade variável segundo a natureza das atividades acadêmicas, sob a responsabilidade imediata de cada docente.

\section{Estrutura do Curso}

Os cursos devem incluir em seu projeto pedagógico os critérios para o estabelecimento das disciplinas obrigatórias e optativas e a organização modular, por créditos ou seriada.

\section{Conexão com a Avaliação Institucional}

O processo de avaliação implica a consideração dos objetivos preestabelecidos, a mensuração dos resultados obtidos, em função dos meios disponíveis, com ênfase nos aspectos técnicocientíficos; didático-pedagógicos e atitudinais. 
Comissão formada pelas professoras Sidinéia Gomes Freitas (ECA/USP) e Dóris Fagundes Haussen (PUC-RS e UFRGS) e pelos professores Hélio Schuch (UFSC), André Parente (UFRJ), Victor Gentilli (UFES) e J.S.Faro (PUC-SP e UMESP)

Diretrizes Curriculares da Área de Comunicação e suas Habilitações

Exposição de Motivos

\section{Objetivos}

Estas Diretrizes Curriculares da Área da Comunicação foram elaboradas procurando atender a três objetivos fundamentais:

- flexibilizar a estruturação dos cursos, não mais submetidos à exigência de um currículo mínimo obrigatório, buscando a diversificação de experiências de formação para atender a variedades de circunstâncias geográficas, político-sociais e acadêmicas, para ajustar-se ao dinamismo da área, e para viabilizar o surgimento de propostas pedagógicas inovadoras e eficientes;

- recomendar procedimentos e perspectivas essenciais, de modo a funcionar como um padrão de referência para todas as instâncias que, buscando a qualidade, objetivem uma sintonia com posições majoritariamente defendidas pelas instituições e entidades representativas da área;

- estabelecer critérios mínimos de exigência, no que se refere à formulação e à qualidade da formação, que possam funcionar como parâmetro básico de adequação e pertinência para os cursos da área.

\section{O Processo de elaboração}

Encarregada de elaborar as Diretrizes Curriculares para a Área da Comunicação e suas habilitações (Jornalismo, Relações Públicas, Editoração, Radialismo, Cinema, Publicidade e Propaganda), a Comissão de Especialistas de Comunicação buscou ouvir extensamente a área. Inicialmente através de edital, foram convidados a expor suas perspectivas e enviar proposições as instituições universitárias e as entidades associativas de escolas, professores, pesquisadores, estudantes e profissionais

Em um segundo momento, com base no material enviado, foi realizado um seminário em Brasília entre a Cee-Com e representantes de entidades (Associação Nacional dos Programas de Pós-Graduação em Comunicação - Compós; Conselho Federal de Relações Públicas Conferp; Executiva Nacional dos Estudantes de Comunicação - Enecos; Federação Nacional dos Jornalistas - Fenaj; Sociedade Brasileira de Estudos Interdisciplinares da Comunicação - Intercom; Associação Paulista dos Bacharéis em Relações Públicas - Apbrp; e União Cristã Brasileira de Comunicação Social - Ucbc). Deste seminário resultou um texto provisório, que foi largamente disseminado, via Internet, para efeito de apresentação de críticas, comentários e novas proposições. Nesta fase, além de manifestações das mesmas entidades, o processo foi novamente aberto para escolas e professores, pesquisadores, profissionais e estudantes que individualmente quisessem trazer suas contribuições.

Durante esta ampla consulta, acontecida nos meses de março e abril de 1999, realizaram-se inúmeros debates, reuniões e seminários abrangendo as diversas habilitações e regiões do país. Dentre eles cabe destacar uma reunião, em Campinas, organizada pela Federação Nacional dos Jornalistas (Fenaj), pelo Fórum de Professores de Jornalismo, pelo Observatório da Imprensa e pelo GT de Jornalismo da Intercom, que estudou detalhadamente o documento. Foram aí acrescentadas proposições específicas referentes ao Jornalismo, além de várias propostas de aperfeiçoamento da parte geral, constituindo-se em relevante contribuição para a formulação final do presente documento.

As proposições e análises reunidas nesta etapa do processo serviram de base para uma última reunião com representantes de entidades (Associação Brasileira de Rádios Comunitárias - Abraço; Compós; Conferp; Enecos; Sindicato dos Radialistas; e Anj como observador). A reunião deliberou sobre o rico material recebido, para efeito de aproveitamento integral ou parcial, chegando-se assim às posições que estruturam o presente texto de Diretrizes da Área da Comunicação.

Através destes múltiplos procedimentos, foi reunida e sistematizada a experiência acumulada ao longo dos anos em que a comunidade vem refletindo sobre a formação dos profissionais e estudiosos do campo da Comunicação.

\section{Premissas}

Algumas premissas básicas foram rapidamente percebidas como predominantes, desde o início dos trabalhos. Os três objetivos que fazem a abertura desta Exposição de Motivos figuram entre estas premissas. Outras ainda nortearam os trabalhos, e encontram guarida seja no encaminhamento geral do texto, seja em itens expressamente propostos. Assim:

a) a área da Comunicação, embora estruturada a partir de diversas especialidades e profissões, apresenta uma forte organicidade, com interpenetração de perspectivas teóricas e de questões referentes a problemas concretos no espaço social. Decorre daí uma premissa que considera um risco para a formação pedagógica e para os diferentes exercícios profissionais qualquer desmembramento dos diferentes cursos da área; e enfatiza a importância de manutenção de todas as formações da área em um mesmo texto de Diretrizes Curriculares; 
b) o que deve direcionar o funcionamento dos cursos, no espaço das presentes diretrizes, é um Projeto Acadêmico - que deixa de ser nucleado em listagens de disciplinas, devendo expressar as concepções gerais que o norteiam, articulando a estas os conteúdos curriculares e os procedimentos pedagógicos;

C) este Projeto Acadêmico deve conceber o currículo pleno do Curso como um conjunto de atividades pedagógicas relevantes, e não como mera listagem de disciplinas;

d) o Projeto Acadêmico definirá suas disciplinas, atividades, conteúdos específicos e procedimentos em função tanto dos perfis, das competências e habilidades, e dos conteúdos básicos expressos nas Diretrizes, como de suas próprias propostas e objetivos de formação, de suas posições intelectuais, críticas e propositivas sobre as formações;

e) a diversidade de Projetos Acadêmicos, assim viabilizada pela Lei de Diretrizes e pelo presente documento, longe de ser uma liberdade isolacionista, deve tornar-se um campo de experimentação pedagógica e organizacional, de pesquisa, de desenvolvimento profissional, e de troca e realimentação mútua entre os projetos diversos, entre escolas portanto;

f) correlata à flexibilidade legal e normativa, a presença dinâmica das entidades da área torna-se um requisito fundamental no sentido de estimular o aperfeiçoamento constante da formação. A formação não estando mais contida e aprisionada em um documento formal (como o Currículo Mínimo), seu direcionamento e sua qualidade passam a depender de um trabalho coletivo constante, envolvendo as escolas, as entidades e a Comissão de Especialistas em Comunicação do MEC, através de suas interações locais, regionais e nacionais;

g) a flexibilidade pretendida deve possibilitar aos estudantes não só a realização de atividades curriculares obrigatórias, mas de um leque significativo de atividades optativas, tornando-os co-responsáveis pela construção de seu currículo pleno e de sua formação universitária;

h) não há correlação entre a formação teórica e a parte geral do Curso; nem entre a formação técnico-profissional e a parte habilitacional. Em primeiro lugar, porque estas diretrizes buscam superar a antiga dicotomia entre teoria e prática, introduzindo como diferenciados e essenciais os conteúdos ético-políticos e analítico-informativos acerca da atualidade. Em segundo lugar porque tanto a parte comum quanto o momento habilitacional envolvem reflexões teóricas, conteúdos analítico-informativos e éticopolíticos, e perspectivas práticas, relativas às tecnologias, técnicas e linguagens da comunicação e de suas habilitações.

Foram ainda adotadas as seguintes perspectivas a partir do Modelo de Enquadramento do MEC:

- a distinção entre Perfil Comum e Perfil Específico foi utilizada para referir respectivamente as características gerais do egresso em Comunicação, em qualquer de suas habilitações profissionais; e para descrever o egresso específico de cada habilitação;

- a distinção entre Competências e Habilidades Gerais e Específicas é similar: gerais para o conjunto de egressos; específicas, somando-se àquelas, para caracterizar as habilitações;

- em Tópicos de Estudo, a distinção entre "básicos" e "específicos" é diversa: "básicos" não se refere apenas à parte geral dos cursos, mas se rebate também sobre as habilitações. "Específicos", por sua vez, serão os modos como cada instituição de ensino superior desenvolverá, concretamente, aqueles conteúdos básicos (tanto na parte geral do Curso, como em cada habilitação;

- o item Estrutura Geral do Curso foi desenvolvido como um roteiro didático para elaboração do Projeto de Curso de Graduação, em especial de seu Projeto Acadêmico e seu Projeto Pedagógico. Este caráter é fundamental para a compreensão e a instrumentalização das diretrizes curriculares, estimulando que os Cursos se organizem de modo abrangente e consistente e favorecendo uma boa organização de seus objetivos e procedimentos, assim como os trabalhos de acompanhamento e avaliação, internos e externos.

\section{Diretrizes Curriculares}

\section{da Área de Comunicação e suas Habilitações}

O presente texto de Diretrizes Curriculares para a área da Comunicação e suas habilitações estabelece um padrão básico de referência para todas as instituições que mantenham Cursos de Graduação em Comunicação com habilitações em Jornalismo, Relações Públicas, Publicidade e Propaganda, Cinema, Radialismo, Editoração, ou outras habilitações pertinentes ao campo da Comunicação que venham a ser criadas. Suas especificações e critérios são igualmente válidos para os Cursos que se constituam exclusivamente como uma habilitação específica ou que se identifiquem como Curso Superior de uma das denominações de área no campo da Comunicação.

\section{Perfil do Egresso}

\section{Perfil Comum}

O perfil comum do egresso corresponde a um objetivo de formação geral que deve ser atendido por todos os Cursos da área e em todas as habilitações de Comunicação, qualquer que seja sua ênfase ou especificidade. Trata-se da base que, assumida na estrutura curricular, garante a identidade do Curso como sendo de Comunicação, e que caracteriza em geral componentes do perfil de todas as profissões da área.

O egresso de Curso de Graduação em Comunicação, em qualquer de suas habilitações, caracteriza-se por suas competências profissionais, sociais e intelectuais em matéria de criação, produção, distribuição, recepção, e análise crítica referentes às mídias, às 
práticas profissionais e sociais relacionadas com estas, e a suas inserções culturais, políticas e econômicas.

Deve ter competências que reflitam a variedade e mutabilidade de demandas sociais e profissionais na área, propiciando uma capacidade de adequação à complexidade e velocidade do mundo contemporâneo.

Deve dispor de uma visão integradora e horizontalizada - genérica e ao mesmo tempo especializada de seu campo de trabalho possibilitando o entendimento da dinâmica das diversas modalidades comunicacionais e das suas relações com os processos sociais que as originam e que destas decorrem.

Deve utilizar criticamente, em sua atividade profissional, o instrumental teórico-prático oferecido em seu curso, sendo portanto competente para posicionar-se de um ponto de vista ético-político sobre o exercício do poder na comunicação, sobre os constrangimentos a que a comunicação pode ser submetida, sobre as repercussões sociais que enseja e ainda sobre as necessidades da sociedade contemporânea em relação à comunicação social.

Para isto, deve ter uma formação que transcenda as especialidades profissionais e proporcione uma compreensão ampla e rigorosa do campo da Comunicação, desenvolvendo assim uma percepção geral sobre este campo no qual as especialidades se inscrevem, e que possibilite participar da discussão pública sobre as significativas temáticas que perpassam toda produção mediatizada em uma sociedade de comunicação.

Com estas características, o perfil do egresso das várias habilitações do campo da Comunicação é baseado em uma dupla fundamentação - a primeira, genérica e universalista; a segunda específica e particularizada - viabilizando que o egresso desenvolva suas competências e habilidades profissionais amparado em uma percepção fundamentada da sociedade contemporânea e da área de Comunicação.

\section{Perfis Específicos}

Os perfis específicos resultam das habilitações diferenciadas do campo da Comunicação, que se caracteriza por uma abrangência sobre diferentes meios, linguagens e práticas profissionais e de pesquisa e, na atualidade, por envolver um acelerado dinamismo social e tecnológico. Para assegurar o desenvolvimento histórico desta área de formação, estudos e exercício profissional, serão desenvolvidas habilitações com uma variedade de perfis específicos, garantindo assim o dinamismo próprio deste campo. Estas habilitações, definidoras dos perfis específicos, se organizam conforme as seguintes premissas:

- a) é mantida a referência básica às habilitações historicamente estabelecidas: Jornalismo, relações públicas, publicidade e propaganda, radialismo, editoração, e cinema (assim como à sua denominação alternativa, cinema e vídeo);

- b) podem ser criadas ênfases específicas em cada uma destas habilitações, que serão então referidas pela denominação básica, acrescida de denominação complementar que caracterize a ênfase adotada;

- c) podem ser criadas novas habilitações pertinentes ao campo da Comunicação.

As habilitações referidas nos itens "b" e "c" acima serão reconhecidas como pertinentes ao campo da Comunicação na medida em que se verifique o atendimento dos seguintes critérios:

- demonstração da dimensão e da complexidade temática e de objeto de estudo que justifiquem um perfil específico de egresso;

- ocorrência de espaço potencial de mercado para um profissional, na área geográfica da instituição, com o perfil específico previsto;

- existência de vinculações profissionais e conceituais com o Campo da Comunicação, suficientes para serem consideradas inscritas neste campo, ou ainda como desdobramentos ou interfaces essenciais deste, caracterizando-se assim o novo perfil específico como diretamente relacionado à área;

- não ocorrência de superposição com habilitação ou profissão já existente e nem distorção de alguma destas;

- caracterização de especificidades de linguagem ou de práticas profissionais ou sociais, de modo a justificar abordagens não restritas apenas a um determinado suporte tecnológico;

- identificação de uma parte comum vinculada ao campo geral da Comunicação, em consonância com o perfil comum especificado nas presentes diretrizes;

- $\quad$ adoção das Diretrizes Curriculares para os Cursos de Comunicação.

\section{Perfis Específicos por Habilitação}

Para as habilitações já estabelecidas, além do perfil comum relacionado no item anterior, devem-se objetivar os perfis a seguir explicitados.

Para outras habilitações que venham a ser criadas, os propositores devem incluir no Projeto Acadêmico a ser submetido ao MEC, além da adoção do perfil comum, do item anterior, caracterização do perfil específico para o egresso, com estrutura similar à dos perfis a seguir delineados para as habilitações existentes. 
O perfil do egresso em Jornalismo, além da inclusão dos componentes comuns do campo da Comunicação, se caracteriza:

- pela produção de conhecimento e cultura voltada para seleções factuais sobre a atualidade e para a estruturação e disponibilização de informações que atendam a necessidades e interesses sociais no que se refere ao conhecimento dos fatos, das circunstâncias e dos contextos do momento presente;

- pelo exercício da objetividade jornalística na apuração, interpretação, registro e divulgação dos fatos sociais;

- $\quad$ pelo exercício da tradução e disseminação de conhecimento sobre a atualidade em termos de percepção geral e de modo a qualificar o senso comum;

- pelo trabalho em veículos de comunicação e instituições que incluam atividades caracterizadas como de imprensa e de informação jornalística de interesse geral ou setorializado, e de divulgação de informações de atualidade;

- pelo exercício de relações entre as funções típicas de Jornalismo e as demais funções profissionais ou empresariais existentes na área da Comunicação, e ainda com outras áreas sociais, culturais e econômicas com as quais o Jornalismo faz interface;

- pelo exercício de todas as demais atividades que, no estado então vigente da profissão, sejam reconhecidas pelo bom senso, pelas entidades representativas ou pela legislação pertinente, como características do Jornalista.

(...)

\section{Competências e Habilidades}

Assim como os perfis dos egressos, organizados em uma parte geral comum e uma parte específica por habilitação, as competências e habilidades também comportam dois níveis, um geral para todas as profissões e formações do campo da Comunicação e um especializado por habilitação.

\section{Competências e Habilidades Gerais}

As competências e habilidades gerais desejadas para todos os perfis objetivados acima são as seguintes:

- assimilar criticamente conceitos que permitam a apreensão de teorias;

- usar tais conceitos e teorias em análises críticas da realidade;

- posicionar-se segundo pontos de vista ético-políticos;

- deter um conjunto significativo de conhecimentos e informações sobre a atualidade;

- dominar as linguagens habitualmente usadas nos processos de comunicação, nas dimensões de criação, de produção, de interpretação e da técnica;

- experimentar e inovar no uso destas linguagens;

- $\quad$ refletir criticamente sobre as práticas profissionais no campo da Comunicação;

- tratar problemas teóricos da Comunicação e problemas profissionais de sua área de atuação, estabelecendo relações factuais e conceituais diante de questões concretas pertinentes à área;

- desenvolver competências para formação e estímulo à aprendizagem na área da Comunicação em geral, e das especialidades incluídas em sua experiência;

- ter competência no uso da língua nacional para escrita e interpretação de textos gerais e especializados na área.

Ao longo de todo o curso, nas disciplinas em que isto seja pertinente, deve ser dada especial atenção às competências referentes ao uso adequado e eficiente da língua portuguesa - tanto na leitura, como na escrita e na oralidade; voltadas tanto para a expressão como para a interpretação de textos e falas. Estas competências podem ser desenvolvidas tanto em disciplinas específicas de língua portuguesa, como em outras que tenham a língua portuguesa como instrumento básico. Devem ser desenvolvidas no nível dos usos profissionalmente especializados, mas também no da utilização universal da língua, e que faz a base sobre a qual se especializa o uso profissional.

\section{Competências e Habilidades específicas por Habilitação}

Além das competências e habilidades gerais acima referidas, outras competências, específicas, podem decorrer da habilitação pretendida, bem como da organização diferenciada que seja dada ao Curso em cada instituição. Dentre estas, recomenda-se particularmente aquelas a seguir explicitadas.

Para outras habilitações que venham a ser propostas, os propositores devem incluir no Projeto Acadêmico a ser submetido ao MEC, em acréscimo à adoção da parte comum, caracterização das competências e habilidades específicas, com formulação similar à das 
habilitações detalhadas no presente documento.

Competências e Habilidades da Habilitação em Jornalismo

- registrar fatos jornalísticos, apurando, interpretando, editando e transformando-os em notícias e reportagens;

- interpretar, explicar e contextualizar informações;

- investigar informações, produzir textos e mensagens jornalísticas com clareza e correção e editá-los em espaço e período de tempo limitados;

- formular pautas e planejar coberturas jornalísticas;

- formular questões e conduzir entrevistas;

- relacionar-se com fontes de informação de qualquer natureza;

- trabalhar em equipe com profissionais da área;

- lidar com situações novas, desconhecidas e inesperadas;

- compreender e saber sistematizar e organizar os processos de produção jornalística;

- desempenhar funções de gestão e administração jornalística;

- desenvolver, planejar, propor, executar e avaliar projetos na área de comunicação jornalística;

- avaliar criticamente produtos, práticas e empreendimentos jornalísticos;

- compreender os processos envolvidos na recepção de mensagens jornalísticas e seus impactos sobre os diversos setores da sociedade;

- identificar o que é informação de interesse público e pautar-se eticamente no tratamento dessas informações;

- identificar e equacionar questões éticas de Jornalismo;

- buscar a verdade jornalística, com postura ética e compromisso com a cidadania;

- manter-se crítico e independente, no que diz respeito às relações de poder e às mudanças que ocorrem na sociedade;

- dominar a língua nacional e as estruturas narrativas e expositivas aplicáveis às mensagens jornalísticas, abrangendo-se leitura, compreensão, interpretação e redação;

- dominar a linguagem jornalística apropriada aos diferentes meios e modalidades tecnológicas de comunicação;

- assimilar criticamente conceitos que permitam a compreensão das práticas e teorias jornalísticas, repercutindo-os sobre sua prática profissional;

- ter as demais competências e habilidades que caracterizam o trabalho nas circunstâncias em que o jornalista é normalmente inserido.

$(\ldots)$

\section{Tópicos de Estudo}

Os Tópicos de Estudos são diferenciados em Conteúdos Básicos e Conteúdos Específicos. Os conteúdos básicos são estabelecidos no presente documento de Diretrizes Curriculares, sendo relacionados tanto à parte comum do curso quanto às habilitações. Os conteúdos específicos serão aqueles que cada instituição, livremente, deve eleger para organizar seu currículo pleno, voltados para o atingimento de seus objetivos e da formação dos perfis e das competências e habilidades definidos nestas Diretrizes.

\section{Tópicos de Estudo - Conteúdos Básicos}

Os conteúdos básicos são caracterizadores da formação geral da área e devem ser previstos nas especificações curriculares - incluindo o plano geral da Comunicação e os espaços específicos de cada habilitação. Envolvem tanto conhecimentos teóricos como práticos, tanto reflexões como aplicações relacionadas ao campo da Comunicação e à área configurada pela habilitação específica. São básicos, portanto, no sentido de que devem atravessar a formação dos graduandos de Comunicação em todas as suas especialidades. Estes conhecimentos são assim categorizados: conteúdos teórico-conceituais; conteúdos analíticos e informativos sobre a atualidade; conteúdos de linguagens, técnicas e tecnologias midiáticas; conteúdos ético-políticos.

Estes conteúdos devem ser referidos tanto ao campo geral da Comunicação, quanto à habilitação específica, inscrevendo-se sempre no contexto da sociedade contemporânea. Observa-se ainda que os quatro conjuntos de conhecimentos não são estanques e se inter- 
relacionam tanto por sua presença comum em problemas práticos e profissionais como nas reflexões teóricas sobre a área. As perspectivas críticas atravessam todas as categorias de conhecimentos, e ainda, o conhecimento de linguagens não se restringe a suas interações com as tecnologias, mas dependem também das questões interpretativas, analíticas e informativas da atualidade.

$\mathrm{Na}$ formulação específica destes conteúdos, o Projeto Acadêmico do Curso deve adotar uma decidida e consistente perspectiva humanística. As próprias tecnologias, com a dimensão transformadora que adquiriram no século XX, devem receber tratamento que faça sua compreensão pelo estudante ultrapassar os aspectos utilitários e alcançar as interações entre a comunicação e a cultura, a política e a economia.

\section{Conteúdos teórico-conceituais}

Visam a desenvolver familiaridade com o uso de conceitos e um raciocínio conceitual, que permita aos alunos apreender e lidar rigorosamente com teorias gerais e específicas, inclusive acionando-as quando do processo de interpretação da realidade social e profissional.

\section{Conteúdos analíticos e informativos sobre a atualidade}

Objetivam propiciar aos alunos um rico estoque de informações sobre variados aspectos da atualidade, pois esta constitui a matéria-prima essencial para os futuros profissionais da comunicação. Estas informações devem, simultaneamente, assegurar a apreensão de interpretações consistentes da realidade e possibilitar aos estudantes a realização de análises qualificadas acerca dos fatos e contextos culturais, políticos, econômicos e sociais.

\section{Conteúdos de linguagens, técnicas e tecnologias midiáticas}

Devem assegurar ao estudante o domínio das linguagens, das técnicas e tecnologias tipicamente empregadas nos processos e nas habilitações de comunicação, bem como assegurar uma reflexão rigorosa sobre suas aplicações e processos. Também devem possibilitar a pesquisa e a experimentação de inovações das linguagens, técnicas e tecnologias, visando a formação de um profissional versátil e em sintonia com as tendências de acelerada mutabilidade dos sistemas e práticas de comunicação e suas habilitações na contemporaneidade.

\section{Conteúdos ético-políticos}

Devem permitir ao estudante posicionar-se sobre a atuação dos profissionais da comunicação, sobre o exercício do poder da comunicação, sobre os constrangimentos a que a comunicação pode ser submetida, sobre as repercussões sociais que ela enseja e sobre as demandas e necessidades da sociedade contemporânea, sempre em uma perspectiva de fortalecimento da idéia de cidadania, com o estímulo do respeito aos direitos humanos, às liberdades, à pluralidade e à diversidade, à justiça social e à democracia, inclusive na área da comunicação.

\section{Tópicos de Estudo - Conteúdos Específicos}

Os conteúdos específicos serão definidos pela Instituição que oferece o Curso, tanto para reflexões e práticas no espaço geral da Comunicação, como para reflexões e práticas da habilitação específica, tendo como referencial básico, de modo integrado: o perfil comum do egresso em Comunicação; os perfis específicos por habilitação; as competências e habilidades gerais e por habilitação; e os conteúdos básicos estabelecidos nestas Diretrizes para o conjunto do Curso (parte geral mais habilitações). Estas referências devem ser então concretizadas pelas disciplinas, atividades e suas articulações, de modo a atingir os objetivos estabelecidos na proposta pedagógica do Curso.

A proposta pedagógica é a parte do Projeto Acadêmico que explicitará os objetivos do curso, a articulação entre as disciplinas, atividades e estágios, e em geral os procedimentos pedagógicos relacionados com as atitudes, perfis, competências e habilidades pretendidas para o egresso (ver Estrutura Geral do Curso adiante).

O planejamento do Curso deve evitar cuidadosamente a inadequada relação entre teoria e parte geral, e entre prática e parte voltada para a habilitação, que parecia decorrer do currículo mínimo de 1984.

O que caracteriza a parte geral do projeto é sua referência ao campo geral da Comunicação - incluindo aí reflexões teóricas, problematizações críticas, conhecimento de atualidade, e práticas sobre linguagens e estruturas midiáticas.

O que caracteriza a parte habilitacional dos cursos corresponde ao recorte, dentro desse campo geral da Comunicação, de conhecimentos e de práticas profissionais, caracterizando uma "habilitação" - e que, também dentro desse recorte determinado, inclui as questões básicas referidas a reflexões teóricas, problematizações críticas, conhecimento de atualidade, e práticas sobre linguagens e estruturas

As entidades representativas das profissões, dos estudantes, da pesquisa, do ensino, enfim de todos os setores interessados tanto no que se refere às questões gerais de Comunicação como no que se refere às questões específicas das habilitações, são instadas a produzir reflexões periódicas sobre o estado do conhecimento e das práticas de suas áreas, de modo a difundir junto aos cursos indicações de temas e conteúdos específicos pertinentes; e de modo a estimular atualizações. Os projetos acadêmicos dos cursos devem procurar sintonia com tais reflexões, e ter a flexibilidade para as atualizações necessárias. 
A duração mínima estabelecida para os cursos de Comunicação é de 2.700 horas. A oferta destas 2.700 horas na estrutura do Curso (Projeto Acadêmico) não deve ser organizada em tempo inferior a quatro anos (ou oito semestres letivos). O estudante terá a possibilidade, na medida de sua competência específica, de sua dedicação intensificada ou do reconhecimento de atividades extraescolares (e portanto de suas circunstâncias especiais diante da estrutura padrão) de lograr integralização daquele número mínimo de horas (2.700) em um decurso de tempo inferior a quatro anos.

A duração máxima fica a critério da Instituição.

\section{Estágios e Atividades Complementares}

(Articulação Teoria-Prática)

Para efeito deste item, a denominação "Estágio" refere os estudos e práticas supervisionados em atividades externas à unidade de oferecimento do Curso. Os demais instrumentos para relacionamento do estudante com a realidade social , econômica e cultural, e de iniciação à pesquisa e ao ensino, serão designados com a denominação "Atividades Complementares".

Observa-se que as diretrizes orientadoras do perfil dos egressos, das competências e habilidades previstas, bem como os tópicos de estudos - conteúdos básicos - abrangem não apenas o ensino em sala de aula, mas todas as atividades curriculares. Assim, as atividades complementares e os estágios devem ser previstos no Projeto Acadêmico do Curso em coerência com aquelas diretrizes.

Os dois tipos de ação pedagógica acima referidos podem caracterizar mecanismos de interação com o mundo do trabalho, assim como possibilidades metodológicas para efeito de uma formação complexa e voltada para o melhor atingimento do perfil pretendido para o egresso.

Assim, além das disciplinas preletivas típicas e tradicionais do ambiente "sala de aula", e das disciplinas práticas, ditas "laboratoriais", com formatação igualmente tradicional versada em um padrão de turma/docente/horas-aula semanais, podem ser previstas Atividades Complementares, justificando créditos ou computação de horas para efeito de integralização do total previsto para o Curso, tais como:

- $\quad$ programas especiais de capacitação do estudante (tipo CAPES/PET);

- $\quad$ atividades de monitoria;

- outras atividades laboratoriais além das já previstas no padrão turma/horas-aula;

- $\quad$ atividades de extensão;

- $\quad$ atividades de pesquisa; etc.

O que caracteriza este conjunto de atividades como diferenciado do padrão turma/docente/horas-aula semanais é justamente a flexibilidade de carga horária semanal, embora certamente devendo ocorrer controle do tempo total de dedicação do estudante no semestre ou ano letivo. Com a flexibilidade horária semanal, deve ocorrer ainda:

- adoção de um sistema de creditação de horas baseado em decisões específicas para cada caso, projeto ou atividade específica, e em função do trabalho realizado, visto que o projeto determina o número de horas, em vez de, como no padrão tradicional, o número de horas preestabelecido determinar as atividades;

- $\quad$ ênfase em procedimentos de orientação e/ou supervisão pelo docente, em substituição ao padrão de controle direto de tipo preletivo;

- ampliação da autonomia do estudante para organizar seus horários, objetivos e direcionamento.

Estas Atividades Complementares devem ser necessariamente orientadas e supervisionadas por docentes do Curso, de modo a serem direcionadas ao melhor atendimento de seus objetivos pedagógicos.

O número máximo de horas dedicadas a este tipo de atividades não pode ultrapassar $20 \%$ do total do curso, não incluídas nesta porcentagem de $20 \%$ as horas dedicadas ao Trabalho de Conclusão de Curso (ou Projetos Experimentais).

O Projeto Acadêmico do Curso pode prever também Estágios Supervisionados, observadas as disposições e restrições legais próprias de cada habilitação. O conceito básico do Estágio Supervisionado refere-se ao fato de que, não sendo possível nem desejável reproduzir internamente, no Curso, todas as características do mundo do trabalho, é pertinente propiciar oportunidades e acompanhar o estudante em circunstâncias criadas no espaço profissional em que possa compatibilizar o processo de formação com uma percepção prática e direta do trabalho. Para que isto não seja mera antecipação do futuro ingresso no mercado de trabalho, é fundamental que o estágio seja orientado por objetivos de formação do futuro profissional; e que seja supervisionado criticamente, o docente supervisor interagindo efetivamente com os aportes recebidos pelos estudantes nas circunstâncias concretas do Estágio.

\section{Reconhecimento de Habilidades e}

Competências Extra-Escolares

Observamos que o presente item, envolvendo procedimentos formalmente comparáveis aos do item anterior (Atividades Complementares e Estágios) introduz um pressuposto diferenciado. Naquele caso, trata-se de estudos e atividades organizadas pelo Curso, ainda que eventualmente realizadas fora dele, como é o caso do Estágio, com definição em Projeto Acadêmico, supervisão e orientação por parte dos docentes da própria instituição. Aqui, trata-se do reconhecimento de projetos personalizados em relação a cada estudante. Também 
serão considerados outros conhecimentos obtidos pelo estudante, não previstos e de natureza extra-escolar, desde que adequadamente aferidos.

Ao criar mecanismos para aproveitamento de conhecimentos adquiridos pelos estudantes através de estudos e práticas independentes, o Projeto Acadêmico do Curso deve prever:

- que o aproveitamento não pode ser automático, nem apriorístico ou generalizado, nem baseado apenas em informação de horas de exercício profissional ou outras atividades extra-escolares;

- que a possibilidade de aproveitamento deve ser verificada caso a caso, observando-se na substância a pertinência dos conhecimentos com relação à formação do estudante, assim como a boa qualidade dos estudos e práticas desenvolvidos e, ainda, as competências e habilidades desenvolvidas;

- que o aproveitamento não pode resultar na substituição, em número de horas, de outras atividades do próprio Curso consideradas básicas para a formação do futuro profissional;

- $\quad$ que o aproveitamento não pode ultrapassar 10\% (dez por cento) do total de horas previstos para a integralização do Curso.

\section{Estrutura Geral do Curso}

A estrutura geral inclui todos os componentes, procedimentos, objetivos, proposta pedagógica, recursos humanos e infra-estruturas, requeridos para que se desenvolva, no Curso, a formação do estudante de modo a resultar efetivamente no perfil estabelecido, fazendo-o chegar, com sucesso, ao domínio das competências e habilidades previstas. É na estrutura do curso que se configura o entendimento dado pela Instituição às presentes diretrizes, em sua totalidade.

Todo o conjunto de recursos materiais e humanos empregados na formação em Comunicação deve ter sua mobilização orientada pela necessidade de conexão orgânica entre as atividades de Ensino, Pesquisa e Extensão, como condição para a qualificação dos profissionais e para a realização da função social que deve ser atribuída aos Cursos, enquanto espaço de reflexão e disseminação de conhecimento.

\section{O Projeto Acadêmico}

A estrutura do Curso, correspondendo à realidade existente ou projetada para efetiva realização, deve ser expressa em um Projeto Acadêmico que, ao descrever e relacionar os diversos componentes, se caracteriza como documento fundamental para a organização e a avaliação do Curso.

O Projeto Acadêmico deve, ao organizar as concepções gerais e os conteúdos que norteiam o currículo do curso, expressar a necessária articulação entre estas concepções gerais, os conteúdos curriculares e os diversos formatos pedagógicos (aulas preletivas, laboratórios, oficinas, estudo orientado, trabalhos de conclusão de curso, e demais atividades) estabelecidos como procedimentos do curso. A adequação pedagógica entre concepções, formatos, procedimentos e conteúdos deve ser ressaltada e incorporada como momento significativo do Projeto Acadêmico.

Se a Instituição oferece mais de uma habilitação em Comunicação, as áreas de formação específica e profissional correspondentes a cada uma delas devem ser abrigadas sob a mesma unidade acadêmica da instituição (Departamento, Faculdade, Instituto, Centro, Escola, etc.) permitindo-lhes um mesmo embasamento teórico-conceitual e prático pertinente ao campo comunicacional, em que se inscrevem. Assim, o Projeto Acadêmico deve ser único para o conjunto de habilitações, contendo as partes que se referem especificamente a cada uma delas e a indicação das linhas de integração que as fazem componentes de um projeto comum.

O Projeto Acadêmico deve prever e expor com clareza todas as características de estrutura e de funcionamento do Curso, assim como os padrões e métodos destinados a assegurar sua qualidade. Proporcionará assim a necessária visibilidade para o conjunto de recursos materiais e humanos mobilizados, bem como o modo de articulá-los e empregá-los na formação dos futuros profissionais.

O Projeto deve incluir descrições e proposições referentes a Proposta Pedagógica, a Corpo Docente, a Estruturas de Serviço e Infraestrutura Material, a Modos de Integração com a Sociedade e o Mercado de Trabalho e a Procedimentos de Acompanhamento e Avaliação, seguindo as recomendações adiante estabelecidas. No seu conjunto, estas especificações do Projeto Acadêmico expressam os padrões de qualidade auto-definidos segundo os quais o Curso será avaliado.

A estrutura de oferta pode ser seriada anual, seriada semestral, por créditos ou módulos. Em qualquer dos casos, devem ser previstos, além dos componentes obrigatórios, componentes caracterizados por oferecer alternativas aos estudantes (opcionalidades).

Para que as opcionalidades sejam efetivas, devem constar, na grade horária de oferta de disciplinas e atividades aos estudantes, a cada ano ou semestre, espaços nos quais o aluno encontre alternativas concretas dentre as quais possa escolher a que convenha melhor a seus objetivos pessoais de formação, elaborando ele próprio, com o concurso da orientação de seus docentes, parte de sua grade curricular.

No caso de uma estrutura de oferta por créditos, o projeto de curso deve preservar a organicidade do conjunto, evitando que o procedimento de oferta resulte em mera acumulação dispersa, pelo aluno, de componentes estanques. Esta organicidade deve decorrer de uma utilização equilibrada (e não excessiva) de seqüências e pré-requisitos; de um planejamento integrado das várias disciplinas e atividades; de um acompanhamento planejado que permita, a cada ano ou semestre, uma formação relacionada com o que se ofereceu anteriormente e baseada na previsão do que sucederá posteriormente. 
No caso de uma estrutura de oferta seriada, o projeto de curso deve preservar, além de uma sequiência harmônica e lógica, uma flexibilidade de caminhos alternativos e a possibilidade de recuperação de parcelas perdidas pelo estudante, sem que este seja obrigado a estacionar em um passo da série em decorrência de dificuldades encontradas em determinados componentes desse passo (ano ou semestre).

Quaisquer referências a "módulo básico", "módulo específico" ou "módulo seqüencial" devem levar em conta as diretrizes acima, e devem estabelecer claramente as funções, objetivos e modos de inserção de tais módulos na estrutura geral do curso.

O projeto deve ainda esclarecer o modo como os procedimentos e atividades, previstos na estrutura do curso, permitem efetivamente realizar as proposições referentes às competências e habilidades pretendidas para os egressos - tanto as estabelecidas nas presentes diretrizes, como as que sejam especificamente acrescentadas pelo Curso.

\section{Proposta Pedagógica}

O Projeto Acadêmico do Curso deve prever e expor com clareza o conjunto de requisitos necessários ao estudante para integralizar sua formação. Entende-se a Proposta Pedagógica como um documento mais abrangente que uma simples listagem de disciplinas com suas ementas e cargas horárias. Deve envolver sobretudo os conceitos e objetivos que dão organicidade ao Curso, o conjunto de disciplinas e demais atividades escolares com as justificativas que dão pertinência àqueles objetivos, os procedimentos de oferta e de interação entre os componentes do Curso e entre docentes e discentes, e todos os demais indicadores que explicitem e organizem o projeto de formação. Devem portanto estar especificados:

- as disciplinas e atividades da Parte Geral, válidas para qualquer habilitação, e referentes ao espaço abrangente do campo da Comunicação, incluindo tanto formação teórico-conceitual, como analítico-informativa, prática, e ético-política. Na existência de mais de uma habilitação na unidade, esta Parte Geral será comum a todas;

- as disciplinas e atividades da Parte Específica por Habilitação, incluindo formação teórico-conceitual, analítico-informativa, prática e ético-política, todas voltadas para a especialidade adotada em cada habilitação;

- a composição adequada entre as disciplinas que comportarão as quatro modalidades de conteúdos referidas no item Tópicos de Estudo, devendo-se evitar relações restritivas, tais como associações simplistas entre a teoria e a parte geral, e entre a prática e a parte específica;

- $\quad$ as disciplinas de caráter obrigatório e as de caráter optativo;

- o sistema de creditação ou seriação de atividades;

- a sequiência de oferta e/ou estrutura de pré-requisitos, ou ainda a indicação dos melhores ajustes entre semestre/ano de curso e as atividades e disciplinas a serem realizadas pelos estudantes. As indicações de sequiência devem evitar padronizações apriorísticas, tais como iniciar o Curso por teorias e finalizar pelas práticas ou o inverso. Deve, ao contrário, relacionar adequadamente teorias e práticas, em cada parte do curso, integradamente, e de acordo com as necessidades de cada tema, problema ou conhecimento trabalhado, seja na parte geral, seja na parte específica, assim como deve seqüenciar com base nos objetivos educacionais e no melhor planejamento de harmonia de procedimentos;

- os objetivos, a formulação curricular e a organização das atividades, adotando as perspectivas expressas no presente documento sobre o perfil geral e específico do egresso, e complementando-os com suas próprias proposições;

- os modos de integração entre as perspectivas teóricas e técnicas no Curso;

- $\quad$ as atividades complementares e os estágios que eventualmente se integram ao currículo pleno;

- a abertura do currículo para a incorporação, sempre que necessário, de novas disciplinas que possibilitem o acompanhamento das mudanças tecnológicas e a abertura de novas modalidades e linguagens de comunicação;

- a abertura do currículo à incorporação de disciplinas optativas que suscitem a co-responsabilização do corpo discente na complementação da sua formação;

- o efetivo envolvimento de discentes em atividades curriculares de Pesquisa;

- $\quad$ projetos de pesquisa previstos como atividades curriculares;

- programas de atividades de Extensão, formais e informais, em caráter curricular e extra-curricular, para os estudantes regulares e para atender a demandas pertinentes da sociedade;

- $\quad$ programas especiais de formação de graduados (a exemplo do PET-CAPES);

- $\quad$ programas de monitorias em disciplinas, com aproveitamento dos estudantes do curso;

- formas de distinção, valorização e divulgação do Trabalho de Conclusão de Curso (com esta denominação ou como Projetos Experimentais) dos discentes, que deve, obrigatoriamente, caracterizar a finalização da formação superior em Comunicação;

- bases para uma produção curricular teórica e técnica cuja circulação ou disponibilidade transcenda o público dos corpos docente e discente; 
- $\quad$ no caso de existência ou previsão de cursos de pós-graduação, os modos de integração destes com o curso de graduação.

\section{Corpo Docente}

O Projeto Acadêmico do Curso deve prever e expor com clareza a estrutura, a formação e a organização do seu corpo docente, de modo a assegurar a efetiva realização competente dos objetivos de ensino, pesquisa e extensão do Curso. Devem portanto estar especificados:

- a caracterização das competências, formação, experiência, dedicação e perspectivas pedagógicas que dão consistência ao conjunto de professores do Curso, explicitando assim o Perfil do Corpo Docente;

- a comprovação de que os docentes têm o perfil, a formação e a experiência adequados aos conteúdos, aos procedimentos e aos objetivos das disciplinas e demais atividades pelas quais se responsabilizam;

- o estabelecimento de titulação mínima do corpo docente;

- a definição do regime de trabalho dos docentes;

- a orientação e o estímulo à capacitação didático-pedagógica dos docentes, desde o início das suas atividades na Instituição;

- o estabelecimento de metas de produção acadêmica teórica, cultural e técnica pelos docentes;

- a definição de efetivo envolvimento de docentes em atividades de pesquisa científica na área da comunicação;

- a existência de plano de capacitação dos docentes com estímulos para a pós-graduação em níveis de especialização, mestrado e doutorado;

- a existência de programa de atualização, reciclagem e qualificação continuada do corpo docente, através de cursos, estágios técnicos e outras formas de intercâmbio com o mercado de trabalho e com setores de reflexão e pesquisa, considerando as disciplinas teóricas e técnicas;

- $\quad$ existência de programa de aperfeiçoamento dos coordenadores e demais gestores dos cursos;

- o índice de dedicação dos professores ao desenvolvimento de atividades de pesquisa e extensão;

- a existência de um determinado número de docentes que ministram disciplinas técnicas e que desenvolvam o exercício profissional em suas áreas de competência especializada pertinente, de forma simultânea à atividade docente, sem deixar de buscar condições que possibilitem sua titulação pós-graduada;

- a existência de um plano de carreira profissional para os docentes.

Estruturas de Serviço e Infra-estrutura Material

O Projeto Acadêmico do Curso deve prever e expor com clareza a estrutura, a formação e a organização de seu corpo técnico e de serviços, e de sua infra-estrutura material requeridos para a efetiva realização competente dos objetivos de ensino, pesquisa e extensão do Curso. Devem portanto estar especificados:

- a dimensão, a diversidade de especialidades e a qualificação do corpo técnico-administrativo responsável pelas atividades de apoio;

- a definição de estímulos à formação continuada do corpo técnico-administrativo;

- $\quad$ as salas de aula, salas para docentes e espaços físicos especialmente destinados às atividades de Pesquisa e Extensão, em número e dimensões compatíveis com a quantidade de estudantes, de docentes, e com a diversidade de atividades previstas;

- os laboratórios voltados para as habilitações em funcionamento, levando em conta os diferentes suportes tecnológicos necessários para suas práticas, com os equipamentos adequados - em quantidade e qualidade - especificando-se o número máximo de alunos por turma, que se mostre adequado ao aproveitamento pedagógico nas disciplinas técnicas;

- os produtos de uso laboratorial existentes para formação prático-profissionalizante dos estudantes, especificando seu caráter permanente ou eventual e sua periodicidade de reposição;

- um sistema de dados englobando: biblioteca e hemeroteca básicas; acervo com arquivo de sons e imagens; arquivo de fotografias; e todos os demais acervos e coleções requeridos pelos objetivos de Ensino, Pesquisa e Extensão;

- as condições físicas do conjunto de locais, assegurando os níveis de claridade, aeração, conforto e adequação à saúde coletiva pertinentes aos objetivos educacionais e necessários para a reunião e presença continuada do número de pessoas envolvidas.

Modos de Integração com a Sociedade e com o Mercado de Trabalho

O Projeto Acadêmico do Curso deve ainda prever e expor com clareza os procedimentos através dos quais assegurará uma efetiva 
interação com a sociedade, cumprindo sua responsabilidade de fornecer recursos humanos qualificados ao mercado de trabalho e de aperfeiçoar o próprio funcionamento social através de suas perspectivas inovadoras e críticas. Devem portanto ser relacionados:

- $\quad$ as atividades regulares de Extensão;

- os meios de acompanhamento da integração dos profissionais formados pela escola ao mercado de trabalho;

- a interação entre o Curso, através de docentes, discentes e profissionais dos serviços de apoio, com entidades representativas dos diversos segmentos da área das comunicações, orientada para a solução de problemas referentes ao mercado de trabalho e cooperação no que se refere às atividades de Ensino, Pesquisa e Extensão;

- a interação entre o Curso, através de docentes, discentes e profissionais dos serviços de apoio, com entidades representativas dos diversos segmentos da área das comunicações e com setores da sociedade civil em geral, que atuem no sentido da busca de soluções para os problemas de interesse público da área;

- a existência de um programa de estágio orientado por objetivos de Ensino, Pesquisa e Extensão e que seja regulamentado e fiscalizado com a participação dos Sindicatos representativos dos setores profissionais pertinentes com jurisdição na região, para evitar o aviltamento do mercado de trabalho;

- a integração das atividades de formação com os veículos e estruturas de serviço e produção de comunicação da própria instituição de ensino superior (publicações, emissoras de rádio e TV, inclusive canais de TV por assinatura, produtoras, agências, editoras ou assessorias);

- previsões referentes ao desenvolvimento de uma vocação regional que oriente aspectos determinados e delimitados na formação, promovendo a adequação do curso às condições sócio-econômicas e culturais da região em que estiver localizada a Instituição e valorizando as habilitações frente às demandas sociais da região;

- o desenvolvimento de atividades de ensino, pesquisa e extensão que estimulem a geração de mercado de trabalho e o surgimento de demandas sociais por atividades profissionais relevantes dos egressos.

Procedimentos de Acompanhamento e Avaliação

O Projeto Acadêmico viabiliza três ângulos referentes à qualidade da formação, possibilitando assim sua efetiva pertinência para os objetivos de acompanhamento e avaliação:

- o próprio Projeto, enquanto explicitador das estruturas do Curso, pode ser objeto de análise dos objetivos e dos esforços e recursos investidos no seu atingimento. É possível portanto, parcialmente, avaliar o Curso observando o bom fundamento de suas propostas e a adequação dos meios postos em ação para realizá-las, conforme expressos no Projeto Acadêmico;

- o Projeto funciona ainda como um explicitador de critérios, definidos pela própria Escola, segundo os quais esta deve ser avaliada podendo-se verificar, na prática, a existência das estruturas e o seu correto funcionamento, em efetiva correlação com o que o Projeto afirma;

- finalmente, o Projeto mesmo deve definir os procedimentos de acompanhamento e avaliação externa e interna do próprio curso, prevendo a obtenção de informações requeridas para o seu aperfeiçoamento continuado e para a superação de problemas de percurso.

Deve assim fazer parte das estruturas gerais do curso - e assim, constar de seu Projeto Acadêmico - a definição de procedimentos de acompanhamento e avaliação externa e interna do próprio curso. Estes procedimentos devem incluir, minimamente:

- descrição dos instrumentos e processos através dos quais o Curso observará seu próprio funcionamento para imprimir redirecionamentos e corrigir problemas, em busca de seu aperfeiçoamento qualitativo;

- projeto de acolhimento de visitas externas de entidades representativas das áreas relacionadas a suas formações, de representantes de setores educacionais públicos e de personalidades competentes nestas formações, com o objetivo de observar seu funcionamento e encaminhar avaliações e propostas de aperfeiçoamento;

- modos de disponibilização, aos setores públicos pertinentes, de informações sobre seus procedimentos pedagógicos, sobre sua estrutura, em quaisquer dos aspectos abordados no presente documento, e sobre os resultados quantitativos e qualitativos de sua atuação;

- definição de uma Comissão de Qualidade da Formação Profissional com existência formalmente assegurada no âmbito da escola. Esta Comissão deve ter participação efetiva na vida administrativa e social da escola, sendo integrada por representantes eleitos por professores e por estudantes, e deve ser aberta à participação das entidades representativas das diversas atividades de Comunicação com jurisdição na região.

- definição de procedimentos para promoção de integração entre os corpos docente e discente, como fator crítico para consecução dos objetivos curriculares e extra-curriculares, e como estímulo didático-pedagógico e político para o exercício da cidadania. 
Brasília, 20 de julho de 1999 


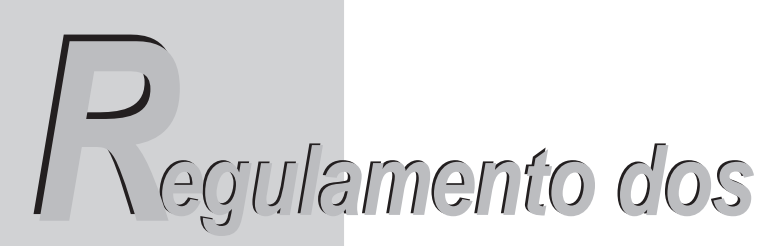

Projetos Experimentais

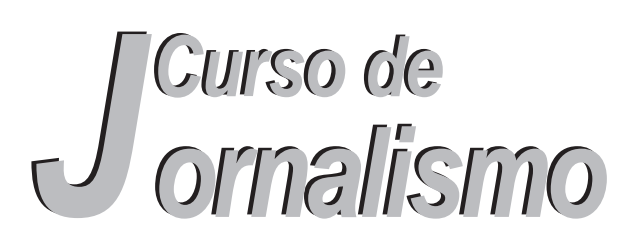


página em que terminou a parte anterior. Sua numeração é em algarismos romanos. Exemplo: CAPÍTULO I -

9. Sub-títulos, subdivisões devem ser numerados de forma homogênea: (Exemplo: 2. ;2.1; 2.2;2.3). Evitar seqüências muito grandes de números, como por exemplo: 2.1.1.2.1.

\section{e. As funções do orientador}

Além de contar com o professor de Metodologia Científica, titular da disciplina Consultoria Metodológica que ordena sistematicamente os passos do trabalho, o estudante precisará escolher um orientador de conteúdo, que o acompanhará e orientará a monografia no que ela tem de específico e da sua pertinência em relação ao objeto de estudo.

Uma vez escolhido o orientador, a relação orientando/ orientador deve levar em conta o diálogo consciente e coerente, de forma que cada um desempenhe seu papel na discussão conjunta e que as decisões relativas ao trabalho sejam partilhadas com maturidade intelectual.

Quanto mais assíduos forem os encontros, mais o processo de produção do PE será implementado e a ciência, o mercado de trabalho e a instituição de ensino superior, sairão ganhando nesse diálogo profissional.

Todas as normas e instruções constantes desse Regulamento que trata sobre os Projetos Experimentais e Pré-Projetos do Curso de Jornalismo da Umesp foram elaboradas inicialmente pelas profas. Dras. Samantha Castelo Branco e Maria Cristina Gobbi, no ano de 2001. As modificações e incorporações de novas sugestões foram realizadas no ano de 2004, pela profa. Dra. Maria Cristina Gobbi e revistas no ano de 2005. 


\section{d. Aspectos gráficos do Relatório Final/Memorial}

1. Tamanho do papel: A 4 na cor branca.

2. Espaçamento: 1,5 (sem espaçamento entre parágrafos). Em notas de rodapé usar espaço simples e letra em tamanho menor.

3. Tamanho da letra: para o texto usar tamanho 12 normal. Para os títulos dos capítulos, as palavras introdução, agradecimento, sumário, referências bibliográficas e anexos: usar tamanho 16, em caixa alta e negrito. Para os títulos dos itens e sub-itens: usar o tamanho 14, minúsculo, negrito.

4. Tipo de letra: Times New Roman ou Arial.

5. Parágrafo: 1 tab para iniciar os parágrafos.

6. Numeração: Em números arábicos, na margem superior, à direita. Para efeito de numeração: todas as páginas, a partir da página de rosto, são contadas, mas só começa a aparecer o número na primeira página do texto (ou seja, na introdução).

7. Margens: superior: $3,0 \mathrm{~cm}$ inferior: $\quad 3,0 \mathrm{~cm}$

direita: $\quad 2,0 \mathrm{~cm}$

esquerda: $3,0 \mathrm{~cm}$

Não usar o verso do papel.

8. Capítulos: Os títulos dos capítulos devem estar situados a partir de $5 \mathrm{~cm}$ da margem superior. Devem ser iniciados sempre numa página nova, mesmo que haja espaço na

\section{Universidade Metodista de São Paulo (Umesp)}

\section{Conselho Diretor}

Augusto Campos de Rezende (presidente); Carlos Alberto Silva Trindade (vice-presidente); Tania Mariza Kuchenbecker Rösing (secretária); Luiz Vergílio Batista da Rosa (Bispo-assistente);

Elio Goulart; Esther Lopes; Ladys Barbosa Gama; Graciela

Duarte Rito Rodrigues Aço; Márcio Miguel de Oliveira Arbex e Nelly Azevedo Matolla

Reitor: Davi Ferreira Barros

Vice-Reitor Acadêmico: Clovis Pinto de Castro Vice-Reitor Administrativo: Marcio de Moraes

\section{Conselho de Política Editoral}

Adolpho Carlos Françoso Queiroz; Clóvis Pinto de Castro (vicepresidente); Davi Ferreira Barros (presidente); José Marques de Melo; José Tolentino Rosa; Leonildo Silveira Campos; Marília Claret Geraes Duran; Peri Mesquita (representante externo);

Reinaldo Brito e Dias; Tania Elena Bonfi e

Vera Maria Barros de Oliveira

\section{Comissão de Livros}

Andréa Dias Quintão dos Santos; Edna Maria Barian Perrotti; Sebastião Carlos Moraes Squirra; Vera Maria Barros de Oliveira (presidente) e Waverli Maia Matarazzo Neuberger

Editor-executivo: Luciano Sathler Rosa Guimarães

FAJORP - Faculdade de Jornalismo e Relações Públicas Curso de Jornalismo

Diretora da Faculdade de Jornalismo e Relações Públicas: Maria Aparecida Ferrari

Coordenador do Curso de Jornalismo: Valdir Aparecido Boffetti Coordenadora dos Projetos Experimentais: Maria Cristina Gobbi 
Dados Internacionais de Catalogação na Publicação (CIP) Biblioteca Central da Universidade Metodista de São Paulo

Regulamento dos Projetos Experimentais do Curso de

Jornalismo da Universidade Metodista de São Paulo - UMESP / Organização e elaboração: Maria Cristina Gobbi. São Bernardo do Campo: UMESP, 2005.

1. Metodologia 2. Relatório Técnico 3. Jornalismo

4. Projetos Experimentais I. GOBBI, Maria Cristina.
- Importância do tema escolhido e relevância social;

-Métodos utilizados na produção do trabalho;

-Originalidade na abordagem e/ ou ineditismo;

-Relevância das fontes, entrevistas e das pesquisas realizadas;

- Coerência com a natureza do projeto;

Domínio da norma culta do português contemporâneo expressa no texto.

b) Produto - Resultado

- Criatividade na produção do trabalho;

-Diagramação/edição/montagem estética do trabalho;

-Capacidade de síntese e comunicabilidade;

-Grau de informação veiculado;

Experimentação / Inovação na linguagem, formato etc;

Qualidade do projeto e do memorial.

c) Defesa oral (a ser avaliado no dia da defesa do Trabalho)

- Capacidade argumentativa oral;

-Adequação das respostas aos questionamentos da banca;

- Conclusão e dedução lógica dos fatos;

-Adequação do material utilizado na exposição.

Agradecemos desde seu empenho e atenção ao nosso convite, reconhecendo sua valorosa contribuição. Estamos a disposição para eventuais esclarecimentos.

Cordialmente,

Profa. Dra. Maria Cristina Gobbi Coordenadora dos Projetos Experimentais Fones: (4366-5819 e 4366-5862)
Ruiversidade Metodista de São Paulo - Umesp
Ruamento, 230 - Rudge Ramos

09640-000 - São Bernardo do Campo - São Paulo

Tel.: (55 11) 4366-5600

Site: www.metodista.br 
Gostaríamos de expressar nossa satisfação em contar com sua participação na banca examinadora no projeto experimental:

Modalidade:

do curso de Jornalismo, da Universidade Metodista de São Paulo. A defesa ocorrerá nesta Faculdade, sita a Rua do Sacramento, 230 - Rudge Ramos - São Bernardo do Campo, São Paulo, no dia de de às

Abaixo apresentamos algumas sugestões que solicitamos sejam adotadas em relação à natureza desta tarefa:

1) Embora o objeto de análise seja um projeto experimental, afeito a inovações diversas, como linguagens, formatos, modelos e métodos, característicos e fundamentais a experimentação, julgue o material com o rigor necessário, pressupondo que os alunos estejam aptos a ingressar no mercado de trabalho. Os projetos devem apresentar nível de qualidade e interesse jornalístico.

2) Analise o material apresentado e não as intenções que ele pode sugerir nas entrelinhas. $O$ trabalho deve testemunhar um semestre de dedicação e esforço centralizado que os alunos Ihe destinaram, além de demonstrar a formação (teórico/prática) recebida pelo aluno nos quatro anos do curso de Jornalismo. Evite, portanto, adotar uma postura complacente.

3) Quando o trabalho não apresentar viabilidade comercial, terá que, necessariamente, demonstrar relevância cultural e/ou acadêmica.

4) Avalie o material apresentado de acordo com os critérios abaixo definidos.

a) Projeto - Idéia - Proposta

\section{Regulamento dos Projetos Experimentais do Curso de Jornalismo*}

\section{Elaboração e Organização}

Profa. Dra. Maria Cristina Gobbi Coordenadora do Projetos Experimentais

* As primeiras normas definidas para os Projetos Experimentais do curso de Jornalismo da Umesp foram elaboradas pelas professoras Dras. Samantha Castelo Branco e Maria Cristina Gobbi, em 2001. As adaptações constantes desse Manual foram realizadas em 2004 pela profa. Dra. Maria Cristina Gobbi e aprovadas pelo colegiado de curso em reunião realizada no dia 16/02/2004. Revisão realizada no ano de 2005 e aprovado pelo colegiado de curso. 
Composição da banca examinadora:

Orientador(es):

Professor Umesp:

Convidado Externo:

OBS.: O contato com os convidados e a entrega do projeto para os mesmos é de responsabilidade dos alunos autores.

\section{Data e horário proposto para apresentação:}

OBS: A data, o horário e a sala de apresentação serão

divulgados no mural até o dia Faremos o possível para mantermos a data e o horário indicados pelos alunos autores, só serão feitas modificações se houver choque de horário ou problemas quanto ao local da apresentação.

Recursos necessários à apresentação (vídeo, power point, projetos, TV etc). Servirá para definição do local da apresentação.

OBS: A responsabilidade pela alocação de recursos não solicitados neste requerimento será dos autores.

Assinatura de um dos alunos autores:

Data de entrega: Visto da secretaria: OBS:

\section{c. Modelo da Folha de Avaliação}

Cada grupo ou aluno será responsável pela entrega para todos os membros da banca examinadora de uma cópia: 1) Produto final; 2) Relatório Técnico/memorial (modelo entregue na disciplina Assessoria aos PE's); 3) Folha de Avaliação (a ser retirada na coordenação do Curso de Jornalismo).

Salientamos que a Folha de Avaliação objetiva somente oferecer aos membros da banca alguns critérios de análise do Projeto Experimental. 
No ato da solicitação deverão ser entregues duas cópias do Produto (modalidades individual ou em grupo) e duas cópias do Memorial.

No caso das monografias, os alunos poderão entregar a cópia em CDRom (para a banca examinadora, a cópia deverá ser impressa e encadernada em espiral).

\section{Anexos}

\section{a. Calendário:}

O calendário de defesas será disponibilizado no sistema SIGA e entregue para os alunos a cada início de semestre letivo na disciplina Assessoria aos Projetos Experimentais e terá como base o calendário da Universidade Metodista de São Paulo.

\section{b. Requerimento de defesa}

Em data definida no calendário dos Projetos Experimentais os alunos / grupos deverão entregar o PE na coordenação do Curso de Jornalismo, preencher o Requerimento de Defesa e retirar a Folha de Avaliação (para ser entregue para os membros da banca examinador.

\section{Universidade Metodista de São Paulo}

$$
\text { Curso de Jornalismo }
$$

Requerimento de Defesa do Projeto Experimental

Esta ficha deve ser deixada na Secretaria do Curso até o dia , quando também serão entregues o projeto e o relatório/memorial

Turno: Modalidade do Projeto:

Tema ou título do projeto:

\section{Sumário}

Apresentação

1. Conceituação ................................................10

2. Natureza ….................................................

2.1. Autoria .11

2.2. Modalidades 11

2.2.1. Conteúdo dos PE's.

3. Local de realização e Condições de Produção..12

4. Orientação .15

5. Freqüência 16

6. Banca examinadora 16

7. Apresentação

8. Avaliação 19

9. Casos omissos .21

10. Validade do Regulamento

11. Solicitação de defesa 


\section{Sumário}

\section{Anexos}

a) Calendário ..........................................................22

b) Requerimento de defesa....................................22

c) Modelo de Folha de Avaliação ..............................23

d) Aspectos gráficos do Relatório Final/Memorial ...26

e) As funções do orientador 27

\section{Casos omissos}

Os casos não contemplados neste Regulamento serão resolvidos, em primeira instância, pelo professor orientador, em concordância com a Coordenação do Curso de Jornalismo e a Coordenação dos Projetos Experimentais.

\section{Validade do Regulamento}

- Este Regulamento passa a vigorar no primeiro semestre de 2004, quando os alunos devem cursar a disciplina preparatória para os PE's, denominada "Introdução ao Projeto Experimental", com o objetivo de elaborar o projeto de trabalho e indicar o orientador do trabalho.

- O Regulamento dos Projetos Experimentais, após algumas discussões entre os professores, Coordenação do Curso de Jornalismo e Direção da Faculdade de Jornalismo e Relações Públicas, foi aprovado em reunião do Colegiado, realizada no dia 14 de fevereiro de 2003.

- As alterações e complementos às normas foram aprovadas em reunião do Colegiado realizada no dia 16 de fevereiro de 2004. Novas diretrizes foram incorporadas em fevereiro de 2005 e aprovadas pelo colegiado de curso no mesmo mês.

\section{Solicitação de defesa}

Cada grupo ou aluno (nas modalidades individuais) deverá requerer na coordenação do Curso de Jornalismo, em data previamente definida no calendário dos PE's, a defesa do Projeto Experimental (através de formulário próprio - conforme modelo anexo) 
f) A banca examinadora poderá atribuir ao trabalho a distinção "com louvor", devendo registrá-la na planilha de avaliação. No histórico escolar do aluno constará apenas a nota do Projeto Experimental.

g) Cabe ao Curso de Jornalismo a divulgação das notas obtidas por todos os alunos do semestre. Também é função do Curso divulgar os melhores trabalhos, por meio de mostras e exposições.

h) As equipes com trabalhos que receberem médias finas de 9,0 (nove) a 10,0 (dez) terão seus PEs indicados para concursos externos, cabendo ao aluno comparecer aos eventos nos quais seu trabalho será exposto ou julgado.

i) Se o professor orientador considerar que o trabalho do aluno não tem condições de ser apresentado para avaliação da banca examinadora, caberá ao professor levar o caso à Coordenação dos PE's, acompanhado de justificativa por escrito. Assim, o aluno estará automaticamente reprovado, cabendo a ele refazer o projeto no semestre seguinte, desde que a disciplina PE's seja oferecida pelo Curso.

j) No decorrer da orientação, o professor orientador poderá reprovar um ou mais integrantes do grupo, inclusive retirando-o da apresentação do trabalho à banca e, consequente, dos créditos referidos.

k) Para cada dia de atraso na entrega da versão definitiva do PE será descontado 0,5 (meio) ponto na média final do projeto (de cada integrante do grupo). Alertamos que entende-se por versão definitiva a cópia avaliada pela banca examinadora. E por média final a composição das notas dadas pela banca e pelo orientador.

\section{Apresentação}

Os Projetos Experimentais (PE's) no Curso de Jornalismo da Umesp objetivam finalizar a formação do aluno no âmbito da graduação, por meio de um trabalho mais aprofundado nas áreas teórica ou prática, aperfeiçoando, assim, o processo de reflexão na área, sendo obrigatório para obtenção do título de bacharel em Comunicação Social - habilitação Jornalismo.

O PE é uma oportunidade para o aluno realizar, com supervisão de um professor do Curso, um trabalho criterioso e de qualidade sobre o tema de sua preferência e na área de sua escolha: livro-reportagem, revista impressa, jornal impresso, assessoria de comunicação, vídeodocumentário, telejornal, radiojornal, jornalismo digital, fotojornalismo ou monografia.É uma disciplina regular da grade curricular e passou a ser regulamentada com normas aprovadas pelo Colegiado do Curso, a partir do ano 2000

Nesse sentido, os PE's do Curso de Jornalismo estão centrados no objetivo de contribuir para a formação de jornalistas conscientes de seu papel de formadores de opinião na sociedade e incentivar críticas, questionamentos e contribuições referentes ao jornalismo praticado em diferentes áreas, veículos e empresas.

Este regulamento contém as normas para elaboração e apresentação dos Projetos Experimentais (PE's), do curso de Jornalismo, da Faculdade de Jornalismo e Relações Públicas, da Universidade Metodista de São Paulo.

As regras aqui definidas têm como base o Regulamento do curso e as Normas da Associação Brasileira de Normas Técnicas (ABNT). Também oferece parâmetros para a apreciação dos trabalhos pelas bancas examinadoras, além de auxiliar o estudante de graduação na elaboração de seu Projeto Experimental.

Este Regulamento entra em vigor em 16 de fevereiro de 2004 (aprovado em reunião do Colegiado do Curso), tornando-se obrigatório para todos os alunos do curso.

Para finalizar, vale ressaltar que as primeiras incursões para regulamentar os PE's do Curso de Jornalismo da Umesp foram realizadas pela profa. Dra. Samantha Castelo Branco, então coordenadora dos PE's. 


\section{Conceituação}

Projeto Experimental (PE) é uma disciplina regular da grade curricular do curso de Jornalismo, cuja carga horária é de 360 h/a. Compreende a produção de um projeto, no último semestre do Curso, sob orientação acadêmica, que reúna as técnicas e os conhecimentos teóricos adquiridos ao longo da graduação. O objetivo do PE é fazer com que o estudante realize, em suas diversas etapas, um trabalho mais aprofundado, nas áreas teórica ou prática, aperfeiçoando, assim, o processo de reflexão na área.

\section{Natureza}

O Projeto Experimental deve ser executado pelo aluno matriculado no último semestre do curso (oitavo semestre), juntamente a disciplina de Metodologia, com o objetivo de garantir a qualidade dos trabalhos. No caso de dependência (DP) em outras disciplinas de semestres anteriores (no máximo duas), o aluno deve executá-las sem prejuízos na elaboração do PE, devendo comprovar, inclusive, disponibilidade para cumprir a carga horária exigida. Para a realização do Projeto Experimental, o aluno deve cursar, no sétimo semestre, uma disciplina preparatória "Introdução ao Projeto Experimental", na qual serão discutidas as questões metodológicas e as relacionadas à viabilidade do projeto. Ao final dessa disciplina, o aluno deve apresentar o projeto do trabalho, inclusive com modalidade e área definidos, além de sugerir o professor orientador.

\section{Avaliação}

a) A banca examinadora (convidados interno e externo) avaliará os PE's em três aspectos: 1) Idéia proposta; 2) Produto final e 3) Defesa. (critérios em anexo).

b) Cada componente da banca examinadora, após conversa/reunião sem a presença dos autores do trabaIho, deve atribuir uma nota, separadamente para cada quesito, de 0 (zero) a 10,0 (dez). As notas individuais serão somadas e calculada a média aritmética simples, obtendo a média final do PE. Essa média será aquela que permitirá a participação dos projetos no Prêmio Metodista de Jornalismo e nos concursos externos (atendendo ao critério de estar entre 9 e dez).

c) A média final do grupo será obtida através da soma da nota da banca com a nota da avaliação individual (de 0 (zero) a 10,0 (dez)) atribuída pelo orientado e calculada a média aritmética simples. Esse valor resultará na média final do Projeto Experimental para cada aluno do grupo. A média final deve atingir, no mínimo, 7,0 (sete) e, no máximo, 10,0 (dez) para garantir a aprovação do aluno/grupo;

d) Assim como nas outras disciplinas do Curso, o Projeto Experimental que obtiver média inferior a 7,0 (sete) ficará reprovado, cabendo ao aluno refazer a disciplina no próximo ano;

e) Cada membro da banca examinadora deve assinar a planilha de avaliação fornecida no dia da defesa. Nessa planilha deve conter a nota individual dada pelos membro da banca e a média final da banca, além das notas individuais dadas pelo orientador. As planilhas de avaliação devem ser entregues pelo orientador na Secretaria do Curso; 


\section{Apresentação}

A apresentação dos Projetos Experimentais ocorrerá na própria Universidade em data, horário e local divulgados previamente pela Coordenação dos Projetos, obedecendo às seguintes normas:

a) Cada equipe ou aluno disporá de, no máximo, 30 minutos para apresentar o trabalho;

b) Cada componente da banca terá entre 10 e 15 minutos para argumentação;

c) A equipe poderá, ainda, responder aos questionamentos da banca, num tempo de 15 minutos;

d) A finalização deverá ser feita pelo orientador, com comentários a seu critério;

e) O tempo total da apresentação não deve ultrapassar $2 \mathrm{~h} ;$

f) A equipe pode utilizar equipamentos e recursos técnicos para a apresentação do trabalho, devendo ser combinado anteriormente com o orientador. A requisição dos equipamentos fica a cargo dos alunos;

g) A apresentação dos PE's tem caráter público e a divulgação das datas e horários é de responsabilidade do Curso de Jornalismo.

h) A apresentação do Projeto será avaliada pela banca examinadora.

\section{1 Autoria}

Os PE's devem ser desenvolvidos preferencialmente em grupo (mínimo 5 componentes), no caso de elaboração de produtos na área jornalística (ver modalidades abaixo), ou individualmente, quando a opção for por trabalhos monográficos ou na área de fotojornalismo, conforme descrição no item seguinte. Na produção dos projetos, todas as atividades, especialmente as desenvolvidas por jornalistas, devem ser executadas por integrantes das equipes, inclusive a locução/narração, diagramação e fotografias. Duplas, trios e quartetos só serão permitidos caso o $\mathrm{n}^{\circ}$ de projetos não ultrapasse 18 (dezoito).

\subsection{Modalidades}

Os Projetos Experimentais podem ser desenvolvidos em oito modalidades, algumas com subdivisões:

a) Livro-reportagem

b) Jornalismo Impresso (revista e jornal)

c) Assessoria de comunicação

d) Jornalismo Televisivo

e) Jornalismo Radiofônico

f) Jornalismo Digital

g) Fotojornalismo - categoria individual ou coletiva (caso o projeto justifique a presença de mais de um participante)

h) Monografia - categoria individual

O número de PE elaborados, desde 2003, não pode exceder a 18 trabalhos por turma, incluindo as modalidades em grupo e individual. Os projetos coletivos terão prioridade.

A Coordenação dos Projetos Experimentais atuará como mediadora entre a Coordenação do Curso de Jornalismo e os grupos formados por alunos e professores orientadores. 


\subsubsection{Conteúdo de PE’s}

As monografias consistem em trabalho de pesquisa, com cunho acadêmico e científico, que aborda um tema de escolha do aluno, dentro do campo do Jornalismo.

No caso dos trabalhos práticos, além da elaboração do referido produto jornalístico, o aluno deverá entregar um memorial que explicite todas as fases de produção, tarefas executadas pelos componentes do grupo, objetivos, tema, dificuldades encontradas, relevância social do projeto etc, de acordo com modelo previamente definido.

\section{Local de realização e condições de Produção}

- Todas as observações feitas neste tópico não permitem exceções.

1) Com o objetivo de igualar as condições utilizadas pelos alunos na elaboração dos PE's, os mesmos devem ser preferencialmente executados nos laboratórios da própria Universida$\mathrm{de}_{2}$ incluindo etapas que exijam gravações, edição em rádio e TV, diagramação etc.

2) Os equipamentos de vídeo e equipe deverão ser agendados, obedecendo ao cronograma previamente definido pela coordenação do curso de Jornalismo e pelo coordenador dos laboratórios de TV e Rádio.

3) Os equipamentos de vídeo e equipe somente poderão ser alocados para atividades relativas aos PE's na Grande São Paulo. c) O grupo deverá entregar quando da solicitação de defesa do projeto, em data previamente definida no calendário, um currículo síntese (até 10 linhas) do professor/profissional externo convidado;

d) Os componentes das bancas devem ser convidados e nomeados com, no mínimo, 15 dias de antecedência da data de apresentação dos PE's. Além disso, cada componente deve receber, individualmente, uma cópia do trabalho/produto, uma cópia do relatório técnico que acompanha o projeto (produtos) e os critérios de avaliação dos Projetos com pelo menos 10 (dez) dias antes da data da apresentação do mesmo.

e) Caso não compareça um ou mais componentes da banca, a apresentação do PE será suspensa e caberá ao professor orientador marcar nova data e horário para exposição do trabalho.

f) O convidado interno - professor da UMESP - não poderá participar de mais de 4 (quatro) bancas examinadoras (este número não inclui as bancas de projetos orientados por ele).

g) Após definição e publicação do calendário de defesas a data, horário e local de realização somente poderão ser alterados com autorização prévia da Coordenação dos Projetos Experimentais.

h) Na solicitação de defesa o aluno deverá (no formulário de Pedido de Defesa - modelo próprio) informar os equipamentos e softwares que serão utilizados (Vídeo, TV, Power Point etc) e dados do convidado externo (placa carro, cor, modelo) para solicitação de estacionamento.

i) O atendimento as solicitações de equipamentos, softwares e estacionamento (somente para os convidados externos) para as defesas ficam condicionados as disponibilidades do material e do espaço da Instituição. 


\section{Freqüência}

É dever do aluno comparecer às horas/aula de orientação combinadas previamente com o professor orientador. Também faz parte das atividades concernentes aos PE's as etapas extraclasse, bem como todas as tarefas determinadas pelo orientador.

É obrigatório que o professor mantenha um diário de orientação (modelo na Secretaria do Curso), em que possa registrar os encontros com seu orientando e as etapas cumpridas. Ao final de cada orientação, professor e aluno devem assinar o referido diário.

\section{Banca examinadora}

Os Projetos Experimentais já concluídos serão avaliados por uma banca examinadora composta de três membros, sendo:

1. um deles o orientador do trabalho;

2. um convidado interno - professor do Curso de Jornalismo da UMESP;

3. um convidado externo, podendo este ser um professor de outra instituição ou um profissional do mercado de trabalho que atue na área com a qual se relaciona o projeto, ou professor de outro curso da Instituição.

a) A banca examinadora tem a função de avaliar e emitir notas finais para a aprovação ou reprovação dos Projetos Experimentais e, consequentemente, do aluno;

b) Compete ao professor orientador, com o conhecimento do aluno, indicar a composição da banca examinadora, cabendo à Coordenação do Curso, juntamente a Coordenação dos Projetos Experimentais, a aprovação final dos membros indicados;
4) As fitas de áudio e vídeo são de responsabilidade dos alunos/grupo. A Universidade não emprestará ou cederá as fitas de áudio, vídeo e filmes fotográficos.

5) Não serão permitidas ligações internacionais e interurbanas na Universidade para a realização do PE.

6) Os alunos/grupos deverão obedecer rigorosamente à planilha de horários, disponibilidade/locais das equipes e dias para a utilização de todos os equipamentos de áudio, vídeo, equipes, laboratórios de informática e estúdios; objetivando o desenvolvimento dos PE's.

7) Os alunos poderão imprimir as monografias e os relatórios que acompanham os PE'S nos laboratórios de informática da Faculdade de acordo com a cota de cópias previamente definida para a turma, respeitando a quantidade autorizada para cada grupo/aluno.

8) É de responsabilidade dos alunos/grupos a obediência aos prazos de entrega dos PE's.

9) Para o uso dos equipamentos para a gravação das entrevistas (viva-voz) do Curso terão prioridades os grupos que estão desenvolvendo projetos na área de Rádio. Para as demais modalidades o uso deverá ser autorizadas previamente pelo orientador do PE e pelo coordenador(a) do curso de Jornalismo ou coordenador(a) dos Projetos Experimentais; obedecendo/respeitando a disponibilidade do equipamento. 
10) No caso de projetos realizados parcialmente ou totalmente em laboratórios externos, o aluno e o professor orientador devem registrar a opção no relatório técnico que acompanha o produto, inclusive esclarecendo os motivos da utilização de equipamentos e laboratórios de outras instituições ou empresas do mercado de trabalho. Essa atitude servirá para situar a banca examinadora dentro do processo de realização do trabalho, minimizando as possíveis desigualdades de execução e facilitando a avaliação por parte dos examinadores.

11) Patrocínios, apoios e financiamentos externos serão possíveis, desde que avaliados e autorizados pelo professor orientador, juntamente a Coordenação dos Projetos Experimentais. Ainda assim, a opção deve ser registrada no relatório técnico, acompanhada de justificativa.

12) Para as modalidades em Jornalismo Televisivo e Radiofônico o número de projetos, por turma, não poderá ultrapassar 5 (cinco). As modalidades individuais (monografia e fotojornalismo) somente serão permitidas se os projetos em grupo (de no mínimo 5 integrantes) não atingirem o número de 18 por turma.

13) Em caso de plágio (comprovado) no PE fica definida a reprovação sumária de todo o grupo na disciplina.

14) Qualquer atuação referente ao desenvolvimento do $P E$ que demande necessidades fora da Grande São Paulo, será de inteira responsabilidade do aluno.

15) Os casos omissos serão decididos pela coordenação do Curso de Jornalismo e pela coordenação dos Projetos Experimentais, com aprovação do Colegiado do curso.

\section{Orientação}

- Os Projetos Experimentais deverão ser orientados preferencialmente por professores do Curso de Jornalismo da Universidade, havendo a possibilidade, em alguns casos, de orientador pertencer a outro curso da área de Comunicação da instituição. Ressalta-se que, no caso dos trabalhos monográficos, os mesmos devem ser orientados preferencialmente por docentes do Curso de PósGraduação em Comunicação Social da UMESP.

- O aluno deverá, quando da definição do PE, relacionar três possíveis orientadores, na ordem de preferência. O que não significa que necessariamente essa ordem será mantida.

- A Coordenação dos Projetos Experimentais fará a consulta prévia ao professor convidado para verificação da aceitação da tarefa por parte dele. No entanto, cabe à Coordenação do Curso, em conjunto com a Coordenação dos Projetos Experimentais, a aprovação final do orientador indicado. Os encontros com o professor escolhido devem resultar em 1h/aula de orientação por semana, na Umesp.

- Cada professor pode orientar, no máximo, cinco projetos por semestre, com o objetivo de garantir a qualidade do processo de orientação e execução dos trabalhos.

- Os alunos devem apresentar os projetos de trabalho previamente (veja cronograma) para que, em reunião do Colegiado, os professores do Curso possam aprovar o número de Projetos e a pertinência das temáticas. 


\title{
CONSELHO NACIONAL DE EDUCAÇ̃̃O \\ CÂMARA DE EDUCAÇÃO SUPERIOR
}

RESOLUÇÃO CNE/CES 16, DE 13 DE MARÇO DE 2002.**)

Estabelece as Diretrizes Curriculares para a área de Comunicação Social e suas habilitações.

O Presidente Câmara de Educação Superior, no uso de suas atribuições legais e tendo em vista o disposto na Lei 9.131, de 25 de novembro de 1995, e ainda o Parecer CNE/CES 492/2001, homologado pelo Senhor Ministro de Estado da Educação em 9 de julho de 2001, e o Parecer CNE/CES 1.363/2001, homologado em 25 de janeiro de 2002, resolve:

Art. $1^{\circ}$ As Diretrizes Curriculares para a área de Comunicação Social e suas habilitações, integrantes dos Pareceres CNE/CES 492/2001 e 1.363/2001, deverão orientar a formulação do projeto pedagógico do referido curso.

Art. $2^{\circ} \mathrm{O}$ projeto pedagógico de formação profissional na área de Comunicação Social e suas habilitações deverá explicitar:
a) o perfil comum e os perfis específicos por habilitação;
b) as competências e habilidades gerais e específicas por habilitação a serem desenvolvidas, durante o período de formação;
c) os conteúdos básicos relacionados à parte comum e às diferentes habilitações e os conteúdos específicos escolhidos pela instituição para organizar seu currículo pleno;
d) as características dos estágios;
e) as atividades complementares e respectiva carga horária;
f) a estrutura do curso;
g) as formas de acompanhamento e avaliação da formação ministrada.

Art. 3ำ A carga horária do curso de Comunicação Social e respectivas habilitações deverá obedecer ao determinado em Resolução própria que normatiza a oferta de cursos de bacharelado.

Art. 4ํㅡsta Resolução entra em vigor na data de sua publicação, revogadas as disposições em contrário.

\author{
ARTHUR ROQUETE DE MACEDO \\ Presidente da Câmara de Educação Superior
}

${ }^{(*)}$ CNE. Resolução CNE/CES 16/2002. Diário Oficial da União, Brasília, 9 de abril de 2002. Seção 1, p. 34. 


\section{UNIVERSIDADE DE MOGI DAS CRUZES}

\section{Quarto ano - PATAMAR ESCOLHER}

\section{Projeto: Vôo solo}

\section{Coordenador: Professor Roberto Medeiros}

Nos dois últimos semestres do curso, na Habilitação Jornalismo o patamar é o Escolher. O projeto chama-se Vôo Solo, uma evidente alusão ao momento muito especial que o aluno vivenciará em seu último ano de curso, quando começará a agir, cada vez mais, com iniciativa própria, finalizando sua preparação para a vida profissional, num mercado que exige, cada vez mais, gente com iniciativa de ações adequadas. É hora, portanto, de fazer o que se convenciona chamar de Projeto Experimental.

Conforme determinação do MEC, Parecer 480/83 de 6 de outubro de 1983, entende-se por projeto experimental a produção, no último ano do curso, de trabalho relacionado com a habilitação específica, em forma de monografia, fita gravada de som e imagem ou de som, filme cinematográfico sonoro, publicação impressa, campanha publicitária, plano de editoração - sempre realizados nos laboratórios da própria escola. O Projeto Experimental é de caráter obrigatório para a obtenção do certificado de conclusão do curso.

O Projeto Experimental, no curso de Comunicação Social da Universidade de Mogi das Cruzes é organizado de forma a solidificar os conhecimentos adquiridos no decorrer dos quatro anos em que se desenvolve o curso. 0 objetivo é promover a vinculação entre os temas e conteúdos abordados nas disciplinas a um projeto experimental, no qual se evidencie a prática embasada em fundamentos metodológicos e teóricos, que contribua para a formação profissional do corpo discente. A realização do Projeto Experimental está concebida também em perfeita consonância com o projeto pedagógico do curso, direcionado para os alunos do sétimo e oitavo semestres, no qual o aluno é gradativamente levado a tomar atitudes conscientes, críticas e indicar, ele próprio, o tema que gostaria de abordar e qual segmento pretende escolher para realizar sua última atividade no curso.

Para realizar o Projeto Experimental, o aluno deverá escolher um segmento específico da área de Jornalismo. Nesta habilitação o aluno irá optar por realizar um trabalho de maior envergadura acadêmica em uma dos seguintes segmentos:

Para realizar o Projeto Experimental o aluno poderá optar por um dos seguintes segmentos de trabalho:

\section{A - Impresso}

a1) Produção e edição de material jornalístico na forma de jornal ou revista , tendo por base um tema central, condutor das pautas necessárias para compor o produto editorial pretendido. Produto final: relatório de fundamentação, 
boneco da edição, textos finais e prova pré-print da edição, no formato final pretendido.

a2) Livro-reportagem texto, centrado em tema único. O texto final deverá ter um mínimo de $100 \mathrm{mil}$ caracteres. Produto final: livro com dimensões em conformidade com normas da ABNT - Associação Brasileira de Normas Técnicas -, encadernado com lombada quadrada, paginado, eventualmente ilustrado com fotografias. É obrigatório incluir no conteúdo do livro a fundamentação e, sempre que for adequado, um capítulo destinado a analisar como o tema é tratado pela Imprensa em geral.

a3) Livro-reportagem fotográfico , centrado em tema único. Este tipo de livroreportagem tem como linguagem principal a fotografia [mínimo de 80 fotos na edição], com textos acessórios e complementares. Produto final: livro com dimensões em conformidade com normas da ABNT - Associação Brasileira de Normas Técnicas -, encadernado com lombada quadrada, paginado. É obrigatório incluir no conteúdo do livro a fundamentação e, sempre que for adequado, um capítulo destinado a analisar como o tema é tratado pela Imprensa em geral.

B - Televisivo

b1) Produção de documentário , em formato vídeo, com duração mínima de 26 minutos e máxima de 28 minutos, necessariamente em dois blocos. Produto final: 1 fita de vídeo em sistema NTSC/SVHS, acompanhada de relatório de fundamentação do trabalho, com material de pesquisa e roteiro completo do documentário.

b2) Produção de vídeo-reportagem, com duração mínima de 12 minutos e máxima de 14 minutos. Produto final: 1 fita de vídeo em sistema NTSC/SVHS, acompanhada de relatório de fundamentação do trabalho, com material de pesquisa e roteiro completo da reportagem.

b3) Produção de uma edição experimental de telejornal temático , com duração mínima de 20 minutos e máxima de 28 minutos. Produto final: 1 fita de vídeo em sistema NTSC/SVHS, acompanhada de relatório de fundamentação do trabalho, com material de pesquisa e roteiro completo da edição do telejornal.

b4) Produção de um programa jornalístico especial, criado para o meio televisão, com duração mínima de 14 minutos e máxima de 28 minutos. Produto final: 1 fita de vídeo em sistema NTSC/SVHS, acompanhada de relatório de fundamentação do trabalho, com material de pesquisa e roteiro completo do programa.

C - Radiofônico

c1) Produção de uma edição experimental de radiojornal temático, com duração mínima de 15 minutos e máxima de 60 minutos. Produto final: 1 fita para reprodução, em sistema cassete ou DAT acompanhada de relatório de fundamentação do trabalho, com material de pesquisa e roteiro completo do radiojornal. 
c2) Produção de um programa jornalístico especial , com duração mínima de 20 minutos e máxima de 40 minutos. Produto final: 1 fita para reprodução, em sistema cassete ou DAT, acompanhada de relatório de fundamentação do trabalho, com material de pesquisa e roteiro completo do programa especial.

C3) Produção de uma reportagem especial , com duração mínima de 10 minutos e máxima de 15 minutos. Produto final: 1 fita para reprodução, em sistema cassete ou DAT, acompanhada de relatório de fundamentação do trabalho, com material de pesquisa e roteiro completo da reportagem especial.

\section{E - Fotográfico}

Produção de ensaio fotográfico, acompanhado de textos de contextualização das imagens e apresentação sob a forma de livro, exposição estática ou dinâmica (vídeo-visual-sonora). Produto final: relatório de fundamentação teórica e metodológica, fotografias em cor ou PB, organizadas em pasta ou em forma de publicação encadernada. [OBS: Não confundir com livro-reportagemfotográfica]

\section{F - Monografia}

Estudo e análise de um tema, centrado em aspecto comunicacional, fundamentado em pesquisa adequada a este tipo de trabalho. O texto final deverá ter um mínimo de 90 mil caracteres. Produto final: Documento, em formato A4, encadernado com capa dura, em cor verde, caracteres em preto, que corresponda efetivamente a um estudo monográfico.

\section{G - Jornalismo Empresarial}

Estudo sobre uma empresa, organização não governamental ou instituição de fins não lucrativos e formulação de um plano completo de comunicação para público externo e interno, com apresentação obrigatória de produtos exemplificativos sugeridos no plano. Produto final: Relatório de fundamentação teórica e metodológica, com o plano e layouts exemplificativos dos mecanismos de comunicação sugeridos no plano.

H - Multimídia

Criação, desenvolvimento e materialização de produtos digitais (e-book, site e áudio-visual) com a correspondente operação experimental, sendo ou não veiculados na rede mundial de computadores. Produto final: Relatório de fundamentação teórica e metodológica, textos e imagens do produto digital pretendido e demonstração em computador, sendo obrigatório, no caso de site, um mínimo de 20 páginas. 


\section{REGULAMENTO}

Dispõe sobre a regulamentação da Monografia de Pesquisa em Comunicação para a conclusão do Curso de Comunicação Social, habilitações em Jornalismo e Publicidade e Propaganda, a Universidade de Ribeirão Preto e dá outras providências.

\section{CAPÍTULO I DO REGULAMENTO E SEUS OBJETIVOS}

Art.1 Este regulamento dispõe sobre a monografia de Pesquisa em graduação, que constitui pré-requisito para a conclusão do curso de graduação em Comunicação Social - habilitações em Jornalismo e Publicidade e Propaganda de acordo com o Novo Currículo, de n 295 (Jornalismo) e de n 296 (Publicidade e Propaganda), aprovado em reunião do Conselho de Ensino e Pesquisa da Universidade de Ribeirão Preto, em 8 de dezembro de 1997.

Art.2 As atividades referentes à elaboração da Monografia de Pesquisa em Comunicação serão desenvolvidas basicamente na Atividade Complementar II_ prevista no currículo pleno do curso de Comunicação Social, desta Universidade com a duração de dois semestres, conforme as determinações regimentais do Curso de Comunicação Social.

Art.3 O coordenador (a) do Curso de Comunicação Social contará com a Comissão de Monografia em Comunicação, criada nos termos deste Regulamento.

Art.4 Compete ao Curso de Comunicação Social aplicar as disposições deste Regulamento. 


\section{CAPÍTULO II \\ DA ESTRUTURA E ORGANIZAÇÃO DA MONOGRAFIA DE PESQUISA EM COMUNICAÇÃO}

\section{SEÇÃO I \\ DOS CONCEITOS BÁSICOS}

Art.5 Para efeitos deste Regulamento entende-se:

I-Monografia de Pesquisa em Comunicação: "Item não seriado, isto é, completo, constituído de uma só parte, ou que se pretende completar em um número preestabelecido de partes separadas".

$\S 1$ A monografia de pesquisa em Comunicação terá caráter eminentemente didático, como treino e iniciação à investigação científica.

§2 Para sua elaboração, não se exigirá que o trabalho seja a comunicação de uma nova teoria, de nova explicação e interpretação dos fatos ou a investigação científica com a característica da originalidade. Exigir-se-á, todavia, que seja pessoal, fruto de reflexão e rigor científico.

Art.6 A atividade Complementar II está subdividida em duas disciplinas: Monografia I e Monografia II.

§1 A disciplina Monografia I consiste na elaboração de um projeto de pesquisa.

§2 A disciplina Monografia II consiste na execução do projeto elaborado em Monografia I, ou seja, na realização da monografia.

\section{SEÇÃO II \\ DO PROJETO}

Art.7 O anteprojeto da Monografia de Pesquisa em Comunicação poderá ser elaborado e concluído na disciplina Metodologia Científica II e será apresentado para a obtenção de aprovação na referida atividade.

Parágrafo Único. Os alunos que não quiserem utilizar o anteprojeto executado na disciplina Metodologia Científica II, deverão elaborar outro anteprojeto sobre novo tema. 
Art.8 O anteprojeto deverá ser elaborado e apresentado por grupos de, no máximo, 3 (três) alunos.

Art.9 O anteprojeto deverá ser apresentado ao Núcleo de Produção Científica em Comunicação, no prazo designado pelo calendário elaborado especialmente para esse fim, para ser avaliado pela coordenação do referido Núcleo. Caso seja aprovado e, de acordo com o tema proposto, o projeto será encaminhado pelo Núcleo a um orientador, seguindo critérios que dizem respeito às linhas de pesquisa existentes no Núcleo e às atividades de pesquisa executadas pelo Corpo Docente Orientador.

Art.10 O projeto de pesquisa será elaborado, efetivamente, na disciplina Monografia I.

Parágrafo Único. Enquanto não obtiver a aprovação do projeto (Monografia I), pelo professor orientador, o aluno não poderá matricular-se em Monografia II.

\section{SEÇÃO III}

\section{DA OBRIGATORIEDADE, DA NATUREZA E CONDIÇÕES DA MONOGRAFIA DE PESQUISA EM COMUNICAÇÃO}

Art.11 A Monografia de Pesquisa em Comunicação será de caráter obrigatório para os alunos do curso de Comunicação Social, habilitações em Jornalismo e Publicidade e Propaganda, e constitui pré-requisito para a colação de grau.

Art.12 Submeter-se-ão à elaboração da Monografia de Pesquisa em Comunicação os alunos das habilitações em Jornalismo e Publicidade e Propaganda matriculados na Atividade Complementar II, que terá a duração mínima de dois semestres.

Parágrafo Único. Estarão aptos a se matricular na Atividade Complementar II os alunos das habilitações em Jornalismo e Publicidade e Propaganda, a partir da $3^{\text {a }}$ etapa, desde que tenham seus anteprojetos aceitos pelo Núcleo de Produção Científica em Comunicação.

Art.13 Os alunos matriculados na Atividade Complementar II deverão apresentar termo de compromisso do Orientador assinado, no prazo designado pelo calendário elaborado especialmente para esse fim.

Art.14 Durante o primeiro semestre os alunos matriculados na Atividade Complementar II elaborarão o projeto de pesquisa e, no segundo semestre, executarão o projeto realizando a monografia.

Art.15 Cursará o segundo semestre de Atividade Complementar II o aluno 
aprovado no primeiro semestre da referida Atividade, com média igual ou superior àquela exigida para a aprovação nas demais disciplinas do curso de Comunicação Social da UNAERP, ou seja, 5,0 (cinco inteiros), desde que tenha entregue também o projeto e parecer favorável do Orientador .

Parágrafo Único. Ficará retido no primeiro semestre da Atividade Complementar II o aluno aprovado que não entregar o projeto nos prazos designados pelo calendário especialmente elaborado para esse fim, ainda que cumprido o disposto no caput deste artigo.

Art.16 Ao término do segundo semestre da Atividade Complementar II, conforme calendário estabelecido, os alunos deverão apresentar a Monografia de Pesquisa em Comunicação para a avaliação de uma Banca Examinadora.

Art.17 Será designada Banca Examinadora para os alunos que obtiverem parecer favorável da Comissão de Monografia em Comunicação.

Parágrafo Único. A aprovação pela Comissão de Monografia em Comunicação restringir-se-á à análise da apresentação formal do trabalho.

Art.18 O calendário semestral da Atividade Complementar será sempre elaborado pela coordenação do Núcleo.

\section{SEÇÃO IV \\ DA COMISSÃO DE MONOGRAFIA EM COMUNICAÇÃO}

Art.19 A Comissão de Monografia em Comunicação, do Curso de Comunicação, tem caráter de coordenação, ressalvada a autonomia intelectual, didática e pedagógica dos professores orientadores, e seus estudos, pareceres, relatórios e decisões ficam submetidos ao Núcleo de Produção Científica em Comunicação.

Art.20 A comissão, constituída por ato do Coordenador do Curso, será composta por até 3 (três) membros do corpo docente lotados ou não no Curso de Comunicação Social, escolhidos e indicados em conformidade com as normas da Instituição. A Comissão será presidida por um de seus membros.

Art.21 A Comissão reunir-se-á ordinariamente de acordo com o seu calendário, e extraordinariamente, por necessidade de deliberação urgente ou quando convocada pelo Coordenador do NPC ou pelo Coordenador do Curso de Comunicação.

Art. 22 São atribuições e competência da Comissão:

I. Deliberar sobre as atividades regulares, apreciando os pareceres ou 
documentos que lhe forem encaminhados, e emitir pareceres, obedecidas as diretrizes deste Regulamento.

II. Responder às consultas encaminhadas pelo Coordenador do Núcleo de Produção Científica, coordenador do curso, membros do Corpo Docente e outros.

III. Emitir parecer sobre recursos interpostos.

IV. Rever suas próprias decisões ou pedidos de reconsideração, quando postulados, em razão de fato novo que a justifique.

V. Elaborar o calendário semestral da Comissão.

VI. Supervisionar a elaboração do horário, local e data da realização das Bancas Examinadoras.

VII. Distribuir eqüitativamente as monografias entre os Professores do Curso, compatibilizando-se, quando possível, a área de atuação do Professor.

Art.23 Compete ao Presidente da Comissão de Monografia em Comunicação:

I. Presidir a Comissão.

II. Determinar a distribuição e a ordem dos trabalhos, bem, como conduzilos.

III. Conceder vistas de processos.

IV. Comunicar ao Coordenador do Núcleo de Produção Científica em Comunicação as deliberações da Comissão e as que reclamem providências ulteriores.

V. Assinar os atos resultantes das deliberações e decisões da Comissão no prazo de até 3 (três) dias úteis após a reunião da mesma.

Art.24 A Secretaria do Núcleo de Produção Científica em Comunicação auxiliará a Comissão, no que couber. 


\section{SEÇÃO V \\ DA BANCA EXAMINADORA}

Art.25 A Banca Examinadora, presidida pelo Orientador, será constituída pelos seguintes membros:

I. Orientador.

II. 2 (dois) Professores indicados pelo professor orientador.

Art.26 Estará impedido de ser Orientador, o Cônjuge ou parente do aluno até terceiro grau, a qualquer título.

Art.27 Anunciada a instalação da Banca Examinadora, o Presidente declarará abertos os trabalhos e, em seguida, concederá o uso da palavra ao grupo de Examinados, que fará um resumo oral da Monografia de Pesquisa em Comunicação, abrangendo a parte metodológica, conteúdo e conclusões, sendo vedada a sua leitura, no prazo de 15 (dez) minutos, prorrogáveis, a critério do Presidente da Banca, por mais 5 (cinco) minutos.

Art.28 Após a exposição oral da Monografia, o uso da palavra será retomado pelo Presidente da Banca, que o concederá aos membros da banca para as suas considerações e argüições ao grupo de Examinados. Na seqüência o Orientador retomará a palavra, para os mesmos fins.

Art.29 Esgotada a etapa de argüições passar-se-á à avaliação do grupo de examinados em sessão secreta.

Art.30 Reabertos os trabalhos deverá ser divulgado ao grupo de examinados o resultado final da avaliação, sendo facultado o uso da palavra aos membros da Banca e ao grupo de examinados, para considerações finais.

$\S 1$ A avaliação da banca é soberana e não poderá ser alterada por nenhum de seus membros.

§2 A constatação de plágio durante ou após avaliação da monografia pela Banca Examinadora resultará na reprovação do(s) aluno(s).

Art.31 Encerrados os trabalhos, o Presidente da Banca Examinadora preencherá um formulário com o resultado final, que será assinado pelos demais membros e entregue no mesmo dia ao NPC.

Art.32 A divulgação da composição das Bancas Examinadoras, salas, datas e 
horários das exposições orais será realizada pelo Núcleo de Produção Científica em Comunicação e afixada no quadro de avisos do Curso de Comunicação, de acordo com o calendário elaborado para este fim.

Art.33 Caberá ao grupo de examinados e ao professor orientador escolher os membros que farão parte da banca examinadora, bem como comunicar ao Núcleo no prazo estipulado em calendário elaborado para este fim.

\section{SEÇÃO VI DO ORIENTADOR}

Art.34 São atribuições, competências e requisitos do Orientador da Monografia de Pesquisa em Comunicação:

I. Assinar o termo de compromisso e responsabilidade no prazo estipulado.

II. Responsabilizar-se pelo projeto da Monografia de Pesquisa em Comunicação, emitindo parecer sobre o mesmo, no prazo estipulado pelo calendário da Atividade Complementar II.

III. Responsabilizar-se pela condução e elaboração da Monografia de Pesquisa em Comunicação deliberando e exigindo cumprimento das atividades que programou.

IV. Elaborar e comentar circunstanciadamente o relatório de acompanhamento do grupo de Orientador matriculado na Atividade Complementar II que conterá parecer favorável.

V. Presidir e conduzir as atividades da Banca Examinadora, bem como apurar as notas e divulgar o resultado final.

VI. Preencher o formulário da reunião da Banca e devolvê-lo ao Núcleo de Produção Científica em Comunicação, juntamente com a cópia da Monografia que tiver obtido aprovação.

\section{SEÇÃO VII \\ DA ESTRUTURA DA MONOGRAFIA \\ E DO PROJETO}

Art.35 A Monografia de Pesquisa em Comunicação e o Projeto, devem seguir as normas da Associação Brasileira de Normas Técnicas (ABNT), bem como as normas contidas nesta seção e as instruções anexas neste regulamento.

Art.36 A Monografia de Pesquisa em Comunicação apresentada conterá, no 
mínimo, 40 (quarenta) laudas de conteúdo temático datilografadas no anverso, em papel sulfite tamanho oficio (A4), branco, digitada em editor de texto para computador, corpo 14, fonte " Times New Roman" (Word), sobre tema na área de Comunicação de livre escolha do grupo que irá executar.

§1 A Monografia conterá nota de rodapé a critério dos autores e orientador.

§2 Será utilizado espaço 01 (um) em citações longas com letra menor (12), notas de rodapé e citações bibliográficas; espaço duplo entre linhas quando se tratar de texto corrido, entre as citações na bibliografia entre parágrafos, entre texto e ilustrações, entre gráfico ou tabela e vice-versa, entre texto e citações longas e vice-versa. Os parágrafos iniciarão no décimo espaço após a margem esquerda. As medidas das margens constarão no anexo.

Art.37 A Monografia será apresentada em 03 (três) exemplares, com encadernação em espiral.

$\S 1$ O grupo deverá entregar os respectivos exemplares da Monografia ao Orientador e aos Professores irão compor a Banca Examinadora.

§2 Após realizar as correções e as alterações sugeridas pela banca, o grupo que obtiver avaliação acima de 9,0 (nove), deverá entregar duas (2) cópias da monografia na cor azul para Publicidade e Propaganda e marrom para Jornalismo e gravação na cor dourada. Uma cópia será destinada à Biblioteca da Universidade e a outra ficará arquivada no Núcleo de Produção Científica de Comunicação.

$\S 3$ O grupo que obtiver avaliação abaixo de 9,0 (nove), após realizar as correções e as alterações sugeridas pela banca, deverá entregar apenas 01(uma) encadernada em espiral, que ficará arquivada no NPC durante, no mínimo, 12 meses.

$\S 4 \mathrm{O}$ aluno terá um prazo de 12 (doze dias), contados a partir do dia seguinte ao da defesa, para a entrega da versão corrigida do trabalho.

\$5 O NPC somente encaminhará a nota dos alunos à Secretaria Geral da Universidade para a divulgação nos boletins após a entrega da versão final do trabalho.

\section{CAPÍTULO III \\ DA AVALIAÇÃO DA BANCA EXAMINADORA}

Art.38 Os critérios de avaliação da Banca Examinadora compõem-se dos seguintes elementos: 
I. Relevância do assunto e delimitação do tema - 0 a 10 pontos

II. Aspecto formal - 0 a 10 pontos

III. Conteúdo da Monografia - 0 a 10 pontos

IV. Apresentação Oral - 0 a 10 pontos

Parágrafo Único. A soma da média dos quatro elementos de cada membro da Banca Examinadora será dividida por 4 (quatro) obtendo-se a média final que não será arredondada.

Art.39 A média de aprovação será igual ou superior a 5 (cinco) pontos, desde que nenhuma das notas atribuídas por qualquer membro da Banca Examinadora seja inferior a 4 (quatro) pontos.

Art.40 Ocorrendo insuficiência da média mínima para aprovação, o grupo de Examinados estará obrigado a inscrever-se novamente no segundo semestre da Atividade Complementar II, para habilitar-se à nova fase e cumprirá as exigências da Atividade e deste Regulamento.

$\S 1 \mathrm{O}$ grupo de alunos reprovados poderá habilitar-se à Banca Examinadora, no semestre seguinte, facultando-se o aproveitamento do mesmo tema utilizado anteriormente.

§2 A ausência de qualquer aluno às apresentações dos trabalhos, implica na reprovação automática do mesmo.

\section{CAPÍTULO IV \\ DAS CONSIDERAÇÕES FINAIS}

Art.41 As Monografias de Pesquisa em Comunicação aprovadas poderão ser utilizadas pela Universidade de Ribeirão Preto - UNAERP com objetivo didático, pedagógico, científico e na sua divulgação sem fins lucrativos, ressalvados os direitos autorais.

Art.42 As eventuais lacunas deste Regulamento serão analisadas e resolvidas pela Comissão de Monografia em Comunicação e, no que couber, pelo Colegiado do Curso de Comunicação Social.

Art.43 Revogam-se as disposições em contrário.

Ribeirão Preto, 4 de fevereiro de 2002

Profa. Elivanete Ap. Zuppolini Barbi

Coordenadora do Curso de Comunicação Social 
INSTRUÇÕES PARA ELABORAÇÃO DO PROJETO DE PESQUISA E DA MONOGRAFIA EM COMUNICAÇÃ̃O

\section{1 - Estrutura do Projeto}

\section{ESTRUTURA FORMAL}

1.1 Elementos Pré-Textuais

1.1.1 Capa

1.1.2 Folha de Rosto

1.2 Elementos Textuais

1.2.1 Introdução

1.2.2 Problema de Pesquisa

1.2.3 Justificativa

1.2.4 Objetivos

1.2.5 Metodologia

1.3 Elementos Pós-Textuais

1.3.1 Bibliografia

1.3.2 Cronograma

1.4 Esboço do Sumário

\section{Apresentação gráfica do Projeto}

2.1 De acordo com as normas técnicas da ABNT

2.2 De acordo com Regulamento da Monografia do Curso de Comunicação Social

\section{Estrutura da Monografia}

3.1 Elementos Pré-Textuais

3.1.1 Capa (obrigatório)

3.1.2 Lombada (opcional)

3.1.3 Folha de rosto (obrigatório)

3.1.4 Errata (opcional)

3.1.5 Folha de aprovação (obrigatório)

3.1.6 Dedicatória(s) (opcional)

3.1.7 Agradecimentos (opcional)

3.1.8 Epígrafe (opcional)

3.1.9 Resumo na língua vernácula (obrigatório)

3.1.10 Resumo em língua estrangeira (obrigatório)

3.1.11 Lista de ilustrações (opcional)

3.1.12 Lista de tabelas (opcional)

3.1.13 Lista de abreviaturas e siglas (opcional)

3.1.14 Lista de símbolos (opcional)

3.1.15 Sumário (obrigatório)

3.2 Elementos Textuais

3.2.1 Introdução

3.2.2 Desenvolvimento

3.2.3 Conclusão

3.3 Elementos Pós-Textuais

3.3.1 Referências (obrigatório)

3.3.2 Glossário (opcional)

3.3.3 Apêndice(s) (opcional)

3.3.4 Anexo(s) (opcional)

3.3.5 Índice(s) (opcional)

\section{Apresentação gráfica da Monografia}

4.1 De acordo com as normas técnicas da ABNT

4.2 De acordo com Regulamento da Monografia do Curso de Comunicação Social e anexos 


\section{CONTEÚDO DO RELATÓRIO DO ORIENTADOR ENTREGUE AO NPC}

1. Atividades programadas pelo Orientador

1.1 Cumprimento das tarefas determinadas pelo NPC

1.2 Assiduidade nas reuniões e nos contatos pré-fixados

1.3 Outras ocorrências ocasionais

2. O relatório deverá apresentar a nota e a assinatura do orientador.

\section{ELEMENTOS QUE DEVEM COMPOR A AVALIAÇÃO DO ALUNO PELO ORIENTADOR NA ATIVIDADE COMPLEMENTAR II}

1. Assiduidade nas reuniões marcadas com o orientador

2. Cumprimento dos prazos de entrega das tarefas determinadas pelo Orientador.

3. Apresentação formal e gráfica do Projeto de Pesquisa e da Monografia de Pesquisa em Comunicação. 


\section{PROCEDIMENTOS PARA RECEPÇÃO DOS PROJETOS E MONOGRAFIAS NO NÚCLEO DE PRODUÇÃO CIENTÍFICA EM COMUNICAÇÃO E REALIZAÇÃO DAS BANCAS EXAMINADORAS}

\section{PROCEDIMENTOS DOS ALUNOS:}

\section{1- PROJETO:}

1.1.1- Apresentar impreterivelmente no prazo indicado pelo calendário, o projeto em uma via com encadernação em espiral.

\subsection{MONOGRAFIA:}

1.2.1- Apresentar impreterivelmente no prazo indicado pelo calendário a Monografia de Pesquisa em Comunicação em 3 (três) vias, com encadernação em espiral.

1.2.2- Entregar os respectivos exemplares da Monografia ao Orientador e Docentes que farão parte da Banca Examinadora.

1.2.3- Anotar dia, horário e local designados para a realização da Banca Examinadora que serão divulgados pelo Núcleo de Produção Científica em Comunicação e afixados em quadro de avisos.

1.2.4- Comunicar ao Orientador e Docentes as informações sobre a realização da Banca Examinadora.

1.2.5- Após as correções sugeridas pela Banca, apresentar uma cópia em disquete para o NPC, duas cópias da monografia encadernadas em capa dura em cor azul para Publicidade e Propaganda e marrom para Jornalismo e gravação na cor dourada, sendo uma para o NPC e uma para a Biblioteca da Universidade.

\section{PROCEDIMENTOS DO NÚCLEO DE PRODUÇÃO CIENTÍFICA EM COMUNICAÇÃO:}

2.1 Recepcionar os documentos entregues pelos alunos.

2.2- Verificar na relação dos professores da disciplina Metodologia II se o aluno está apto a matricular-se no $1^{\circ}$. Semestre da Atividade Complementar II, e na relação de pareceres de Orientadores, se o aluno consta como apto a ingressar no $2^{\circ}$ da Atividade Complementar II. 
2.3- Verificar listagem do Núcleo de Produção Científica em Comunicação que informa sobre documentação pendente.

2.4- Verificar a documentação entregue, o teor do parecer e do relatório do Orientador das respectivas Atividades e assinaturas em geral.

2.5- Receber os projetos dos grupos de alunos para o encaminhamento à coordenação do Núcleo, para apreciação.

2.6- Emitir recibo de entrega de documentos em duas vias .

2.7- Em caso de documentação pendente e/ ou parecer desfavorável não receber o projeto e/ou a Monografia.

2.8- Reter 02 (dois) exemplares da Monografia para arquivo e documentação na Biblioteca da Universidade e no NPC

2.9- Reter uma cópia do trabalho em disquete para arquivo do NPC

\section{III -PROCEDIMENTO DO ORIENTADOR:}

3.1-O Orientador na data designada para a realização da Banca Examinadora deverá retirar no NPC em Comunicação a "Ficha de Avaliação de Monografia de Pesquisa em Comunicação, preenche-la e devolve-la ao término dos trabalhos." 
ANEXOS 
UNIVERSIDADE DE RIBEIRÃO PRETO

CURSO DE COMUNICAÇÃO SOCIAL

HABILITAÇÃO EM JORNALISMO OU PUBLICIDADE E PROPAGANDA

NOME DO TRABALHO

AUTORES

RIBEIRÃO PRETO

MÊS/ANO 


\section{UNIVERSIDADE DE RIBEIRÃO PRETO \\ CURSO DE COMUNICAÇÃO SOCIAL \\ HABILITAÇÃO EM JORNALISMO OU PUBLICIDADE E PROPAGANDA}

PROJETO DE PESQUISA ELABORADO POR EXIGÊNCIA DA DISCIPLINA MONOGRAFIA I, SOB A ORIENTAÇÃO DO(A) PROF.(A) DR. 


\section{UNIVERSIDADE DE RIBEIRÃO PRETO \\ CURSO DE COMUNICAÇÃO SOCIAL \\ HABILITAÇÃO EM JORNALISMO OU PUBLICIDADE E PROPAGANDA}

NOME DO TRABALHO

AUTORES

MONOGRAFIA APRESENTADA COMO EXIGÊNCIA PARCIAL PARA A OBTENÇÃO DO TÍTULO DE BACHAREL EM COMUNICAÇÃO SOCIAL, COM HABILITAÇÃO EM ..................SOB A ORIENTAÇÃO PROF(A.) DR 
Autor:

Título do Trabalho:

O presente trabalho foi examinado, nesta data, pela Banca Examinadora composta dos seguintes membros:

Prof.(a). Orientador(a)

Prof.(a)

Prof.(a) 


\section{MODELO SUMÁRIO}

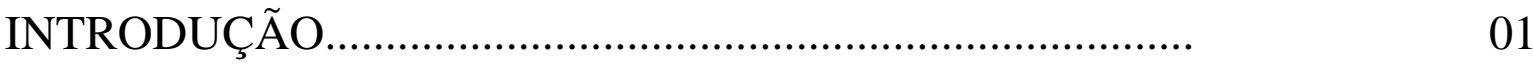

METODOLOGIA............................................................

CAPÍTULO I XXXXXXXXXXXXX 00

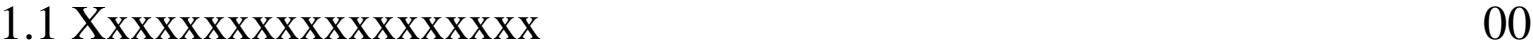

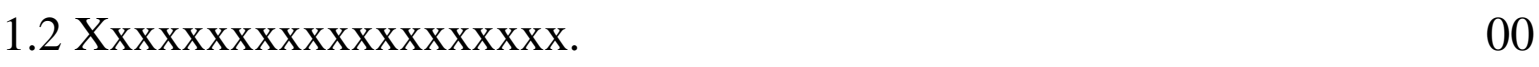

1.2.1 XXXXXXXXXXXXXXX

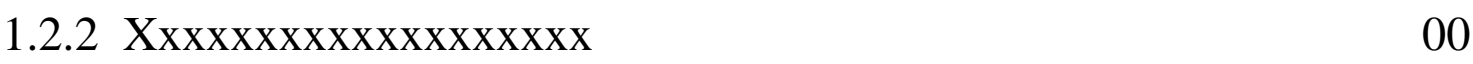

CAPÍTULO II XXXXXXXXXXXXX

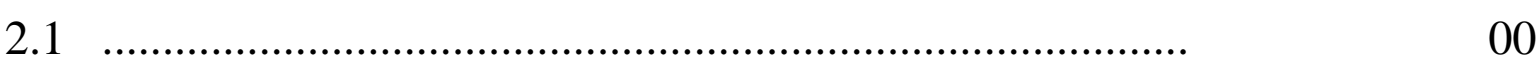

2.2

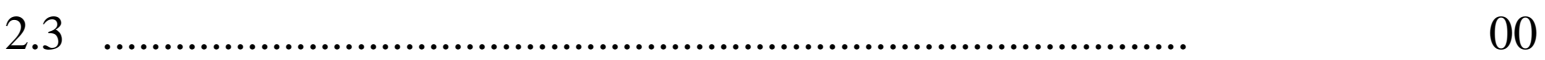

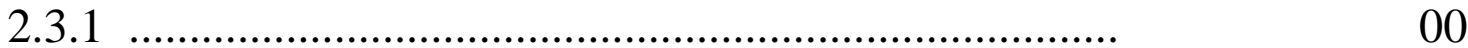

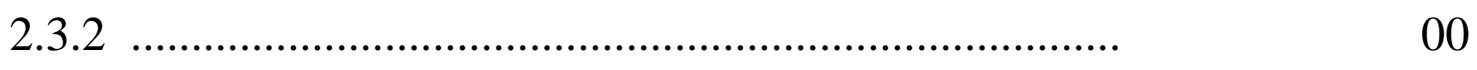

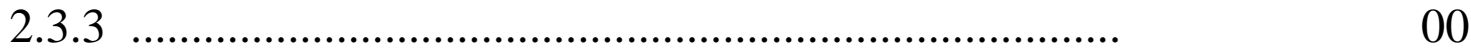

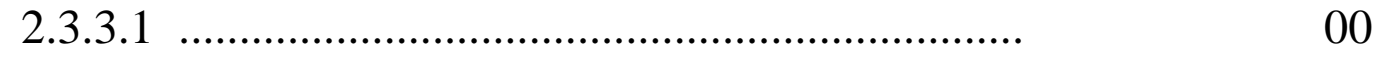

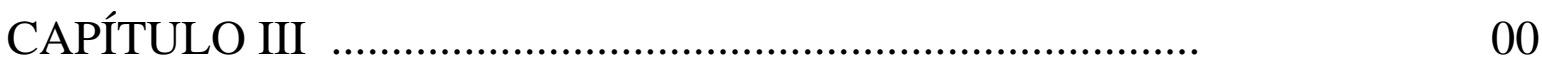

CONSIDERAÇÕES FINAIS ...........................................

REFERÊNCIAS BIBLIOGRÁFICAS..................................

ANEXOS .................................................................. 
22

MEDIDAS: CAPA, FOLHA DE ROSTO, FOLHA DE TEXTO CORRIDO

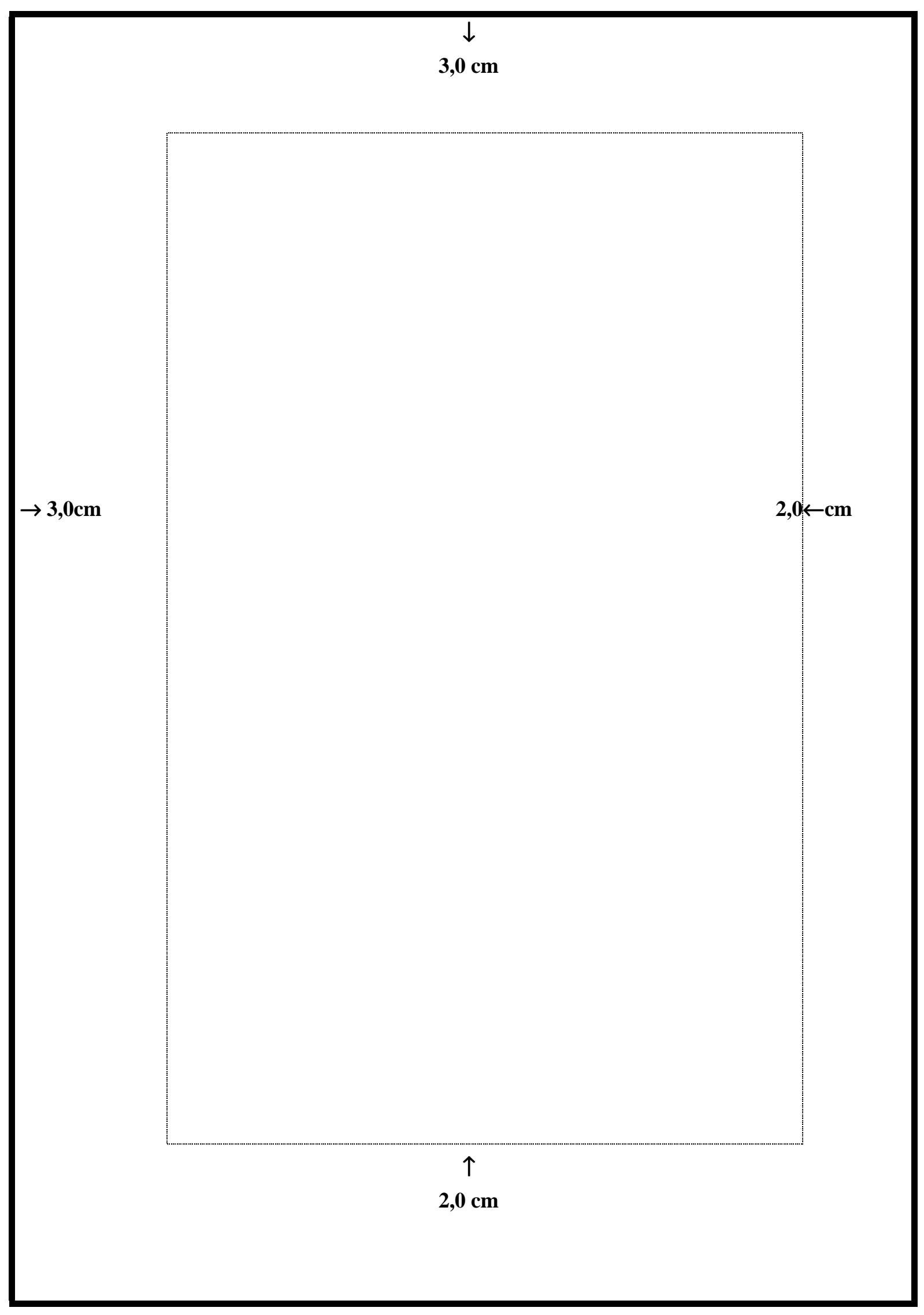




\section{MEDIDAS: INÍCIO DE CAPÍTULO, RESUMO, CONSIDERAÇÕES FINAIS, ETC.}

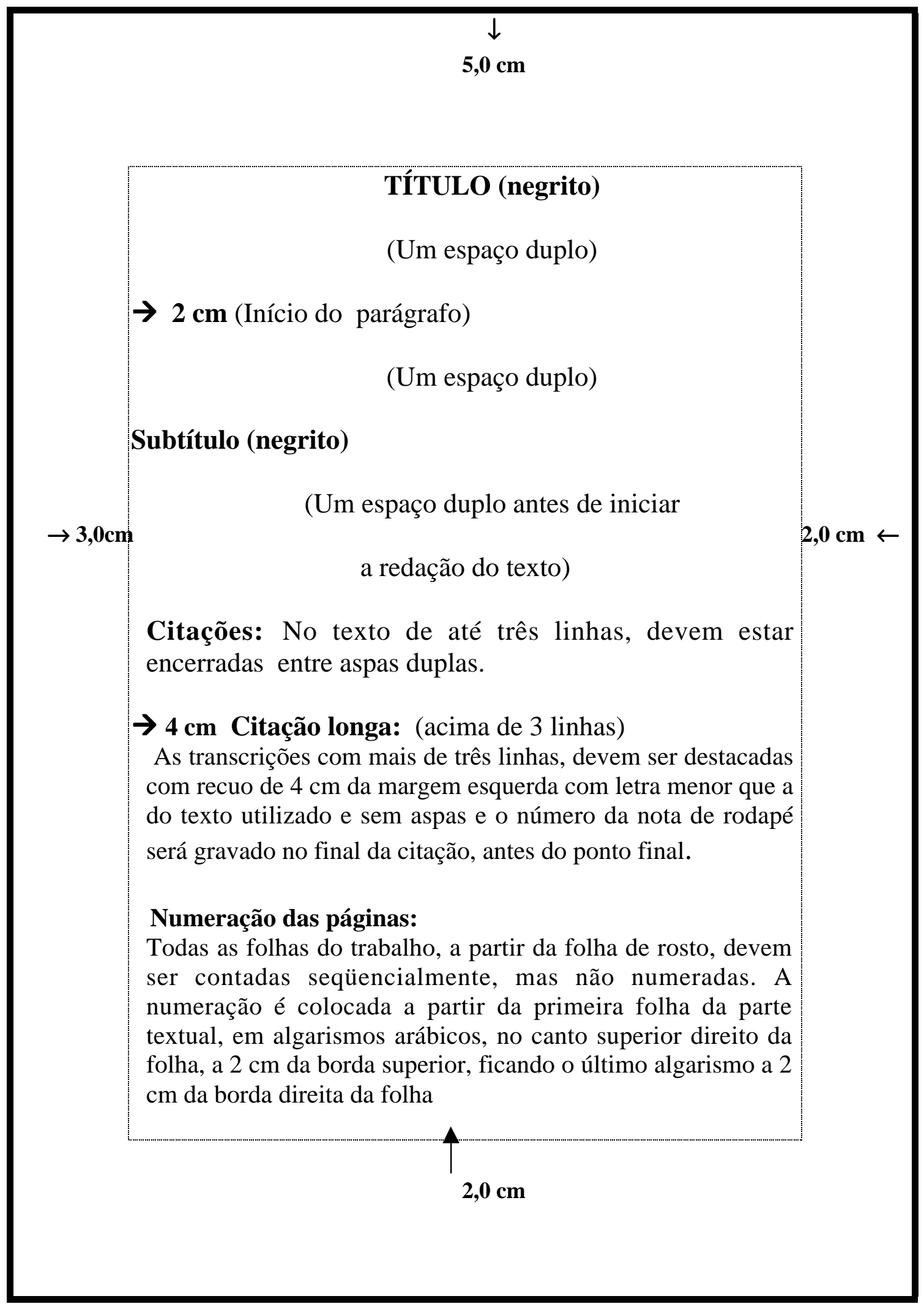


FOLHA DE INÍCIO

\section{UNIVERSIDADE DE RIBEIRÃO PRETO CURSO DE COMUNICAÇÃO SOCIAL HABILITAÇÃO EM JORNALISMO OU PUBLICIDADE E PROPAGANDA \\ (Fonte: Times New Roman . N. ${ }^{\text {: }}$ 14)}

\section{NOME DO TRABALHO}

(Fonte: Times New Roman. N. ${ }^{\circ}: 14$ a 16)

\section{AUTORES}

(Fonte: Times New Roman. N. ${ }^{\circ}: 14$ )

PROJETO DE PESQUISA ELABORADO POR EXIGÊNCIA DA DISCIPLINA MONOGRAFIA I, SOB A ORIENTAÇÃO DO PROF.(A) DR.

(Fonte: Times New Roman. N. $\left.{ }^{\circ} 12\right)$

\section{RIBEIRÃO PRETO}

MÊS/ANO (Fonte: Times New Roman.N. ${ }^{\circ}{ }^{14}$ ) 


\section{BIBLIOGRAFIA BÁSICA}

ANDRADE, Maria Margarida de. Introdução à metodologia do trabalho científico. São Paulo: Atlas, 1994.

ASSOCIAÇÃO BRASILEIRA DE NORMAS TÉCNICAS. NBR 10520: apresentação de citação de documentos: Rio de Janeiro. Agosto de 2002.

NBR. 6024 Numeração progressiva das seções de um documento. Rio de Janeiro. Agosto de 1989

_. NBR 6027 Sumário Rio de Janeiro. Agosto de 1989

—. NBR 6023 Informação Documentação, Referências e Elaboração.. Rio de Janeiro. Agosto de 2002.

.NBR 14724 Informação e documentação. Trabalhos acadêmicos. Apresentação. Rio de Janeiro. Agosto de 2002.

BARROS, Aidil Jesus Paes de, LEHFELD, Neide Ap. de Souza. Fundamentos de metodologia. 2.ed. São Paulo: Makron Books, 2000.

.Projeto de pesquisa: propostas metodológicas. 13. ed. Petropólis: Vozes, 2002.

BOAVENTURA, Edivaldo. Como ordenar as idéias. São Paulo: Ática, 1988.

CERVO, Amado Luiz, BERVIAN, Pedro Alcino. Metodologia científica. 4.ed. São Paulo: Makron Books, 1996.

DEMO, Pedro. Metodologia científica em ciências sociais. São Paulo: Atlas, 1985.

FERREIRA, Maria Nazareth. Aspectos teóricos da pesquisa em comunicação na América Latina. São Paulo: ECA-USP, 1986.

GIL, Antonio Carlos. Como elaborar projetos de pesquisa. São Paulo: Atlas, 1991.

LAKATOS, Eva Maria, MARCONI, Marina de Andrade. Fundamentos de metodologia científica. 3.ed. São Paulo: Atlas, 1991.

MARCANTÔNIO, Antônia Terezinha, SANTOS, Martha Maria dos, LEHFELD, Neide Aparecida de Souza. Elaboração e divulgação do trabalho científico. São Paulo: Atlas, 1996.

RUIZ, João Álvaro. Metodologia científica: guia para eficiência nos estudos. 3.ed. São Paulo: Atlas, 1995.

TRIVINOS, Augusto N. S.. Introdução à pesquisa em ciências sociais. São Paulo: Atlas, 1987.

UMBERTO ECO. Como se faz uma tese.12. ed. São Paulo: Perspectiva, 1995. 


\section{MODELO DE CRONOGRAMA}

\section{CRONOGRAMA DE DESENVOLVIMENTO DA MONOGRAFIA}

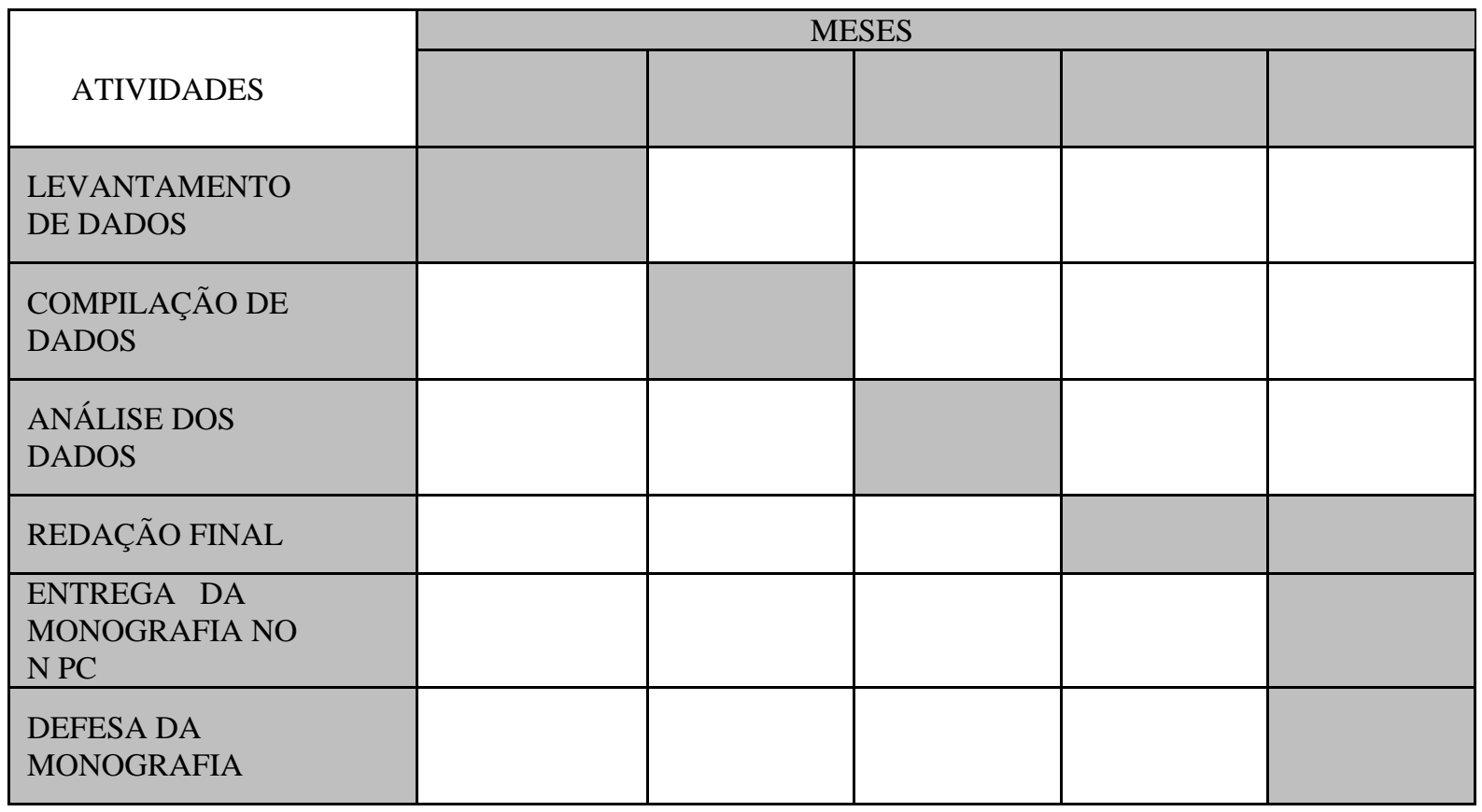


MODELO DE ETIQUETA PARA OS DISQUETES COM CÓPIA DA MONOGRAFIA

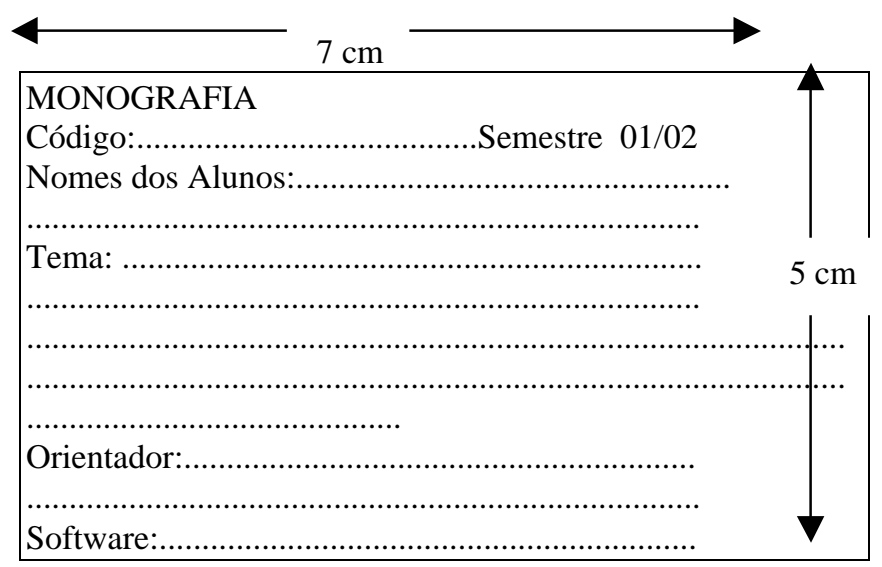

OBS:- A Monografia deve ser gravada em disquete preferencialmente em um único arquivo. 


\section{SOBRE O PROJETO DE PESQUISA Prof. Dr. Sebastião Geraldo}

Pesquisa científica é procedimento intelectual na busca da descoberta de novos fatos ou dados em qualquer campo do conhecimento. É um procedimento reflexivo, sistemático e crítico. O conhecimento da essência de um fenômeno, objeto de análise, e suas formas de manifestação consistem no objetivo central de qualquer trabalho científico. É importante lembrar que o conhecimento é a unidade do reflexo do sensorial e do racional, é a união indissolúvel entre a teoria $^{1}$ e a prática.

A importância do projeto é dar segurança e orientação à pesquisa científica e evitar desperdício de esforços e recursos. Pesquisar não significa simplesmente a abordagem de um objeto de estudo através da observação ou mesmo de um questionário. É necessário elaborar o planejamento da pesquisa. Pesquisa sem planejamento é improvisação e pode resultar em prejuízo. A concretização do planejamento de pesquisa se dá mediante a elaboração de um projeto que é o "documento explicitador das ações a serem desenvolvidas ao longo do processo de pesquisa". ${ }^{2}$ Não existe um modelo fixo para um projeto de pesquisa. Enquanto alguns autores indicam dez etapas outros sintetizam-nas em apenas quatro ou cinco $^{3}$. Os tópicos que mais freqüentemente aparecem nos projetos de pesquisa são: a) identificação; b) escolha e delimitação do tema e formulação do problema; c) justificativa; d) objetivos; e) hipóteses; f) variáveis; g) procedimentos metodológicos; h) fundamentação teórica/ (revisão bibliográfica); i) orçamento; j) cronograma; l) anexos e m) bibliografia.

\section{A ESTRUTURA FORMAL DO PROJETO DE PESQUISA IDENTIFICAÇÃO}

Responde à questão quem?

1.1- Capa: entidade, título, identificação do(s) pesquisador (es), local e data. 1.2- Folha de rosto: repete as informações da capa adicionando dados referentes ao propósito do trabalho.

\section{3- Introdução (com revisão da bibliografia) Introdução (apresentação)}

- fornecer idéia geral sobre o tema, bem como o que pretende enfocar;

- relevância e interesse do trabalho

1- Teoria é explicação da essência, regularidade, vínculos e contradições dos acontecimentos, dos fenômenos (o que pode ser percebido pelos sentidos).

2- GIL, Antonio Carlos. Como elaborar projetos de pesquisa. 3. ed. São Paulo: Atlas, 1991. p. 22

3- BARROS, Aidil Jesus Paes de \& LEHFELD, Neide Ap. de Souza. Fundamentos de Metodologia. Rio de Janeiro: McGraw-Hill, 1989. p. 97 
- $\quad$ intenções do autor em relação ao trabalho a ser desenvolvido.

- levantar o estado do tema em questão, o que já foi escrito sobre, considerando as idéias dos principais autores (revisão bibliográfica: ver a seguir).

\section{Revisão bibliográfica}

$\mathrm{Na}$ atualidade, pesquisa alguma parte da estaca zero. Em algum lugar um pesquisador ou um grupo já desenvolveu pesquisas idênticas, semelhantes ou complementares ou, ainda, desenvolveu estudos sobre temas que podem fornecer subsídios a alguns aspectos da pesquisa pretendida. A revisão bibliográfica cuida do resgate desses dados.

Nessa etapa devem ser apresentados os elementos de fundamentação teórica da pesquisa e a definição dos conceitos empregados.

Para o desenvolvimento de um trabalho de caráter interpretativo, no que se refere aos dados ou fatos obtidos, "é imprescindível correlacionar pesquisa com o universo teórico, optando-se por um modelo teórico que serve de embasamento à interpretação do significado dos dados levantados". Nesse sentido, todo projeto de pesquisa "deve conter as premissas ou pressupostos teóricos sobre os quais o pesquisador fundamentará sua interpretação". 4

Nesta fase o pesquisador normalmente encontra dificuldades como a falta livros e revistas atualizadas, deficiência na leitura de línguas estrangeiras com publicações de considerável importância na área em que está investigando (publicações traduzidas são demoradas e ficam defasadas), o que pode resultar na falta de embasamento teórico para explicar, compreender e dar significado aos fatos que se investiga.

O cientista trabalha com conceitos que representam simbolicamente os fenômenos perceptíveis na natureza e na sociedade e o mundo psíquico do homem. Para que não ocorram interpretações ambíguas no momento de comunicar esses fenômenos é necessário defini-los com precisão. Ex.: classe social, Q.I., pessoas idosa, jovem, etc.

No projeto deve-se evitar citações. Recomenda-se apresentar uma síntese das idéias dos principais autores que tenham trabalhos relevantes sobre o tema escolhido, fazendo referência aos mesmos, bem como, dos principais conceitos utilizados no trabalho.

\section{4- Formulação do problema de pesquisa}

Toda pesquisa inicia-se com uma questão ou dúvida a ser esclarecida. A formulação de um problema é tarefa difícil especialmente para quem têm pouca experiência, escassas informações sobre o tema que propõe pesquisar e, ainda, para aqueles cuja formação teórica é pouco consistente. O problema de pesquisa pode ser determinado por razões de ordem prática para resolver problemas imediatos, para subsidiar uma determinada ação (ex.: produto, campanha política), ou por razão de ordem intelectual como testar uma teoria, se

4- LAKATOS, Eva Maria, MARCONI, Marina de Andrade. Fundamentos de metodologia Científica. 3.ed. São Paulo: Atlas, 1991. p. 224 
aprofundar nos conhecimentos sobre uma determinada cultura.

Para Antônio Carlos $\mathrm{Gil}^{5}$ o problema deve ser claro e preciso, deve ser suscetível de solução (envolve variáveis que podem ser testadas) e delimitado a uma dimensão viável de ser resolvido.

$\mathrm{O}$ autor recomenda, ainda, que o problema deve ser formulado como pergunta pois considera ser a maneira mais fácil de faze-lo, além de facilitar sua identificação por parte de quem consulta o projeto ou o relatório de pesquisa : ex. "Que fatores provocam o divórcio em Ribeirão Preto?”, “O nível de escolaridade determina a preferência político-partidária dos eleitores brasileiros?"

\section{5- Justificativa}

Consiste em expor, de forma sucinta, o motivo da escolha do tema em questão, a relevância e oportunidade do assunto, razões de ordem teórica e prática que tornam importante a realização da pesquisa. É o item que apresenta a resposta à questão por quê fazer?

\section{A justificativa deve enfatizar:}

- importância do tema do ponto de vista geral;

- importância do tema para as questões específicas;

- relevância social do problema a ser investigado;

- contribuições teóricas que a pesquisa pode trazer tais como: confirmação geral, confirmação nas especificidades em que se insere a pesquisa, clarificação da teoria; resolução de casos obscuros.

$\mathrm{Na}$ justificativa, quando se "trata de analisar as razões de ordem teórica ou se referir ao estágio de desenvolvimento da teoria, não se pretende explicitar o referencial teórico que irá adotar, mas apenas ressaltar a importância da pesquisa no campo da teoria." Neste momento, porém, não é recomendado apresentar citações de outros autores. ${ }^{6}$

\section{6- Objetivo (s)}

Indicação do que se pretende alcançar com a pesquisa, os resultados que se pretende obter com a pesquisa. Responde à questão para que fazer?

Os objetivos podem ser classificados como geral ou específicos, de acordo com a abrangência.

O objetivo geral está vinculado à visão global e abrangente do tema, à própria significação da tese proposta pelo projeto. É o fim que se pretende atingir como resposta ao problema formulado.

Os objetivos específicos procuram descrever situações pormenorizadas, aspectos mais detalhados, situações particulares que permitam alcançar o objetivo geral de um trabalho científico.

5 - GIL, op. cit. p. 30-32

6 - LAKATOS \& MARCONI, op. cit. p.219 


\section{7- Metodologia}

Nesse item deve ser explicitado se se trata de pesquisa bibliográfica, descritiva ou experimental, com trabalho de campo ${ }^{7}$ ou de laboratório, pesquisa teórica ou aplicada e mesmo se combinará várias formas de pesquisa. Responde às seguintes questões: como, com que, onde e quando fazer?

Diretamente relacionada com o tipo de pesquisa devem ficar claros os métodos e as técnicas a serem adotadas, a delimitação do universo a ser pesquisado e o tipo de amostragem.

\subsection{1- Sobre o método}

Método é o conjunto dos procedimentos sistemáticos e racionais adotados para o desenvolvimento de uma pesquisa, de um trabalho científico. É o caminho ordenado para se chegar a um fim, para alcançar o objetivo definido.

O método ratifica uma importante diferença entre a ciência e outras formas de conhecimento, pois representa a "existência de uma organização lógica entre as afirmações que constituem uma teoria científica, e a possibilidade de justificála" 8

Não há uma única maneira de classificar os métodos. Existem divergências quanto a classificação de métodos, técnicas e processos, especialmente nas pesquisas sociológicas. A ausência critério objetivo dessa classificação permite ocorrer que, o que alguns chamam de método outros chamam de processo ou, ainda, de técnica. ${ }^{9}$

O método tem como finalidades conduzir à descoberta de verdades ainda desconhecidas; permite demonstrar e provar uma verdade já conhecida e, ainda, verificar conhecimentos para averiguar se são ou não verdadeiros. É, portanto, um instrumento racional que para a aquisição, demonstração e verificação de conhecimentos. ${ }^{10}$

O que existe de mais consensual é a caracterização dos métodos de abordagem como mais amplos sobre os fenômenos da natureza e da sociedade, em nível de abstração mais elevado. Constituem-se de procedimentos gerais, baseados em princípios lógicos, permitindo sua utilização em várias ciências. São exclusivos entre si, embora se admita a possibilidade de mais de um método de abordagem ser empregado em uma pesquisa.

Conforme o tipo de raciocínio empregado, os métodos de abordagem recebem as seguintes denominações: dedutivo, indutivo e dialético.

\section{Método Indutivo}

\footnotetext{
7- Pesquisa ou trabalho de campo ocorre quando o pesquisador colhe os dados no local (campo) onde se dão os fenômenos. As denominações " pesquisa de campo" e "pesquisa de laboratório" referem-se ao ambiente em que elas se realizam e não às características ou o tipo da pesquisa.

8- LUNGARZO, Carlos. O que é ciência. 7. Ed. São Paulo: Brasiliense, 1995. p. 41

9 - BAZARIAN, Jacob. Introdução à sociologia: as bases materiais da sociedade. 2. Ed. São Paulo: AlfaOmega, 1986. p.80

10- CHAUI, Marilena. Convite ã filosofia São Paulo: Ática 1994. p. 157
} 
A indução é o raciocínio que parte do particular para o geral, colocando a generalização como um produto posterior do esforço de coleta dos casos particulares. Procede da observação dos fenômenos para as leis que os regem. O raciocínio indutivo parte do estudo de um certo número de casos e, com base nos dados observados, se infere uma idéia geral. Permite inferir o conhecimento de algo desconhecido partindo do que conhece. Coloca como ponto de partida a observação verificável.

A indução, diz Bazarian" "é o método científico por excelência e, por isso mesmo, é o método fundamental das ciências naturais e sociais". Ao partir do particular ao geral não assegura a verdade da conclusão. É incompleta e passível de erro, mesmo assim é o raciocínio mais utilizado nas ciências.

\section{Método dedutivo}

É o raciocínio que vai do conhecimento geral ao particular. O ponto de partida, portanto, é um princípio tido como verdadeiro a priori. O ponto de chegada é aquilo que se quer provar; uma tese, uma conclusão.

O método dedutivo goza de prestígio desde Aristóteles. Nele as explicações científicas devem ter uma forma de dedução lógica. No raciocínio dedutivo as premissas devem ser verdadeiras, razão pela qual a condução também o será.

\section{Método Dialético}

A dialética é aceita desde a Antigüidade grega. Platão não deixou sistematizado seu processo de pensamento, nem esquematizou um modelo. A dialética platônica procede da maiêutica socrática. Para Platão o diálogo deveria caminhar à procura da razão e da essência das coisas, partindo de noções sensíveis e incertas até alcançar idéias imutáveis e perfeitas. Com esse propósito, debates desinteressados por amor à pesquisa giravam em torno da justiça, virtude, piedade e bondade.

Retomada Hegel, idealista alemão do século XIX, a dialética ganha outro sentido. Ele estabelece uma nova atitude filosófica sobre o conhecimento. Supera o racionalismo que endeusa a razão como verdade absoluta, mostrando que o conhecimento não é absoluto, mas constituído através de um movimento dos contrários (lei da dialética: tese, antítese e síntese). Marx e Engels, numa crítica a sociedade capitalista como forma de organização social e na tentativa de apresentarem propostas para a sua superação, retomam a visão de Hegel, e elaboram uma nova concepção do mundo, o que supõem uma nova teoria do conhecimento: o materialismo dialético. ${ }^{12}$ Nessa concepção, a realidade não é estática, mas está em constante transformação movida pelas contradições internas. Este método aplicado à história é o materialismo histórico.

O método dialético é um método de investigação da realidade que se apresenta em forma de leis. Ampliado em Hegel, Engels reduz a três o número de leis da 
dialética. São elas: Lei da passagem da qualidade à quantidade; lei da unidade da luta dos contrários e a lei da negação da negação. ${ }^{13}$

O princípio da passagem da quantidade em qualidade é uma possibilidade em todos os fenômenos e objetos. Certos graus de mudanças quantitativas geram mudanças qualitativas como, por exemplo, as alterações da intensidade de calor na água, a quantidade de informação que um indivíduo tem para julgar um fato, a mudança do modo de produção capitalista (aumento quantitativo do proletariado, das diferenças de classes, da acumulação de riquezas) para o socialista. Esse princípio explica como ocorre o desenvolvimento.

O princípio da unidade e da luta dos contrários explica por que ocorre o desenvolvimento. Considerando a realidade em movimento, as transformações são decorrentes da contradição interna, da luta dos contrários. Os opostos estão em permanente interação funcionando como fonte essencial do movimento. Os contrários são interdependentes; um não existe sem o outro, o que constitui a unidade dos contrários.

A lei da negação da negação explica a relação existente entre o velho e o novo no processo de transformação dos fenômenos. É resultado da luta dos contrários e significa a passagem do inferior para o superior ou vice-versa. A terceira condição gerada pelas forças em contradição, não significa a destruição do velho, mas sua recriação. O novo também envelhece e é negado por outro fenômeno. O movimento do mundo e do pensamento é explicado, portanto, pela tese, antítese e síntese. A dialética, portanto, não substitui a indução, assim como a indução não substitui a dedução. "A dialética pressupõe ambas pelo fato de serem elas insuficientes às ciências humanas nascentes, lacuna que ela veio preencher."14

\section{Métodos de procedimento particulares das ciências sociais}

Constituem etapas mais concretas de investigação, com finalidades mais restritas para a explicação geral dos fenômenos menos abstratos. Ao contrário dos métodos de abordagem, têm caráter mais específico, relacionando-se com as etapas de um plano de trabalho e não com o plano geral. ${ }^{15}$ Os métodos histórico, comparativo, estatístico, funcionalista, monográfico (ou estudo de caso), são alguns métodos de procedimento no campo das ciências sociais.

Método histórico: Consiste no estudo de acontecimentos, instituições, sociedades e culturas de tempos diferentes na busca de compreender a origem e seu processo de transformação.

Método Comparativo: Consiste na realização de comparações de fenômenos

13 - TRIVIÑOS, Augusto N.S. Introdução à pesquisa em ciências Sociais. São Paulo: Atlas, 1987. p.65 14 - BASTOS, Cleverson, KELLER, V. Introdução à metodologia científica. 8. ed. Petrópolis: Vozes, 1996. p. 91.

15 - ANDRADE, Maria Margarida de. Introdução à metodologia do trabalho científico. São Paulo: Atlas, 1994. p. 107. 
sociais ocorridos na mesma época ou em momentos históricos distintos com a finalidade de verificar aspectos diferentes e semelhantes, dados específicos, gerais, constantes e ocasionais.

Método Estatístico: É a descrição, análise e demonstração dos fenômenos de forma quantitativa. Possibilita a investigação dos processos de obtenção, organização e análise de dados tanto no campo das ciências humanas quanto naturais, bem como, as formas de prognosticar e tirar conclusões com base nesses dados. Com base em alguns fatores, por exemplo, pode prognosticar o índice do aumento da população de Ribeirão Preto no ano 2005.

Método Funcionalista: $O$ funcionalismo estuda a sociedade sob o ponto de vista das funções de suas unidades. A sociedade é tida como um organismo, tendo cada unidade sua função. Estabelece-se analogia entre o corpo social e o biológico através da idéia de que cada parte ajuda a preservar o todo, ou seja, da mesma forma que um órgão (coração, pulmão, fígado) mantém a vida no ser humano o indivíduo ou a instituição (família, igreja, escola) mantém a ordem social vigente. $\mathrm{O}$ funcionalismo está ligado ao nome de Malinowski. Constituise muito mais em um método de interpretação dos fatos do que em um método de investigação.

Método Monográfico: Teve como pioneiro Le Play. Era aplicado em estudo profundo sobre um objeto de pesquisa bem delimitado como religião e os hábitos morais da família, a história da família, os modos de vida, etc. Posteriormente essa orientação foi desenvolvida e aperfeiçoada. Passou a ser utilizado também de forma mais abrangente. Ao invés de servir para estudar um aspecto de um grupo, passou a ser utilizado para estudar vários aspectos de um grupo.

\subsection{2- Técnicas de Pesquisas}

São as etapas de aplicação de um método. O método é a estratégia e as técnicas são as táticas necessárias para sua aplicação. $\mathrm{O}$ método estabelece o que fazer e as técnicas como fazer. Corresponde à parte prática da coleta de dados.

São os diversos procedimentos ou os diversos recursos utilizados, peculiares a cada objeto de estudo ou a cada área do conhecimento.

Lakatos e Marconi ${ }^{16}$ apresentam duas grandes divisões de técnicas: documentação indireta e documentação direta.

1.7.2.1- Documentação indireta: Refere-se à pesquisa bibliográfica e documental

- explica um fenômeno a partir de referências publicadas em livros, revistas especializadas, etc.; 
- procura conhecer e analisar contribuições culturais ou científicas existentes sobre um determinado assunto;

- constitui geralmente o primeiro passo de qualquer pesquisa científica;

- pode ser realizada como parte de uma pesquisa descritiva ou experimental ou, ainda, de forma independente;

- a pesquisa bibliográfica é um meio de formação por excelência.

\subsubsection{2- documentação direta}

Esta fase divide em observação direta intensiva e observação direta extensiva

\section{Observação direta intensiva:}

observação - é a utilização dos sentidos na obtenção de determinadas informações sobre a realidade. Consiste em ver, ouvir e examinar fatos ou fenômenos que se deseja estudar. Pode ser: sistemática, assistemática; participante, não-participante; Individual, em equipe; na vida real, em laboratório.

entrevista - consiste na conversação realizada face a face, de maneira metódica que proporciona ao entrevistador as informações necessárias.

Tipos: padronizada ou estruturada, despadronizada ou não-estruturada.

\section{Observação direta extensiva:}

questionário: constituído por uma série de perguntas que devem ser respondidas por escrito e sem a presença do pesquisador;

formulário: roteiro de perguntas enunciadas pelo entrevistador e preenchidas por ele com as respostas do pesquisado;

medidas de opinião e de atitudes: instrumento de "padronização", por meio do qual se pode assegurar a equivalência de diferentes opiniões e atitudes, com a finalidade de compará-las;

testes: instrumentos utilizados para obter dados que permitam medir o rendimento, a freqüência, a capacidade ou a conduta de indivíduos, de forma quantitativa;

sociometria: técnica quantitativa que procura explicar as relações pessoais entre indivíduos de um grupo;

análise de conteúdo: permite a descrição sistemática, objetiva e quantitativa do conteúdo da comunicação;

história de vida: tenta obter dados relativos à "experiência íntima" de alguém que tenha significado importante para o conhecimento do objeto em estudo;

pesquisa de mercado: é a obtenção de informações sobre o mercado, de maneira organizada e sistemática, tendo em vista ajudar o processo decisivo nas empresas, minimizando a margem de erros.

Seja qual for a técnica(s) escolhida(s), é importante descrever as características e a forma de sua aplicação, indicando, inclusive, como se pretende codificar e 
tabular os dados obtidos.

\section{8- Referências Bibliográficas}

Relação ordenada dos livros, artigos, entrevistas, documentos e publicações utilizadas nas diversas fases da pesquisa e de acordo como as normas da ABNT (Associação Brasileira de Normas Técnicas).

\section{9- Cronograma}

Previsão de tempo para cada fase da pesquisa. Algumas das fases podem ser executadas simultaneamente pelos membros da equipe ou pelo pesquisador, enquanto outras dependem das fases anteriores.

Também responde à questão quando fazer? 


\section{BIBLIOGRAFIA}

ANDRADE, Maria Margarida de. Introdução à metodologia do trabalho científico. São Paulo: Atlas, 1994.

BARROS, Aidil Jesus Paes de, LEHFELD, Neide Ap. de Souza. Fundamentos de metodologia. Rio de Janeiro: McGraw-Hill, 1989.

.Projeto de pesquisa: propostas metodológicas. 13. ed. Petropólis: Vozes,2002.

BASTOS, Cleverson; KELLER, V. Introdução à metodologia científica. 8.ed. Petrópolis: Vozes, 1996.

BAZARIAN, Jacob. Introdução à sociologia: as bases materiais da sociedade. 2.ed. São Paulo: Alfa-Omega, 1986.

BOAVENTURA, Edivaldo. Como ordenar as idéias. São Paulo: Ática, 1988.

BORGES, Vavy Pacheco. O que é história. 10.ed. São Paulo: Brasiliense, 1986.

CERVO, Amado Luiz, BERVIAN, Pedro Alcino. Metodologia científica. 4.ed. São Paulo: Makron Books, 1996.

DEMO, Pedro. Metodologia científica em ciências sociais. São Paulo: Atlas, 1985.

FACHIN, Odília. Fundamentos de metodologia. São Paulo: Atlas, 1993

GALLIANO, A. Guilherme. Método científico: teoria e prática. S.d.

GIL, Antonio Carlos. Como elaborar projetos de pesquisa. São Paulo: Atlas, 1991.

LAKATOS, Eva Maria, MARCONI, Marina de Andrade. Fundamentos de metodologia científica. 3.ed. São Paulo: Atlas, 1991.

LOPES, Maria Immacolata Vassalo. Pesquisa em comunicação: formulação de um modelo metodológico. São Paulo: Edições Loyola, 1990.

LUNGARZO, Carlos. O que é ciência. 7.ed. São Paulo: Brasiliense, 1995.

MARCANTONIO, Antonia Terezinha, SANTOS, Martha Maria dos, LEHFELD, Neide Ap. de Souza. Elaboração e divulgação do trabalho científico. São Paulo: Atlas, 1993.

RUIZ, João Álvaro. Metodologia científica: guia para eficiência nos estudos. 3.ed. São Paulo: Atlas, 1995.

TRIVIÑOS, Augusto N.S. Introdução à pesquisa em ciências Sociais. São Paulo: Atlas, 1987. 


\section{UNIVERSIDADE SANTA CECÍLIA}

\section{DIRETRIZES PARA ELABORAÇÃO DE TRABALHO DE CONCLUSÃO DE CURSO DE GRADUAÇÃO (TCC)}

Santos - SP

Janeiro/2007

\section{APRESENTAÇÃo}

A Universidade Santa Cecília (UNISANTA), atenta à produção, ao registro e à divulgação do conhecimento no âmbito da universidade, traz aos corpos docente e discente a segunda versão das DIRETRIZES PARA ELABORAÇÃO DE TRABALHO DE CONCLUSÃO DE CURSO DE GRADUAÇÃO (TCC), dividida em três partes.

Num primeiro momento, seguem normas destinadas à realização dos Trabalhos de Conclusão de Curso dos diversos Cursos de Graduação mantidos pela Universidade Santa Cecília (UNISANTA). Todo e qualquer TCC desenvolvido nesta Universidade, a partir do $1^{\circ}$. semestre letivo de 2007, passa a ser regido por tais diretrizes, devidamente apreciadas e aprovadas pelo Conselho de Ensino, Pesquisa e Extensão de Serviços à Comunidade e homologadas pelo Conselho Universitário.

Em segundo lugar, aponta-se a estrutura formal de um trabalho científico, com a devida explanação de cada elemento constitutivo de um texto acadêmico.

Em terceiro plano, colocam-se instruções gerais para elaboração de trabalhos acadêmicos.

Cabe ressaltar que as recomendações aqui preconizadas têm como base as estabelecidas pela Associação Brasileira de Normas Técnicas - ABNT -, entidade que, no Brasil, padroniza e disciplina normas técnicas e documentárias. Portanto, frisa-se uma vez mais que todos os TCCs produzidos nesta Universidade, embora diferentes quanto à sua natureza, extensão e profundidade, devem observar os critérios da metodologia científica apresentados.

Não parece demais alertar que a simples observância das convenções e normas contidas neste documento é incapaz, por si só, de assegurar a qualidade e a relevância do estudo desenvolvido pelo aluno/pesquisador. Para tanto, é preciso, além do rigor formal, a escolha adequada do tema, o acesso a fontes autorizadas que dêem suporte à fundamentação teórica, uma orientação competente e, de modo imprescindível, o trabalho árduo e desafiante que caracteriza a atividade de pesquisa.

Profa. Ms. Ana Fátima B. Silva Monteiro

Prof. Ms. Antonio Carlos Simonian dos Santos

Profa. Ms. Deborah Cristina S. G. Rapoport

Prof. Dr. Deovaldo de Moraes Júnior

Profa. Dra. Katya Lais Ferreira Patella - (Relatora)

Profa. Dra. Maria Lúcia de Godoy

Prof. Dr.Roberto Fernandes da Costa

Prof. Dr. Robson Bastos da Silva - (Coordenador)

Prof. Dr. Valter Librandi 


\section{NORMAS PARA ELABORAÇÃO DE TRABALHO DE CONCLUSÃO DE CURSO DE GRADUAÇÃO}

O Conselho de Ensino, Pesquisa e Extensão de Serviços à Comunidade da Universidade Santa Cecília, nos termos do Capítulo III, artigo 31, inciso X do Estatuto, Título II, Capítulo III, artigo 16 do Regimento Geral e ainda de acordo com a legislação em vigor sobre o assunto, baixa as Normas para Elaboração de Trabalho de Conclusão de Curso dos diversos Cursos de Graduação mantidos pela Universidade.

\section{CAPÍTULO I}

\section{Da Natureza e das Finalidades}

Art. 10. - A Universidade Santa Cecília, dotada de autonomia didático-científica, exercida na forma da lei, estabelece Normas para a realização obrigatória de Trabalho de Conclusão de Curso (doravante TCC) de seus diversos Cursos de Graduação.

Art. $2^{\mathbf{o}}$. - O estabelecimento de tais Normas visa assegurar aos corpos docente e discente da Universidade condições de desenvolvimento pleno das atividades relacionadas ao TCC nos diferentes Cursos de Graduação.

Art. $3^{\circ}$. - O TCC consiste em um estudo aprofundado sobre determinado tema de interesse, vinculado ao Curso no qual o aluno está se graduando.

Art. $4^{\circ}$. - O TCC propicia a complementação do processo ensino-aprendizagem. É planejado, executado, acompanhado e avaliado conforme os conteúdos programáticos e calendários escolares, constituindo-se em enriquecimento curricular, no que tange ao aperfeiçoamento técnico-cultural, científico e humano.

Art. 5'. - O tema do TCC poderá ser desenvolvido individualmente ou em grupo com número de componentes a ser definido pela Comissão de TCC de cada curso.

Parágrafo único: A Comissão de TCC é composta pelos seguintes membros: Diretor do Curso, Coordenador do Curso e Coordenador de TCC do Curso.

Art. $6^{0}$. - O TCC poderá assumir caráter monográfico ou profissional. No que se refere à monografia, encontram-se, nas partes 2 e 3 deste documento, instruções para sua elaboração. No que tange ao trabalho profissional, este deve vir acompanhado de relatório técnico, cujo padrão segue incluso também nas partes 2 e 3 deste documento.

\section{CAPÍTULO II}

Da Escolha do Tema

Art. $7^{\circ}$. - O tema, de livre escolha do aluno/grupo, deve estar vinculado à sua futura atuação profissional.

\section{CAPÍTULO III}

\section{Das Fases de Desenvolvimento do Trabalho de Conclusão de Curso}

Art. $\mathbf{8}^{\mathbf{0}}$ - São as seguintes as fases do TCC:

I - escolha do tema; 
II - indicação do Professor-Orientador;

III - preenchimento e protocolização, na Secretaria ou Coordenação do Curso, da Ficha de Inscrição para Início de Orientação (anexo A).

\section{CAPÍTULO IV}

\section{Da Escolha do Professor-Orientador}

Art. $9^{\circ}$ - O aluno/grupo poderá indicar seu professor-orientador, dentre o Corpo Docente do Curso.

Parágrafo único - O aluno/grupo poderá solicitar a troca de orientador, desde que apresente, por escrito, justificativa para tal solicitação e declaração de disponibilidade do novo orientador para exercer a função.Tal justificativa será avaliada pela Comissão de TCC responsável pelo curso (anexo B).

Art. 10 - A Coordenação do Curso reservará, no Plano de Trabalho dos membros do Corpo Docente, 01 (uma) hora-aula semanal, por trabalho, para orientação, exame e elaboração de pareceres para a aferição do TCC.

Art. 11 - O aluno/grupo, quando da indicação de seu orientador, deverá considerar os seguintes aspectos:
a) experiência docente;
b) afinidades intelectuais, profissionais e pessoais;
c) linhas de pesquisa mais adequadas ao seu trabalho;
d) disponibilidade do docente.

\section{CAPÍTULO V}

\section{Do Professor-Orientador do TCC}

Art. 12 - Cabe ao Professor-Orientador do TCC:

I - organizar e supervisionar todas as atividades do TCC;

II - criar mecanismos operacionais que facilitem a condução, com segurança e aproveitamento, do TCC desenvolvido pelo aluno/grupo;

III - orientar o aluno/grupo no desempenho de suas atividades, complementando a formação educacional/profissional do discente;

IV - fazer cumprir os cronogramas e os prazos das atividades do TCC;

V - registrar todas as atividades desenvolvidas com o aluno/grupo, em ficha padronizada (anexo C). Tal ficha deverá ser entregue à Comissão de TCC de cada curso, segundo o cronograma estabelecido por tal comissão;

VI - zelar pelo cumprimento das Diretrizes e Normas do TCC.

Art. 13 - Cada Professor-Orientador assumirá, no máximo, 4 (quatro) trabalhos. Casos excepcionais serão resolvidos pela Comissão de TCC de cada curso.

\section{CAPÍtULO VI}

\section{Da Banca Examinadora}

Art. 14 - A Banca Examinadora será composta, obrigatoriamente, pelo professor-orientador, que a preside, e por outros 2 (dois) membros, indicados e designados pela Comissão de TCC 
§ $\mathbf{1}^{\mathbf{0}}$. - Poderá fazer parte da Banca Examinadora um membro escolhido entre os professores de outras áreas, com interesse na área de abrangência da pesquisa, ou de Cursos de Instituições de Ensino Superior, ou ainda entre profissionais de nível superior que exerçam atividades afins com o tema do TCC.

$\S 2^{\circ}$. - A banca examinadora somente poderá realizar seus trabalhos com a presença dos 3 (três) membros.

§ 3'. - Não comparecendo algum dos professores designados para a Banca Examinadora, tal ausência deverá ser comunicada, por escrito, à Comissão de TCC.

$\S 4^{\circ}$. - Não havendo o comparecimento do número mínimo de membros da Banca Examinadora fixado no $\S 2^{\circ}$, a Comissão de TCC marcará nova data para a defesa.

§ $5^{\circ}$. - Deverá, sempre que possível, ser mantida a eqüidade no número de indicações de cada professor para compor as Bancas Examinadoras, procurando, ainda, evitar-se a designação de quaisquer dos docentes para um número superior a $10(\mathrm{dez})$ bancas examinadoras por ano.

\section{CAPÍTULO VII}

\section{Da Apresentação do Trabalho de Conclusão de Curso}

Art. 15 - A apresentação do TCC dar-se-á em duas etapas - escrita e oral - e obedecerá às exigências constantes das presentes Normas na parte referente ao Regulamento da Defesa, que assim se dispõe:

I - Quanto à parte escrita da monografia ou do relatório técnico:

a) Cada aluno/grupo deverá fornecer 3 (três) cópias espiraladas do TCC, sendo 1 (uma) para o ProfessorOrientador e 2 (duas) para os outros 2 (dois) membros da Banca Examinadora.

b) Após a defesa oral, o aluno/grupo aprovado terá prazo máximo de 15 (quinze) dias para entregar ao Coordenador de TCC a versão final do trabalho, ou seja, uma cópia em capa dura, com as devidas correções sugeridas pela Banca e acatadas pelo orientador. ATENÇÃO: a divulgação da nota está condicionada a essa entrega. Ressalta-se que só farão parte do acervo da biblioteca da UNISANTA trabalhos que obtiverem nota igual ou superior a 9,0 (nove).

c) O TCC, obrigatoriamente, deverá conter pré-texto, texto e pós-texto, especificados na parte 2 deste documento.

II - Quanto à parte oral:

a) O cronograma de apresentação será fornecido pela Comissão de TCC de cada curso, respeitado o calendário escolar.

b) Todo TCC será defendido, oralmente, pelo seu(s) autor(es). No caso de trabalhos realizados em grupo, todos os integrantes do mesmo devem expor, individualmente, a parte pela qual ficaram responsáveis.

c) Serão concedidos, no máximo, 30 minutos para o aluno/grupo apresentar seu trabalho, podendo utilizar-se dos meios disponíveis pela Universidade para uma suficiente defesa do TCC.

d) Cada integrante da Banca Examinadora terá prazo máximo de 10 minutos para argüir o aluno/grupo, sendo obrigatória a participação de todos os docentes.

e) A sessão de defesa do TCC será pública.

Parágrafo único - Não será permitido aos membros das bancas examinadoras tornarem públicos os conteúdos dos trabalhos antes de suas defesas.

Art. 16 - O aluno/grupo somente poderá participar da defesa oral mediante aprovação do Professor-Orientador. 


\section{CAPÍTULO VIII}

\section{Da Avaliação do Trabalho de Conclusão de Curso}

Art. 17 - O processo de avaliação do TCC ocorrerá em 3 (três) etapas, antes da Banca Examinadora:

a) Primeira Avaliação: o aluno/grupo irá elaborar uma Proposta de Trabalho (briefing, anteprojeto ou similares) onde deverão constar todas as informações sobre o desenvolvimento do seu trabalho durante o ano. Ex: Introdução ou Apresentação, Objetivos, Custos, Cronograma, Metodologia, Referências.

b) Segunda Avaliação: cada aluno/grupo fará uma apresentação pública do Trabalho. Para tanto, deverá entregar um resumo com as atividades desenvolvidas e a desenvolver, para a pré-banca, composta de dois professores, que argüirão e avaliarão o aluno/grupo. É facultada a participação do orientador. Critérios para a apresentação: 10 minutos de exposição e 5 minutos para a argüição de cada avaliador (anexo D)

c) Terceira Avaliação: o orientador deverá elaborar um relatório onde descreverá, de forma clara, objetiva e criteriosa, o desenvolvimento de seu(s) orientando(s). Nesse documento, ele deverá atribuir uma nota de 0 (zero) a 10,0 (dez) a cada aluno. Nota inferior a 5,0 (cinco) implica reprovação, isto é, o aluno/grupo só poderá apresentar o trabalho no semestre seguinte, conforme calendário estipulado pela Comissão de TCC de cada curso. Itens mínimos presentes no relatório: frequiência/participação; cumprimento do cronograma; pesquisa bibliográfica; desenvolvimento do trabalho; redação do texto; métodos empregados.

Art. 18 - Os trabalhos que, após as três avaliações explicitadas no art. 17, forem aprovados para a apresentação final deverão ser entregues e protocolados na Secretaria da Direção ou na Coordenação de Curso e/ou Coordenação de TCC de cada curso, na data determinada pela Comissão de TCC. Após essa data, não será mais possível proceder à sua entrega.

Art. 19 - A atribuição de notas dar-se-á após o encerramento da etapa de argüição, obedecendo ao sistema de notas individuais por examinador, levando em consideração o texto escrito (monografia ou relatório técnico), a parte prática (quando for o caso), a sua exposição oral e a defesa, quando da argüição pela banca examinadora.

§ $\mathbf{1}^{\mathbf{0}}$ - Utilizar-se-ão, para a atribuição das notas, fichas de avaliação individuais (anexo E), onde o professor aporá suas notas para cada item a ser considerado.

$\S 2^{\mathbf{o}}$ - A nota final do aluno será o resultado da média aritmética das notas atribuídas pelos membros da comissão examinadora e da avaliação feita pelo professor-orientador (vide capítulo VIII - art. 17 - item c).

$\S 3^{\circ}$ - Para aprovação, o aluno deverá obter nota igual ou superior a 7,0 (sete) na média das notas individuais atribuídas pelos membros da banca examinadora. Ao aluno/grupo que obtiver média abaixo de 7,0 (sete), será concedido um prazo para a refacção do TCC. Esse prazo será estabelecido pela Comissão de TCC de cada curso.

Parágrafo único: A nota final do aluno/grupo que refizer o trabalho terá o valor máximo de 7,0 (sete), sendo o valor mínimo 5,0.

Art. 20 - O discente que, sem justificativa, deixar de comparecer à apresentação oral de seu trabalho será reprovado.

Parágrafo único - O aluno/grupo poderá solicitar recurso à Comissão de TCC de seu curso, que analisará o pedido, observando o regimento da Universidade.

\section{CAPÍTULO IX}

Das Disposições Gerais e Transitórias

\section{Art. 21 - DIREITO AUTORAL}

LEI 9.610 - Presidência da República 19/02/1988.

Art. $1^{\circ}$ Esta Lei regula os direitos autorais, entendendo-se sob esta denominação os direitos de autor e os que lhes são conexos. 
Art. $7^{\circ}$ São obras intelectuais protegidas as criações do espírito, expressas por qualquer meio ou fixadas em qualquer suporte, tangível ou intangível, conhecido ou que se invente no futuro, tais como:

I - os textos de obras literárias, artísticas ou científicas;

II - as conferências, alocuções, sermões e outras obras da mesma natureza;

Art. 22 -

(APENAS PARA OS CURSOS DE DIREITO DA UNISANTA).

O Trabalho de Curso é componente curricular obrigatório, desenvolvido individualmente, com conteúdo a ser fixado pelas Instituições de Educação Superior em função de seus Projetos Pedagógicos.

Parágrafo Único: AS IES deverão emitir regularmentação própria aprovada por Conselho competente, contendo necessariamente, critérios, procedimentos e mecanismos de avaliação, além das diretrizes técnicas relacionadas com a sua elaboração.

Fonte: Artigo 10.- Conselho Nacional de Educação Superior - Resolução no 9 de 29/092004. (Diretrizes Curriculares Nacionais dos Cursos de graduação em Direito)

Art. 23 - Os casos omissos serão resolvidos pela Comissão de TCC de cada curso.

Art. 24- As presentes Normas para Elaboração de Trabalho de Conclusão de Curso de Graduação (TCC) passarão a vigorar a partir da apreciação e aprovação do Conselho de Ensino, Pesquisa e Extensão de Serviços à Comunidade e homologação do Conselho Universitário. 


\section{REFERÊNCIAS}

ASSOCIAÇÃO BRASILEIRA DE NORMAS TÉCNICAS. Informação e Documentação - Referências - Elaboração: NBR 6023, Rio de Janeiro, 2000.

Resumos. NBR 6028. Rio de Janeiro, 1988.

. Sumário: NBR 6027. Rio de Janeiro, 1988.

BARRAS, R. Os cientistas precisam escrever. Guia de redação para cientistas, engenheiros e estudantes. Trad. Leila Moraes e Leonidas Negenberg. São Paulo: EDUSP, 1979.

BASTOS, L. R. et al. Manual para a elaboração de projetos e relatórios de pesquisa, teses, dissertações e monografias. 4 ed. Rio de Janeiro: LTC, 1998.

CERVO, A. L.; BERVIAN, P.A. Metodologia Científica. 4 ed. São Paulo: Makron Books, 1996.

COSTA, Roberto Fernandes; SANTOS, Antonio Carlos Simonian dos. Manual de normas para elaboração de monografias. Santos: Universidade Santa Cecília, 2004.

ECO, U. Como se faz uma tese. 12. ed. Perspectiva: São Paulo, 1985.

GAVA, N. S.; GIORGETTI, M. .F. Norma recomendada para elaboração de plano de pesquisa, dissertação e teses. São Carlos: Escola de Engenharia de São Carlos da Universidade de São Paulo, 1980.

LAKATOS, E. M; MARCONI, M. A. Metodologia Científica. 2 ed. São Paulo: Atlas, 1991.

MORAES Jr., Deovaldo; MORAES, Marlene da Silva. Recomendações para elaboração de relatórios de experimentos didáticos, trabalhos de iniciação científica, dissertações e teses. Normas brasileiras. Digitação de equações e tabelas. Santos: UNISANTA, 2004

MORETTI FILHO, J. Redação de dissertação e tese. Piracicaba: Fundação de Estudos Agrários Luiz de Queiroz, 1982.

NOGUEIRA, J.B.; NOGUEIRA, M.C.A. Manual de redação de trabalhos científicos. São Carlos: Escola de Engenharia de São Carlos da Universidade de São Paulo, 1985.

PESCUMA, D.; CASTILHO, A. P. F. Referências Bibliográficas: um guia para documentar suas pesquisas. São Paulo: Olho dágua, 2001.

SEVERINO, A. J. Metodologia do Trabalho Científico. 21 ed., São Paulo: Cortez, 2000. 
ANEXO A - Modelo de Ficha de Inscrição para Início de Orientação

UNIVERSIDADE SANTA CECÍLIA

FACULDADE DE ARTES E COMUNICAÇÃO

JORNALISMO

FICHA DE INSCRIÇÃO PARA INÍCIO DE ORIENTAÇÃO DE TRABALHO DE CONCLUSÃO DE CURSO DE GRADUAÇÃO

1. Identificação do aluno ou grupo

\begin{tabular}{|l|l|l|l|l|}
\hline Nome do aluno & No.matrícula & Assinatura do aluno & Telefone(s) para contato & e-mail \\
\hline & & & & \\
\hline & & & & \\
\hline
\end{tabular}

2. Título provisório do trabalho

3. Tema do trabalho

4. Objetivo(s) do trabalho

5. Breve justificativa para a realização do trabalho

6. Nome completo do orientador

7. Titulação do orientador: ( ) Graduado ( ) Especialista ( ) Mestre ( ) Doutor

8. Área de atuação do orientador

9. Apreciação do orientador, manifestando sua concordância em orientar o aluno/grupo

10. Assinatura do orientador Local e data 
ANEXO B - Modelo de Formulário para Troca de Orientador

UNIVERSIDADE SANTA CECÍLIA

FACULDADE DE ARTES E COMUNICAÇÃO

JORNALISMO

FORMULÁRIO PARA TROCA DE ORIENTADOR DE TRABALHO DE CONCLUSÃO

DE CURSO DE GRADUAÇÃO

1. Identificação do aluno ou grupo

\begin{tabular}{|l|l|l|l|l|}
\hline Nome do aluno & No.matrícula & Assinatura do aluno & Telefone(s) para contato & e-mail \\
\hline & & & & \\
\hline & & & & \\
\hline
\end{tabular}

2. Título provisório do trabalho

3. Nome completo do ex-orientador

4. Breve justificativa para a realização de troca de orientador

5. Nome do novo orientador

5. Titulação do novo orientador

7. Área de atuação do novo orientador

8. Apreciação do novo orientador, manifestando sua concordância em orientar o aluno ou o grupo

9. Assinatura do novo orientador

10. Assinatura do ex-orientador

11. Apreciação da Coordenação de TCC

12. Local e data 
ANEXO C - MODELO de Ficha de Registro das Atividades Desenvolvidas pelo Aluno/Grupo de Trabalho de Conclusão de Curso

UNIVERSIDADE SANTA CECÍLIA

FACULDADE DE ARTES E COMUNICAÇÃO

JORNALISMO

FICHA DE REGISTRO DAS ATIVIDADES DESENVOLVIDAS PELO ALUNO/GRUPO

DE TRABALHO DE CONCLUSÃO DE CURSO

1. Identificação do aluno/grupo

\begin{tabular}{|l|l|l|}
\hline Nome do aluno & Número de matrícula & Assinatura do aluno \\
\hline & & \\
\hline & & \\
\hline
\end{tabular}

2. Título provisório do trabalho

3. Nome completo do orientador

4.Registro das reuniões entre orientador e aluno/grupo

\begin{tabular}{|l|l|l|l|}
\hline Data da reunião & Local da reunião & Aluno(s) presente(s) & $\begin{array}{l}\text { Atividades } \\
\text { programadas }\end{array}$ \\
\hline & & & \\
& & & \\
\hline & & & \\
\hline & & & \\
& & & \\
\hline
\end{tabular}


ANEXO D - Modelo de Ficha de Avaliação de Trabalho de Conclusão de Curso de Graduação - Pré-Banca

UNIVERSIDADE SANTA CECÍLIA

FACULDADE DE ARTES E COMUNICAÇÃO

JORNALISMO FICHA DE AVALIAÇÃO DE TRABALHO DE CONCLUSÃO DE CURSO
PRÉ-BANCA

1. Identificação do aluno/grupo

\begin{tabular}{|l|l|l|}
\hline Nome do aluno & Número de matrícula & Assinatura do aluno \\
\hline & & \\
\hline & & \\
\hline
\end{tabular}

2. Nome completo do orientador

3 Título provisório do trabalho

4. Objetivo do trabalho

5. Pertinência da pesquisa

6. Viabilidade da execução do trabalho

7. Observações

Prof.

Prof.

Santos, __de___ de 
ANEXO E - Modelo de Ficha de Avaliação de Trabalho de Conclusão de Curso de Graduação

UNIVERSIDADE SANTA CECÍLIA

FACULDADE DE ARTES E COMUNICAÇÃO

JORNALISMO

INDICAÇÕES PARA A BANCA EXAMINADORA:

\section{1 - TEMA:}

Viabilidade e Relevância da Pesquisa para a área.

\section{2- TEXTO:}

(Clareza, Objetividade, Ortografia, Adequação da linguagem ao tema Proposto).

\section{3 - PESQUISA:}

(De campo, Bibliográfica, Entrevista).

\section{4 - APRESENTAÇÃO ORAL:}

(Clareza, Correção, Postura, Desembaraço, Utilização de recursos audio-visuais. ) 

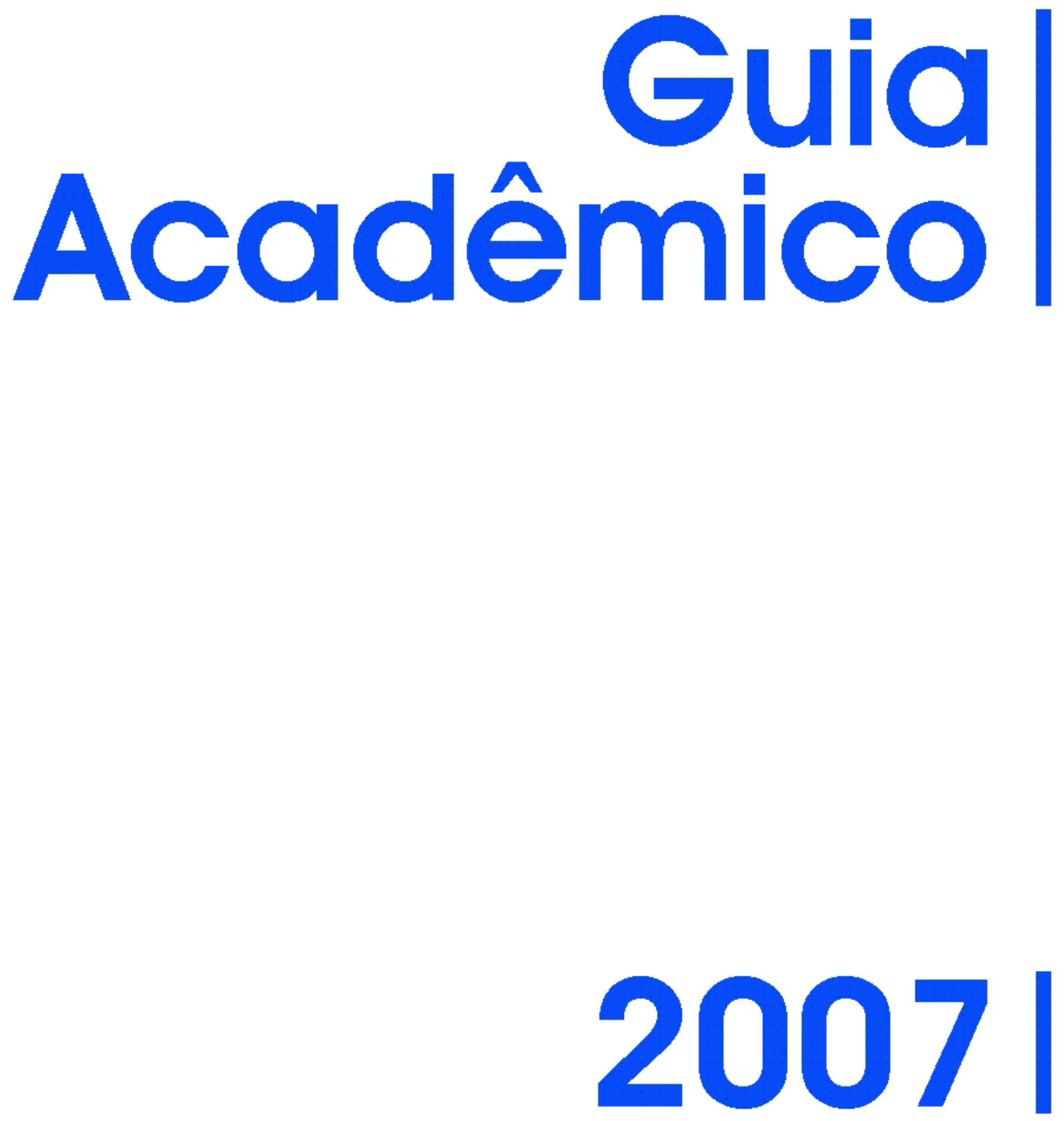


\section{Saudação}

em-vindo (a) ao ano acadêmico de 2007! É com grande alegria que a Reitoria da Católica UNISANTOS lança a nova edição do Guia Acadêmico. O objetivo é apresentar aos alunos, professores e funcionários as linhas gerais do novo ano acadêmico, familiarizar os novos alunos com as normas e rotinas da vida universitária,bem como oferecer informações sobre os principais setores da instituição.

Esperamos que a leitura seja útil. O Guia tem a função de orientar alunos e professores sobre todos os procedimentos necessários para que possam ter um período letivo bastante produtivo, tanto no que se refere à produção acadêmica, quanto na construção da comunidade universitária.

No Guia Acadêmico 2007 encontram-se informações sobre a estrutura organizacional da Universidade, seu funcionamento administrativo, orientações sobre bibliotecas, calendário escolar, órgãos de apoio, regulamentos diversos e eventos.

Esperamos que estes dados possam facilitar a vivência acadêmica de todos os segmentos que compõem a Católica UNISANTOS e, ao mesmo tempo, aproveitamos para desejar um excelente ano de estudos, pesquisas, produção e crescimento pessoal e profissional.

\section{A Reitoria}




\section{Marco Referencial}

Universidade Católica de Santos - UNISANTOS - é uma Instituição de Ensino
Superior Confessional, que se rege por seu Estatuto e Regimento Geral, pela legislação em vigor e por este Marco Referencial, que explicita a Identidade Católica da Instituição.

A UNISANTOS, como Universidade, é uma comunidade acadêmica que, de modo rigoroso e crítico, contribui para a defesa e o desenvolvimento da dignidade humana, como também para a herança cultural, mediante a investigação, o ensino e os serviços prestados à comunidade.

Juntamente com os valores comuns a toda Universidade, a UNISANTOS se empenha, de modo especial, no cultivo dos valores humanos e da ética cristã, para a construção de uma sociedade democrática renovada, mais justa, mais igualitária.

Afirma o primado do homem sobre as coisas, do espírito sobre a matéria, da ética sobre a técnica, de modo que a ciência e a técnica estejam a serviço do homem.

Reconhece e defende o direito universal à educação e à livre escolha do indivíduo quanto ao tipo de educação. Inserida numa sociedade pluralista, aceita todas as pessoas, sem distinção de raça, cor ou credo, desde que satisfeitas as exigências legais e o respeito à Identidade Católica da Instituição.

A UNISANTOS tem como uma de suas finalidades, preparar profissionais com sólida formação cristã, notáveis no saber, habilitados ao eficiente desempenho de suas funções, com senso de responsabilidade social e que sejam testemunhas no mundo de sua Identidade Católica.

Os membros do corpo docente da Universidade são escolhidos entre pessoas de valor científico, competência técnica, seriedade profissional e probidade de vida socialmente aceita e respeito aos princípios da Doutrina Católica.

A entrada e permanência no quadro docente, discente e administrativo é uma opção livre, individual, o que implica, como atitude de coerência, o compromisso de respeito aos princípios que orientam a Instituição.

Todo exercício de cargos ou funções é um serviço a ser prestado com dedicação à comunidade universitária.

Coerente consigo mesma e com este Marco Referencial, a UNISANTOS se dispõe a um processo de permanente auto-avaliação de seu desempenho, em busca de seu aperfeiçoamento institucional e do cumprimento de seus objetivos. 


\section{Estrutura da Universidade}

\section{REITORIA}

\section{Chanceler}

Dom Jacyr Francisco Braido, CS

\section{Reitora}

Prof ${ }^{\mathrm{a}}$ Maria Helena de Almeida Lambert

Pró-Reitora Acadêmica

Prof $^{a}$ Me. Ermelinda Maura Chezzi

Pró-Reitor Comunitário

Prof. Cláudio José dos Santos

Pró-Reitor Administrativo

Prof. Marcos Medina Leite

Pró-Reitor de Pastoral

Dom David Picão

Secretário Geral Executivo

Prof. Henrique Noé de Almeida

Secretária Geral de Registros Acadêmicos

Prof ${ }^{a}$ Maria Salgado Paz 


\section{Diretores de Centros}

\section{Ciências da Comunicação e Artes}

Arquitetura e Urbanismo; Jornalismo; Publicidade e Propaganda; Relações Públicas; e Tecnológico em Design de Interiores

Diretor: Prof. Dr. Ouhydes João Augusto da Fonseca

\section{Ciências Jurídicas e Sociais Aplicadas}

Administração; Ciências Contábeis; Ciências Econômicas; Direito; Psicologia - Formação Psicólogo;Serviço Social; Tecnológico em Logística Empresarial; e Seqüencial de Formação Específicaem Gestão de Terminais Portuários.

Diretor: Prof. José de Oliveira Silva

\section{Ciências Exatas e Tecnológicas}

Ciências da Computação; Engenharia Civil; Engenharia Elétrica (Computação e Telecomunicações); Engenharia de Produção; Sistemas de Informação; Química Tecnológica;Seqüencial de Formação Específica em Tecnologia e Gestão em Redes de Computadores;Tecnológico em Petróleo e Gás; e Tecnológico em Gestão Ambiental.

Diretor: Prof. Me.Sérgio Novita Fortis

\section{Ciências da Saúde}

Enfermagem e Obstetrícia; Farmácia;Fisioterapia; Nutrição;e Seqüencial de Formação Específicaem Gastronomia.

Diretor: Prof. Dr. Paulo Ângelo Lorandi

\section{Ciências da Educação}

Licenciaturas: Ciências Biológicas; Filosofia; Geografia; História; Letras; Matemática; Pedagogia; Psicologia; e Química. Bacharelados: Ciências Biológicas- ênfase em Meio Ambiente e ênfase em Biotecnologia; Filosofia; Geografia- ênfase em Análise Ambiental; História; e Tradução e Interpretação.

Diretor: Prof. Me Drauzio Costa Pires de Campos 


\section{ÍNDICE}

NORMAS ACADÊMI CAS

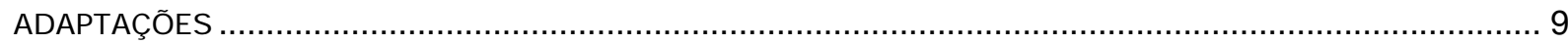

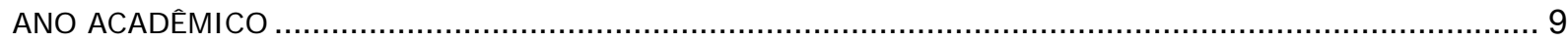

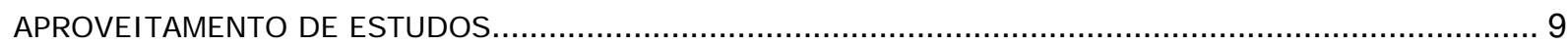

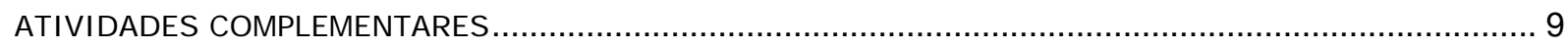

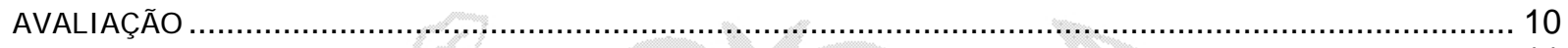

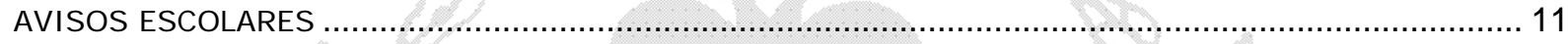

BOLSAS DE ESTUDO

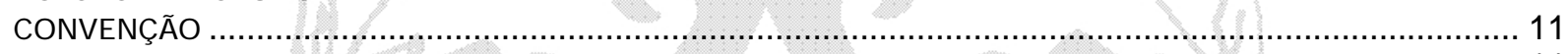

CULTURA $\ldots \cdots \cdots \cdots \cdots$

FIDELI ZAÇÃO

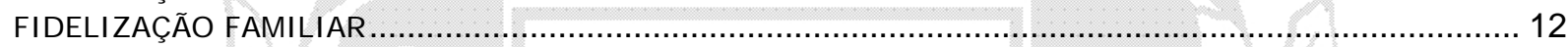

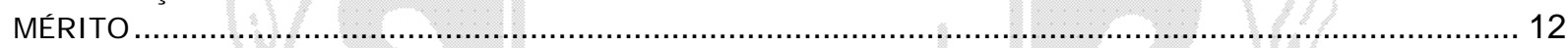

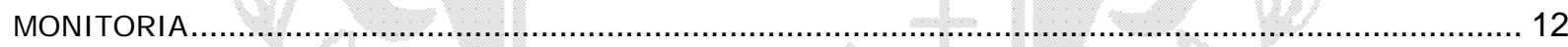

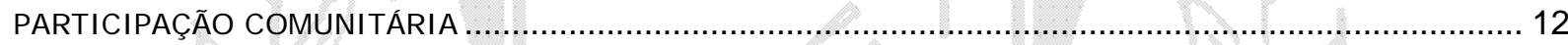

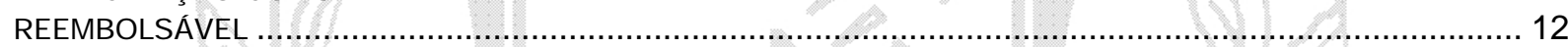

RETORNO …

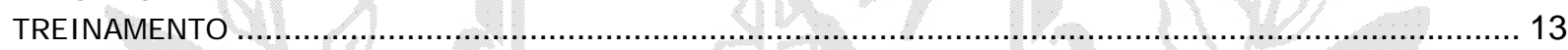

CENTROS DE APOIO

COLAÇÃO DE GRAU.

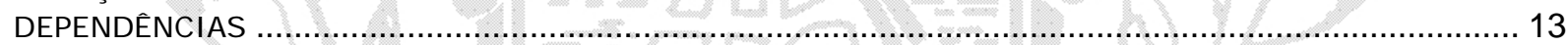

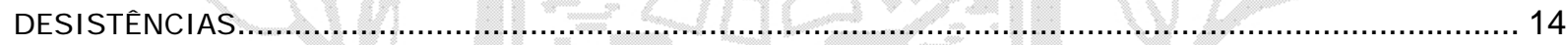

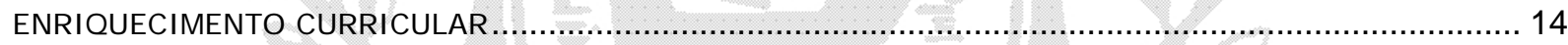

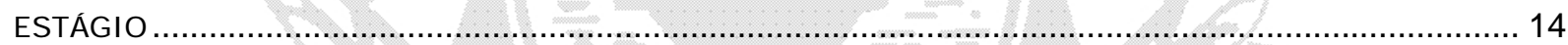

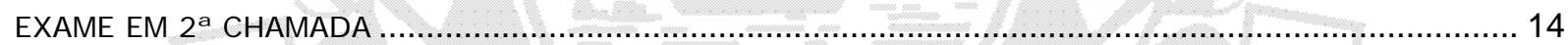

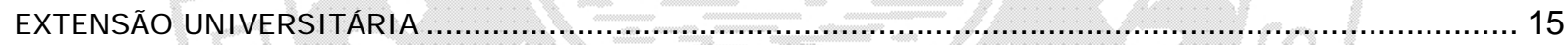

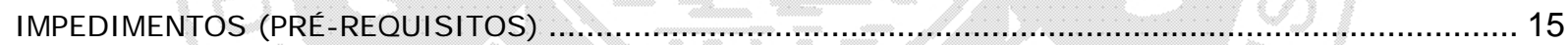

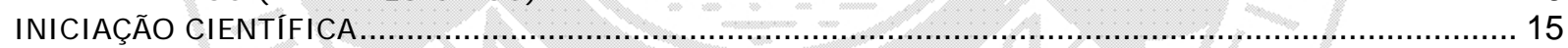

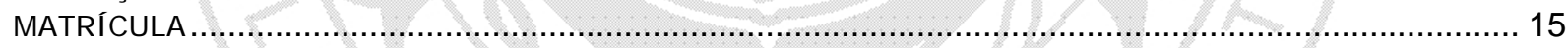

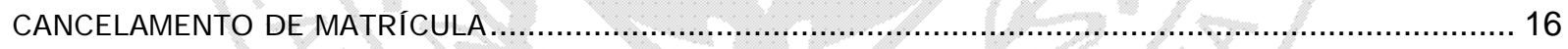

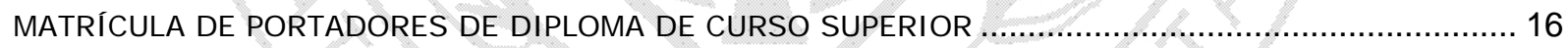

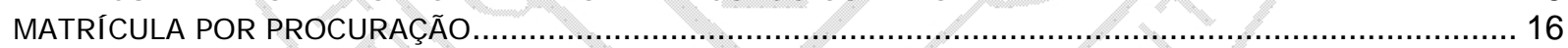

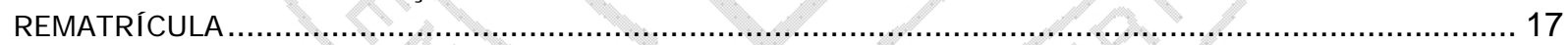

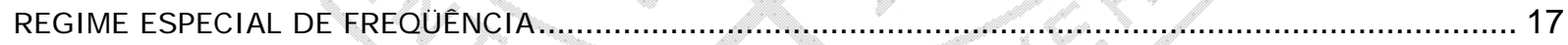

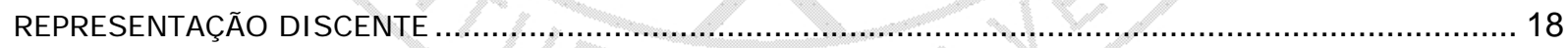

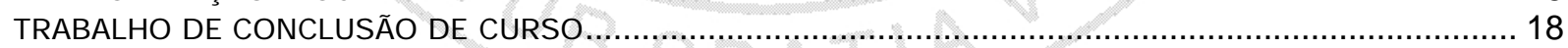

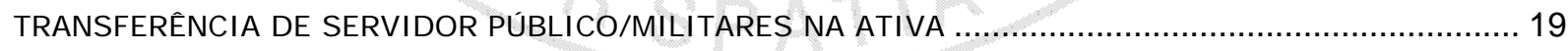

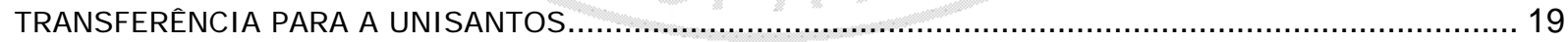

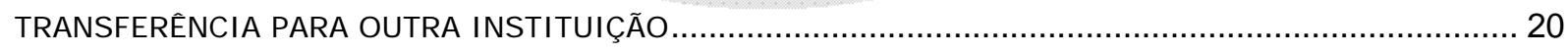

ÓRGÃOS EXECUTI VOS, SUPLEMENTARES E DE APOIO

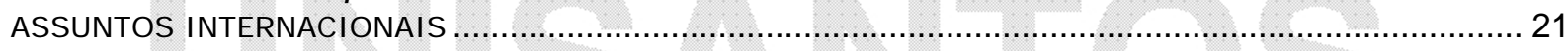

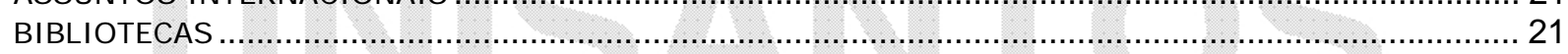

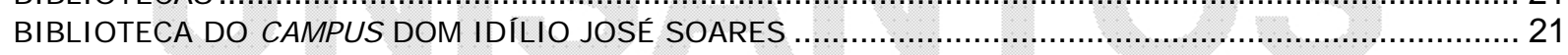

BIBLIOTECA DO CENTRO DE CIÊNCIAS DA EDUCAÇÃO "PROFESSOR MARIANO LAET GOMES" ............... 22

BIBLIOTECA DE COMUNICAÇÃO SOCI AL "PROFESSOR ROLDÃO MENDES ROSA" ................................... 22

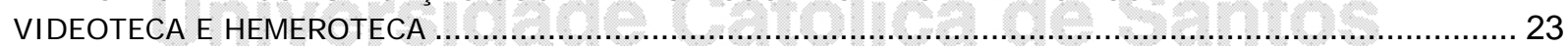

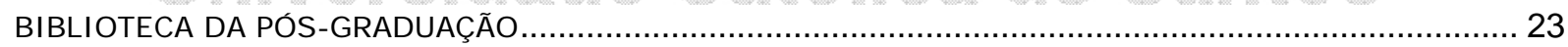

BIBLI OTECA DE ARQUITETURA E URBANISMO “ANÍ BAL MARTINS CLEMENTE" ................................... 23

BIBLIOTECA DO CURSO DE DIREITO CENTRO DE CIÊNCIAS JURÍDICAS E SOCIAIS APLICADAS ............. 24

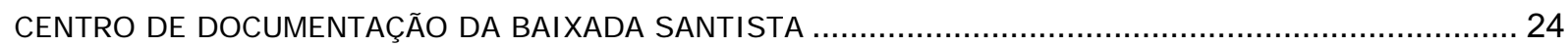

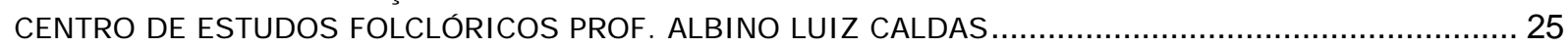

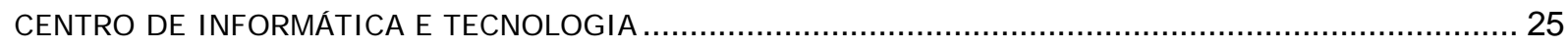

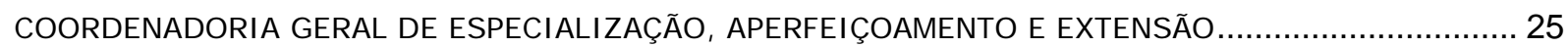

COORDENADORIA GERAL DE PÓS- GRADUAÇÃO STRICTO SENSU E PESQUISA …................................. 26

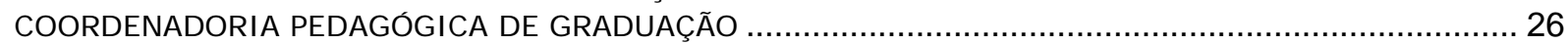

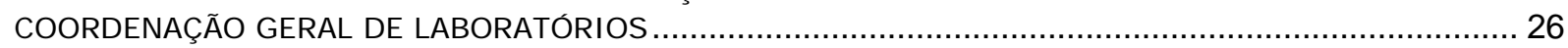

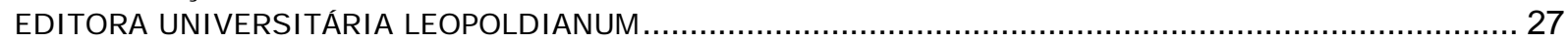

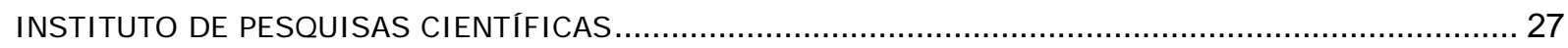

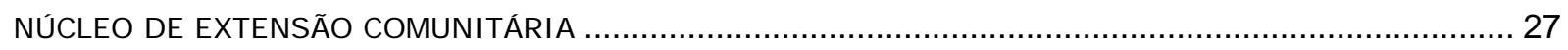




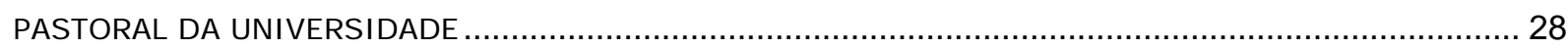

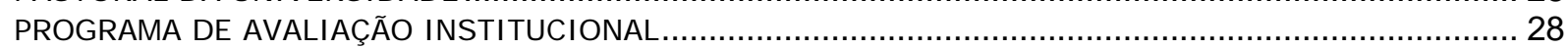

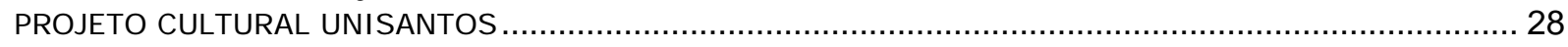

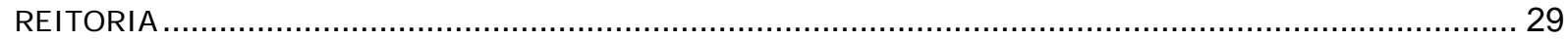

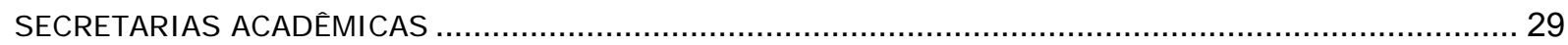

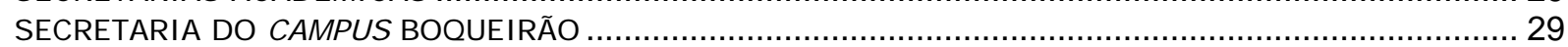

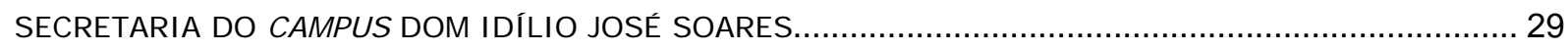

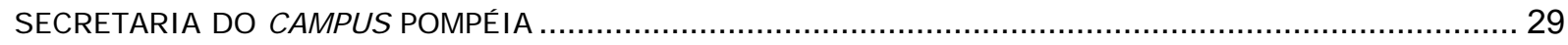

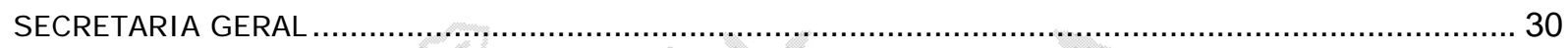

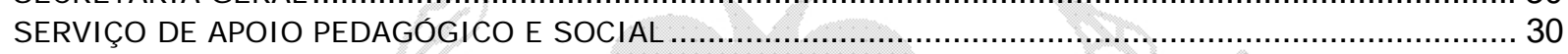

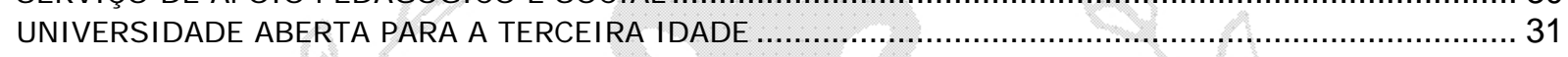

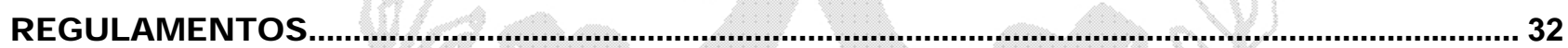

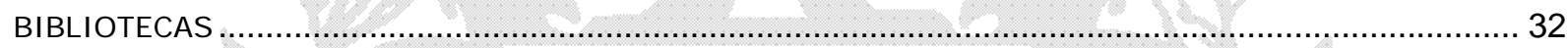

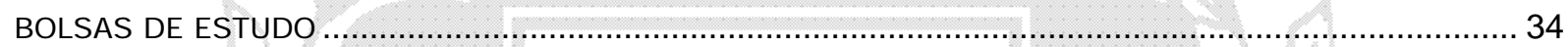

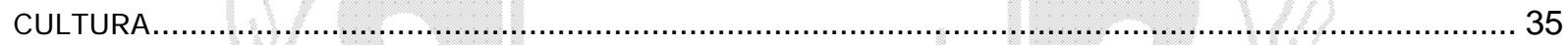

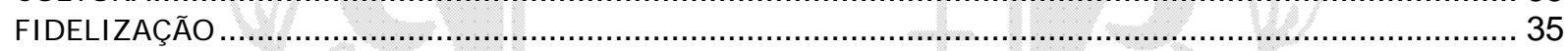

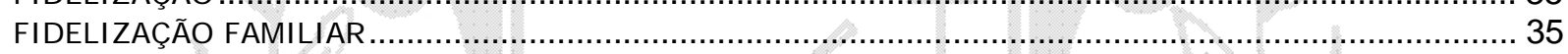

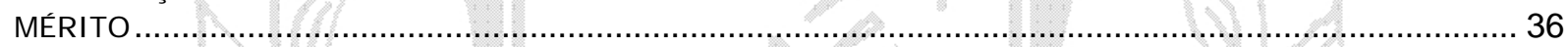

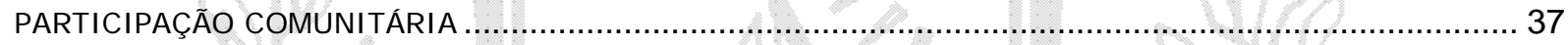

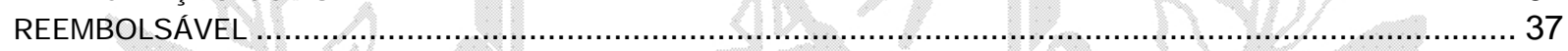

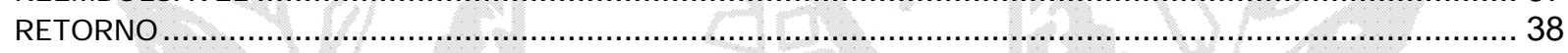

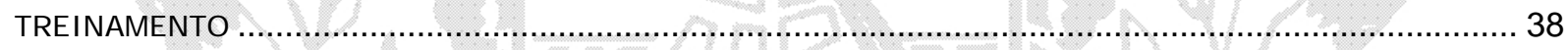

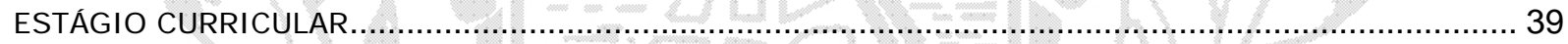

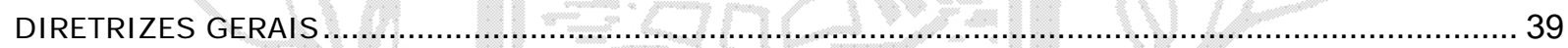

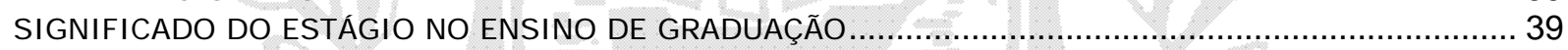

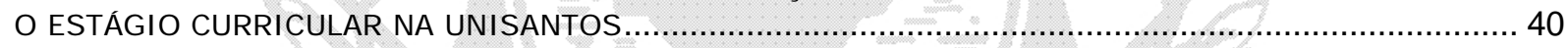

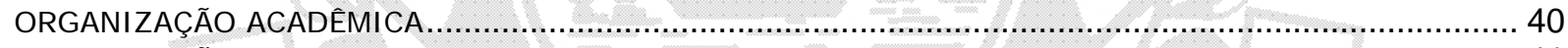

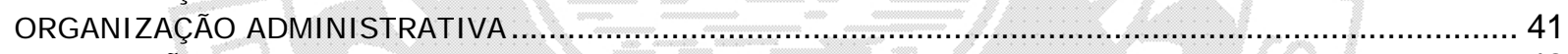

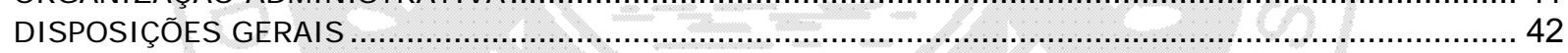

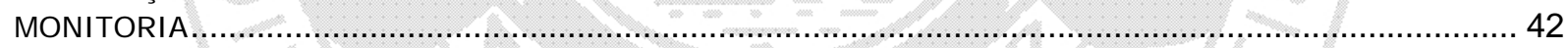

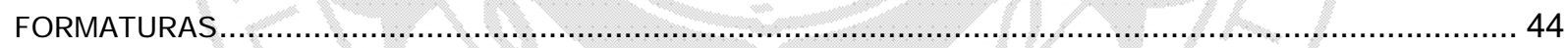

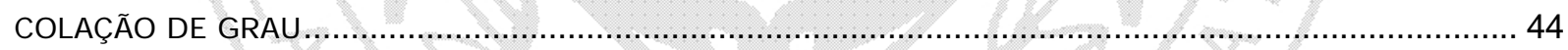

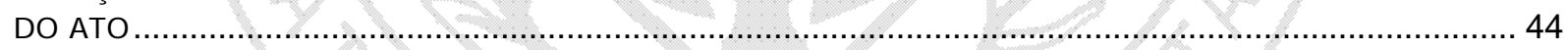

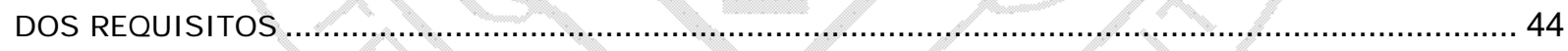

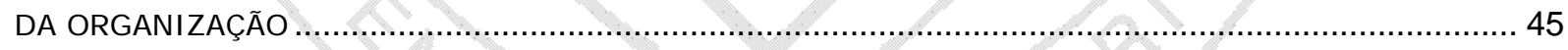

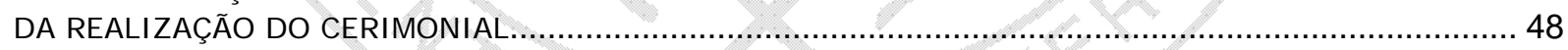

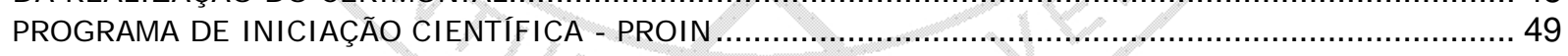

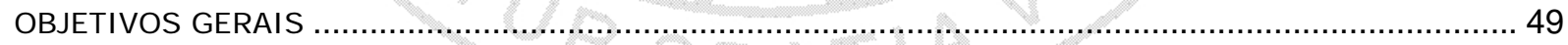

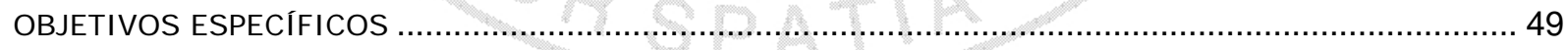

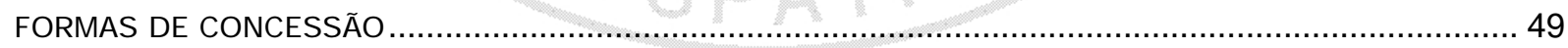

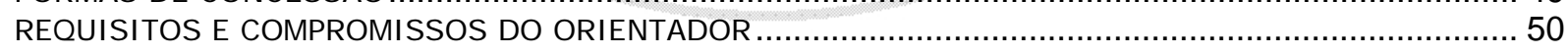

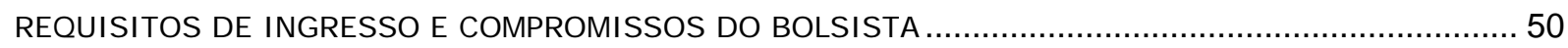

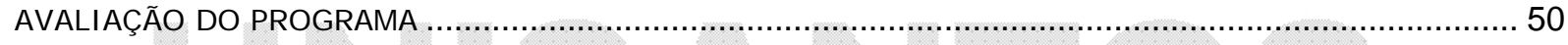

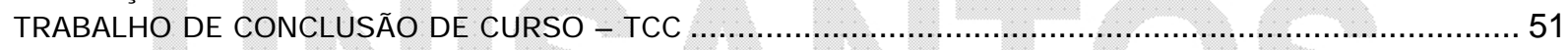

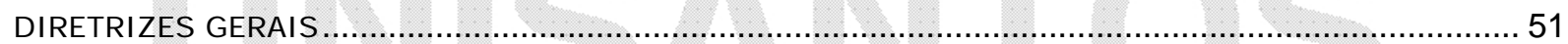

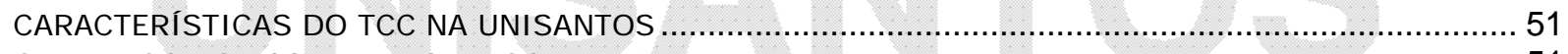

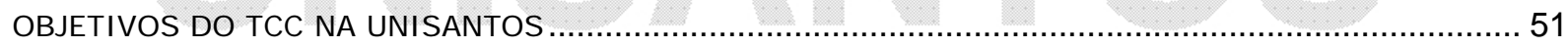

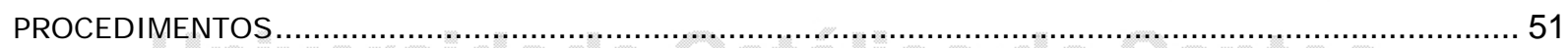

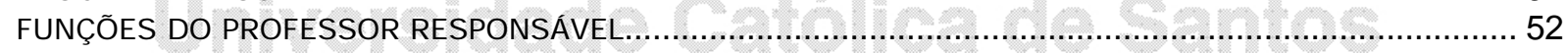

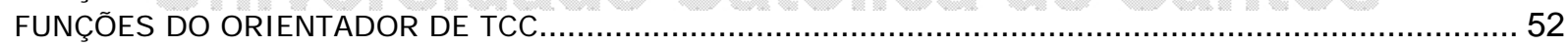

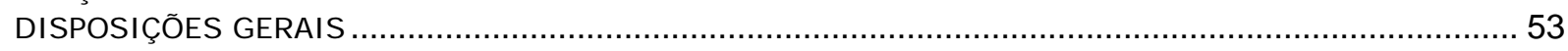

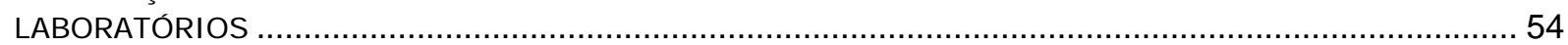

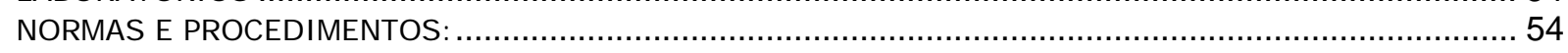

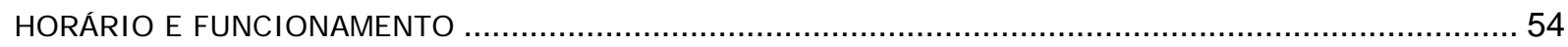

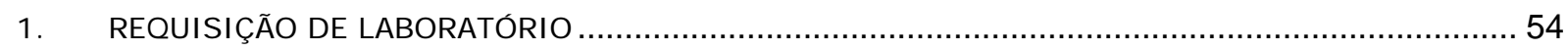

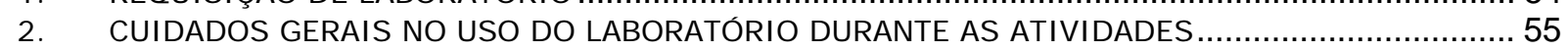

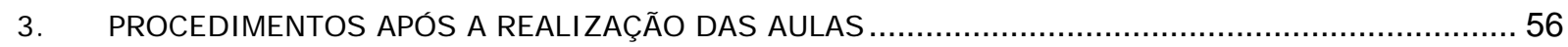

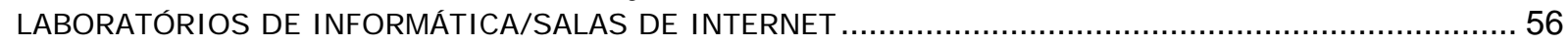

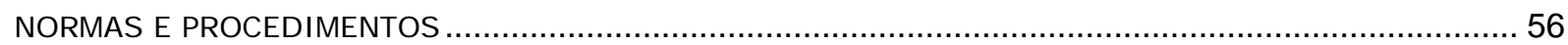

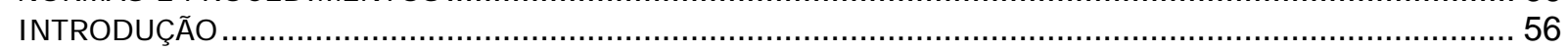

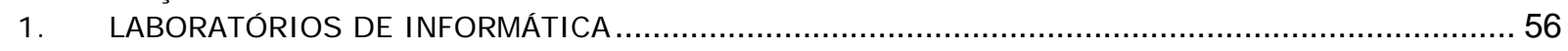

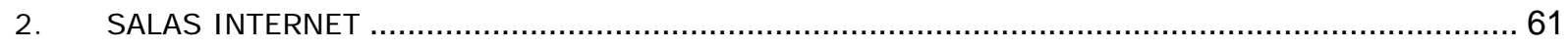


3. MONITORAMENTO DO USO 62

4. USO INDEVIDO E PENALIDADES

5. RESTRIÇÕES E BLOQUEIOS 64

6. ATRIBUI ÇÕES E RESPONSABILIDADES 64

7. USO DOS ARMÁRIOS
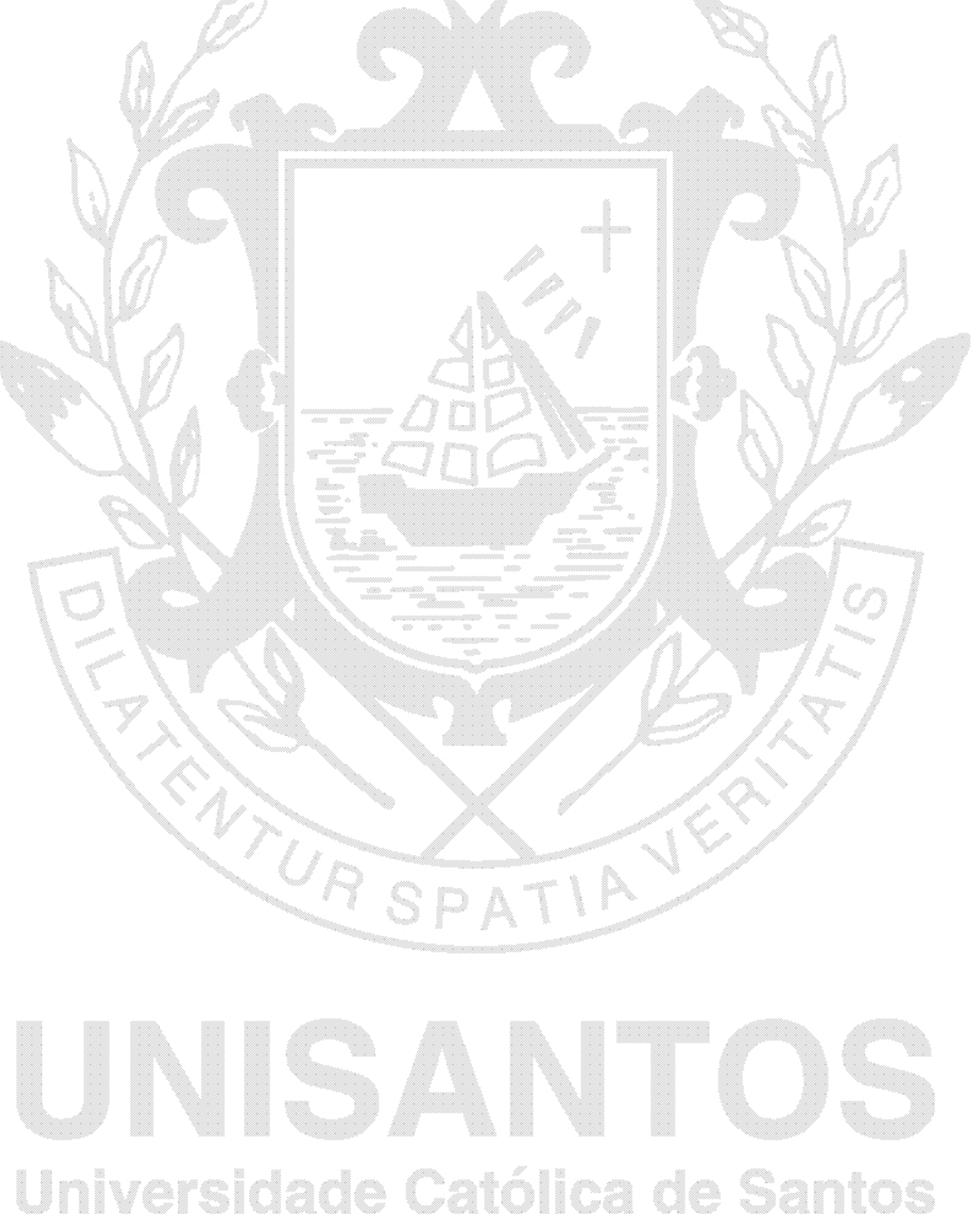


\section{Normas Acadêmicas}

\section{Adaptações}

As adaptações poderão ser incluídas dentro do limite máximo de créditos fixado para o semestre e curso de matrícula do aluno. Porém, quando a somatória dos créditos das disciplinas em que o aluno se matricular, incluídas as adaptações, ultrapassar o limite fixado para o semestre, serão cobrados os créditos excedentes.

\section{Ano Acadêmico}

O ano acadêmico constará de dois períodos letivos regulares (semestres) com duração estabelecida pelo CALENDÁRIO ESCOLAR.

\section{Aproveitamento de Estudos}

O aluno poderá requerer, dentro do prazo fixado no CALENDÁRIO ESCOLAR, aproveitamento de disciplinas, juntando ao requerimento o histórico escolar já cumprido em outra instituição de ensino superior com discriminação da carga horária e das notas. Deverá juntar também o(s) programa(s) da(s) disciplina(s) já cursada(s).

O aproveitamento de estudos será concedido com observância da legislação em vigor e disposições do Conselho de Ensino e Pesquisa - Cepes.

O aluno deverá freqüentar as aulas da disciplina enquanto aguarda o deferimento de seu pedido de aproveitamento.

\section{Atividades Complementares}

As atividades complementares são componentes curriculares que possibilitam 0 reconhecimento, mediante avaliação de habilidades, conhecimentos e competências do aluno, tanto as adquiridas no ambiente acadêmico como fora dele, incluindo a prática de estudos e atividades independentes, transversais, opcionais, de interdisciplinaridade, especialmente nas relações com o mundo do trabalho e com as ações de extensão junto à comunidade.

As atividades complementares não abrangem o estágio curricular e o trabalho de conclusão de curso. 


\section{Avaliação}

A verificação do rendimento escolar será feita por disciplina, levando-se em conta:

\section{1. freqüência}

A freqüência mínima obrigatória é de $75 \%$ das aulas previstas. O aluno que obtiver freqüência inferior a $75 \%$ estará automaticamente reprovado na disciplina;

Observação: cabe ao professor a responsabilidade de verificação e registro da freqüência dos alunos.

\section{2. aproveitamento}

O aproveitamento escolar será avaliado através de verificações parciais e de exame final. A média de cada semestre é o resultado da avaliação em notas de zero a dez, atribuídas em pontos e meios pontos. Para a avaliação do rendimento escolar a cada semestre, é obrigatória a aplicação de pelo menos dois instrumentos escritos, sendo um deles individual.

O aluno que obtiver média semestral igual ou superior a 7,0 (sete) estará dispensado de exame semestral e considerado aprovado.

O aluno cuja média semestral for inferior a 7,0 (sete) e igual ou superior a 3,0 (três) fará exame semestral precisando integralizar, com a média semestral e a nota do exame, no mínimo, 10,0 (dez) pontos para a aprovação. Nesse caso, a média final do semestre será decorrente da somatória da média do semestre e da nota do exame semestral, dividida por dois. A média mínima para aprovação é 5,0 (cinco).

No componente curricular Trabalho de Conclusão de Curso (TCC) ou Trabalho Final de Graduação (TFG), a nota mínima para aprovação será 7 (sete). A aprovação no TCC I ou TFG I constitui-se em pré-requisito para matrícula em TCC II ou TFG II. O aluno que não obtiver no TCC II ou TFG II a nota mínima de aprovação 7 (sete) poderá submeter-se a uma única reavaliação no mesmo período letivo.

Nas disciplinas ou atividades com avaliação conceitual será considerado aprovado o aluno que, tendo cumprido a exigência de freqüência mínima, tenha obtido conceito mínimo de aprovação estipulado pela organização curricular.

O aluno cuja matrícula estiver com seus efeitos suspensos ou por outra razão seu nome não constar do diário de classe não poderá participar das avaliações, sob pena de nulidade.

Será concedido exame em $2^{a}$ Chamada de exame final em situações especiais.

Ver: Exame em $2^{\text {a }}$ Chamada 
A revisão da nota do exame final, desde que o aluno apresente razões objetivas para discordar do julgamento do professor, deverá ser requerida, mediante justificativa, no prazo máximo de 48 (quarenta e oito) horas após a publicação. Caso ocorra discordância da revisão, o aluno poderá requerer, mediante justificativa, uma banca examinadora, composta por 3 (três) professores, da qual fará parte o professor da disciplina ou atividade no prazo de 48 (quarenta e oito) horas após a publicação da decisão da revisão. Da decisão da banca examinadora não caberá recurso.

\section{Avisos Escolares}

Os avisos, portarias e circulares são afixados em quadros espalhados pelas dependências das Unidades.

O aluno deve lê-los diariamente para ficar bem informado e não deixar de cumprir as disposições neles registradas.

\section{Bolsas de Estudo}

O Programa de Bolsas de Estudo da UNISANTOS oferece as seguintes modalidades: Ver: Regulamentos

\section{Convenção}

Concedida a professores, funcionários, filhos ou dependentes legais, por força de convenção coletiva de trabalho, nas condições expressamente definidas pelas respectivas convenções.

Setor concedente: Sociedade Visconde de São Leopoldo.

\section{Cultura}

Concedida a estudantes com comprovada vocação para manifestações artístico-culturais nessa atividade, mediante análise de rendimento cultural e acadêmico, além de compromisso de colaborar em atividades de interesse da Universidade, quando convocados.

Setor concedente: Pró-Reitoria Comunitária.

\section{Fidelização}

Concedida a alunos oriundos do Liceu Santista, integrante da Sociedade Visconde de São Leopoldo.

Setor concedente: Pró-Reitoria Comunitária. 


\section{Fidelização Familiar}

Concedida a alunos integrantes da mesma família, limitando-se a cônjuges, filhos ou irmãos.

Setor concedente: Pró-Reitoria Comunitária.

\section{Mérito}

Concedida ao melhor aluno dos três semestres finais de cada curso, ou conjunto de cursos, com média superior a 9,0 (nove) e ao primeiro classificado geral, entre todos os cursos, exceto os Tecnológicos e Seqüenciais, no Processo Seletivo da Universidade.

Setor concedente: Reitoria.

\section{Monitoria}

Concedida para atuação do aluno, matriculado a partir do $5^{\circ}$ semestre, junto a professores, em tarefas de apoio ao ensino e projetos específicos.

Setor concedente: Pró-Reitoria Acadêmica.

\section{Participação Comunitária}

Concedida a estudantes matriculados a partir do $3^{\circ}$ semestre para atuação em projetos comunitários, subordinados ao Núcleo de Extensão Comunitária - Necom - ou a órgãos assemelhados.

Setor concedente: Pró-Reitoria Comunitária.

\section{Reembolsável}

Concedida após avaliação sócio-econômica-financeira familiar, com reembolso iniciado imediatamente após o término do benefício.

Setor concedente: Pró-Reitoria Comunitária.

\section{Retorno}

Concedida a alunos que tenham concluído curso superior na UNISANTOS.

Setor concedente: Pró-Reitoria Comunitária. 


\section{Treinamento}

Concedida a estudantes, a partir do $3^{\circ}$ semestre, que realizem treinamento na área de sua formação, em órgãos internos da Universidade ou entidades conveniadas.

Setor concedente: Pró-Reitoria Comunitária.

Observação: A UNISANTOS oferece bolsas através de participantes nos programas governamentais Prouni, do Ministério da Educação; Financiamento Estudantil (Fies), da Caixa Econômica Federal; e Escola da Família, da Secretaria da Educação do Estado de São Paulo.

\section{Centros de Apoio}

A Universidade mantém à disposição dos alunos, professores, funcionários e da comunidade em geral centros de estudos e pesquisas.

Ver: Órgãos Executivos, Suplementares e de Apoio

\section{Colação de Grau}

Ver: Regulamentos

A cerimônia é realizada em sessão solene, presidida pelo diretor do Centro ou pela autoridade máxima da Universidade. A organização e a coordenação geral do cerimonial são responsabilidades do Setor de Relações Públicas da UNISANTOS. Somente os alunos que concluíram o curso (inclusive os estágios obrigatórios e o ENADE regularizado) poderão participar da solenidade.

Ao aluno que não puder comparecer à sessão solene poderá ser conferido grau, em dia e hora fixados pelo Diretor do Centro ou Coordenador de Curso, mediante requerimento formulado pelo estudante na secretaria acadêmica de seu curso.

\section{Dependências}

As dependências serão sempre cobradas. Quando o aluno estiver matriculado em classe regular, deverá pagar o valor do crédito fixado para o seu curso. Em caso de classe especial, o valor a ser cobrado ficará condicionado às Normas Regulamentares para cumprimento de Dependências. 


\section{Desistências}

O aluno que, por qualquer motivo, tiver abandonado seus estudos na UNISANTOS poderá solicitar seu retorno ao curso.

Ver: Cancelamento de Matrícula, em MATRÍCULA

\section{Enriquecimento Curricular}

O aluno matriculado a partir do $3^{0}$ semestre em curso de graduação da UNISANTOS, desde que aprovado em todas as disciplinas oferecidas nos semestres já cursados, portanto, sem dependência(s) e/ou adaptação(ões) a cumprir, poderá matricular-se, dentro do prazo estipulado pelo calendário escolar, sem qualquer pagamento, e cursar uma única disciplina de sua escolha de qualquer outro curso, dentre as oferecidas pela Universidade, respeitado o limite de vagas. A disciplina cursada, com aprovação, será incluída em seu histórico escolar.

O portador de diploma de curso superior também poderá matricular-se em uma única disciplina de seu interesse, desde que efetue o pagamento correspondente no prazo fixado no CALENDÁRIO ESCOLAR. Nesse caso receberá certificado.

\section{Ver: Matrícula}

\section{Estágio}

O Estágio deverá ser cumprido durante a graduação de acordo com os regulamentos de cada curso. O aluno deveinformar-se sobre as exigências legais para cumpri-lo sem problemas.

Observação: Todo e qualquer tipo de atividade prática, desenvolvida por aluno da UNISANTOS, regularmente matriculado, que se denomine estágio, está condicionada à existência de instrumento jurídico (convênio), entre a UNISANTOS e a entidade/empresa/organização, e à supervisão acadêmica.

\section{Exame em 2a chamada}

Será concedida $2^{a}$ chamada de exame final por motivo de doença, luto ou gala, devidamente comprovado, ao aluno que requerer tal providência até 48 (quarenta e oito) horas após a realização do ato escolar a que não compareceu. 


\section{Extensão Universitária}

A UNISANTOS promove cursos nas diversas áreas de conhecimento e abertos à participação da comunidade em geral. Esses cursos são organizados pela Coordenadoria Geral de Especialização, Aperfeiçoamento e Extensão - Coeae.

Ver: Órgãos Executivos, Suplementares e de Apoio

\section{Impedimentos (Pré-requisitos)}

Não deverá haver pagamento da disciplina considerada pré-requisito, quando cursada em semestre posterior ao semestre em que é oferecida regularmente, pois já houve pagamento da mesma e também daquela que a substituiu por ocasião do curso regular, considerada como dependência.

\section{Iniciação Científica}

O Programa Institucional de Iniciação Científica - Proin - é um programa dirigido à formação científica de estudantes de graduação, em todas as áreas de conhecimento, por meio da participação ativa em projetos de pesquisa com qualidade acadêmica, mérito científico e orientação sistemática e individualizada, com vistas à continuidade de seus estudos na pós-graduação.

O Proin buscará agregar o discente, desde a graduação, às atividades de pesquisa da Instituição, favorecendo a articulação necessária entre os níveis da graduação e da pósgraduação. Possibilitará, também, o processo de investigação da realidade regional, através do desenvolvimento de projetos de pesquisa que podem ser realizados em áreas trabalhadas nos projetos de extensão da Universidade.

\section{Matrícula}

A matrícula é o ato formal que vincula o aluno à UNISANTOS. É efetuada antes do início do semestre acadêmico, no período fixado no CALENDÁRIO ESCOLAR.

$O$ aluno matriculado em qualquer curso poderá, ainda, proceder, dentro do prazo fixado pelo CALENDÁRIO ESCOLAR, a ajustes quanto a inclusões e/ou cancelamento de disciplinas (dependências ou adaptações), constantes na grade curricular de sua matrícula. 


\section{Cancelamento de Matrícula}

O aluno poderá requerer o cancelamento de sua matrícula na Secretaria da Unidade, saldando o débito, caso exista, no Departamento de Cobrança, e devolvendo sua Carteira de Identificação Estudantil. O retorno ao curso será possível com a efetivação de nova matrícula, se houver vaga, e com a adaptação de currículo, se necessário.

\section{Matrícula de Portadores de Diploma de Curso Superior}

A matrícula de portadores de diploma de Curso Superior poderá ser feita em qualquer curso quando houver vaga remanescente do Processo Seletivo.

O candidato deverá requerer sua matrícula na Secretaria da Unidade, dentro do prazo fixado no CALENDÁRIO ESCOLAR, juntando ao requerimento (fornecido pela Secretaria e a ser preenchido no ato da matrícula) os seguintes documentos em uma via:

a) Diploma do Curso Superior, devidamente registrado;

b) Histórico Escolar com notas e carga horária;

C) Programas das disciplinas cursadas em que pretenda obter aproveitamento de estudos;

d) Cédula de Identidade;

e) CPF;

f) Título Eleitoral;

g) Certificado de Regularização do Serviço Militar;

h) Certidão de Nascimento ou de Casamento (esta última obrigatória para os que alteraram o nome);

i) Certificado de Conclusão e Histórico Escolar do Curso Médio ou equivalente;

j) Duas fotografias $3 \times 4$, recentes.

Observações: 1) as autenticações em cartório serão dispensadas em caso da apresentação dos documentos originais; 2) os documentos recolhidos à Secretaria não serão devolvidos.

\section{Matrícula por Procuração}

O aluno que não puder efetuar pessoalmente sua matrícula ou rematrícula deverá fazê-lo através de procuração simples, com firma reconhecida. Quando o aluno for menor de idade (18 anos) deverá comparecer acompanhado de seu responsável civil, com o CPF, para assinar o contrato. 


\section{Rematrícula}

Para a rematrícula o aluno deverá observar o prazo previsto no CALENDÁRIO ESCOLAR, nas condições fixadas pelos órgãos da Universidade. Quando o aluno for menor de idade (18 anos) deverá comparecer acompanhado de seu responsável civil, com o CPF, para assinar o contrato.

\section{Trancamento de Matrícula}

Salvo nos cursos superiores seqüenciais e tecnológicos, o aluno que, por motivo justificado, não puder prosseguir seus estudos, poderá requerer, o trancamento de sua matrícula por dois semestres letivos, obrigando-se, no entanto, a pagar as parcelas da semestralidade escolar vincendas, correspondentes ao semestre de trancamento, e a devolver sua Carteira de Identificação Estudantil.

O trancamento só poderá ocorrer após a efetivação da matrícula e dentro dos prazos estabelecidos pelo CALENDÁRIO ESCOLAR.

O aluno que não reiniciar suas atividades escolares, após o término do período de trancamento, perderá sua vaga e será considerado desistente.

$\underline{\text { Ver: Desistências }}$

\section{Regime Especial de Freqüência}

Às estudantes em estado de gravidez pode ser concedido um regime de atendimento acadêmico especial, por um período de três meses, a contar do $8^{\text {o }}$ mês de gestação, desde que seja requerido à direção da respectiva Unidade, apresentando-se a devida comprovação médica.

$O$ regime consiste em:

1. substituição da freqüência às aulas, durante o período em questão, por exercícios domiciliares orientados pelos professores das respectivas disciplinas;

2. possibilidade de prestar noutra ocasião as avaliações que incidirem no período de afastamento.

Há ainda regime especial de atendimento acadêmico para alunos amparados pelo Decreto-Lei N o 1.044/69 (incapacidade física). Este Regime só será aplicado para afastamentos com duração não inferior a 15 (quinze) dias corridos.

Em ambos os casos o REGIME ESPECIAL DE FREQÜÊNCIA deverá ser requerido, no máximo em até 3 (três) dias úteis após o início, e nunca após o período solicitado, porque NÃO TEM EFEITO REATROATIVO. 
Observação: não há abono de faltas, exceto no caso de convocação militar que obrigue o aluno a faltar.

\section{Representação Discente}

O corpo discente tem representação, com direito a voz e voto, nos órgãos colegiados acadêmicos da Universidade, nos termos da legislação vigente.

Compõem a representação discente:

1. o Diretório Central dos Estudantes (DCE);

2. os Diretórios Acadêmicos (DAs) ou Centros Acadêmicos (CAs);

3. os representantes discentes nos órgãos colegiados.

O DCE, órgão máximo da representação discente na Universidade, congrega todos os alunos da Instituição.

Os Diretórios Acadêmicos ou Centros Acadêmicos são órgãos setoriais de representação discente, congregando os alunos de cada uma das Unidades.

Os órgãos de representação discente indicam seus representantes junto aos órgãos colegiados acadêmicos, obedecidas as exigências da legislação em vigor.

Os representantes discentes e seus respectivos suplentes são indicados para o Conselho Universitário - Consu - e para o Conselho de Ensino e Pesquisa - Cepes - pelo Diretório Central dos Estudantes. Os representantes discentes e seus respectivos suplentes junto aos Colegiados de cada Unidade serão indicados dentre os representantes de classe, eleitos por seus pares. O mandato da representação estudantil será de um ano.

É vedado o exercício simultâneo da representação estudantil nos órgãos colegiados superiores (Cepes e Consu) pelo mesmo aluno.

\section{Trabalho de Conclusão de Curso}

Ver: Regulamentos

Para a graduação exige-se do aluno a elaboração de um Trabalho de Conclusão (TCC/TFG). Cada curso possui regulamento específico para seu trabalho de conclusão, conforme diretrizes da Pró-Reitoria Acadêmica. A nota mínima para aprovação semestral neste componente curricular será 7 (sete). A aprovação no TCC I ou TFG I constitui-se em pré-requisito para matrícula no TCC II ou TFG II.

O aluno que não obtiver no TCC II ou TFG II a nota mínima de aprovação 7,0 (sete) poderá submeter-se a uma única reavaliação no mesmo período letivo. 


\section{Transferência de Servidor Público/Militares na Ativa}

O pedido de matrícula, ditado pela remoção ou transferência de servidor público, civil ou militar, bem como de seus dependentes, será aceito independentemente da existência de vaga e de época.

O candidato deverá requerer a matrícula dentro de 30 (trinta) dias, contados a partir da publicação do ato, juntando ao requerimento:

1. cópia autenticada do ato de transferência ou remoção ou sua publicação oficial;

2. histórico escolar, com discriminação de carga horária, freqüência e notas;

3. programas das disciplinas cursadas, autenticados pela instituição de origem;

4. atestado de regularidade de matrícula;

5. documentos exigidos para a matrícula.

Ver: Matrícula

\section{Transferência para a UNISANTOS}

O candidato à transferência deve, necessariamente, anexar ao requerimento os seguintes documentos:

1. atestado de regularidade de matrícula na instituição de origem;

2. histórico escolar expedido pela instituição de origem, com discriminação de notas, carga horária, justificativa das interrupções do curso, se houver;

3. programas (planos de estudo) das disciplinas cursadas, autenticados pela secretaria da instituição de origem;

4. no caso de estabelecimento estrangeiro, o candidato deverá apresentar os documentos citados nos itens 1, 2 e 3, contendo a chancela do Consulado Brasileiro no país de origem e, ainda, a chancela do Ministério da Fazenda do Brasil.

Todos esses documentos deverão estar no idioma Português (do Brasil), traduzidos por tradutor juramentado. Além desses, deverá apresentar uma cópia autenticada do Passaporte e visto de permanência no País.

O deferimento do pedido de transferência observará as determinações regimentais da UNISANTOS. A matrícula do candidato far-se-á mediante apresentação à Unidade da declaração da instituição de origem de que a transferência foi requerida e que a respectiva guia está em andamento. Exige-se também a documentação própria para a matrícula.

Ver: Matrícula 


\section{Transferência para outra Instituição}

O aluno regular poderá requerer, em qualquer época do período letivo, sua transferência para outra instituição de ensino superior, juntando, para tanto, a declaração de vaga fornecida para a qual irá transferir-se.

Não fará jus à guia de transferência quem perdeu a condição de aluno, mas poderá obter Certidão de Currículo Escolar. 


\section{Órgãos Executivos, Suplementares e de Apoio}

\section{Assuntos Internacionais}

A Assessoria de Assuntos Internacionais - Asseint - tem a finalidade de estabelecer contatos e firmar convênios com universidades e instituições estrangeiras. Entre suas atribuições está a agilização de ações que divulguem o nome da UNISANTOS no Exterior, por meio da participação de professores e alunos em pesquisas, estágios, cursos, treinamentos e outros eventos acadêmicos ou técnicos. Como membro do Fórum das Universidades Brasileiras para Assuntos Internacionais, busca a cooperação internacional de instituições de qualidade e credibilidade reconhecidas, assessorando a ida e a permanência de pessoal da Universidade em países como Portugal, Espanha, França, Moçambique, México e Argentina.

\section{Bibliotecas}

\section{Ver: Regulamentos}

O Sistema de Bibliotecas está diretamente ligado à Reitoria da Universidade Católica de Santos e é composto de seis bibliotecas, uma videoteca e uma hemeroteca, que têm como objetivo oferecer à comunidade acadêmica produtos e serviços de informação que auxiliem no desenvolvimento de programas de ensino, pesquisa e extensão.

As bibliotecas estão localizadas nos campi e interligadas, viabilizando, dessa forma, a consulta do usuário.

\section{Biblioteca do Campus Dom Idílio José Soares}

Local: Campus Dom Idílio José Soares - Avenida Conselheiro Nébias, 300 - Vila Mathias, Santos/SP. CEP 11015-002 - Tel.: (13) 3228-1200

E-mail: biblicen@unisantos.br

Horário: segunda a sexta-feira, das 8 às 22 horas, e sábados, das 8 às 16 horas.

Acervo: o acervo está constituído de aproximadamente 75 mil volumes entre livros e periódicos nacionais e estrangeiros para atender as áreas de Enfermagem, Fisioterapia, Nutrição, Farmácia, Administração de Empresas, Ciências Econômicas, Ciências Contábeis, Ciências da Computação, Sistemas de Informação, Engenharia Civil e Elétrica, Ciências Biológicas, Serviço Social, Psicologia e Química Tecnológica.

Serviços: empréstimo para alunos, professores da UNISANTOS e entre bibliotecas de instituições de ensino superior. 
A Biblioteca fica aberta ao público externo, a partir do Ensino Médio, para consulta local, às terças e quintas- feiras, mediante apresentação da Cédula de Identidade original.

\section{Biblioteca do Centro de Ciências da Educação "Professor Mariano Laet Gomes"}

Local: Campus Pompéia - Rua Euclides da Cunha, 264 - Pompéia, Santos/SP - CEP 11065-902 - Tel.: (13) 3205-5555, ramais 656 e 633 -

E-mail: biblifafis@unisantos.br

Horário: segunda a sexta-feira, das 8 às 22 horas, e sábados, das 8 às 16 horas.

Acervo: o acervo está constituído de aproximadamente 90 mil volumes entre livros e periódicos. Em função do caráter interdisciplinar da Biblioteca, o acervo é geral, abrangendo quase todas as áreas do conhecimento, tais como: Filosofia, Religião, Ciências Sociais, Educação, Pedagogia, Ciências Exatas, Psicologia da Educação, Línguas, Literatura, Geografia e História.

\section{Biblioteca de Comunicação Social "Professor Roldão Mendes Rosa"}

\section{Centro de Ciências da Comunicação e Artes}

Cursos de Jornalismo, Publicidade e Propaganda e Relações Públicas

Local: Campus Pompéia - Rua Euclides da Cunha, 264 - Pompéia, Santos/SP - CEP 11065-902 - Tel.: (13) 3205-5555, ramais 654 e 617.

Horário: segunda a sexta-feira, das 8 às 22 horas, e sábados, das 8 às 16 horas.

Acervo: o acervo é constituído especificamente para atender a área de Comunicação Social, nas suas habilitações: Jornalismo, Relações Públicas e Publicidade e Propaganda. Conta com aproximadamente 10 mil volumes de livros abrangendo assuntos, principalmente, das áreas de Comunicação, Jornalismo, Propaganda, Marketing, Relações Públicas, Teatro, Cinema, Rádio, Televisão e Fotografia. Além de jornais diários e revistas das áreas de Comunicação Social, Jornalismo, Relações Públicas, Publicidade e Propaganda e assuntos gerais.

Serviços: empréstimo para alunos e professores da UNISANTOS e entre bibliotecas de instituições de ensino superior.

A Biblioteca fica aberta ao público externo, a partir do Ensino Médio, para consulta local, àsterças e quintas-feiras, mediante apresentação da Cédula de Identidade original. 


\section{Videoteca e Hemeroteca}

Local: Campus Pompéia - Anexo à Biblioteca de Comunicação Social "Professor Roldão Mendes Rosa" - Centro de Ciências da Comunicação e Artes - Rua Euclides da Cunha, 264 - Pompéia, Santos/SP - CEP $11065-902$ - Tel.: (13) 3205-5555, ramais 654 e 617.

Horário: segunda a sexta-feira, das 8 às 22 horas, e sábados, das 8 às 16 horas.

Acervo: o acervo da Videoteca possui aproximadamente 900 vídeos. Os assuntos são variados e principalmente voltados para área de Educação e Ensino. A Hemeroteca possui 90 títulos de jornais formando coleções de material primário de consulta desde o século passado até os dias de hoje. Os jornais podem ser consultados no local. Parte desse acervo está microfilmado e os jornais atuais estão sendo digitalizados.

Serviços - Vídeos: podem ser retirados para empréstimo por alunos, professores e entre bibliotecas da UNISANTOS. Na Videoteca o usuário também pode assistir aos vídeos em cabines individuais ou em grupos de seis pessoas. Jornais: estão disponibilizados apenas para consulta no local, não sendo permitidas cópias.

A Videoteca e a Hemeroteca ficam abertas ao público externo, a partir do Ensino Médio, para consulta local,às terças e quintas-feiras, das 8 às 22 horas, mediante apresentação da Cédula de Identidade original.

\section{Biblioteca da Pós-Graduação}

Local: Campus Vila Mathias - Rua Dr. Carvalho de Mendonça, 144 - Vila Mathias, Santos/SP - CEP 11070-906 - Tel.: (13) 3205-5555, ramal 717 -

E-mail: biblipos@unisantos.br

Horário: segunda a sexta-feira, das 8 às 22 horas, e sábados, das 8 às 16 horas.

Acervo: o acervo é constituído de obras específicas para os cursos de Mestrado em Direito, Educação, Gestão de Negócios, Informática e Saúde Coletiva.

Serviços: empréstimo para alunos e professores da UNISANTOS.

\section{Biblioteca de Arquitetura e Urbanismo “Aníbal Martins Clemente”}

\section{Centro de Ciências da Comunicação e Artes}

Local: Campus Boqueirão - Avenida Conselheiro Nébias, 595 - Boqueirão, Santos/SP CEP 11045-901 - Tel.: (13) 3205-5555, ramais 802 e 821.

E-mail: bibliaes@unisantos.br

Horário: segunda a sexta-feira, das 8 às 22 horas, e sábados, das 8 às 16 horas.

Acervo: o acervo é constituído de aproximadamente 18 mil volumes entre livros e periódicos nacionais e estrangeiros. Abrange as áreas de Arquitetura, Urbanismo, 
Ecologia e Meio Ambiente, Planejamento Urbano, Metropolitano e Uso do Solo, além de multimeios iconográficos como slides, coleção de mapas da Baixada Santista e demais localidades, fotografias e plantas de projetos arquitetônicos.

Serviços: empréstimo para alunos e professores da UNISANTOS e entre bibliotecas de instituições de ensino superior.

A Biblioteca fica aberta ao público externo, a partir do Ensino Médio, para consulta local, às terças e quintas-feiras, mediante apresentação da Cédula de Identidade original.

\section{Biblioteca do Curso de Direito Centro de Ciências Jurídicas e Sociais Aplicadas}

Local: Avenida Conselheiro Nébias, 589/1 andar- Bairro Boqueirão, Santos/SP - CEP 11045-900 - Tel.: (13) 3205-5555, ramal 818 -

E-mail: biblidir@unisantos.br

Horário: segunda a sexta-feira, das 8 às 22 horas, e sábados, das 8 às 16 horas.

Acervo: o acervo é constituído de aproximadamente 27 mil volumes entre livros e periódicos abordando basicamente obras especializadas nas áreas de Direito Público e Privado, Legislação e Jurisprudência tais como: Introdução ao Direito, Direito Constitucional, Direito Penal, Processo Penal, Direito Civil, Processo Civil, Direito do Trabalho, Direito Administrativo, Direito Financeiro e Tributário, Direito Canônico, Direito Comercial e Medicina Legal.

Serviços: empréstimo para alunos e professores da UNISANTOS e entre bibliotecas de instituições de ensino superior.

A Biblioteca fica aberta ao público externo, a partir do Ensino Médio, para consulta local, às terças e quintas-feiras, mediante apresentação da Cédula de Identidade original.

\section{Centro de Documentação da Baixada Santista}

\section{Campus Pompéia}

Criado em 1983, o Centro de Documentação da Baixada Santista desenvolve pesquisas sistemáticas sobre a história da Baixada Santista e estudos para a localização de sítios e monumentos de interesse. O Centro tem a guarda e a custódia de documentos ou fundos documentais de relevante significação histórica.

Aberto à comunidade para consulta, seu acervo é formado por fotografias, mapas, textos, objetos, livros, monografias, dissertações de mestrado, filmes, fitas, discos e outros materiais sobre a região. 


\section{Centro de Estudos Folclóricos Prof. Albino Luiz Caldas}

\section{Campus Pompéia}

O Centro de Estudos Folclóricos Prof. Albino Luiz Caldas abriga todo o acervo desse folclorista, falecido em 1984. A finalidade do Centro é promover exposições, palestras e cursos sobre a cultura popular, preservar o trabalho de artesãos e de grupos folclóricos, orientando, ainda, a pesquisa e o estudo sobre o folclore regional. Possui biblioteca especializada, além de acervo de discos, slides e de literatura de cordel.

\section{Centro de Informática e Tecnologia}

\section{Campus Dom Idílio José Soares}

Ver: Regulamentos - Laboratórios de Informática/Salas de Internet

O Centro de Informática e Tecnologia - Ceite - é um órgão suplementar à Reitoria e deve atender à Instituição na sua totalidade, ou seja, Mantenedora,Universidade Católica de Santos,Liceu Santista e demais unidades que possam ser criadas pela Sociedade Visconde de São Leopoldo.

O órgão tem como objetivo suportar os sistemas de informação da Instituição, integrar as áreas administrativa e acadêmica, racionalizar processos, levando a Instituição à eficácia e à otimização no ensino, na pesquisa, na extensão e na sua administração através de recursos tecnológicos e humanos adequados à atual realidade do mercado da Informática.

É responsável pela instalação e manutenção de laboratórios de Informática e Salas de Internet nos vários campi da UNISANTOS.

- Campus Boqueirão (Avenida Conselheiro Nébias, 589 e 595).

- Campus Dom Idílio José Soares (Avenida Conselheiro Nébias, 300).

- Campus Pompéia (Rua Euclides da Cunha, 247 e 264).

- Campus Vila Mathias (Rua Dr. Carvalho de Mendonça, 144).

\section{Coordenadoria Geral de Especialização, Aperfeiçoamento e Extensão}

\section{Campus Vila Mathias}

Subordinada à Pró-Reitoria Acadêmica, a Coordenadoria Geral de Especialização, Aperfeiçoamento e Extensão - Coeae - é o setor responsável pelo desenvolvimento, estruturação e oferecimento de cursos de especialização, aperfeiçoamento, extensão e serviços educacionais nas diversas áreas do conhecimento e níveis de formação profissional. 
Seu objetivo é desenvolver a capacidade intelectual e habilidades do ser humano, através da educação continuada de qualidade; para isso, procura estabelecer contatos e convênios com outras instituições alinhadas com o objetivo de prover a geração e a evolução das diferentes capacidades humanas.

\section{Coordenadoria Geral de Pós-Graduação Stricto Sensu e Pesquisa}

\section{Campus Vila Mathias}

A Coordenadoria Geral de Pós-Graduação Stricto Sensu e Pesquisa - Copop - é subordinada à Pró-Reitoria Acadêmica e sua atribuição é manter os programas em nível de mestrado acadêmico em áreas distintas, atendendo carências de titulação no ensino superior, proporcionando o aperfeiçoamento profissional e o envolvimento em trabalhos nos campos do ensino e da pesquisa.

As áreas atendidas são Educação, Direito, Gestão de Negócios, Saúde Coletiva e Informática.

\section{Coordenadoria Pedagógica de Graduação}

\section{Campus Dom Idílio José Soares}

A Coordenadoria Pedagógica de Graduação - Copeg - está subordinada à Pró-Reitoria Acadêmica e presta serviços aos diferentes cursos que compõem a Universidade, auxiliando no processo de elaboração e desenvolvimento dos Projetos Pedagógicos, bem como o contínuo aperfeiçoamento do corpo docente.

\section{Coordenação Geral de Laboratórios}

\section{Campus Dom Idílio José Soares}

\section{Ver: Regulamentos}

Os Laboratórios possuem atividades práticas relacionadas principalmente às disciplinas dos cursos de graduação. As atividades de laboratórios são indispensáveis para que o aluno, em contato direto com o material a ser estudado, possa desenvolver o pensamento lógico, a vivência do método científico e suas aplicações.

O trabalho prático tem como objetivo principal desenvolver no aluno a capacidade para aplicar em situações reais a teoria estudada em sala de aula, além do senso de observação e análise de dados e fatos, bem como a habilidade de experimentar, concluir, conceituar e generalizar. Todos os laboratórios estão administrativamente ligados a uma Coordenadoria Geral e a Pró-Reitoria Acadêmica. Estão situados no Centro de Pesquisa 
e Tecnologia, no Campus Dom Idílio José Soares, em 38 salas destinadas às áreas de Ciências Biológicas, Saúde, Exatas e Tecnológica.

São imprescindíveis normas ou requisitos básicos de manuseio, conduta e procedimentos de segurança em qualquer das dependências dos laboratórios para um bom andamento e desenvolvimentos das atividades práticas.

\section{Editora Universitária Leopoldianum}

\section{Campus Dom Idílio José Soares}

Criada em 1974, a Editora Universitária Leopoldianum — Edul - já publicou cerca de 130 títulos entre livros, revistas e cadernos, sendo conhecida pela qualidade de seu trabalho junto à comunidade acadêmica do País. Seu objetivo é editar trabalhos produzidos pelos professores e pesquisadores da Instituição, prioritariamente, por estudantes da Graduação e da Pós-Graduação, além de projetos de interesse cultural. Entre as metas atuais, busca ampliar a distribuição de seus produtos, investindo nas parcerias com livrarias comerciais e universitárias e na participação em feiras e eventos literários. Sua publicação mais conhecida é a Leopoldianum, revista de estudos e comunicações, primeira obra do gênero em Santos.

\section{Instituto de Pesquisas Científicas}

\section{Campus Dom Idílio José Soares}

O Instituto de Pesquisas Científicas - Ipeci - é um órgão suplementar da Universidade. Tem o propósito de prestar serviços e realizar pesquisas para empresas e instituições. Utiliza os mesmos recursos humanos dos corpos docente e discente, os quais são coordenados pelo Instituto.

Áreas principais de atuação:

- controle de qualidade;

- desenvolvimento tecnológico;

- planejamento metropolitano;

- projetos de iniciação científica.

\section{Núcleo de Extensão Comunitária}

\section{Campus Dom Idílio José Soares}

A Universidade Católica de Santos operacionaliza a ação comunitária através do Núcleo de Extensão Comunitária - Necom - e como parte integrante da extensão universitária. 
Criado em 1986 e oficializado em 1988, o Núcleo é um órgão interdisciplinar ligado à PróReitoria Comunitária e é formado por professores e alunos de vários cursos.

Tem como objetivos gerais contribuir para a transformação social, tornando a população sujeito de sua própria história; ampliar o conhecimento através da apropriação da realidade na qual se vai agir; favorecer a retro-alimentação de conhecimento e a formação adequada de profissionais cidadãos.

\section{Pastoral da Universidade}

\section{Campus Dom Idílio José Soares}

A Pastoral da Universidade - PdU —, subordinada à Pró-Reitoria de Pastoral e diretamente ligada à Coordenação de Pastoral da Diocese de Santos, é um serviço à disposição de funcionários, alunos e professores, prestado por uma comissão composta por leigos e religiosos, vinculados à Universidade, com o objetivo de, divulgando a mensagem cristã, desenvolver atividades litúrgico-sociais enquadradas no projeto de evangelização da Igreja Católica.

\section{Programa de Avaliação Institucional}

\section{Campus Dom Idílio José Soares}

O Programa de Avaliação Institucional - Proai - tem como objetivo proceder ao diagnóstico dos serviços prestados na Universidade, envolvendo sua comunidade interna, bem como a externa à Instituição, por meio de consultas em diferentes momentos. $O$ Programa, vinculado ao Gabinete da Reitora, coordenado por equipe multidisciplinar, procura detectar os aspectos positivos e aqueles que precisam de correções, na perspectiva de processo participativo, visando à excelência na qualidade de ensino.

\section{Projeto Cultural UNISANTOS}

\section{Campus Pompéia}

Além das atividades acadêmicas, caracterizadas pela oferta dos cursos regulares e de extensão, especialização e aperfeiçoamento, a UNISANTOS, através da Pró-Reitoria Comunitária, desenvolve um amplo projeto cultural, aberto a alunos, professores, funcionários e comunidade em geral. O Projeto Cultural compreende uma série de manifestações culturais, envolvendo teatro, corais, música erudita e popular. 


\section{Reitoria}

\section{Campus Dom Idílio José Soares}

A Reitoria é órgão executivo que superintende, coordena e fiscaliza as atividades universitárias. É constituída por um reitor, auxiliado em suas funções pelos pró-reitores acadêmico, administrativo, comunitário e de pastoral.

\section{Secretarias Acadêmicas}

Cada campus possui sua secretaria acadêmica, sob a responsabilidade de um secretário e subordinada à Secretaria Geral da UNISANTOS. Nas secretarias são registradas as faltas, as notas, o histórico escolar, requerimentos diversos, solicitações e toda a documentação necessária à regularização da vida acadêmica de quem faz um curso superior.

\section{Secretaria do Campus Boqueirão}

Atende aos cursos de Graduação em Arquitetura e Urbanismo e Direito e o curso Tecnológico em Design de Interiores.

\section{Secretaria do Campus Dom Idílio José Soares}

Atende aos cursos de Graduação: Administração, Ciências Biológicas, Ciências Contábeis, Ciências da Computação, Ciências Econômicas, Enfermagem e Obstetrícia, Engenharia Civil, Engenharia Elétrica, Engenharia de Produção, Farmácia, Fisioterapia, Nutrição, Psicologia, Química Tecnológica, Serviço Social e Sistemas de Informação. Atende, também, aos Cursos Seqüenciais de Formação Específica em Gestão de Terminais Portuários, Gastronomia e de Tecnologia e Gestão em Redes de Computadores, além dos cursos superiores de Tecnologia em Petróleo e Gás, em Gestão Ambiental e em Logística Empresarial.

\section{Secretaria do Campus Pompéia}

Atende aos cursos de Graduação em Comunicação Social, nas habilitações de Jornalismo, Publicidade e Propaganda e Relações Públicas, Filosofia, Geografia, História, Letras, Matemática, Pedagogia e Tradução e Interpretação, além das licenciaturas dos cursos de Psicologia, Ciências Biológicas e Química (cujos bacharelados são atendidos pela secretaria acadêmica do Campus Dom Idílio). 


\section{Secretaria Geral}

\section{Campus Dom Idílio José Soares}

A Secretaria Geral - Seger - é o setor da Universidade responsável pela aplicação da Lei de Diretrizes e Bases da Educação, dos procedimentos legais estabelecidos pelo MEC e pela orientação e supervisão do cumprimento das NORMAS ACADÊMICAS da UNISANTOS. Coordena o trabalho de todas as secretarias dos campi, incluindo as secretarias da Coeae e da Copop,no registro e controle acadêmico de professores e alunos. É responsável também pela expedição e registro dos diplomas da Universidade, em todos os níveis de ensino, bem como pela expedição de todos os certificados da Coeae.

\section{Serviço de Apoio Pedagógico e Social}

\section{Campus Dom Idílio José Soares}

O Serviço de Apoio Pedagógico e Social - Sapes -, vinculado à Pró-Reitoria Comunitária, tem como objetivo criar mecanismos que favoreçam o crescimento e a valorização da comunidade acadêmica, desenvolvendo, entre outras, as seguintes atividades:

1. avaliação das solicitações de Bolsas de Estudo Reembolsáveis;

2. idem dos pedidos de financiamento estudantil (Fies) da Caixa Econômica Federal;

3. idem dos pedidos de bolsa do Programa Escola da Família do Governo do Estado;

4. idem para as bolsas do Programa Universidade Para Todos (Prouni), do Ministério da Educação;

5. plantão psico-social de atendimento a alunos em seus problemas emergenciais que estejam interferindo na vida acadêmica;

6. orientação educacional, prestando apoio no processo de aprendizagem;

7. ação junto a representantes de classe, visando à valorização e ao fortalecimento do seu papel;

8. controle do cadastro do Balcão de Serviço Temporário.

Mais informações: Serviço de Apoio Pedagógico e Social

Rua Dagoberto de Gasgon, 6 - Campus Boqueirão

Atendimento: segunda a sexta-feira, das $8 \mathrm{~h} 15$ às $12 \mathrm{~h} 30$ e das 15 às 20h30; sábado, das 8 às $11 \mathrm{~h} 30$.

Tel.: (13) 3205-5555 - Ramais 816/823 - E-mail: sapes@unisantos.br 


\section{Universidade Aberta para a Terceira Idade}

\section{Campus Pompéia}

A Universidade Aberta para a Terceira Idade - Uati - é um programa da Pró-Reitoria Acadêmica da UNISANTOS que proporciona atualização cultural às pessoas com 50 anos de idade, ou mais, possibilitando a auto-identificação de potencialidades e habilidades culturais e ocupacionais. Como visa o resgate e a valorização do idoso na comunidade, desenvolve um curso básico, com duração de quatro semestres, destinado às pessoas com qualquer nível de escolaridade. A proposta possui um eixo comum, com disciplinas que abordam aspectos biológicos, psicológicos e sociais, complementado pela parte recreativa, com atividades voltadas para o teatro, cinema, a promoção de viagens culturais e passeios históricos. 


\section{Regulamentos}

\section{Bibliotecas}

Art. 1ํ - São usuários das bibliotecas da Universidade Católica de Santos: professores, alunos e funcionários de posse de Carteira de Identificação de acesso à Universidade.

Parágrafo único: O cartão de acesso da Universidade é de uso pessoal e intransferível, devendo ser apresentado no ato de empréstimos e renovações.

Art. 2 - As bibliotecas estão abertas para consulta local para usuários da comunidade e de outras instituições, em dias e horários estabelecidos pela Reitoria e Coordenadoria de Bibliotecas.

§ 1ํ- - Os ex-alunos da Universidade Católica de Santos terão acesso às bibliotecas, de segunda-feira a sábado, apenas para consulta local, não sendo permitida retirada de material.

§ 20 - Os usuários da comunidade e de outras instituições devem ser cadastrados no sistema de controle eletrônico de acesso.

Art. 3ํ - Bolsas, pastas, sacolas, mochilas e fichários devem ser deixados no guardavolumes na recepção de cada biblioteca.

Parágrafo único: será fornecida chave de armário para guarda de material durante a permanência do usuário na biblioteca.

Art. 4 - Ressalvada a biblioteca do Centro de Ciências da Educação, o acervo é de livre acesso, abrangendo as áreas de interesse de cada curso da Universidade Católica de Santos.

Parágrafo único: Na biblioteca do Centro de Ciências da Educação, as obras devem ser requisitadas no balcão de empréstimo e referência.

Art. 5 - Nas dependências da biblioteca veda-se o uso de celulares e o ingresso de alimentos e bebidas.

Art. 60 - As consultas devem ser feitas no recinto da biblioteca. Nos demais casos, 0 usuário deve apresentar-se ao funcionário do balcão de empréstimo, inclusive para extração de cópias reprográficas ou retiradas de material destinado à sala de aula.

Art. 7ํ- - Após a consulta, o material deve ser deixado sobre as mesas ou nos carrinhos de apoio para reposição no acervo.

Art. 8 - Os usuários regularmente cadastrados podem solicitar empréstimo de materiais em todas as bibliotecas da Universidade Católica de Santos. 
Parágrafo único: Demais interessados serão atendidos por consulta local e através de EEB (Empréstimo entre Bibliotecas).

Art. 9 - O Sistema de Bibliotecas pode fornecer aos órgãos e departamentos internos da UNISANTOS, empréstimo permanente, mediante solicitação por escrito de seus respectivos responsáveis, de publicações necessárias ao desenvolvimento de suas atividades de ensino, pesquisa e extensão.

Art. 10 - Não estão à disposição para empréstimo domiciliar obras de referência, obras raras, materiais em condições especiais, códigos vigentes, periódicos, CD-Rom, normas técnicas e livros com tarja de não circulação ou reservados para consulta.

Art. 11ำ - Excluído o dia do começo, o prazo de empréstimo é de:

a) 15 (quinze) dias para professores;

b) 15 (quinze) dias para alunos dos cursos de Pós-graduação Stricto Sensu;

c) 7 (sete) dias para alunos dos cursos de Pós-graduação Lato Sensu, de aperfeiçoamento e extensão e de graduação.

Art. 12 - As quantidades e prazos de material a serem retirados ficam assim definidos:

a) professores: até 10 (dez) publicações por empréstimo, sendo 5 (cinco) livros e outras 5 (cinco) publicações (vídeos, CD-Rom e periódicos em duplicata) em cada biblioteca;

b) alunos: até 6 (seis) publicações por empréstimo, sendo 4 (quatro) livros e outras 2 (duas) publicações (vídeos, CD-Rom e periódicos em duplicata) em cada biblioteca.

§ $1^{\text {o }}$ - Empréstimo de CD-Rom e outros materiais especiais fica a critério de cada biblioteca da UniSantos.

§ 2ㅇ - É permitido o empréstimo de um único exemplar de cada título por usuário.

§ 3ํ - Cabe ao usuário, ao retirar o material, observar as suas condições e comunicá-las ao funcionário em caso de dano.

§ 4ㅇ- - O usuário é pessoalmente responsável pelo material emprestado, vedada a sua entrega ou transferência do empréstimo a outrem, mesmo que seja usuário cadastrado.

§ 5 - Os empréstimos, devoluções e renovações só poderão ser efetuados até 15 minutos antes do término do expediente da biblioteca.

Art. 13ํ - O empréstimo poderá ser renovado desde que não haja solicitação de reserva por outro usuário e nem esteja em atraso.

Art. 14ํ - A reserva de livros e outros materiais podem ser feitas pela Internet, no site da biblioteca, ou nas ilhas de consulta das bibliotecas. $O$ atendimento às reservas obedece à ordem cronológica das solicitações.

Parágrafo único: Ao usuário não é permitida a reserva de material que já se encontra em seu poder. 
Art. 15 - O usuário é responsável pelo material emprestado devendo zelar pelo uso, conservação e cumprimento dos prazos de devolução, bem como se responsabilizar por perdas e danos.

§ 1ํ- - Obras com edição esgotada devem ser substituídas por outra, de valor equivalente e de conteúdo similar.

§ 20 - O material bibliográfico danificado ou extraviado, durante o período de empréstimo deverá ser reposto ao acervo da biblioteca, às expensas do usuário, no prazo de 30 (trinta) dias, a contar do aviso ou da data fixada para a devolução, pena de suspensão automática de todos os direitos do usuário até a regularização da situação.

§ 3ำ - O usuário em débito com o Sistema de Bibliotecas está sujeito às restrições e penalidades previstas no Regimento Geral da Universidade Católica de Santos.

Art. 16 - O não cumprimento dos prazos, estabelecidos pela biblioteca e atrasos na devolução do material emprestado implicará em cobrança de multa ao usuário responsável.

§ $1^{\circ}$ - A partir do primeiro dia de atraso, o usuário estará sujeito ao pagamento de multa no valor de $\mathrm{R} \$ 2,00$ (dois reais), por material, para cada dia de atraso.

§ 20 - Livros retirados para consulta em classe e não devolvidos no prazo, o usuário estará sujeito ao pagamento de multa no valor de $\mathrm{R} \$ 5,00$ (cinco reais), por material, para cada dia de atraso.

§ 3ำ - Livros retirados para fotocópia, não devolvidos no prazo, o usuário estará sujeito ao pagamento de multa no valor de $R \$ 5,00$ (cinco reais), por material, para cada dia de atraso.

§ 4ำ - A não devolução das chaves de armários na saída da biblioteca, implicará cobrança de taxa de empréstimo no valor de $\mathrm{R} \$ 10,00$ (dez reais)por dia.

Art. 17ํ - Os casos omissos serão apreciados pela Coordenadoria de Bibliotecas e Reitoria da Universidade Católica de Santos.

\section{Bolsas de Estudo}

As Bolsas de Estudo oferecidas pela Universidade Católica de Santos em 2007 serão concedidas obedecendo aos regulamentos e procedimentos abaixo relacionados.

Não terá direito a qualquer das Bolsas de Estudo o aluno que estiver reprovado em mais de duas disciplinas por semestre, não podendo acumular mais de três dependências. 


\section{Cultura}

1. $\mathrm{O}$ aluno interessado deve preencher e protocolar requerimento na respectiva Unidade de ensino, anexando comprovante de pagamento da matrícula 2007, currículo artísticocultural e histórico acadêmico.

2- No caso de aluno do primeiro semestre, o histórico acadêmico será substituído por comprovante da nota obtida no Processo Seletivo.

3 Serão concedidas bolsas correspondentes a 10 parcelas mensais, de fevereiro a junho e de agosto a dezembro.

40 Ao receber a bolsa, o aluno assume, automaticamente, os seguintes compromissos:

a) apresentar à coordenação do Projeto Cultural relatórios bimestrais de sua produção artístico-cultural;

b) representar a UNISANTOS com dignidade e espírito cultural nas atividades de sua área;

c) colaborar, quando convocado, e se possível, em atividades culturais, sociais e comunitárias promovidas ou de interesse da UNISANTOS.

5o A concessão da bolsa é de competência da Pró-Reitoria Comunitária, que também poderá cancelar ou transferir o benefício a outro interessado a qualquer momento e a seu próprio juízo.

60 A concessão da bolsa não significa a garantia de sua manutenção por mais de um ano letivo, devendo ser renovada ao início de cada ano, de acordo com o Calendário Escolar.

\section{Fidelização}

1. Concedida a alunos oriundos do Liceu Santista, desde que estejam adimplentes com a Sociedade Visconde de São Leopoldo.

2o A bolsa é exclusiva para o Ensino de Graduação e equivalentes.

3 o $O$ aluno deve preencher requerimento junto à Secretaria Acadêmica.

4- A bolsa tem valor de $25 \%$ das mensalidades de fevereiro a junho do $1^{\circ}$ período e de agosto a dezembro no segundo período.

\section{Fidelização Familiar}

1․ Concedida a alunos integrantes da mesma família, limitando-se a cônjuges, filhos ou irmãos, desde que estejam adimplentes com a Sociedade Visconde de São Leopoldo.

2- A bolsa é exclusiva para o Ensino de Graduação e equivalentes, Pós-Graduação Lato Sensu e Pós-Graduação Stricto Sensu.

3o $\mathrm{O}$ aluno deve preencher requerimento junto à Secretaria Acadêmica. 
4 A bolsa tem valor de $20 \%$ das mensalidades de fevereiro a junho do $1^{\circ}$ período e de agosto a dezembro no segundo período.

\section{Mérito}

10 Serão concedidas ao melhor aluno classificado no Processo Seletivo (1ำ colocado entre todos os cursos da Universidade, exceto os Tecnológicos e Seqüenciais) e ao melhor aluno dos três semestres finais dos cursos elencados no item $2^{\circ}$ deste Regulamento e observadas as condições estabelecidas no item $7^{\circ}$.

2 Para efeito da concessão do que trata o item $1^{\circ}$, as bolsas terão a seguinte distribuição: Direito; Arquitetura e Urbanismo; Enfermagem/Nutrição; Farmácia/Fisioterapia; Administração; Ciências Contábeis/Ciências Econômicas; Ciências da Computação/Sistemas de Informação; Engenharias/Química Tecnológica; Psicologia; Serviço Social; Pedagogia; Letras/Tradução; Licenciaturas; Jornalismo; Publicidade; e Relações Públicas.

3ำ As bolsas têm valor de $40 \%$ das mensalidades escolares durante um semestre letivo, excetuando-se a matrícula e a rematrícula que deverão ser pagas integralmente. Terão como base para concessão o desempenho acadêmico do aluno no semestre do curso imediatamente anterior em que estiver matriculado, avaliado na forma do item $4^{0}$ deste Regulamento.

4 Para efeito de concessão, será necessário que o aluno tenha sido matriculado no período a que se refere o item $3^{\circ}$ e atingido a média aritmética final igual ou superior a 9,0 (nove), calculada sobre as médias finais de cada disciplina, obtidas com ou sem exame final.

5 Quando houver empate de médias, o valor da bolsa será dividido entre os alunos nessa situação.

6 A manutenção da bolsa está sujeita à conduta pessoal do beneficiado, compatível com as normas regimentais da Universidade.

7ำ A manutenção e a regulamentação do Programa de Bolsas serão revistas semestralmente e sua execução sujeita às disponibilidades orçamentárias.

8ㅇ Os casos não previstos nesse Regulamento serão analisados pela Câmara de Relações Estudantis e Assuntos Comunitários do Conselho de Ensino e Pesquisa Cepes - e submetidos à aprovação da Reitoria. 


\section{Participação Comunitária}

1 Concedida a alunos matriculados a partir do $3^{\circ}$ semestre, para atuação em projetos comunitários, subordinados ao Núcleo de Extensão Comunitária - Necom — ou a órgãos assemelhados.

2ㅇ São oferecidas 70 bolsas anuais, com descontos de $20 \%$ e $30 \%$ nas mensalidades de fevereiro a junho e de agosto a dezembro.

3 Os interessados deverão preencher e protocolar requerimento próprio no Núcleo de Extensão Comunitária - Necom.

\section{Reembolsável}

10 Este regulamento define as normas de concessão das Bolsas de Estudo Reembolsáveis, segundo critérios estabelecidos pelo Serviço de Apoio Pedagógico e Social - Sapes, e aprovados pela Reitoria da Universidade e pela Diretoria da Sociedade Visconde de São Leopoldo.

2- As bolsas solicitadas através de formulário próprio, disponível na Secretaria do Sapes e dentro do prazo estabelecido no calendário escolar, são válidas para o ano letivo em que forem concedidas. Os índices variam de 20\% a 40\% para primeiranistas e de $20 \%$ a $50 \%$ para os demais. Deverão ser renovadas mediante acompanhamento sistemático do desempenho do aluno e da avaliação da situação econômico-social que motivou a concessão.

3 A partir do mês de novembro, o bolsista receberá, via Correios, expediente pelo qual manifestará interesse pela renovação do benefício. Para tanto, bastará que assine termo aditivo após a rematrícula para o período letivo seguinte. Somente haverá necessidade de novo processo quando houver mudança de fiador ou alteração no percentual do benefício. 4 $\mathrm{O}$ benefício só poderá ser concedido a alunos que não possuam bolsa do Fundo de Financiamento Estudantil (Fies), da Caixa Econômica Federal.

5ำ A concessão ficará sujeita à avaliação técnica do Sapes, feita a partir de:

a) análise do formulário de solicitação e da documentação anexada;

b) entrevista com o candidato, quando for o caso;

c) sindicância, se necessário.

6 Após a avaliação, o Sapes emitirá parecer e, em caso de concessão, sugerirá o percentual do benefício à Pró-Reitoria Comunitária, que o ratificará ou não.

7º $\mathrm{O}$ início da vigência do período de concessão pressupõe a assinatura de:

a) contrato específico pelo beneficiário junto ao Sapes, dentro do prazo estabelecido; 
b) termo de fiança de uma ou duas pessoas idôneas cuja somatória de rendimentos mensais seja igual ou superior a duas vezes o valor da mensalidade.

Observação.: o contrato referido na letra a deverá ser assinado pelo requerente, por um responsável (pai ou mãe, se for menor) e pelo(s) fiador(es) até 15 dias corridos a partir da publicação nos quadros informativos das Secretarias.

8- Durante o período de concessão, o aluno terá acompanhamento sistemático do rendimento escolar, devendo comparecer a entrevistas quando convocado, sob pena de cancelamento da bolsa.

9 A equipe do Sapes poderá solicitar às Coordenações de Cursos informações sobre o desempenho geral do aluno, sempre que necessário para uma avaliação pormenorizada. 10을 Caberá à Reitoria fixar, a cada ano, os valores destinados à concessão de Bolsas Reembolsáveis, tendo como base a previsão orçamentária de cada exercício.

11. Para efeito de apuração do valor a ser reembolsado, a soma dos percentuais concedidos será convertida em parcelas da anuidade escolar e o reembolso feito pelo valor vigente de cada parcela no ato do pagamento. A quitação do reembolso será feita a partir do mês imediatamente após o término do benefício e com base na mensalidade em vigor.

\section{Retorno}

10 Concedida a alunos que tenham concluído curso superior na UNISANTOS, desde que estejam adimplentes com a Sociedade Visconde de São Leopoldo.

2- A bolsa é exclusiva para o Ensino de Graduação ou equivalentes, e não se aplica a bacharelados vinculados a licenciaturas.

3o $O$ aluno deve preencher e protocolar requerimento na secretaria acadêmica de sua Unidade de Ensino.

4 A bolsa tem valor de $50 \%$ das mensalidades de fevereiro a junho do $1^{\circ}$ período e de agosto a dezembro no segundo período. Não será cumulativa com qualquer outra bolsa.

\section{Treinamento}

1. Bolsa anual, concedida a estudantes a partir do $3^{\circ}$ semestre para que realizem treinamento na área de sua formação em órgãos internos da Universidade ou em entidades conveniadas.

20 A jornada de estágio será de 20 horas semanais, com percentual de desconto de $30 \%$ sobre a mensalidade, a partir do mês de início do treinamento, excetuando-se sempre as parcelas referentes à matrícula e rematrícula. 
3 A pedido dos órgãos interessados, os bolsistas são selecionados pelos coordenadores de curso, que enviarão seus nomes à Pró-Reitoria Comunitária para as providências.

\section{Estágio Curricular}

\section{Diretrizes gerais}

Nas diretrizes curriculares, o estágio é uma atividade obrigatória em quase todos os cursos de graduação. Configura-se a partir da inserção do aluno em espaços institucionais e em clínicas universitárias, escritórios experimentais, agências ou similares, com o objetivo de capacitá-lo para o exercício profissional.

Dependendo da natureza de cada atividade profissional, conforme o previsto nas diretrizes curriculares, o estágio requer supervisão sistemática. Esta supervisão poderá ocorrer no âmbito do curso e, ao mesmo tempo, no local onde se realiza o estágio, distinguindo-se a supervisão acadêmica da orientação de campo. A orientação de campo está afeta aos profissionais que atuam nos locais de estágio e acompanham o desenvolvimento do aluno no campo.

\section{Significado do estágio no ensino de graduação}

A primeira aproximação que o aluno tem com o espaço da prática profissional se dá mediante o estágio. Como atividade discente, deve caracterizar-se por ser um espaço de aprendizagem.

Sob esta perspectiva, pode-se afirmar que o estágio é o momento em que o aluno tem oportunidade de apreender, identificar-se e apropriar-se de sua futura profissão.

Mediante a experiência vivida no estágio, é possível que o aluno estabeleça relações mediatas entre os conhecimentos teóricos, que já tem e os que estão em construção, e a realidade da prática profissional, a partir das quais poderá desenvolver sua capacidade técnico-operativa e as habilidades desejáveis ao exercício profissional.

O estágio, portanto, se constitui em um processo de aprendizagem do aluno em relação à sua futura profissão. Nesse processo, enquanto aprendiz, ele pode reconhecer os nexos entre a prática profissional e o contexto mais amplo da relação de sua profissão com a sociedade. Em outros termos, o aluno deve apreender também, o significado social da profissão que escolheu e sua importância no conjunto do trabalho da sociedade em que vive.

Como espaço de aprendizagem profissional, o estágio propicia a apreensão da profissão pelo aluno e, para tanto, incorpora aspectos cognitivos, culturais e sócio-profissionais de sujeitos, identificando-se com o mundo profissional, absorvendo os papéis e atitudes dos 
profissionais com os quais convive. Este processo se dá por etapas sucessivas e contínuas de apreensão do agir profissional, através de sua experiência em espaço e tempo determinados.

\section{O estágio curricular na UNISANTOS}

$\mathrm{Na}$ Universidade Católica de Santos, o estágio deve ser considerado como um componente curricular, cujas atividades se realizam fora da sala de aula (nos espaços organizacionais e no espaço escolar), e que propicia aos cursos da Universidade uma relação de proximidade com as demandas profissionais.

Enquanto espaço de aprendizagem, o estágio é um prolongamento do curso e reflete, também, a qualidade do ensino que se objetiva nos Projetos Políticos Pedagógicos.

Para que o estágio, como componente curricular, atinja sua finalidade é necessária uma organização acadêmica e administrativa.

\section{Organização acadêmica}

O estágio deve estar devidamente conceituado nos Projetos Políticos Pedagógicos dos cursos, de acordo com o perfil profissional almejado e ter sua carga horária mínima estipulada, obedecendo às Diretrizes Curriculares. Quando exigir supervisão sistemática (de natureza acadêmica ou de orientação de campo), ambas devem, também, ser conceituadas, tendo em vista o processo de ensino-aprendizagem do aluno.

Cada curso deverá elaborar normas ou regulamentos de estágio, onde estejam previstos, no mínimo, os seguintes aspectos:

a) a carga horária mínima;

b) uma programação a ser cumprida pelo aluno, uma vez que o estágio é atividade discente obrigatória;

c) os critérios necessários para o credenciamento dos locais de estágio, visando à qualidade do processo de ensino-aprendizagem;

d) a forma de acompanhamento dos estágios em relação aos locais credenciados;

e) a forma de acompanhamento e desenvolvimento dos estágios nas clínicas, escritórios experimentais, agências ou similares;

f) a forma e a periodicidade da supervisão acadêmica;

g) as formas ou critérios de credenciamento dos supervisores de estágio;

h) os critérios estipulados para as avaliações sistemáticas, sejam na supervisão acadêmica, sejam na orientação de campo; 
i) os momentos de avaliação sistemática do aluno, posto que o estágio é processo de aprendizagem.

\section{Organização administrativa}

De forma geral, os estágios nos cursos da UNISANTOS deverão estar sob a responsabilidade de um professor, com carga horária estabelecida para essa tarefa, de acordo com a natureza do estágio e das especificidades de cada curso.

Compete ao professor responsável pelos estágios em cada curso:
a) a catalogação e a seleção dos locais de estágio;
b) as providências para a realização de convênios;
c) o trâmite de documentos (termos de compromisso, seguro dos alunos e outros que se fizerem necessários);

d) o encaminhamento dos alunos aos estágios, às clínicas, escritórios, agências ou similares;

e) o credenciamento dos supervisores de estágio;

f) a distribuição dos alunos em grupos de supervisão (quando a mesma ocorrer no âmbito do curso) e dos grupos entre os supervisores;

g) elaborar a documentação para o controle das atividades dos alunos no estágio e na supervisão;

h) estabelecer com os supervisores a programação a ser desenvolvida com os alunos e sua forma de avaliação;

i) garantir ao aluno a efetividade e a qualidade da supervisão acadêmica/orientação de campo;

j) garantir a avaliação sistemática do aluno pelo supervisor;

k) manter os registros em prontuários sempre atualizados (carga horária e outros documentos referentes ao estágio dos alunos) para envio à Secretaria Acadêmica;

I) manter vínculo com os locais de estágio existentes e estar atento para abertura de novos campos;

m) manter vínculo com as clínicas, escritórios experimentais, agências ou similares para acompanhar a realização dos estágios;

n) garantir o cumprimento das normas ou regulamentos do estágio;

o) garantir que os objetivos acadêmicos se realizem através da boa organização administrativa. 


\section{Disposições gerais}

a) o professor responsável pelos estágios deverá ser escolhido pela Direção do Centro/Coordenação do Curso, de acordo com o perfil desejado para este tipo de atividade acadêmica e administrativa;

b) dependendo da natureza do estágio e da especificidade do curso, a supervisão acadêmica deverá estar prevista nas grades curriculares;

c) quando não prevista na grade curricular, a supervisão será remunerada em horas/atividade.

d) quando a supervisão tiver natureza acadêmica, essa deverá ser efetuada no recinto escolar.

e) nos cursos em que a Universidade mantém clínicas, escritórios experimentais, agências ou similares, o aluno poderá cumprir parte da carga horária de seu estágio nesses espaços;

f) todos os cursos deverão adaptar suas normas ou regulamentos de estágio a essas diretrizes para sua implementação em 2007.

\section{Monitoria}

Normas e procedimentos para o exercício da Monitoria em toda a Universidade Católica de Santos.

1ํ $\mathrm{O}$ exercício da monitoria consiste na realização de atividades a serem desenvolvidas em cursos de graduação da Universidade, nos locais e horários mutuamente acertados entre o professor responsável e o monitor, respeitado rigorosamente o horário escolar do aluno.

2 a Cumpre ao monitor colaborar no processo pedagógico da disciplina ou área de disciplina afim para a qual foi designado, participando de:
a) organização de seminários;
b) orientação e discussão de textos indicados pelo professor;
c) preparação do material didático (aulas teóricas ou práticas);
d) aplicação de exercícios práticos;
e) assistência aos alunos em aulas práticas;
f) dar atendimento em plantões para dirimir dúvidas de alunos

3 É vedado ao monitor ministrar aulas e participar da elaboração ou correção de provas e qualquer outra modalidade de avaliação. 
4ª A monitoriasomente poderá ser exercida por aluno matriculado a partir do $5^{\circ}$ semestre do curso de graduação da Universidade, que tenha obtido média final não inferior a 7,0 (sete) na disciplina para a qual foi selecionado.

Observação: os prazos de indicação de alunos para o exercício da monitoria serão estabelecidos anualmente no CALENDÁRIO ESCOLAR.

5a $\mathrm{O}$ monitor voluntário estará sujeito às mesmas exigências do monitor bolsista, tendo direito ao Certificado de Monitoria, ao término do período de atividade.

6a A seleção será efetuada pelo professor responsável pela disciplina, o qual deverá estabelecer e divulgar os critérios de seleção, bem como solicitar à Secretaria a publicação dos benefícios para posterior encaminhamento à Pró-Reitoria Acadêmica, que deverá proceder aos trâmites necessários.

7ª Caberá ao professor responsável, a elaboração do plano de atividades do monitor, bem como seu registro, acompanhamento e avaliação, encaminhando semestralmente à PróReitoria Acadêmica toda a documentação que lhe for solicitada.

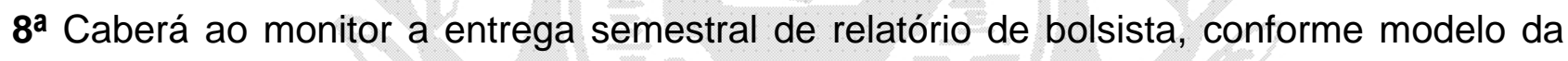
Pró-Reitoria Acadêmica.

9a O monitor estará obrigado a prestar, no mínimo, 6 e, no máximo, 12 horas semanais de atividades, respeitado seu horário de aulas.

10 $\mathrm{a}$ mesmo aluno não poderá exercer a monitoria remunerada em mais de uma disciplina.

11'- O monitor, além da disciplina em que presta monitoria, poderá também, de comum acordo, assessorar a coordenação do curso no que the for solicitado. Nesta situação receberá um atestado.

12a O monitor que, após avaliação por escrito do professor, tiver cumprido todas as exigências, terá direito a certificado de monitoria, expedido pela Direção do Centro/Coordenação do Curso.

13a $\mathrm{O}$ aluno que, no exercício da monitoria, sofrer qualquer tipo de sanção disciplinar prevista no Regimento Geral da Universidade, será afastado da atividade e perderá os direitos a ela vinculados.

14ª - monitor que não puder continuar no exercício da monitoria, deverá solicitar dispensa, por escrito, ao professor responsável, que a encaminhará à Direção do Centro/Coordenação do Curso e posteriormente à Pró-Reitoria Acadêmica a quem caberá tomar as providências necessárias quanto ao cancelamento da monitoria. 
15 $\mathrm{O}$ professor que desejar dispensar o monitor por motivos que julgar relevantes, poderá fazê-lo a qualquer tempo, devendo encaminhar justificativa, por escrito, à Direção do Centro/Coordenação do Curso que dará seguimento aos trâmites necessários.

16 A substituição de um monitor deverá obedecer a ordem de classificação dos candidatos efetuada no início do período.

17 Todo monitor deverá assinar termo de compromisso pelo qual declara estar ciente dos seus direitos e deveres.

18 A critério do professor, o aluno poderá exercer a monitoria por mais de um período letivo, desde que respeitadas as prioridades dos demais candidatos.

19ª Os casos omissos deverão ser resolvidos pela Pró-Reitoria Acadêmica.

\section{Formaturas}

\section{Colação de Grau}

\section{Do Ato}

1) A Colação de Grau é ato oficial e obrigatório para conclusão de curso e emissão do respectivo diploma de Graduação.

2) A colação de grau é realizada em Sessão Solene e pública e é prerrogativa da Universidade Católica de Santos, presidida pela Reitora, secretariada pela secretária acadêmica dos Centros. Durante a cerimônia é conferido, publicamente, aos concluintes habilitados, o grau acadêmico. É uma cerimônia oficial da Universidade e de responsabilidade do Cerimonial Universitário.

3) O Setor de Relações Públicas é o responsável pela elaboração do planejamento, organização e execução das solenidades de colação de grau. Todos os projetos serão encaminhados para aprovação da Reitoria.

4) A Reitora poderá delegar a presidência da cerimônia de colação de grau aos PróReitores, Diretores de Centro e Coordenadores de Curso.

5) Todas as solenidades de colação de grau devem ser organizadas de acordo com as orientações estabelecidas nestas normas. A solenidade oficial é dirigida, por roteiro previamente aprovado pela Reitoria, de acordo com as normas relacionadas abaixo:

\section{Dos Requisitos}

6) Para o acadêmico ser considerado apto para participar da cerimônia de colação de grau deverá ter atendido aos requisitos abaixo relacionados:

\section{- Ter cumprido o currículo total do curso em que estiver matriculado}

- Estar com a documentação completa junto à secretaria 


\section{Da Organização}

7) A comissão de formatura deverá comparecer ao Setor de Relações Públicas para retirada do Cadastro de Colação de Grau e Declaração de Comparecimento.

8) A data de realização da cerimônia de colação de grau será agendada pela comissão de formatura junto ao Setor de Relações Públicas, obedecido o prazo máximo de 10 meses e mínimo de 3 meses, regressivamente da data provável em que deverá ocorrer o ato. As formaturas serão realizadas no período de janeiro a março.

9) A data correta será reservada pelo Setor de Relações Públicas assim que a Comissão de Formatura retornar o cadastro de colação grau preenchido na data estipulada na declaração de comparecimento.

10) $O$ cadastro de colação de grau deverá ser entregue devidamente preenchido e assinado pela comissão de formatura, impreterivelmente, até 30 dias da data inicial estabelecida na declaração de comparecimento.

11) No cadastro de colação de grau a comissão de formatura deverá indicar ao Setor de Relações Públicas os seguintes representantes:

> Patrono : Protetor, padroeiro. A mais importante das homenagens. Não discursa

> Paraninfo: Padrinho da turma. Faz discurso de no máximo sete minutos.

> Juramentista: aluno da turma que lerá o juramento do curso na colação de grau. 0 juramentista dirige-se até a tribuna e, com o braço direito estendido, lê o juramento, enquanto os demais formandos, em pé, também com o braço direito estendido e, em voz alta, acompanham a leitura do juramento

> Impositor do Grau: melhor aluno da turma, que recebe o grau acadêmico representando todos os formandos.

> Orador da Turma: aluno escolhido pela classe, que fará o discurso em nome de todos os formandos. $\mathrm{O}$ orador da turma deve dirigir-se à tribuna e fazer seu pronunciamento, em nome dos colegas, no tempo máximo de seteminutos

> Professores homenageados: professores que turma gostaria de prestar uma homenagem.No máximo três.

> Funcionários homenageados: aqueles que ajudaram a turma durante o curso. No máximo dois.

$>$ Homenagens aos Pais

$>$ Outras homenagens: pessoas que direta ou indiretamente contribuíram com a turma. No máximo duas.

12) $O$ formando que não puder participar da colação de grau na data prevista poderá solicitar data especial, mediante requerimento e comprovação junto à Secretaria. 
13) Caberá a direção do Centro e ao coordenador do Curso dar deferimento ao pedido, bem como agendar nova data, local e horário da colação de grau.

14) A escolha do local para a realização da cerimônia será decidida entre a comissão de Formaturae o Setor de Relações Públicas, dando prioridade aos locais existentes na Universidade Católica de Santos

15) Se o número de formandos exceder aos espaços da Universidade, esta comprometese em ressarcir a Comissão de Formatura em 25\% do valor total da locação (excetuandose o Mendes Convention Center), se todos os formandos estiverem participando da cerimônia.

16) O desmembramento de turmas será prerrogativa do Diretor do Centro em decisão conjunto com o Coordenador do Curso. Esta decisão deve ser ratificada pela Reitoria.

17) A Universidade fornecerá para a cerimônia de colação de grau: cerimonial, mestre de cerimônias, canudos, recepcionistas e decoração floral simples. Quando realizada dentro dos espaços da universidade inclui-se som, microfones e reserva do local.

18) O número máximo de homenagens permitido por turma será o de dez.

19) Os formandos poderão contratar empresa especializada que ficará responsável pelas fotos, filmagem, corais (opcional), entre outros itens, desde que autorizados pelo Setor de Relações Públicas/Pró-Reitoria Comunitária.

20) Os convites de luxo para a cerimônia de colação de grau e para o baile ficarão a cargo da Comissão de Formatura, devendo os mesmos serem revisados pelo Setor de Relações Públicas. Deverá constar no convite:

> Nome completo da Universidade e seu símbolo (Logomarca);

$>$ Nome do Centro;

> Convite formal, mencionando dia, local e hora das solenidades;

> Relação nominal do Corpo Diretivo da Universidade Católica de Santos

$>$ Nome dos homenageados, Patrono, Paraninfo e Orador

$>$ Relação, em ordem alfabética, contendo o nome, por extenso, de todos os

$>$ professores homenageados;

> Juramento oficial para Colação de Grau, conforme texto fornecido por esta Universidade

$>$ Relação nominal de todos formandos aprovados, em ordem alfabética;

$>$ Poderão ser incluídos agradecimentos especiais e fotos da Turma;

$>$ projeto (layout) de confecção dos convites de formaturas, obrigatoriamente deverá receber a aprovação do Cerimonial da UniSantos;

$>$ Traje e confirmação de presença. 
21) Os convites deverão ser enviados aos docentes e homenageados com 15 dias de antecedência da data da realização da cerimônia.

22) O roteiro da cerimônia de colação de grau ficará a cargo do Setor de Relações Públicas, que repassará à Comissão de Formatura uma cópia para as providências. Qualquer alteração no roteiro da colação de grau deverá ser solicitado ao Setor de Relações Públicas, a quem compete deferir ou indeferir.

23) O ensaio de colação de grau será no dia da cerimônia, no período matutino.

24) É obrigatório o uso de beca e capelo por todos os formandos. As mulheres deverão estar trajando meia fina preta e sapato preto. Para os homens, calça, meia e sapato preto.

25) Os formandos deverão alugar as becas, capelos e comprar as homenagens.

26) No caso de empresa contratada, esta deverá fornecer beca e capelo a todos os formandos mediante empréstimo ou locação, e fazer o rateio de homenagens, mediante preço justo, independente do contrato firmado com a turma, não podendo qualquer acadêmico formando ser coagido ou proibido de participar dos atos oficiais.

27)Em caso de empresa contratada pela comissão de formatura, a mesma não poderá fazer nenhum tipo de divulgação ou propaganda nas das dependências internas e externas da universidade. Serão permitidas, apenas, fixações de cartazes nos murais da universidade após aprovação e devida autorização do Setor de Relações Públicas.

28) As empresas de formaturas contratadas pelas comissões para adentrar nas dependências da Universidade deverão enviar um e-mail ao Setor de Relações Públicas solicitando a liberação para entrada nos Campi

29) As vestes talares serão utilizadas pela Reitoria nas cerimônias do curso de Direito. Políticos, empresários e demais participantes da mesa que não sejam membros acadêmicos da universidade utilizarão terno (a partir das 18 horas, em cor escura) e as mulheres traje social.

30) Existem três cores a serem utilizadas nas becas de colação de grau conforme classificação adotada pelo CNPq. Oficialmente apenaspreto, branco, azul, vermelho e verde podem ser utilizados, tolerando-se o cinza em determinadas circunstâncias, pois as cores simbolizam as diversas áreas de conhecimento: a cor azul representa o Reino Mineral, o conhecimento ligado às Ciências Exatas e da Natureza. A cor vermelha representa o Reino Animal, o conhecimento relacionado às Ciências Jurídicas e Sociais. A cor verde representa o Reino Vegetal, o conhecimento ligado às Ciências da Saúde.

- Vermelho - Corresponde à inclusão de Ciências Sociais Aplicadas, Ciências Humanas e Linguística, Letras e Artes conforme terminologia adotada pelo Censo Educacional do MEC. 
- Verde - Corresponde à inclusão de Ciências da Saúde e Ciências Biológicas, conforme terminologia adotada pelo Censo Educacional do MEC.

- Azul - Corresponde à inclusão de Ciências Exatas e da Terra, Ciências da Engenharia e Tecnologia, conforme terminologia adotada pelo Censo Educacional do MEC.

31) Serão utilizadas, também, as cores definidas pelos Conselhos de cada área.

32) Além do presidente da cerimônia, poderá entregar o canudo, os pais de formandos que fizerem parte do corpo docente do curso que estiver sendo graduado. Estes são convidados, durante a sessão solene, pela Reitora ou por seu representante legal, para proferir a entrega.

\section{Da Realização do Cerimonial}

33) A cerimônia de Colação de Grau iniciará no horário previsto, salvo intercessão da maior autoridade presente.

34) A sequência dos atos oficiais da colação de grau é a seguinte:

- Entrada dos convidados (pais de alunos e familiares)

- Apresentação (Mestre de Cerimônia)

- Composição da mesa

- Entrada dos formandos

- Abertura oficial: (Reitora ou seu representante)

- Hino Nacional

- Leitura do Termo de Concessão de grau

- Juramento dos formandos

- Outorga do Grau (melhor aluno)

- Chamada individual dos formandos para entrega dos canudos

- Discurso do Orador

- Discurso do Paraninfo

- Homenagens

- Encerramento

35) A outorga do grau será conferida pela Reitora ou por alguém delegado por ela.

36) Os pronunciamentos protocolares permitidos durante a solenidade de Colação de Grau obedecerão o disposto no item 10.

37) Corais ou grupos musicais apresentarão, no máximo, quatro músicas, em momentos determinados (Entrada dos Formandos, Hino Nacional, Homenagem aos Pais, 
Encerramento). O Coral poderá fazer fundo (sem voz) na composição da mesa, entrega dos diplomas e homenagens.

38) Quando a Comissão de Formatura contratar projeção de clip em telão, esta deverá ser feita antes ou após o término da cerimônia.

39) Mestre de cerimônia é de responsabilidade da Universidade.

40) Os casos não previstos por este regulamento serão resolvidos pelo Setor de Relações Públicas, Direção do curso e Reitoria da Universidade.

\section{Setor de Relações Públicas}

E-mail: rp@unisantos.br

Telefones: 3228-1237 ou 3205-5555, ramal 1409

\section{Programa de Iniciação Científica - PROIN Objetivos gerais}
a) Contribuir para a formação de recursos humanos para a pesquisa institucional.
b) Contribuir para a melhoria da qualidade da formação acadêmica dos alunos de Graduação e desenvolver seu espírito investigativo.
c) Promover maior articulação entre a Graduação e a Pós-graduação.

\section{Objetivos específicos}

a) Estimular pesquisadores a integrarem estudantes de Graduação na atividade científica e tecnológica.

b) Estimular a formação de grupos de pesquisa, identificando novas vocações para expandir e renovar o quadro de pesquisadores.

c) Estimular o aumento da produção científica individual e institucional.

d) Proporcionar a sistematização, divulgação e institucionalização das pesquisas desenvolvidas na Universidade.

e) Incentivar o ingresso de alunos de iniciação científica à Pós-graduação.

\section{Formas de concessão}

a) Caberá à Reitoria estabelecer anualmente o valor e o número de bolsas a serem atribuídas para iniciação científica, mediante proposta da Pró-Reitoria Acadêmica.

b) As bolsas de iniciação científica serão concedidas anualmente, sob a forma de cotas, a alunos de Graduação inseridos em projetos de pesquisa de professores, preferencialmente com titulação de mestre ou doutor, devidamente aprovados pelo Comitê de Pesquisa Institucional da UniSantos e, quando necessário, pelo Comitê de Ética em Pesquisa da Universidade. 
c) Caberá à Comissão de Iniciação Científica do Comitê de Pesquisa Institucional, sob a coordenação da Pró-Reitoria Acadêmica, o acompanhamento do Programa, bem como a definição dos critérios de seleção e de avaliação dos projetos, orientadores e bolsistas.

d) O número máximo de bolsistas será de 3(três) por projeto.

e) Caberá ao professor orientador a seleção dos bolsistas, mediante os critérios estabelecidos pelo Comitê de Pesquisa Institucional da UniSantos.

f) Além dos alunos bolsistas, a critério da Comissão de Iniciação Científica e do Comitê de Pesquisa Institucional, na ocasião de avaliação do projeto de pesquisa, poderão participar do Programa, alunos voluntários, desde que não ultrapassem o número máximo previsto por projeto.

g) A renovação, ampliação ou redução da cota de cada projeto de pesquisa será feita mediante avaliação de desempenho do aluno e da capacidade do professor pesquisador em proceder orientações e acompanhamento do aluno.

\section{Requisitos e compromissos do orientador}

a) Ter produção científica, tecnológica ou artístico-cultural nos últimos três anos.

b) Ter projeto de pesquisa avaliado pelo Comitê de Pesquisa Institucional, que contenha o plano de trabalho do bolsista.

c) Orientar o bolsista em todas as fases do trabalho e na elaboração dos relatórios parciais e final.

\section{Requisitos de ingresso e compromissos do bolsista}

a) Poderão ingressar ao programa alunos regularmente matriculados em cursos de Graduação que estejam cursando até 0 antepenúltimo semestre e que tenham disponibilidade de dedicação às atividades de pesquisa, no mínimo, por 12 horas semanais.

b) No caso de renovação, o bolsista poderá estar no último semestre de Graduação.

c) Apresentar semestralmente relatório de atividades e outros documentos que the forem exigidos pelo orientador e pela Comissão de Iniciação Científica.

\section{Avaliação do programa}

Anualmente, todos os projetos do Proin serão apresentados em seminário de iniciação científica e avaliados pela Comissão de Iniciação Científica. Após a avaliação anual, serão publicados no Livro de Resumos, com a finalidade de divulgar os resultados obtidos pelas pesquisas. Os resumos deverão conter título, autoria, objetivos, metodologia, resultados parciais ou finais e as conclusões do trabalho. 


\section{Trabalho de Conclusão de Curso - TCC}

\section{Diretrizes gerais}

O Trabalho de Conclusão de Curso (TCC) na Universidade Católica de Santos deve constituir-se em um trabalho científico no qual o aluno tenha oportunidade de mostrar sua capacidade de produção/sistematização de conhecimentos por meio de um processo reflexivo e crítico.

\section{Características do TCC na UNISANTOS}

a) O TCC é entendido como etapa conclusiva do processo de ensino-aprendizagem do aluno, devidamente conceituado e definido nos Projetos Políticos Pedagógicos dos Cursos. Portanto, mais do que uma exigência legal estabelecida nas Diretrizes Curriculares, o TCC deve ser significativo para a formação profissional e para o perfil do egresso.

b) O TCC é resultado de um processo integrador/interdisciplinar de acordo com o estabelecido pelos Projetos Políticos Pedagógicos dos Cursos.

c) O TCC será anual e realizado no último ano de formação, mesmo no regime semestral.

d) O TCC será realizado em grupo ou individualmente, de acordo com o que for estabelecido nas normas ou regulamentos de cada curso.

e) O TCC deverá ser devidamente orientado.

\section{Objetivos do TCC na UNISANTOS}

a) Ampliar o domínio específico sobre um determinado tema.

b) Favorecer ao grupo/aluno a realização de uma síntese integradora de conhecimentos teóricos e práticos.

c) Desenvolver/ampliar o espírito investigativo.

d) Favorecer a reflexão sobre a prática profissional.

e) Desenvolver habilidades que favoreçam ao grupo/aluno a busca de alternativas criadoras no exercício profissional.

f) Desenvolver estudos e projetos interdisciplinares.

\section{Procedimentos}

a) O TCC deverá ter uma organização administrativa em cada Curso, para que ocorra o efetivo controle acadêmico.

b) Cada Curso deverá ter um professor responsável para essa função.

c) Caberá a cada Curso a elaboração de normas ou regulamentos para o desenvolvimento das atividades acadêmicas e administrativas do TCC.

d) Cada Curso deverá credenciar um quadro de professores-orientadores a partir de critérios estabelecidos em suas normas ou regulamentos. 


\section{Funções do professor responsável}

a) Acompanhar todas as atividades inerentes à realização do TCC.

b) Responsabilizar-se pelos trâmites administrativos junto à Secretaria, mantendo a Direção do Centro/Coordenação do Curso informadas.

c) Atender aos grupos/alunos no que se refere a orientações de caráter geral, prazos, normas ou regulamentos.

d) Elaborar a listagem dos orientadores credenciados.

e) Encaminhar aos orientadores a relação dos TCC e dos grupos/alunos a eles destinados.

f) Manter com os orientadores espaço para discussão das atividades inerentes ao processo de orientação e o adequado desenvolvimento do TCC.

g) Garantir o processo de orientação dos alunos (em grupo ou individual).

h) Organizar o processo de apresentação do TCC, elaborando o respectivo cronograma.

i) Quando a apresentação do TCC exigir banca examinadora caberá ao professor responsável homologar os nomes indicados para compô-la.

j) Garantir o cumprimento das normas ou regulamentos do TCC pelos orientadores e grupos/alunos.

\section{Funções do orientador de TCC}

O processo de orientação consiste em uma relação essencialmente educativa, onde orientador e orientando interagem no sentido do preparo e desenvolvimento do aluno para a elaboração de um trabalho científico. Esse processo supõe:

a) que o orientador mantenha com o grupo/aluno diálogo franco e aberto;

b) que transmita segurança e conhecimento em relação ao conteúdo e desenvolvimento do trabalho;

c) que auxilie a construção de todo o procedimento metodológico para o conhecimento científico;

d) que incentive e auxilie o grupo/aluno a superar possíveis lacunas de sua formação;

e) que discuta com o grupo/aluno, a viabilidade e consistência da proposta do trabalho, as idéias e que apresente sugestões e críticas;

f) que cuide do processo de amadurecimento intelectual do grupo/aluno, não assumindo as tarefas por ele;

g) que esteja atento para a coerência entre objetivos, metodologia, referencial teórico e resultados obtidos; 
h) que oriente a redação do trabalho para evitar ambigüidades, generalidades e imprecisão;

i) que seja rigoroso quanto à disciplina intelectual, sem ser desestimulador;

j) que seja presente e atenda ao grupo/aluno nos horários marcados para orientação;

I) que esteja atento aos prazos e procedimentos administrativos e acadêmicos;

m) que garanta ao aluno/grupo a avaliação sistemática do trabalho, obedecendo aos critérios pré-estabelecidos nas normas ou regulamentos do TCC;

n) que atenda às determinações das normas ou regulamentos do TCC, mantendo o professor responsável sempre informado de possíveis intercorrências durante o processo de orientação.

\section{Disposições gerais}

a) O professor responsável deverá ser escolhido pela Direção do Centro/Coordenação do Curso, de acordo com o perfil desejado para esse tipo de atividade acadêmica e administrativa.

b) Os orientadores deverão estar credenciados para a função e poderão ser substituídos quando não cumprirem as normas ou regulamentos estabelecidos pelo Curso.

c) Preferencialmente, deverá estar prevista nas grades curriculares, a carga horária destinada ao processo de orientação.

d) Quando a orientação do TCC não constar da carga horária da grade curricular, essa será remunerada em horas/atividade de acordo com tabela elaborada pela Pró-Reitoria Acadêmica.

e) O processo de orientação deverá ocorrer no recinto escolar.

f) Quando o TCC exigir banca examinadora, essa deverá ser composta por professores do quadro da Universidade Católica de Santos.

g) Dependendo da temática poderão ser convidados examinadores externos, só havendo remuneração para esses, salvo se prevista no custo do Curso.

h) Todos os Cursos deverão adaptar suas normas e regulamentos do TCC a essas Diretrizes Gerais para sua implementação em 2007. 


\section{Laboratórios}

\section{Normas e Procedimentos:}

Todos os laboratórios devem seguir as normas gerais da Instituição.

As normas listadas a seguir devem ser cumpridas por todos os usuários, professores e alunos, exceto quando as normas específicas se referirem a um procedimento diferenciado.

\section{Horário e funcionamento}

Os laboratórios funcionarão regularmente obedecendo aos horários previstos para as aulas práticas. A Administração dos laboratórios permanecerá aberta a partir das 7 e até às 23 horas, de segunda a sexta-feira, e aos sábados, das 7 às 18 horas.

\section{Requisição de laboratório}

1.1. A requisição do uso de qualquer laboratório para procedimentos dentro do planejamento pedagógico deverá ser efetuada com, no mínimo, sete dias de antecedência e por escrito (em formulário próprio), pelo professor da disciplina ao técnico dos laboratórios. Para solicitações que incluam animais estas deverão ser efetuadas com um prazo mínimo de 15 dias. Para as aulas práticas no laboratório de Nutrição e Gastronomia as solicitações devem ser efetuadas com 15 dias de antecedência. Para procedimentos diferentes do planejado, o prazo deverá ser verificado com o coordenadortécnico do laboratório. Esta requisição deve ser realizada na Administração dos Laboratórios e ASSINADA pelo professor constando:

a) data da utilização;

b) horário de início e fim da aula;

c) material a ser utilizado;

d) procedimentos específicos;

e) informar se é necessário à presença do professor na preparação da aula.

1.2. Os laboratórios podem ser requisitados para que alunos os utilizem, apenas quando se tratar de projetos, pesquisa de iniciação científica ou coleta de dados para complementarem as aulas laboratoriais. Para tanto a solicitação deve ser realizada pelo professor responsável, ficando este responsável pelo aluno e suas ações dentro do laboratório. Neste caso o aluno deve ser acompanhado pelo monitor, bolsista treinamento ou pelo próprio professor.

1.2.1. Os monitores e/ou bolsistas deverão estar identificados com crachás confeccionados pela Administração dos laboratórios.

1. $3 . \quad$ Não haverá reposição de aula prática. 
1. 4. Especificamente no caso de pesquisa, o laboratório poderá ser requisitado pelo Professor com 24 horas de antecedência, desde que não necessite do apoio dos técnicos, e que haja disponibilidade de horário e de materiais.

\section{Cuidados gerais no uso do laboratório durante as atividades}

O Laboratório é uma área que deve ser reconhecido como um local de risco controlado. Convive no mesmo espaço - equipamentos, reagentes controlados ou não, soluções, organismos vivos ou fixados, microorganismos vivos ou fixados, livros, papéis e principalmente pessoas. Portanto, o laboratório deverá ser utilizado com cuidado e responsabilidade.

$\mathrm{Na}$ ausência do funcionário responsável ou de um professor que se responsabilize pelo laboratório, é expressamente proibida a permanência de pessoas estranhas ao laboratório.

2.1. Qualquer pessoa que utilize o laboratório deverá:

a) Verificar e informar caso haja quebra de materiais e equipamentos.

b) Verificar se houve derramamento de produtos químicos e limpar. No caso disto ocorrer durante o período de aula, informar imediatamente o técnico e ou professor.

c) Descartar os materiais nos seus lixos específicos (normal, séptico e industrial) e não jogá-los dentro das pias.

d) Na área da Saúde e Biológicas trajar calça comprida ou saia longa, sapato fechado, avental branco de manga longa e comprimento até os joelhos, e quando necessário, máscara, luvas ou óculos de segurança.

2.2. Dentro dos laboratórios é proibido:

a) Cabelos longos soltos, estes devem ser mantidos presos.

b) Comer, beber, fumar.

c) Utilizar aparelho celular.

d) Ler revistas e jornais ou realizar atividades estranhas à aula.

2.3. Cabe ao professor estabelecer e comunicar as normas de segurança a serem seguidas pelos alunos durante $o$ transcorrer da aula:

a) O comportamento de usuários deverá ser compatível com o local, podendo os mesmos, serem advertidos em situações inadequadas. Em casos de reincidência o Coordenador do Curso será comunicado.

b) Todos os equipamentos dos laboratórios devem ser utilizados somente por pessoas devidamente habilitadas e previamente autorizados.

c) Fica vetado o uso dos equipamentos dos laboratórios por alunos sem a devida assistência do professor ou técnico responsável. 
d) Qualquer problema ocorrido dentro do laboratório, durante a aula, será de inteira responsabilidade do professor.

e) Ao utilizar os laboratórios fora de aula, os usuários devem antes de sair, desligar todos os equipamentos que não precisarem permanecer ligados.

f) Quando em horários de aulas o laboratório será exclusivo para este fim. A permanência de alunos estranhos à turma dependerá do consentimento do professor da disciplina em aula.

g) Terão a preferência à utilização dos laboratórios as disciplinas de Graduação e Pósgraduação.

\section{Procedimentos após a realização das aulas}

3.1. Cabe ao professor e ao aluno que utilizar o laboratório ter o seguinte procedimento antes de sair do laboratório:
a) desligar os equipamentos, gás e água;
b) verificar as bancadas e válvulas em geral;
c) verificar e informar quebra de materiais e equipamentos;
d) verificar se houve derramamento de produtos químicos e comunicar imediatamente ao técnico;

e) descartar os materiais nos seus lixos específicos (normal, séptico e industrial);

f) limpar os equipamentos, quando necessário;

g) organizar a bancada de trabalho e lavar o material utilizado.

\section{Laboratórios de Informática/Salas de Internet}

\section{Normas e Procedimentos}

\section{Introdução}

Este documento apresenta as políticas, normas e procedimentos para os laboratórios de informática e salas internet a serem adotadas a partir de janeiro de 2007.

\section{Laboratórios de informática}

\subsection{Objetivos}

O objetivo principal dos laboratórios de informática é oferecer recursos computacionais para aulas práticas de qualquer disciplina oferecida pela UNISANTOS.

Observação: quando não alocadas para aulas, as salas ficarão liberadas para utilização dos alunos regularmente matriculados, segundo a política definida para as salas internet. 


\subsection{Horário de funcionamento}

Os laboratórios de informática estão disponíveis nos seguintes horários:

\section{Campus}

Dom Idílio

Boqueirão

Pompéia

Vila Mathias horário (segunda a sexta)

7:30 às $23: 00$

$7: 30$ às $23: 00$

$7: 30$ às $22: 30$

$7: 30$ às $22: 30$

\section{Horário (sábado)}

$7: 30$ às $18: 00$

7:30 às $18: 00$

7:30 às $17: 00$

7:30 às 17:00

\subsection{Política de uso dos laboratórios de informática}

1.3.1. A utilização dos laboratórios de informática, como instrumento para aulas práticas, poderá ser efetuada por qualquer professor da UNISANTOS mediante reserva antecipada.

1.3.2. Não existe prioridade para o uso dos laboratórios de informática. O professor poderá reservar a sala em qualquer horário livre (ver item 2.4).

1.3.3. Se a sala não for ocupada pelo professor em até 15 minutos após o início do período reservado, o laboratório será liberado para uso dos alunos até o início do horário da próxima reserva. A pró-reitoria acadêmica receberá mensalmente um relatório de utilização dos laboratórios de informática.

1.3.4. A utilização das salas internet poderá ser efetuada por qualquer aluno regularmente matriculado na UNISANTOS, através de um usuário e de uma senha de acesso.

1.3.5. Durante o período de aula, o professor poderá utilizar qualquer dos softwares disponíveis, desde que especificados no momento da reserva da sala. A relação dos softwares disponíveis estará publicada no APEP.

1.3.5.1. Fica proibida a instalação e/ou configuração de software durante as aulas, exceto em casos específicos em que a instalação fizer parte da própria aula - esta solicitação deverá ser efetuada juntamente com a reserva da sala. Mesmo nestas situações, somente será permitida a instalação dos softwares disponíveis. A relação dos softwares disponíveis estará publicada no APEP.

1.3.5.2. Fica proibido o download de arquivos durante o período de aulas. Todos os arquivos necessários devem ser especificados no momento da reserva da sala.

1.3.6. Durante o período de aula, o professor poderá utilizar quaisquer recursos web (sites, messengers, chats, fóruns, etc.), desde que especificados no momento da reserva (vide item "Uso indevido dos laboratórios de informática e salas internet”); 
1.3.7. O professor deve seguir as políticas, normas e procedimentos gerais definidos para os laboratórios de informática. Cabe a ele, no entanto, especificar e comunicar as normas de uso e de conduta que devem ser seguidas pelos alunos durante sua aula específica (vide item "Uso indevido e penalidades").

1.3.7.1. O professor e os alunos são responsáveis por todas as ações realizadas durante o período da aula, bem como pela integridade dos recursos a eles disponibilizados.

1.3.7.2. Antes do início de cada aula, o técnico deverá informar ao professor quaisquer irregularidades existentes nos equipamentos da sala.

1.3.7.3. Ao final da aula, o técnico do laboratório deve elaborar um relatório simples da situação do laboratório, incluindo todas as ocorrências observadas durante a aula. Este relatório ficará à disposição da pró-reitoria acadêmica, do coordenador do curso, do professor coordenador do CEITE e do coordenador dos laboratórios de informática e salas internet.

1.3.8. O professor deverá finalizar a aula dentro do horário de sua reserva. Não será permitido prolongar a aula além do previsto, mesmo que o próximo horário esteja disponível (isto porque a programação de cada sala é fechada e publicada com um dia de antecedência).

1.3.9. O professor deverá estar presente durante todo o período de aula, a menos que eleja um representante (professor ou monitor ), que o substitua durante este período. Isso, no entanto, não o isenta das responsabilidades pelas ações realizadas no laboratório durante o período da aula.

1.3.10. Quando necessário, o usuário deverá copiar os arquivos gravados no disco rígido antes de encerrar sua sessão, pois estes arquivos serão automaticamente removidos.

1.3.11. Em todos os campi, existe pelo menos um microcomputador ligado a um scanner, um gravador de CD e uma porta USB para livre utilização dos alunos.

1.3.12. Se necessário, professores e alunos poderão utilizar equipamentos pessoais nos laboratórios de informática.

1.3.12.1. Antes da entrada no laboratório de informática, o usuário (aluno ou professor) deverá registrar os equipamentos pessoais com o técnico do laboratório.

1.3.12.2. A UNISANTOS não é responsável por nenhum dano causado nos equipamentos pessoais utilizados nos laboratórios de informática.

1.3.12.3. Nenhum equipamento pessoal poderá ser ligado diretamente na rede. 
1.3.12.4. O técnico do laboratório não será responsável pela instalação de qualquer equipamento pessoal.

1.3.12.5. Se o equipamento pessoal a ser utilizado exigir a instalação de algum software nas máquinas do laboratório, isto deverá ser solicitado no momento de reserva da sala.

1.3.12.6. O técnico do laboratório não fará instalação de nenhum software em equipamentos pessoais.

1.4. Reserva dos laboratórios de informática

1.4.1. Qualquer sala de laboratório de informática poderá ser reservada por qualquer professor da UNISANTOS.

1.4.1.1. Os professores convidados para alguma atividade específica também poderão utilizar os laboratórios de informática, desde que um professor da UNISANTOS se responsabilize por esta utilização. Para isso, o setor responsável pela atividade deverá informar o setor de atendimento do CEITE, com 2 (dois) dias de antecedência, os dados necessários (nome do professor, nome da atividade, período da atividade, nome do professor da UNISANTOS responsável).

1.4.1.2. Antes do início das aulas de cada semestre, os coordenadores de curso poderão reservar as salas para as aulas planejadas para os laboratórios de informática. Esta reserva poderá ser efetuada diretamente com o coordenador dos laboratórios de informática que, no caso de coincidência de horários, agendará uma reunião com os interessados para encontrar uma solução para o problema.

1.4.2. A requisição do uso de qualquer laboratório de informática, para procedimentos dentro do planejamento pedagógico, deverá ser efetuada com, no mínimo, 2 (dois) dias úteis de antecedência, pelo professor da disciplina. Ao fazer a reserva, o professor deverá informar:

- data da utilização;

- horário inicial e final da aula;

- softwares que serão utilizados, especificando e justificando, quando a instalação tiver que ser realizada durante a aula;

- recursos web que devem ser liberados e/ou bloqueados;

- arquivos que devem ser baixados via ftp, antes da aula, e informações necessárias para que o ftp seja feito;

- nome de seu representante legal, se for o caso.

1.4.2.1. Caso o professor necessite de um software free que ainda não conste da relação dos softwares disponíveis, a reserva deverá ser feita com, no mínimo, 7 (sete) dias úteis de antecedência. 
1.4.2.2. Caso o professor necessite de liberação de recursos internet que exijam testes, como liberação de portas, a reserva deverá ser feita com no mínimo, 7 (sete) dias úteis de antecedência.

1.4.3. Reservas efetuadas com mais de dois dias de antecedência deverão ser confirmadas, através de e-mail, ou telefone ao setor de atendimento do CEITE, com 2 (dois) dias úteis de antecedência à data de utilização do laboratório (até às 12:00 horas).

1.4.3.1. As reservas realizadas pelos coordenadores de curso, antes do início do período letivo, também deverão ser confirmadas pelos professores 2 (dois) dias antes da data reservada.

1.4.3.2. Todas as reservas não confirmadas serão automaticamente canceladas. 0 cancelamento se dará às 12:00 horas da data limite para a confirmação da reserva. Com isso, ela será liberada para reserva para outro professor.

\subsection{Softwares disponíveis}

1.5.1. É proibido o uso de qualquer software ou material pirata nos laboratórios de informática.

1.5.2. Poderão ser instalados nos microcomputadores dos laboratórios de informática apenas os softwares homologados. Estes softwares são de livre utilização (software free) ou estão legalmente licenciados por:

- aquisição feita pela UNISANTOS;

- convênios da UNISANTOS com o fabricante ou distribuidor do software.

1.5.3. Caso, no momento da reserva do laboratório, o professor especifique um software free ainda não homologado, este será incluído na relação dos softwares disponíveis após homologação feita pelo CEITE.

1.5.3.1. A homologação de qualquer software free será feita em, no máximo, 7 (sete) dias úteis.

1.5.3.2. Em caso de não homologação de algum software solicitado, o coordenador dos laboratórios de informática e salas internet deverá enviar ao professor solicitante, um relatório justificando a decisão tomada. Estes relatórios estarão disponíveis para todos os interessados.

1.5.4. Alguns softwares estão disponíveis para todas as salas. Outros, por restrições técnicas de equipamentos ou por restrições de licenciamento, estão disponíveis apenas em salas específicas. Essas características estão assinaladas na relação dos softwares disponíveis, publicada no APEP.

1.6. Recursos web 
1.6.1. Não existem restrições para utilização de recursos web em aulas práticas nos laboratórios de informática.

1.6.1.1. Todos os recursos web devem ser definidos no momento da reserva do laboratório;

1.6.1.2. Todos os recursos solicitados serão liberados durante a preparação do laboratório para o horário reservado. Durante as aulas não será permitido a liberação ou bloqueio de nenhum recurso web.

1.6.1.3. O professor é responsável pelas ações decorrentes das liberações e/ou bloqueios solicitados.

\section{Salas internet}

\subsection{Objetivos}

O objetivo das salas internet é oferecer recursos computacionais para que alunos regularmente matriculados possam acessar a internet, ou utilizar ferramentas para a elaboração de trabalhos vinculados às atividades acadêmicas.

2.2. Horário de funcionamento

\section{Campus}

Dom Idílio

Boqueirão

Pompéia

Vila Mathias horário (segunda a sexta)

$8: 00$ às $22: 00$

$7: 30$ às $22: 30$

$7: 30$ às $22: 30$

$7: 30$ às $22: 30$
Horário (sábado)

8:00 às 16:00

7:30 às 18:00

$7: 30$ às $17: 00$

7:30 às 17:00

\section{Observações:}

1. Os laboratórios de informática, quando não reservados por professores para aulas práticas, funcionarão como salas internet. Estes horários serão divulgados, diariamente, através de uma planilha de horários fixada na porta dos laboratórios.

2. A sala de internet do campus Dom Idílio está localizada dentro da biblioteca - assim, ela segue o horário de funcionamento da biblioteca.

\subsection{Política de uso das salas internet}

2.3.1. A utilização das salas internet poderá ser efetuada por qualquer aluno regularmente matriculado na UNISANTOS, através de um usuário e de uma senha de acesso.

2.3.2. Não existe prioridade para o uso das salas internet - o controle do acesso aos micros deve ser feito pelos próprios usuários.

2.3.3. O software disponível nas salas internet estará publicado no APEP. Além desses, nenhum outro software será permitido. 
2.3.4. O usuário é o único responsável pelo equipamento e por todo tipo de utilização, inclusive pelos acessos à internet, que dele fizer durante todo o tempo em que estiver conectado à rede.

2.3.5. As restrições de acesso adotadas nas salas internet estão descritas no item 5.1 (Caracterização de Uso Indevido). São de responsabilidade de cada usuário as ações, sites acessados e conteúdo divulgado na web através do equipamento por ele utilizado.

2.3.6. Não é permitida a utilização de equipamentos particulares nas salas internet.

2.3.7. A sala internet do campus Dom Idílio poderá ser utilizada para treinamento / divulgação dos sistemas de busca e bases de dados disponíveis na biblioteca. A confirmação de alocação deverá ser feita com 2 (dois) dias de antecedência para que a reserva seja divulgada para os alunos. Essas alocações podem ser feitas nos seguintes horários:

- terças, das 20:00 às 21:00 horas;

- quintas, das 09:00 às 10:00 horas.

3. Monitoramento do uso

3.1. Mecanismos utilizados

3.1.1. A utilização das salas, equipamentos e recursos web será registrada em arquivos que possibilitem provar a responsabilidade ou efetuar eventual rastreamento de uso indevido ou prova de responsabilidade.

3.1.1.1. A identificação do uso dos equipamentos se dá através da autenticação do usuário com sua senha de acesso.

3.1.1.2. O histórico do agendamento das salas ficará gravado em um arquivo específico.

3.1.2. O uso de cada equipamento, e seu respectivo $I P$, será registrado através de um arquivo que grava o horário de autenticação e o horário em que o usuário finalizou sua sessão no equipamento.

3.1.3. O acesso à internet será gravado em um arquivo que indica, por $I P$, quais as URL's acessadas e o horário de acesso.

\section{Uso indevido e penalidades}

4.1. Caracterização de uso indevido

4.1.1. Fica proibida a prática de qualquer ação que possa ser prejudicial à instituição de ensino, à comunidade acadêmica e à sociedade em geral.

4.1.2. É proibido danificar, remover, substituir e alterar qualquer item do patrimônio do laboratório ou sala internet (equipamento, mesas, cadeiras, lousas, móveis em geral, instalações físicas, etc.). 
4.1.3. É proibido o desenvolvimento e/ou disseminação de código malicioso (vírus, spam, spy ware, etc.) através dos equipamentos dos laboratórios.

4.1.4. É proibido, e está sujeito a delação, o acesso a sites com conteúdo que faça apologia a drogas, apologia ao crime, discriminação racial, pornografia ou pedofilia.

4.1.5. É proibida, e está sujeito a delação, a divulgação de qualquer material com conteúdo pornográfico, difamatório, pejorativo ou injurioso, discriminatório (em relação a sexo, raça, cor ou credo), ou que faça apologia a drogas, apologia ao crime, pedofilia.

4.1.6. É proibida a prática de invasão a qualquer site ou servidor.

4.1.7. É proibida a prática de invasão a qualquer sistema de acesso restrito e controlado.

4.1.8. É proibida a prática de qualquer tipo de pirataria através da Internet (software, música, vídeo, etc.).

4.1.9. É proibida a utilização de equipamentos para acessar chats, messengers, jogar ou assistir a vídeos quando houver pessoas aguardando a liberação de algum microcomputador.

4.1.10. É proibida a utilização de equipamentos para desenvolver trabalhos não ligados diretamente ao seu(s) curso(s).

4.1.11. É proibido o uso dos laboratórios e salas internet para desenvolvimento de trabalhos de cunho comercial;

4.1.12. É proibido fumar nos laboratórios e salas internet.

4.1.13. É proibido o consumo de qualquer tipo de alimento ou bebida nos laboratórios. Será do usuário a responsabilidade por qualquer dano causado pelo mau uso dos equipamentos a ele disponibilizados.

4.2. Penalidades

Os usuários que não observarem as proibições descritas no item "Uso Indevido dos Laboratórios de Informática e Salas Internet” estarão sujeitos às seguintes penalidades:

4.2.1. Penalidades aplicadas pelo comitê dos laboratórios estratégicos dos laboratórios de informática e salas internet mediante relatório enviado pelo Técnico do laboratório:

4.2.1.1. Pagamento dos reparos dos danos causados por mal uso do equipamento;

4.2.1.2. Reposição do equipamento danificado em casos críticos em que não for possível um reparo dos danos causados pelo mau uso;

4.2.1.3. Perda do direito de uso dos laboratórios de informática e salas internet;

4.2.1.4. Outras penalidades previstas no Regimento Geral da UNISANTOS.

4.2.2. Responsabilidades civis e criminais cabíveis dentro da lei. 


\section{Restrições e bloqueios}

A atual política para os laboratórios e salas internet procurou fazer, dentro dos recursos disponíveis, o mínimo de bloqueio possível. Essa política estará sendo continuamente revista, tanto para ampliar os recursos como para evitar eventuais abusos e má utilização dos recursos disponibilizados.

5.1. Bloqueios por motivos técnicos

Estão bloqueados, por limitações da banda internet:

- Rádios on-line;

- Sites de vídeos;

- Download de arquivos;

- Skype.

Ao fazer a reserva de um laboratório, o professor poderá solicitar a liberação destes bloqueios para a aula. Após a aula esses desbloqueios serão cancelados.

5.2. Bloqueios por motivos éticos

- Sites com conteúdo pornográfico, difamatório, pejorativo ou injurioso, discriminatório (em relação a sexo, raça, cor ou credo), ou que faça apologia a drogas, apologia ao crime e pedofilia estão bloqueados.

\subsection{Restrições por motivos técnicos}

Por limitações da banda internet, foram definidas as seguintes restrições:

- A banda será limitada a 6Kbytes por conexão;

- O uso de instant messenger está liberado apenas via web.

\section{Atribuições e responsabilidades}

6.1. Comitê estratégico dos laboratórios de informática e salas internet

6.1.1. Objetivo

Garantir, em nível estratégico, o alinhamento das estratégias dos laboratórios e salas internet com os projetos políticos pedagógicos dos cursos oferecidos pela UNISANTOS.

6.1.2. Composição

O Comitê Estratégico dos laboratórios é composto por:

6.1.2.1. pró-reitoria acadêmica;

6.1.2.2. um coordenador de cada centro;

6.1.2.3. um representante do COEAE;

6.1.2.4. coordenador do CEITE;

6.1.2.5. coordenador dos laboratórios de informática e salas internet.

6.1.3. Responsabilidades: 
6.1.3.1. Definir políticas, normas e procedimentos para os laboratórios de informática e salas internet;

6.1.3.2. Aprovar os projetos de expansão e modernização dos laboratórios a serem submetidos ao comitê estratégico de segurança e tecnologia da informação;

6.1.3.3. Resolver conflitos relativos aos laboratórios e salas internet.

6.2. Coordenador do CEITE

6.2.1. Atribuições e responsabilidades

6.2.1.1. Representar o CEITE junto ao comitê estratégico dos laboratórios de informática e salas internet;

6.2.1.2. Administrar o orçamento destinado aos laboratórios;

6.2.1.3. Encaminhar ao comitê estratégico dos laboratórios de informática e salas internet as sugestões, reclamações, problemas e solicitações que estejam fora de seu escopo de decisão.

6.3. Coordenador dos laboratórios de informática

6.3.1. Atribuições e responsabilidades

A coordenação dos laboratórios de informática e salas internet está sob a área de gerência de infra-estrutura do CEITE.

Como coordenador dos laboratórios, é responsável por:

6.3.1.1. Administrar os recursos materiais e recursos humanos dos laboratórios e salas internet;

6.3.1.2. Homologar softwares free solicitados;

6.3.1.3. Administrar licenças de softwares utilizados nos laboratórios;

6.3.1.4. Participar da negociação e administrar convênios relativos aos laboratórios e salas de internet;

6.3.1.5. Garantir a operacionalidade dos laboratórios de informática e salas internet segundo as políticas, normas e procedimentos aprovados;

6.3.1.6. Encaminhar ao coordenador do CEITE as sugestões, reclamações, problemas e solicitações que estejam fora de seu escopo de decisão;

6.3.1.7. Decidir, juntamente com o coordenador do curso, penalidades por uso indevido dos recursos disponíveis, conforme normas estabelecidas pelo comitê estratégico dos laboratórios de informática e salas internet;

6.3.1.8. Participar do comitê estratégico dos laboratórios de informática e salas internet;

6.3.1.9. Promover eventos de divulgação e/ou treinamento de softwares de interesse aos professores e alunos.

6.4. Técnicos de laboratório 


\subsubsection{Atribuições}

São atribuições dos técnicos dos laboratórios de informática e salas internet:

6.4.1.1. Atendimento aos alunos, professores, coordenadores, colegas da universidade e visitantes;

6.4.1.2. Instalação e configuração dos softwares necessários aos laboratórios e salas internet;

6.4.1.3. Agendamento e administração dos laboratórios segundo os procedimentos e normas definidos.

6.4.2. O técnico de laboratório é responsável por:

6.4.2.1. Preparar os laboratórios de informática segundo informações fornecidas pelo professor no momento da reserva;

6.4.2.2. Solicitar a confirmação das reservas se o professor não o fizer no prazo estipulado;

6.4.2.3. Liberar as salas no caso de ausência do professor, ou no caso de cancelamento das reservas;

6.4.2.4. Elaborar vistoria da situação do laboratório antes do início e após o término de cada aula;

6.4.2.5. Zelar pela conservação das salas de internet e elaborar relatórios diários das ocorrências de danos, mau comportamento ou qualquer outro evento que necessite alguma providência por parte da coordenação dos laboratórios;

6.4.2.6. Publicar, diariamente, em local visível, o cronograma de uso dos laboratórios de informática do próprio dia e do dia seguinte;

6.4.2.7. Quando for o caso, identificar, através de um documento legal, o representante nomeado pelo professor ao fazer a reserva do laboratório.

6.4.2.8. Oferecer suporte básico sobre uso dos recursos disponibilizados.

6.4.3. O técnico de laboratório NÃO é responsável por:

6.4.3.1. Dar orientações sobre os softwares específicos disponibilizados nos laboratórios e salas internet;

6.4.3.2. Dar orientações sobre softwares específicos.

6.4.4. O técnico de laboratório NÃO deve:

6.4.4.1. Digitar ou formatar documentos pessoais ou de cunho acadêmico de alunos ou professores;

6.4.4.2. Realizar qualquer trabalho de cunho pessoal ou acadêmico de professores ou alunos;

6.4.4.3. Executar tarefas de gravação de CD/DVD, pen drive, disquete, etc. 
6.4.4.4. Fazer digitalização de imagens

\subsection{Professor}

\subsubsection{Responsabilidades}

6.5.1.1. Seguir as políticas, normas e procedimentos definidos para os laboratórios de informática e salas internet;

6.5.1.2. Indicar softwares de interesse para os laboratórios, considerando sempre a possibilidade de avaliar softwares de livre utilização (software free);

6.5.1.3. Cancelar as reservas por ele feitas quando souber que não serão utilizadas;

6.5.1.4. Definir antecipadamente, os recursos que serão por ele utilizados durante as aulas nos laboratórios de informática;

6.5.1.5. Definir normas de uso e de conduta durante suas aulas nos laboratórios de informática coerentes com as políticas, normas e procedimentos gerais aprovados.

Os professores e os alunos são responsáveis pelo patrimônio, por todas as ações realizadas e ocorrências durante o período de suas aulas nos laboratórios de informática.

\subsection{Aluno}

\subsubsection{Responsabilidades}

6.6.1.1. Seguir as políticas, normas e procedimentos definidos para os laboratórios;

6.6.1.2. Seguir as normas de uso e conduta definidas pelo professor;

6.6.1.3. Zelar pelas instalações físicas e pelos recursos colocados à sua disposição nos laboratórios de informática e salas internet;

6.6.1.4. Utilizar os recursos dos laboratórios e salas internet para fins exclusivamente acadêmicos.

O professor e os alunos são responsáveis pelo patrimônio, por todas as ações realizadas e ocorrências durante o período de suas aulas nos laboratórios de informática.

\section{Uso dos armários}

Para comodidade dos alunos, a UNISANTOS oferece, em alguns laboratórios de informática e salas internet, armários para uso dos alunos durante o período de utilização dos laboratórios e salas informática.

Os armários possuem chaves individuais.

\subsubsection{Procedimento de uso}

7.1.2. Os armários disponíveis podem ser usados, durante o período de utilização dos laboratórios de informática e salas internet, por qualquer aluno regularmente matriculado na UNISANTOS; 
7.1.3. As chaves serão fornecidas pelo técnico de laboratório mediante entrega de um documento de identificação do aluno. Este documento deverá ter fotografia do aluno e ficará retido até a devolução da chave.

7.1.3.1. No caso de não devolução da chave num prazo de 24 horas, o aluno terá seu acesso aos microcomputadores dos laboratórios de informática e das salas internet bloqueado. A liberação do acesso se dará mediante a devolução da chave.

7.1.3.2. No caso de perda da chave, o aluno deverá pagar a confecção de uma nova cópia. 


\section{CALENDÁRIO ESCOLAR - ANO LETIVO DE 2007}

\section{(Aprovado pelo CEPES em 20/11/2006)}

\section{1ㅇ SEMESTRE LETIVO \\ 103 dias letivos}

\section{JANEIRO}

2 a 28 - Recesso de Professores

8 a 25 - Rematrículas

8 a 25 - Cursos de Nivelamento

26 - Dia da Cidade (Feriado Municipal)

29 - Início do Período Letivo

29 a 31 - Encontro de Professores

\section{FEVEREIRO (17)}

1ํ a 3 - Encontro de Professores

\section{5 - Início das aulas}

16 - Término do prazo para indicação de Monitores

17 a 20 - Recesso de Carnaval

21 - Recesso de Carnaval (Quarta-feira de Cinzas)

\section{MARÇO (27)}

3 - Término do prazo para requerer:

- Bolsas de Estudo

- aproveitamento (dispensa) de disciplinas

- matrícula em disciplinas para enriquecimento curricular

- ajustes de matrícula (cancelamento ou inclusão de disciplinas)

12 a 17 - Eleições dos Representantes de Classe

19 a 24 - Eleições dos Representantes para os Órgãos Colegiados

31 - Último dia para requerer Trancamento de Matrícula (Cancelamento de Matrícula pode ser requerido a qualquer momento)

ABRIL (20)

5 a 7 - Semana Santa (Recesso dos Professores)

21 - Tiradentes (Feriado Nacional)

30 - Recesso de Professores 
MAIO (26)

1- Dia Nacional do Trabalho

14 a 16 - Jornada de Serviço Social

17 a 19 - I Jornada Científica da Saúde

24 e 25 - Jornada de Gastronomia

JUNHO (13)

7 - Corpus Christi (Feriado Religioso)

16 - Último dia de aula e entrega (digitação) de notas

19 - Término do prazo para indicação de Monitores

\section{8 a 27 - Exames finais}

18 - II Jornada das Licenciaturas

27 - Último dia para entregar (digitar) as notas de exames

28 - II Jornada de Iniciação Científica

\section{8 e 29 - Exames em 2 ${ }^{\text {a }}$ Chamada}

30 - Último dia para entregar (digitar) as notas de exames em $2^{\mathrm{a}}$ Chamada

\section{SEMESTRE LETIVO \\ 101 dias letivos}

\section{JULHO}

2 a 31 - Férias dos Professores (30 dias)

9 - Revolução Constitucionalista de 1932 (Feriado Estadual)

10 a 20 - Rematrícula (exceto sábado dia 14)

\section{AGOSTO (26)}

10 - Início do Período Letivo - Encontro de Professores

\section{2 - Início das aulas do 2 - período letivo}

9 a 11 - Jornada Jurídica

13 - Término do prazo para requerer:

- aproveitamento (dispensa) de disciplinas

- ajustes de matrícula (cancelamento ou inclusão de disciplinas)

- matrículas em disciplinas para enriquecimento curricular

23 a 25 - Jornada da Psicologia

29 a 31 - Intercom 


\section{SETEMBRO (23)}

$1^{\circ}-$ Intercom

7 - Independência do Brasil (Feriado Nacional)

8 - Nossa Senhora do Monte Serrat (Feriado Municipal)

26 - Último dia para requerer Trancamento de Matrícula (Cancelamento de Matrícula pode ser requerido a qualquer momento)

16 a 22 - Fafiana

26 a 28 - Jornada de Administração, de Economia, de Ciências Contábeis, de Gestão Portuária e de Logística

27 a 29 - Encontro de Profissões - CCE

\section{OUTUBRO (25)}

3 a 5 - III Encontro Científico do Centro de Ciências Exatas e Tecnológicas

12 - Nossa Senhora Aparecida (Feriado Nacional)

13 - Comemoração do Dia do Professor

22 a 24 - Semana da Doutrina Social da Igreja

24 a 26 - Jornada de Arquitetura e Design

\section{NOVEMBRO (23)}

2 - Dia de Finados (Feriado Religioso)

3 - Recesso de Professores

15 - Proclamação da República (Feriado Nacional)

28 e 29 - 4ํEncontro de Trabalhos Científicos da Área de Saúde

\section{DEZEMBRO (4)}

5 - Último dia de aula e entrega (digitação) das notas

6 a 17 - Exames finais (turmas semestrais e anuais)

8 - Nossa Senhora da Conceição (Feriado Religioso)

\section{8 e 19 - Exames em 2ª Chamada}

\section{0 - Último dia para entrega das notas dos exames finais}

22 - Confraternização de Natal dos funcionários (Recesso Administrativo)

24 a 31 - Recesso dos Professores (8 dias)

24 a 31 - Férias Coletivas Administrativas (8 dias) 


\section{CALENDÁRIO DE EVENTOS}

\section{MAIO}

14 a 16 - Jornada de Serviço Social

17 a 19 - I Jornada Científica da Saúde

24 e 25 - Jornada de Gastronomia

\section{JUNHO}

18 - II Jornada das Licenciaturas

28 - II Jornada de Iniciação Científica

\section{AGOSTO}

9 a 11 - Jornada Jurídica

23 a 25 - Jornada da Psicologia

29 a 31 - Intercom

\section{SETEMBRO}

$1^{\circ}-$ Intercom

16 a 22 - Fafiana

26 a 28 - Jornada de Administração, de Economia, de Ciências Contábeis, de Gestão Portuária e de Logística

27 a 29 - Encontro de Profissões - Centro de Ciências da Educação

\section{OUTUBRO}

3 a 5 - III Encontro Científico do Centro de Ciências Exatas e Tecnológicas

22 a 24 - Semana da Doutrina Social da Igreja

24 a 26 - Jornada de Arquitetura e Design

\section{NOVEMBRO}

28 e 29 - 4ํㅡㄹ Encontro de Trabalhos Científicos da Área de Saúde 


\title{
UNIVERSIDADE DE TAUBATÉ \\ Departamento de Comunicação Social \\ Coordenação de Projetos Experimentais
}

\section{NORMAS PARA ELABORAÇ̃̃O DOS PROJETOS EXPERIMENTAIS}

\author{
TAUBATÉ - SP \\ 2008
}

\section{REGULAMENTO \\ CAPÍTULO I \\ DISPOSIÇÕES PRELIMINARES}

Art. 1. Este regulamento visa estabelecer as diretrizes gerais para as atividades relacionadas com o Projeto Experimental do currículo pleno do curso de Comunicação Social da Universidade de Taubaté.

Art. 2. O Projeto Experimental consiste em um estudo aprofundado no nível de Graduação - Monografia ou Trabalho Profissional - sobre tema vinculado à habilitação na qual o aluno estará se formando - Jornalismo, Publicidade e Propaganda e Relações Públicas, sob a orientação de um professor escolhido pelo graduando.

Art. 3. O Projeto Experimental tem como objetivo possibilitar uma organização sistemática dos conhecimentos adquiridos durante os 4 anos do curso pelo aluno, além de fornecer subsídios para desenvolver pesquisas e descobrir soluções para a área de Comunicação Social.

\section{CAPÍTULO II DA ORGANIZAÇÃO}

Art. 4. A Coordenação de Projetos Experimentais é constituída por um professor Coordenador Geral, preferencialmente com título de Doutor ou Mestre.

$\S \mathbf{1}^{\circ} \mathrm{O}$ Coordenador Geral é indicado anualmente pelo Chefe do Departamento.

$\S \mathbf{2}^{\circ}$ A carga horária será de 14 aulas semanais.

\section{CAPÍTULO III \\ DA COORDENAÇÃO}

Art. 5. Compete à Coordenação de Projetos Experimentais:

I - atender aos alunos matriculados na disciplina Projetos Experimentais em horário e local preestabelecidos;

II - elaborar e encaminhar aos professores orientadores todos os formulários relativos à disciplina Projetos Experimentais;

III - convocar, sempre que necessário, reuniões com os professores orientadores e alunos matriculados na disciplina Projetos Experimentais;

IV - sugerir professores orientadores para os alunos que não os têm;

V - submeter à Chefia do Departamento nomes dos professores orientadores e sua respectiva carga horária;

VI - definir cronograma de execução das atividades dos alunos;

VII - manter arquivos atualizados dos Projetos em andamento;

VIII - receber os Projetos e encaminhá-los à Banca Examinadora;

IX - providenciar o encaminhamento de cópias dos Projetos Experimentais aprovados à Biblioteca do Departamento;

$\mathbf{X}$ - apresentar à Secretaria do Departamento, ao final do ano letivo, as notas atribuídas à disciplina Projetos Experimentais;

XI - levantar as linhas de pesquisa dos professores orientadores e divulgá-las aos alunos;

XII - tomar, no âmbito de sua competência, todas as medidas necessárias para o efetivo cumprimento deste Regulamento. 


\section{CAPÍTULO IV \\ DA COMISSÃO DE PROJETOS}

Art. 6. Parágrafo Único. Á Comissão de Projetos será composta pelos seguintes membros:

I - Chefe do Departamento;

II - Coordenador de Projetos Experimentais;

III - Coordenador do Curso envolvido;

IV - Orientador(es) responsável(eis) pelo Projeto.

\section{CAPÍTULO V \\ DA NATUREZA DO TRABALHO}

Art. 7. O Projeto Experimental pode ser:

I - Pesquisa de natureza Acadêmica (Monografia): Trabalho no qual se deve privilegiar a fundamentação teórica para estimular o interesse pela pesquisa.. A monografia só poderá ser orientada por doutores, mestres ou mestrandos. Casos especiais serão avaliados pela Comissão de Projetos.

II - Projeto de natureza Profissional: Trabalho no qual se devem privilegiar produtos e serviços voltados para o mercado de Comunicação Social. Exemplos: 1) Grande Reportagem; 2) Organização de Assessorias de Comunicação; 3) Filmes, vídeos, fotos e audiovisuais científicos ou artísticos; 4) Campanhas; 5) Eventos; 6) Planejamento de Marketing; 7) Projetos de Relações Públicas; 8) Programas de Identidade Visual. Outras modalidades serão encaminhadas para avaliação da Comissão de Projetos.

\section{CAPÍTULO VI \\ DO TEMA E DA COMPOSIÇÃO DO GRUPO}

Art. 8. O Projeto Experimental de caráter monográfico poderá ser desenvolvido por, no máximo, dois alunos.

Art. 9. O Projeto Experimental de natureza profissional poderá ser desenvolvido ou em grupo de até 3 (três) alunos da mesma habilitação ou de até 4 (quatro) alunos em habilitações diferentes. (Projeto Interdisciplinar), porém sendo do próprio Departamento (ex: Jornalismo e Publicidade ou Relações Públicas e Jornalismo etc).

Art. 10. O Projeto poderá ter caráter interdisciplinar, teórico e/ ou prático e deverá estar integrado à linha de pesquisa de cada professor orientador.

Parágrafo Único - Os Trabalhos que forem realizados por alunos de habilitações diferentes (Publicidade e Propaganda, Jornalismo e Relações Públicas), dependendo da natureza do Projeto ou linha de pesquisa, deverão ser orientados por um ou mais docentes. $\mathrm{O}(\mathrm{s})$ professor(es)-orientador(es) e a Banca Examinadora deverão levar em conta a interdisciplinaridade da proposta e avaliar o Projeto como um trabalho único e não dividido pelas respectivas habilitações.

Art. 11. O tema é de livre escolha do(s) aluno(s), devendo ter vínculos com a atuação profissional futura ou com a sua habilitação específica.

Art. 12. Para iniciar sua orientação, o(s) aluno(s) deverá(ão) preencher formulário próprio na Coordenação de Projetos, que consta dos seguintes itens: 1) Tema; 2) Natureza de Projeto; 3) Resumo; 4) Nome dos integrantes do grupo; e 5) Nome e assinatura do orientador escolhido. Esse formulário deverá ser entregue na Coordenação de Projetos, conforme cronograma (Anexo I).

\section{CAPÍTULO VII \\ DOS ALUNOS}

Art. 13. Compete ao aluno:

I - escolher o professor orientador e o tema para o seu Trabalho;

II - participar das atividades para as quais for convocado pelo professor orientador ou pela Coordenação;

III - respeitar o cronograma de trabalho, aprovado pelo orientador;

IV - cumprir as tarefas solicitadas pelo orientador;

V - entregar ao orientador e à Coordenação os relatórios e as avaliações das atividades desenvolvidas;

VI - entregar à Coordenação de Projetos Experimentais no mínimo 4 (quatro) cópias impressas e 01 cópia digital ( disquete ou Cd) do Trabalho Final, autorizado pelo professor orientador. Estas cópias servirão para análise pelos componentes da Banca Examinadora e para a Biblioteca do Departamento.

VII - comparecer no dia, hora e local determinados para acompanhar apresentação do Trabalho Final perante a Banca Examinadora.

\section{CAPÍTULO VIII DA ORIENTAÇÃO}

Art. 14. O Projeto Experimental deverá ser orientado por um professor do Curso de Comunicação Social solicitado pelo(s) aluno(s); 
I Os alunos, quando forem propor o nome dos seus respectivos orientadores, deverão levar em consideração os seguintes aspectos:

a - experiência docente e/ou profissional;

b - afinidades intelectuais, profissionais e pessoais;

c - linha de pesquisa mais adequada ao seu trabalho.

II -Os trabalhos que tiverem natureza profissional deverão ser orientados apenas por professores das respectivas habilitações específicas (JO, PP e RP). Somente haverá exceção quando for comprovado, por parte do orientador, experiência profissional ou titulação acadêmica em área afim do projeto.

III - Será facultada aos alunos e professores a mudança de orientação, proposta e tema, conforme cronograma (Anexo I). Para oficializar a alteração será necessário preencher um novo formulário de inscrição e encaminhá-lo à Coordenação de Projetos, podendo ser deferido ou não.

IV - Caso seja necessário haver a colaboração de outros professores em algumas fases específicas do Projeto, estes poderão dar assessoria ou apoio técnico para a execução de algumas tarefas como: fotografia, vídeo, áudio, planejamento gráfico etc.

V. Como regra geral, a orientação deverá ocorrer nas salas dos quartos anos do Departamento, quando não houver aula ou em sala de estudo.

VI. Cada orientador perceberá uma hora/aula semanal por trabalho orientado.

\section{CAPÍTULO IX \\ DA ORIENTAÇÃO DE LÍNGUA PORTUGUESA}

Art. 15. O acompanhamento por um professor de Língua Portuguesa não será obrigatório no desenvolvimento dos Projetos, porém haverá, na ficha de avaliação da Banca Final, um item referente à eficiência da produção textual. A avaliação será de no máximo 1,0 (um) ponto na média final. E será atribuída pelos professores membros da Banca Final.

Parágrafo Único. Os professores de Língua Portuguesa estarão à disposição dos grupos que desejarem realizar o acompanhamento dos seus Trabalhos durante o ano, conforme disponibilidade dosprofessores.

\section{CAPÍTULO $\mathrm{X}$ \\ DOS PROFESSORES ORIENTADORES}

Art. 16. Compete ao professor orientador:

I - participar das reuniões convocadas pela Coordenação de Projetos Experimentais;

II - fornecer horários de orientação à Coordenação de Projetos;

III - atender semanalmente seus orientandos, em horário e local previamente fixados;

IV - entregar à Coordenação os relatórios de avaliação e nota de seus orientandos, conforme cronograma (Anexo I);

V - providenciar formas de controle das orientações (lista de chamada, relatório etc) dos seus grupos, pois dessa forma poderá fazer um acompanhamento constante dos trabalhos facilitando a elaboração das avaliações;

VI - presidir a defesa pública do Projeto de seu orientando;

VII - elaborar e assinar, juntamente com os demais membros da Banca Examinadora, a ata final de defesa pública do Projeto;

VIII - zelar pela avaliação correta do Projeto, permitindo que os demais avaliadores tenham liberdade e autonomia ao fazer suas análises e notas;

IX - cumprir e fazer cumprir este regulamento.

$\$ 1^{\circ}$. O professor orientador poderá assumir no máximo 4 (quatro) trabalhos por período (matutino/noturno).

$\$ \mathbf{2}^{\mathbf{0}}$. A troca de professor orientador somente será permitida quando outro professor assumir formalmente a orientação, mediante concordância expressa do professor orientador e anuência do Coordenador Geral de Projetos.

\section{CAPÍTULO XI \\ DA AVALIAÇÃO}

Art. 17. Os Projetos Experimentais passarão por duas etapas de avaliação:

1. Avaliação do processo pedagógico, realizada pelo orientador.

O orientador deverá entregar à Coordenação um relatório pormenorizado (conforme modelo disponível na Coordenação) avaliando as atividades executadas durante o ano, atribuindo a nota de cada aluno para a Banca Examinadora Final. Valor de 0 (zero) a (2,0) dois pontos. CASO O PROJETO SEJA AVALIADO COM A NOTA O (ZERO), NÃO IRÁ PARA A BANCA FINAL ESTANDO REPROVADO. Estará anexado ao Relatório Final as observações da Pré-banca.

\subsection{Pré-bancas:}

Para as Pré-bancas, os alunos devem entregar à Coordenação 3 (três) vias da Proposta e apresentar-se em dia, horário e local determinados, para serem avaliados observando as seguintes orientações:

I - As Pré-bancas serão compostas por, no máximo, 2 (dois) professores, que farão OBSERVAÇÕES E SUGESTÕES sobre o projeto, sendo que estas deverão obrigatoriamente ser registradas no Relatório de Prébanca ( modelo disponível na Coordenação). 
II - O grupo deverá relatar o que foi desenvolvido no $1^{\circ}$ semestre e o que pretende desenvolver nas próximas etapas do Projeto.

III - Cada grupo terá no máximo 10 minutos para expor o Trabalho.

IV - Os professores avaliadores terão, no máximo, 5 minutos para as suas considerações.

V - Cada apresentação deverá ter um presidente e não deverá exceder 20 minutos no tempo total.

VI - Caso seja necessário conversar com o grupo além do tempo regulamentar, a pré-banca deverá anotar no relatório e solicitar uma reunião com o grupo ou com o orientador.

VII - O professor orientador não participará desta etapa de avaliação.

VIII - Os membros da banca deverão levar em consideração na apresentação os seguintes aspectos:

1) Comunicação Oral;

2) Objetividade;

3) Relevância para área de Comunicação Social;

4) Coerência entre o Tema e o Trabalho;

5) Pesquisa (campo, entrevista, opinião, mercado, outras);

6) Etapas desenvolvidas (Cronograma);

7) Referencial Bibliográfico.

\section{Avaliação da banca examinadora final.}

Nesta segunda etapa, a avaliação será efetuada pela Banca Examinadora, de conformidade com o previsto no Capítulo XIV.

Esta avaliação será realizada pela Banca Examinadora, com notas individuais de 0 (zero) a 8 (oito), com intervalo de 0,1 ponto.

À média atribuída pelos professores-avaliadores será acrescida a nota do orientador $(\mathbf{2 , 0 )}$ dois pontos, as quais comporão a Média Final, que constará do histórico escolar do aluno na disciplina Projetos Experimentais.

\section{CAPÍTULO XII \\ DA APRESENTAÇÃO ESCRITA E ORAL}

Art. 18. Os Trabalhos de natureza acadêmica (monografias) serão normatizados pela Coordenação de Projetos Experimentais.

$\S \mathbf{1}^{\mathbf{0}}$. Caso o Trabalho seja de natureza profissional, como: a elaboração de filme, vídeo, fotos, audiovisual ou produção semelhante, o grupo deverá elaborar suportes que permitam a análise do material pela Banca Examinadora, como por exemplo: cópias das fitas, roteiro, fotos ou outras produções.

$\S 2^{\circ}$. Os trabalhos profissionais ou técnicos na área de Jornalismo deverão ser acompanhados por um relatório técnico fundamentando, onde estarão descritas todas as etapas do processo de produção e criação. Estão isentos de Relatório na área de PP os seguintes trabalhos: Planejamento de Campanha, Planejamento de Marketing e Identidade Visual.

Art. 19. Todos os Projetos deverão ser apresentados pelo(s) membro(s) do grupo de forma oral e pública para uma Banca Examinadora, cuja exposição deve acontecer no prazo de 20 minutos, acompanhada ou não de recursos audiovisuais.

$\S \mathbf{1}^{\mathbf{0}}$. A data de apresentação dos Projetos será determinada pela Coordenação de Projetos levando em conta a disponibilidade de horário dos professores orientadores.

$\S \mathbf{2}^{\mathbf{0}}$. O aluno que, sem justificativa, deixar de comparecer à apresentação oral de seu trabalho, será reprovado. Poderá o aluno solicitar recurso à Comissão de Projetos, que analisará o seu pedido, observando o mérito ou não da questão. Caso seja aprovada a solicitação será marcada uma nova data para a apresentação.

\section{CAPÍTULO XIII DA ENTREGA DOS PROJETOS}

Art. 20. Todas as vias impressas dos Projetos, material produzido (mínimo 4) e uma cópia digital, deverão ser entregues e protocoladas na Coordenação de Projetos, conforme Cronograma (Anexo I).

$\S 1^{\circ}$. Não serão aceitos, em hipótese alguma, trabalhos após o prazo estabelecido, estando automaticamente reprovados os alunos cujos trabalhos forem entregues fora do prazo.

§ $\mathbf{2}^{\mathbf{0}}$. Não será permitida, em hipótese alguma, a substituição de cópias entregues no período regular, nem o acréscimo de material além do que foi entregue na Coordenação.

$\S 3^{\mathbf{0}}$.Os Trabalhos interdisciplinares deverão entregar cópias para todos os professores-avaliadores.

\section{CAPÍTULO XIV \\ DA BANCA EXAMINADORA}

Art. 21. A versão final do Projeto será apresentada pelo(s) membro(s) do grupo perante a Banca Examinadora composta pelo professor orientador, que a preside, e por outros dois membros.

$\S \mathbf{1}^{\mathbf{0}}$. No caso de Projetos Interdisciplinares, a Banca Examinadora deverá ter, além dos orientadores, outros dois professores sendo um de cada área específica. 
§ $2^{\circ}$. Para participar da Banca Examinadora os professores do Departamento devem se inscrever para o Projeto de sua área de atuação profissional e/ou acadêmica. Os professores serão indicados pela Comissão de Projetos Experimentais, podendo o orientador vetar a participação de algum membro, encaminhando justificativa para a Comissão de Projetos que analisará, deferindo ou não o veto.

$\S \mathbf{3}^{\circ}$. Os professores que forneceram assessoria ou apoio técnico não poderão participar destes respectivos Projeto nas Bancas Examinadoras.

$\S \mathbf{4}^{\mathbf{0}}$. É facultado ao aluno e orientador convidar 1 (um) participante de fora - desde que esteja ligado ao tema - para compor a Banca como assistente. Esse convidado poderá analisar o Projeto, mas não atribuirá nota. Ao realizar o convite, os alunos deverão avisar com antecedência a Coordenação de Projetos e ter o aceite do orientador.

$\S 5^{\circ}$. É facultado ao orientador convidar no máximo 1 (um) docente de outro Departamento da Unitau ou de outra Universidade para participar da Banca como professor convidado. Ele deverá ser de área afim ao trabalho e poderá, caso o orientador permita, atribuir nota como os demais professores da Banca.

$\S \mathbf{6}^{\circ}$. Caso algum membro da Banca Examinadora falte no dia da apresentação, ela deverá funcionar, excepcionalmente, com 2 (dois) professores. A Banca somente será adiada na ausência do orientador ou dos outros dois membros.

§ $7^{\mathbf{0}}$. Não comparecendo todos os membros da Banca Examinadora, deverá ser marcada nova data para a apresentação.

$\S \mathbf{8}^{\mathbf{0}}$. O professor que se comprometer em participar da Banca e se ausentar no dia da apresentação receberá falta.

§ $\mathbf{9}^{\mathbf{0}}$. A avaliação da Banca Examinadora é soberana não cabendo recursos após sua avaliação final.

$\$ \mathbf{1 0}^{\mathbf{0}} \mathrm{A}$ Banca Examinadora avaliará os seguintes aspectos:

I - O trabalho entregue por escrito antecipadamente;

II - Apresentação oral;

III - O material produzido pelos alunos. (Ex: vídeo, fotos, cartazes, etc.)

$\S 11^{\circ} \mathrm{Cada}$ membro da Banca atribuirá notas individuais de $\mathbf{0}$ (zero) a 8,0 (oito), com intervalo de 0,1 ponto, para cada aluno do trabalho apresentado. Após a soma e divisão das notas, utilizando a média aritmética simples será acrescida a nota do orientador $(2,0)$ dois pontos,compondo assim a Média Final de cada aluno. $\S 12$ Os membros da Banca deverão, logo após a apresentação do(s) aluno(s), avaliar o Projeto e o presidente comunicar em seguida as médias parciais a média final para os membros do grupo.

$\S$ 13. Estarão aprovados os alunos cujos Trabalhos tiverem Média igual ou superior a 6,0 (seis).

\section{CAPÍTULO XV \\ DAS DISPOSIÇÕES GERAIS E FINAIS}

Art. 22. Serão nulos de pleno direito os atos praticados por acadêmicos com intencional objetivo de desvirtuar, modificar, alterar ou fraudar preceitos contidos no presente Regulamento, bem como a ocorrência de plágio de fontes digitais/impressas.

Art. 23. Todas as atividades de orientação, supervisão, acompanhamento, avaliação e coordenação relacionadas a Projetos Experimentais são consideradas atividades docentes.

Art. 24. Seguir cronograma estabelecido anualmente pela Coordenação de Projetos Experimentais.

Art. 25. Os casos omissos neste Regulamento serão resolvidos pela Comissão de Projetos Experimentais. A Comissão será formada de acordo com o previsto no Capítulo IV. Excepcionalmente o(s) aluno(s) ou seu(s) representante(s) poderão participar, mas sem direito a voto.

\section{COORDENAÇÃO DE PROJETOS EXPERIMENTAIS}

\section{CRONOGRAMA PROJETOS EXPERIMENTAIS 2008}

ATÉ 20 DE MARÇO (QUINTA-FEIRA):

Data limite para mudança de PROJETO e ORIENTADOR.

ATÉ 14 DE ABRIL(SEGUNDA-FEIRA):

Data limite para a entrega de nova Proposta dos alunos cujo trabalho foi indeferido pela Comissão de Projetos.

Entrega do material elaborado pelos alunos para avaliação das Pré-Bancas ( 3 VIAS).

DE 05 DE MAIO (SEGUNDA-FEIRA) A 16 DE MAIO (SEXTA-FEIRA):

Realização das Pré-Bancas.

ATÉ 26 DE JUNHO (QUINTA-FEIRA):

Entrega do relatório do orientador a respeito do primeiro semestre do processo de orientação.

DE 18 ( $2^{\mathrm{a}}$ FEIRA) A 20 ( $4^{\mathrm{a}}$ FEIRA) DE AGOSTO

Agendamento da data e local de apresentação do TCC 
Entrega do relatório de AVALIAÇÃO FINAL DO ORIENTADOR aprovando ou não o projeto para a Banca Examinadora. $\mathrm{O}$ orientador deverá dar uma nota de 0 (zero) a 2,0 (dois). O aluno que obtiver a nota 0 (zero) estará REPROVADO.

DE 23 DE OUTUBRO (TERÇA-FEIRA) A 30 DE OUTUBRO(QUINTA-FEIRA):

ENTREGA DOS PROJETOS:

Deverão ser entregues na Coordenação:

*4 (quatro) cópias IMPRESSAS E UMA VIA DIGITAL (CD - contendo o trabalho e um resumo de 10 linhas do mesmo) e o material que será avaliado pela Banca Examinadora.

NÃO HAVERÁ PRORROGAÇÃO.

DE 17 DE NOVEMBRO (SEGUNDA-FEIRA) A 13 DE DEZEMBRO (SÁBADO): APRESENTAÇÃO DOS TRABALHOS À BANCA EXAMINADORA. 